\title{
Episodic burial and exhumation in North-East Greenland before and after opening of the North-East Atlantic
}

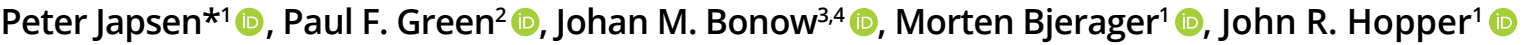 \\ ${ }^{1}$ Geological Survey of Denmark and Greenland (GEUS), Copenhagen, Denmark. ${ }^{2}$ Geotrack International, Brunswick West, Victoria, Australia. \\ ${ }^{3}$ Geovisiona AB, Bro, Sweden. ${ }^{4}$ Uppsala University, Uppsala, Sweden.
}

\begin{abstract}
The geology of North-East Greenland $\left(70-78^{\circ} \mathrm{N}\right)$ exposes unique evidence of the basin development between the Devonian collapse of the Caledonian Orogen and the extrusion of volcanics at the Paleocene-Eocene transition during break-up of the North-East Atlantic. Here we pay special attention to unconformities in the stratigraphic record - do they represent periods of stability and non-deposition or periods of subsidence and accumulation of rocks followed by episodes of uplift and erosion? To answer that and other questions, we used apatite fission-track analysis and vitrinite reflectance data together with stratigraphic landscape analysis and observations from the stratigraphic record to study the thermo-tectonic history of North-East Greenland. Our analysis reveals eight regional stages of post-Caledonian development: (1) Late Carboniferous uplift and erosion led to formation of a sub-Permian peneplain covered by coarse siliciclastic deposits. (2) Middle Triassic exhumation led to removal of a thick cover including a considerable thickness of upper Carboniferous - Middle Triassic rocks and produced thick siliciclastic deposits in the rift system. (3) Denudation at the transition between the Early and Middle Jurassic affected most of the study area outside the Jameson Land Basin and produced a weathered surface above which Middle-Upper Jurassic sediments accumulated. (4) Earliest Cretaceous uplift and erosion along the rifted margin and further inland accompanied the Mesozoic rift climax and produced coarse-grained sedimentary infill of the rift basins. (5) Mid-Cretaceous uplift and erosion initiated removal of Cretaceous post-rift sediments that had accumulated above the Mesozoic rifts and their hinterland, leading to cooling of Mesozoic sediments from maximum palaeotemperatures. (6) End-Eocene uplift was accompanied by faulting and intrusion of magmatic bodies and resulted in extensive mass wasting on the East Greenland shelf. This event initiated the removal of a thick post-rift succession that had accumulated after break-up and produced a peneplain near sea level, the Upper Planation Surface. (7) Late Miocene uplift and erosion, evidenced by massive progradation on the shelf, resulted in the formation of the Lower Planation Surface by incision below the uplifted Upper Planation Surface. (8) Early Pliocene uplift raised the Upper and the Lower Planation Surfaces to their present elevations of about 2 and $1 \mathrm{~km}$ above sea level, respectively, and initiated the formation of the present-day landscape through fluvial and glacial erosion. Additional cooling episodes of more local extent, related to igneous activity in the early Eocene and in the early
\end{abstract}

\author{
*Correspondence: pj@geus.dk \\ Received: 28 Nov 2018 \\ Accepted: 26 Mar 2021 \\ Published: 8 Oct 2021 \\ Keywords: Erosion, hiatus, peneplain, uplift, \\ tectonics
}

\author{
Abbreviations: \\ a.s.l.: above sea level \\ AFTA: Apatite fission-track analysis \\ ARCO: Atlantic Richfield Company \\ EPCM: Elevated passive continental margin \\ ES: Etch surface \\ IMU: Intra-Miocene Unconformity \\ LPS: Lower Planation Surface \\ ODP: Ocean drilling program \\ PDMF: Post-Devonian Main Fault \\ PSE: Projected surface elevation \\ UPS: Upper Planation Surface \\ VR: Vitrinite reflectance \\ VT: Vertical transect
}

GEUS Bulletin is an open access, peer-reviewed journal published by the Geological Survey of Denmark and Greenland (GEUS). This article is distributed under a CC-BY 4.0 licence, permitting free redistribution, and reproduction for any purpose, even commercial, provided proper citation of the original work. Author(s) retain copyright.

Edited by: Catherine N. Jex (GEUS, Denmark)

Reviewed by: Finn Surlyk (University of Copenhagen, Denmark), Sierd Cloetingh (Utrecht University, Netherlands)

Funding: See page 85

Competing interests: None declared

Additional files: See page 85 
Miocene, primarily affected parts of northern Jameson Land. The three earliest episodes had a profound impact beyond Greenland and accompanied the fragmentation of Pangaea. Younger episodes were controlled by plate-tectonic processes, possibly including dynamic support from the Iceland Plume. Our results emphasise that gaps in the stratigraphic record often reflect episodes of kilometre-scale vertical movements that may result from both lithospheric and sub-lithospheric processes. 


\section{Introduction}

North-East Greenland $\left(70-78^{\circ} \mathrm{N}\right)$ exposes unique evidence of the basin development between the Devonian collapse of the Caledonian Orogen and the extrusion of volcanics at the Paleocene-Eocene transition during break-up of the North-East Atlantic (Figs 1, 2; Haller 1971; Escher \& Watt 1976; Surlyk 1990, 2003; Stemmerik 2000; Higgins et al. 2008; Larsen et al. 2008a; Henriksen et al. 2009). The region hosts spectacular mountains reaching $2.8 \mathrm{~km}$ above sea level (a.s.I.) within the study area, and the highest mountain in Greenland, Gunnbjørn Fjeld (3.7 km a.s.l., c. $68^{\circ} \mathrm{N}$ ), carved in Palaeogene volcanics, is located just south of the region. Of particular interest are the development of the modern topography along this passive continental margin and its importance for the formation of the $3 \mathrm{~km}$ thick Greenland ice sheet.

The stratigraphic record of North-East Greenland includes several major unconformities. For example, there are no pre-Quaternary sediments younger than the Paleocene - lowermost Eocene rocks within our study area, leaving a gap of about $50 \mathrm{Myr}$ in the stratigraphic record (Nøhr-Hansen et al. 2011; Larsen et al. 2014; Stoker et al. 2017). A key question in regard to the evolution of the region is whether such gaps represent periods of stability and non-deposition or periods in

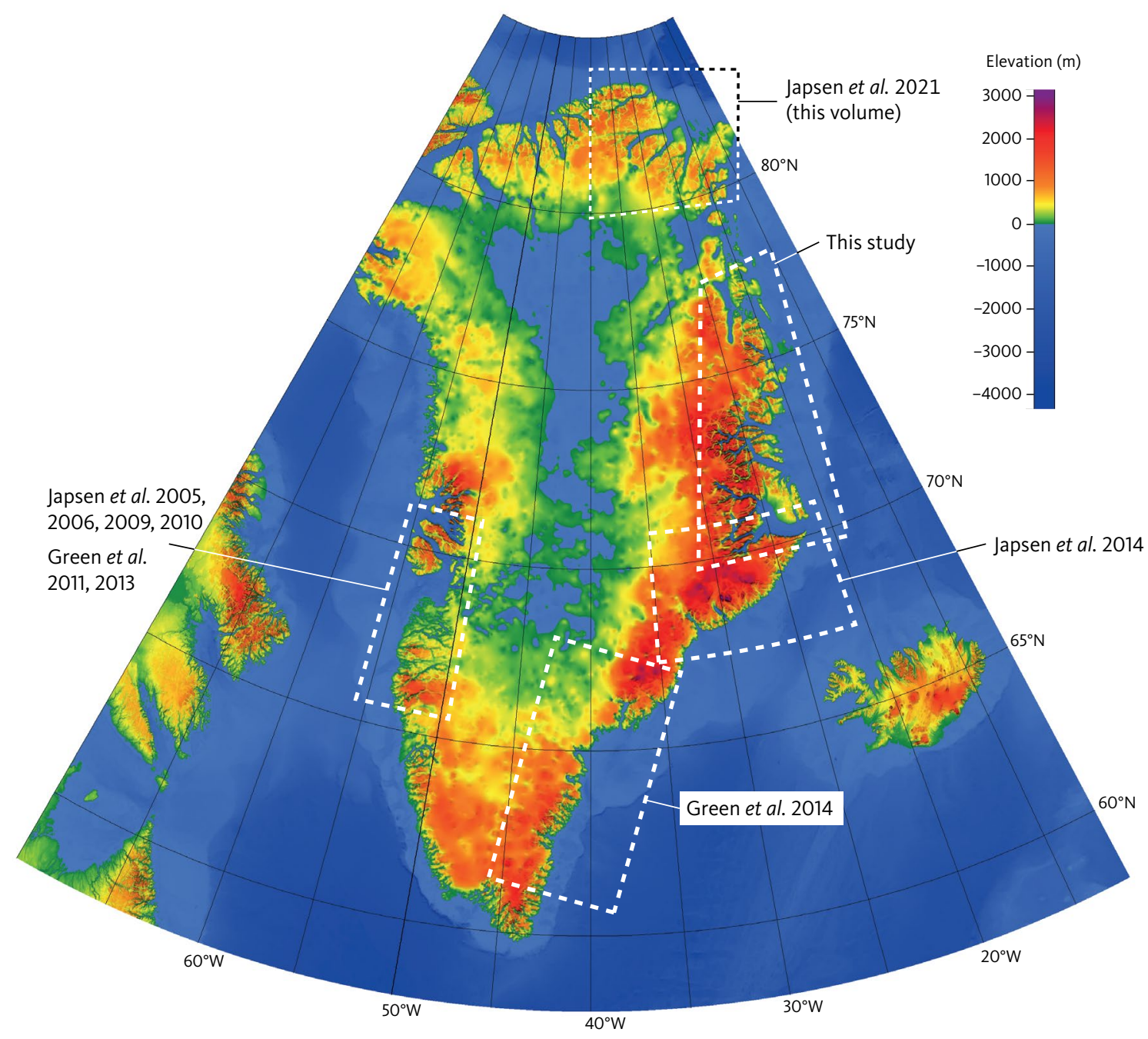

Fig. 1 Location of study area in North-East Greenland $\left(70-78^{\circ} \mathrm{N}\right)$ and present-day topography of the bedrock of Greenland. The burial and exhumation history of various parts of Greenland have been investigated using apatite fission-track analysis (AFTA) data in a series of publications, as indicated on the map (Japsen et al. 2005, 2006, 2009, 2010, 2014, 2021 (this volume); Green et al. 2011, 2013 , 2014). The load of the Greenland ice sheet causes up to $850 \mathrm{~m}$ subsidence of the bedrock topography of central Greenland. Peripheral bulging caused by this ice loading has a negligible effect $(<20 \mathrm{~m})$ on the elevation of the Greenland margins (Medvedev et al. 2013). Elevation data from Amante \& Eakins (2009). 
which significant thicknesses of rock were deposited and then removed as a result of uplift and erosion? In either case, such intervals represent gaps in our understanding of the full geological development of the region. When the gaps represent burial followed by exhumation, we are left with a censored view of the geological history, and of the tectonic processes that shaped the surface of the Earth as we know it today. Here we will investigate the nature of major post-Devonian unconformities in the stratigraphic record of North-East Greenland.

North-East Greenland is a typical example of an elevated passive continental margin (EPCM), which occur in different climatic zones and along margins of different ages across the world, including Scandinavia, Brazil and south-east Australia Japsen et al. 2012a; Green et al. 2013, 2018). These margins typically have Mesozoic-Palaeogene rift systems parallel to the coast (both onshore and offshore in the case of North-East Greenland; Hamann et al. 2005; Døssing et al. 2016) and a transition from continental to oceanic crust farther offshore. Also in North-East Greenland, escarpments separate low-lying coastal areas from the mountains that are characterised by elevated plateaus and deeply incised valleys (Bonow \& Japsen 2021, this volume). Furthermore, syn- and post-rift sediments at the landward margin of these rifts dip away from the EPCM towards the rifts and are truncated by one or more unconformities (Japsen \& Chalmers 2000).

The timing and nature of the processes driving the formation of EPCMs have been topics of much debate in recent years (Nielsen et al. 2009, 2010; Chalmers et al. 2010; Pedersen et al. 2012; Japsen et al. 2012a, 2013, 2019; Green et al. 2013, 2018; Colli et al. 2014, 2016; Braun 2018, 2019). Are they remnants of ancient mountain chains? Are these mountains remnants of rift shoulders from the time of rifting and break-up? Or are they young expressions of dynamic topography or of far-field transmission of stress (Braun 2010; Cloetingh \& Burov 2010; Colli et al. 2016)? Can elevated topography be sustained on timescales of hundreds or only tens of millions of years?

In this study, we examine the formation of the coastal mountains in North-East Greenland. We present new apatite fission-track analysis (AFTA ${ }^{\circledR}$ ) data that shed light on the episodes of subsidence, burial, uplift and erosion that affected the region both prior to and after break-up of the North-East Atlantic. We integrate stratigraphic landscape analysis (Lidmar-Bergström et al. 2013) with new and published AFTA and vitrinite reflectance (VR) data. These approaches provide complementary information (Green et al. 2013). While stratigraphic landscape analysis provides a relative denudation chronology, AFTA can provide absolute timing constraints for the onset of denudation episodes, which initiate the formation of peneplains identified from the landscape analysis. The age for the final formation of the peneplains can be constrained by cover rocks, where present. We have previously published results from southern East Greenland $\left(68-71^{\circ} \mathrm{N}\right)$ based on integration of AFTA data and stratigraphic landscape analysis (Bonow et al. 2014; Japsen et al. 2014) and results from South-East Greenland (61$66^{\circ} \mathrm{N}$ ) based on AFTA data alone (Green et al. 2014). In part one of this volume, we presented an outline of the thermo-tectonic development of the Wandel Sea Basin, North Greenland (Japsen et al. 2021, this volume).

We also consider the impact of exhumation and igneous activity on the hydrocarbon systems in the sedimentary basins of North-East Greenland. The outcropping sedimentary basins of North-East Greenland have long been recognised as potential analogues for understanding offshore basins and their hydrocarbon systems; particularly relative to those on the conjugate Norwegian margin (Surlyk 1990; Stemmerik \& Worsley 2005). The US Geological Survey concluded that the North-East Greenland shelf could be an important future petroleum province but stressed that Cenozoic uplift and erosion are important risk factors for the development of the hydrocarbon system (Gautier et al. 2011). Christiansen (2011) found uplift to be the main exploration risk in East and North-East Greenland, but he also assigned a significant uncertainty to the limited stratigraphic control due to lack of geophysical and well data. Major oil companies acquired several licences for hydrocarbon exploration off North-East Greenland between 76 and $80^{\circ} \mathrm{N}$ in 2012 and 2013 (Bojesen-Koefoed et al. 2014). However, this acreage has now been relinquished.

Finally, we consider the impact of the reconstructed history of uplift and subsidence on the development of the Greenland ice sheet. It is unclear whether the ice sheet persisted for millions of years or whether Greenland has been ice-free for extended periods during the Pleistocene (Bierman et al. 2016; Schaefer et al. 2016; Christ et al. 2021). Numerical models of the development of the Greenland ice sheet traditionally use the present-day bedrock geometry as a boundary condition (Letreguilly et al. 1991). But recently, Solgaard et al. (2013) investigated the influence of late Neogene mountain building in Greenland on the initiation of the ice sheet. We review these results.

The stratigraphic record and the large-scale landscapes of the study area form the backbone of our investigation (Chapters 2 and 3; Bonow \& Japsen 2021, this volume). A synthesis of AFTA data and associated thermal-history interpretations from 217 outcrop samples is presented in Chapter 4. We integrate these results with observations from the geological record and with results from the stratigraphic landscape analysis (Chapters 5 and 6) similar to our approach in studies 


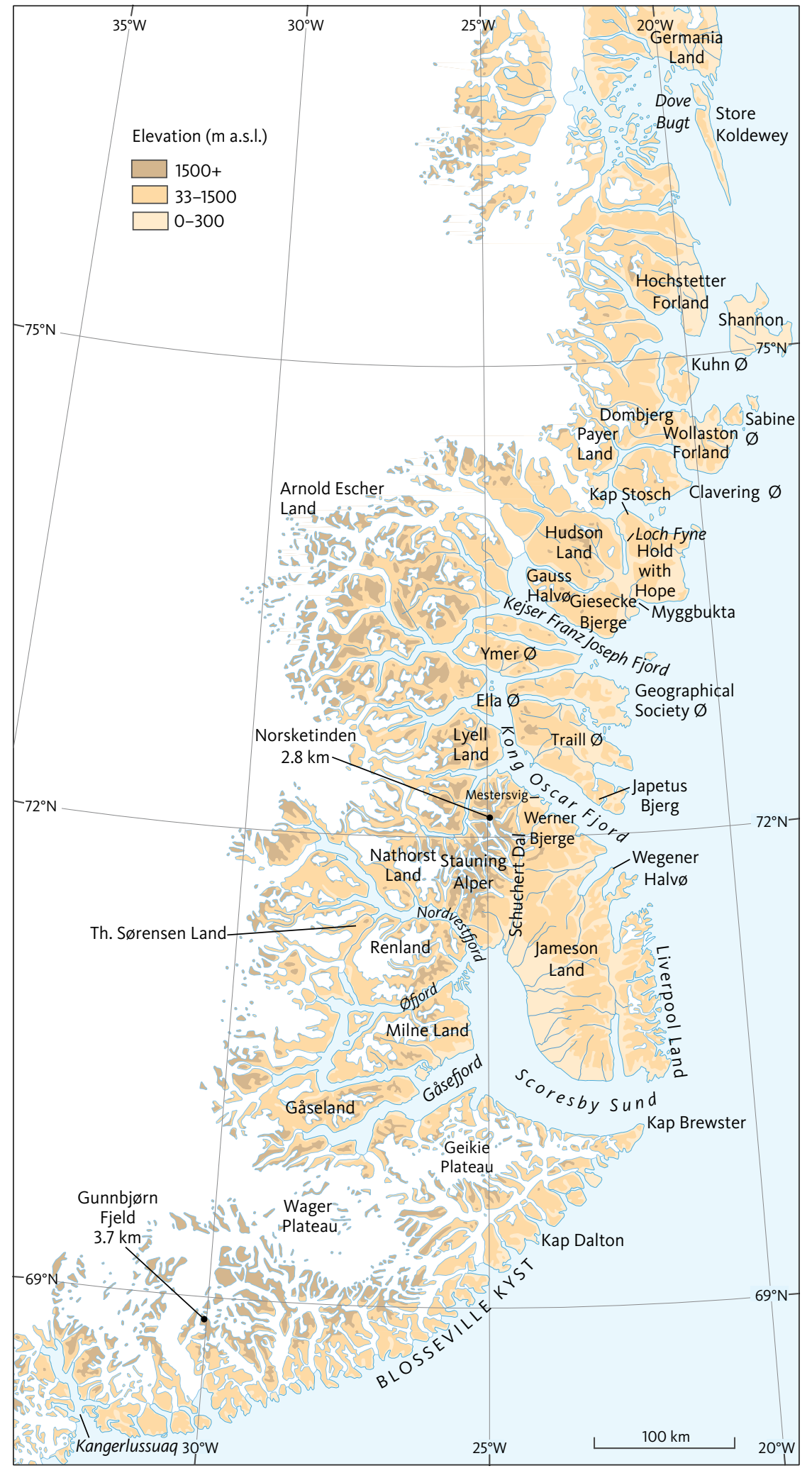

Fig. 2 Elevation and place names of the study area in North-East Greenland (north of Scoresby Sund) and of southern East Greenland (between Scoresby Sund and Kangerlussuaq). 


\section{Post-Caledonian geology}

The roots of the East Greenland Caledonian fold belt are well exposed between 70 and $81^{\circ} 30^{\prime} \mathrm{N}$ as a $1300 \mathrm{~km}$ long and up to $300 \mathrm{~km}$ wide belt parallel to the coast (Higgins et al. 2008). Large regions of the fold belt are characterised by reworked Precambrian basement rocks overlain by Proterozoic and lower Palaeozoic sedimentary rocks, all of which form parts of westward-directed, major thrust sheets formed during the climax of collision between Laurentia and Baltica in mid-Silurian times (the Caledonian Orogeny). Extensional collapse of an overthickened crust initiated basin formation in East Greenland. From Middle Devonian times, more than $8 \mathrm{~km}$ of mainly coarse siliciclastic sediments accumulated in the continental Old Red Sandstone Basin in North-East Greenland (Larsen et al. 2008a). The initial phase of the collapse resulted in major exhumation, evident from the deposition of Old Red Sandstone in the Eifelian (early Middle Devonian; 393-388 Ma) shortly after a phase of high-pressure metamorphism at c. $405 \mathrm{Ma}$ (Gilotti \& McClelland 2008). In this chapter, we briefly describe the post-Caledonian geology of North-East Greenland.

\subsection{Carboniferous-Cretaceous cover and unconformities}

A series of Carboniferous-Mesozoic sedimentary basins developed in East Greenland following initial, post-Caledonian Devonian deposition (Fig. 3). The basin evolution was governed by a system of old first-order faults, some of which were formed by reactivation of Caledonian or older thrusts and weakness zones (Surlyk 2003). New faults formed during continued extensional movements. In the south, a very deep basin was formed in the Jameson Land area in Late Devonian - early Permian times (see the stratigraphic scheme in Fig. 4). This area then acted as a wide, coherent platform in late Permian - Jurassic times. Subsidence was accommodated mainly along basin margin faults, and there was no syn-sedimentary faulting of the platform. This is in contrast to the region north of Jameson Land, notably the Wollaston Forland - Kuhn $\varnothing$ area, which was fragmented into narrow tilted blocks during Middle Jurassic - earliest Cretaceous rifting.

Tectonic models of the Carboniferous-Permian basins of North-East Greenland have emphasised rifting and half graben formation along the so-called Post-Devonian Main Fault (PDMF; Vischer 1943) - a north to north-easttrending fault, which appears as a marked scarp in the terrain, and defines the present-day western boundary of the sedimentary basins north of Kong Oscar Fjord. South of the fjord, it was termed the Stauning Alper Fault. We will refer to these two faults as the Post-Devonian Main Fault system. However, Bütler (1955) observed offsets of Tertiary dykes on Ymer $\varnothing$ and on Geographical Society $\varnothing$ along the Post-Devonian Main Fault and concluded that the main faulting took place during and after the emplacement of the Tertiary dykes. Bütler (1955, p. 128) wrote that "the term 'Post-Devonian Main Fault' for this part of the large fault line seems therefore rather indefinite".

During rifting in the latest Devonian and Carboniferous, deposition took place in a system of north-south elongated and relatively narrow half-grabens. The Carboniferous redbeds of the Traill $\varnothing$ Group in North-East Greenland accumulated during initial rifting of the northern North Atlantic (Vigran et al. 1999; Stemmerik 2000). Deposition took place in a system of westward tilted halfgrabens, exposed from Clavering $\varnothing$ in the north to Jameson Land in the south (Surlyk et al. 1984; Stemmerik et al. 1990, 1991). A hiatus spans the mid-Carboniferous in East Greenland (Stemmerik et al. 1991), and upper Carboniferous deposits rest on basement on Germania Land and Holm Land farther north (Piasecki et al. 1994).

A major hiatus spanning the latest Carboniferous to early Permian separates tilted strata of the Traill $\varnothing$ Group from the overlying upper Permian conglomerates of the Huledal Formation (Surlyk 1990; Vigran et al. 1999; Stemmerik 2000). This unconformity marks the most profound change in tectonic style and overall depositional environment in the post-Caledonian development of East Greenland (Surlyk 1990). The succession below the unconformity was uplifted and deeply eroded along the basin margins during a final phase of rotational block-faulting, and a vast peneplain developed (Haller 1971; Larsen 1988; Surlyk 1990). The widespread deposits of the Huledal Formation accumulated on the peneplain with pronounced unconformable contact and marks the transition from a long period of crustal extension to a period of subsidence governed mainly by thermal relaxation of the rifted crust (Surlyk 1990). The mid-late Permian Røde $\varnothing$ Conglomerate downfaulted against the basement of the southern interior (west of Milne Land), is an equivalent to the Huledal Formation, and thus testifies to the former regional extent of these deposits (Stemmerik \& Piasecki 2004).

In the late Permian, the sea transgressed the area for the first time since the Caledonian Orogeny, allowing deposition of the Foldvik Creek Group. Haller (1971, p. 320) summarised this change in the structural development and emphasised that the Caledonian mountain had disappeared by then: "When the upper Permian sea transgressed across the present outer fjord region most 


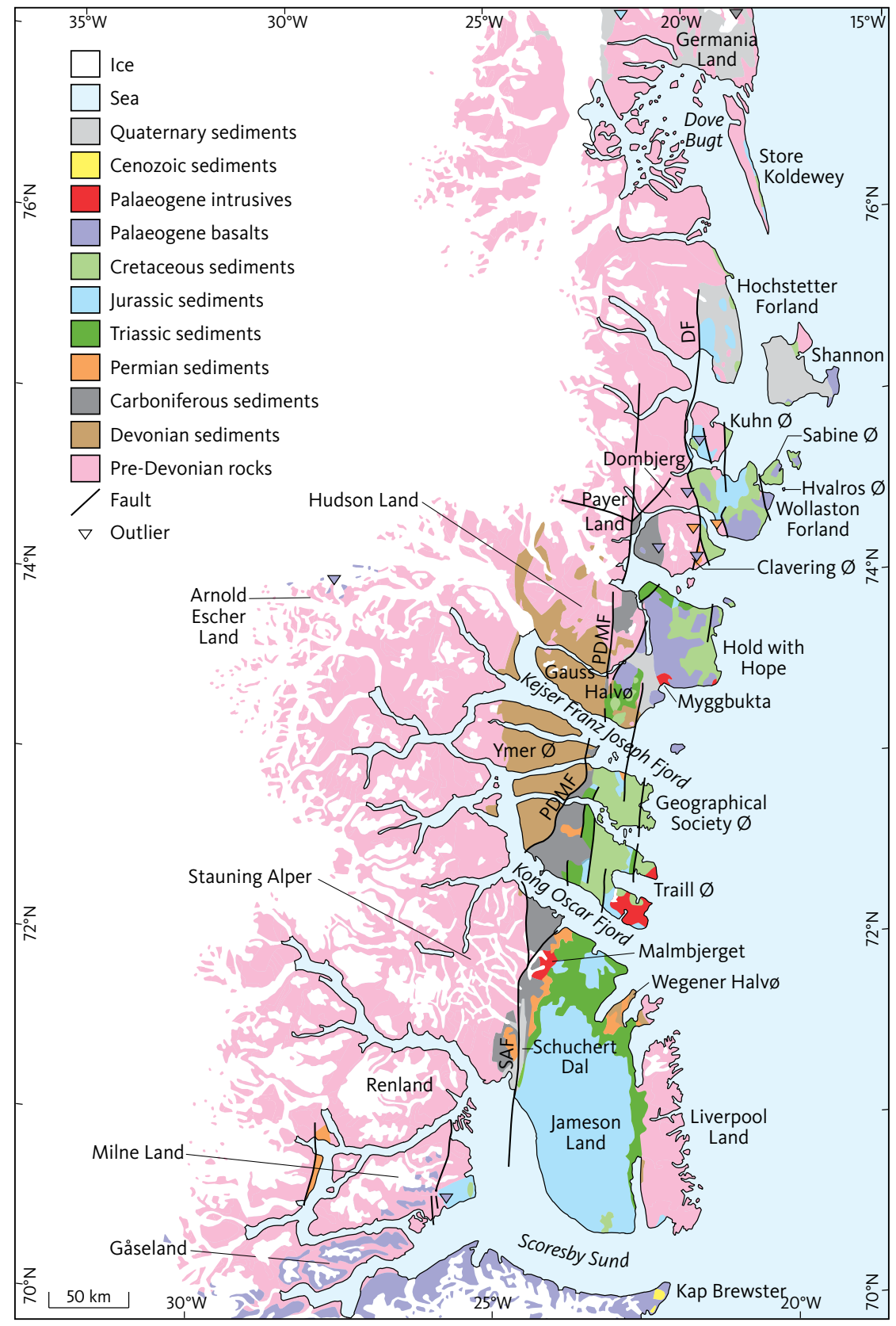

Fig. 3 Geological map of North-East Greenland (Escher \& Pulvertaft 1995; Henriksen 2003; Surlyk 2003; Christoffersen \& Jepsen 2007). Major post-Devonian faults are shown (Surlyk 2003; Guarnieri 2015). A middle Jurassic outlier on Germania Land is located just north of the map frame (Bojesen-Koefoed et al. 2012). DF: Dombjerg Fault. PDMF: Post-Devonian Main Fault. SAF: Stauning Alper Fault. We refer to the two latter faults collectively as the Post-Devonian Main Fault system.

of the intra-Permian fault escarpments had been worn away. The late Palaeozoic block mountain ranges had disappeared and given place to lowlands. In the course of this Permian denudation considerable quantities of Carbono-Permian molasse deposits must have been removed, in particular from the protruding edges of tilted fault blocks".

The marine upper Permian - Lower Triassic succession in East Greenland is up to $1 \mathrm{~km}$ thick and includes an upper Permian carbonate and mudstone-dominated succession and a Lower Triassic sandstone and mudstone succession (e.g. Stemmerik et al. 1993; Seidler et al. 2004; Bjerager et al. 2006). Marine organic-rich mudstones of the upper Permian Ravnefjeld Formation of the Foldvik Creek Group are widespread in East Greenland. The mudstones were deposited along the axis of a more than $400 \mathrm{~km}$ long and at least $80 \mathrm{~km}$ wide, marine basin, flanked by shallow-water carbonate platforms. Rifting began at the Permian-Triassic transition (Surlyk et al. 2017).

Two Early Triassic marine rifting events were recognised in East Greenland by Seidler et al. (2004), who correlated the later event with rhyolitic intrusions in Liverpool Land with an Ar-Ar age of $244 \pm 4$ Ma. Early Triassic rifting was followed by Middle Triassic deposition of the coarse-grained, continental conglomerates and sandstones of the Pingo Dal Group, which overlies the Early Triassic marine mudstones of the Wordie 

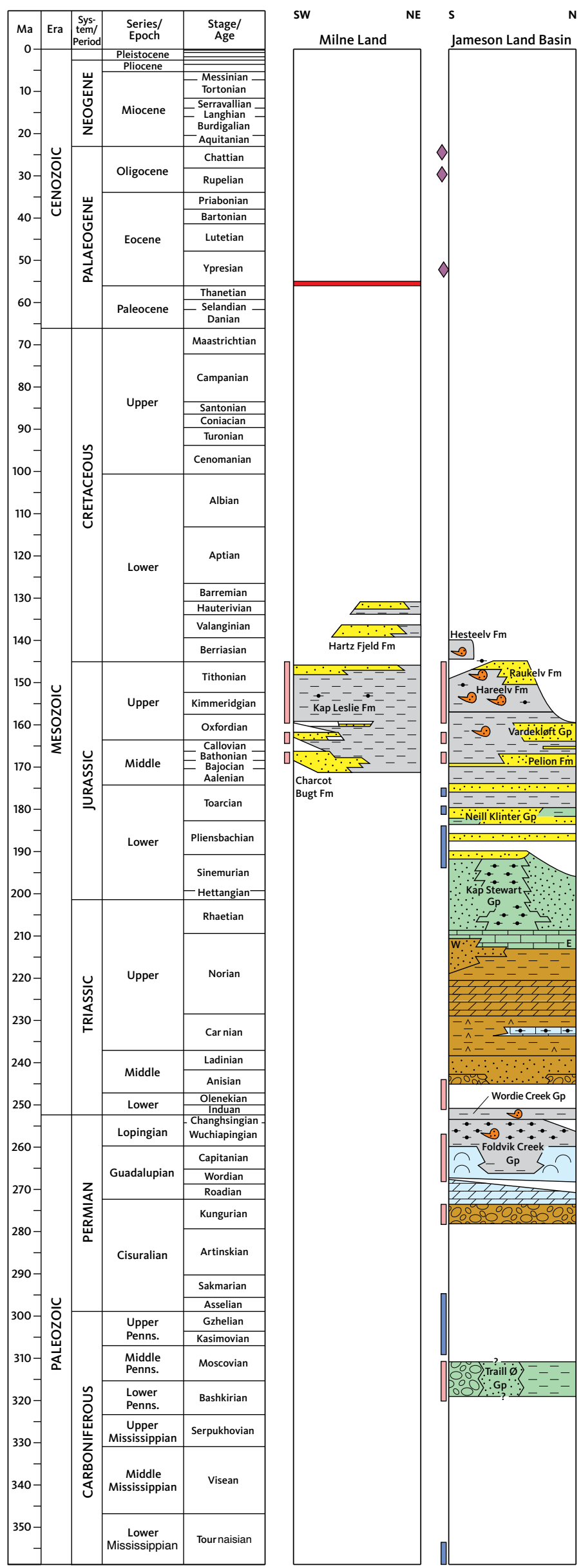

N S

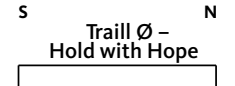

Wollaston Foreland - E
Kuhn $\varnothing$
-
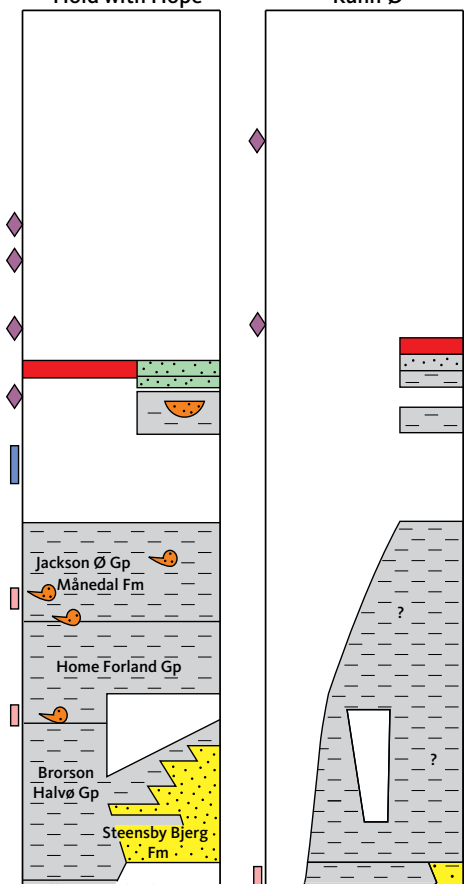

Store Koldewey

(1)

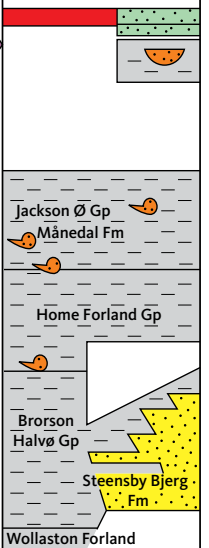
Wollaston Forland

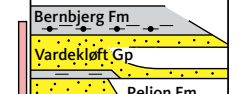

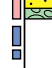
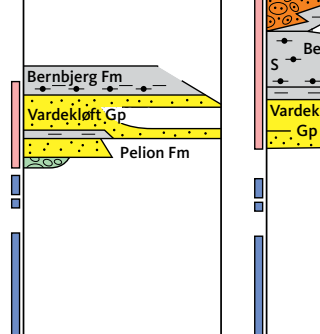

$\because$ Bernbjerg $\ldots \mathrm{N}$
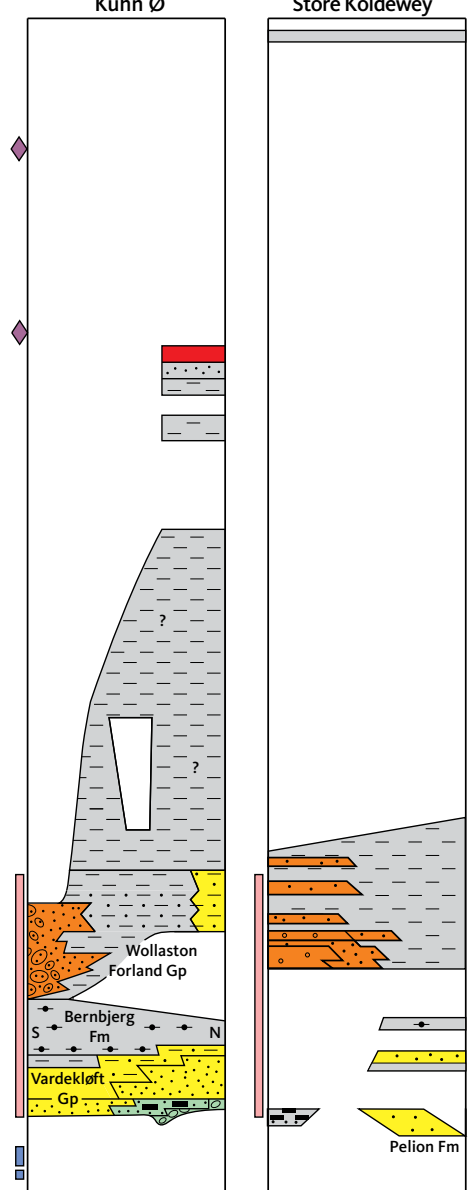

Pelion $\mathrm{Fm}$
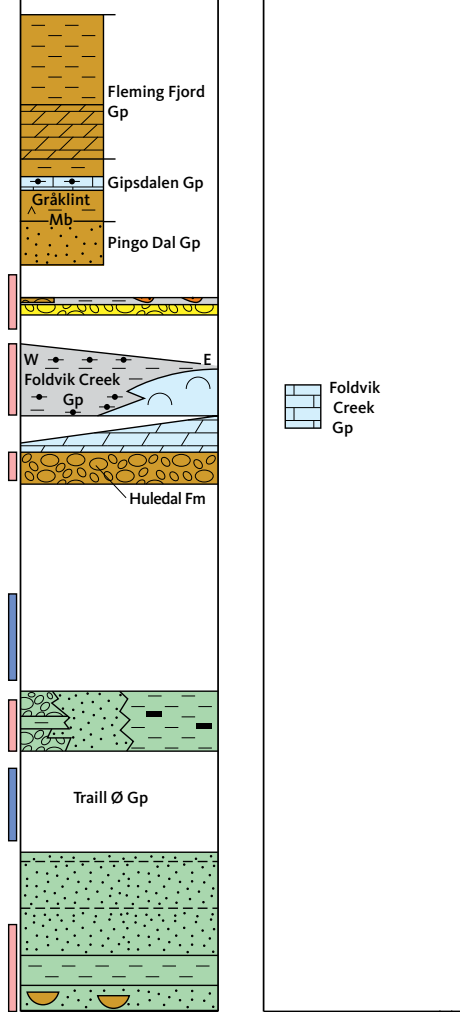

Fig. 4 Caption and legend on the next page. 
Sedimentary environments

\begin{tabular}{|c|c|}
\hline & Arid terrestrial \\
\hline & $\begin{array}{l}\text { Humid terrestrial/ } \\
\text { marginal marine }\end{array}$ \\
\hline & $\begin{array}{l}\text { Shallow marine } \\
\text { sandstone (shelf) }\end{array}$ \\
\hline & $\begin{array}{l}\text { Deep marine sandstone } \\
\text { (beyond shelf break) }\end{array}$ \\
\hline & $\begin{array}{l}\text { Marine carbonate, } \\
\text { including chalk seas }\end{array}$ \\
\hline & Marine mudstone \\
\hline Extrus & ive igneous rocks \\
\hline & Volcanics \\
\hline Litholo & gical symbols \\
\hline $\begin{array}{ll}0 & 0\end{array}$ & Ice-rafted dropstone \\
\hline 0 & Conglomerate \\
\hline$\therefore$ & Sandstone \\
\hline & Siltstone \\
\hline & Mudstone/shale \\
\hline & $\begin{array}{l}\text { Organic rich } \\
\text { mudstone/shale }\end{array}$ \\
\hline 19 & Limestone \\
\hline 4 & $\begin{array}{l}\text { Dolomite/evaporites/ } \\
\text { limestone }\end{array}$ \\
\hline - & Coal layers \\
\hline$\wedge \wedge \wedge$ & Anhydrite/gypsum \\
\hline Other & symbols \\
\hline$\frown$ & Bioherm \\
\hline c & Base-of-slope fans \\
\hline$\nabla$ & Channel fills \\
\hline Z & $\begin{array}{l}\text { Prograding shelf-margin } \\
\text { sediment wedge }\end{array}$ \\
\hline
\end{tabular}

Intrusive magmatism

Mainly mafic

Tectonic and orogenic events

Rifting/extension

Inversion/compression/ uplift
Fig. 4 (continued) Lithostratigraphic scheme for North-East Greenland. The columns for the Jameson Land Basin, Traill $\varnothing$ - Hold with Hope, Wollaston Forland - Kuhn $\varnothing$ are based on Surlyk (1990) and on later compilations (Gautier et al. 2011; Hopper et al. 2014; Stoker et al. 2017; Bjerager et al. 2020; Clemmensen et al. 2020; Surlyk et al. 2021). Intrusive magmatism after Hopper et al. (2014) and Larsen et al. (2014). Tectonic and orogenic events after Hopper et al. (2014). Base of Pingo Dal Group placed at $245 \mathrm{Ma}$ (Seidler et al. 2004; Oftedal et al. 2005); Gråklint Beds at 232 Ma, mid-Carnian (Andrews et al. 2014). Timescale after Gradstein et al. (2012). Penns: Pennsylvanian.

Creek Group above a pronounced unconformity, for example in northern Jameson Land (Clemmensen et al. 2020). The deposition of the Pingo Dal Group was the result of a major phase of basin-margin uplift and rapid fault-controlled basin subsidence in Early Triassic time (late Scythian) leading to the formation of a northsouth-trending intermontane graben, about $300 \mathrm{~km}$ long and $75 \mathrm{~km}$ wide (Clemmensen 1980; Surlyk 1990).

The transgressive development during the deposition of the Rhaetian - lower Bajocian pre-rift succession was terminated by erosion that took place broadly at the Early-Middle Jurassic boundary (Surlyk 2003; Surlyk et al. 2021). The uplift event that affected the area north of Jameson Land at this time is reflected in a short, mid-Bajocian hiatus between the Sortehat and Pelion formations. On Kuhn $\varnothing$, the marine Pelion Formation rests on peneplained basement (Surlyk 2003). The subsequent onset of a long-term rifting episode began in the Middle Jurassic, peaked in the Late Jurassic and persisted into the earliest Cretaceous (Surlyk 2003).

The southern part of the basin complex in Jameson Land contains a relatively complete Rhaetian-Ryazanian succession deposited during uniform subsidence, only affected by minor tilting during Middle Jurassic - earliest Cretaceous rifting. In contrast, Rhaetian - Lower Jurassic deposits are absent on Milne Land and north of Jameson Land, and the northern region was fragmented into strongly tilted fault blocks during the protracted rift event. On Milne Land and in areas north of Jameson Land, Middle and Upper Jurassic sandstones (e.g. the Charcot Bugt and Pelion formations) onlap Triassic and upper Permian sediments and crystalline basement. Surlyk $(1977,1978 a, 2003)$ speculated whether the Rhaetian - lower Bajocian succession may have been removed by erosion during late Early Jurassic domal uplift of northern East Greenland followed by subsidence and Middle Jurassic onlap.

The main sources for the Jurassic sedimentary basin complex in North-East Greenland were Precambrian and Caledonian metamorphic and intrusive rocks and thick Proterozoic sedimentary successions (Surlyk 2003). Source terranes of minor importance were Devonian conglomerates, sandstones and mudstones as well 
as Carboniferous sandstones and mudstones. Triassic conglomerates, sandstones and mudstones constituted an additional source in the Early Jurassic due to uplift of the areas north of Jameson Land.

The most important phase of extensional tectonics since the Carboniferous - early Permian, culminated in middle Volgian times (Tithonian-Berriasian transition around $145 \mathrm{Ma}$; Surlyk \& Ineson 2003), at the Jurassic-Cretaceous boundary (Surlyk 1978b, 2003; Surlyk \& Korstgård 2013). The area north of Kong Oscar Fjord broke up into tilted blocks, which became progressively fragmented and narrower with time, and deposition was almost exclusively coarse grained. The Jameson Land area, south of Kong Oscar Fjord, underwent only mild tilting but enormous quantities of coarse sands were shed into the basin in the tectonically active period from middle Volgian to late Ryazanian time (corresponding to late Tithonian - late Berriasian). The tectonic phase faded out in the latest Valanginian.

Post-Valanginian, Cretaceous sediments crop out from Traill $\varnothing$ in the south to Store Koldewey in the north. They comprise a mudstone-dominated succession up to several kilometres thick with significant coarse-grained units intercalated (Nøhr-Hansen 1993; Stemmerik et al. 1993; Bjerager et al. 2020). Post-Valanginian sedimentation was controlled by transgression and thermal contraction, and the main sedimentation pattern reflects the formation of a broad thermal sag above the Volgian-Valanginian fault blocks (Surlyk 1990). Prominent coarse-grained units, for example the Rold Bjerge and Månedal formations, were suggested to represent significant Cretaceous, possibly rift-associated, fault pulses superimposed on the long-term regional subsidence (Surlyk \& Noe-Nygaard 2001). Recently, the Cretaceous succession has been reviewed biostratigraphically (Nøhr-Hansen et al. 2019) and subdivided into three main tectonostratigraphic units represented by the upper Hauterivian - middle Albian Brorson Halvø Group, the middle Albian - Coniacian Home Forland Group and the Turonian - Lower Maastrichtian Jackson $\varnothing$ Group (Bjerager et al. 2020). The Brorson Halvø Group is dominated by slope and basinal, mud-dominated deposits, filling the sea-floor relief inherited from the Late Jurassic - Early Cretaceous rift phase (Bjerager et al. 2020). The Steensby Bjerg Formation occurs locally on Hold with Hope and comprises a deltaic - shallow marine sand-dominated system that developed in an evolving relay ramp setting during the Barremian - early Albian (Kelly et al. 1998; Larsen et al. 2001). The fault-related mega-breccia of the re-dated Aptian Rold Bjerge Formation (Surlyk \& Noe-Nygaard 2001) occurs locally on Traill $\varnothing$. A pronounced mid-Albian (c. $105 \mathrm{Ma}$ ) unconformity marks the base of the overlying Home Forland Group and is linked to localised fault re-activation and a drowning event. The group is dominated regionally by marine deep-water mud-dominated deposits of the middle Albian - Coniacian Fosdalen Formation, but locally fault associated conglomerates occur at the base on Clavering $\varnothing$ (Bjerager et al. 2020). The base of the Jackson $\varnothing$ Group rests on a prominent Turonian erosional unconformity and the group represents a new phase of fault activity. On Traill $\varnothing$, the basal strata comprise submarine slope breccias and conglomerates of the Månedal Formation (Surlyk \& Noe-Nygaard 2001). In eastern Hold with Hope, the basal part is marked by the Coniacian condensed Nanok Member (Stemmerik et al. 1993, Kelly et al. 1998). Turbidite sandstones and basinal mudstones succeed these units. The lower Campanian Leitch Bjerg Formation of channelised slope-apron conglomerates occurs locally on eastern Geographical Society $\varnothing$ (Bjerager et al. 2020). Campanian-Maastrichtian strata are also present in the Kangerlussuaq area to the south (Soper \& Costa 1976; Larsen et al. 2001).

\subsection{Cenozoic cover and unconformities}

The final North-East Atlantic rift episode was initiated near the Campanian-Maastrichtian boundary and lasted until continental separation at the Paleocene-Eocene transition, c. $56 \mathrm{Ma}$ (Skogseid et al. 2000). More than $6 \mathrm{~km}$ of flood basalts (the Main Basalts) were extruded during rapid subsidence in the area along Blosseville Kyst, south of Scoresby Sund (Larsen et al. 1989; Pedersen et al. 1997; Larsen \& Tegner 2006; Brooks 2011).

The first volcanics were partly erupted in a marine environment in Paleocene time. Furthermore, there are marine sediments within the youngest flood basalts, the lower Eocene Igtertivâ Formation, and within the lower Eocene to lower Oligocene Kap Dalton Group (Soper \& Costa 1976; Nielsen et al. 1981; Larsen et al. 1989, 2002, 2013). The presence of marine deposits above and below the Main Basalts, which were extruded on a largely horizontal plain, implies that the landscape was low-lying during the volcanic eruptions. Consequently, subsidence approximately kept pace with the outpouring lavas, so that the land surface at the end of the eruptions remained close to sea level (Pedersen et al. 1997; Brooks 1985, 2011; see review by Bonow et al. 2014). A phase of middle Miocene volcanism is documented by the presence of the lava flows of the Vindtop Formation (c. 14-13 Ma; Storey et al. 2004) that crop out on nunataks within a small area at $2.7-2.9 \mathrm{~km}$ a.s.I. (c. $69^{\circ} \mathrm{N}$ ).

Remnants of the Main Basalts are also present in Gåseland and in Milne Land. Further north, lavas erupted at the Paleocene-Eocene transition and in the early Eocene between 73 and $75^{\circ} \mathrm{N}$ (Geographical Society $\emptyset$ to Shannon; Fig. 5; Larsen et al. 2014). Outliers of Palaeogene basalts are located on nunataks far from the coast $\left(74^{\circ} \mathrm{N}, 28^{\circ} \mathrm{W}\right.$; Fig. 3). 


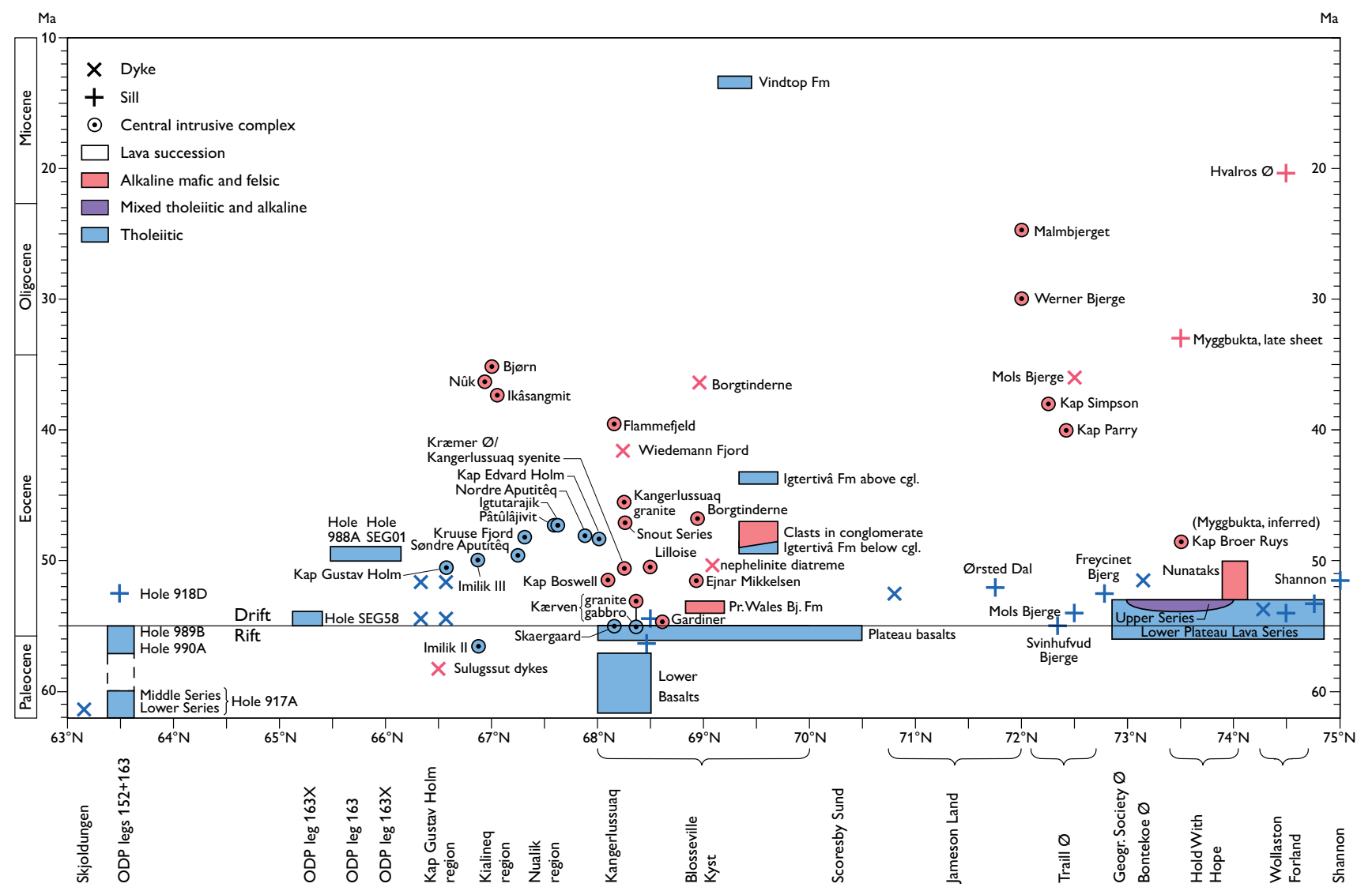

Fig. 5 Radiometric ages of Cenozoic igneous rocks along the East Greenland margin (Larsen et al. 2014). ODP: Ocean Drilling Program. Transition from rift to drift is indicated at $55 \mathrm{Ma}$. Bj: Bjerg. cgl: conglomerate. Pr: Prinsen.

Larsen et al. (1989) studied zeolites, the late-stage minerals that fill cavities in basalts, in the Scoresby Sund region, to infer amounts of removed basalts since their extrusion. Zeolite isograds, which are contours that represent the first occurrence of a zeolite mineral, delineate regionally extensive mineral zones throughout the Main Basalts between Scoresby Sund and Kangerlussuaq. These zones are essentially uniform in thickness and transgress lava stratigraphy (Larsen et al. 1989; Neuhoff et al. 1997). Analysis of the isograds suggests that $400 \mathrm{~m}$ of the basalts were removed by erosion in the area just south of Scoresby Sund, whereas the erosion increases to 700 and $900 \mathrm{~m}$ towards the north, across Gåseland and Milne Land in agreement with the gradual truncation of the basalt units in that direction (Bonow et al. 2014). The zeolitisation thus had a regional character and took place before the tilting and erosion of the lava sequence (Larsen et al. 1989).

Major offsets post-dating Palaeogene basalts and intrusions occur along the PDMF and adjacent faults systems, for example more than $500 \mathrm{~m}$ on western Hold with Hope (Bütler 1955; Upton et al. 1980; Hartz et al. 2006; Surlyk \& Noe-Nygaard 2001).

Scattered occurrences of Palaeogene sediments are found in North-East Greenland, where they unconformably overlie Cretaceous sediments and are capped by Palaeogene basalts. Nøhr-Hansen et al. (2011) showed that the marine, Palaeogene sediments (now up to 700 m a.s.l.) on Wollaston Forland, Hold with Hope and Sabine $\varnothing$, comprise Paleocene and lowermost Eocene strata with a hiatus that probably spans the major part of the Selandian and Thanetian. Nøhr-Hansen et al. (2011) found indications of uplift and erosion at the Maastrichtian-Paleocene transition because the Palaeogene sediments contained large amounts of reworked late Maastrichtian marine palynomorphs. Furthermore, they noted that the ages of the youngest Palaeogene sediments and the oldest flood basalts are almost identical.

Stratigraphically extensive, ice-rafted debris, including macroscopic dropstones, occur in late Eocene to early Oligocene sediments from the Norwegian-Greenland Sea, indicating sediment rafting by continental ice, rather than sea ice, and East Greenland as the likely source (Eldrett et al. 2007). However, continental ice on East Greenland was probably restricted to alpine outlet glaciers across the Eocene-Oligocene transition (Eldrett et al. 2009). Material from offshore drill cores suggests that full glacial conditions were established in South-East 
A

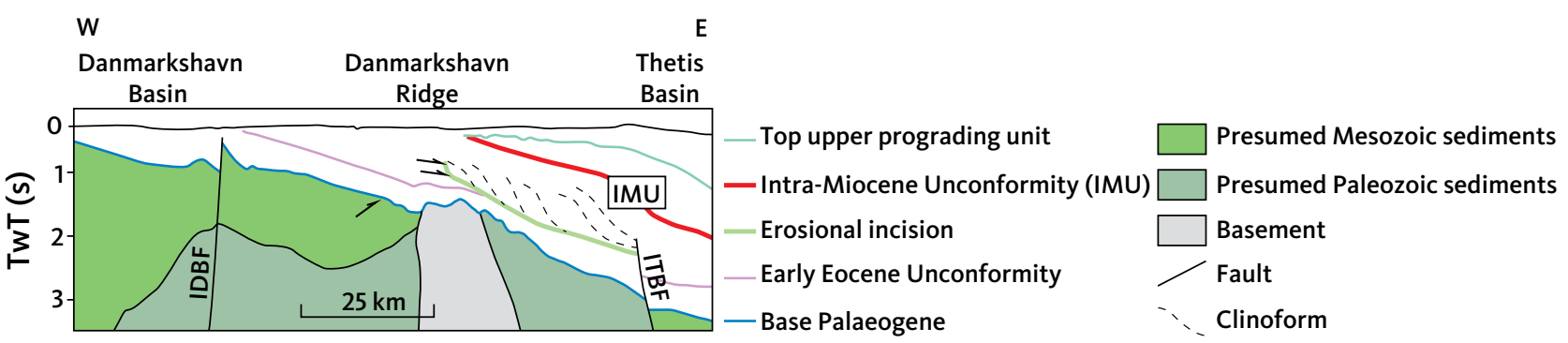

B

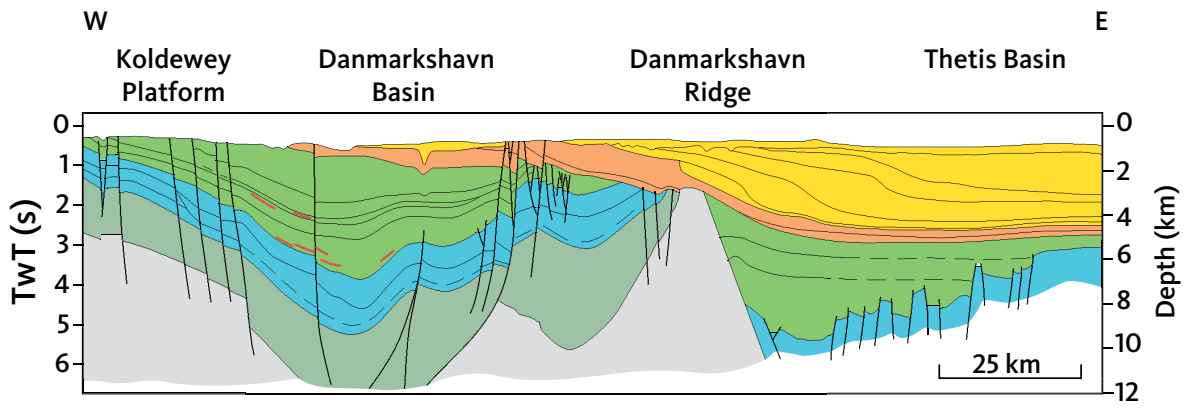

C

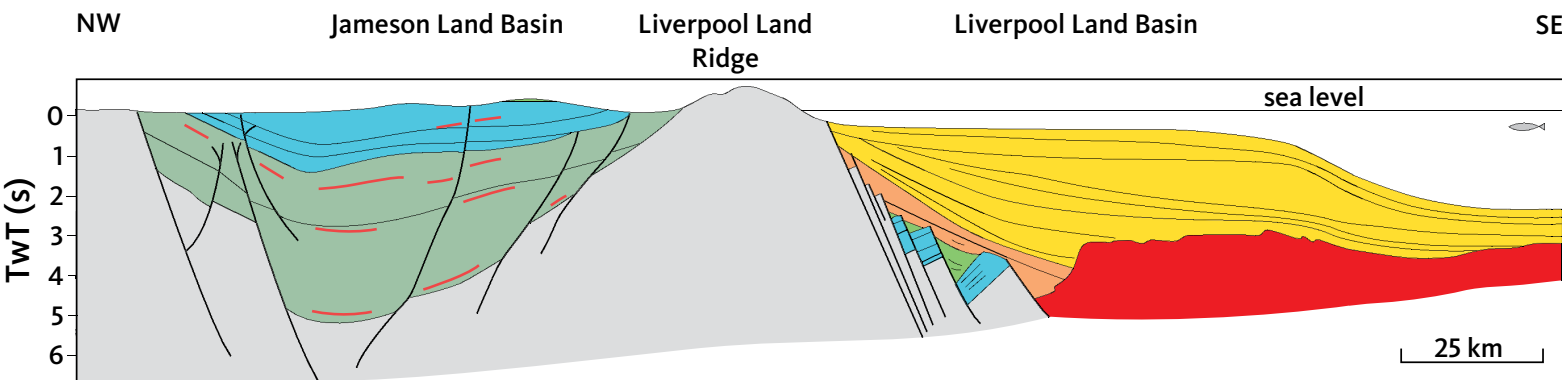

D

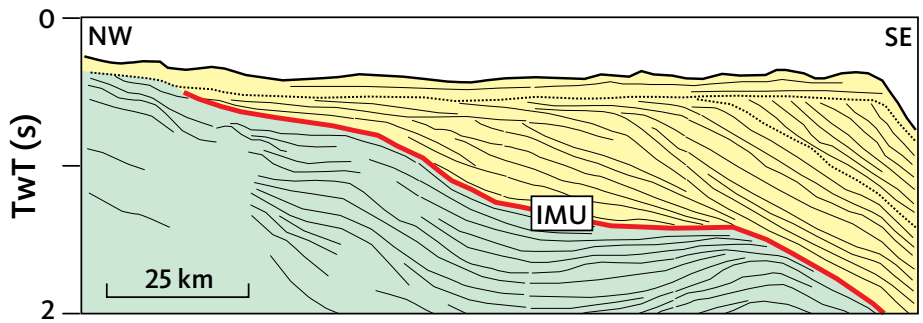

E

$\begin{array}{ll}\square \text { Neogene } & \square \text { Upper Permian - Jurassic } \\ \square \text { Palaeogene } & \square \text { Basement } \\ \square \text { Cretaceous } & \square \text { Volcanian - Middle Permian }\end{array}$
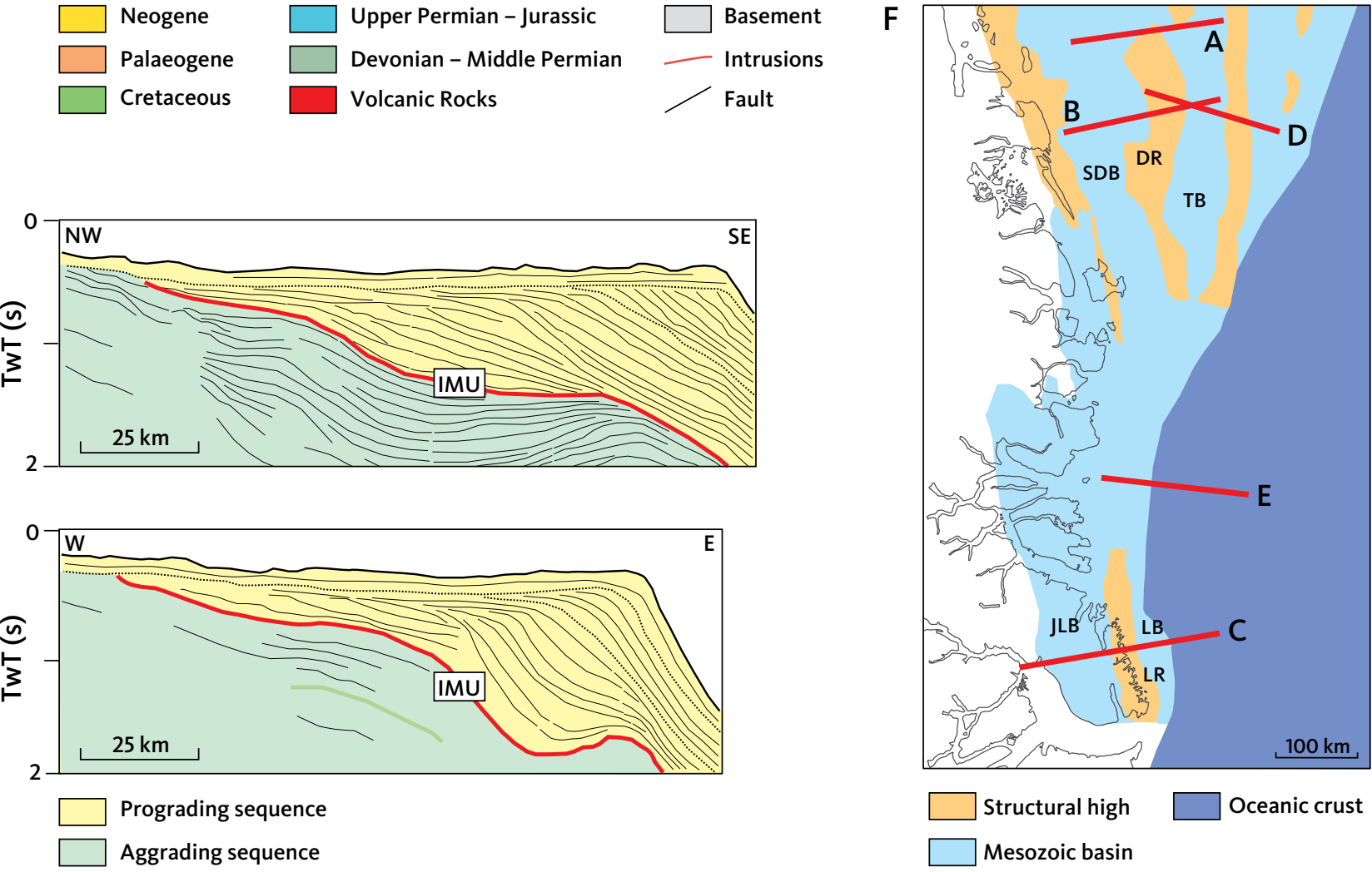

Fig. 6 Interpreted seismic profiles from the margin of North-East Greenland. A: Profile across the North-East Greenland shelf (redrawn after Petersen 2019). Prograding wedges are visible above the early Eocene unconformity and above the Intra-Miocene Figure 6 continued on next page 
Unconformity (IMU; middle to late Miocene, 15-10 Ma; Døssing et al. 2016). The Cenozoic succession is tilted across the Danmarkshavn Basin and Danmarkshavn Ridge and offset by faults. B: Profile across the North-East Greenland shelf (Hamann et al. 2005; Hopper et al. 2014). C: Profile across Jameson Land and the Liverpool Land Basin (Larsen 1990; Stoker et al. 2017). D, E: Profiles across the North-East Greenland shelf illustrating the IMU within the Cenozoic succession. DR: Danmarkshavn Ridge. IDBF: Intra-Danmarkshavn Basin Fault. ITBF: Intra-Thetis Basin Fault. JLB: Jameson Land Basin. LB: Liverpool Land Basin. LR: Liverpool Land Ridge. SDB: Southern Danmarkshavn Basin. TB: Thetis Basin. TwT: Two-way time. The locations of panels A-E are shown in panel F.

Greenland at 7 Ma (Larsen et al. 1994b). However, biomolecules extracted from silt at the base of deep ice cores in central southern Greenland indicate that the region was forested within the past million years (Willerslev et al. 2007). Further, Schaefer et al. (2016) showed that Greenland was deglaciated for extended periods during the Pleistocene epoch (from 2.6 Ma to 11700 years ago), based on measurements of cosmic-ray-produced isotopes in a bedrock core from central Greenland. Recently, Christ et al. (2021) concluded that the Greenland ice sheet persisted through much of the Pleistocene but melted and reformed at least once since 1.1 Ma based on investigations of sub-glacial sediments at the base of a thick ice core. The Greenland ice sheet, which today has a thickness of up to $3 \mathrm{~km}$, thus appears to have had a discontinuous history.

\subsection{Palaeogene intrusives}

A large number of intrusions and magmatic complexes were emplaced in East Greenland during and after breakup in the North-East Atlantic at the PaleoceneEocene transition (see Fig. 5 for an overview of igneous activity along the coast). Several major intrusive complexes are present within the study area; from south to north they include (Nielsen 2002; Larsen et al. 2014):

- Werner Bjerge Complex and Malmbjerget in the northern part of Jameson Land of Oligocene age, c. $30 \mathrm{Ma}$ and $25 \mathrm{Ma}$, respectively.

- Kap Simpson and Kap Parry in the eastern part of Traill $\varnothing$ of middle Eocene age, c. 39 Ma.

- Kap Broer Ruys on the south-eastern edge of Hold with Hope of middle Eocene age, c. $47 \mathrm{Ma}$.

- Myggbukta on the south-western edge of Hold with Hope with an inferred middle Eocene age (c. $47 \mathrm{Ma}$ ) based on the nearby intrusive complex at Kap Broer Ruys. A late sheet is dated to be of early Oligocene age, c. $33 \mathrm{Ma}$.

Many areas are dominated by dykes and sills, including:

- Jameson Land. Dykes of early Eocene age (c. $52 \mathrm{Ma}$ ).

- Mols Bjerge on Traill Ø. Sills of early Eocene age (c. 54 $\mathrm{Ma}$ ) and dykes of late Eocene age (c. $36 \mathrm{Ma}$ ).
- Hvalros $\varnothing$, north-east of Wollaston Forland. Dyke dated to early Miocene (c. $20 \mathrm{Ma}$ ).

\subsection{Sediments and unconformities off- shore North-East Greenland}

The North-East Greenland margin is narrow off Liverpool Land (about $80 \mathrm{~km}$ wide) but broadens considerably to the north where it is over $300 \mathrm{~km}$ wide east of Store Koldewey (Fig. 6). There is a dense array of seismic reflection data over the margin but only limited seismic refraction data. In addition, there is very little sampling or drilling of the offshore sediments. Most of what is known about the pre-basalt strata in the offshore area is thus based on seismic interpretation with reference to onshore geology and comparison to the conjugate Norwegian margins. Hamann et al. (2005) and Tsikalas et al. (2005) provided overviews of the margin based on seismic data collected in the early 1990s, and Fyhn et al. (2012) provided an update based on all data available at that time.

The narrowest part of the margin is heavily affected by Palaeogene volcanism. Deeper basins and structures are thus obscured and cannot be defined. To the north as the margin widens, the influence of volcanism decreases and the less volcanic region is broadly divided into the Danmarkshavn and Thetis basins, separated by a structural high, the Danmarkshavn Ridge. Both basins can be subdivided into smaller basins and the ridge is a complex structure that becomes less pronounced to the north (Hopper et al. 2014). The more landward Danmarkshavn Basin is located between the Koldewey Platform and the Danmarkshavn Ridge. Both the Danmarkshavn and Thetis basins are marked by sill intrusions, but evidence for significant extrusive volcanism is only found seaward near the continent-ocean transition zone, south of the Danmarkshavn and Thetis basins (south of $76^{\circ} \mathrm{N}$, Hamann et al. 2005).

The margin has experienced a number of rift episodes with intervening periods of thermal subsidence from the late Palaeozoic up to final continental break-up and seafloor spreading by the Eocene. The northern Danmarkshavn Basin, and parts of the Thetis basin, include thick salt units that were mobilised and became diapiric in many parts of the basin. Based on the age of evaporites onshore and comparison to the south-west Barents Sea, 
the salt is presumed to be late Carboniferous - Permian in age. Significant reflectivity is observed below the base salt, indicating that the Devonian-Carboniferous basins in the onshore areas are well expressed offshore as well. Above the interpreted salt horizons, thick successions of Mesozoic and Cenozoic sediments are observed. The profiles in Figs 6A, B do not however, cross the salt structures.

Deposits of inferred latest Jurassic - Early Cretaceous age are present over wide areas, and the basal boundary of this unit is marked by one of the highest amplitudes and regionally most extensive horizons on the North-East Greenland Shelf (Hamann et al. 2005). It shows a characteristic low-angle, erosional truncation of the underlying high-amplitude reflectors. Hamann et al. (2005) correlated this unconformity to the mid-Volgian unconformity (c. $145 \mathrm{Ma}$ ) at the base of the Wollaston Forland Group onshore and interpreted it to mark the onset of rifting in the latest Jurassic. Deposition in the Danmarkshavn Basin, off Store Koldewey, was controlled by a few major faults similar to those at the margins of the Jameson Land Basin (Fig. 6C), in contrast to the large number of smaller scale faults described in the northern part of onshore East Greenland.

Thermal subsidence led to continued deposition of thick Cretaceous successions prior to a second major rift episode that culminated with the final break-up and the onset of sea-floor spreading at the Paleocene-Eocene transition. Although Cenozoic deposition continued postbreakup, much of this has been removed, most recently by glacial erosion of the shelf. The nearshore parts of the margin in many places have only a thin Quaternary cover with Mesozoic sediments sub-cropping near the sea floor.

Two important phases of progradation away from North-East Greenland occurred after break-up. The youngest of these prograding wedges are up $200 \mathrm{~km}$ wide and are bounded below by a distinct angular unconformity, the Intra-Miocene Unconformity (IMU; Figs 6D, E; Hamann et al. 2005; Berger \& Jokat 2008; Døssing et al. 2016; Petersen 2019). Berger \& Jokat (2008) dated the IMU at c. $14 \mathrm{Ma}$ based on correlation between seismic lines and results from Ocean Drilling Program (ODP) site 913 and suggested that the onset of progradation may have been caused by rapid changes in sea level and/or glacial erosion by an early ice sheet or coastal glaciers. However, Døssing et al. (2016) suggested that the age of the IMU was middle to late Miocene (15-10 Ma). Defining an age for the IMU is difficult due to poor recovery of material around the IMU at ODP site 913 (Myhre et al. 1995). The definition was later improved by including reanalyses of data from all seven sites of this leg of the ODP (Hull et al. 1996).

The IMU is associated with low-amplitude folds and reverse, margin-parallel faults, with throws up to $200 \mathrm{~m}$, suggested to be related to mild compression (Hamann et al. 2005). Margin-parallel, open folds that occur on Traill $\varnothing$ have likewise been interpreted as evidence of post-breakup compression, possibly in late Cenozoic time (Price et al. 1997). Others have observed that the IMU defines a $20 \mathrm{~km}$ wide, domal structure with associated faulting within the continent-ocean transition zone, and that the dome resulted from a mild compressional phase (Døssing et al. 2016). The IMU marks the termination of synrift deposition in the deep-sea basins and the formation of a continuous plate boundary along the Mohns and Knipovich ridges in the North-East Atlantic, which leads to an accelerated widening of the Fram Strait (Døssing et al. 2016). The IMU event is linked to mild compression and to the onset of late Miocene uplift and massive shelf progradation on the North-East Greenland margin. The correlation between margin uplift and plate motion changes demonstrate that the uplift was triggered by plate tectonic forces (Døssing et al. 2016).

Older prograding clinoforms are steep and occur above a horizon defining erosional incision (Petersen 2019). This erosional horizon truncates an early Eocene unconformity, which can be relatively well dated due to its association with volcanism at break-up, but the erosional horizon does not truncate the IMU and cannot be dated directly. As a significant sedimentary succession is present between the erosional horizon and the IMU, Petersen (2019) dated the erosional horizon as late Eocene - mid-Miocene. The steeply prograding clinoforms are caused by extensive mass wasting into the outer part of the shelf (the Thetis Basin) due to uplift of the inner part of the shelf (the Danmarkshavn Basin and Danmarkshavn Ridge). The most likely source areas for this progradational event are the south Danmarkshavn Ridge, the Danmarkshavn Basin and the area onshore North-East Greenland south of Store Koldewey (Petersen 2019). Petersen also found that the steepness of the incision, in combination with the chaotic nature of the material transported into the Thetis Basin resulting from the mass-wasting event, indicated a rapid and significant tectonic movement. 
www.geusbulletin.org

\section{Stratigraphic landscape analysis}

Large-scale landscapes, such as mountains, plains and valley systems, are the visible expressions of the longterm effects of major erosional and tectonic events (Brunsden 1993; Ahnert 1998). The analysis of largescale landscapes thus affords insights into the tectonic development of a region over long time spans (Lidmar-Bergström 1996; Bonow et al. 2006a, b, 2014; Green et al. 2013; Lidmar-Bergström et al. 2013). Evidence of uplift and subsidence may be obtained from stratigraphic landscape analysis, which is based on observation of cross-cutting relationships between peneplains and stratigraphic constraints from the sedimentary cover that preserved them (Lidmar-Bergström et al. 2013). Here we adopt the definition that all surfaces graded to a base level are peneplains, irrespective of whether their detailed form is hilly or flat (Green et al. 2013; Lidmar-Bergström et al. 2017). The formation of a peneplain involves kilometre-scale erosion of rock during valley incision and valley widening by running water and slope processes, whereas the final shape of the peneplain depends on the climatic conditions during its formation. In this way, stratigraphic landscape analysis allows construction of a relative chronology of denudation episodes leading to surface formation and to identification of the corresponding tectonic events.

Bonow et al. (2014) mapped regional erosion surfaces in southern East Greenland $\left(68-71^{\circ} \mathrm{N}\right)$ and Bonow \& Japsen (2021, this volume) extended this mapping to North-East Greenland, south of $78^{\circ} \mathrm{N}$. In this chapter, we summarise the results of these studies.

\subsection{Pre- and post-basalt peneplains}

Elevated plateaus with deeply incised valleys characterise the large-scale landscape of North-East Greenland. Bonow et al. (2014) identified three peneplains in southern East Greenland a pre-basaltic, etch - or weathered - basement surface (ES; Etch Surface) and the post-basalt Upper and the Lower Planation Surfaces (UPS and LPS, respectively). Bonow \& Japsen (2021, this volume) continued the work of Bonow et al. (2014) by presenting coherent maps and analyses of the large-scale landscape of North-East Greenland (north of Scoresby Sund, $\left.70-78^{\circ} \mathrm{N}\right)$, where these surfaces are important markers for the tectonic development of the margin.

The ES extends across crystalline basement along Scoresby Sund (Larsen et al. 1989). The surface is characterised by distinct hills, a few hundred metres high, and limited by narrow valleys along old fracture systems. On Milne Land, the surface is preserved below Middle Jurassic sediments and at different locations around
Scoresby Sund, below the more widespread Palaeogene basalts (Birkelund \& Perch-Nielsen 1976; Larsen et al. 1989). This surface occurs at various elevations, from sea level up to $1800 \mathrm{~m}$ a.s.l. The sub-Jurassic ES is tilted along the east coast of Milne Land and cut off by the near-horizontal UPS.

The UPS defines the high plateaus, where it cuts across Palaeogene basalts and older rocks (Fig. 7). The UPS north of Scoresby Sund is a major surface at c. $2 \mathrm{~km}$ a.s.l. away from the coast, where it extends across an area up to $200 \mathrm{~km}$ wide. It is dominated by basement terrains but also includes basement covered by Palaeogene basalts (Bonow \& Japsen 2021, this volume). In the northern interior, the UPS also cuts across the Palaeogene basalts near the Greenland ice sheet at about 2.2 $\mathrm{km}$ a.s.l. (Arnold Escher Land; $74^{\circ} \mathrm{N}, 28^{\circ} \mathrm{W}$ ).

In the northernmost part of the study area the UPS is at slightly lower elevation, at around $1.5 \mathrm{~km}$, but reaches elevations $>3 \mathrm{~km}$ south of Scoresby Sund (Bonow et al. 2014). The UPS is often covered by ice due to its high elevation, and in large areas north of $74^{\circ} \mathrm{N}$ the UPS disappears below the Greenland ice sheet. Where the ice sheet becomes coherent, the UPS is only visible as flattish remnants at the ice margin. The extensive ice covers that reach the coast prevent a clear correlation between the well-developed UPS in the south and the remnants in the north. Landscapes across the sedimentary basins along the coast are characterised by many ridges. Here, the UPS is interpreted to correspond to minor flattish summits at c. $2 \mathrm{~km}$ a.s.l., for example on western Traill $\varnothing$. At Stauning Alper, summits reach an elevation of $2.8 \mathrm{~km}$ a.s.l., the highest elevation within the study area. Here, the contours of the UPS define a domal pattern that can be traced up to $2.3 \mathrm{~km}$ a.s.l. and indicates a localised, tectonic movement after the formation of the UPS.

In parts of the Blosseville Kyst region, south of Scoresby Sund, there is little angular discordance between the UPS and underlying basalt flows, but the discordance is pronounced in the inner parts of Scoresby Sund (Larsen et al. 1989; Pedersen et al. 1997). Study of zeolite zones in the basalts by Larsen et al. (1989) led to the conclusion that regional erosion removed the uppermost basalt units after tilting of the lava succession, and that 700 to $900 \mathrm{~m}$ of lavas had been removed by erosion across Gåseland and Milne Land (Fig. 9).

The LPS is incised below the UPS and is thus younger (Fig. 8). The LPS is readily identified north of Scoresby Sund, particularly around Milne Land, where it forms valley benches at approximately $1 \mathrm{~km}$ a.s.l. below the UPS (Figs 8, 9). Towards the coast, the valley benches merge 

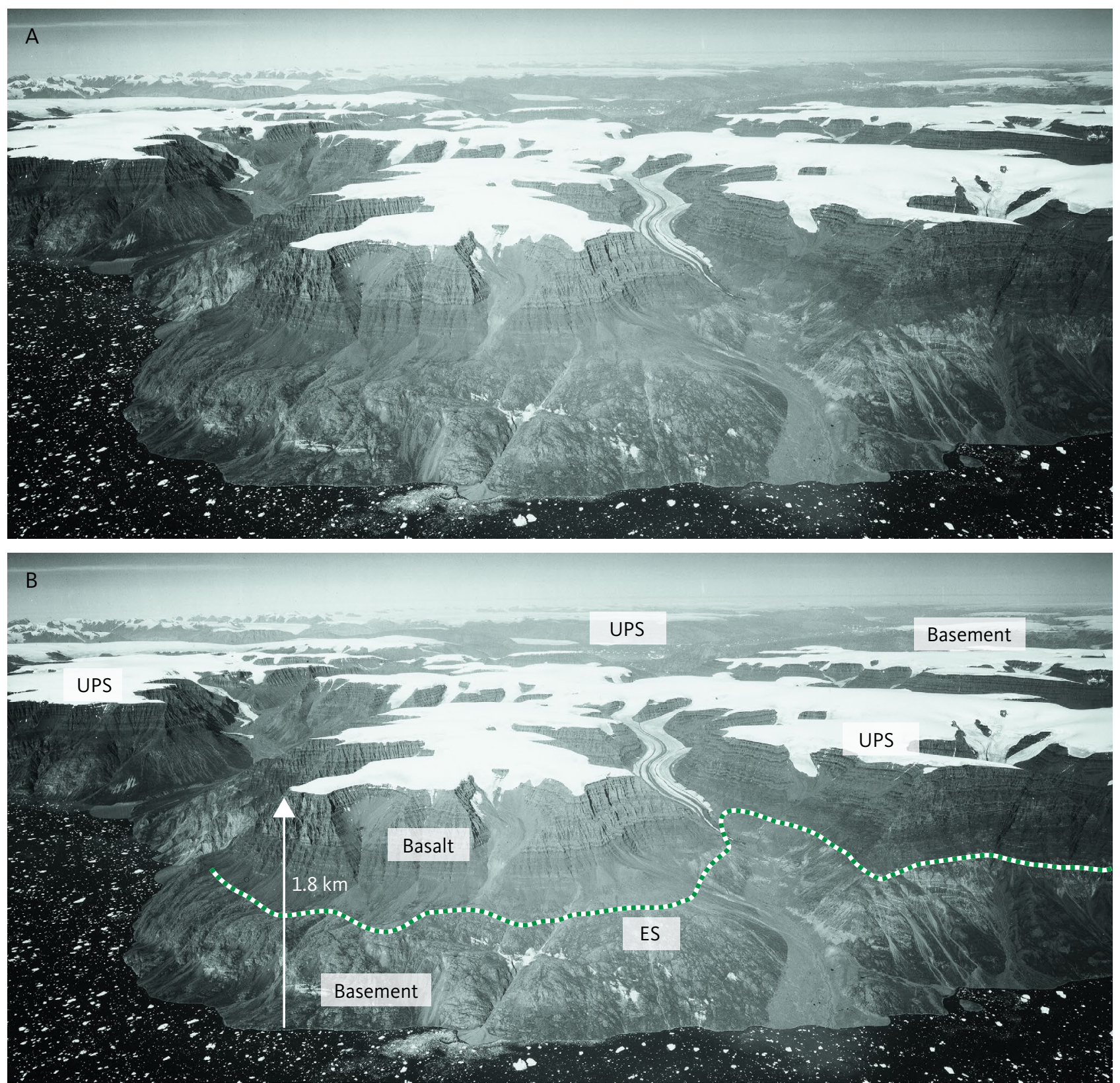

SE

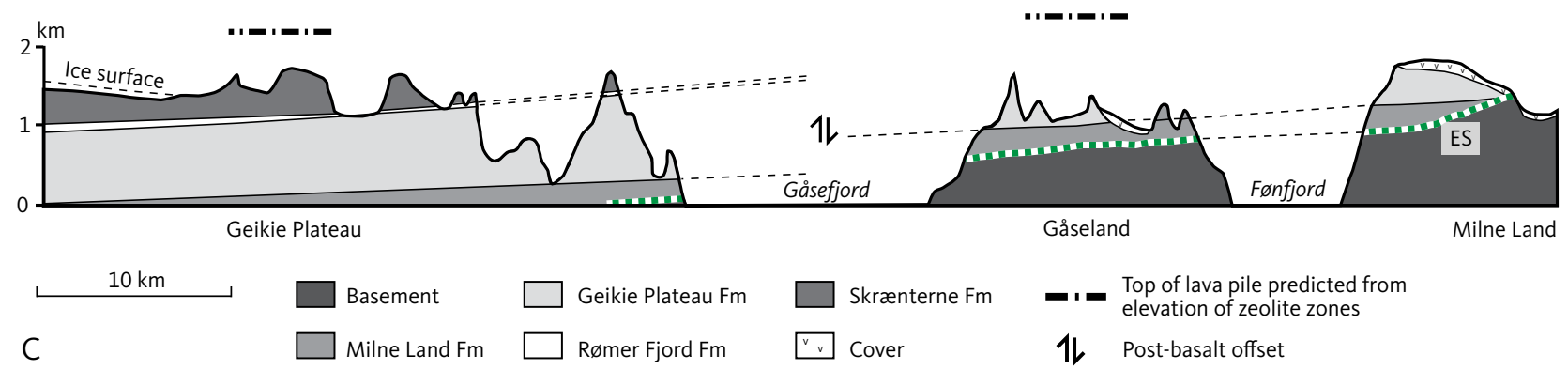

Fig. 7 The Upper Planation Surface (UPS) is well developed across the Palaeogene basalts on Gåseland and across basement rocks on Milne Land (background of the photo). A: View towards north-west across the inner part of Gåsefjord. B: The same view with annotations. The basalts cover an undulating, deeply weathered basement surface; the Etch Surface (ES). The elevation of UPS towards the coast is c. $1.8 \mathrm{~km}$ a.s.I. C: Profile showing the inclined and truncated strata of the Main Basalts and the original top of the lava pile estimated from the elevation of zeolite zones across Milne Land, Gåseland and Geikie Plateau (Larsen et al. 1989). The present-day lava surface is consequently an erosional feature and the tilt and offset of the basalt formations are post-basalt features. The UPS on Gåseland marked in B is thus about $700 \mathrm{~m}$ below the original top of the volcanic pile. Note the tilt of four formations of the Main Basalts: Geikie Plateau Fm, Skrænterne Fm, Milne Land Fm and Rømer Fjord Fm. The profile in C crosses Gåseland a few kilometres west of where the photo was taken. Location of photo and profile in Fig. 9. Reproduced from Bonow \& Japsen (2021, this volume); based on Larsen et al. (1989) and Bonow et al. (2014). 

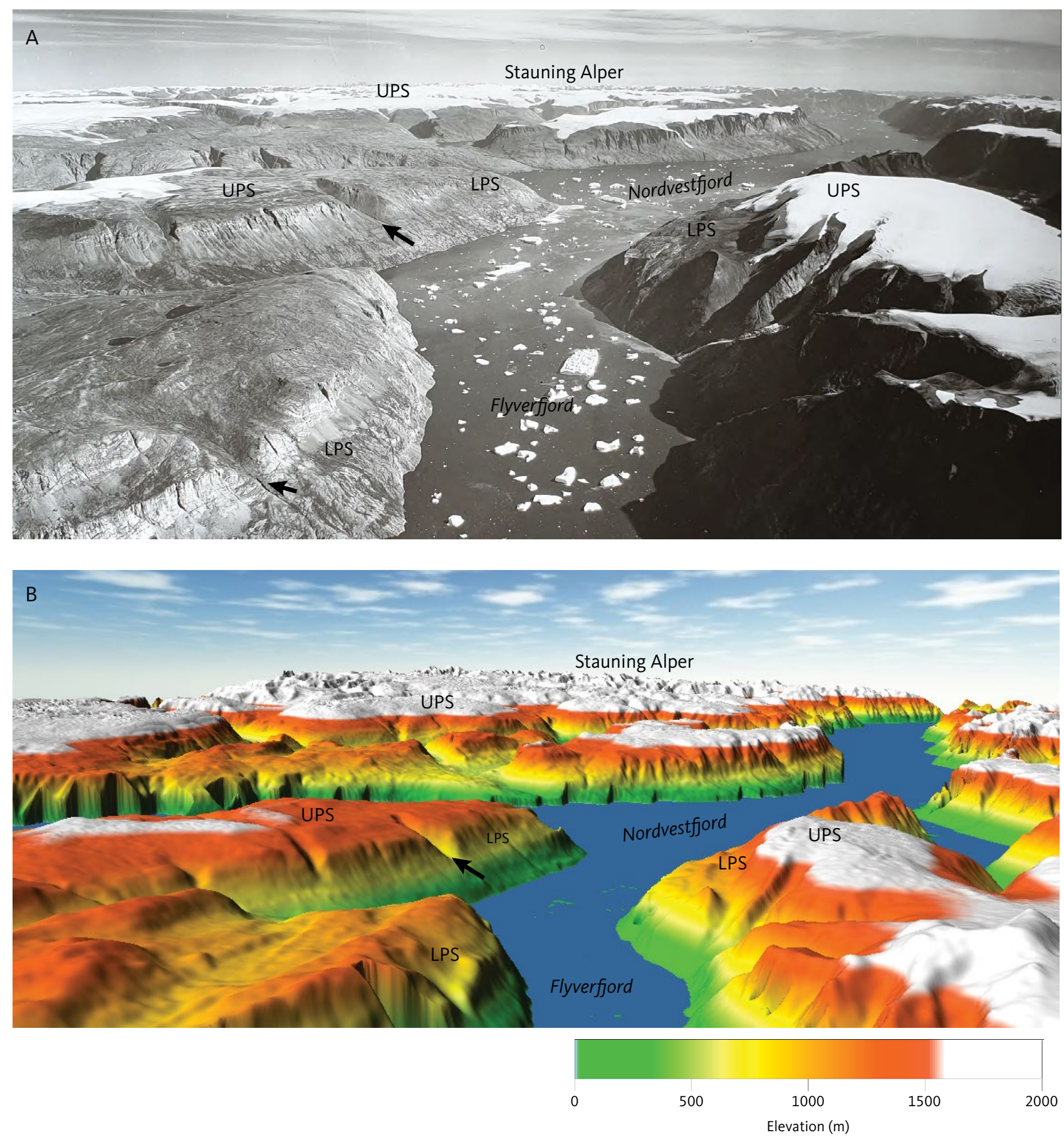

Fig. 8 Relationship between the Upper and Lower Planation Surfaces along Nordvestfjord (UPS and LPS, respectively). A: LPS along Flyverfjord and Nordvestfjord; view towards north-east across Th. Sørensen Land towards Nathorst Land and Stauning Alper. B: 3D elevation model in approximately the same position as photo in A. The LPS is developed as valley benches along the main fjords. Note that some minor valleys stop to incise at the LPS (arrows). Map location in Fig. 9. Reproduced from Bonow \& Japsen (2021, this volume).

to form a more coherent surface that extends across an up to $100 \mathrm{~km}$ wide zone. In the areas where sedimentary rocks crop out, the LPS is defined by flat-topped summits, while in the areas with basement rocks, the LPS is more extensive and less dissected. North of $74^{\circ} \mathrm{N}$, the LPS dominates the ice-free areas of the upper-plateau landscape in near-coastal areas. The elevation of the LPS is relatively low in the northernmost parts of the study area, for example $600 \mathrm{~m}$ a.s.I. on Germania Land, but it reaches $2 \mathrm{~km}$ a.s.l. south of Scoresby Sund (Bonow et al. 2014).

The UPS is well developed in basalts south of Scoresby Sund with no evidence of faulting. In contrast, north of Scoresby Sund, where the PDMF is a prominent feature, the UPS is not preserved east of the fault. However, the 


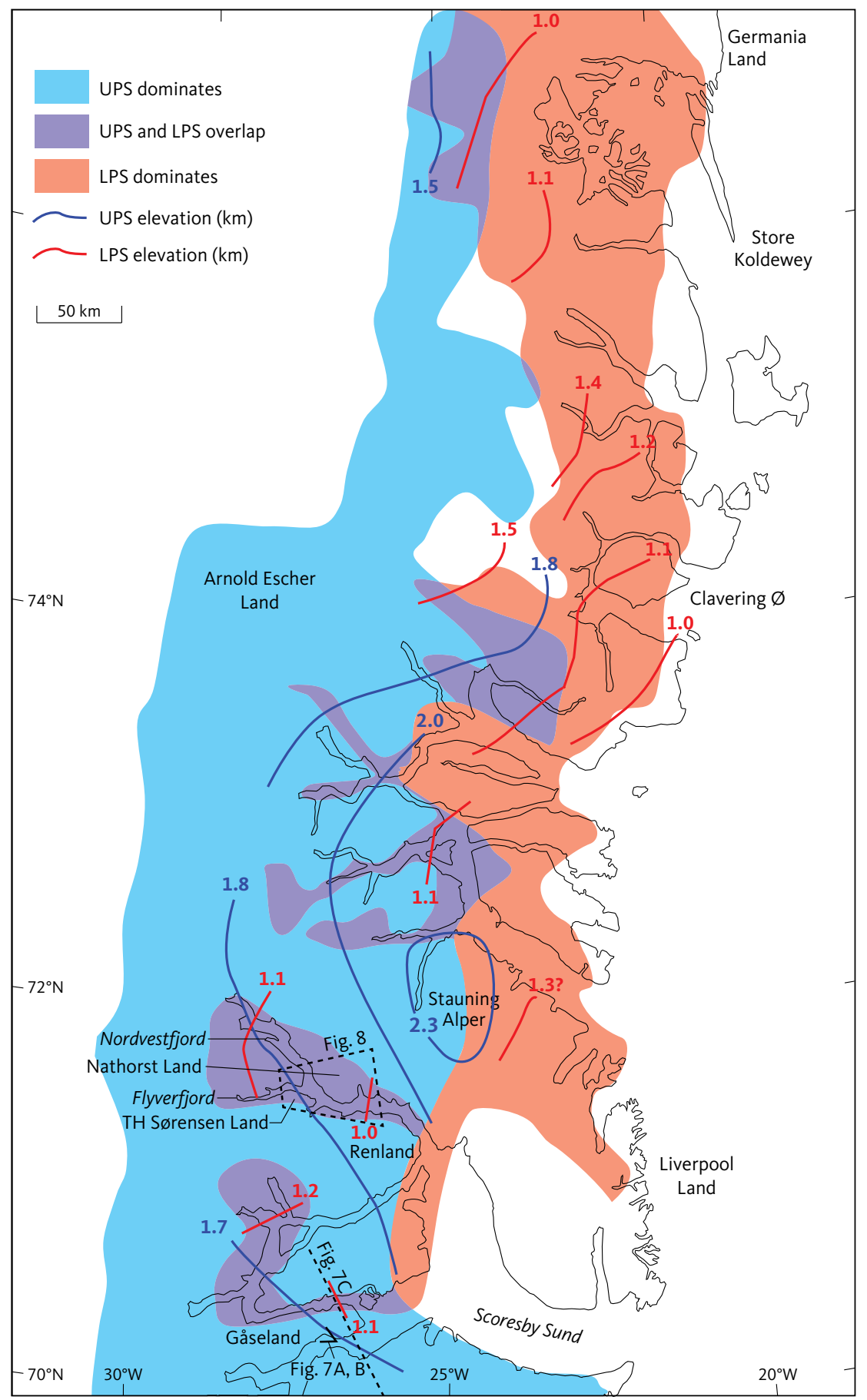

Fig. 9 Extent and elevation of the Upper and Lower Planation Surfaces (UPS and LPS, respectively). The UPS is typically 2 $\mathrm{km}$ a.s.l. south of $74^{\circ} \mathrm{N}$ at some distance from the coast. North of $74^{\circ} \mathrm{N}$, the UPS is only identified as small remnants close to the ice sheet. The LPS, which typically is at $1 \mathrm{~km}$ a.s.l., formed by incision along valleys below the UPS, but the LPS along the valleys coalesces to form a coherent surface towards the coast. Note the domal structure of the UPS centred at Stauning Alper. This pattern suggests a tectonic doming after formation of the UPS. The profile in Fig. $7 C$ extends about $25 \mathrm{~km}$ south of the map. Modified from Bonow \& Japsen (2021, this volume).

LPS is defined on both sides of the fault at about the same elevation. West of the fault, wide valley benches define the LPS, and the surface continues at the same elevation east of the fault, where flat-topped summits define the surface. The step (escarpment) between the UPS and the LPS follow the incision along the major valleys, whereas the pronounced topographical step across PDMF is caused by the differences in lithology. The UPS and LPS dominate the appearance of the landscape and can be identified along the entire margin, despite intense fluvial and glacial erosion after the formation of the LPS (Fig. 9).

\subsection{Relative denudation chronology}

Bonow \& Japsen (2021, this volume) concluded that the UPS is a peneplain that represents a single erosional phase that affected the entire margin of East Greenland between 68 and $78^{\circ} \mathrm{N}$. The UPS formed by erosion into the Palaeogene basalts and the underlying crystalline basement, implying that the peneplain was graded to base level after the extrusion of the Palaeogene basalts. The base level at that time was the level of the adjacent Atlantic Ocean. Consequently, the present elevation of the UPS is the result of uplift that affected the margin after the formation of the UPS. South of Scoresby Sund 
(c. $69^{\circ} \mathrm{N}$ ), the volcanics of the middle Miocene Vindtop Formation accumulated on the UPS, which had therefore formed by middle Miocene times (Storey et al. 2004; Bonow et al. 2014).

A significant change in base level (uplift) terminated the development of the UPS, leading to incision of valleys below the UPS and to development of a new surface grading towards the new base level defined by the adjacent ocean. This led to the formation of the LPS. As the difference in elevation between the UPS and LPS typically is about $1 \mathrm{~km}$, the magnitude of rock uplift in this episode was $1 \mathrm{~km}$.
A final phase of uplift interrupted the development of the LPS, leading to incision of valleys below the LPS and to the formation of the present-day relief. The elevation of the LPS is about $1 \mathrm{~km}$ a.s.l., and this implies that magnitude of rock uplift since the formation of the LPS was $1 \mathrm{~km}$. The timing for this event is uncertain based on landscape evidence alone, but the valley benches associated with the LPS are fluvial in origin. This suggests that the LPS existed prior to the onset of the major late Cenozoic glaciations around 2.5 Ma (Thiede et al. 1998). Glacial action contributed to the destruction of the UPS and LPS. 


\section{Apatite fission-track analysis data}

AFTA is a method for determining thermal histories of rocks at temperatures generally less than $130^{\circ} \mathrm{C}$. The method depends on analysis of radiation damage features, fission tracks, in either accessory apatite crystals separated from igneous rocks or detrital apatite grains from sedimentary rocks (Green et al. 1989, 2013; Green \& Duddy 2012). In this Chapter, we describe the principles of AFTA and present new data from samples from outcrops in North-East Greenland. These data are supplemented by new VR data from Mesozoic sediments. We derive thermal-history solutions in terms of discrete episodes of cooling for each of the samples and produce a regional synthesis of ten regional episodes of cooling ranging from the Carboniferous to the Pliocene (Appendix 1). We discuss the mechanisms of cooling and heating inferred from the AFTA data, based on the information derived from the variation in palaeotemperatures with elevation in vertical transects (VTs; Appendix 2). The origin of each of these episodes is discussed in detail in Chapters 5 and 6.

\subsection{AFTA and VR principles}

Fission tracks in apatite crystals are generated continuously through time by spontaneous fission of uranium atoms, present as an impurity within the apatite lattice and typically at levels of parts per million. These tracks are revealed in a polished surface by etching with dilute acid. The number of tracks that intersect a unit area of an apatite grain surface (track density) depends on the uranium content of the grain and the time over which tracks accumulated, following the laws of radioactive decay and on the track length (see Galbraith (2005) for a detailed exposition of the underlying method). If all tracks have the same length, unaffected by heating, then by counting the number of tracks in unit surface area and measuring the uranium content, the time over which tracks accumulated can be determined - a time referred to as a fission-track age, which is not a geological age. In practice, tracks in natural apatites have a distribution of track lengths, determined by the thermal history. Therefore, a fission-track age does not indicate the timing of a specific event but must be interpreted in conjunction with the measured distribution of track lengths to obtain constraints on the underlying thermal history (Green \& Duddy 2012).

Tracks are formed with an initial length within a narrow range, but once formed they shorten by a process known as annealing, at a rate dependant on the prevailing temperature. Because temperature dominates over time in the kinetics of the shortening process, as the sample temperature increases, all tracks are reduced to around the same length regardless of when they were formed. This process is irreversible, so if the temperature drops, all tracks formed up to that time are effectively 'frozen' at the length attained at the maximum temperature. Tracks which form after cooling are longer, due to the lower prevailing temperatures. Thus, at the end of a history involving simple heating and cooling, a sample will contain two populations of tracks; shorter tracks formed up to the onset of cooling and longer tracks formed after cooling. The proportion of short to long tracks will reflect the time of cooling relative to the total time over which tracks have been retained, while the mean length of the shorter component of tracks reflects the maximum palaeotemperature attained prior to cooling (Green \& Duddy 2012). Because the probability of tracks intersecting the surface (and contributing to the fission-track age) depends on track length, the shorter population of tracks will contribute a smaller proportion to the fission-track age compared to the longer tracks. Therefore, the fission-track age underestimates the time over which tracks have accumulated.

At some critical palaeotemperature the damage constituting the track is totally repaired, and the length is reduced to zero, referred to as total annealing. The precise temperature at which this occurs depends on the heating rate and the chlorine content of the apatite, but is typically in the range 100 to $130^{\circ} \mathrm{C}$. In samples that reached higher palaeotemperatures prior to cooling, tracks are only retained after cooling below this limit. AFTA data from such samples provide only a minimum estimate of the maximum palaeotemperature, but typically provide good constraints on the timing of the cooling episode. Throughout this manuscript, we use the terms 'palaeothermal episode' and 'cooling episode'. Palaeothermal episode refers to the time when the samples were hotter than they are now, whereas cooling episode refers specifically to the subsequent time when cooling began.

Figure 10 illustrates the development of fission tracks in an apatite crystal through a notional history involving initial cooling from $>110^{\circ} \mathrm{C}$ at time $=t_{1}$ to $10^{\circ} \mathrm{C}$ at $t_{2}$, representing exhumation of basement to the surface. Tracks formed during this initial cooling phase will have a range of lengths, as they experienced different maximum temperatures during cooling (situation E2 in Fig. 10). Tracks formed during reheating (representing reburial) between $t_{2}$ and $t_{3}$ are progressively shortened until the onset of cooling at $t_{3}$. Because the temperature does not subsequently exceed the maximum value reached at $t_{3}$, all tracks formed up to this point retain 
A
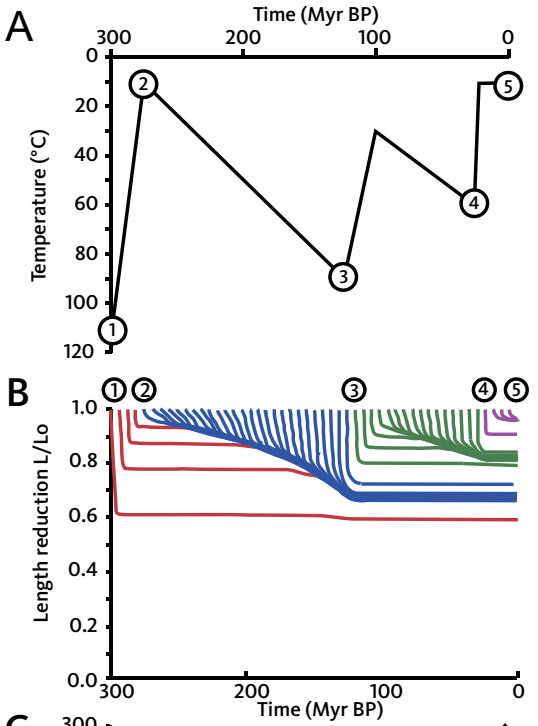

C

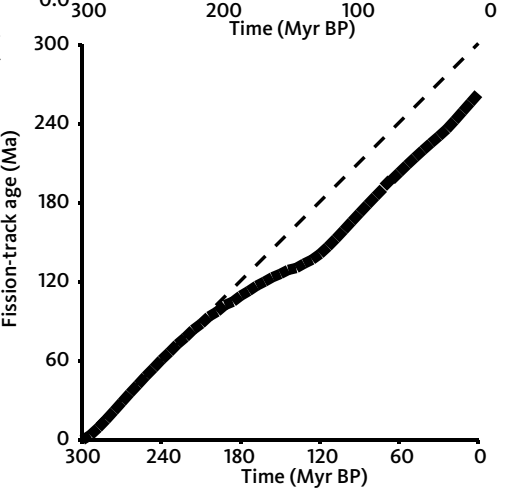

D

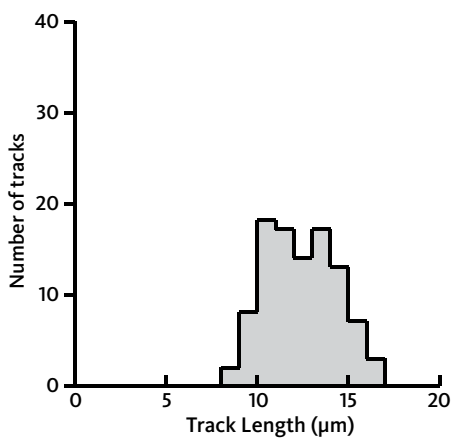

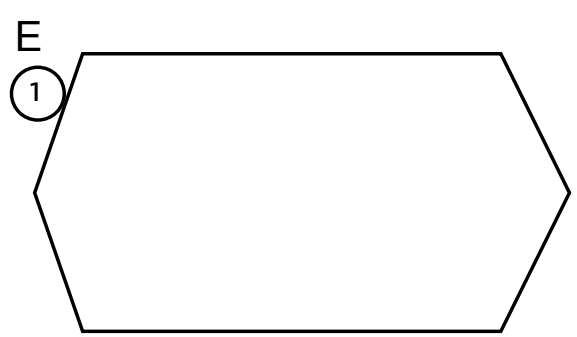
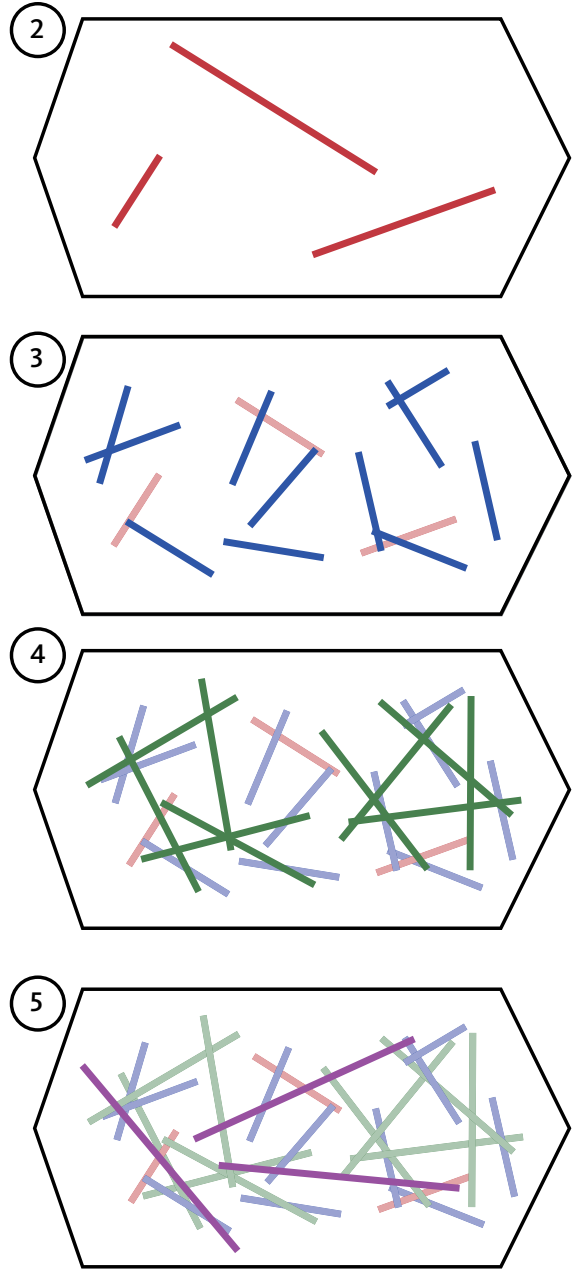

$t_{1}: 300 \mathrm{Ma}, \mathrm{T}=110^{\circ} \mathrm{C}$.

No tracks present.

$t_{2}: 275 \mathrm{Ma}, \mathrm{T}=10^{\circ} \mathrm{C}$.

Tracks formed during cooling have different lengths, reflecting different maximum temperatures. $t_{3}: 125 \mathrm{Ma}, \mathrm{T}=90^{\circ} \mathrm{C}$.

More tracks formed, and all those formed since $t_{2}$ (blue) are shortened to a length determined by the maximum temperature at $t_{3}$. Most of the tracks formed prior to $t_{2}$ are also shortened to the same length; only tracks that were shorter than this length remains with their length at $t_{2}$.

$t_{4}: 25 \mathrm{Ma}, \mathrm{T}=60^{\circ} \mathrm{C}$.

A new population of tracks formed between $t_{3}$ and $t_{4}$; all these are shortened to a length determined by the temperature at $t_{4}$, and are all longer than the tracks formed between $t_{2}$ and $t_{3}$.

$t_{5}: 0 \mathrm{Ma}, \mathrm{T}=10^{\circ} \mathrm{C}$.

A few tracks formed between $t_{4}$ and $t_{5}$ are longer than all other tracks in the sample.

Fig. 10 Schematic illustration of the AFTA method (Green \& Duddy 2012; Green et al. 2013). A: Schematic thermal history illustrating three periods of exhumation and two intervening periods of burial; points 1 to 5 corresponding to $\mathbf{t}_{\mathbf{1}}$ to $\mathbf{t}_{\mathbf{5}}\left(\right.$ time $\left.=t_{n}\right)$. B: Shortening trajectories for tracks formed at different times through the history. Tracks formed during different segments of the history are coloured-coded corresponding to the images in panel E (1 to 5). C: Evolution of apatite fission-track age with time through the thermal history shown in A. The fission-track age initially evolves linearly with time (dashed line). As $t_{3}$ approaches, the temperature nears $90^{\circ} \mathrm{C}$ causing length reduction (see B) resulting in significant age reduction. After cooling, length reduction is less severe and age evolution approaches linearity again. At $t_{5}$ the measured age is less than the total duration of the history, due largely to length reduction at $t_{3}$. D: Resulting distribution of track lengths, reflecting the presence of three populations of tracks, shortened to differing degrees as shown in B. The natural spread in track length is $c . \pm 1 \mu \mathrm{m}$ within a single population of tracks. Tracks belonging to the separate populations shown in B cannot be resolved, so individual tracks cannot be attributed to unique populations. E: Schematics of tracks in a notional apatite grain through the thermal history in A. Tracks colour-coded as in B.

the length they attained prior to cooling. The sample is reheated (reburied) towards the peak temperature at $t_{4}$, shortening tracks formed after $t_{3}$. When cooling begins again at $t_{4}$, these tracks remain longer than those formed prior to the earlier cooling event at $t_{3}$. Thus, the shorter tracks formed prior to cooling at $t_{3}$ preserve evidence of the earlier cooling episode. After cooling at $t_{4}$ temperature remains low and tracks formed between $t_{4}$ and $t_{5}$ are longer than all tracks formed previously.

The track-length distribution measured at the present 


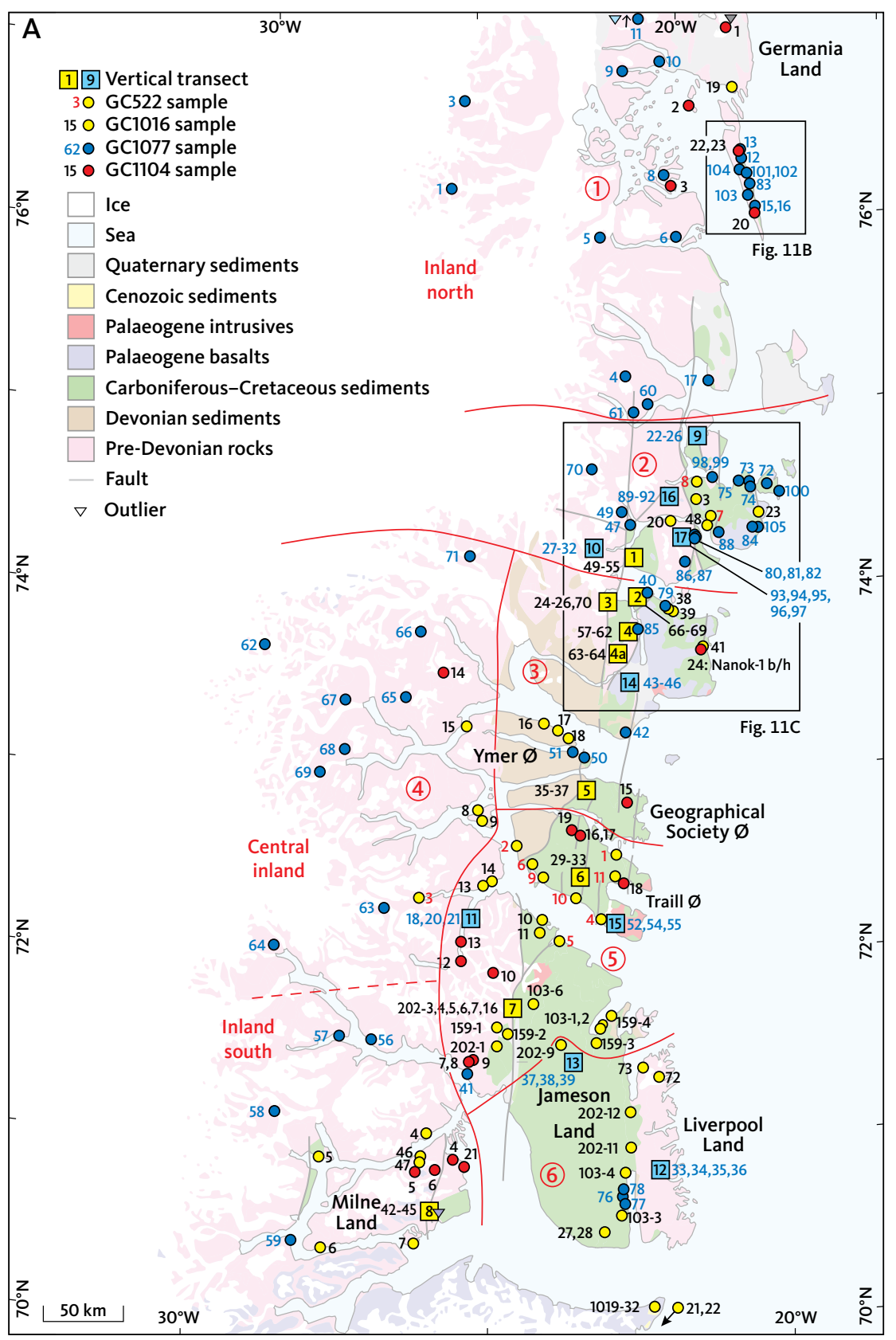

Fig. 11 Sample locations. A: AFTA samples across the entire study area. One sample from a parallel study (GC101932; Japsen et al. 2014), for which data are not presented here, is also shown. Red lines indicate the six regions (numbered 1-6) referred to in Table 1. B: AFTA and VR samples on Store Koldewey. C: AFTA and VR samples in the Clavering $\varnothing$ area. DF: Dombjerg Fault. PDMF: Post-Devonian Main Fault. Geology based on Fig. 3. Arrow at the northern edge of the map points to the location of sample GC107711 just north of the map frame. day (Fig. 10D) is dominated by two populations of tracks: shorter tracks formed up to $t_{3}$ and longer tracks formed between $t_{3}$ and $t_{4}$, plus a small proportion of very long tracks formed after $t_{4}$. The proportion of these longest tracks is very small because cooling was recent, and these cannot be easily resolved in the distribution (Fig. 10D). The final fission-track age $\left(t_{5}\right)$ is reduced due to shortening of the tracks formed before $t_{3}$. Peak palaeotemperatures and the time at which cooling began in the two episodes ( $t_{3}$ and $t_{4}$ ) can be determined using the relative proportions of longer and shorter tracks in the track-length distribution, in conjunction with the fission-track age (see Appendix 1 for further explanation). In addition, the history of the apatites in the sediment provenance terrain ( $t_{1}$ to $t_{2}$ ) may be determined, if the temperature at $t_{3}$ was not sufficiently high to overprint this part of the thermal history.

Where heating is predominantly due to depth of burial, palaeotemperatures determined from AFTA in isolated outcrop samples can be converted to former depth of burial, and hence amounts of removed section, using an assumed palaeogeothermal gradient. Where samples are analysed over a range of depths in a borehole or over a range of elevations in mountainous terrain, the allowed range of palaeogeothermal gradients can be determined directly. In principle, this allows more precise determination of amounts of removed section. However, this analysis is subject to a range of assumptions (Green \& Duddy 2012; Green et al. 2013) and results should be viewed with caution. 


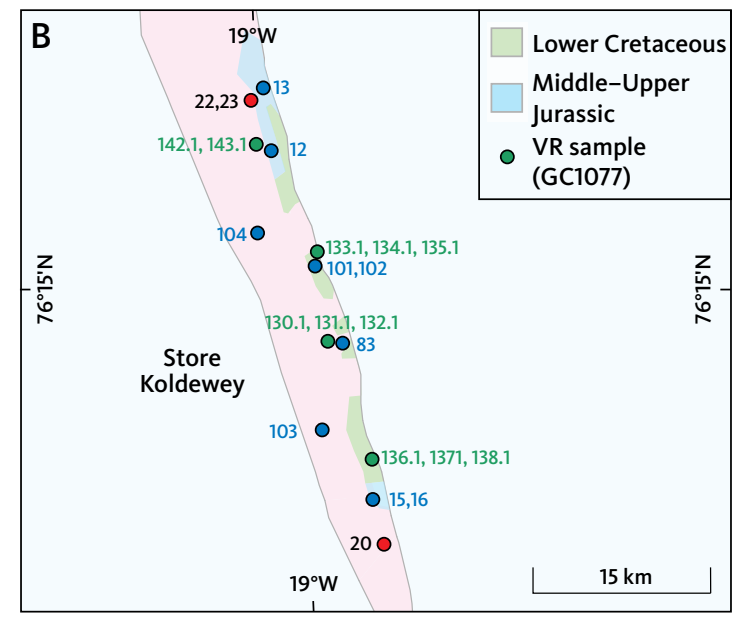

Fig. 11 (continued) Sample locations. A: AFTA samples across the entire study area. One sample from a parallel study (GC1019-32; Japsen et al. 2014), for which data are not presented here, is also shown. Red lines indicate the six regions (numbered 1-6) referred to in Table 1. B: AFTA and VR samples on Store Koldewey. C: AFTA and VR samples in the Clavering $\varnothing$ area. DF: Dombjerg Fault. PDMF: Post-Devonian Main Fault. Geology based on Fig. 3. Arrow at the northern edge of the map points to the location of sample GC1077-11 just north of the map frame.

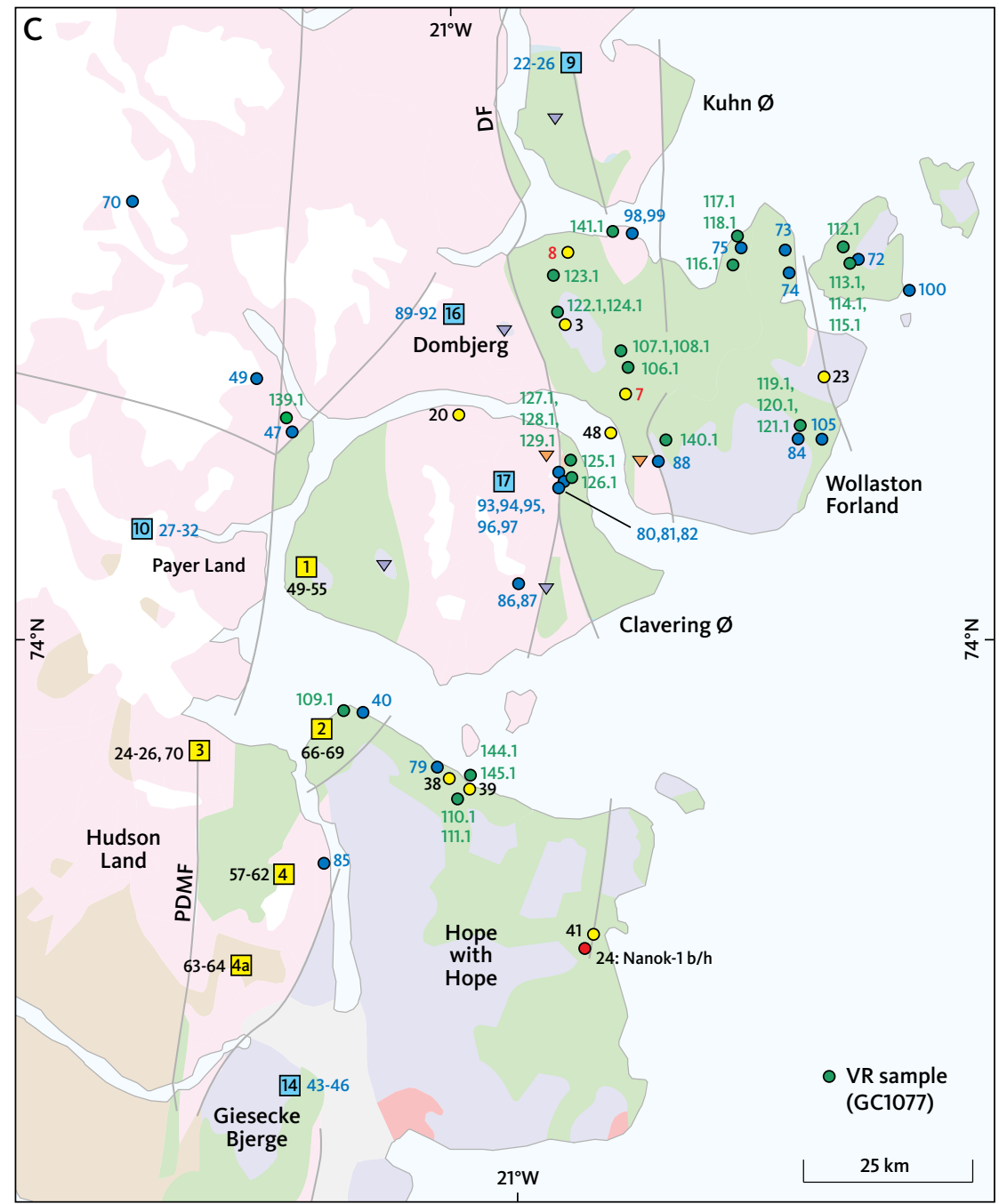

VR data provide a useful complement to AFTA data in providing independent estimates of maximum post-depositional palaeotemperatures. VR is based on the reflectance of coaly material in sediments, which increases at a rate that depends on temperature. The kinetics of this process are well documented (Sweeney \& Burnham 1990) and are similar to those of fission-track annealing in apatite (see Green \& Duddy 2012). Integration of AFTA and VR allows data to be collected from different lithologies within the same succession and provides an independent check on maximum post-depositional palaeotemperatures obtained from either method. 


\subsection{Previous apatite fission-track studies}

Previous apatite fission-track studies in North-East Greenland provide important insights into the thermal and tectonic history of the region. Early studies focussed on the Palaeogene intrusions along the margin south of Scoresby Sund (e.g. Gleadow \& Brooks 1979), detailing the post-intrusion cooling of these bodies. Further studies of basement terrains and sedimentary successions of Jameson Land revealed major Cenozoic cooling along the margin, interpreted in terms of kilometre-scale denudation related in some way to the process of rifting and separation of the North Atlantic Ocean (Hansen 1988, 1992, 1996).

Thomson et al. (1999) published AFTA results from the sedimentary successions to the north of Jameson Land (sample locations shown in Fig. 11 with the prefix GC522), reporting two Cenozoic cooling episodes which began between 40 and $30 \mathrm{Ma}$ (late Eocene - Oligocene) and between 10 and $5 \mathrm{Ma}$ (late Miocene). An earlier episode of cooling, which began sometime between 225 and $165 \mathrm{Ma}$, was also recognised in inland samples. The late Eocene - Oligocene episode was interpreted to be due either to uplift and erosion or to hydrothermal effects associated with igneous bodies of that age. The late Miocene episode, in which several samples cooled from palaeotemperatures as high as 90 to $100^{\circ} \mathrm{C}$, was interpreted as due to uplift and erosion related to a change in the North Atlantic spreading vector. Thomson et al. (1999, p. 1045) noted that "No palaeo-thermal effects have been identified related to the onset of rifting in the Early Tertiary".

Johnson \& Gallagher (2000) interpreted results from samples of Carboniferous sandstones from a vertical transect on Clavering $\varnothing$ as defining progressive cooling through late Palaeozoic and Mesozoic times in a series of stages prior to accelerated Cenozoic cooling. The section sampled by Johnson \& Gallagher (2000) is overlain by Palaeogene basalts, showing that their uppermost sample must have been at near-surface temperature in the Palaeogene. However, their analysis took no note of this basic constraint on the thermal history of the succession, leading to serious underestimation of final Mesozoic cooling and Palaeogene re-burial prior to the onset of Cenozoic cooling (Japsen et al. 2010; Green et al. 2013). Johnson \& Gallagher (2000) reported no evidence of Palaeogene palaeothermal effects.

Hansen et al. (2001) reported results from the Jameson Land Basin and adjacent regions, showing a consistent regional pattern with youngest ages less than $25 \mathrm{Ma}$ restricted to a region around the north and south coasts of Kong Oscar Fjord, surrounded by a wider region characterised by ages between 25 and $45 \mathrm{Ma}$. Older ages were largely restricted to higher elevations and locations to the south and west of Jameson
Land. Hansen et al. (2001) interpreted these results as reflecting a complex interplay between deeper burial prior to Cenozoic exhumation, circulation of hot fluids associated with mid-Cenozoic intrusive activity around the eastern end of Kong Oscar Fjord and possibly elevated basal heat flow in eastern Traill $\varnothing$. Hansen et al. (2001) favoured an onset of exhumation at c. 55 Ma in the south of the basin, and before $25 \mathrm{Ma}$ in the north, suggesting removal of as much as $4-5 \mathrm{~km}$ for palaeogeothermal gradients around $25^{\circ} \mathrm{C} / \mathrm{km}$. The apatite fission-track ages presented by Hansen et al. (2001) show an erratic variation, suggesting significant local heating effects. In view of these observations, any evidence for Palaeogene exhumation in their dataset is tentative at best. Palaeogene palaeothermal effects thus appear to be restricted either to contact heating from intrusions and associated hydrothermal effects.

Apatite (U-Th)/He ages of basement rocks reported by Swift et al. (2008) from locations close to those studied previously by Thomson et al. (1999) and Johnson \& Gallagher (2000), showed erratic variation with elevation. These results were interpreted as indicating a phase of rapid denudation, beginning $74 \pm 15 \mathrm{Ma}$. This is a stark contrast to previous studies in the region, which showed no evidence of regional Late Cretaceous - Palaeogene cooling. Swift et al. (2008) interpreted their $(\mathrm{U}-\mathrm{Th}) / \mathrm{He}$ ages in terms of cooling below $35-75^{\circ} \mathrm{C}$. However, subsequently, abundant evidence has emerged that the thermal response of the apatite (U-Th)/He system is more complicated, and that a range of external factors affect the measured ages (Green \& Duddy 2018). For this reason, no significance can be attached to the conclusions of Swift et al. (2008). This is further emphasised by results from further south on the east coast of Greenland presented by Hansen \& Reiners (2006), who reported that thermal histories indicated by apatite fission-track and (U-Th)/He data were inconsistent, and the He-ages should be discounted.

Japsen et al. (2014) interpreted AFTA data in 90 samples from southern East and South-East Greenland, primarily between 68 and $70^{\circ} \mathrm{N}$, in terms of nine discrete cooling episodes since the late Palaeozoic. Some of these episodes were regional while others were more localised. Japsen et al. (2014) combined the interpretation of the AFTA data with results from stratigraphic landscape analysis (Bonow et al. 2014) and found that three regional phases of uplift and exhumation shaped the present-day margin: (1) A late Eocene phase of uplift led to formation of a regional erosion surface, the UPS, near sea level. (2) Late Miocene uplift led to formation of another erosion surface, the LPS, by incision below the uplifted UPS. (3) Pliocene cooling could not be resolved in the AFTA data, but a pronounced Pliocene phase of uplift and incision was established from landscape 
evidence (Bonow et al. 2014), which led to the final creation of the present-day topography of the region.

Thus, despite several regional thermal-history studies of the East Greenland margin, opinions differ with regard to the precise time at which individual rock units reached their palaeothermal maximum, how this timing varies across the region, and the nature of the mechanisms responsible for heating and cooling.

\subsection{New AFTA and VR data}

AFTA has been applied to 217 outcrop samples of basement and sedimentary rocks in North-East Greenland between 70 and $78^{\circ} \mathrm{N}$ (Fig. 11). Methods are described in Green et al. (2013). Methods for sample preparation, analytical details, basic AFTA data in individual samples and the thermal-history interpretations derived from AFTA data in each sample are reported in three Geotrack company reports and are available as supplementary material:

- Report GC1016 (95 samples; Green 2009; Supplementary File S1)

- Report GC1077 (99 samples; Green 2011; Supplementary File S2)

- Report GC1104 (23 samples; Green 2012; Supplementary File S3).

All sample details (Appendix 1.2), AFTA data (Appendix 1.3) and thermal-history interpretations (Appendix 1.4) are available in Supplementary File S4. Supplementary File S5 contains sample coordinates and thermal-history solutions in $\mathrm{kmz}$ format.

Results in 11 outcrop samples from Traill $\varnothing$, originally published by Thomson et al. (1999), are included in Geotrack report GC1016 (samples with prefix GC522). These samples were reanalysed and reported in Geotrack report GC1016 to incorporate measurement of $w t \% \mathrm{Cl}$, providing updated thermal-history interpretations for these samples. Both the basic AFTA parameters and the interpretations are similar to those quoted by Thomson et al. (1999). Apatite separates of 20 Palaeozoic and Mesozoic sedimentary rocks from the Jameson Land region were kindly made available by Kirsten Hansen (samples with prefix GC103, GC159, GC202). These samples were first analysed in the 1980s by Geotrack for Atlantic Richfield Company (ARCO) and results were published by Hansen et al. (2001). The samples were recounted and re-interpreted using modern techniques and included in Geotrack Report GC1016. Coordinates of samples from previous studies were digitised from published maps (Thomson et al. 1999; Hansen et al. 2001). While we have used these elevations in Appendix 2, sample elevations derived in this way were found to conflict with values quoted by Hansen et al. (2001; particularly for samples from Schuchert Dal, western Jameson Land), so some doubt surrounds these data.

Rocks sampled in this study comprise Precambrian and Caledonian basement, Palaeozoic intrusions, Palaeozoic and Mesozoic sedimentary rocks and a small number of Cenozoic sedimentary and intrusive rocks. Results from two samples of Palaeogene sediments at Kap Dalton $\left(69.5^{\circ} \mathrm{N}\right)$, and from one sample (GC1019-32) of Palaeogene sediments from Kap Brewster were published by Japsen et al. (2014). Apatite yields were generally excellent. While some samples provided lower amounts of apatite than generally required for an analysis of the highest quality, interpretations derived from such data are still reliable within the stated uncertainties (95\% confidence limits), although these will be broader than those from higher quality data. Nevertheless, results from such samples are still useful when assessed alongside higher quality data. Samples collected at different elevations within restricted areas constitute 17 near-vertical transects (VTs; Appendix 2.1), to quantify palaeogeothermal gradients and amounts of removed section.

Geotrack report GC1077 (Green 2011; Supplementary File S2) also contains results of VR analyses undertaken by Keiraville Konsultants, Australia, of 40 samples of outcropping sedimentary units from locations in the Clavering $\varnothing$ area and on Store Koldewey (Figs 11B, C). VR data, including maximum palaeotemperatures and the associated thermal episodes to which they are attributed are listed in Appendix 1.5 (and in Supplementary File S4).

The variation in measured apatite fission-track ages across the region is shown in Fig. 12. Such a map can be misleading because measured fission-track ages are not only sensitive to the thermal history but also to depositional ages as well as external factors such as the composition of apatites within each sample and the sample elevation. Regional variation is better addressed by investigating the palaeotemperatures in individual episodes estimated from the thermal-history interpretation of the data, as discussed in Section 4.4. However, some broad generalisations are possible based on Fig. 12. Youngest fission-track ages ( $<25 \mathrm{Ma}$ ) occur in samples from eastern Traill $\varnothing$ and north-eastern Jameson Land, on either side of Kong Oscar Fjord. Fission-track ages increase north, west and south of these areas. Away from the focus of young ages, a background pattern is evident where locations close to sea level typically yield ages around 100 to $200 \mathrm{Ma}$ while samples at highest elevations yield ages >200 Ma. Elsewhere, fission-track age variation with elevation is more erratic, for example, on north-west Jameson Land where ages show little correlation with elevation. The variation in thermal history within the vertical sample transects is discussed in 


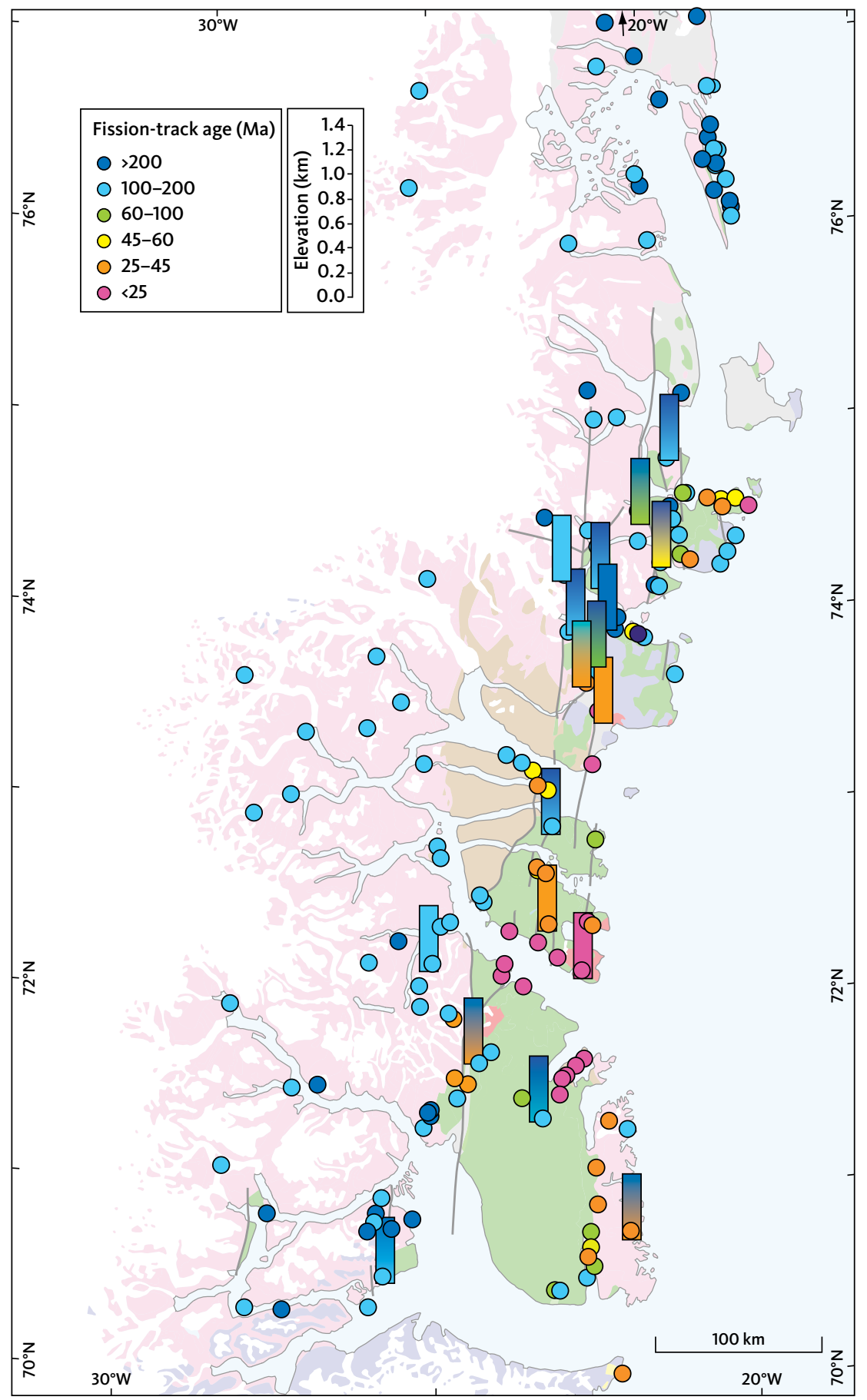

Fig. 12 Fission-track ages in individual outcrop samples. Rectangular symbols refer to vertical profiles. Significant regional variation is evident, with youngest ages around the eastern end of Traill $\varnothing$ and north-east Jameson Land. Arrow at the northern edge of the map points to the location of sample GC1077-11 just north of the map frame. Geology as in Fig. 11.

greater detail in Section 4.6 and in Appendix 2. For now, we simply note a complex variation in thermal history across the area, and in some cases at a local scale.

Mean track lengths measured in each sample are plotted against fission-track age in Fig. 13A alongside published data. None of the fission-track ages are older than c. $300 \mathrm{Ma}$, showing that the data are dominated by the Phanerozoic history. The data define a broadly consistent pattern, although this is rather more complex than the simple 'boomerang trend', which characterises a suite of samples affected by a single dominant palaeothermal episode (Green 1986). The more complex relationships in Fig. 13A can be understood in terms of the superposition of a series of separate 'boomerang trends' (Fig. 13B), suggesting that the samples have undergone a series of palaeothermal episodes, with different samples being heated to different temperatures in each episode.

\subsection{Thermal-history solutions from AFTA} Thermal-history solutions derived from the AFTA data in each sample (using the approach described in Appendix 1) are provided in Appendix 1.4. Solutions are presented as intervals representing $95 \%$ confidence limits on the 

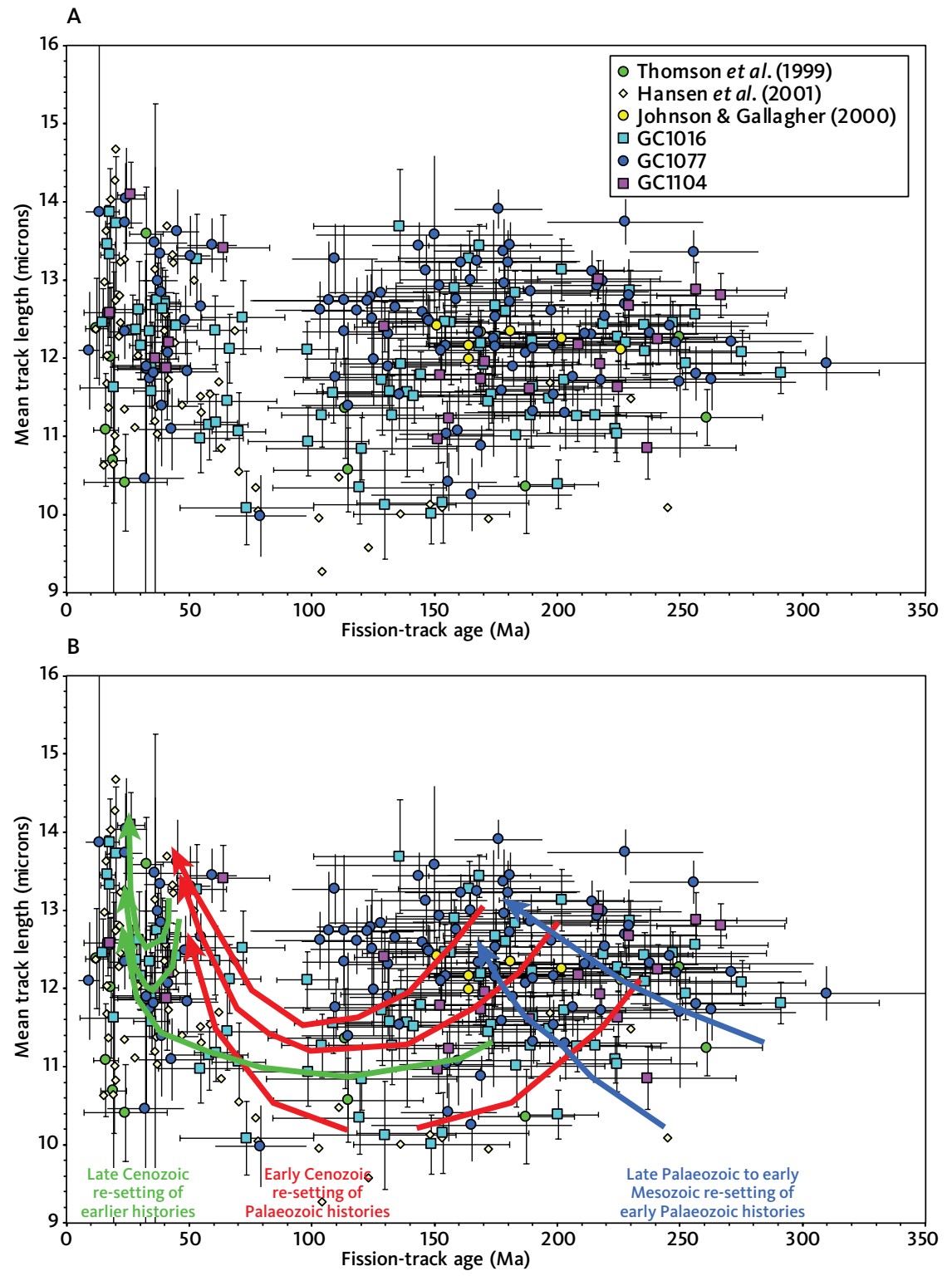

Fig. 13 Relationship between mean track length and fission-track age. A: Outcrop samples from North-East Greenland. The new data span the range of previous studies. B: Same as A, overlain with coloured lines to indicate the cumulative effects of resetting by several separate palaeothermal episodes, each of which has affected individual samples to varying degrees. maximum palaeotemperature and timing of cooling (as defined in Appendix 1.1) from one, two or three palaeothermal episodes (i.e. periods when samples were hotter than they are today). The number of palaeothermal episodes that can be defined in each sample depends on how well separated the events are in temperature and time, as well as the number of track lengths and fission-track ages measured in each sample.

Estimates of the timing of discrete cooling episodes in individual samples are compared in Appendix 1.6 for six regions along the coast, illustrated in Fig. 11A (these regions are defined simply to present the data in convenient sub-sections). Based on the general uniformity of the data, we have sought to define the minimum number of regionally synchronous cooling episodes, which can explain the results in all samples. Where palaeotemperatures and estimates of the onset of cooling are similar in adjacent samples, the constraints are interpreted, as representing a common episode. In this way, samples with quite broad constraints can still be allocated to specific regional events. As an example, all samples from VT1 are interpreted as defining the earliest Cretaceous C3 cooling episode, even though the timing constraints for this episode are quite broad in some samples (for example, 320-60 Ma, sample GC1016-50). However, the constraints on the C3 palaeotemperatures for VT1 are tightly constrained and show consistent variation with elevation (Appendix 2.2), and it is thus reasonable to assume that all VT1 samples cooled in episode C3. This illustrates how data with quite broad constraints can provide useful conclusions.

The timing of regionally synchronous cooling episodes in the six regions are presented in Table 1 . In many cases the timing of these major cooling episodes is consistent between different regions. In a few cases, cooling is seen in some regions and not others. Thus, 
Table 1 Intervals defining the onset of cooling episodes (Ma) based on AFTA data in 217 outcrop samples

\begin{tabular}{|c|c|c|c|c|c|c|c|c|c|}
\hline Event & Region 1 & Region 2 & Region 3 & Region 4 & Region 5 & Region 6 & Synthesis & $\begin{array}{c}\text { Onset of cooling } \\
\text { (chronostratigraphy) }\end{array}$ & Mechanism \\
\hline $\mathrm{CO}$ & $325-300$ & $400-250$ & & $320-260$ & $350-270$ & & $320-300$ & Late Carboniferous & Regional uplift and erosion \\
\hline C1 & $245-200$ & $250-240$ & $240-220$ & $270-240$ & $245-215$ & $300-215$ & c. 240 & Middle Triassic & Regional uplift and erosion \\
\hline C2 & $205-180$ & $185-175$ & $200-165$ & $185-180$ & $220-165$ & $180-170$ & c. 180 & Early Jurassic & Regional uplift and erosion \\
\hline C3 & $165-135$ & $150-140$ & $155-130$ & $145-140$ & & & $145-140$ & Earliest Cretaceous & Regional uplift and erosion \\
\hline C4 & $105-80$ & $100-90$ & $120-75$ & $110-90$ & $95-65$ & & $95-90$ & Mid-Cretaceous & Regional uplift and erosion \\
\hline C5 & & $65-55$ & $62-42$ & & $55-45$ & $60-48$ & c. 55 & Early Eocene & Local effects of intrusions \\
\hline C6 & & $38-35$ & $40-35$ & & $38-30$ & $37-25$ & $37-35$ & End-Eocene & $\begin{array}{l}\text { Regional uplift and erosion } \\
\text { Local effects of intrusions }\end{array}$ \\
\hline C7 & & & & & $20-18$ & & $25-18$ & Early Miocene & $\begin{array}{l}\text { Local effects of intrusions } \\
\text { Local uplift and erosion }\end{array}$ \\
\hline C8 & $10-5$ & c. 10 & $10-7$ & $15-10$ & $12-10$ & $12-10$ & c. 10 & Late Miocene & Regional uplift and erosion \\
\hline C9 & & $25-0$ & $5-0$ & & c. 5 & & c. 5 & Early Pliocene & $\begin{array}{l}\text { Incision of relief during } \\
\text { regional uplift }\end{array}$ \\
\hline
\end{tabular}

Regions defined in Figure 11A. Also shown are possible origins of the cooling during each episode. Region 1: Germania Land, Store Koldewey, Inland north. Region 2: Clavering $\varnothing$, Wollaston Forland, Kuhn $\varnothing$. Region 3: Hold with Hope, Hudson Land, Ymer $\varnothing$, Geographical Society $\varnothing$. Region 4: Inland (central and south), Milne Land. Region 5: Traill $\varnothing$, Stauning Alper, Jameson Land north, Schuchert Dal. Region 6: Jameson Land south, Liverpool Land, Blosseville Kyst. Appendix 1.6 displays the timing of discrete cooling episodes in individual samples.

we can distinguish between regional and local episodes. Ten cooling episodes (CO-C9) are recognised within the study area. The onset of cooling in each episode ranges from the late Palaeozoic to the early Pliocene (Table 1).

\subsection{Regional variation in the magnitude of palaeothermal episodes}

Maps of palaeotemperatures characterising the ten palaeothermal episodes that preceded the cooling episodes (CO to C9) are shown in Fig. 14. Palaeotemperatures derived from VR data from 40 samples presented in Geotrack Report GC1077 are also included where data are available (mainly from locations in the Clavering $\varnothing$ area and on Store Koldewey). Results from the VR data are attributed to regional events based on palaeotemperatures from AFTA in nearby samples (Appendix 1.5). Detailed palaeotemperature maps for Store Koldewey and for the region around Clavering $\varnothing$ are shown in Figs 15 and 16, respectively. The palaeotemperature maps illustrate how some events only affected restricted areas, while others affected much of the region. Here we discuss general trends within these data. Evidence for mechanisms of heating and cooling in each episode provided by the variation of palaeotemperatures with elevation in vertical transects is discussed in Section 4.6.

It is clear from these maps that many areas have undergone several regional cooling episodes. Because only three events can typically be resolved from AFTA data in a single sample, this can cause difficulties in resolving discrete episodes in individual samples, particularly where events that are close in time are of similar magnitude. Thus, in some cases, the quoted thermal-history solutions may represent the combined effects of two or more unresolved multiple cooling episodes. This is particularly important also at low temperatures $\left(<70^{\circ} \mathrm{C}\right)$, where differences in track-length reduction caused by separate palaeothermal episodes may be insufficient to allow multiple episodes to be resolved. However, the generally consistent results discussed here suggest that this does not constitute a serious problem in interpretation. A few cases where this problem may be acute are discussed.

\subsubsection{Late Carboniferous episode (CO)}

Cooling began between 320 and $300 \mathrm{Ma}$. Episode CO is recognised mainly in basement samples from the north and south of the region (CO in Fig. 14). Maximum palaeotemperatures in this episode are in excess of $100^{\circ} \mathrm{C}$ for all samples in which this episode is recognised. Since this is the earliest of the palaeothermal episodes identified across the region, it is only recorded in areas where palaeotemperatures in subsequent episodes have remained sufficiently low, such that evidence of this episode was not overprinted. Locations that record episode CO therefore represent relatively stable areas, which have undergone less post-Permian heating and cooling than surrounding regions. Note that the small number of samples that preserve evidence of the $\mathrm{CO}$ episode emphasises the magnitude of post-Palaeozoic palaeothermal effects in the study area, which have probably overprinted the effects of this episode over most of the region. 

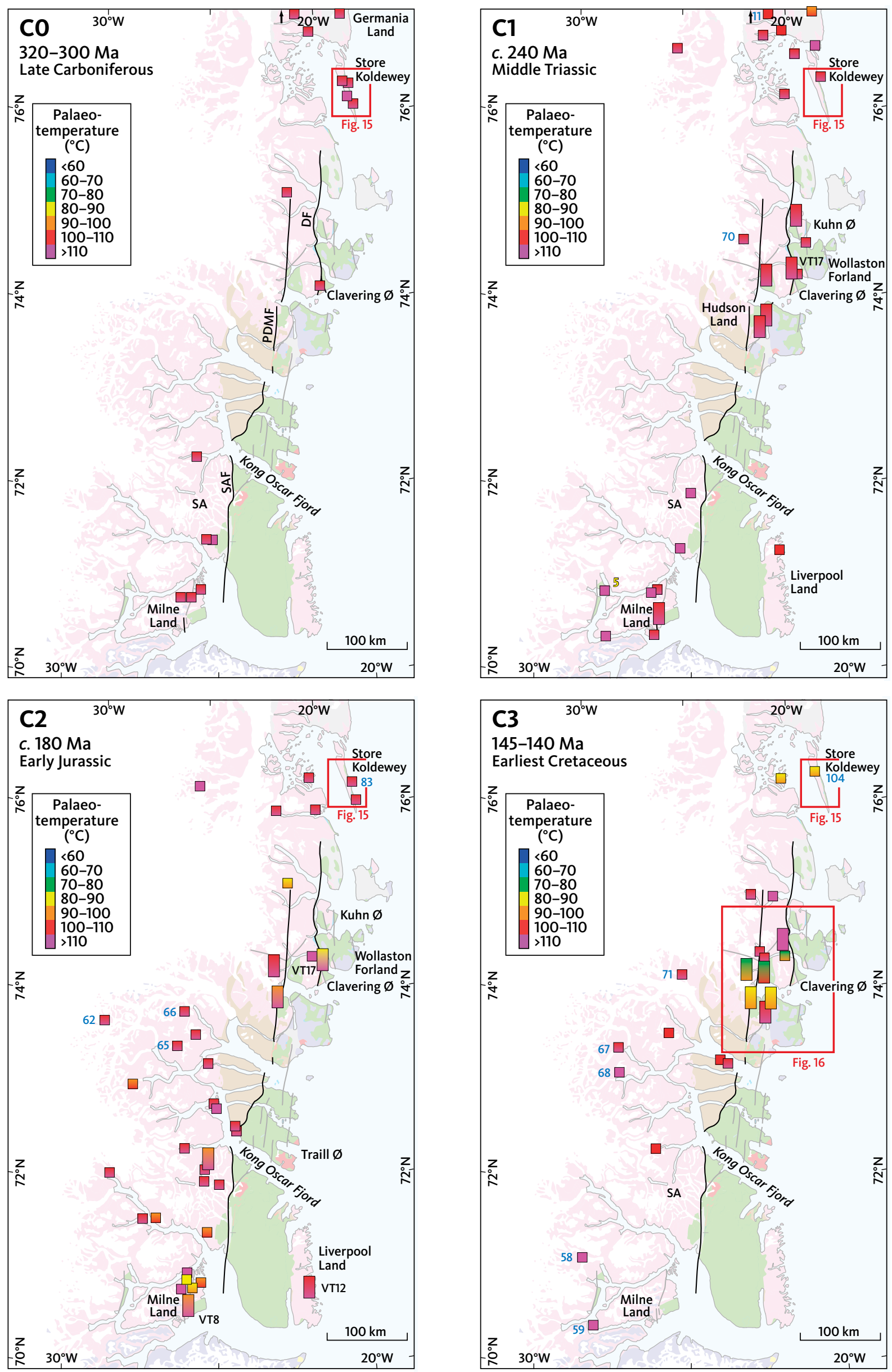

Fig. 14 Caption on page 31. 

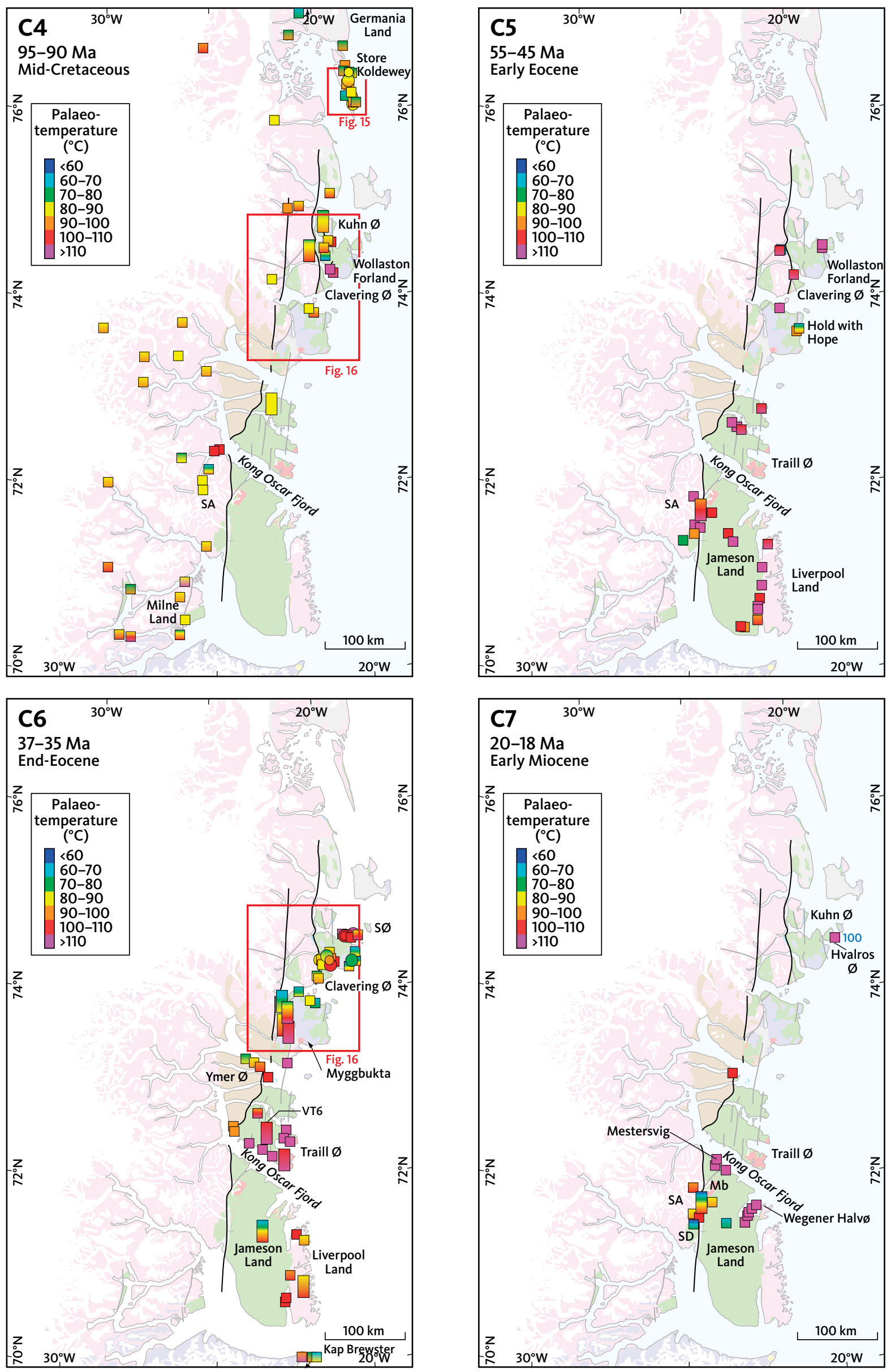

Fig. 14 (continued) Caption on page 31. 


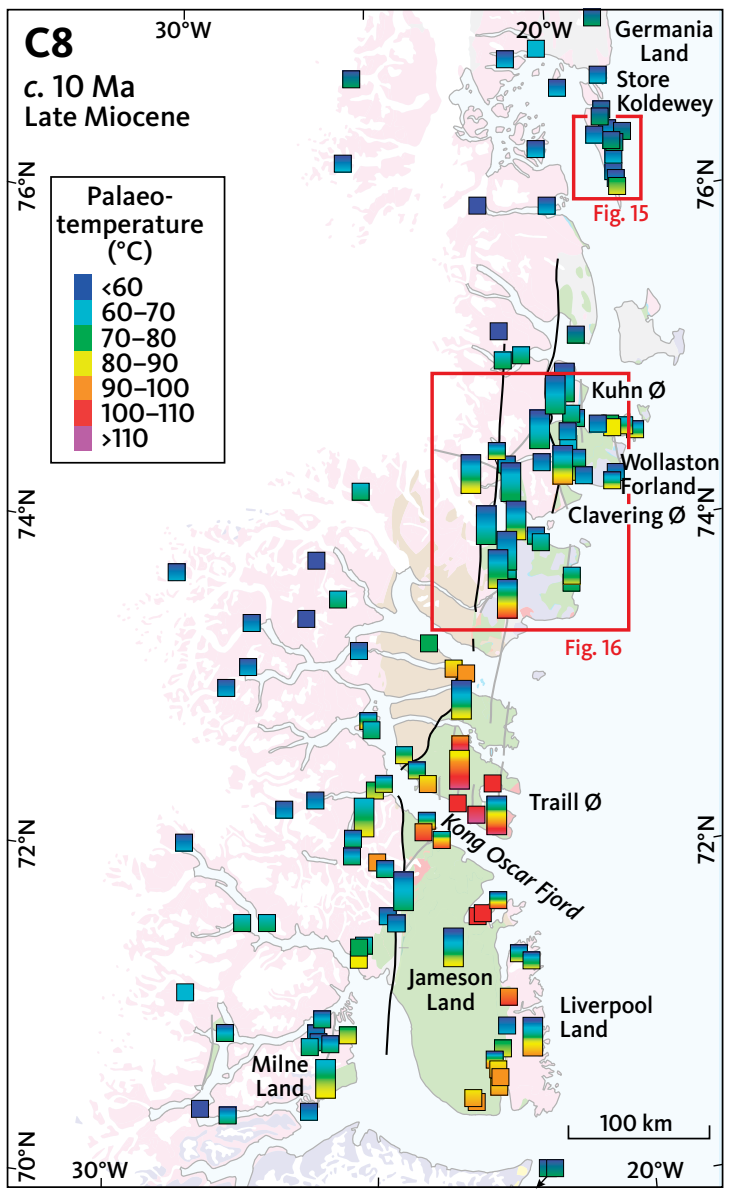

$\square$ Palaeotemperature from AFTA data
$\square$ Palaeotemperature along vertical transect from AFTA data
Palaeotemperature from VR data

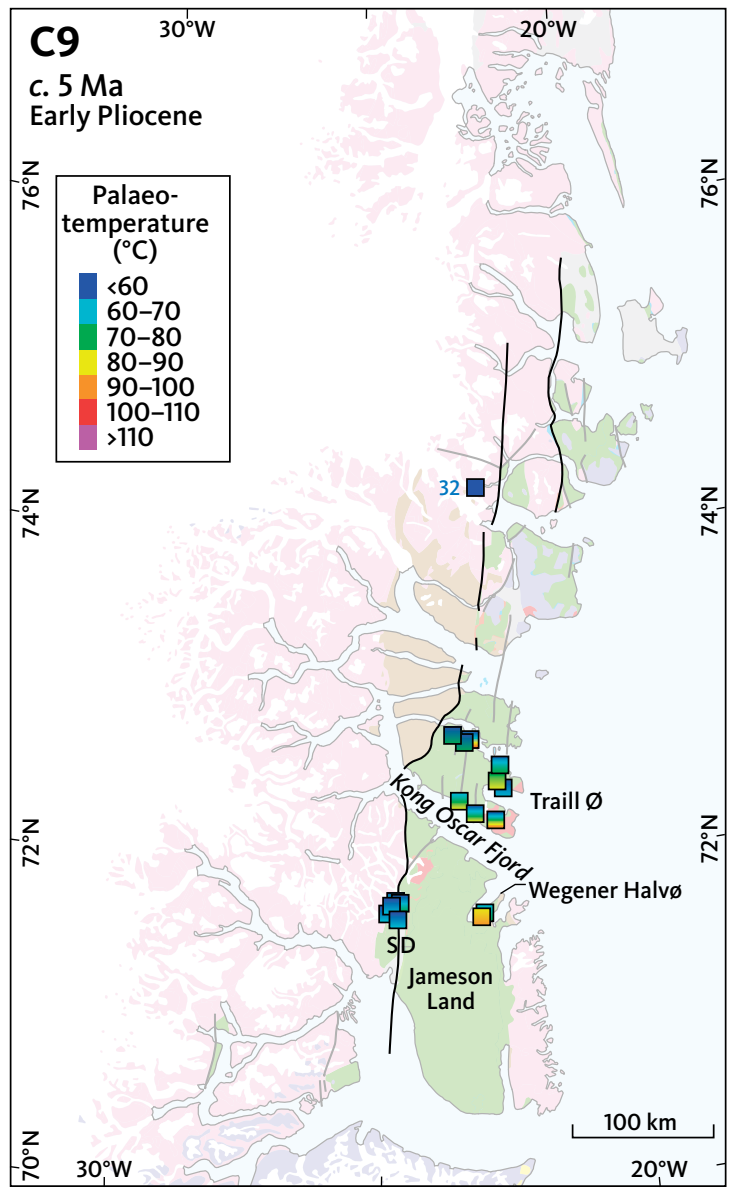

5 GC1016 sample
68 GC1077 sample

Fig. 14 (continued) Maps of palaeotemperatures derived from AFTA data. Individual samples are attributed to palaeothermal episodes C0-C9 (Table 1) and thermal history constraints are listed in Appendix 1.4. Detailed maps of palaeotemperatures derived from AFTA and VR data for Store Koldewey and the area around Clavering $\varnothing$ are shown in Fig. 15 and Fig. 16, respectively. DF: Dombjerg Fault. Mb: Malmbjerget. PDMF: Post-Devonian Main Fault. SA: Stauning Alper. SAF: Stauning Alper Fault. SD: Schuchert Dal. SØ: Sabine $\emptyset$. VT: Vertical transect. Arrow at the northern edge of the map points to the location of sample GC1077-11 just north of the map frame. Sample locations in Fig. 11.

\subsubsection{Middle Triassic episode (C1)}

Cooling began at c. 240 Ma. Episode C1 is recognised sporadically in samples across much of the region (C1 in Fig. 14). Maximum palaeotemperatures in this episode are also in excess of $100^{\circ} \mathrm{C}$ for all samples in which this episode is recognised. Around Clavering $\varnothing$, the $C 1$ episode is recognised in many samples east of the PDMF, but one sample west of that fault records C1 palaeotemperatures in excess of $130^{\circ} \mathrm{C}$ because of high chlorine content in the apatites in this sample (GC107770). Thus, it seems likely that $C 1$ cooling affected areas both west and east of the fault, but samples west of the fault generally cooled below $110^{\circ} \mathrm{C}$ in cooling episodes after $\mathrm{C} 1$. As with the $\mathrm{C} 0$ episode, Middle Triassic cooling is only recorded in areas where palaeotemperatures in subsequent episodes have remained sufficiently low as to not overprint evidence of this episode.

\subsubsection{Early Jurassic episode (C2)}

Cooling began c.180 Ma. Episode C2 is recognised in many locations across the study area, in samples of basement and early Palaeozoic sedimentary rocks, particularly where Lower Jurassic sediments are absent (e.g. Milne Land, Traill $\varnothing$, Clavering $\varnothing$ and Store Koldewey; C2 in Fig. 14). As such it is not recognised in coastal locations south of Clavering $\varnothing$, except for VT12 on Liverpool Land (Appendix 2.3). Maximum palaeotemperatures in this episode are around $100^{\circ} \mathrm{C}$ or above in most of the samples in which this episode is recognised, with a tendency towards lower values at the farthest 


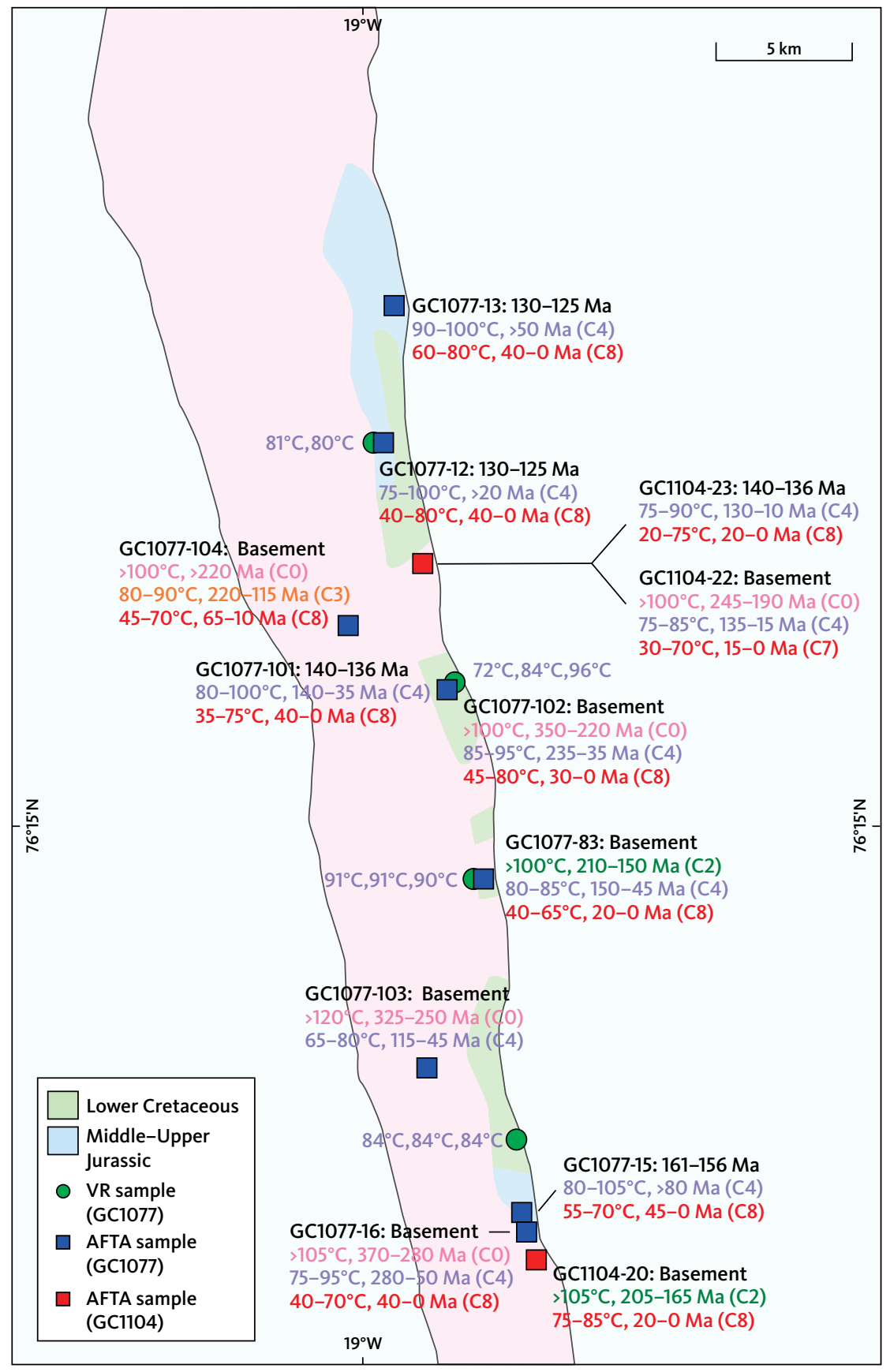

Fig. 15 Thermal-history solutions derived from AFTA and VR data for Store Koldewey. Stratigraphic ages listed alongside the sample numbers. Palaeotemperature and timing constraints are listed for each sample together with the regional cooling episode assigned to the constraints. Maximum palaeotemperatures derived from the mean VR value in each sample are compared with the thermal history solutions derived from AFTA data in samples from the same area. The maximum palaeotemperatures indicated by the VR data in Mesozoic sediments are consistent with mid-Cretaceous C4 palaeotemperatures derived from AFTA, showing that they cooled from maximum post-depositional palaeotemperatures in the C4 episode. Map location in Fig. 11.

inland locations and at higher elevations. This episode is only recorded in areas where palaeotemperatures in later episodes have remained sufficiently low, so as not to overprint evidence of this episode, which probably accounts for the absence of episode C2 in coastal and near coastal locations (C5 and C6 in Fig. 14).

\subsubsection{Earliest Cretaceous episode (C3)}

Cooling began between 145 and $140 \mathrm{Ma}$. Episode C3 is recognised most prominently in the region around the western side of Clavering $\varnothing$, as well as in several samples across the interior of the study area (C3 in Fig. 14). This contrasts with the Early Jurassic C2 episode, which is recognised at inland locations across the entire study area. Palaeotemperatures characterising this episode are more variable than those identified in earlier events, although values are again in excess of $100^{\circ} \mathrm{C}$ at many locations, precluding definition of earlier events. Palaeotemperatures also show a progressive decrease with increasing elevation in vertical transects which is particularly well displayed in data from Clavering $\varnothing$ (VT1; Appendix 2.3). Offsets by faulting may occur between some of the inland sample locations. Whereas some samples cooled from $>110^{\circ} \mathrm{C}$ in this episode (e.g. GC1077- 71, -67 , -68), neighbouring samples cooled below c. $100^{\circ} \mathrm{C}$ in the Early Jurassic C2 episode (e.g. samples GC1077-62, -65, -66, -69). Similarly, in the south-west, samples GC107758 and -59 cooled below $110^{\circ} \mathrm{C}$ in this episode while 
nearby samples cooled from similar palaeotemperatures in either the Middle Triassic C1 or Early Jurassic C2 episodes. Given the sporadic evidence for this episode in the interior of the study area it appears likely that episode C3 affected the entire region but was overprinted in more coastal regions by later episodes.

\subsubsection{Mid-Cretaceous episode (C4)}

Cooling began between 95 and 90 Ma. Palaeotemperatures characterising episode C4 are recognised across much of the same area as the Early Jurassic C2 episode (C4 in Fig. 14). Palaeotemperatures are around 80 to $100^{\circ} \mathrm{C}$ across most of the study area. Some locations, particularly at low elevations, give values in excess of $100^{\circ} \mathrm{C}$. This episode is not recognised at coastal locations between the northern shores of Hold with Hope and Jameson Land, reflecting the dominance of Cenozoic events at these locations. However, the relative uniformity of the episode, where it is revealed, suggests that it probably also affected those areas but has been overprinted by later events.

\subsubsection{Early Eocene episode (C5)}

Cooling began c. $55 \mathrm{Ma}$. Episode C5 is more restricted in extent than earlier episodes (C5 in Fig. 14), focussed mainly around Jameson Land, where palaeotemperatures are around $100^{\circ} \mathrm{C}$ or above. Five AFTA samples and two VR samples from northerly locations around Clavering $\varnothing$ also show palaeotemperatures $>100^{\circ} \mathrm{C}$ in this episode. These samples were collected close to mapped intrusive bodies of similar age. This, together with the sporadic occurrence of this episode, suggests that C5 is directly related to intrusive bodies. The abundance of early Eocene intrusions across Jameson Land (NoeNygaard 1976) suggests a similar mechanism. We therefore interpret the effects of episode $\mathrm{C} 5$ to reflect local heating associated with the widespread Eocene intrusive activity across the region (Fig. 5; Larsen et al. 2014).

\subsubsection{End-Eocene episode (C6)}

Cooling began between 37 and 35 Ma. Episode C6 is observed at coastal locations south of Kuhn $\varnothing$ (C6 in Fig. 14). Palaeotemperatures from samples at sea
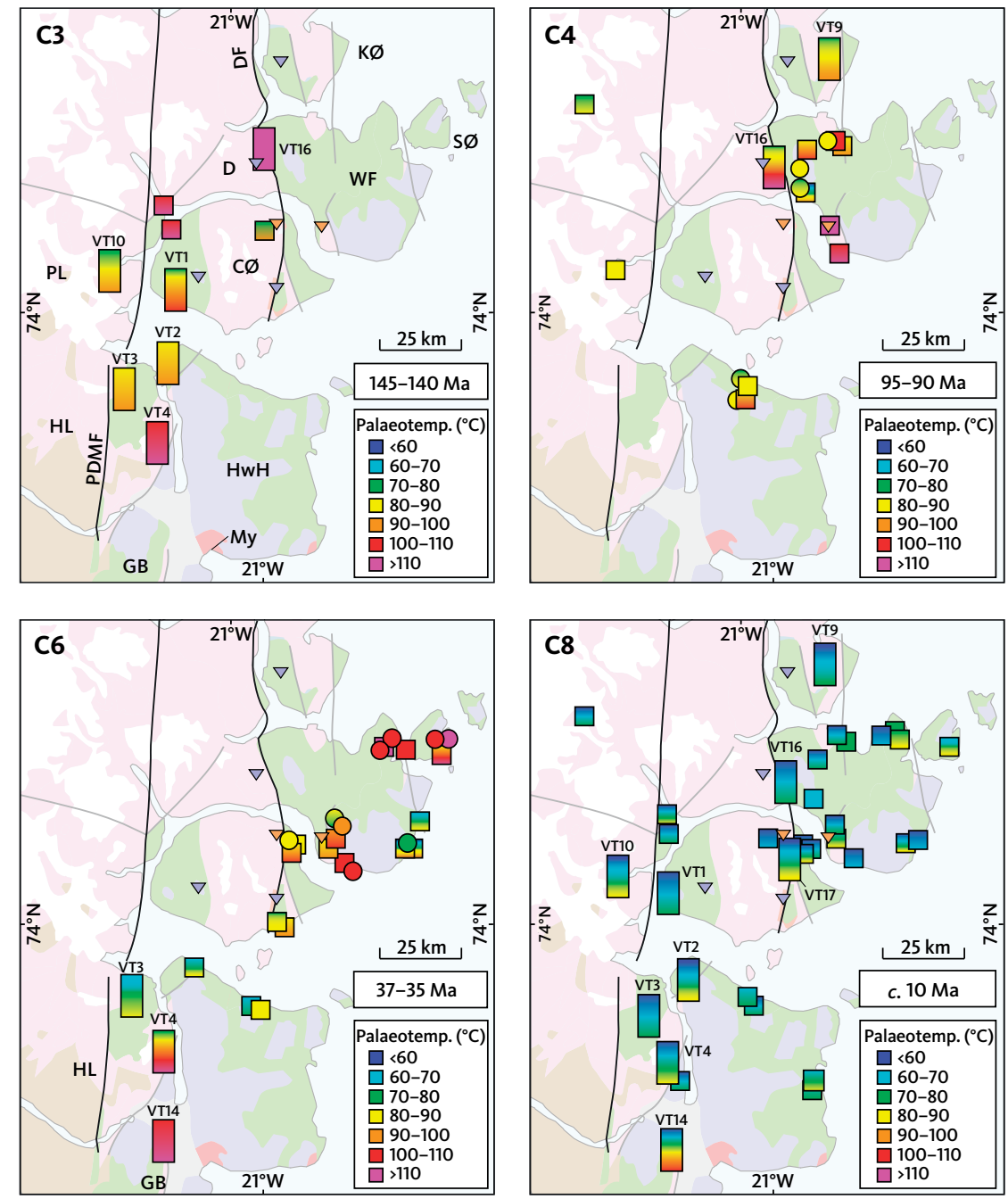

Fig. 16 Focussed view of palaeotemperatures from AFTA and VR around Clavering $\varnothing$ for episodes C3, C4, C6 and C8 (Table 1). Cø: Clavering Ø. D: Dombjerg. DF: Dombjerg Fault. GB: Giesecke Bjerge. HL: Hudson Land. HwH: Hold with Hope. KØ: Kuhn Ø. My: Myggbukta. PDMF: Post-Devonian Main Fault. PL: Payer Land. Sø: Sabine $\varnothing$. VT: Vertical transect. WF: Wollaton Forland. Sample locations and geology legend in Fig. 11. Map location in Fig. 14. 
level suggest a progressive westerly decrease from the coast to inland, while this event is most emphatically expressed around the Eocene intrusive centres in the eastern part of Traill $\varnothing$, in Myggbukta and Sabine $\varnothing$. Highest $\mathrm{C} 6$ palaeotemperatures in excess of $110^{\circ} \mathrm{C}$ are recognised from locations close to late Eocene igneous intrusions on Traill $\varnothing$, while samples near sea level in Wollaston Forland and Hold with Hope reached c. $100^{\circ} \mathrm{C}$ at this time. A decrease of palaeotemperatures with increasing elevation is also evident in samples from vertical transects on Traill $\varnothing$ northwards to Hudson Land (VT6, VT4; Appendix 2.3). The absence of this event in samples away from intrusions indicates distinct hot spots around these intrusive centres. Similar timing between episode $\mathrm{C} 6$ and the age of intrusive bodies at these three hot spots, provides further evidence that C6 is in some way related to these intrusions (Section 5.7).

\subsubsection{Early Miocene episode (C7)}

Cooling began between 20 and 18 Ma. Palaeotemperatures for episode C7 are highly localised to northern Jameson Land (C7 in Fig. 14). Palaeotemperatures exceed $110^{\circ} \mathrm{C}$ around Mestersvig and Wegener Halvø. Values are slightly lower around Schuchert Dal (80$100^{\circ} \mathrm{C}$ ). It seems likely that palaeotemperatures in this episode are related to the intrusive centre of Werner Bjerge, located within the focus area of this episode. The intrusion age of the Malmbjerget stock (25.8 Ma; Fig. 5) within the centre suggests that cooling was somewhat protracted. Late-stage intrusive and hydrothermal activity are alternative possible explanations. The contrast between this episode affecting the southern shores of Kong Oscar Fjord and the end-Eocene C6 episode on the northern shore is a striking feature. The timing constraints from AFTA define this difference very clearly (Appendix 1.6). Early Miocene palaeotemperatures on the southern shore probably overprinted the end-Eocene signature in that region. Cooling attributed to this time interval is identified in data from sample GC1077100 of the early Miocene intrusion on Hvalros $\varnothing(20.3 \pm$ $0.2 \mathrm{Ma}$; Larsen et al. 2014) and interpreted as immediate post-emplacement cooling.

\subsubsection{Late Miocene episode (C8)}

Cooling began at c. $10 \mathrm{Ma}$. Of all the palaeothermal episodes recognised in this study, episode C8 is the most regional in extent, recognised in almost all samples (C8 in Fig. 14). Palaeotemperatures characterising this episode are generally around 60 to $80^{\circ} \mathrm{C}$ at inland locations close to sea level, decreasing with increasing elevation in vertical transects (Appendix 2.3). Note that the timing constraints from AFTA data attributed to this episode in individual samples show some inconsistencies, and in some cases, it remains possible that palaeotemperatures related to the C8 event may in fact relate to either the early Miocene C7 or early Pliocene C9 episodes. This problem relates partly to the relatively low palaeotemperatures characterising this episode in many samples, but also reflects the difficulty in resolving separate episodes that are closely spaced in time. A clear hotspot of palaeotemperatures around $100^{\circ} \mathrm{C}$ is evident at some locations around the eastern end of Kong Oscar Fjord towards the eastern end of Traill $\varnothing$ and near Mestersvig, where AFTA data are dominated by the end-Eocene and early Miocene episodes, respectively. Late Miocene palaeotemperatures decrease in all directions onshore away from these areas, defining a broadly concentric pattern (see Section 6.3).

\subsubsection{Early Pliocene episode (C9)}

Cooling began at c. $5 \mathrm{Ma}$. Episode $\mathrm{C} 9$ is recognised mainly around the eastern end of Traill $\varnothing$ (C9 in Fig. 14). This area is the focus of highest palaeotemperatures in the early and late Miocene episodes (C7, C8), and the early Pliocene episode is defined most clearly in samples for which late Miocene palaeotemperatures around $90^{\circ} \mathrm{C}$ or above have been defined. In these samples, it is clear that two discrete cooling episodes are required within the last $10 \mathrm{Myr}$ or so, due to higher palaeotemperatures in the earlier episode. We infer that the early Pliocene episode was most likely of regional extent and has affected the entire region, but it is only definitively recognised at these locations due to the higher temperatures that remained following late Miocene cooling (see Section 6.3). Early Pliocene cooling is also interpreted for one inland sample on Payer Land, for which the palaeotemperature defined from AFTA is much lower than those attributed to the late Miocene episode at higher elevations (GC1077-32; VT10; Appendix 2.3).

Since several samples from Traill $\varnothing$ and Wegener Halvø define both the C8 and C9 episodes, it seems likely that both episodes did affect the whole region. But over most of the region, with late Miocene palaeotemperatures $<60^{\circ} \mathrm{C}$ in samples at elevations less than $1 \mathrm{~km}$, resolution of distinct $\mathrm{C} 8$ and $\mathrm{C} 9$ episodes is not possible, and in most cases, the effects of both are merged into a single event attributed to the late Miocene.

\subsection{Palaeogeothermal gradients inferred from AFTA in vertical transects}

\subsubsection{Principles of the method}

Where palaeotemperatures can be defined from AFTA over a range of elevations (in outcrop) or depths (in wells), the rate of increase with depth allows definition of the range of palaeogeothermal gradients that can explain the data. Extrapolation of fitted palaeogeothermal gradients from the corresponding unconformity surface to an appropriate value of palaeosurface 
temperature then allows estimation of the amount of additional section required to explain those palaeotemperatures (Green \& Duddy 2012).

Estimating amounts of removed section in this way is subject to a number of critical assumptions. Green et al. (2013) discussed these in detail, and we summarise the major points here. The most critical assumption is that the palaeogeothermal gradient was linear throughout the entire section at the time of maximum palaeotemperatures. This assumption may be invalid if non-burial-related heating (e.g. confined fluid flow) or major differences in lithology produce severely non-linear palaeotemperature profiles, which can result in linear extrapolation overestimating the amount of removed section. For this reason, the values quoted here should be viewed as upper limits to the total amount of section removed. Selection of an appropriate surface temperature is also critical.

Another crucial assumption is that where multiple episodes of exhumation occur within a period not represented by preserved rock, these methods define the thickness of rock that was present at the onset of cooling in each episode. They do not define the total amount of rock removed in any single event (except for the most recent event) because the history between the separate cooling episodes is not constrained (see Appendix 1). For example, in this study, the amount of reburial (if any) prior to the onset of late Miocene cooling/exhumation is not known. Therefore, it is not clear what proportion of the total amount of section present above the Palaeogene basalts, when end-Eocene cooling began, was removed prior to the onset of late Miocene cooling.

If sediments or lavas deposited between the two cooling episodes are still present, the situation is different. In this case, the underlying rock must have been exhumed to the surface and thus cooled to the surface temperature at the time of deposition. The palaeosurface temperature at the appropriate time can be used as a constraint on the reconstruction of the burial and exhumation history of the underlying rock. In addition, the sedimentary remnant provides clear evidence of the additional section (albeit seriously diminished) that is required to explain the palaeotemperatures reached in the subsequent episode.

\subsubsection{Palaeotemperature profiles in vertical transects}

We collected samples from 17 vertical transects (locations in Fig. 11). In Appendix 2 we present a detailed discussion of the results in each transect. For each transect we have avoided including samples over too wide a horizontal distance, to guard against lateral variation in the magnitude of palaeothermal effects, which might arise due to variation in heat flow, differential uplift (tilting) or offsets across major faults. Comparing results from adjacent profiles suggests that this approach is justified (Appendix 2.3).

Reliable definition of palaeotemperature profiles is only possible for the more recent palaeothermal episodes because most samples were totally annealed in the pre-Cenozoic episodes, providing only minimum palaeotemperature estimates. Only in rare situations do samples provide finite palaeotemperature constraints in earlier episodes over a sufficient range of elevations to allow determination of the allowed ranges of palaeogeothermal gradients and removed section.

\subsubsection{Estimates of palaeogeothermal gradients}

For a number of the vertical transects, sufficient constraints are available to justify quantitative determination of palaeogeothermal gradients and removed sections, and here we summarise the results presented in Appendix 2. Maximum likelihood values of palaeogeothermal gradient for the analysed transect, together with the corresponding 95\% confidence limits, are compared in Fig. 17. In most cases, the data only allow definition of broad constraints on the range of palaeogeothermal gradients. This is due partly to limited vertical ranges over which samples are

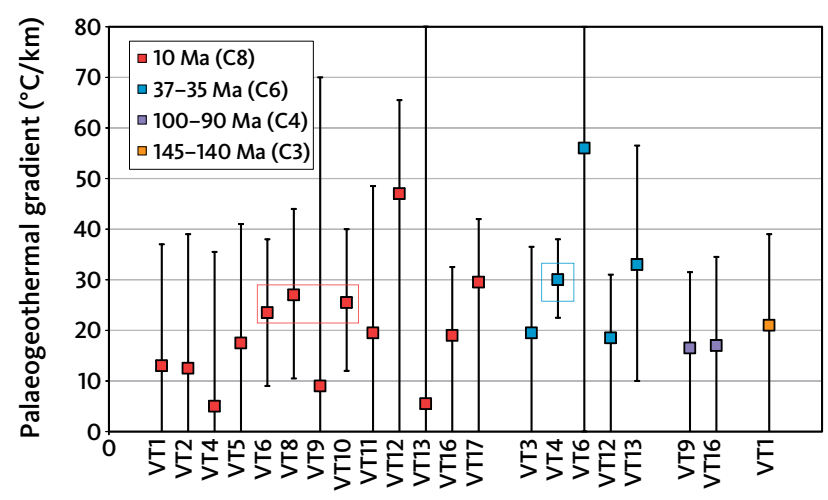

Fig. 17 Comparison of palaeogeothermal gradients in four palaeothermal episodes (C), C4, C6, C8; Table 1) determined from AFTA-derived palaeotemperatures in vertical transects (VTs). Maximum likelihood estimates (squares) with upper and lower 95\% confidence intervals are shown. In most cases, only broad constraints are possible on the range of palaeogeothermal gradients allowed by the data. This is due partly to limited vertical ranges over which samples are available, and partly due to broad palaeotemperature constraints. The best-controlled values are highlighted in boxes, VT6, VT8 and VT10 for the late Miocene C8 episode and VT4 for the end-Eocene C6 episode. All three of the best-constrained estimates for the late Miocene episode define maximum likelihood values around $25^{\circ} \mathrm{C} / \mathrm{km}$. While results from most of the other transects are consistent with this value, end-Eocene constraints from VT4 and VT6 favour higher values that may be due to enhanced heat flow around intrusive bodies of the same age. Location in Fig. 11. Further discussion in Appendix 2. 
available and partly due to broad palaeotemperature constraints in most cases.

Only VT1 provided useful constraints on the earliest Cretaceous C3 episode, suggesting a value close to $20^{\circ} \mathrm{C} /$ $\mathrm{km}$, while no constraints are possible on any of the earlier episodes in any of the transects. VT9 and VT16 provide broad constraints on the mid-Cretaceous C4 episode, again suggesting values around $20^{\circ} \mathrm{C} / \mathrm{km}$. Five transects provide constraints on the end-Eocene C6 episode, of which the tightest constraint is from VT4, suggesting a value around $30^{\circ} \mathrm{C} / \mathrm{km}$. Thirteen transects provide some constraint on the late Miocene C8 episode, of which VT6, VT8 and VT10 are most tightly constrained. Results from these three transects define maximum likelihood values around $25^{\circ} \mathrm{C} / \mathrm{km}$, while results from the other transects are consistent with this value.

\subsubsection{Summary}

In general, estimates of palaeogeothermal gradients in different events are consistent with values around $25^{\circ} \mathrm{C} /$ $\mathrm{km}$ and rule out values in excess of c. $40^{\circ} \mathrm{C} / \mathrm{km}$ (Fig. 17). Early Jurassic palaeotemperature constraints from the VT3 transect (discussed in Appendix 2) suggest a much higher palaeogeothermal gradient, but we regard this as an outlier, perhaps due to faulting, and it is not discussed further. On this basis, we favour an interpretation in which all pre-Cenozoic palaeothermal episodes, as well as the late Miocene and Pliocene episodes, were characterised by palaeogeothermal gradients around $25^{\circ} \mathrm{C} / \mathrm{km}$. Such gradients imply that heating reflects the effects of deeper burial prior to cooling due to exhumation. This is emphasised by the constant offset in palaeotemperature profiles characterising the $\mathrm{C} 1, \mathrm{C} 3$ and $\mathrm{C} 8$ episodes in VT1, Clavering $\varnothing$, while the C1, C2 and C8 episodes in VT17, north-east Clavering $\varnothing$ (Appendix 2.3) provide another example.

A palaeogeothermal gradient around $25^{\circ} \mathrm{C} / \mathrm{km}$ also applies to end-Eocene C6 palaeotemperatures at locations away from intrusive bodies, while VT4 and VT6 define higher palaeogeothermal gradients suggesting locally enhanced heat flows near late Eocene intrusions on Traill $\varnothing$ and eastern Hudson Land. The more localised palaeotemperatures defining the early Eocene C5 and early Miocene C7 episodes are interpreted as localised effects of contact heating around intrusive bodies. 


\section{Integration of AFTA results with geological evidence}

In this Chapter we compare the timing of the ten cooling episodes defined from AFTA (Table 1) with the regional tectono-stratigraphic framework for North-East Greenland (Figs 4, 5), to provide insights into the nature of each episode. We also compare the AFTA results from NorthEast Greenland with two thermal-history studies based on AFTA from East Greenland between 61 and $70^{\circ} \mathrm{N}$ to establish which episodes of cooling and exhumation have affected the entire margin of East Greenland. Note that Fig. 14 displays regional palaeotemperature maps for episodes CO to C9, whereas Fig. 16 displays detailed palaeotemperature maps for episodes C3, C4, C6 and C8 in the Clavering $\varnothing$ region.

\subsection{Late Carboniferous episode (CO)}

The C0 episode (beginning between 320 and $300 \mathrm{Ma}$ ) correlates with the regional latest Carboniferous to mid-Permian unconformity (ranging from about 310 to $280 \mathrm{Ma}$ ), which separates the upper Permian sediments of the Huledal Formation from the underlying, tilted and truncated latest Devonian to Carboniferous strata of the Traill Ø Group (Fig. 18; Surlyk 1990; Vigran et al. 1999; Stemmerik 2000). This unconformity marks the most profound change in tectonic style and overall depositional environment in the post-Caledonian development of East Greenland (Surlyk 1990). This is supported by our results that demonstrate removal of a kilometre-thick rock column between the onset of $\mathrm{CO}$ exhumation and the deposition of Permian sediments on Clavering $\varnothing$, where a basement sample (GC1077-86) in depositional contact with upper Permian sediments, cooled from $>105^{\circ} \mathrm{C}$ to a late Permian surface temperature of $c .25^{\circ} \mathrm{C}$ during episode $\mathrm{CO}$. The unconformity is represented by a sub-Permian peneplain covered by the upper Permian sediments of the Huledal Formation (Haller 1971; Surlyk et al. 1984, Larsen 1988; Surlyk 1990, 2003). This, together with the recognition of this episode over a wide area (CO in Fig. 14) suggests that the CO cooling episode reflects exhumation of present-day basement terrains, for example, west of Jameson Land and Traill $\varnothing$ during the interval represented by this unconformity. This episode of regional exhumation resulted in the formation of the peneplain, which was subsequently buried below the mid-Permian Huledal Formation.

\subsection{Middle Triassic episode (C1)}

The C1 episode (beginning c. $240 \mathrm{Ma}$ ) post-dates the late Permian to Lower Triassic rift succession and correlates with the deposition of the thick siliciclastic wedges of the Pingo Dal Group in the sedimentary basins on Jameson
Land and Traill $\varnothing$ (Fig. 18). These units overly the marine mudstones of the Wordie Creek Group on northern Jameson Land (Clemmensen 1980; Bjerager et al. 2006). Extensive $\mathrm{C} 1$ cooling in the basement areas west of these basins (C1 in Fig. 14) suggests that this event represents regional erosion of the areas to the west, providing sedimentary input to the basins (the Pingo Dal Group and younger units of the Scoresby Land Group). This indicates differential movement on the PDMF system at this time in the southern part of the study area. In the north, however, $\mathrm{C} 1$ exhumation dominates the area east of the PDMF system, suggesting a different tectonic history. The Early-Middle Triassic rifting and regional exhumation represents an important phase during the break-up of Pangaea (Seidler et al. 2004; Oftedal et al. 2005).

\subsection{Early Jurassic episode (C2)}

The C2 episode (beginning c. $180 \mathrm{Ma}$ ) corresponds to major regional uplift and erosion in East Greenland around the Early-Middle Jurassic boundary that has been established from stratigraphic and sedimentological observations (Figs 18-20; Surlyk \& Ineson 2003; Surlyk 2003). We therefore interpret the C2 episode as representing regional denudation that affected areas west, east and north of the Jameson Land Basin (C2 in Fig. 14). The $C 2$ episode could not be resolved in the AFTA data from Jameson Land, where both Lower Jurassic and Triassic strata are present. The extensive denudation that started in the Early Jurassic eventually provided siliciclastic input to the Jurassic basins; in particular corresponding to the Middle Jurassic sandstones of the Charcot Bugt and Pelion formations that overlie Triassic and upper Permian sediments or peneplained basement on Milne Land and Kuhn $\varnothing$ (see fig. 44 in Surlyk 2003). The C2 episode slightly predates the Middle Jurassic (Bajocian) sequence boundary at c. $170 \mathrm{Ma}$ in the Jameson Land Basin but overlaps with the Toarcian (183-174 Ma; Cohen et al. 2013) uplift and erosion on Wollaston Forland and Kuhn $\varnothing$ indicated (Fig. 20; Surlyk \& Ineson 2003). Given that the deposition of the Pelion Formation that rests on the Jurassic peneplain on Kuhn $\varnothing$ began at the Bajocian-Bathonian transition (c.170 $\mathrm{Ma})$, we can estimate the duration of exhumation during the C2 episode to be in the order of $10 \mathrm{Myr}$.

AFTA data provide evidence for Early Jurassic exhumation of the basement terrains in the interior of the study area. However, Lower Jurassic sediments are present in the Jameson Land Basin, so whereas the basin subsided, the areas to the west of the basin were uplifted, and this implies that the PDMF system west of 


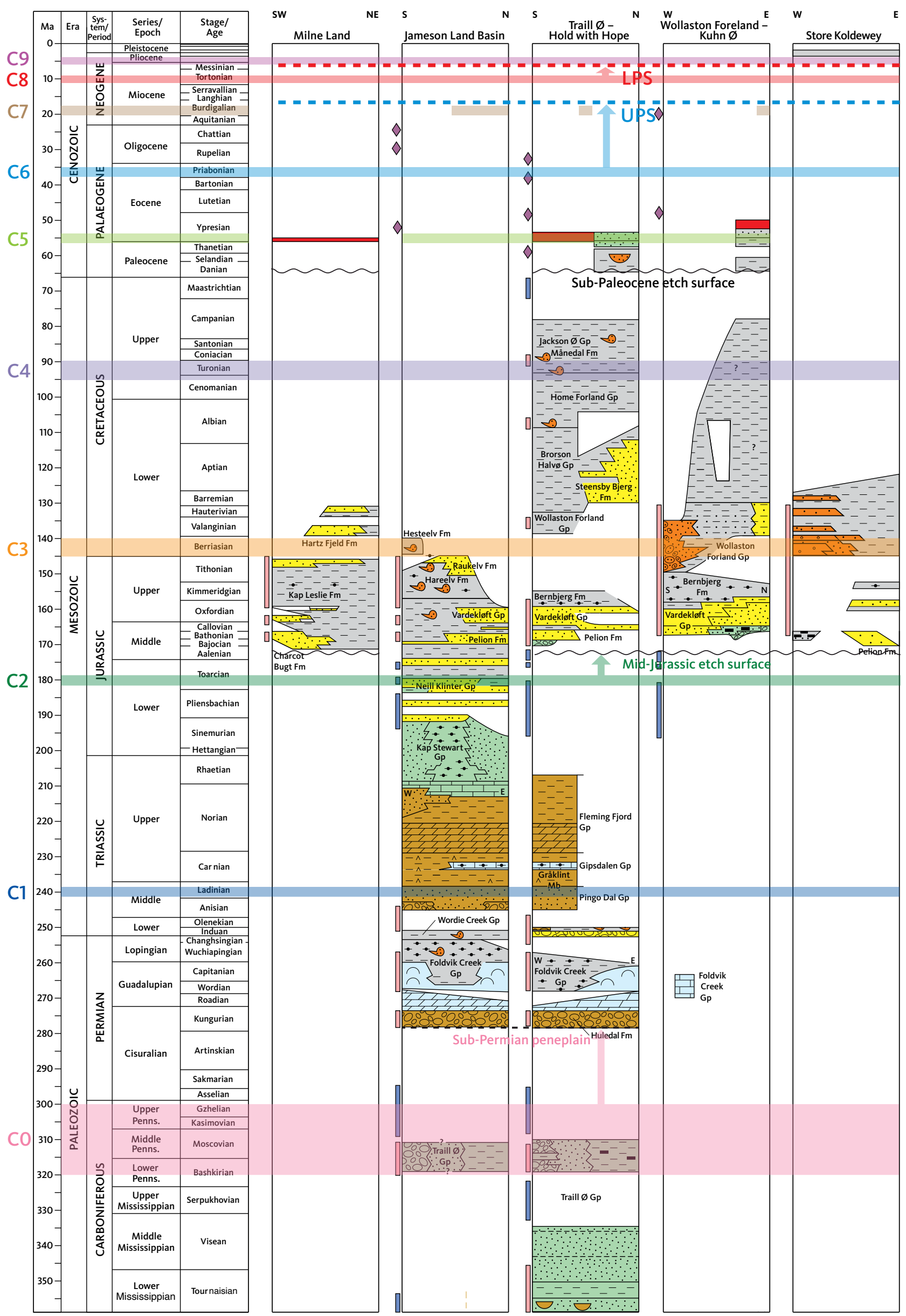

Fig. 18 Caption and legend on the next page. 
Sedimentary environments

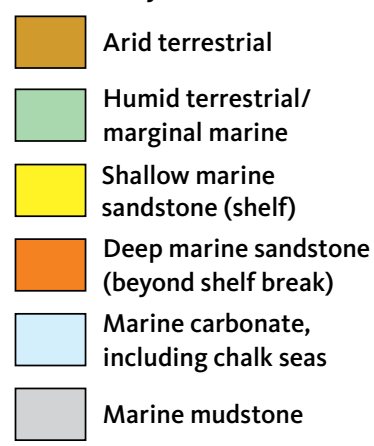

Extrusive igneous rocks

Volcanics

Lithological symbols

\begin{tabular}{|c|c|}
\hline $\begin{array}{ll}0 & 0\end{array}$ & Ice-rafted dropstone \\
\hline 20 & Conglomerate \\
\hline & Sandstone \\
\hline$\div \div \dot{*}$ & Siltstone \\
\hline$[-]$ & Mudstone/shale \\
\hline & $\begin{array}{l}\text { Organic rich } \\
\text { mudstone/shale }\end{array}$ \\
\hline \begin{tabular}{|l|l|}
1 \\
1
\end{tabular} & Limestone \\
\hline 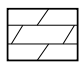 & $\begin{array}{l}\text { Dolomite/evaporites/ } \\
\text { limestone }\end{array}$ \\
\hline - & Coal layers \\
\hline$\wedge \wedge \wedge$ & Anhydrite/gypsum \\
\hline Other & symbols \\
\hline$\cap$ & Bioherm \\
\hline C & Base-of-slope fans \\
\hline$\nabla$ & Channel fills \\
\hline ל & $\begin{array}{l}\text { Prograding shelf-margin } \\
\text { sediment wedge }\end{array}$ \\
\hline
\end{tabular}

Intrusive magmatism

$\diamond$ Mainly mafic

Tectonic and orogenic events

Rifting/extension

Inversion/compression/ uplift

Peneplains

- - - Planation surface

$\frown$ Etch surface

Formation of peneplain

Time interval during which

cooling began
Fig. 18 (continued) Regional cooling episodes recognised from AFTA data in this study (Table 1), time intervals for the formation of peneplains and the lithostratigraphic scheme for North-East Greenland (Fig. 4). Vertical extent of the horizontal, coloured bars indicates uncertainty in cooling episode onset. Exhumation in episodes $\mathrm{C} 0-\mathrm{C} 4, \mathrm{C} 6, \mathrm{C} 8$ and $\mathrm{C} 9$ were of regional extent whereas episodes C5 and C7 were local, partly related to magmatic activity. LPS: Lower Planation Surface. UPS: Upper Planation Surface.

Jameson Land was again active during the C2 episode. On Kuhn $\varnothing$, in the northern part of the study area, the presence of a peneplain below Middle Jurassic sediments indicates that uplift and erosion not only affected the hinterland but also parts of the rift. This agrees with the interpretation of Surlyk (1978a) that Early Jurassic uplift and erosion was caused by a dome centred north of Jameson Land. However, our results show that the exhumation also affected areas far into the hinterland. The erosional products derived from C2 exhumation, for example the Pelion Formation, eventually reached the rift basins along most of the margin, and it thus seems likely that there were active movements also along the northern part of the PDMF system during this episode.

\subsection{Earliest Cretaceous episode (C3)}

The C3 episode (beginning between 145 and $140 \mathrm{Ma}$ ) coincides with the most important phase of extensional tectonics in the Mesozoic that was initiated in middle Volgian times (Tithonian-Berriasian transition, c. $145 \mathrm{Ma}$; Surlyk \& Ineson 2003). During this phase, the area north of Kong Oscar Fjord was broken up into tilted blocks and deposition was almost exclusively coarse grained in proximity to active faults (Surlyk 2003; Figs 19, 20). The primary area where the $\mathrm{C} 3$ episode has been recognised overlaps with the area influenced by the latest Jurassic to earliest Cretaceous rift climax that led to the deposition of the deep-water, conglomerate-dominated Wollaston Forland Group (C3 in Figs 14, 16; Surlyk 1978b, 2003; Surlyk \& Korstgård 2013; Henstra et al. 2016a). In this region, centered on Clavering $\varnothing$, the AFTA data define the C3 episode in samples west of the Dombjerg Fault (Surlyk 1978b). This fault system constituted the western boundary fault during the rift climax and formed the high and steep, western coastline of the sea in the earliest Cretaceous (Surlyk 1978b). The source area for the Wollaston Forland Group was the area to the west of the boundary fault with the coarsest basin fill derived from the crestal areas along the fault in agreement with outline of the region affected by exhumation during episode C3 (Surlyk 1978b, 2003). We therefore interpret this episode as the result of regional uplift and erosion that accompanied the rift climax (Fig. 18), not only along the margin of the rift but also of hinterland areas at considerable distance 
S

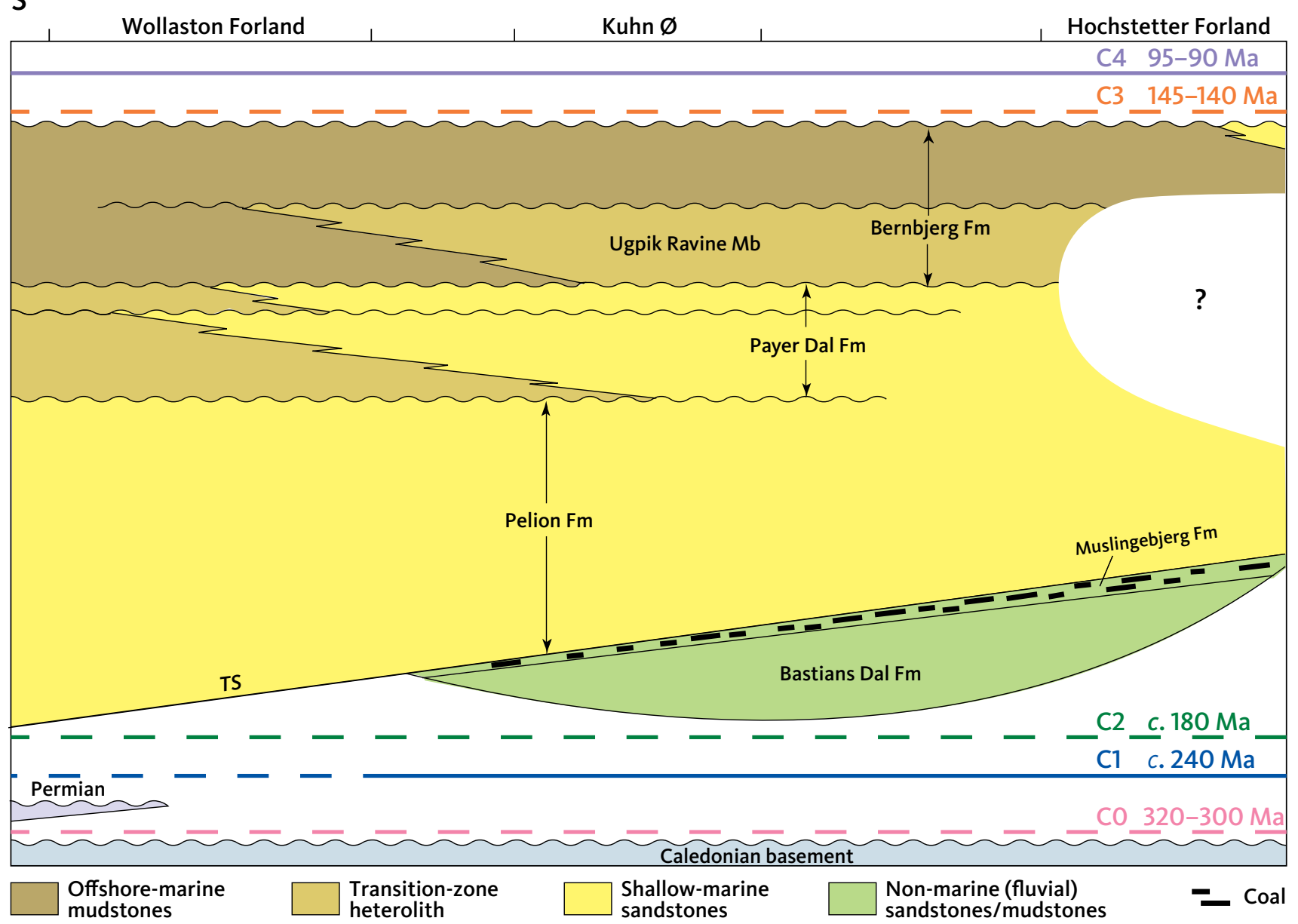

Fig. 19 Jurassic stratigraphy in the Wollaston Forland area along a N-S profile and timing of the pre-Cenozoic cooling episodes estimated from AFTA (Table 1). The erosional unconformity at the base of the Jurassic is caused by Early Jurassic doming and regional uplift of northern East Greenland (Surlyk 1978a, 2003). Earlier events may have contributed to the pre-Jurassic denudation, e.g. during the Middle Triassic. The Middle Triassic C1 episode dominates the AFTA data to such a degree that the Early Jurassic C2 episode cannot be resolved along the profile. Maximum palaeotemperatures (and burial) of the Mesozoic sediments occurred prior to regional uplift and erosion during the mid-Cretaceous C4 episode. Samples from Wollaston Forland cooled below $100^{\circ} \mathrm{C}$ in the $\mathrm{C} 4$ episode, so no earlier events can be resolved from this area. Solid line: Cooling episode resolved along the transect. Dashed line: Cooling episode not resolved along the transect. TS: Transgressive surface. Modified after Surlyk (2003).

from the rift basins (e.g. sample GC1077-71, about 150 $\mathrm{km}$ west of the Dombjerg Fault).

Given the widespread, yet sporadic, occurrence of this event west of Milne Land and in the interior (west of Ymer $\varnothing$ and Clavering $\varnothing$ ) it seems likely that exhumation during episode C3 affected a much wider region. This assertion is supported by the contemporaneous siliciclastic deposits of the Hartz Fjeld Formation (Milne Land) and Raukelv Formation (Jameson Land). In the interior, it also seems likely that some degree of Mesozoic faulting has taken place because samples with high C3 palaeotemperatures are adjacent to samples with high C2 or C1 palaeotemperatures.

On the North-East Greenland shelf, the base of deposits of inferred latest Jurassic - Early Cretaceous age defines a characteristic low-angular, erosional truncation of the underlying strata (Hamann et al. 2005). Hamann et al. (2005) correlated this unconformity to the mid-Volgian unconformity (c. $145 \mathrm{Ma}$ ) at the base of the Wollaston Forland Group onshore and interpreted it to mark the onset of rifting in the latest Jurassic. We suggest that this offshore unconformity corresponds to exhumation onshore.

\subsection{Mid-Cretaceous episode (C4)}

The C4 episode (beginning between 95 and $90 \mathrm{Ma}$ ) most likely corresponds to the mid-Turonian, erosional base of the Jackson $\varnothing$ Group that records a phase of basin reorganization (Fig. 18; Bjerager et al. 2020). The exhumation involved erosion of Jurassic and Triassic 


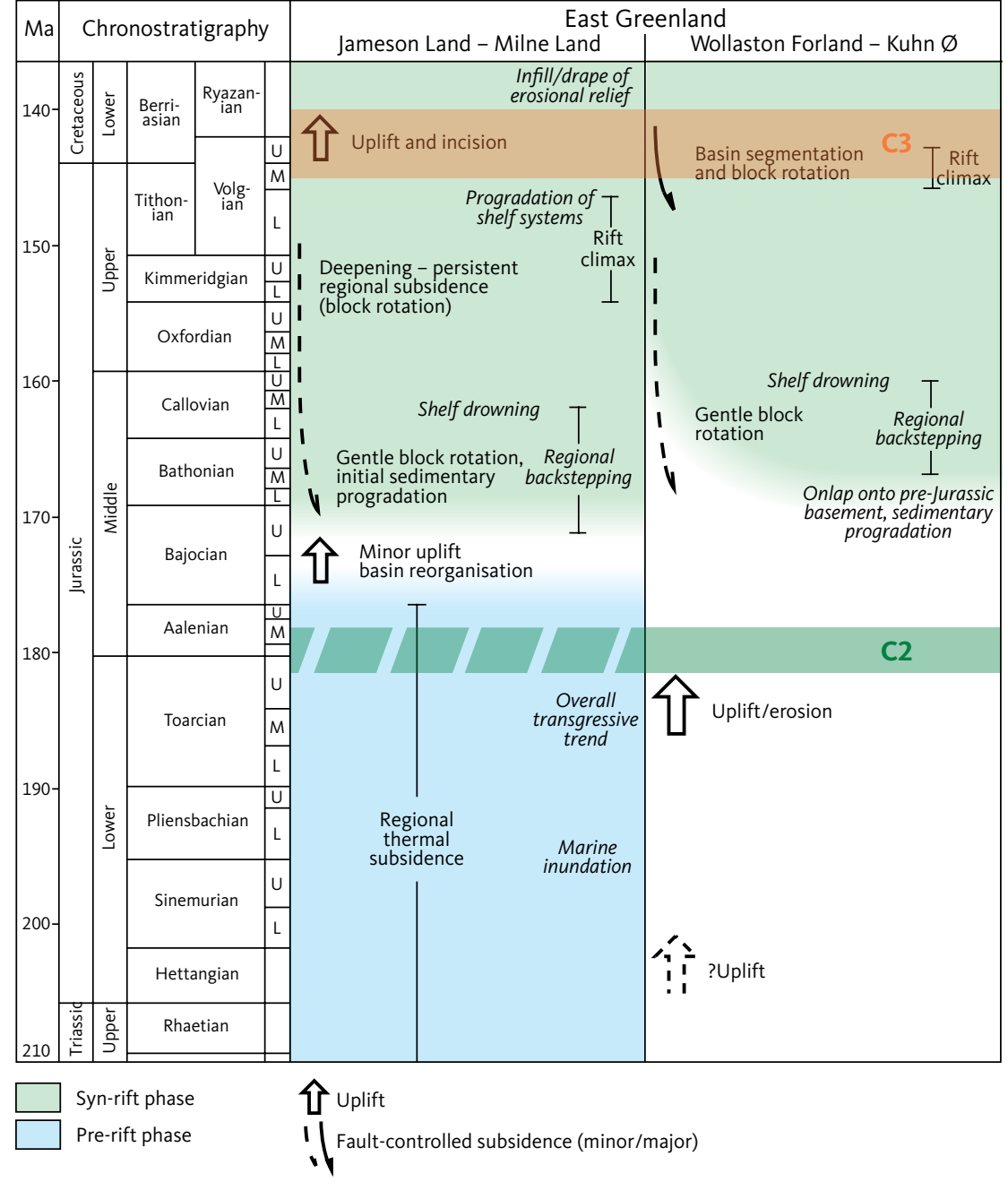

Fig. 20 Summary of the main tectonic events and trends in Jurassic - Early Cretaceous basin evolution in East Greenland compared with the timing for the onset of cooling in the Early Jurassic C2 and the earliest Cretaceous C3 episodes. Note that C2 is not resolved on Jameson Land as indicated by the dashed green band. Arrows indicating uplift from Surlyk \& Ineson (2003). Modified from Surlyk \& Ineson (2003). sandstones, Permian carbonates and a wide spectrum of Caledonian-derived crystalline clasts that were reworked into the Månedal Formation (Surlyk \& NoeNygaard 2001). Note that Upper Cretaceous strata of post-Turonian age are only known from the easternmost parts of Wollaston Forland and Hold with Hope and locally on Traill $\varnothing$ and Geographical Society $\varnothing$ (Donovan 1957; Parsons et al. 2017; Nøhr-Hansen et al. 2019; Bjerager et al. 2020). However, the relative uniformity of the cooling in episode C4 across the entire study area outside the Jameson Land Basin and the coastal areas, suggests that exhumation affected most of the study area - even the coastal areas where the AFTA data were overprinted by later events (C4 in Fig. 14,16).

AFTA data do not record cooling related to the pronounced mid-Albian (c. $105 \mathrm{Ma}$ ) fault-associated unconformity that is observed on Hold with Hope, Clavering $\varnothing$ and Wollaston Forland (Kelly et al. 1998; Whitham et al. 1999; Bjerager et al. 2020). This indicates that the fault activity predominantly occurred during subsidence of hanging-wall blocks.

\subsection{Early Eocene episode (C5)}

The sporadic occurrence of cooling (beginning at c. 55 $\mathrm{Ma})$, together with the clear proximity of these samples to mapped intrusive rocks of similar age, suggest that episode C5 is related to intrusive bodies (Fig. 21). This is clearly the case on Jameson Land, where the extent of this episode overlaps with intensive Palaeogene intrusive activity, and where a dyke is dated to c. $53 \mathrm{Ma}$ (NoeNygaard 1976; Larsen et al. 2014). Except for the few isolated occurrences in the north, episode C5 is strikingly focussed within the vicinity of Jameson Land.

We therefore suggest that the palaeotemperatures characterising this episode are most likely due to either contact or hydrothermal effects associated with igneous activity. No evidence for any regional Maastrichtian-Paleocene or Paleocene-Eocene exhumation has been identified in this study, but there is a hiatus at the base of the Paleocene succession and material derived from reworked Upper Cretaceous units are present within the Paleocene deposits (Nøhr-Hansen et al. 2011). As discussed in Section 2.3, thick volumes of volcanic and sedimentary rocks accumulated across 


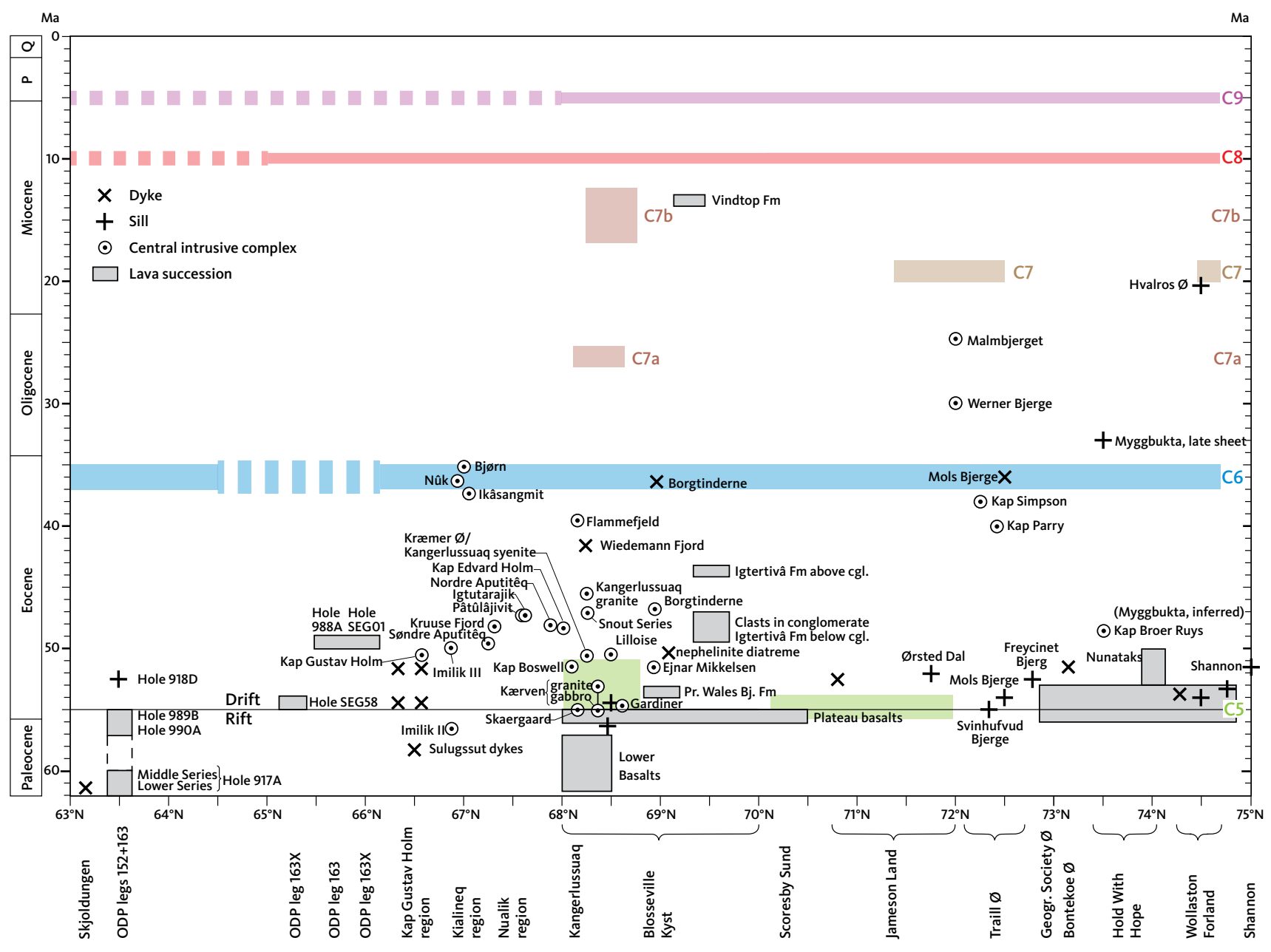

Fig. 21 North-south extent of Cenozoic cooling events identified from AFTA data along the East Greenland margin (Green et al. 2014; Japsen et al. 2014; this study) compared to igneous activity from Fig. 5 (Larsen et al. 2014). Coloured bands along the south-north axis represent the geographical extent of each episode. Vertical extent of the coloured bands indicate uncertainty for the onset of the cooling episode. Dashed bands represent areas where the presence of these episodes is inferred. The presence of the C9 episode between 68 and $70^{\circ} \mathrm{N}$ was inferred by Japsen et al. (2014) by integration of AFTA data with results from stratigraphic landscape analysis (Bonow et al. 2014). The C6, C8 and C9 episodes are interpreted as representing regional events of uplift and erosion in the end-Eocene, late Miocene and early Pliocene episodes, respectively. The early Eocene C5 episode is related to the intense magmatic activity during breakup. C7, C7a and C7b are discrete events along the coast that are partly related to thermal activity and partly to exhumation in the early Miocene, late Oligocene and middle Miocene episodes, respectively.

the East Greenland margin in response to subsidence during and after break-up. Therefore, maximum palaeotemperatures were likely achieved after, rather than before, continental break-up in the earliest Eocene, and consequently any early Palaeogene exhumation cannot not be detected by AFTA.

\subsection{End-Eocene episode (C6)}

The C6 episode (beginning between 37 and $35 \mathrm{Ma}$ ) correlates with the regional post-breakup unconformity that separates the Palaeogene basalts from Quaternary deposits. The episode is recognised in AFTA data in samples of Palaeogene and older age in a band from Wollaston Forland over Ymer $\varnothing$ to Traill $\varnothing$ and in Liverpool Land, south-eastern Jameson Land and Blosseville Kyst (C6 in Figs 14, 16). Evidence of this episode is most strongly expressed on eastern Traill $\varnothing$, but absent on western and northern Jameson Land - possibly due to the local effects of the early Eocene C5 and the early Miocene C7 episodes.

Constraints on the $\mathrm{C} 6$ episode are tight along some vertical transects. For example, on Hudson Land (VT4) where the palaeogeothermal gradient varies between 20 and $40^{\circ} \mathrm{C} / \mathrm{km}$ (Appendix 2.3). Additional burial is required to explain the palaeotemperatures in this episode, with an additional contribution from elevated heat flow around intrusive bodies. The summit intercept at VT4 for this episode is about $70^{\circ} \mathrm{C}$, which requires that 2 $\mathrm{km}$ or more have been removed since the late Eocene at this location. Palaeogene basalts are not present on the summits of Hudson Land, but they do occur on nearby summits, for example on Clavering $\varnothing$. It thus seems likely that the end-Eocene palaeotemperatures were 
mainly due to burial below a cover of Eocene basalts and sediments. See further discussion in Section 6.1.1.

We have not recognised episode $\mathrm{C} 6$ in the western part of our study area where the mid-Cretaceous C4 episode dominates and thus apparently makes it difficult to resolve the effects of the end-Eocene episode in the AFTA data. The effects of the end-Eocene episode appear to decrease rapidly westwards, such that the boundary between regions showing the C4 and C6 episodes is almost mutually exclusive (Fig. 14), although some degree of overlap does exist in the region around Hold with Hope to Wollaston Forland. See Section 6.1.2 for a discussion on extent of exhumation during the $\mathrm{C} 6$ episode in relation to stratigraphic landscape analysis. In the central part of the region, this and later periods of uplift are represented by a north-south-trending, left-lateral fault system that crosscut the margin and reactivated older fault systems in a strike-slip tectonic regime, with south-east-north-west-oriented, maximum horizontal stress (Guarnieri 2015).

The C6 episode affected the entire East Greenland margin (Fig. 21). Consequently, we interpret it as representing regional uplift resulting in kilometre-scale exhumation. Results from Traill $\varnothing$ suggest a significantly higher basal heat flow in that area. This is consistent with the presence of major igneous bodies of similar age in this region (Price et al. 1997; Larsen et al. 2014).

Off North-East Greenland, steep prograding clinoforms occur above a horizon defining erosional incision that Petersen (2019) dated broadly as late Eocene to mid-Miocene age (Fig. 6E). The clinoforms are caused by extensive mass wasting into the outer part of the shelf due to tectonic uplift of the inner part of the shelf and onshore areas, south of Store Koldewey (Petersen 2019). We suggest that the mass wasting is due to the uplift of the margin of North-East Greenland during the end-Eocene $\mathrm{C} 6$ episode, and thus that the horizon defining the erosional incision can be dated to about $35 \mathrm{Ma}$.

\subsection{Early Miocene episode (C7)}

The C7 episode (beginning between 20 and $18 \mathrm{Ma}$ ) is restricted to the northern parts of Jameson Land around the igneous centre of Werner Bjerge and Malmbjerget (C7 in Fig. 14), suggesting that it does not reflect regional exhumation. Although these centres are older (Oligocene, Fig. 21) than the onset of cooling in this episode, the spatial association of cooling with the intrusive centre implies a direct link. We therefore conclude that this episode represents a local palaeothermal anomaly associated with emplacement of the igneous centres on northern Jameson Land. However, a component of uplift and erosion is likely to be associated with episode C7 (see the discussion of landscape analysis of Stauning Alper in Section 6.4).

\subsection{Late Miocene episode (C8)}

The C8 episode (beginning at c. $10 \mathrm{Ma}$ ) also correlates with the regional post-breakup unconformity that separates the Palaeogene basalts from Quaternary deposits (Fig. 18) and is recognised across almost the entire study area (C8 in Figs 14, 16). At most locations, palaeogeothermal gradients around $25^{\circ} \mathrm{C} / \mathrm{km}$ provide a satisfactory description of the palaeotemperatures in this episode. We therefore interpret palaeotemperatures characterising this episode in terms of depth of burial, with cooling due to exhumation. While episode C8 is not recognised in the western parts of Jameson Land, because of the strong signature of the early Miocene $\mathrm{C7}$ episode there, it seems likely that late Miocene cooling also affected that region to some degree.

In the interior highlands, late Miocene palaeotemperatures in samples that also record the mid-Cretaceous C4 episode can be explained by palaeoburial below a late Miocene palaeosurface, corresponding to the general summit level (UPS) in these mountains (Fig. 22). The C8 episode in the interior highlands can thus be explained in terms of the incision of the present-day relief below the present-day summits (UPS), with little or no regional denudation. In contrast, over much of the coastal region, an additional section above the present-day summit levels must have been present when cooling began at c. $10 \mathrm{Ma}$ in this episode (Section 6.2). This is demonstrated by C8 palaeotemperatures that extrapolate to likely values of palaeosurface temperatures at elevations well above the present-day topography (Appendix 2.3; e.g. VT1-6, 9, 12-16).

As Palaeogene basalts are present in the summits at several localities, much of the additional kilometre or more of removed section must represent additional basalts and post-basalt sediments. Results from the vertical transects in the coastal region typically require a cover above the summits of about $1 \mathrm{~km}$ in the late Miocene (palaeogeothermal gradient $25^{\circ} \mathrm{C} / \mathrm{km}$, late Miocene surface temperature $15^{\circ} \mathrm{C}$; Appendix 2). Around eastern Traill $\varnothing$, C8 palaeotemperatures are in excess of $100^{\circ} \mathrm{C}$ close to igneous intrusions, and palaeogeothermal gradients are higher than in areas immediately to the west. However, similar amounts of missing section are inferred here as in the areas away from the intrusions.

We therefore interpret late Miocene palaeotemperatures over the study region as representing deeper burial, combined with an elevated heat flow in the vicinity of Traill $\varnothing$. This represents a diminishing signature of late Eocene intrusive activity away from the main intrusive centres. This is probably also true in samples around the early Miocene intrusions at Werner Bjerge. Late Miocene cooling therefore reflects regional exhumation, where cooling of inland samples reflects incision of the present-day relief below the present-day summit 


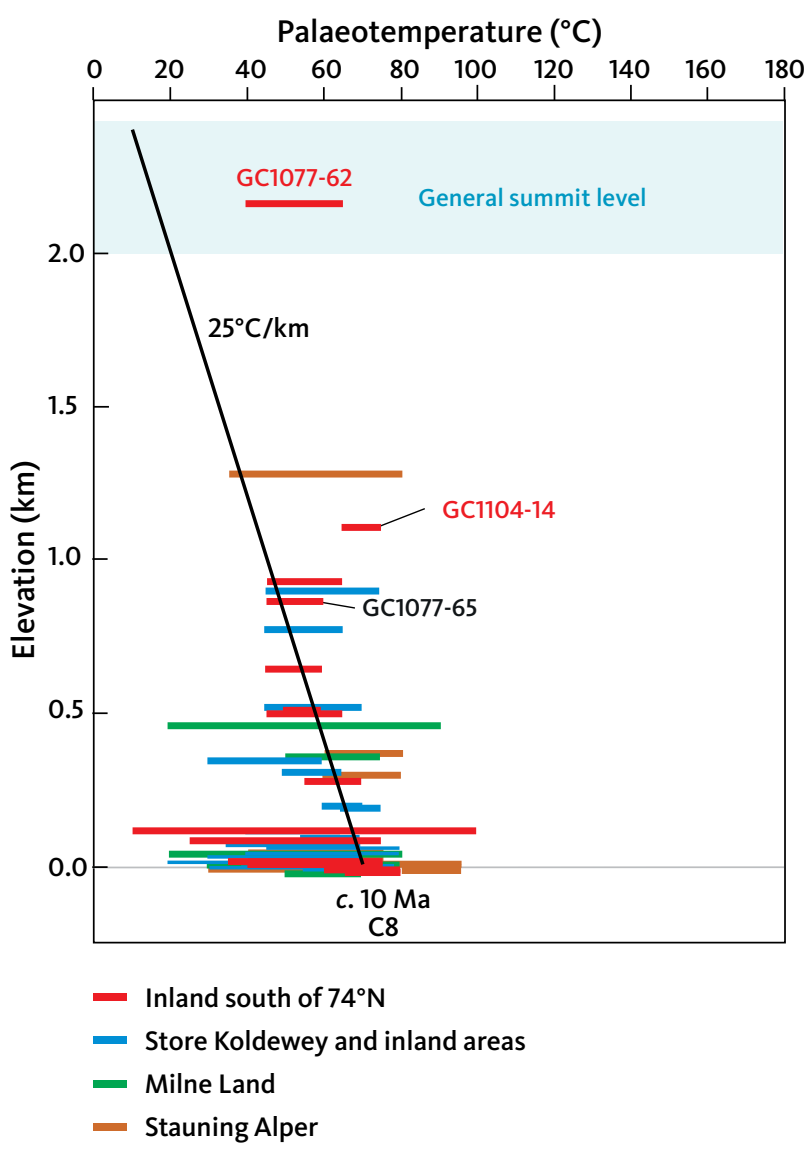

Fig. 22 Late Miocene C8 palaeotemperature constraints from AFTA in samples from four sub-regions in the interior basement terrains plotted against elevation. Outlying samples in which the mid-Cretaceous C4 episode is not identified are omitted. Results from these regions are consistent with a linear gradient of $25^{\circ} \mathrm{C} /$ $\mathrm{km}$ and extrapolate to a typical palaeosurface temperature at the general summit level of 2.0 to $2.5 \mathrm{~km}$ a.s.l. (corresponding to the UPS, the Upper Planation Surface). Cooling from these palaeotemperatures over the last $10 \mathrm{Ma}$ can be explained by incision below the regional summit level. Sample GC1104-14 for which episode C4 is not resolved, is included to illustrate the likely influence of unresolved cooling events. The results for this sample and for GC1077-65 from about the same elevation and area provide a clear example of the importance of unresolved multiple cooling episodes. Only the constraints for sample GC1077-62 plot above the regional trend.

level (UPS). This cooling episode is therefore interpreted as representing the main uplift of the continental margin after break-up in the North-East Atlantic.

Off North-East Greenland, massive shelf progradation occurred above a distinct angular unconformity, the IMU (Fig. 6; Hamann et al. 2005; Berger \& Jokat 2008; Døssing et al. 2016; Petersen 2019). Døssing et al. (2016) estimated the age of the IMU to be middle to late Miocene (15-10 Ma) based on ODP data (Myhre et al. 1995; Hull et al. 1996). The IMU marks the termination of synrift deposition in the deep-sea basins and the accelerated widening of the Fram Strait, and it is linked to the onset of late Miocene uplift and massive shelf progradation on the North-East Greenland margin (Døssing et al. 2016). We therefore suggest that the uplift onshore and the subsequent progradation offshore began during the late Miocene episode, and thus that the IMU can be dated to about $10 \mathrm{Ma}$.

\subsection{The early Pliocene episode (C9)}

The $\mathrm{C} 9$ episode (beginning at c. $5 \mathrm{Ma}$ ) is recognised only in areas where palaeotemperatures in the early or late Miocene episodes $(C 7, C 8)$ are particularly high (e.g. eastern Traill Ø; compare C7-C9 in Fig. 14). This episode also correlates with the regional post-breakup unconformity that separates the Palaeogene basalts from Quaternary deposits. Since the extent of the exhumation during this event cannot be established from AFTA or the stratigraphic record, we return to this in Section 6.5 where we discuss episode C9 alongside evidence from stratigraphic landscape analysis.

\subsection{Comparison with results from adjacent areas of East Greenland}

Thermal-history studies based on AFTA data have previously been published for two regions of East Greenland to the south of the present study region: South-East Greenland (Green et al. 2014; 61-66 $\mathrm{N}$ ) and southern East Greenland (Japsen et al. 2014; primarily $68-70^{\circ} \mathrm{N}$ ). Compilation of the results of these studies and those of the present study show that the timing of cooling in many of the palaeothermal episodes recognised in each of these regions show a high level of consistency (Fig. 23).

The results presented here concerning the Cenozoic development of North-East Greenland reveal cooling in the end-Eocene $\mathrm{C} 6$ and late Miocene $\mathrm{C} 8$ episodes, representing exhumation, interpreted to have affected most (perhaps all) of the region (see Sections 6.1 and 6.2). Early Pliocene C9 exhumation, resolved in restricted locations, is also inferred to have affected much of the region. We regard these three episodes as representing key phases of uplift in the regional development of the present-day continental margin of North-East Greenland.

End-Eocene $\mathrm{C} 6$ and the late Miocene C8 episodes correlate closely with events in southern East Greenland and South-East Greenland (Fig. 23). In southern East Greenland $\left(68-71^{\circ} \mathrm{N}\right)$, episodes $\mathrm{C} 6$ and $\mathrm{C} 8$ represent the main events involved in the uplift of the present-day mountains of the continental margin Japsen et al. 2014). Integration of AFTA data with results from stratigraphic landscape analysis (Bonow et al. 2014), led Japsen et al. (2014) to conclude that a significant episode of early Pliocene uplift also affected that region. Thus, our results define a consistent style of development of the continental margin in these two areas of East Greenland. In South-East Greenland $\left(61-66^{\circ} \mathrm{N}\right)$, while cooling 

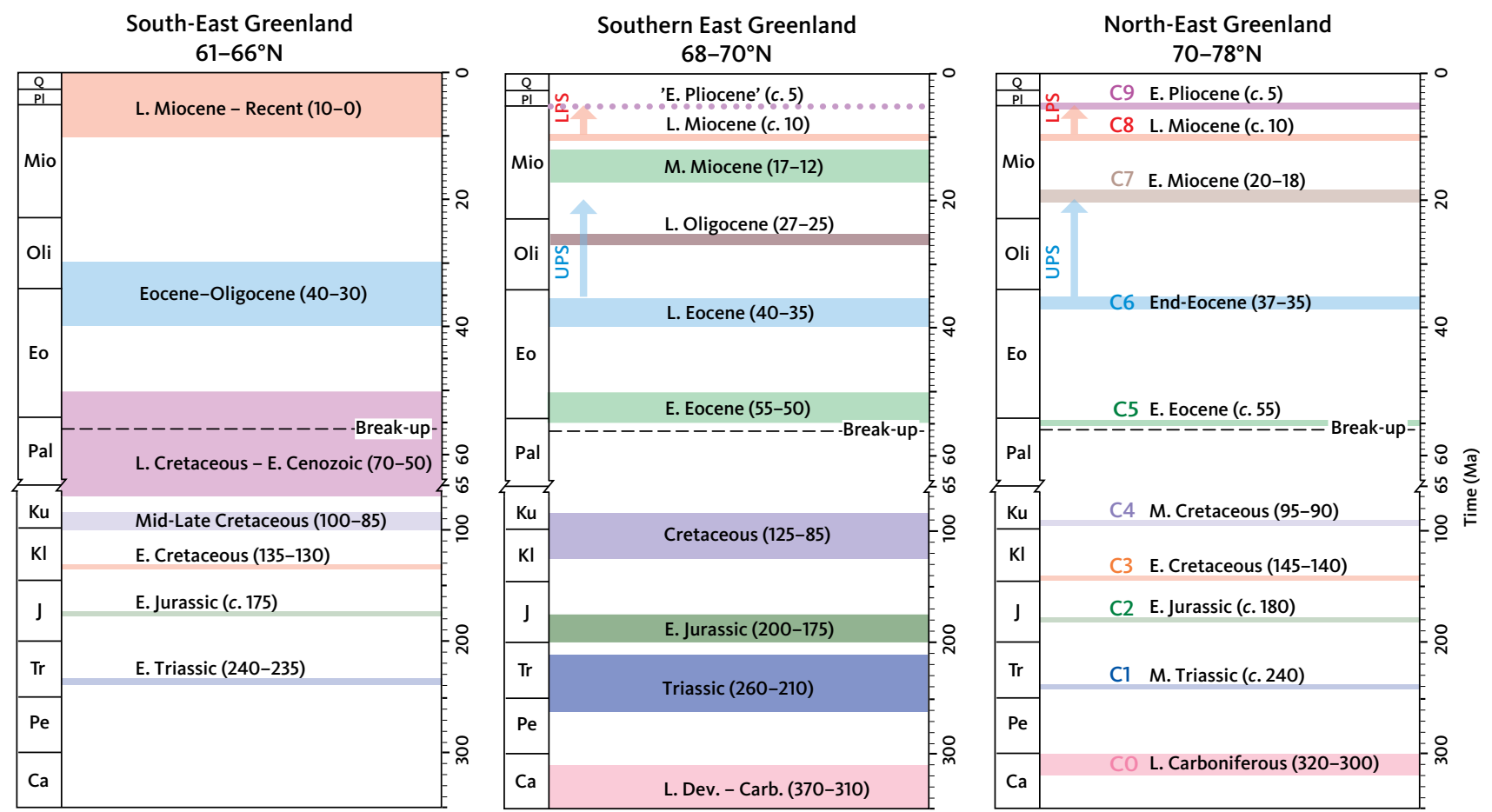

\footnotetext{
Uplift event from stratigraphic landscape analysis - Time interval during which cooling began (10-0) Onset of cooling (Ma) from AFTA
}

Fig. 23 Timing of post-Devonian cooling episodes in East Greenland estimated from AFTA data and time intervals for formation of peneplains. South-East Greenland (Green et al. 2014; 47 samples, 61-66 N); southern East Greenland (Japsen et al. $2014 ; 90$ samples, primarily $68-70^{\circ} \mathrm{N}$ but samples as far south as $64^{\circ} \mathrm{N}$ ), North-East Greenland (this study, Table $1 ; 217$ outcrop samples, $70-78^{\circ} \mathrm{N}$ ). The vertical extent of the horizontal, coloured bars indicates the uncertainty for the onset of the cooling episode. Ca/ Carb: Carboniferous. Dev: Devonian. E: Early or earliest. Eo: Eocene. J: Jurassic. KI: Lower Cretaceous. Ku: Upper Cretaceous. L: Late. LPS: Lower Planation Surface. M: Mid. Mio: Miocene. Oli: Oligocene. Pal: Paleocene. Pe: Permian. PI: Pliocene. Q: Quaternary. Tr: Triassic. UPS: Upper Planation Surface.

in the 40-30 Ma interval correlates closely with events in more northerly regions, only a single event is defined within the last 10 Myr. Nevertheless, based on the overall consistency a similar development seems likely in that region too (Green et al. 2014).

The end-Eocene episode identified in this study is closely related to igneous activity around Traill $\varnothing$ and other areas, although this event is dominated by exhumation over most of the region. Many of the other Cenozoic cooling episodes identified in this and previous studies also show close association with intrusive activity along much of the margin (Fig. 21). Early Miocene C7 cooling identified in this study is interpreted as representing local effects related to intrusive bodies of similar age. In southern East Greenland, Japsen et al. (2014) also identified Cenozoic cooling episodes of very restricted areal extent along Blosseville Kyst. A late Oligocene episode was interpreted as reflecting localised uplift and erosion north-east of a major fault along Kangerlussuaq. A middle Miocene episode, coeval with the extrusion of the lavas of the Vindtop Formation, was interpreted as reflecting circulation of hot fluids, probably during some degree of crustal extension. These events have no counterparts outside those areas.

Early Eocene cooling in North-East Greenland and southern East Greenland is also associated mainly with minor intrusions. However, from the southernmost tip of East Greenland, Green et al. (2014) reported evidence of a Late Cretaceous - early Cenozoic episode, which was thought to represent exhumation due to major movements along east-west-oriented faults. Thus, a somewhat more complex evolution is possible in that area compared to regions to the north.

The Mesozoic C1, C2 and C4 episodes identified in this study (Middle Triassic, Early Jurassic and mid-Cretaceous, respectively) have correlative cooling events in other areas (Fig. 23) and appear to have affected most of the margin of East Greenland south of $78^{\circ} \mathrm{N}$. In contrast, timing constraints on the earliest Cretaceous episode in this study (145-140 Ma) and South-East Greenland (135-130 $\mathrm{Ma}$ ) are slightly different between the two regions. Given the consistency of different cooling episodes in the three 
regions in Fig. 23, it is possible that the difference in the earliest Cretaceous constraints simply reflects minor statistical inconsistencies within the dataset. Alternatively, some slight diachroneity across the region is possible. Nevertheless, it is clear that Early Cretaceous cooling occurred at broadly similar times across the margin of East Greenland from $61^{\circ} \mathrm{N}$ to $78^{\circ} \mathrm{N}$, suggesting control by regional tectonic processes.
The late Carboniferous CO cooling episode identified in this study coincides with a cooling episode in southern East Greenland, again suggesting regional exhumation associated with tectonism. This episode is not recognised in South-East Greenland, largely because later events dominate the history of that region where Palaeozoic events were overprinted. 


\section{Development of the continental margin of North-East Greenland after break-up}

Subaerial Palaeogene basalts occur onshore in East Greenland between 68 and $75^{\circ} \mathrm{N}$ (Henriksen et al. 2009). The basalts reach elevations up to $3.7 \mathrm{~km}$ a.s.l. (Gunnbjørn Fjeld; c. $68^{\circ} \mathrm{N}$ ). Offshore, between 63 and $76^{\circ} \mathrm{N}$, correlative, subaerial basalts are truncated below the seabed and dip away from the land areas, until they are buried below more than $2 \mathrm{~km}$ of sedimentary cover farther offshore (Fig. 24; Berger \& Jokat 2008). In contrast to this present-day configuration, the East Greenland margin was characterised by net subsidence during the eruption of the basalts (Larsen 1990; Pedersen et al. 1997; Brooks 2011). Early studies concluded that onshore uplift post-dated volcanism by about 20-30 $\mathrm{Ma}$, in agreement with more recent results (Larsen \& Marcussen 1992; Japsen et al. 2014). Here we investigate the evidence for Eocene subsidence and burial along the margin and for the present topography being younger than $10 \mathrm{Ma}$. Finally, we integrate the results from AFTA

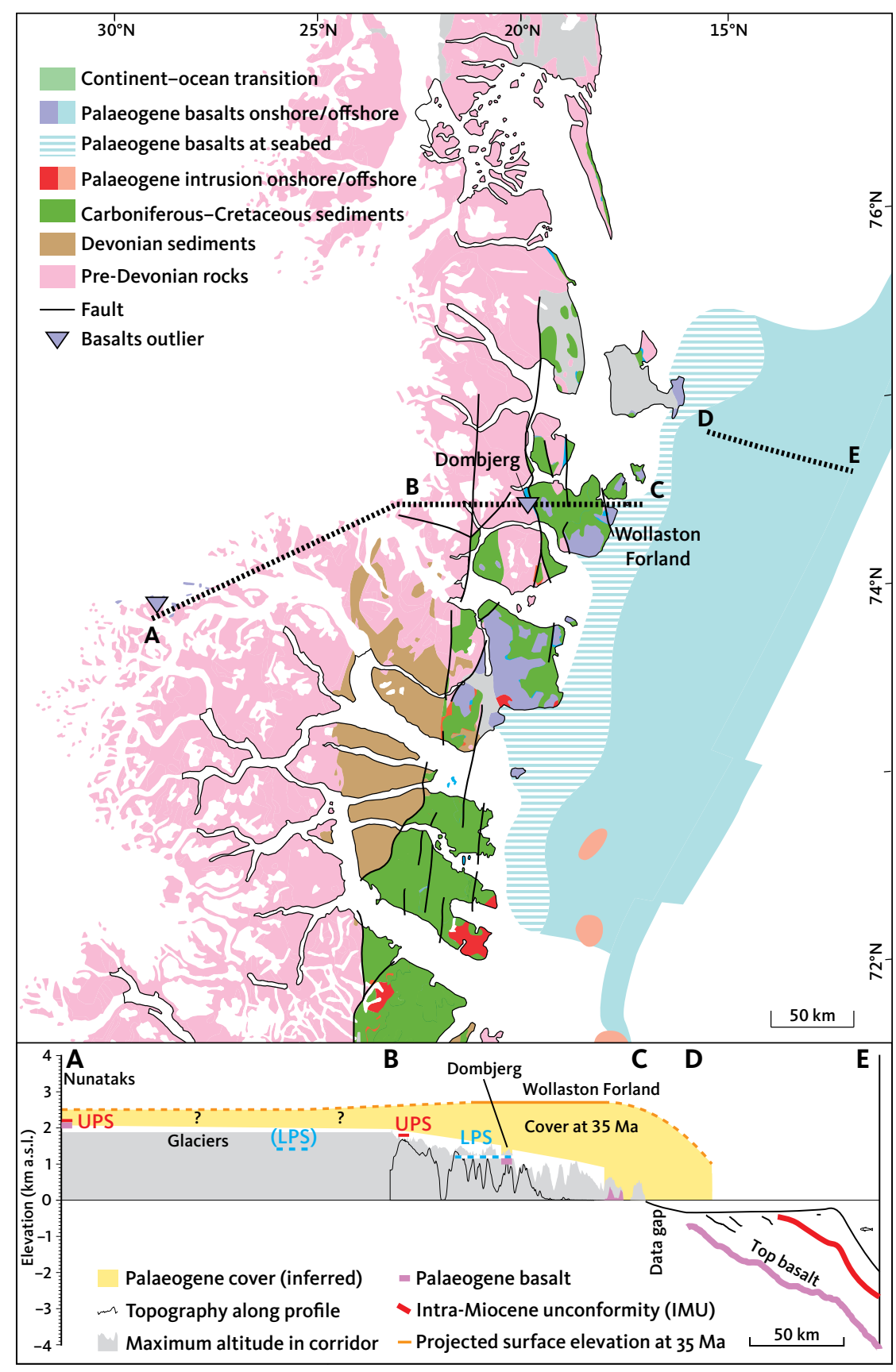

Fig. 24 Geology of the northern part of the study area. Upper panel: Present-day extent of subaerial Palaeogene basalts across the northern part of the study area, onshore (Fig. 11) and offshore (Henriksen et al. 2009). Lower panel: Onshore-offshore profile illustrating the change in elevation/depth of the subaerial Palaeogene basalts from 2 to $-4 \mathrm{~km}$ a.s.l. (A-E in upper panel). These indications of strong, differential vertical movements along the margin in post-basalt time were noted by Larsen (1990). The late Eocene projected surface elevation (PSE) over Dombjerg is based on extrapolation of palaeothermal constraints from samples on Wollaston Forland and eastern Clavering $\varnothing$ (Figs 25, 26). The topography along the inland part of the profile (i.e. $A B$ ) is not indicated because it is primarily defined by the ice surface. Nunataks with a cover of basalts at 'A' are cut by the Upper Planation Surface (UPS; Bonow \& Japsen 2021, this volume). The elevation of the Lower Planation Surface (LPS) at some distance from the profile is marked. The offshore unit above the Intra-Miocene Unconformity (IMU, 15-10 Ma; Døssing et al. 2016) is characterised by prograding successions that are truncated below the seabed along the coast (see Fig. 6). Offshore profile from Berger \& Jokat (2008). 
with those from stratigraphic landscape analysis to produce a model that explains key features of the modern topography of North-East Greenland.

\subsection{Eocene burial and exhumation}

\subsubsection{Evidence for Eocene subsidence/burial and uplift/exhumation}

The end-Eocene projected surface elevation (PSE) is a measure of the elevation of the late Eocene land surface relative to present-day sea level. PSE is calculated by adding the thickness of the additional cover required to explain the end-Eocene palaeotemperature defined from AFTA in an outcrop sample to its present-day elevation (Fig. 25). If the end-Eocene surface was close to sea level at the onset of exhumation, the PSE thus provides a measure of the total amount of rock uplift since the onset of exhumation relative to present sea level

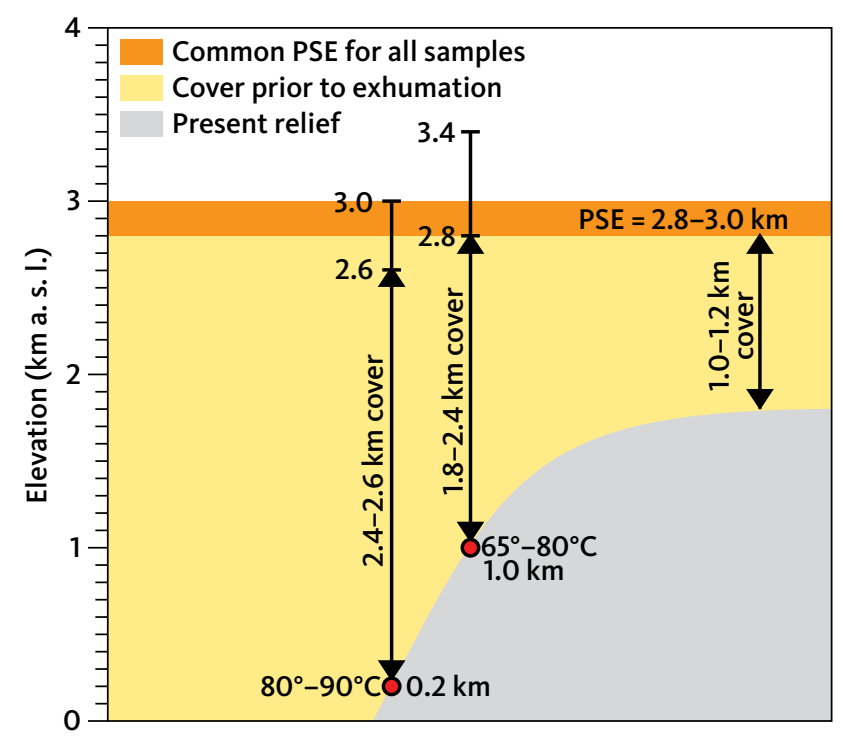

Fig. 25 Projected surface elevation (PSE) corresponding to palaeotemperatures for a palaeothermal episode identified in AFTA data for samples within a minor area (vertical transect). The temperature range for each sample can be converted to estimates of thickness of the cover above each sample at that time, e.g. assuming a surface temperature of $20^{\circ} \mathrm{C}$ and a palaeogeothermal gradient of $25^{\circ} \mathrm{C} / \mathrm{km}$. PSE at that time for each sample is the sum of the sample elevation above present sea level and the thickness of the former cover (since removed). PSE is a proxy for uplift since the onset of exhumation if the surface at that time was near sea level. The common PSE for all samples is the range of PSE values that falls within the PSE intervals for all samples. Assuming a common palaeogeothermal gradient in different regions implies that areas characterised by an elevated palaeogeothermal gradient will have higher PSEs. Such a situation may arise if the cover rocks removed during an episode of exhumation were relatively unconsolidated sediments with lower thermal conductivities compared to the underlying basement rocks (Appendix 2). Grey: present-day terrain. Yellow: removed cover that was present prior to exhumation. Orange: common PSE for both samples. Modified after Japsen et al. (2014).
(Japsen et al. 2014). The thickness of the additional cover is calculated from the end-Eocene palaeotemperature, assuming a surface temperature of $20^{\circ} \mathrm{C}$ and a palaeogeothermal gradient of $25^{\circ} \mathrm{C} / \mathrm{km}$ in the late Eocene $\left(30^{\circ} \mathrm{C} / \mathrm{km}\right.$ for VT3, VT4, $40^{\circ} \mathrm{C} / \mathrm{km}$ for VT6, VT14). AFTA and VR data from some samples along the northern coast indicate heating to end-Eocene palaeotemperatures in excess of $100^{\circ} \mathrm{C}$ (e.g. north-east Wollaston Forland). These values stand out as anomalies that are likely to be related to intrusive bodies similar to those at the eastern part of Traill $\varnothing$ (Fig. 26).

The PSE for the end-Eocene C6 episode is fairly uniform at around $3 \mathrm{~km}$ (a.s.l.) over much of the region where the episode is resolved, possibly increasing to $3.5 \mathrm{~km}$ or more at some locations nearer the coast (Fig. 26). The regional, end-Eocene PSE of c. $3 \mathrm{~km}$ is higher than all summits in the study area and thus also above the regional peneplains, UPS and LPS (Chapter 3). This indicates that rocks now exposed in the summits from Wollaston Forland to Liverpool Land, were buried below a considerable thickness of rock when end-Eocene exhumation began, typically by around $1.5 \mathrm{~km}$ or more. Therefore, the UPS, which is younger than the Palaeogene basalts, was formed as a result of uplift and erosion beginning end-Eocene.

Around Clavering $\varnothing$ Palaeogene basalts are exposed on many summits, and consequently these summits must have been buried below Palaeogene basalts and Eocene post-basalt sediments prior to the onset of uplift and erosion in the late Eocene (Fig. 24). Erosion removed these deposits, leaving the remnant basalt outcrops as the only visible evidence that this additional section once existed. This is further underpinned by AFTA data from one sample of Paleocene sandstone from Hold with Hope that reached a palaeotemperature of $65-85^{\circ} \mathrm{C}$ prior to end-Eocene cooling, corresponding to burial below a significant Paleocene-Eocene cover (sample GC1077-40; C6 in Fig. 16).

Geological evidence shows that the region south of Scoresby Sund was characterised by net subsidence during and after the eruption of the basalts at the Paleocene-Eocene transition (Section 2.2). Furthermore, palaeotemperatures estimated for samples of early Eocene sandstones from Blosseville Kyst (Fig. 27) indicate that a succession of Eocene sediments about $2 \mathrm{~km}$ thick covered the region prior to the onset of end-Eocene 66 cooling.

Consequently, subsidence and burial dominated along the margin of North-East Greenland throughout the Eocene. Such a history of burial during post-rift thermal subsidence is to be expected from classic theory of continental stretching (McKenzie 1978; White \& McKenzie 1988). 


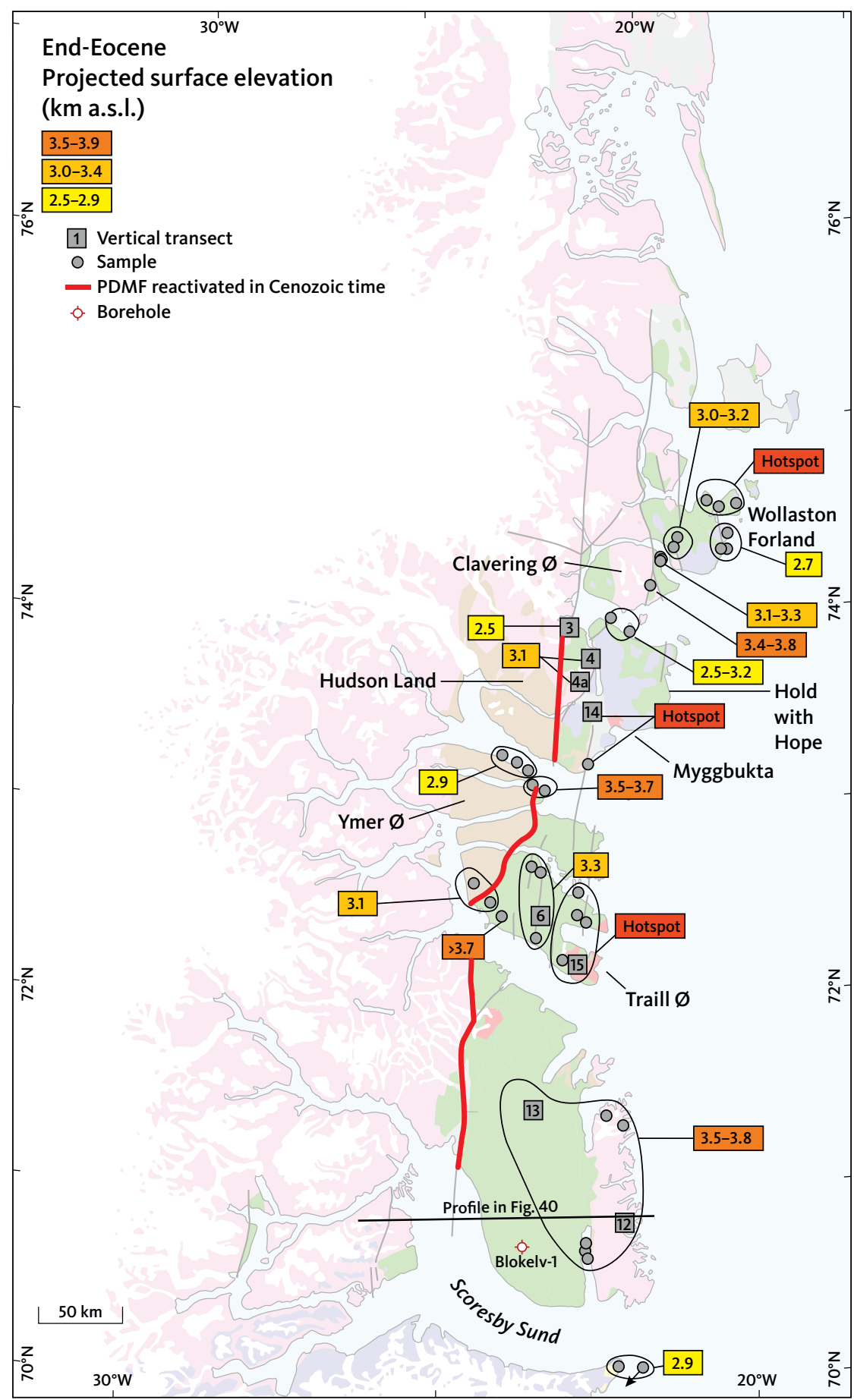

Fig. 26 Common projected surface elevation (PSE; Fig. 25) above present sea level for the end-Eocene $\mathrm{C} 6$ episode for groups of samples outlined by thin black lines. PSE is calculated for a surface temperature of $20^{\circ} \mathrm{C}$ and a palaeogeothermal gradient of $25^{\circ} \mathrm{C} / \mathrm{km}$ (VT3, VT4 $30^{\circ} \mathrm{C} / \mathrm{km}$; VT6 $\left.40^{\circ} \mathrm{C} / \mathrm{km}\right)$. Values for the intrusive centres are omitted. Due to the uncertainty in elevation of the samples for VT7, data from the GC103, GC159 and GC202 reports were not used. At all sample locations, the end-Eocene PSE is higher than the present-day summits indicating that all summits, fjords and valleys were buried below a column of rocks at that time. PSE increases over a short distance, e.g. along the northern coast of Ymer $\varnothing$ and on Hudson Land between VT3 and VT4 (Fig. 29). PDMF: Post-Devonian Main Fault. Geology in Fig. 3.

\subsubsection{Extent of Eocene cover and of end- Eocene exhumation}

The end-Eocene $\mathrm{C} 6$ episode is resolved in the AFTA data in coastal areas in a band from Blosseville Kyst over Liverpool Land and Jameson Land to Traill $\varnothing$, Hudson Land, Hold with Hope, eastern Clavering $\varnothing$ to Wollaston Forland (Fig. 14). The event is, however, also identified in AFTA data from samples farther from the coast, for example west of the PDMF on western Traill $\varnothing$ and eastern Ymer $\varnothing$.
The region underwent post-rift burial throughout the Eocene. Given the relative uniformity of the palaeotemperatures across the region, it is likely that this cover was continuous between the locations where end-Eocene palaeotemperatures are recognised from AFTA. As the end-Eocene palaeotemperatures in the Clavering $\varnothing$ region reflect post-rift burial below at least $2 \mathrm{~km}$ of Palaeogene basalts and Eocene sediments, it is likely that this cover extended further inland beyond where the presence of the cover can be constrained. 


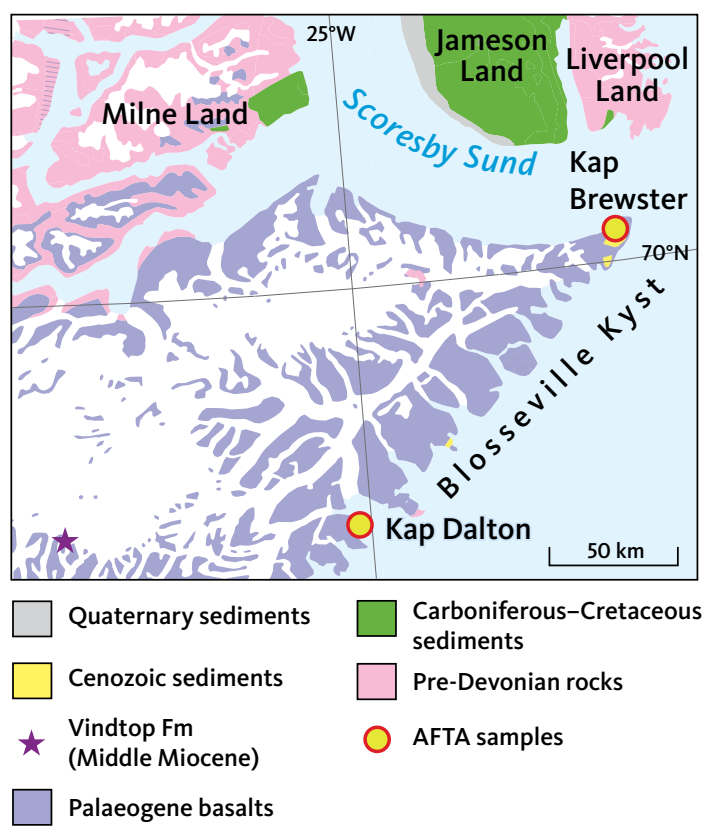

End-Eocene

C6 palaeotemperatures

Kap Brewster, GC1019-32

Bopladsen Fm,

early Eocene (post-basalt): $>90^{\circ} \mathrm{C}$

$>2.8 \mathrm{~km}$ Eocene cover

Kap Dalton, GC1016-21, 22

Igertivâ Fm,

early Eocene (intra-basalt):

$>75-100^{\circ} \mathrm{C}, 60-100^{\circ} \mathrm{C}$

2.2-3.2 km Eocene cover
Fig. 27 Post-basalt heating of lower Eocene sediments at Blosseville Kyst (Larsen et al. 2013; Japsen et al. 2014). End-Eocene C6 palaeotemperatures in three samples (yellow circles) correspond to burial below a c. $2.5 \mathrm{~km}$ thick Eocene succession assuming a palaeothermal gradient of $25^{\circ} \mathrm{C} / \mathrm{km}$ and a surface temperature of $20^{\circ} \mathrm{C}$. The deposition of this succession took place over an interval of c. $12 \mathrm{Myr}$ (between 48 and $36 \mathrm{Ma})$.
The Eocene cover most likely extended to the nunataks in the interior where lower Eocene basalts are preserved (near letter A in Fig. 24), and where the UPS corresponds to the summits at c. $2 \mathrm{~km}$ a.s.l. Consequently, much of the rock column removed during the formation of the UPS across this central region was Eocene basalts and sediments. Note that the basalts on the nunataks are distinctly younger than those in the coastal region (Fig. 5). This may indicate that younger basalts were part of a continuous cover extending to the coastal zone (where only a deeper level of basalt is preserved) and offshore.

North of Wollaston Forland, the end-Eocene cooling event cannot be resolved in the AFTA data. This is for instance the case for the samples from Dombjerg and Kuhn $\varnothing($ VT16, VT9), located a few tens of kilometres from samples on Wollaston Forland and eastern Clavering $\varnothing$ indicative of an end-Eocene PSE of 2.7 and $3.4 \mathrm{~km}$ a.s.I., respectively (Fig. 26). Since the LPS on Clavering $\varnothing$ is 1.2 $\mathrm{km}$ a.s.l., the Palaeogene basalts now exposed on the LPS must have been buried below an Eocene cover of about $1.5 \mathrm{~km}$ in the late Eocene. If we consider that the Eocene burial reflects post-rift thermal subsidence, it is likely that the summits of Kuhn $\varnothing$, where Palaeogene basalts are present, were also buried below this Palaeogene cover. The cover was, however, possibly thinner than those on Clavering $\varnothing$. The absence of evidence for elevated end-Eocene palaeotemperatures on Kuhn $\varnothing$ may be due to the difficulty in resolving multiple cooling episodes from the AFTA data, particularly where these are closely spaced in both time and palaeotemperature. Two events dominate the late-stage cooling of the AFTA data from Kuhn $\varnothing$ : The mid-Cretaceous C4 and late Miocene C8 episodes for which palaeotemperatures in the summits are about $60-70$ and $30-40^{\circ} \mathrm{C}$, respectively. Intermediate end-Eocene palaeotemperatures between these ranges are not likely to be resolved by the AFTA data.

On Store Koldewey, the end-Eocene episode was also not resolved in the AFTA data. Here, common palaeotemperatures for the mid-Cretaceous C4 episode are $85-95^{\circ} \mathrm{C}$ at sea level and those for the late Miocene episode are $60-70^{\circ} \mathrm{C}$. Again, this implies that end-Eocene palaeotemperatures within or below this range are not likely to be resolved by the AFTA data. Removal of a cover of for instance $1 \mathrm{~km}$ of Palaeogene basalts and Eocene sediments in the end-Eocene episode would not be detected.

The end-Eocene event was not resolved in the AFTA data for Milne Land. Here, and on the adjacent island of Gåseland, the UPS defines a clear erosional truncation of both Palaeogene basalts and Precambrian basement (Fig. 7). The former presence of a thicker cover of basalts on Milne Land is supported by a study of zeolite zones in the basalts there (Larsen et al. 1989). These authors suggested that the absence of the shallow and less altered zeolite zones on Milne Land likely reflected removal of these zones by regional erosion after tilting of the basalts. Larsen et al. (1989) assumed that the palaeogeothermal gradient was $40^{\circ} \mathrm{C} / \mathrm{km}$ and concluded that about $900 \mathrm{~m}$ of basalts were removed across Milne Land.

In summary, AFTA data show that a cover of up to 2 $\mathrm{km}$ of Palaeogene basalts and Eocene sediments were deposited south of Scoresby Sund and in the Clavering $\varnothing$ region. As the cover was deposited during post-rift thermal subsidence, it must have been continuous along the entire margin, even reaching the inland nunataks as well as Milne Land. North of Wollaston Forland, the removal of this Palaeogene cover cannot be resolved in the AFTA 
data, probably due to the high palaeotemperatures during the mid-Cretaceous and late Miocene episodes.

\subsubsection{End-Eocene differential, vertical movements}

End-Eocene palaeotemperature profiles from vertical transects in Appendix 2.3 show differences between various locations, suggestive of differential vertical movements (i.e. amounts of exhumation). Figure 28 illustrates thermal-history constraints estimated at summit level on Hudson Land derived from palaeothermal constraints from AFTA in two vertical transects, VT3 and VT4, integrated with the geological record (locations on Fig. 11B). Samples from VT3 are from outcrops of Carboniferous sandstones, whereas samples from VT4 are from outcrops of crystalline basement. VT3 is located c. $20 \mathrm{~km}$ north-west of VT4. Both transects are east of the PDMF (Fig. 3). The Storelv Fault, south-east of VT4, separates down-faulted, Palaeogene basalts from basement (Fig. 29). No Palaeogene basalts are present above these transects. However, since basalts are preserved on nearby summits, it is likely that summit rocks on Hudson Land were near the surface during extrusion of the basalts in the early Eocene.

Palaeotemperatures extrapolated to present-day summit elevations are higher for VT4 than for VT3 during the earliest Cretaceous C3 and end-Eocene C6 episodes, but not during the late Miocene C8 episode. These differences are also seen when comparing the end-Eocene PSE over the short distance between VT3 and VT4 (Fig. 26). There are two possible explanations: differential vertical movements of several hundreds of metres between the two transects after the onset of C6 cooling or higher heat flow prior to episode C8 at VT4 or a combination of both. Comparison of the profiles in Appendix 2.5 (combined with the proximity of the two locations) appears to rule out a significant difference in heat flow between the two locations.

Fieldwork in 2010 confirmed the presence of the Storelv Fault in the area, so we interpret the different

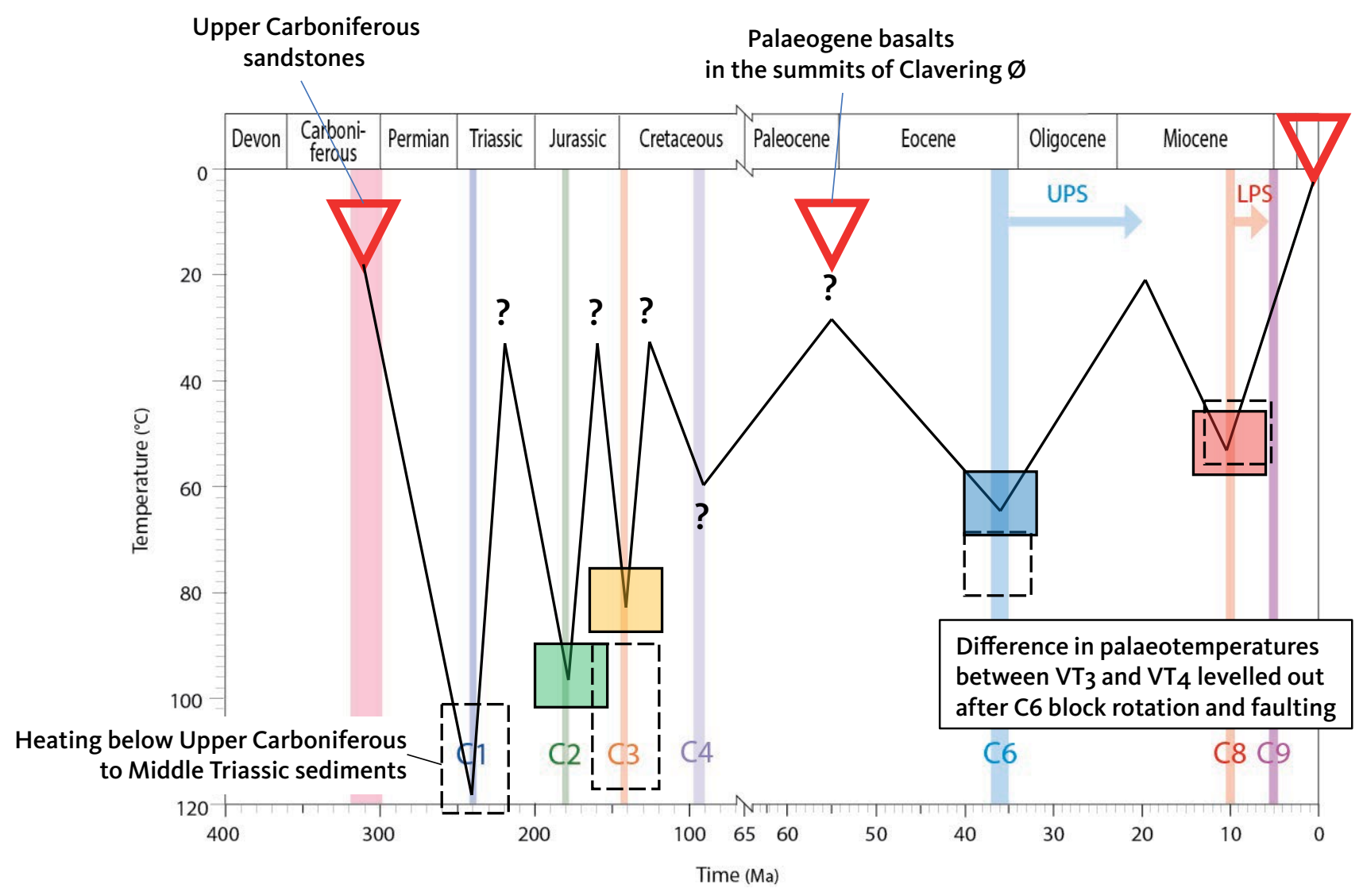

Fig. 28 Thermal-history for the summits of Hudson Land, based on palaeothermal constraints from AFTA, the geological record and stratigraphic landscape analysis (see discussion in Appendix 3). Palaeotemperatures are estimated for individual samples and projected to the elevation of the local summits. No Palaeogene basalts are present in the summits above VT3 and VT4, but basalts are present at summits on Clavering $\varnothing$ and Hold with Hope. The palaeotemperatures estimated are higher for VT4 than VT3 during the earliest Cretaceous C3 and end-Eocene C6 episodes, but not during the late Miocene C8 episode. This difference is primarily due to differential exhumation between the two transects during the $\mathrm{C} 6$ episode caused by end-Eocene block rotation and faulting. Post-basalt faulting also occurred just east of VT4 along the Storelv Fault (Fig. 29). Shaded boxes: VT3. Dashed boxes: VT4. 


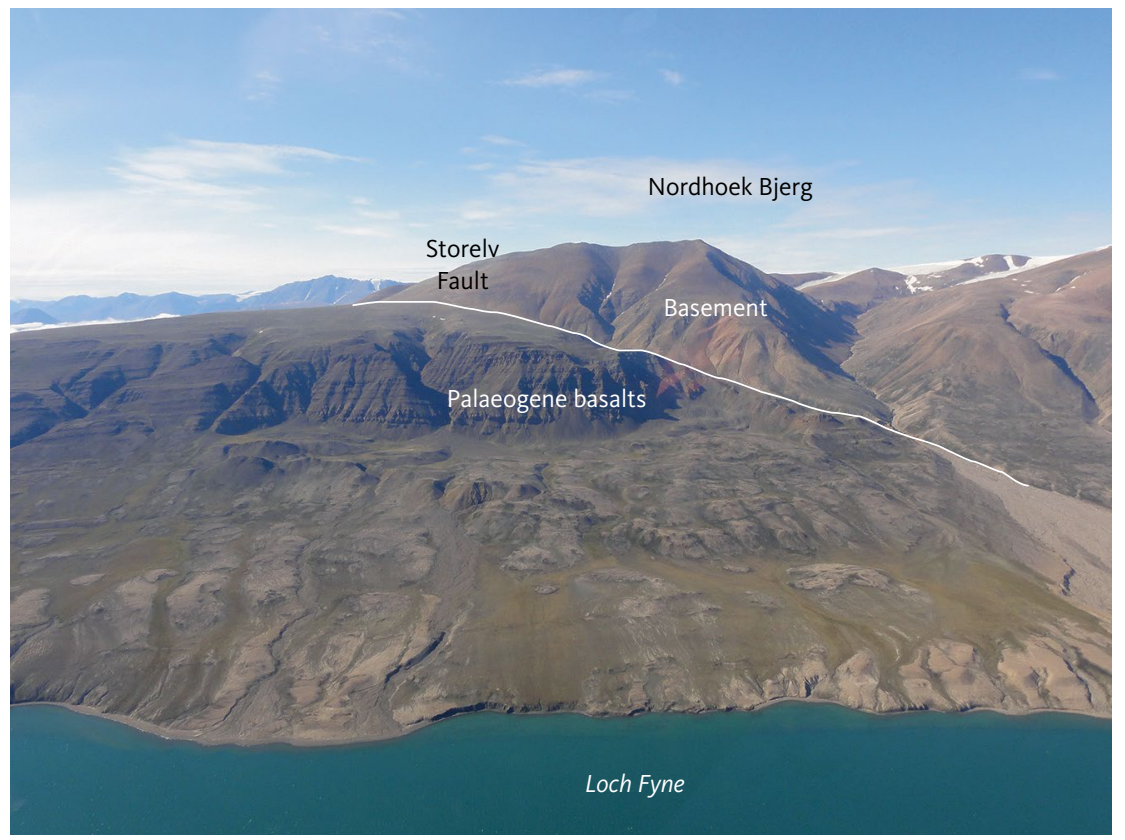

Fig. 29 Contact between basement and Palaeogene basalts along the Storelv Fault, Hudson Land (looking west). Samples along vertical transect VT4 were taken in basement rocks just north of this locality. AFTA data from VT4 and VT3 in this region indicate faulting during the end-Eocene $\mathrm{C} 6$ episode between these locations (Fig. 28). Photo: P. Guarnieri (see also Guarnieri 2015).

thermal histories at VT3 and VT4 as caused by block rotation during the end-Eocene $C 6$ episode of the eastern part of Hudson Land (Figs 28, 29; Guarnieri 2015). The easternmost part of the block (VT4) thus underwent more uplift and erosion than farther inland (VT3) where Carboniferous sediments are preserved. During this rotation, the basalts were downfaulted to the east of the Storelv Fault. Finally, by the late Miocene, the two blocks were locked in their present position as demonstrated by the similar palaeotemperatures for the two transects at that time.

The Storelv Fault is located just west of Loch Fyne that hosts the major, post-basalt fault zone in the Hold with Hope and Gauss Halvø region, and this fault zone has an eastward throw of over 500 m (see location in Figs 2, 29; Upton et al. 1980). We infer that the faulting along Loch Fyne also occurred in the late Eocene. The magnitude of end-Eocene block rotation on Hold with Hope is $600 \mathrm{~m}$ as estimated by the difference between end-Eocene PSE at VT4 and VT3 (Fig. 26), which is in good agreement with the estimate of Upton et al. (1980).

The end-Eocene PSE also varies over a short distance along the north coast of Ymer $\varnothing$, from $2.9 \mathrm{~km}$ to c. 3.5 $\mathrm{km}$ a.s.l. from west to east (Fig. 26). However, the late Miocene PSE also varies over a short distance there, so it is possible that a part of the offset across the PDMF occurred in the late Miocene (Section 6.2.2).

Where AFTA data reveal cooling during the C6 episode they correspond closely to the rift basins east of the PDMF, from Jameson Land to Wollaston Forland. We interpret this to imply that exhumation had a greater magnitude across the rift basins, and that they consequently suffered more inversion in this episode than regions west of the PDMF where the effects of the mid-Cretaceous C4 episode dominate. Consequently, we infer that the PDMF was active during the end-Eocene uplift phase. This interpretation is supported by Bütler's (1955) observation that Tertiary dykes on Ymer $\varnothing$ and on Geographical Society $\varnothing$ are offset along the PDMF; see also Hartz et al. (2006). Mid-Cenozoic compressional deformation affected the East Greenland shelf (Tsikalas et al. 2005), providing further support for the scenario described here.

\subsection{Miocene burial and exhumation}

\subsubsection{Development of the present-day} topography within the last $10 \mathrm{Myr}$

The late Miocene C8 PSE is between 2 and $2.5 \mathrm{~km}$ a.s.l. across most of the study area, with values reaching $3 \mathrm{~km}$ or more east of the PDMF on Geographical Society $\varnothing$, Traill $\varnothing$, Jameson Land and Liverpool Land (Fig. 30). The thickness of the cover at that time is calculated from the late Miocene palaeotemperature, assuming a surface temperature of $15^{\circ} \mathrm{C}$ and a palaeogeothermal gradient of $25^{\circ} \mathrm{C} / \mathrm{km}\left(30^{\circ} \mathrm{C} / \mathrm{km}\right.$ for eastern Traill $\varnothing$, zones 2 and 3 , and VT14). The late Miocene PSE is calculated for samples where the mid-Cretaceous C4 or the end-Eocene C6 episodes were resolved, suggesting that C8 palaeotemperatures are defined with confidence. Only one sample in the interior highlands stands out as anomalous relative to the general picture (GC1077-62). This is probably a result of unresolved events in the AFTA data, or else represents a statistical outlier.

In the interior highlands, the late Miocene PSE corresponds to the general present-day summit level in these mountains and is close to the elevation of the UPS 


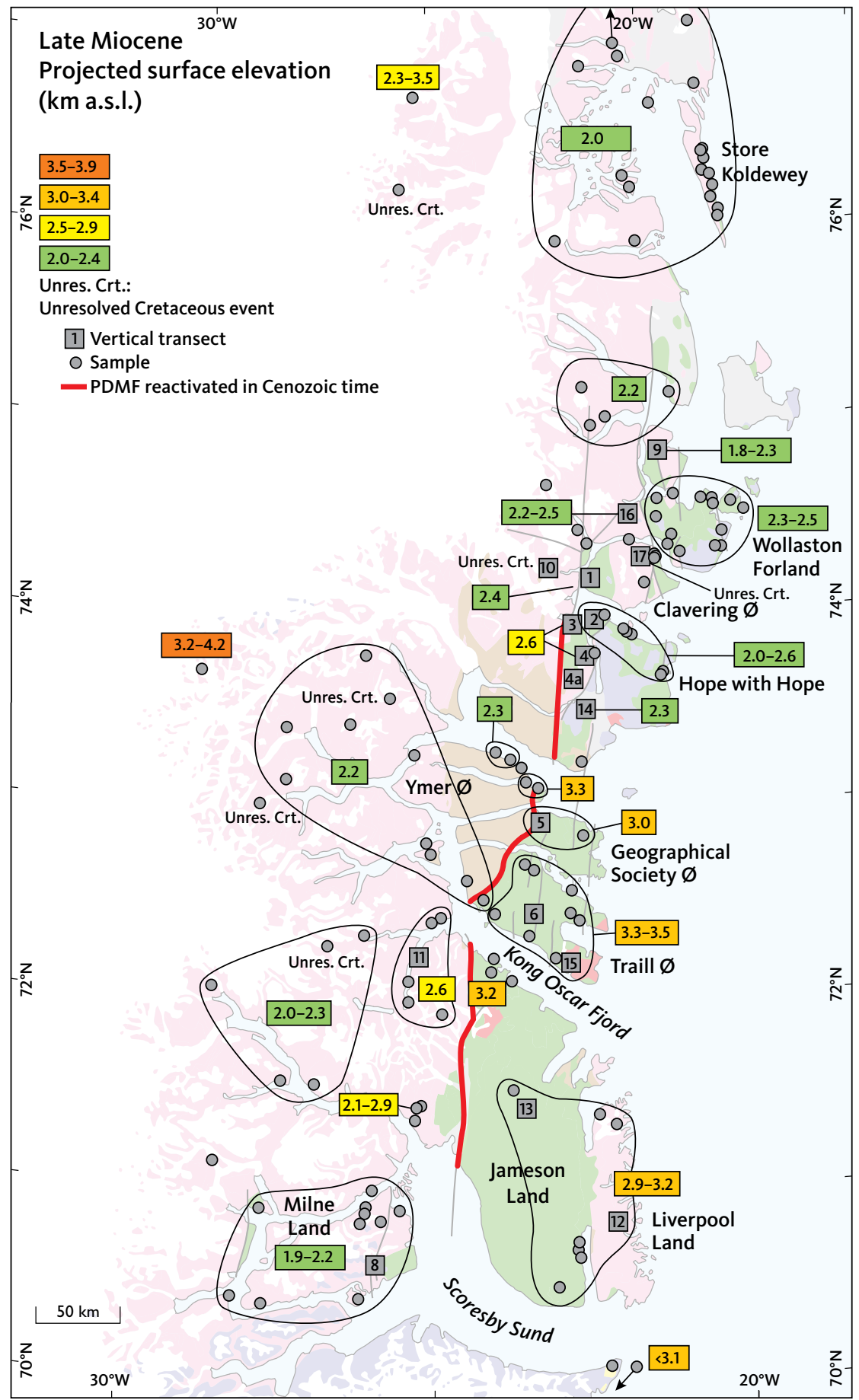

Fig. 30 Common projected surface elevations (PSE; Fig. 25) above present sea level for the late Miocene episode for groups of samples outlined by thin black lines. PSE is calculated for a surface temperature of $15^{\circ} \mathrm{C}$ and a palaeogeothermal gradient of $25^{\circ} \mathrm{C} / \mathrm{km}\left(30^{\circ} \mathrm{C} /\right.$ $\mathrm{km}$ for eastern Traill $\varnothing$, zones 2 and 3 (Fig. 32), and VT14). For a clearer overview, single outliers within $300 \mathrm{~m}$ of the common PSE for a group of samples, are not shown. PSEs for samples in which the mid-Cretaceous C4 episode is not resolved are not shown, but their locations are indicated (not for vertical transects). Due to the uncertainty in the sample elevation, data from the GC103, GC159 and GC202 reports were not used. Data for GC1077-77 were of poor quality and not used. Two main PSE levels are shown: c. 2.0 to $2.5 \mathrm{~km}$ a.s.l. in the north and western interior; $3 \mathrm{~km}$ a.s.l. or more in the south-east. PSE values in Stauning Alper are around $2.6 \mathrm{~km}$. The jump of PSE values across the Post-Devonian Main Fault (PDMF), is indicative of Miocene reactivation of the fault (e.g. along the north coast of Ymer $\varnothing$ ). Only one sample in the interior highlands stands out as a significant outlier relative to the general picture (GC1077-62).

(Figs 9, 22, 30). Following the definition of the PSE, this implies that the UPS and the present-day summit level correspond to the late Miocene surface. Therefore, late Miocene cooling in samples at elevations below the summits (i.e. below the UPS) in this region can be explained in terms of removal of the rock below the summit (UPS) by incision of the present-day relief. Since incision is the result of uplift of the present-day mountains, formation of the relief since $10 \mathrm{Ma}$ implies, in turn, that uplift began at c. $10 \mathrm{Ma}$.

At coastal locations, stretching from Store Koldewey to Liverpool Land, the late Miocene PSE is higher than the summits that define the LPS, and also higher than the UPS where its presence can be inferred. Further, late Miocene palaeotemperature profiles in coastal regions show increasing offsets to higher temperatures compared to inland locations (Fig. 31). In coastal locations, the summits must have been buried by a considerable cover when cooling began at c. $10 \mathrm{Ma}$.

The results from Clavering $\varnothing$ (VT1; Appendix 2.1) are a good example of this interpretation. Palaeogene basalts are present in the summits that coincide with the LPS at 

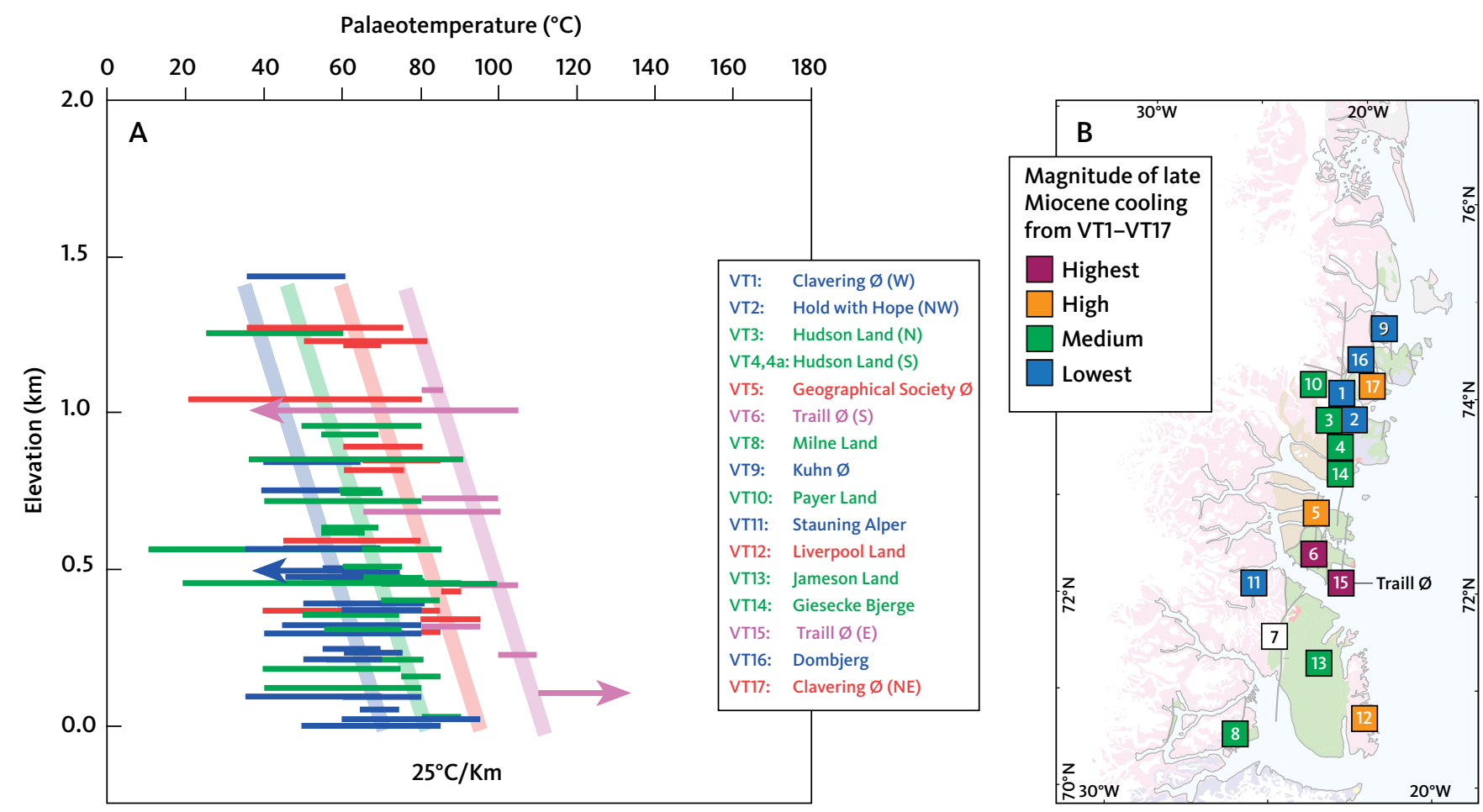

Fig. 31 Constraints on late Miocene C8 palaeotemperatures from vertical transects. A: Vertical transects for four groups of data (location in Fig. 31B) define sub-parallel trends offset to higher temperatures. The largest offsets may define a higher palaeogeothermal gradient (VT6 and VT15 from Traill Ø). B: Relative variation in exhumation across the study region. Data from VT7 are not discussed due to uncertainties in elevation. VT: vertical transect.

an elevation of c. $1.2 \mathrm{~km}$ a.s.l. (Fig. 9). Taking constraints from all VT1 samples into account, the late Miocene PSE becomes $2.4 \mathrm{~km}$ a.s.l. implying that magnitude of rock uplift since $10 \mathrm{Ma}$ (Fig. 30). The cover above the basalts on Clavering $\varnothing$ in the late Miocene are therefore estimated to be c. $1.2 \mathrm{~km}$, consisting of Palaeogene basalts and younger sediments. There is no stratigraphic evidence that could refine the age of these Cenozoic rocks, but the elevation of the UPS - a measure of rock uplift since the formation of the surface - provides some constraints. The UPS is not preserved on Clavering $\varnothing$, but it is present to the south-west on western Hudson Land, where its elevation is $1.8 \mathrm{~km}$ a.s.l. (Fig. 9). This elevation is $700 \mathrm{~m}$ above that of the LPS on Clavering $\varnothing$, which is a typical distance between the UPS and LPS across most of the region. It therefore seems reasonable to extrapolate the UPS elevation to Clavering $\varnothing$. The late Miocene PSE on Clavering $\varnothing(2.4 \mathrm{~km}$ a.s.I.) is $600 \mathrm{~m}$ above the elevation of the UPS (1.8 km a.s.l.), suggesting that the UPS was buried below $600 \mathrm{~m}$ of rock when uplift began at $10 \mathrm{Ma}$. The UPS was eroded to sea level as a result of uplift and erosion beginning $35 \mathrm{Ma}$. So, it seems reasonable to conclude that the additional $600 \mathrm{~m}$ of rock that was present above the UPS was mainly Miocene sediments, deposited between the creation of the surface (some time prior to $10 \mathrm{Ma}$ ) and the onset of late Miocene uplift (beginning $10 \mathrm{Ma}$ ).
Applying a higher palaeogeothermal gradient would reduce the estimate of the late Miocene PSE and of the thickness of the removed cover, but some thickness of cover would still be required (see further discussion in Appendix 2). We therefore suggest that there is good evidence that up to $600 \mathrm{~m}$ of mainly Miocene sediments accumulated in the coastal zone around Clavering $\varnothing$.

To generate the accommodation space necessary for the accumulation of the Miocene sediments in the coastal zone, this area must have subsided, in contrast to the areas further inland. This must have happened during a period of crustal extension prior to the onset of late Miocene uplift. The high values of the late Miocene PSE along the coast in turn indicate that rock uplift since $10 \mathrm{Ma}$ was higher than further inland. This implies that the coastal zone must have been in compression during the late Miocene, which agrees with observations both onshore and offshore North-East Greenland (see Section 2.4.1; Price et al. 1997; Hamann et al. 2005; Døssing et al. 2016).

The relatively smooth variation of the late Miocene PSE across wide areas (Fig. 30), demonstrates that the topography in the late Miocene was characterised by a low-relief surface. In the interior topography was dominated by the UPS (which had been graded to base level following post-basalt uplift and erosion) and in the 
coastal zone by the top of lower to middle Miocene sediments that accumulated during a phase of subsidence prior to late Miocene uplift. In any case, the late Miocene land surface cannot have been much above sea level. Consequently, the altitude of the late Miocene PSE is a measure of post-late Miocene uplift of these surfaces, prior to their dissection.

\subsubsection{Late Miocene differential, vertical movements}

In the southern part of the study area (south of $c .73^{\circ} \mathrm{N}$ ) there is good east-west data coverage. Here, the late Miocene PSE increases from about $2 \mathrm{~km}$ a.s.l. across wide areas of the interior highlands to about $3 \mathrm{~km}$ a.s.l. in the coastal zone (Fig. 30). Part of this increase could be due to a higher palaeogeothermal gradient in the coastal zone. At some locations this change takes place over a short distance. Specifically:

- Along Kong Oscar Fjord. Values increase from c. 2.2 $\mathrm{km}$ a.s.l. in the inner part of the fjord to $3.5 \mathrm{~km}$ a.s.l. along the northern coast and to $3.2 \mathrm{~km}$ a.s.l. on the southern coast. The palaeogeothermal gradient there is constrained by the AFTA data to increase from about 25 to $30^{\circ} \mathrm{C} / \mathrm{km}$ along the fjord (Fig. 32), so the observed difference in PSE cannot be explained solely by different heat flow and differential exhumation is clearly a dominant factor. Only by assuming a palaeogeothermal gradient of $50-60^{\circ} \mathrm{C} / \mathrm{km}$ can the late Miocene PSE for VT6 be reduced to about $2 \mathrm{~km}$ a.s.l., but this is not allowed by the data.

- Along the north coast of Ymer $\varnothing$. A similar increase is observed, from c. $2.3 \mathrm{~km}$ a.s.l. in the west to $3.3 \mathrm{~km}$ a.s.I. in the east. Analogous with those along Kong Oscar Fjord, we interpret these differences as largely due to differential uplift and erosion.

- Jameson Land and Liverpool Land. Whereas the values over most of the southern interior are around 2 $\mathrm{km}$ a.s.l., the PSE on Jameson Land and Liverpool Land range from 2.9 to $3.2 \mathrm{~km}$ a.s.l., respectively.

Thus, some coastal areas were subjected to deeper exhumation after $10 \mathrm{Ma}$ than areas farther inland. The strong lateral difference in the estimated rock uplift over short distances across the PDMF, indicates that late Miocene, differential movements possibly occurred across this fault. In Section 6.2.1, we showed that a thick cover of Miocene sediments accumulated in the coastal zone during a period of crustal extension prior to late Miocene uplift during a compressional phase. It is thus possible that both burial and subsequent exhumation in the coastal zone were guided by differential movements along the PDMF.

\subsection{Cenozoic events in the Traill $\varnothing$ area}

Late Miocene VTs that plot furthest to the right in Fig. $31 A$ are from Traill $\varnothing$, in proximity to late Eocene intrusive bodies where end-Eocene palaeotemperatures define an elevated palaeogeothermal gradient (Section 5.8). Palaeotemperatures in end-Eocene $\mathrm{C} 6$ and late Miocene C8 episodes define local maxima around the Palaeogene igneous centres on Traill $\varnothing$ (Fig. 14; Price \& Witham 1997; Price et al. 1997). In addition, this area is one of the few parts of the study area where early Pliocene cooling episode C9 is recorded.

To further investigate vertical and horizontal variation of palaeotemperatures, we divided the region around Traill $\varnothing$ into four zones and plotted palaeotemperatures in episodes C6, C8 and C9 against elevation in each zone (Fig. 32). Zone 3 represents the igneous centre and zone 0 represents background effects at some distance from the igneous centre. In both zones 2 and 3, palaeotemperature constraints for the C6, C8 and $C 9$ episodes show a clear separation into 3 separate linear profiles, where palaeotemperatures increase with decreasing elevation (representing palaeoburial) in each episode. Higher palaeotemperatures in each episode in these zones allow resolution of the separate late Miocene and early Pliocene cooling episodes. In contrast, constraints in samples from zones 0 and 1 do not allow clear discrimination of three separate events. Here, some samples provide palaeotemperature constraints, which would be more consistent with a profile offset towards greater depths compared to the majority of samples, and are therefore attributed to the lower magnitude, early Pliocene C9 episode.

In zones 1, 2 and 3, C6 palaeotemperatures increase towards the igneous centres at the eastern extremity of Traill $\varnothing$ (zone 3). Although not definitive, the profiles for episode C6 in Fig. 32 are consistent with an eastwards-increasing palaeogeothermal gradient from $c$. $25^{\circ} \mathrm{C} / \mathrm{km}$ in zone 1 to c. $45^{\circ} \mathrm{C} / \mathrm{km}$ (or possibly higher) in zone 3 , as might be expected due to the presence of the igneous centres.

Late Miocene C8 palaeotemperatures also show a clear increase from west to east from zones 0 to 3 . The profiles (drawn by eye) through the constraints suggest an increasing palaeogeothermal gradient from $25^{\circ} \mathrm{C} / \mathrm{km}$ in zones 0 and 1 to $c .30^{\circ} \mathrm{C} / \mathrm{km}$ in zones 2 and 3 . This indicates that some residual elevated heat flow related to the intrusive activity may have remained c. 25 Myr after intrusion. The progressive offset in the late Miocene profiles towards higher palaeotemperatures from zones 0 to 3 reflects progressively deeper levels of palaeoburial prior to the onset of cooling, which we interpret as due predominantly to exhumation.

Early Pliocene C9 palaeotemperatures in zones 2 and 3 are consistent with linear profiles defined by a 


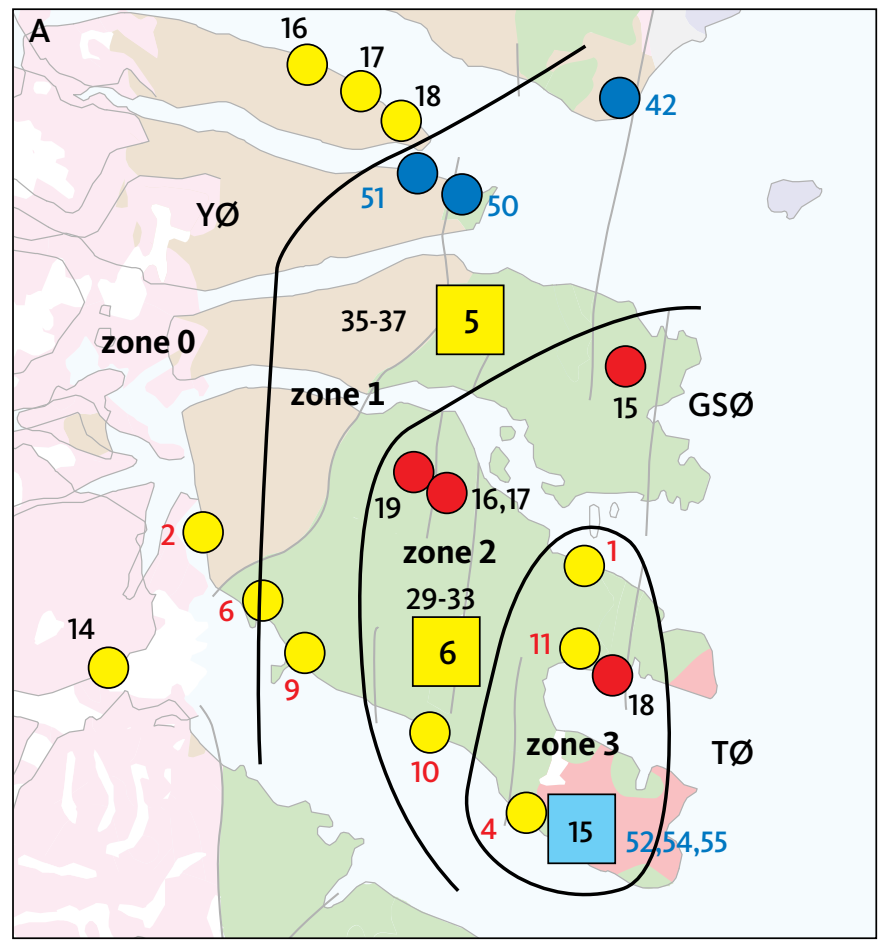

Fig. 32 Palaeotemperature constraints from AFTA in samples from four zones of the Traill $\varnothing$ region. A: Sample locations and zonation (zones 0-3). B-E: Palaeotemperature profiles vs. elevation a.s.I. constraining three palaeothermal episodes (C6, C8 and C9). Palaeotemperature constraints for $\mathrm{C} 5$ in zone 2 and $\mathrm{C} 6$ in zone 0 are not shown. Constraints in each zone are separated into a series of linear profiles where palaeotemperatures increase with decreasing elevation (representing palaeoburial). This allows improved attribution of constraints to the discrete regional cooling episodes, and this information was employed to attribute constraints to individual episodes (Appendix 1.7, also available online in Supplementary File S4). C6 palaeotemperatures and palaeogeothermal gradients increase towards the igneous centres at the eastern extremity of Traill $\emptyset$ (zone 3). C8 palaeotemperatures also increase towards eastern Traill $\varnothing$, but the palaeogeothermal gradient only shows a minor variation in that direction, indicating depth of burial was the dominant factor for increasing palaeotemperatures. GSØ: Geographical Society $\emptyset$. TØ: Traill $\emptyset$. Yø: Ymer $\emptyset$. Circles and quadrants with numbers: AFTA sample(s) and vertical transects, respectively (see Fig. 11).
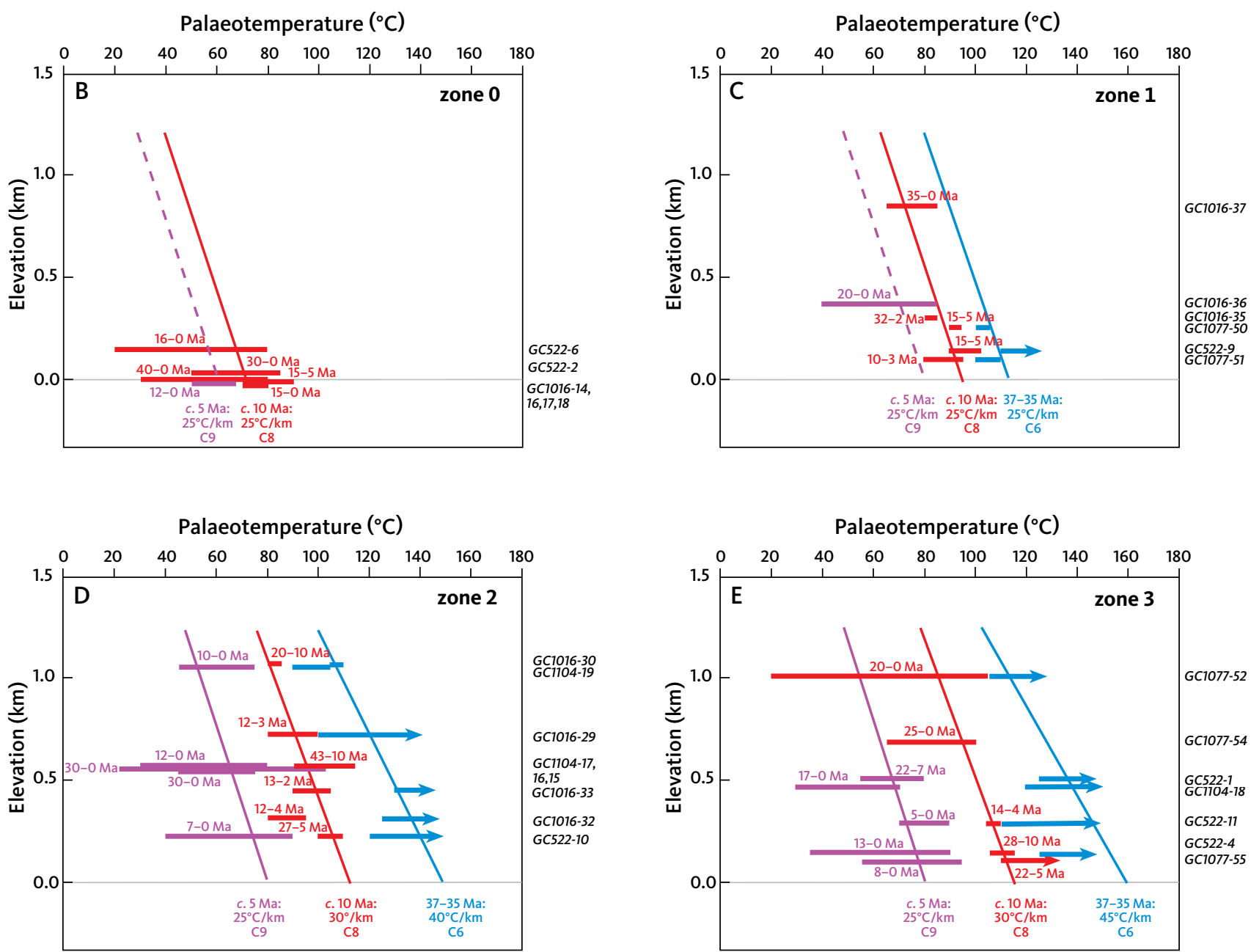
palaeogeothermal gradient of $25^{\circ} \mathrm{C} / \mathrm{km}$. In zone 3 , AFTA data in the three 'deepest' samples (i.e. those closest to sea level) clearly resolve both the C8 and the C9 cooling episodes, due mainly to higher C8 palaeotemperatures of around $100^{\circ} \mathrm{C}$ or more, where the technique is most sensitive. Similar comments apply to the 'deepest' sample in zone 2. In samples from higher elevation, the AFTA data do not allow resolution of two separate episodes. However, comparing results from the two 'highest' samples in zone 2 , define the most recent cooling episode from $80-90^{\circ} \mathrm{C}$ beginning between 20 and $10 \mathrm{Ma}$ (sample GC1016-30), and cooling from $45-75^{\circ} \mathrm{C}$, beginning between 10 and 0 Ma (sample GC1104-19). These two events plots on the profiles characterising the C8 and C9 episodes, respectively.

These results show that two discrete episodes of cooling have occurred in the region around Traill $\varnothing$ within the last $10 \mathrm{Myr}$. The failure to resolve discrete C8 and C9 episodes in areas other than Traill $\varnothing$ is probably due to a lower magnitude of Pliocene exhumation across the wider region, such that palaeotemperatures were too low to be defined from AFTA (i.e. $<50^{\circ} \mathrm{C}$ ). However, at the eastern extremity of Traill $\varnothing$, significant Pliocene exhumation combined with high $\mathrm{C} 6$ and $\mathrm{C} 8$ palaeotemperatures allows resolution of the separate the $\mathrm{C} 8$ and C9 cooling episodes.

\subsection{Stauning Alper}

At Stauning Alper, elevations reach $2.8 \mathrm{~km}$ a.s.l. There is significant alpine relief, and it is one of the most dissected areas in North-East Greenland. According to the stratigraphic landscape analysis (Chapter 3), the UPS defines the summits of Stauning Alper. The elevation of the UPS around Stauning Alper forms a domal structure with maximum UPS elevations of c. $2.3 \mathrm{~km}$ a.s.I. (Fig. 9). This relief is probably not related to differences in rock type because similar bedrock (mainly crystalline basement) occurs in nearby areas at almost the same elevation (e.g. Renland and Milne Land). However, the UPS is very well preserved in these areas.

Stauning Alper clearly experienced more uplift than the surrounding areas after the formation of the UPS, and these mountains thus have a tectonic history that deviates from the regional pattern. For example, uplift here may have started earlier than in the rest of the region, leaving more time for the destruction of the UPS, and thus stronger valley incision and relief rejuvenation. Further erosion may have been by cirque glaciers that formed at high elevation. The early Miocene C7 episode is identified across northern Jameson Land, just east of Stauning Alper. The onset of uplift in Stauning Alper may have begun in the early Miocene rather than in the late Miocene. An uplift component due to the C7 episode does seem to be a reasonable interpretation, given the emplacement of the massive igneous bodies during the latest Oligocene at, for example, Malmbjerget, at the eastern edge of Stauning Alper. More work, involving detailed sampling of known igneous bodies and their elevation, would be required to resolve these remaining uncertainties.

\subsection{A stepped topography formed after three phases of uplift and incision}

The palaeothermal constraints from AFTA, combined with the denudation chronology defined from the stratigraphic landscape analysis, as well as the geological record, provide clear constraints on the history of vertical motions of the East Greenland margin. Based on stratigraphic landscape analysis, Bonow \& Japsen (2021, this volume) identified two peneplains across NorthEast Greenland and established a relative denudation chronology for their formation after break-up and onset of drift (Fig. 33; Section 3.2):

1. The UPS (typically at $2 \mathrm{~km}$ a.s.I.) cuts across Palaeogene basalts and older rocks (Fig. 33B). A first phase of uplift in post-basalt times led to the formation of the UPS by erosion to a base level defined by the Atlantic Ocean. The UPS had formed before the extrusion of the Vindtop Formation in the mid-Miocene (Bonow et al. 2014).

2. The LPS (typically at $1 \mathrm{~km}$ a.s.I.) is defined by broad valleys below the UPS in the Milne Land region and by broader zones along the coast (Fig. 33D). A second phase of uplift led to the formation of the LPS by river incision to base level below the uplifted UPS.

3. A third phase of uplift raised the UPS and the LPS to their present elevations (Fig. 33F).

The presence of two elevated peneplains across the region thus requires three phases of post-breakup uplift.

Our synthesis of AFTA data identifies three regional phases of uplift and erosion after break-up (Section 4.5), during (1) the end-Eocene C6 episode (Fig. 33A); (2) the late Miocene C8 episode (Fig. 33C) and (3) the early Pliocene C9 episode (Fig. 33E). We suggest that each of these episodes of uplift and erosion led to the formation of distinct steps in the landscape (Fig. 34) as follows:

1. Following end-Eocene maximum burial at c. $35 \mathrm{Ma}$, uplift and erosion led to formation of the UPS as a peneplain graded to sea level.

2. Late Miocene uplift at c. 10 Ma led to formation of the LPS by incision and valley widening below the uplifted UPS. In parts of the coastal zone, a phase of Miocene burial preceded the uplift (Section 6.2.1).

3. Early Pliocene uplift at c. 5 Ma led to incision of the 

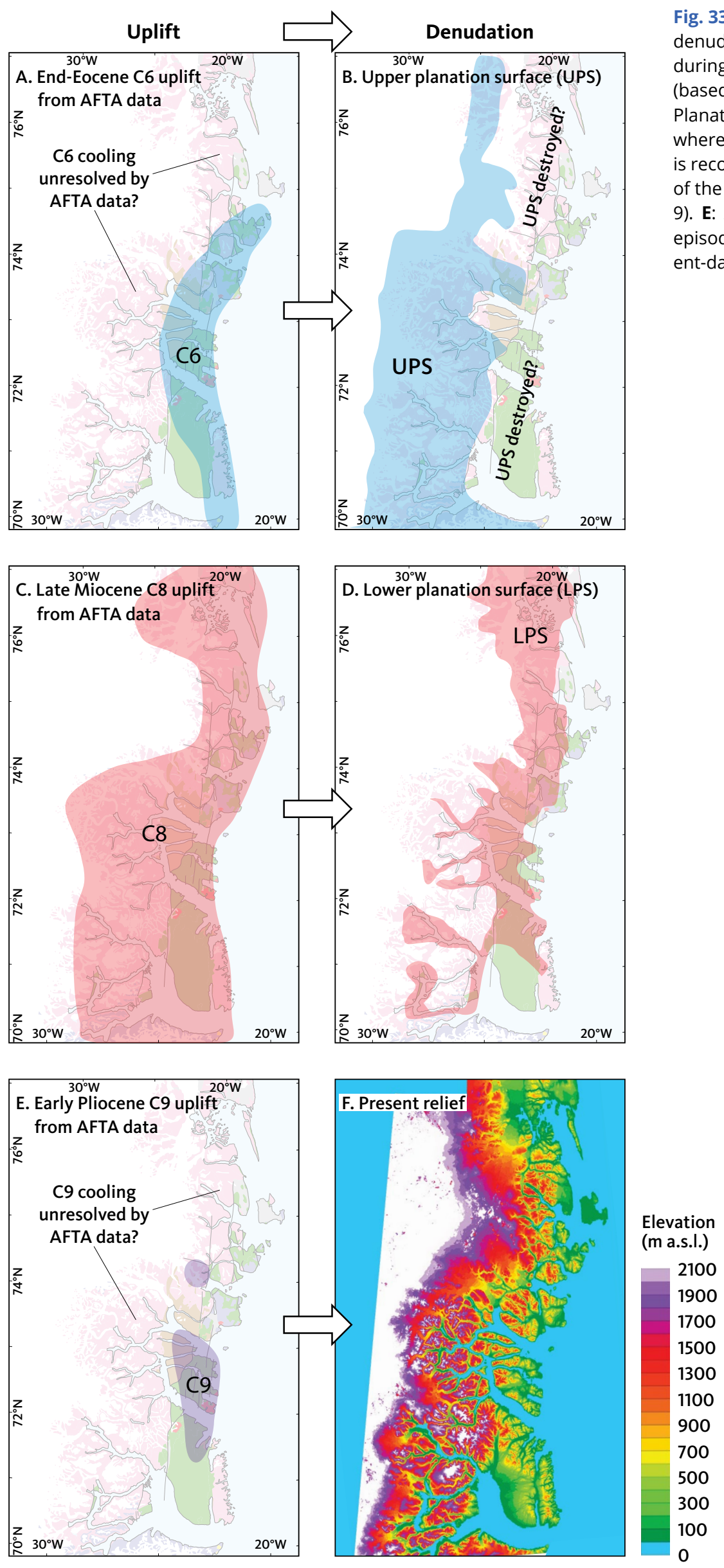

Fig. 33 Cenozoic uplift events and relief formed by denudation in the study area. A: Area where uplift during the end-Eocene $\mathrm{C} 6$ episode is recognised (based on Fig. 14). B: Mapped extent of the Upper Planation Surface (UPS; based on Fig. 9). C: Area where uplift during the late Miocene C8 episode is recognised (based on Fig. 14). D: Mapped extent of the Lower Planation Surface (LPS; based on Fig. 9). E: Area where uplift in the Early Pliocene C9 episode is recognised (based on Fig. 14). F: Present-day relief (Amante \& Eakins 2009). 
present-day valley floors below the uplifted LPS and to formation of the present-day landscape. Therefore, this is the third of the Cenozoic episodes that correlates with the regional post-breakup unconformity as discussed in Sections 5.7 and 5.9.

With this sequence of events, it is possible to explain the presence of two elevated peneplains that formed in post-basalt times with the three regional events of uplift and exhumation since break-up defined by AFTA.

However, the areal extent of the two peneplains and of the regions where the three uplift events have been recognised, only partially overlap (Fig. 33). The UPS primarily extends across basement terrains in the interior highlands, typically at elevations about $2 \mathrm{~km}$ a.s.l. (Fig. 33B). North of $74^{\circ} \mathrm{N}$, where the Greenland ice sheet and extensive glaciers are closer to the coast than to the south, the UPS is only defined in narrow patches along the ice cover or as nunataks. The LPS defines the summits around $1 \mathrm{~km}$ a.s.l. in a c. $100 \mathrm{~km}$ wide band along the coast, but it continues as elevated palaeovalleys below the UPS in the interior highlands (Fig. 33D).

The two denudation surfaces and their remnants are thus both identified across most of the interior highlands south of $74^{\circ} \mathrm{N}$ as well as across Hudson Land and western Traill $\varnothing$. Farther north, there is only limited overlap between the areas where the surfaces are identified.

Of the three palaeothermal episodes in post-breakup time, only the late Miocene episode is identified across the entire region. There is, however, evidence to suggest that the other two episodes of uplift and erosion also acted on a regional scale.
The end-Eocene episode is only recognised in the eastern part of the study area (Fig. 33A), but this area overlaps with the extent of both the UPS and the LPS in the inner part of the coastal zone from Traill $\varnothing$ to Hudson Land (Figs 33B, D). Furthermore, we argued in Section 6.1.2, that an Eocene cover is likely to have been present across wide parts of the study area and then removed without necessarily being detected in the AFTA data. We therefore find that the continuity of the UPS from this central region into the interior supports the conclusion that the UPS there was also formed after end-Eocene uplift and exhumation. Furthermore, the continuity of the LPS from this central region towards the north suggests that these areas were also affected by end-Eocene uplift and formation of the UPS, followed by a phase of uplift and formation of the LPS. Apparently, in these northerly regions, Eocene burial and exhumation were relatively minor compared to the magnitudes of the mid-Cretaceous and late Miocene events. Other evidence for regional uplift and exhumation includes the regional nature of the late Miocene event comparable to that of the LPS (Figs 33C, D), and that present-day elevation of the LPS is due to early Pliocene C9 uplift. Whereas the LPS is recognised at an elevation of around $1 \mathrm{~km}$ a.s.l. across most of the region, the early Pliocene episode was only identified in AFTA data from a limited area (Fig. 33E). However, as argued previously, we suggest that the Pliocene event also affected the wider region.

Interestingly, the continuity of the LPS on both sides of the PDMF in the south-western part of the study area (Section 3.1), indicates that this fault system was

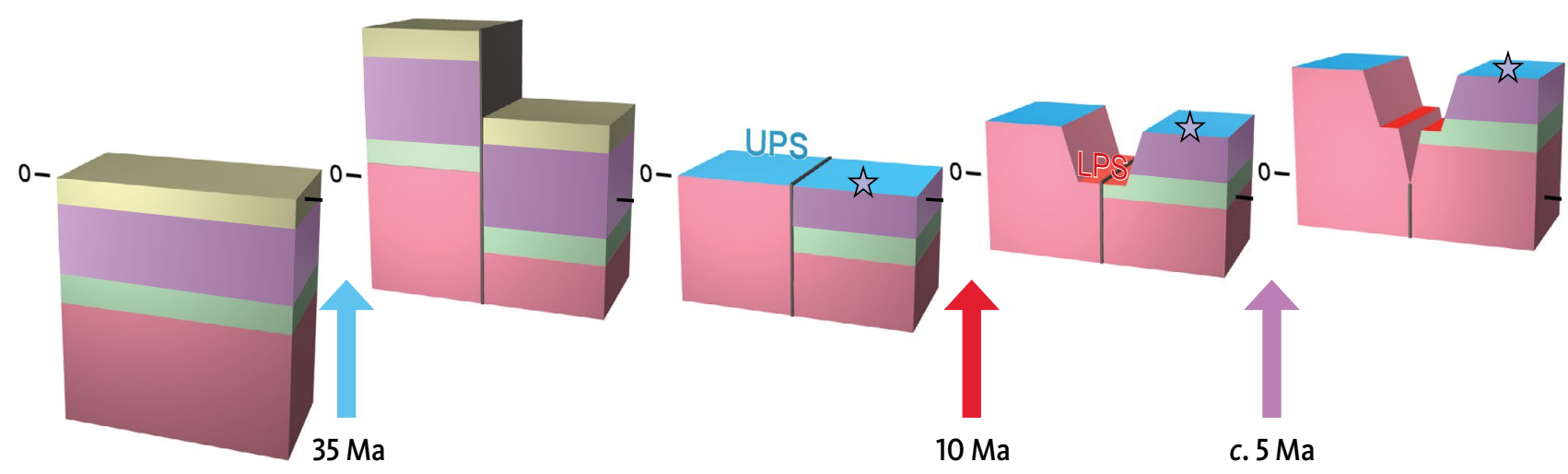

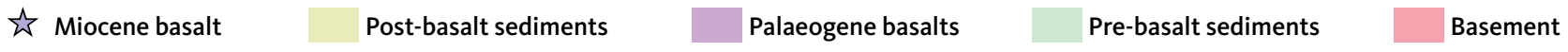

Fig. 34 Block diagrams illustrating the post-rift development of the East Greenland margin since Cenozoic maximum burial below a Palaeogene succession of volcanics and sediments by end of the Eocene. Three events of uplift and exhumation (end-Eocene C6, late Miocene C8 and early Pliocene C9) led to the formation of the present-day landscape with two elevated plains, the Upper and Lower Planation Surface (UPS and LPS, respectively). The presence of the mid-Miocene basalts flows of the Vindtop Formation (Storey et al. 2004; Figs 21, 27) on the UPS shows that this surface was formed in pre-glacial times (Bonow et al. 2014). 
not active during the early Pliocene episode. This is in contrast to the movements of the PDMF that we have inferred for the end-Eocene and late Miocene episodes further north (Sections 6.1.3 and 6.2.2, respectively).
We conclude that the presence of the UPS and LPS as two major steps in the landscape of North-East Greenland can be explained as a consequence of sequential uplift and incision beginning in the end-Eocene, late Miocene and early Pliocene. 


\section{Palaeozoic-Mesozoic thermal histories}

In this Chapter, we present reconstructed thermal histories for locations that reveal the regional variation in Palaeozoic and Mesozoic tectonic processes. Whereas deeper burial and exhumation control the regional variation in thermal histories, for the most part, evidence for vertical offsets across faults is also present. We also discuss the age and thickness of the covers that were present prior to the pre-Cenozoic episodes of uplift and erosion, based on information presented in Chapters 4 and 5.

\subsection{Thermal-history reconstructions, Store Koldewey}

Thermal-history solutions derived from AFTA in three samples of Caledonian basement from Store Koldewey are shown in Fig. 35. Many basement samples from the region north of $75^{\circ} \mathrm{N}$ share essentially similar thermal histories, undergoing exhumation and cooling below c. $100^{\circ} \mathrm{C}$ in the late Carboniferous $\mathrm{CO}$ episode, sometime between 320 and $300 \mathrm{Ma}$. Furthermore, deep basement levels were exhumed in the Middle Devonian prior to deposition of Old Red Sandstones (Gilotti \& McClelland 2008).
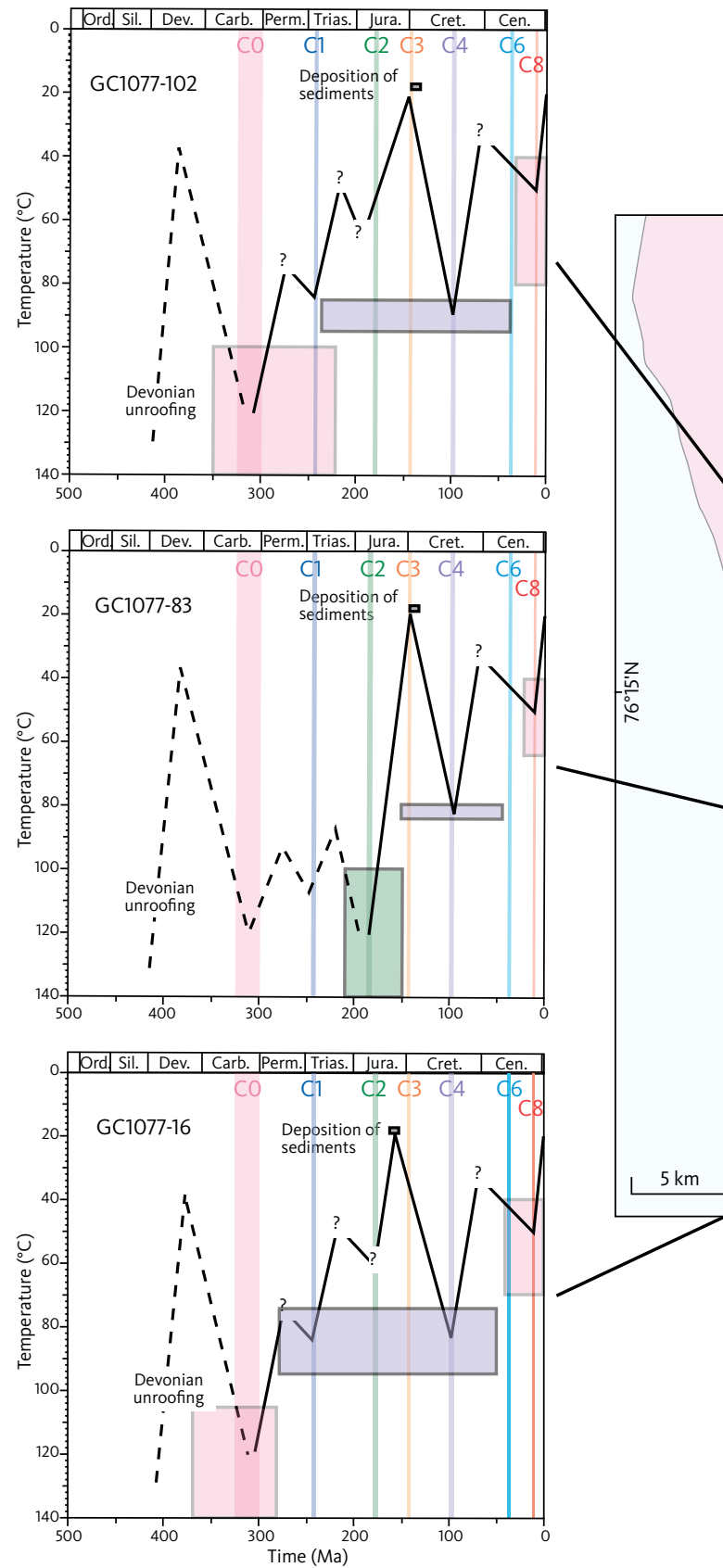

Fig. 35 Variation in thermal histories in Caledonian basement samples from Store Koldewey. Coloured vertical bars define the onset of regional cooling episodes (Table 1). Coloured boxes define the palaeotemperature-time constraints for individual samples. The $95 \%$ uncertainty limits on the onset of cooling are quite wide for some samples. Attribution to regional episodes is based on a comparison of samples within a restricted region. Map location in Fig. 11. Ord.: Ordovician. Sil.: Silurian. Dev.: Devonian. Carb.: Carboniferous. Perm.: Permian. Trias.: Triassic. Jura.: Jurassic. 


\subsubsection{Samples GC1017-16, -102, crystalline} basement, near sea level

Basement samples GC1077-16 and -102, both from low elevations, cooled below C. $100^{\circ} \mathrm{C}$ in the late Carboniferous CO episode and were exhumed to the surface by the Late Jurassic (GC1077-16) and Early Cretaceous (GC1077-102), when sediments were deposited on top of the sampled basement. Both sediments and basement were then reburied to reach maximum palaeotemperatures around 80 to $90^{\circ} \mathrm{C}$, from which cooling/ exhumation commenced in the mid-Cretaceous C4 episode (between 95 and $90 \mathrm{Ma}$ ). VR and AFTA data from the overlying sedimentary successions corroborate evidence of this re-burial, as summarised in Fig. 15. The palaeotemperature constraints for the mid-Cretaceous C4 (c. Turonian) episode for all samples from Store Koldewey are consistent with a PSE (Fig. 25) of about 2.8 $\mathrm{km}$ for a palaeogeothermal gradient of $25^{\circ} \mathrm{C} / \mathrm{km}$ and a surface temperature of $20^{\circ} \mathrm{C}$. For the samples of Lower Cretaceous sediments near sea level, this elevation corresponds to burial below a Cretaceous cover of the same magnitude. The cover removed since the onset of the mid-Cretaceous event must have been of AptianTuronian age as the youngest Cretaceous sediments on Store Koldewey are of earliest Aptian age (Bjerager et al. 2020). Intervening re-burial may have occurred following mid-Cretaceous exhumation prior to the final phase of exhumation in the late Miocene.

\subsubsection{Sample GC1017-83, crystalline basement, near sea level}

In contrast to samples GC1077-16 and -102, basement sample $\mathrm{GC} 1077-83$ did not cool below $100^{\circ} \mathrm{C}$ until the Early Jurassic (c. $180 \mathrm{Ma}$ ), although the subsequent history is very similar. Since sample GC1077-83 is located between samples GC1077-16 and -102, the Early Jurassic cooling though $\mathrm{C} .100^{\circ} \mathrm{C}$ in sample GC1077-83, must reflect major faulting and tectonic offsets in this region. Significant faulting must have taken place prior to the mid-Cretaceous as nearby samples show very different thermal histories prior to that episode (e.g. samples GC1077-8 and GC1104-3). Although no constraints on palaeogeothermal gradients are available from this region, results from locations to the south suggest that the thermal histories shown in Fig. 35 reflect primarily the history of sequential exhumation/burial/exhumation. Compare this with the thermal-history diagram for basement samples from Store Koldewey in Appendix 3.12.

\subsection{Thermal-history reconstructions of pre-Mesozoic terrains}

There is broad variation between thermal histories of Palaeozoic sedimentary and intrusive rocks and crystaline basement across the region between 70 and $74^{\circ} \mathrm{N}$
(Fig. 36). The basement was exhumed from great depth in the Middle Devonian prior to deposition of Old Red Sandstones (Gilotti \& McClelland 2008). Here, we review a representative selection of samples to illustrate this regional variation.

\subsubsection{Sample GC1016-62, crystalline} basement, Hudson Land (123 m a.s.l.)

This sample cooled from $>120^{\circ} \mathrm{C}$ in the earliest Cretaceous C3 episode, followed by end-Eocene C6 cooling from $110-120^{\circ} \mathrm{C}$ and finally late Miocene C8 cooling from $40-80^{\circ} \mathrm{C}$. Compare this with the thermal-history diagram for VT4 in Appendix 3.4. Note the difference in C3 palaeotemperature compared to nearby sample GC1016-55 from Clavering $\varnothing$ (next Section).

\subsubsection{Sample GC1016-55, Carboniferous sediments, Clavering Ø (52 m a.s.I.)}

This sample cooled from palaeotemperatures $>100^{\circ} \mathrm{C}$ in the Middle Triassic C1 episode (data from this sample do not definitively record this episode, which is inferred from adjacent samples). The sample subsequently cooled from $95-105^{\circ} \mathrm{C}$ in the earliest Cretaceous C3 episode and from $65-75^{\circ} \mathrm{C}$ in the late Miocene C8 episode. Based on data from adjacent samples, it is likely that the region from which this sample was collected also underwent Early Jurassic C2 cooling (C2 in Fig. 14). Compare with the thermal-history diagram for VT1 in Appendix 3.1.

\subsubsection{Sample GC1016-9, Devonian sediments, Ella $\varnothing$ ( $1 \mathrm{~m}$ a.s.I.)}

This sample cooled below $120^{\circ} \mathrm{C}$ in the Early Jurassic C2 episode and subsequently cooled from $60-75^{\circ} \mathrm{C}$ in the late Miocene C8 episode. Data from adjacent samples suggest that this sample most likely also underwent cooling in the earliest Cretaceous C3 and the end-Eocene $\mathrm{C} 6$ episodes, although these events cannot be resolved in data from this sample.

\subsubsection{Sample GC1016-45, Ordovician intrusion, Milne Land (458 $\mathrm{m}$ a.s.I.)}

This sample cooled below $100^{\circ} \mathrm{C}$ in the Middle Triassic $\mathrm{C} 1$ episode. Based on regional geological considerations, the intrusion was unroofed in the Middle Devonian and subsequently covered by sedimentary rocks prior to $\mathrm{C} 1$ cooling. The sample subsequently cooled from $95-110^{\circ} \mathrm{C}$ in the Early Jurassic C2 episode, which is also interpreted as representing exhumation. Finally, this sample cooled from a late Miocene C8 palaeotemperature of $20-90^{\circ} \mathrm{C}$. The presence of nearby Palaeogene basalts shows that the sample was close to the surface in the early Eocene. 

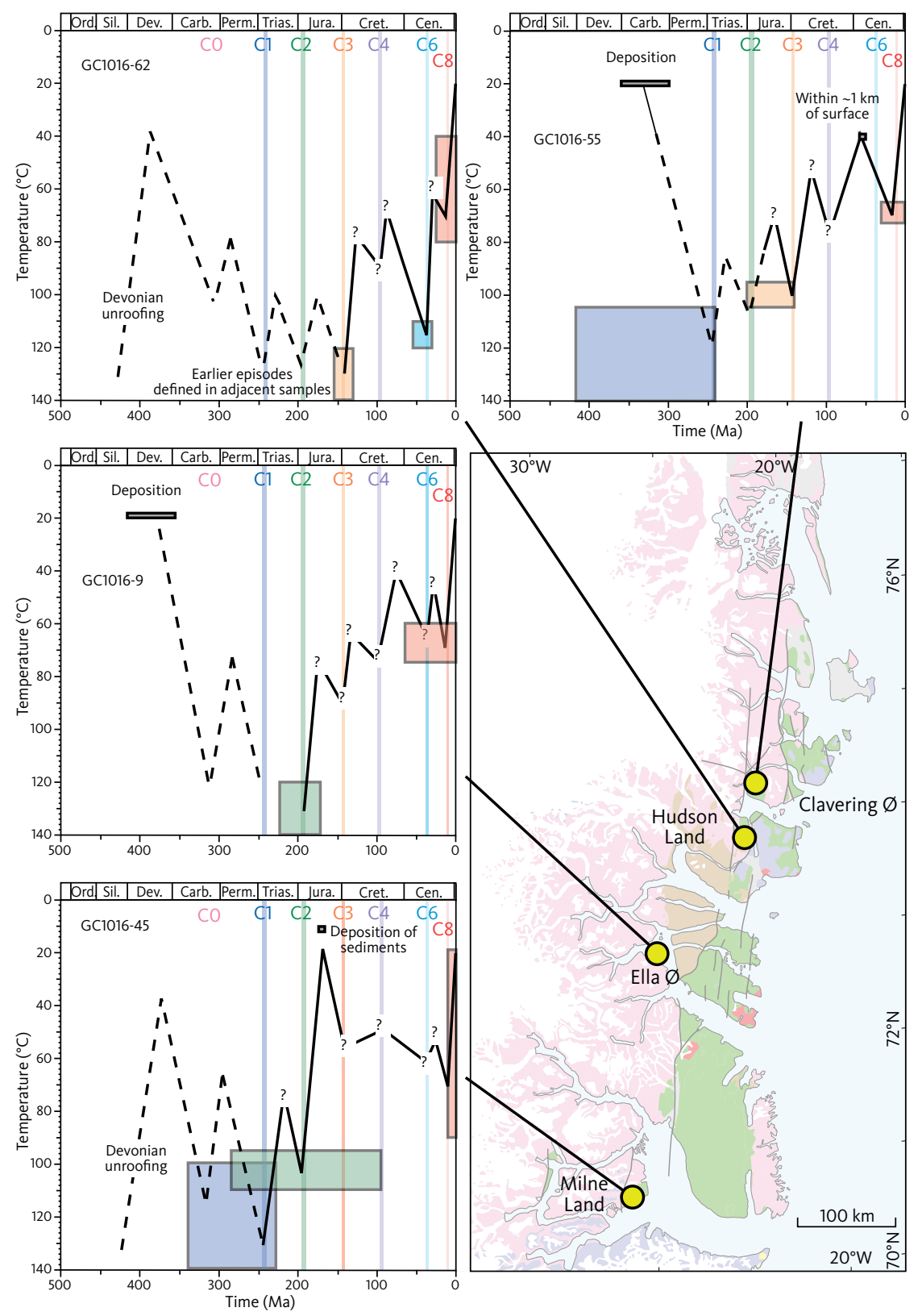

(1)
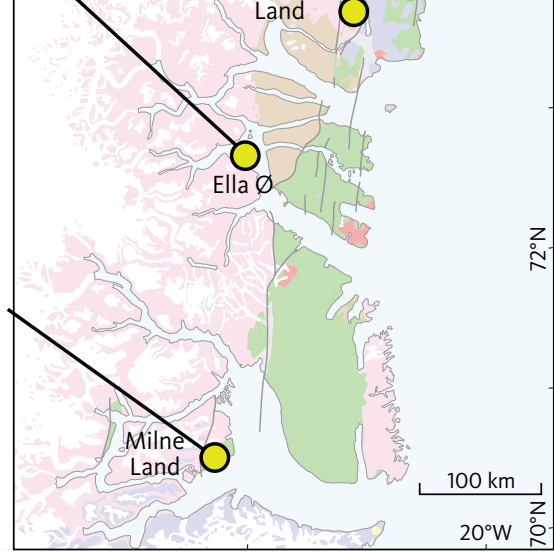

Fig. 36 Variation in thermal histories in samples of pre-Mezozoic age. Coloured vertical bars define the onset of regional cooling episodes (Table 1). Coloured boxes define the palaeotemperaturetime constraints for individual samples. The 95\% uncertainty limits on the onset of cooling are quite wide for some samples. Attribution to regional episodes is based on a comparison of samples within a restricted region. Ord.: Ordovician. Sil.: Silurian. Dev.: Devonian. Carb.: Carboniferous. Perm.: Permian. Trias.: Triassic. Jura.: Jurassic.

\subsection{Thermal-history reconstructions of Mesozoic terrains}

The broad range of thermal histories for samples from Mesozoic sedimentary rocks across the region is shown in Fig. 37. Representative examples are reviewed below.

\subsubsection{Sample GC1016-69, Triassic sediments, Hold with Hope (94 $m$ a.s.I.)}

Mid-Cretaceous C4 cooling across Hold with Hope is supported by data from this sample, which cooled from $95-100^{\circ} \mathrm{C}$ sometime between 175 and $80 \mathrm{Ma}$. The adjacent sample, GC1016-38, cooled from similar palaeotemperatures between 120 and $20 \mathrm{Ma}$. Sample 69 was subsequently affected by late Miocene $\mathrm{C} 8$ cooling from $60-80^{\circ} \mathrm{C}$. The presence of Palaeogene basalts nearby again suggests that this sample was close to surface temperature during the early Eocene. Adjacent samples suggest that sample 69 also most likely underwent some degree of end-Eocene $\mathrm{C} 6$ cooling. Compare with the thermal-history diagram for VT2 in Appendix 3.2.

\subsubsection{Sample GC522-7, Jurassic sediments, Wollaston Forland (150 $\mathrm{m}$ a.s.I.)}

This sample reached a maximum palaeotemperature of $85-95^{\circ} \mathrm{C}$ prior to end-Eocene $\mathrm{C} 6$ cooling. The sample subsequently cooled from $20-75^{\circ} \mathrm{C}$ in the late Miocene C8 episode. The presence of extensive Palaeogene basalts on Wollaston Forland suggests that the sample was close to surface temperatures during the early Eocene, suggesting relatively rapid heating to the end-Eocene palaeothermal peak. Data from adjacent samples also suggest that this sample may have undergone earliest 

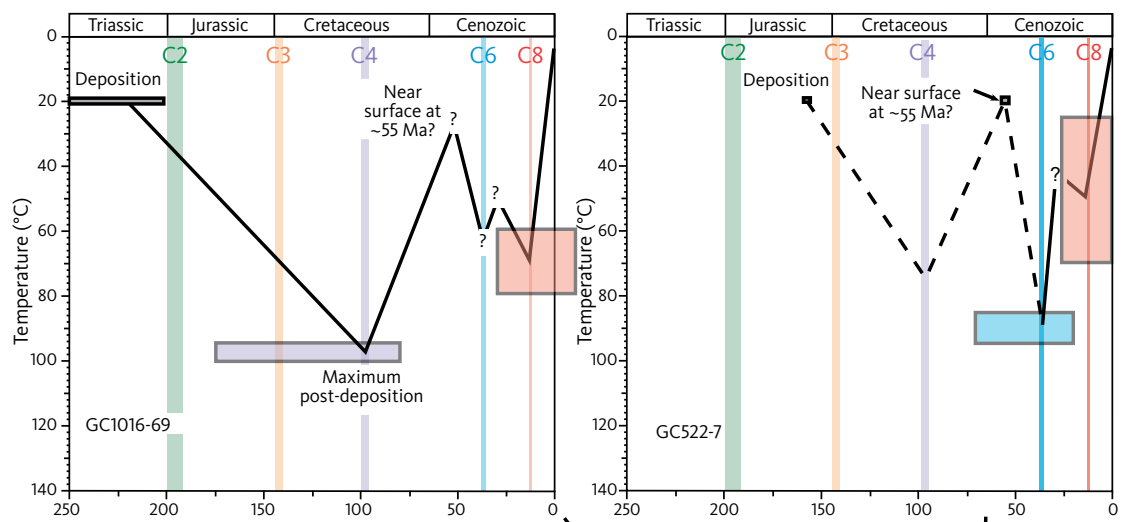

Fig. 37 Variation in thermal histories in samples of Mesozoic age. Coloured vertical bars define the onset of regional cooling episodes (Table 1). Coloured boxes define the palaeotemperaturetime constraints for individual samples. The 95\% uncertainty limits on the onset of cooling are quite wide for some samples. Attribution to regional episodes is based on a comparison of samples within a restricted region.
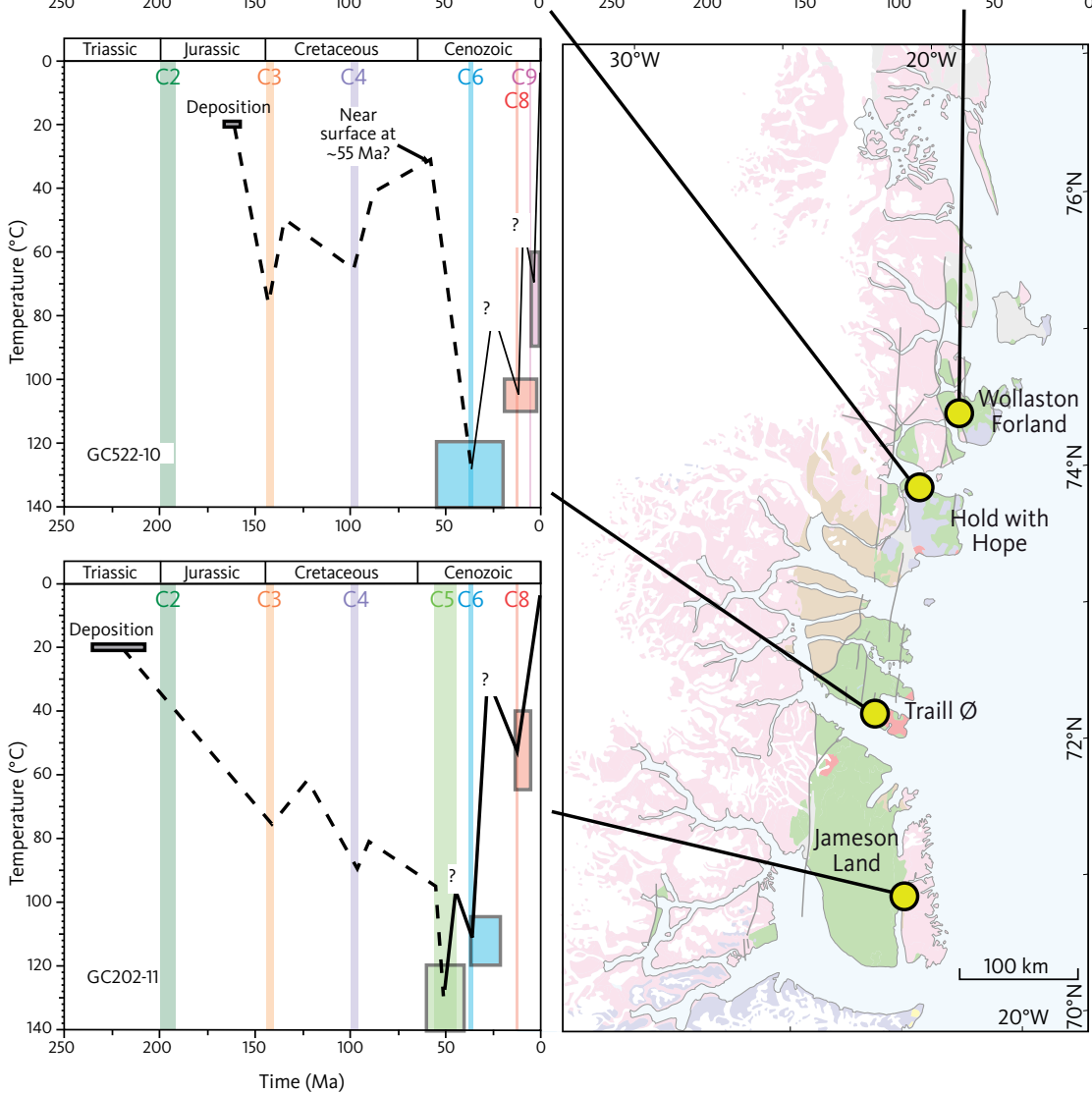

Cretaceous C3 cooling, although palaeotemperatures at this time were lower than those reached in the end-Eocene palaeothermal maximum.

\subsubsection{Sample GC522-10, Jurassic sediments,}

Traill $\varnothing ~(230 \mathrm{~m}$ a.s.I.)

This sample cooled below $120^{\circ} \mathrm{C}$ in the $\mathrm{C} 6$ episode. It subsequently cooled from $100-110^{\circ} \mathrm{C}$ in the $\mathrm{C} 8$ episode and finally from $60-90^{\circ} \mathrm{C}$ within the last $5 \mathrm{Myr}$ (during the early Pliocene C9 episode). Evidence of the prelate Eocene history is overprinted by the severity of end-Eocene heating, but earlier events almost certainly affected this location. Compare this with Fig. 32 and with the thermal-history diagram for VT6 in Appendix 3.6.

\subsubsection{Sample GC202-11, Triassic sediments,} south-eastern Jameson Land (150 m a.s.I.)

This sample cooled below $120^{\circ} \mathrm{C}$ in the early Eocene C5 episode (beginning c. $55 \mathrm{Ma}$ ). This is interpreted as reflecting contact or hydrothermal heating associated with Palaeogene intrusive activity (see Section 5.6). It seems likely that burial may have been continuous during the Paleocene and Eocene. This sample subsequently cooled from $95-105^{\circ} \mathrm{C}$ in the end-Eocene C6 episode, probably due to the onset of exhumation of the continental margin at this time. Finally, this sample cooled from a late Miocene C8 palaeotemperature of $40-65^{\circ} \mathrm{C}$, interpreted as the final onset of exhumation of the continental margin. 


\subsection{Palaeozoic-Mesozoic removed covers}

It is possible to refine the heating and cooling (burial and exhumation) history for several localities by combining the interpretation of AFTA data in (1) basement samples with geological constraints from sediments that rest on basement and (2) sediment samples with their stratigraphic age. Based on a regional comparison of estimated palaeogeothermal gradients (Section 4.6), we convert palaeotemperatures to thickness of covers based on a gradient of $25^{\circ} \mathrm{C} / \mathrm{km}$ for all pre-Cenozoic episodes; see further discussion in Appendix 2. We assume a palaeosurface temperature of $20^{\circ} \mathrm{C}$. Sample locations mentioned in the following sections are shown in Fig. 11. The maps of the appropriate palaeotemperatures are presented in Fig. 14.

\subsubsection{Cover prior to exhumation in the Middle Triassic episode (C1)}

In the southern interior, west of Milne Land, one sample of the mid-Permian Røde $\varnothing$ Conglomerate (Stemmerik \& Piasecki 2004) was $>110^{\circ} \mathrm{C}$ when $\mathrm{C} 1$ cooling began (GC1016-5). Consequently, a cover of more than $3.5 \mathrm{~km}$ of mid-Permian - Middle Triassic sediments must have been present above this sample at the onset of $C 1$ cooling.

In the summits of western Clavering $\varnothing$, a sample of upper Carboniferous sandstone reached a C1 palaeotemperature between 105 and $115^{\circ} \mathrm{C}$ (GC1016-49; VT1; Appendix 3.1). This must have been caused by burial below a thick cover (>3 km) of upper Carboniferous to Middle Triassic sediments.

On Germania Land, where Upper Carboniferous outliers are present, samples that cooled from C1 palaeotemperatures of $100^{\circ} \mathrm{C}$ or more reflect burial below a thick Upper Carboniferous - Middle Triassic cover (e.g. GC1077-11; Appendix 3.13; Piasecki et al. 1994). Stemmerik et al. (1993) used thermal maturity data from upper Permian deposits from Clavering $\varnothing$ to northern Jameson Land, to estimate burial below an overburden of $1.5-3 \mathrm{~km}$.

The former presence of a kilometre-thick upper Carboniferous (locally Permian) - Middle Triassic cover is thus documented at very disparate locations on both sides of the PDMF system. It seems likely that this cover was present across much of the study area prior to $\mathrm{C} 1$ exhumation.

\subsubsection{Cover prior to exhumation in the Early Jurassic episode (C2)}

The constraints on the thermal history for two adjacent samples of Palaeozoic granite and Middle Jurassic sandstones from Milne Land provide insights into the magnitude of exhumation in the Early Jurassic C2 episode (GC1016-45 and -44, respectively; VT8). Whereas the sandstones were deposited on the eroded granite at an assumed temperature of $c .20^{\circ} \mathrm{C}$, AFTA data show that the basement sample was at $\mathrm{C} .100^{\circ} \mathrm{C}$ when $\mathrm{C} 2$ cooling began. For any reasonable palaeogeothermal gradient, this palaeotemperature implies burial below a kilometre-thick cover of pre-Middle Jurassic rocks prior to C2 exhumation.

On Store Koldewey, Middle Jurassic sediments rest on basement and reached a C2 palaeotemperature $>100^{\circ} \mathrm{C}$, which again requires removal of a kilometre-thick pre-Jurassic and Lower Jurassic rocks during the C2 episode (GC1077-83; Appendix 3.12).

A kilometre-thick cover was thus present above outcropping pre-Jurassic rocks when cooling began during the Early Jurassic, both west and east of the PDMF system.

\subsubsection{Cover prior to exhumation in the earliest Cretaceous episode (C3)}

AFTA data from Clavering $\varnothing$ suggest a succession of $2 \mathrm{~km}$ or more of Carboniferous to lowermost Cretaceous sediments was present there at the palaeothermal peak prior to earliest Cretaceous C3 cooling (compare this with the thermal-history diagram for VT1, Appendix 3.1).

On Store Koldewey, Lower Cretaceous sediments rest on basement that reached an earliest Cretaceous C3 palaeotemperature of $80-90^{\circ} \mathrm{C}$ (GC1077-104; Fig. 15). This implies removal of about $2.5 \mathrm{~km}$ of Cretaceous rocks during the $\mathrm{C} 3$ episode. Elsewhere, most of the evidence for C3 palaeotemperatures are from samples of basement terrains that do not offer chronostratigraphic constraints on the age of the rocks removed during this episode.

Additional insight into the nature of the C3 episode can be obtained from the AFTA data from the north-west coast of Hold with Hope (VT2; Appendix 3.2). Here, samples GC1016-66 to 69 of Triassic sandstone units cooled from almost $100^{\circ} \mathrm{C}$ in the earliest Cretaceous episode. As these units are overlain by Middle Jurassic deposits, the high C3 palaeotemperatures must have been produced by burial beneath a kilometre-thick cover of Middle to Upper Jurassic sediments.

\subsubsection{Cover prior to exhumation in the mid- Cretaceous episode (C4)}

At several localities within the study area, Middle Jurassic to Lower Cretaceous sediments were heated to mid-Cretaceous C4 palaeotemperatures of 80 to $100^{\circ} \mathrm{C}$. This is the case on Store Koldewey where C4 palaeotemperatures reached $80-90^{\circ} \mathrm{C}$ for most samples (including basement and sedimentary rocks; Appendix 3.12). VR values between 0.43 and $0.58 \%$ (equivalent to maximum palaeotemperature of 72 to $96^{\circ} \mathrm{C}$ ) obtained for Lower Cretaceous sediments there (Fig. 15) are consistent with the $\mathrm{C} 4$ palaeotemperatures from AFTA. This shows that these Lower Cretaceous sediments cooled from their maximum post-depositional palaeotemperatures in 


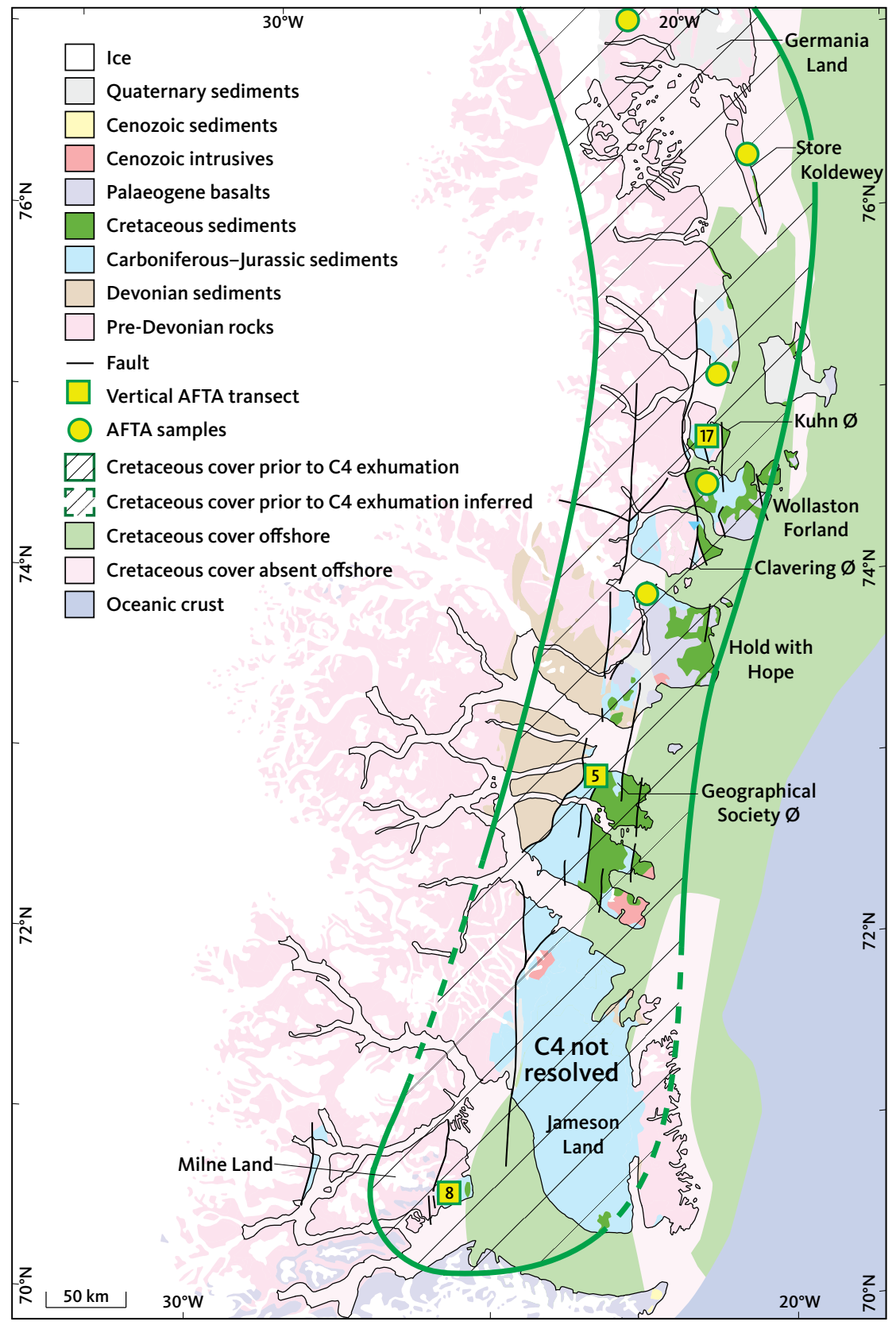

Fig. 38 Outline of the kilometre-thick Middle Jurassic to Upper Cretaceous deposits (Aalenian-Turonian) present prior to exhumation in the mid-Cretaceous C4 episode. The map is based on samples of Jurassic to Cretaceous depositional age that define $\mathrm{C} 4$ cooling and older samples that define C4 cooling adjacent to Jurassic-Cretaceous outliers, e.g. on Germania Land (Appendix 3.13). The cover thus included the post-rift succession deposited after rift-climax at the Jurassic-Cretaceous transition. Due to thermal subsidence, the post-rift succession also covered terrain beyond the rift itself (i.e. 'steer-head' geometry). Most of this cover was removed prior to Palaeogene volcanic extrusions. Here, we assume that the extent of the postrift cover reaches c. $50 \mathrm{~km}$ away from the data points. We infer that this cover also extended across Jameson Land where Cretaceous sediments are largely absent. C4 cooling could not be resolved in the AFTA data from Jameson Land, possibly because of the many later cooling episodes that affected this region. Offshore geology according to Stoker et al. (2017).

this episode. These palaeotemperatures correspond to burial below a c. $2.5 \mathrm{~km}$-thick Cretaceous succession. Similarly, C4 palaeotemperatures correspond to values derived from VR data in the Clavering $\varnothing$ region (as far south as Hold with Hope) at some distance from Palaeogene intrusive centres, where palaeotemperatures derived from VR data reflect end-Eocene $C 4$ values (C4 and $\mathrm{C6}$ in Fig. 16).

Middle Jurassic sediments on Kuhn $\varnothing$ onlap basement close to the summits (c. $1.2 \mathrm{~km}$ a.s.l.) where the basement was heated to a C4 palaeotemperature around $70^{\circ} \mathrm{C}$ (VT9, Appendix 3.7). This palaeotemperature corresponds to burial of the summits of Kuhn $\varnothing$ below a 2 $\mathrm{km}$ thick Middle Jurassic to mid-Cretaceous cover when C4 cooling began (representing maximum burial of the
Mesozoic succession). This succession thus accumulated in the interval between C2 and C4 exhumation and thus included sediments of Toarcian to Turonian age; not least a Cretaceous post-rift succession that is no longer present on Kuhn $\emptyset$.

On Jameson Land, Cretaceous sediments are largely absent and the $\mathrm{C} 4$ episode could not be resolved by AFTA data. This is probably due to the dominance of the C3 episode in this region.

Figure 38 illustrates the wide extent of the corresponding kilometre-thick Middle Jurassic to Cretaceous (Aalenian-Turonian) deposits present prior to C4 exhumation. The cover included the post-rift succession deposited in a broad thermal sag after rift-climax at the Jurassic-Cretaceous transition (Surlyk 1978b, 1990). 


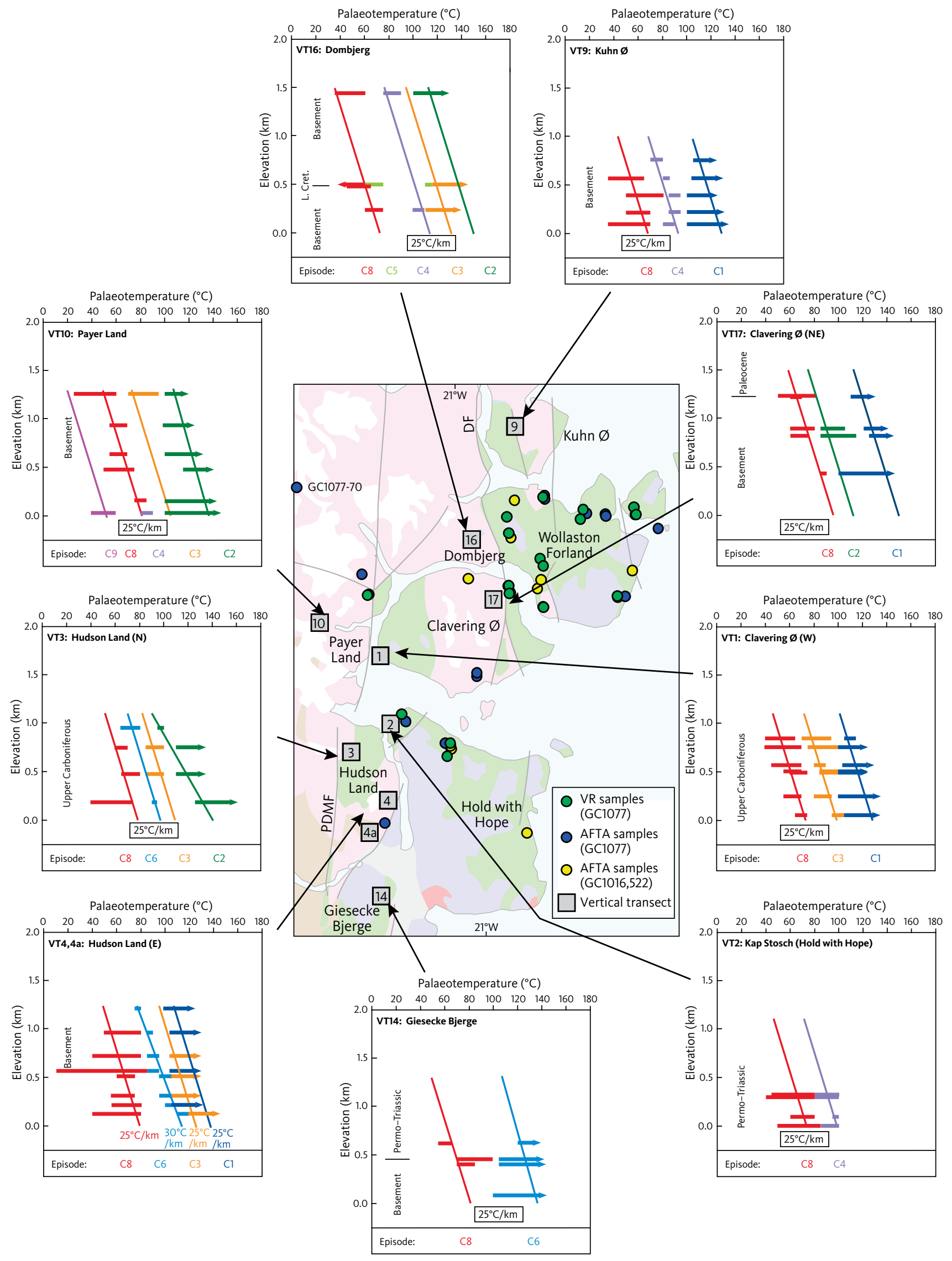

Fig. 39 Comparison of palaeotemperature constraints from AFTA in samples from vertical transects (VTs) around Clavering $\emptyset$, plotted against elevation. Major offsets are apparent in the magnitude of pre-Cenozoic palaeothermal episodes. E.g. between VT10 (in which Early Jurassic C2 cooling dominates) and VT1 (in which Middle Triassic C1 cooling dominates). All vertical transects are shown in Appendix 2.3. DF: Dombjerg Fault. PDMF: Post-Devonian Main Fault. 
Thus, we interpret this episode as representing the time of maximum burial across most of the onshore Mesozoic basins between Store Koldewey and Hold with Hope and possibly farther south. Due to post-rift thermal subsidence, the post-rift succession also covered terrains beyond the rift (i.e. 'steer-head' geometry). If we make the conservative assumption that the post-rift cover reached up to $50 \mathrm{~km}$ from documented locations, the extent of the former cover would have reached from Germania Land and southwards to Geographical Society $\varnothing$ and beyond, and in a wide zone around Milne Land.

It thus seems likely that a thick cover of Cretaceous post-rift sediments accumulated above the Mesozoic rift basins and their hinterland prior to C4 exhumation. Palaeogene basalts are present in the summits across much of the study area (e.g. western Hold with Hope, Kuhn $\varnothing$ and Milne Land), implying that most of this Cretaceous cover had been removed by the time that volcanic activity began.

\subsection{Fault movements in the Clavering $\emptyset$ area}

Palaeotemperature profiles for the Clavering $\varnothing$ region in Fig. 39 show significant differences between adjacent locations indicating differential exhumation in various events, and major offsets across faults (Fig. 16). For example, while results from Payer Land (VT10) are dominated by the Early Jurassic C2 episode, those from the nearby Clavering $\varnothing$ (VT1) are dominated by the Middle Triassic C1 episode (Appendices 3.8, 3.1). These two locations are on opposite sides of the PDMF, and the results suggest that rocks on the western side (VT10) were more deeply buried in the Early Jurassic compared to the eastern side (VT1). Both locations show earliest Cretaceous C4 cooling of broadly similar magnitude, suggesting that the western block was more uplifted during or after the Early Jurassic episode and that the differential movements were mainly complete prior to the C4 episode.

West of the PDMF, the Middle Triassic C1 episode is recognised in one sample, which records palaeotemperatures in excess of $130^{\circ} \mathrm{C}$ (GC1077-70). This episode is recognised in many samples east of the fault. This indicates that $\mathrm{C} 1$ cooling probably affected areas both west and east of the fault but is only seen in sample GC107770 due to the presence of higher wt $\% \mathrm{Cl}$ apatites, which are more retentive than lower wt $\% \mathrm{Cl}$ grains (wt $\% \mathrm{Cl}$ are provided in Supplementary Files S1-S3).

Palaeotemperature profiles for VT9 (Kuhn $\varnothing$ ) and VT16 (Dombjerg) show marked differences for the pre-Miocene episodes at these locations (Appendices 3.7, 3.10). VT9 cooled below c. $100^{\circ} \mathrm{C}$ in the Middle Triassic C1 episode, whereas VT16 cooled below similar temperatures in the Early Jurassic C2 episode implying that VT9 was colder than VT16 in the Early Jurassic episode. That relationship persisted to the mid-Cretaceous C4 episode when the palaeotemperatures at summit level were about $20^{\circ} \mathrm{C}$ cooler for VT9 than for VT16. Basalts are found in the summits at both locations, so any offsets were levelled out prior to the Cenozoic. Consequently, the offset between the C2 and C4 palaeotemperatures can be explained by movements of the Dombjerg Fault during the mid-Cretaceous episode, where the Dombjerg block underwent more exhumation than the Kuhn $\varnothing$ block.

At all locations around Clavering $\varnothing$, the summits are at almost identical elevations above present sea level. This implies that any thermal offset between two locations during a palaeothermal episode was levelled out by subsequent differential, vertical movements that ultimately resulted in the uniform present-day temperatures in the summits at similar elevation. Offsets of palaeotemperature profiles between two locations can be levelled either by movement of a fault between the two vertical transects (on separate fault blocks; e.g. across the PDMF) or by rotation of the fault block where both transects are located (e.g. VT3 and VT4 on Hudson Land). Basalts occur in the summits of Clavering $\varnothing$, Kuhn $\varnothing$ and on Dombjerg (VT1, VT17, VT9 and VT16, respectively) at almost the same elevation. This implies that there have been no major relative movements between these locations since the extrusions of the basalts at c. $55 \mathrm{Ma}$.

Detailed discussion of these differences is beyond the scope of this study, requiring integration with structural information to define different generations of movements. The time-temperature constraints for the different episodes provided in Appendix 1.4 allow such investigations by those interested in these aspects of the data. 
www.geusbulletin.org

\section{Hydrocarbon prospectivity}

In this Chapter, we discuss the hydrocarbon prospectivity of the sedimentary basins in North-East Greenland relative to their burial and exhumation history. We investigate when Mesozoic sediments may have reached their maximum palaeotemperatures prior to episodes of exhumation and briefly discuss the interplay between igneous bodies, hydrothermal effects, mineralisation and hydrocarbon generation.

\subsection{Store Koldewey}

AFTA data from samples of basement and Mesozoic sediments in the northernmost part of the study area around Store Koldewey show that Mesozoic sediments reached maximum palaeotemperatures in the mid-Cretaceous C4 episode (Figs 15, 35, 38; Appendix 3.12). For the onshore areas, this implies that hydrocarbon generation from any source rocks would have ceased at the onset of cooling between 95 and $90 \mathrm{Ma}$ (c. Turonian). Successful exploration would therefore depend on longlived seals or remigration. Factors such as seal breach during exhumation introduce additional risk. Based on the palaeothermal constraints from AFTA, the basement rocks now exposed on Store Koldewey were covered by about 2.4 and $2.0 \mathrm{~km}$ of sediments prior to mid-Cretaceous and late Miocene exhumation, respectively (palaeogeothermal gradient $25^{\circ} \mathrm{C} / \mathrm{km}$, palaeosurface temperature of $20^{\circ} \mathrm{C}$ ).

While these conclusions seem to apply across much of the onshore study area (Fig. 38), different conditions are to be expected offshore where there was less mid-Cretaceous exhumation. Source rocks may then have generated hydrocarbons during Late Cretaceous Cenozoic burial in wide areas across the offshore.

Exhumation of the margin was also significant during the late Eocene and late Neogene, but Eocene and Miocene burial were also important, and the combination of these factors makes it difficult to predict the net effect on thermal history of source rocks some distance from the coast. The interplay between burial and exhumation is likely to exert a critical influence on hydrocarbon prospectivity in offshore basins. Correlation between the onshore phases of uplift established in this study and offshore unconformities will be useful in establishing a regional tectonic framework.

\subsection{Exhumed oil accumulations on Traill $\varnothing$}

The importance of intrusive activity and exhumation to hydrocarbon exploration in East Greenland is illustrated by remnants of exhumed oil accumulations hosted in
Jurassic sandstones now at elevations of around $1 \mathrm{~km}$ on Traill $\varnothing$ (Price \& Whitham 1997). The present study provides insight into the magnitude of the sedimentary succession that has been removed on the East Greenland margin in the vicinity of these exhumed oil accumulations, together with the timing of the main episodes of uplift and erosion. This provides a framework for understanding the evolution of the margin and associated petroleum systems. In recent years, the implications of these accumulations have been intensely debated (Andrews et al. 2020a, b; Christiansen et al. 2020).

Interpretation of AFTA data from Traill $\varnothing$ suggests that prior to the onset of uplift and erosion of the margin in the late Eocene, c. $2 \mathrm{~km}$ of additional section was present above the present-day summit level of $1 \mathrm{~km}$ a.s.l. (Section 6.1.1; Fig. 26; Appendix 3.6). Estimates of up to $3 \mathrm{~km}$ have been suggested in previous studies (Price et al. 1997; Price \& Whitham 1997), but we argue that these studies have underestimated the role of enhanced heat flow associated with the late Eocene intrusions in and around eastern Traill $\varnothing$ (Fig. 32), and their impact on maturity levels, sandstone porosity, permeability and other factors.

The generation of hydrocarbons in the vicinity of eastern Traill $\varnothing$ from Upper Jurassic source rocks (Price \& Whitham 1997; Price et al. 1997) was most likely enhanced due to the increased heat flow in this region associated with the intrusions in the late Eocene (combined with the palaeoburial at that time). The organic content of the reservoir rocks is much lower than would be expected if the petroleum was degraded through biogeochemical processes upon exhumation of the reservoir (J. Bojesen-Koefoed pers.comm. 2018). The low organic content is thus more likely explained by destruction of previously reservoired hydrocarbons by high temperature, than by leakage and biodegradation.

Further afield, in areas where heat flow was not enhanced, any source rocks present would have remained at lower maturity levels at the end of the Eocene. Particularly in offshore regions that were not affected by end-Eocene exhumation, such source rocks may then have generated hydrocarbons during later burial in areas of Neogene subsidence. Therefore, the presence of these exhumed oil accumulations may be seen as a positive feature for exploration in the offshore region, instead of the more negative impact generally attributed to exhumation. 


\subsection{Maturation studies of the Jameson Land Basin}

Basin modelling and maturation studies of the Jameson Land Basin have used apatite fission-track data to investigate the history of uplift and denudation (Christiansen et al. 1992; Mathiesen et al. 2000). Christiansen et al. (1992) based their exhumation estimate on a range of observations including thermal maturity parameters, apatite fission-track parameters, porosity and seismic velocities; in particular they reported VR values up to $0.6 \%$ for organic-rich Permian and Jurassic formations at outcrop. They found that between 1.5 and $3 \mathrm{~km}$ of overburden had been removed across the basin, and that the lost cover likely consisted of more than $1 \mathrm{~km}$ of Cretaceous sediments as well as 1-2 km of Palaeogene basalts (primarily across the southern part of the basin). Mathiesen et al. (2000) assumed that generation of hydrocarbons was controlled by the burial resulting from deposition of the thick volcanic pile during the early Paleocene and prior to denudation beginning in the late Paleocene, with a total of $2-3 \mathrm{~km}$ of section removed since that time.

In contrast to these earlier studies, our results suggest that early Eocene $\mathrm{C} 5$ thermal effects in and around the Jameson Land are dominated not by depth of burial but by hydrothermal and contact effects of igneous intrusive bodies. We find that the regional palaeothermal maximum was reached later, in the end-Eocene $C 6$ episode (note, however, that the effects of the mid-Cretaceous C4 episode could not be resolved in the AFTA data from the Jameson Land Basin). Because of the localised high C5 palaeotemperatures, severe local variation in maturity levels within potential Jurassic source rocks successions is likely to exist in parts of the basin. Source rocks will have been heated locally above the gas-generation window. In adjacent areas, similar units may remain immature, while conditions within the main oil-generation window will undoubtedly have been reached in some areas. But amounts of hydrocarbons generated in this episode are likely to be small, given the local extent of early Eocene palaeothermal effects. Eocene burial following the early Eocene C5 episode and prior to maximum Cenozoic burial at the regional palaeothermal peak of the $\mathrm{C} 6$ episode, will have caused further regional-scale maturation of any source rocks that remained immature after the early Eocene. Ultimately, the potential yield as well as the potential for migration of hydrocarbons through the succession will, however, be much reduced as a result of early Eocene effects (Green et al. 2017a).

Green \& Japsen (2018) defined three palaeothermal episodes from AFTA data in two Upper Jurassic core samples from the $231 \mathrm{~m}$ deep Blokelv-1 borehole, Jameson Land (location in Fig. 26; east-west profile in Fig. 40), combined with VR data and regional AFTA data. They interpreted localised early Eocene palaeotemperatures (corresponding to episode C5) as representing heating related to intrusive activity, and end-Eocene C6 and late Miocene C8 palaeotemperatures as representing deeper burial followed by successive episodes of exhumation. The end-Eocene palaeotemperatures defined by AFTA require that the marine, Upper Jurassic succession in the borehole was buried below a $2750 \mathrm{~m}$ thick cover of Upper Jurassic - Eocene rocks prior to the onset of end-Eocene exhumation (assuming a palaeogeothermal gradient of $30^{\circ} \mathrm{C} / \mathrm{km}$ and $20^{\circ} \mathrm{C}$ at the surface). As these marine sediments are now near outcrop at c. $200 \mathrm{~m}$ above sea level, they have been uplifted by at least $3 \mathrm{~km}$ since maximum burial during post-rift thermal subsidence (c. $3.5 \mathrm{~km}$ assuming a palaeogeothermal gradient of $25^{\circ} \mathrm{C} / \mathrm{km}$; Fig. 26).

The estimated magnitude of rock uplift of about 3 $\mathrm{km}$ for sediments penetrated by the Blokelv drillcore (Green \& Japsen 2018) is consistent with the results of

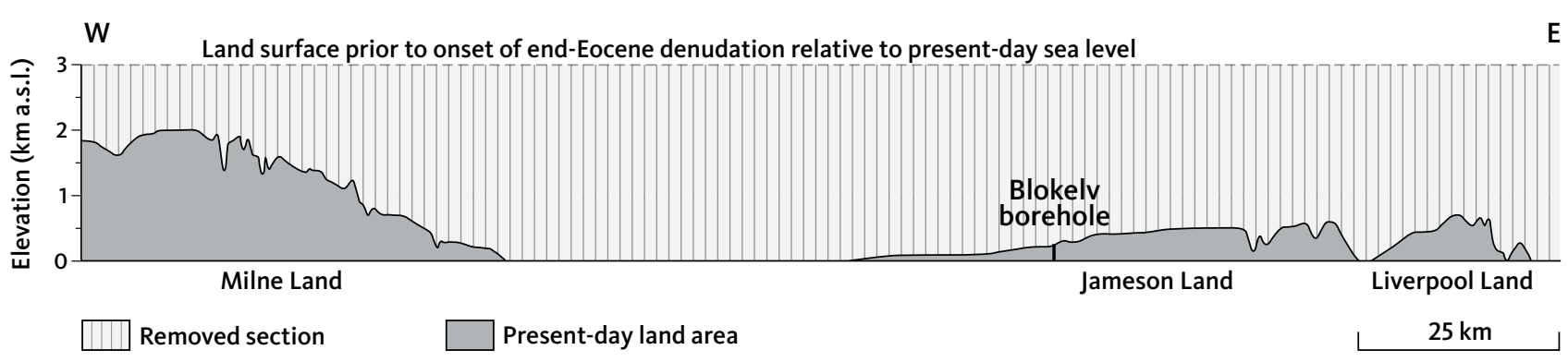

Fig. 40 Present-day elevation profile from Milne Land to Liverpool Land. The elevation of the late Eocene land surface relative to present sea level is indicated. End-Eocene projected surface elevation (PSE) calculated from AFTA data for Jameson Land and Liverpool Land (including results for the Blokelv borehole; assuming a palaeogeothermal gradient of $30^{\circ} \mathrm{C} / \mathrm{km}$ ) and estimates of rock uplift for Milne Land (Bonow et al. 2014). The late Eocene land surface was at low elevation after Eocene subsidence, so the elevation of this surface relative to the present sea level is a measure of the amount of rock uplift since then (Fig. 26). Location of the Blokelv borehole and of the profile in Fig. 26. Modified after Green \& Japsen (2018). 
Larsen et al. (1989) and Bonow et al. (2014). Larsen et al. (1989) investigated zeolite isograds in the vesicles of basalts in the region around Scoresby Sund and argued that the absence of the shallow and less altered zeolite zones could be explained by the removal of these zones by erosion. For Milne Land they concluded that a succession of about $900 \mathrm{~m}$ had been removed above the basalt flows that cover the summits there (assuming a palaeogeothermal gradient of $40^{\circ} \mathrm{C} / \mathrm{km}$ at the time of zeolite formation). Bonow et al. (2014) argued that the surface of the volcanic successions was near sea level during the formation of the zeolites because this happened shortly after the eruption of the volcanic units at the Paleocene-Eocene transition at a time of regional subsidence (Brooks 2011). Consequently, the basalts, now at c. $1800 \mathrm{~m}$ a.s.l., were uplifted $2700 \mathrm{~m}$ (1800+ $900 \mathrm{~m}$ ) since the formation of the zeolites in the Eocene. Assuming a lower thermal gradient at the time of the zeolite formation would result in a higher estimate of removed rocks.
Figure 40 shows a present-day elevation-profile across Milne Land, Jameson Land and Liverpool Land and the elevation of the end-Eocene land surface relative to present sea level (the end-Eocene PSE). The late Eocene land surface was at low elevation after Eocene subsidence, so the elevation of this surface relative to the present sea level is a measure of the amount of rock uplift since then.

The influence of younger events in northern Jameson Land was also recognised in previous studies. Temperatures of 115 to $150^{\circ} \mathrm{C}$ were quoted by Christiansen et al. (1990) for formation of various mineral phases in upper Permian carbonates in Wegener Halvø, based on isotope data and fluid inclusion temperatures. Christiansen et al. (1992) noted that apatite fission-track ages were very young (25-15 Ma) in this region (Fig. 12). These observations suggest a clear link between these hydrothermal effects and the early Miocene C7 palaeotemperatures revealed by the AFTA data (Fig. 14). This highlights the potential for further studies of the relationship between igneous bodies, hydrothermal effects, mineralisation and hydrocarbon generation in this basin. 


\section{Episodes of uplift and erosion in Greenland and Scandinavia}

In this Chapter, we compare the regional events of uplift and erosion in Greenland and Scandinavia. Previous studies combining stratigraphic landscape analysis and thermal-history reconstruction in Greenland and southern Scandinavia have identified a series of post-Caledonian regional cooling episodes, mainly representing exhumation (Japsen et al. 2006, 2014, 2016, 2018). Here we compare the timing of key cooling episodes and identify periods of synchroneity and lack of synchroneity in the onset of cooling across the region (Fig. 41). We consider likely mechanisms driving the phases of exhumation and suggest different mechanisms for different tectonic regimes. We discuss the phases of exhumation prior to break-up of Pangaea, then the subsequent phases that occurred before the opening of the NorthEast Atlantic. Finally, we discuss exhumation in the region after the opening of the North-East Atlantic. We also address the development of the modern-day topography and landscapes of Greenland and Scandinavia.

\subsection{Phases of exhumation prior to break-up of Pangaea}

In a review of the supercontinent cycle Nance et al. (2014) argued that episodic supercontinent assembly and breakup had a profound influence on the course of the Earth's geological, climatological, and biological evolution. Worsley et al. (1984) argued that supercontinents would become epeirogenically uplifted as heat accumulated beneath them. Models of 3D spherical mantle convection have shown that supercontinents shield the underlying mantle from subduction of old oceanic plates, resulting in heat accumulation that produces a

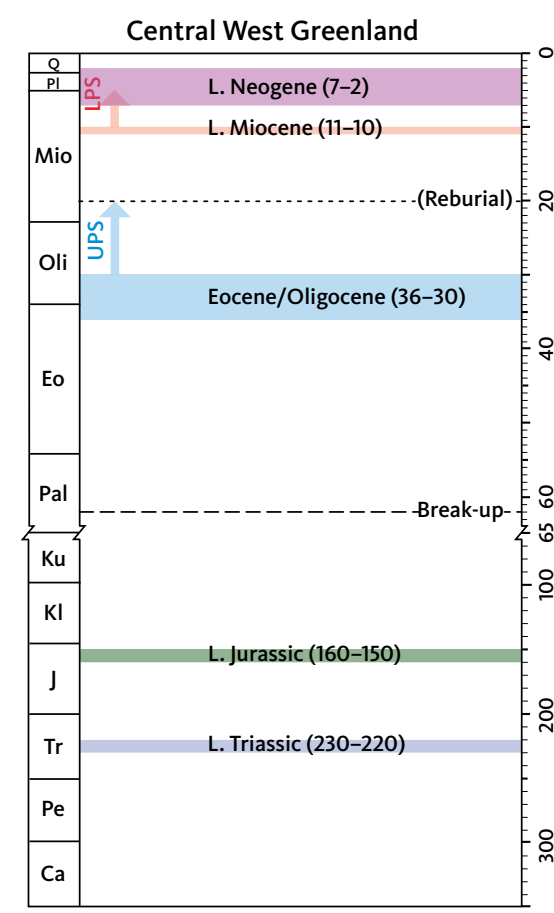

- Uplift event from stratigraphic landscape analysis - Time interval during which cooling began (7-2) Onset of cooling (Ma) from AFTA
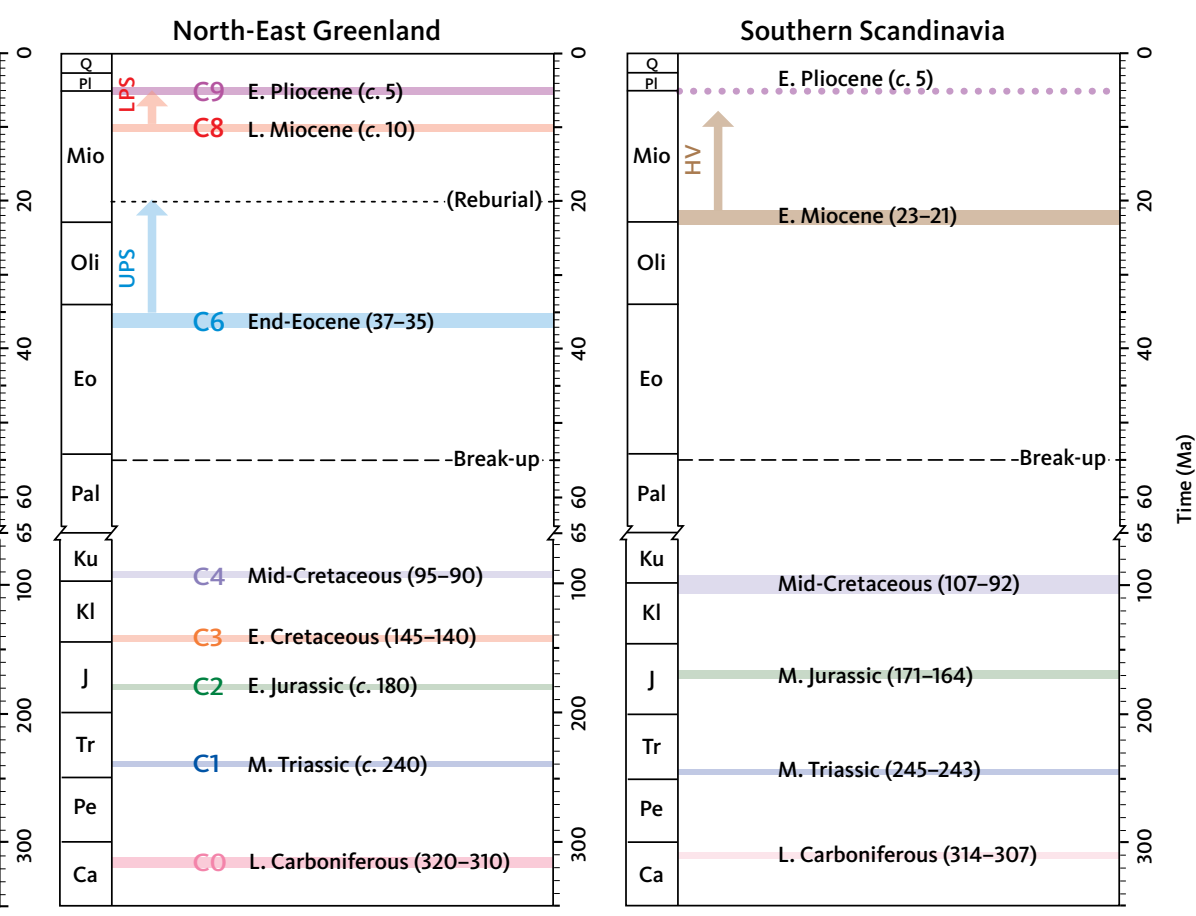

Fig. 41 Timing of regional, post-Devonian episodes of uplift and erosion estimated from AFTA data in North-East Greenland (episodes C0-C9; Table 1), central West Greenland (Japsen et al. 2006, 2009) and southern Scandinavia (Japsen et al. 2007, 2016, 2018). Time intervals for the formation of Cenozoic peneplains (Bonow et al. 2006a, b, 2014; Bonow \& Japsen 2021, this volume; Japsen et al. 2006, 2018) are shown. The figure illustrates the similarity of the post-breakup development of the passive margins of West and East Greenland, where Cenozoic uplift began in the late Eocene. This contrasts with southern Scandinavia, where Cenozoic uplift began in the early Miocene, c. 10 Myr later than in Greenland. Reburial of the UPS in West and East Greenland is tentatively shown at 15 Ma. C: Carboniferous. Dev: Devonian. E: Early or earliest. Eo: Eocene. HV: Hardangervidda. J: Jurassic. KI: Lower Cretaceous. Ku: Upper Cretaceous. L: Late. LPS: Lower Planation Surface. M: Mid. Mio: Miocene. Oli: Oligocene. Pal: Paleocene. Pe: Permian. PI: Pliocene. Q: Quaternary. Tr: Triassic. UPS: Upper Planation Surface. 
concentration of plumes beneath the supercontinent (Phillips \& Bunge 2005, 2007). Epeirogenic uplift will dominate tectonic activity during the lifespan of a supercontinent as trapped mantle heat accumulates beneath the largely stationary supercontinent, ultimately manifesting as hot-spot activity and fragmentation (Nance et al. 2014).

In southern Norway, Sweden and West Greenland, late Carboniferous, Middle Triassic and Middle Jurassic exhumation episodes have been identified with a timing that is similar or very close to those of the episodes identified in this study (Fig. 41; Japsen et al. 2016, 2018). These exhumation episodes identified across southern Scandinavia were suggested to be the result of the three main phases of epeirogenic uplift accompanying fragmentation of Pangaea (Japsen et al. 2016). The mid-Carboniferous (c. $320 \mathrm{Ma}$ ) amalgamation of Gondwanaland and Laurussia and formation of the Variscan fold belt resulted in accumulation of heat beneath Pangaea and thermal uplift (represented by a stratigraphic gap between 320 and $300 \mathrm{Ma}$ ) that finally led to the first phase of extension and rifting of Pangaea at c. $300 \mathrm{Ma}$ (Veevers 2004, 2013). The extension generated accommodation space for globally synchronous, cratonic sedimentary successions. The supercontinent was inherently unstable, resulting in almost simultaneous assembly and onset of continental break-up (Doré et al. 1999). Veevers $(2004,2013)$ presented a detailed account of the merger and breakup of Pangaea based on stratigraphy and radiometric dating. In the following sections we compare their account with results from North-East Greenland and elsewhere.

\subsubsection{Late Carboniferous episode (CO)}

The onset of $\mathrm{CO}$ exhumation in North-East Greenland (between 320 and $300 \mathrm{Ma}$ ) correlates with the onset of a similar period of exhumation in southern Scandinavia (between 314 and 307 Ma; Fig. 41). In North-East Greenland, exhumation led to the formation of a peneplain overlain by the upper Permian conglomerates of the Huledal Formation (Fig. 18; Haller 1971; Surlyk et al. 1986; Surlyk 1990). In North-West Europe, there is evidence of an important phase of exhumation in the Southern Permian Basin towards the end of the Carboniferous (Doornenbal \& Stevenson 2010). Here, the orogenic activity in the Variscan Fold Belt ceased during the latest Westphalian (313-307 Ma; middle Pennsylvanian). But in large parts of the basin, the stratigraphic record after the cessation of the tectonic activity is represented by a major, latest Carboniferous hiatus focused on the Stephanian (307-299 Ma; late Pennsylvanian), corresponding to a pronounced base-Permian unconformity. Based on the overlap between the timing of late Carboniferous exhumation in North-East Greenland and
North-West Europe and stratigraphic constraints, we suggest that the onset of this episode was most likely at c. $310 \mathrm{Ma}$ across the entire region. Late Carboniferous cooling has not been identified as yet in West Greenland, but this might be because all rocks studied so far cooled below $110^{\circ} \mathrm{C}$ in the Triassic, so any evidence for Carboniferous cooling has been overprinted.

Veevers (2004) noted that the first stage of extension of Pangaea (c. $300 \mathrm{Ma}$ ) was accompanied by intense magmatic activity in, for example, the Danish Basin and the Oslo Rift (Vejbæk 1989; Larsen et al. 2008b). In East Greenland, rifting was not accompanied by volcanism (Surlyk 1990). AFTA studies have also reported late Carboniferous exhumation across Ireland, Namibia, northeast Brazil and Angola (Green et al. 2000, 2009; Japsen et al. 2012b; Green \& Machado 2015). We thus consider the late Carboniferous phase of exhumation in NorthEast Greenland and southern Scandinavia to be part of the first phase of break-up of Pangaea.

\subsubsection{Middle Triassic episode (C1)}

The onset of the C1 episode (c. $240 \mathrm{Ma}$ ) corresponds closely to that of a similar event in southern Scandinavia (beginning between 245 and 243 Ma; Fig. 41), in Scotland (245-225 Ma, Holford et al. 2010) and in eastern Canada (244-225 Ma; Japsen et al. 2017). We suggest that Triassic exhumation in all these areas represents manifestations of a common tectonic event. The uplift and erosion at this time led to the deposition of coarse-grained siliciclastic sediments across the region: the Pingo Dal Group on Jameson Land (Fig. 18; Clemmensen 1980; Oftedal et al. 2005), the Middle-Upper Triassic Skagerrak Formation (or Hegre Formation) around southern Scandinavia (Bertelsen 1980; Goldsmith et al. 2003) and the Triassic Sherwood Sandstone across the British Isles. In a review of published Triassic stratigraphic nomenclatures for North-West Europe, Goldsmith et al. (2003) noted that the precise chronostratigraphic equivalence of these units is uncertain. Nonetheless, they interpreted deposition of the Skagerrak Formation to have begun in the Anisian at $245 \mathrm{Ma}$. We thus regard the episodes of Middle Triassic uplift and erosion in North-East Greenland and North-West Europe as expressions of the same geological event that probably began around $245 \mathrm{Ma}$. The recognition of the Middle Triassic episode across such a wide area of the northern hemisphere provides further evidence in support of the interpretation of Japsen et al. (2016): that this episode represents the second phase of break-up of Pangaea.

There is a mismatch of 15-20 Myr between Late Triassic cooling in West Greenland and Middle Triassic cooling in other areas (Fig. 41). It is unclear if this represents a real diachroneity in cooling across the region or some artefact of the data. However, given the ubiquity of 
Triassic cooling across a vast area it seems reasonable to suggest that Triassic cooling in these areas are expressions of the same phenomenon. The time difference may simply indicate that the episode affected East Greenland earlier than West Greenland, which would also imply that early Mesozoic rifting was probably delayed on the west coast relative to the east coast of Greenland. However, this cannot be tested as no Triassic sediments have been recorded onshore or offshore West Greenland. Larsen et al. (2009) found highly alkaline, volatile-rich melts formed in small volumes in the deep lithosphere. These were indicative of incipient stretching in West Greenland during Late Triassic to Late Jurassic (c. 220-150 Ma), and thus indicate delayed Triassic rifting in West Greenland compared to East Greenland.

\subsubsection{Early Jurassic episode (C2)}

The onset of C2 exhumation (c. $180 \mathrm{Ma}$ ) identified here is slightly earlier than the Middle Jurassic event identified from AFTA data in Scandinavia (171-164 Ma; Fig. 41). Surlyk \& Ineson (2003) showed that the main tectonic events and stratigraphic trends in East Greenland, Denmark and adjacent areas are highly similar. They found that major regional uplift and erosion took place broadly at the Early-Middle Jurassic boundary (c. 175 $\mathrm{Ma}$ ) in both areas, (Fig. 18, 21). Subsequent subsidence began in the Aalenian (c. $172 \mathrm{Ma}$ ) in the North Sea and in the late Bajocian (c. $169 \mathrm{Ma}$ ) in East Greenland associated with the onset of rifting, resulting in major regional onlap and transgression. In North-East Greenland, Middle Jurassic transgression occurred across peneplained basement (Surlyk 1977, 1978a, 2003). We thus regard the episodes of uplift and erosion in North-East Greenland and North-West Europe as expressions of the same geological event that probably began around $175 \mathrm{Ma}$ at the Early to Middle Jurassic transition. These observations indicate that the Middle Jurassic, central North Sea Dome (Ziegler 1990; Underhill \& Parkington 1993; Nielsen 2003) is also part of a super-regional phenomenon - the third phase of the fragmentation of Pangaea (Japsen et al. 2016). AFTA studies also record mid-Jurassic exhumation in northern Australia, north-west Canada, Angola, South Africa and north-east Brazil where Upper Jurassic sediments onlap basement (Duddy et al. 2004; Green et al. 2005; Magnavita et al. 2005; Green \& Machado 2015; Green et al. 2017b). The mid-Jurassic is also a time of copious igneous activity in southern Africa (Svensen et al. 2012).

The timing of the Late Jurassic cooling episode defined from AFTA in West Greenland (onset between 160 and $150 \mathrm{Ma}$ ) occurs about $25 \mathrm{Myr}$ later than the AFTA-derived C2 episode in East Greenland (Fig. 41). No Jurassic sediments have been encountered onshore or offshore West Greenland, but Larsen et al. (2009) found that melts intruded in a $60 \mathrm{~km}$ long swarm of scattered alkaline dykes were indicative of increased extension in West Greenland around $150 \mathrm{Ma}$ (Tithonian). The first evidence of rifting west of Greenland is dated at $135 \mathrm{Ma}$, much later than in East Greenland (Chalmers \& Pulvertaft 2001). In East as well as West Greenland, Jurassic exhumation led to stripping of the basement over large areas (Surlyk 2003; Bonow 2005; Japsen et al. 2006, 2009). The subsequent transgression began much later in the west where Albian sediments rest on basement in the Nuussuaq Basin, compared to the east, where Bajocian sediments rest on basement, for example on Wollaston Forland (Surlyk 2003; Dam et al. 2009). We thus conclude that the Late Jurassic episode of exhumation in West Greenland reflects the same geological process as in North-East Greenland, but with a considerable delay.

In summary, we find it unlikely that exhumation in these disparate locations at three broadly similar times should be a coincidence, and therefore we conclude that exhumation during episodes $\mathrm{C} 0, \mathrm{C} 1$ and $\mathrm{C} 2$ recorded in North-East Greenland are manifestations of global processes related to the break-up of Pangaea.

\subsection{Phases of exhumation after break-up of Pangaea and before the opening of the North-East Atlantic}

\subsubsection{Earliest Cretaceous episode (C3)}

The onset of C3 exhumation (145-140 Ma) occurs about 20 Myr later than the Late Jurassic event in West Greenland (160-150 Ma; Fig. 41). We consider it likely that these events reflect different geological processes, in particular because the Late Jurassic episode in West Greenland shares characteristics with the Early Jurassic C2 episode in North-East Greenland (Section 9.1.3).

We interpret the C3 episode as the result of regional uplift and erosion that accompanied the Mesozoic rift climax in North-East Greenland, not only along the margin of the rift but also of hinterland areas at considerable distance from the rift basins. Uplift and erosion associated with the rifting contributed to the coarse-grained basin infill, for example, the Wollaston Forland Group (Fig. 18). The C3 episode has no known counterpart based on AFTA data from Scandinavia. However, there are reports of erosion of fault crests and of turbiditic sands at the Jurassic-Cretaceous transition in the North Sea (McLeod et al. 2002; Andsbjerg \& Dybkjær 2003), which may represent a contemporaneous tectonic event.

\subsubsection{Mid-Cretaceous episode (C4)}

The C4 episode (beginning between 95 and $90 \mathrm{Ma}$; Fig. 41) most likely corresponds to the mid-Turonian, erosional base of the Jackson $\varnothing$ Group that records a phase of basin reorganization (Fig. 18; Bjerager et al. 2020). We suggest that this episode represents regional 
exhumation that led to removal of much of post-rift succession that had accumulated above the rift and its margins in the interior of North-East Greenland after the rift climax at the Jurassic-Cretaceous transition (Fig. 38; Sections 5.5 and 7.4.4).

The Lofoten margin of northern Norway forms the conjugate margin to North-East Greenland. Here, an episode of early Late Cretaceous uplift and erosion (beginning in the middle Cenomanian; c. $95 \mathrm{Ma}$ ) is represented by a regional unconformity (Henstra et al. 2016b). Further south on the Møre-Trøndelag margin of western Norway, a significant intra-Turonian unconformity most likely formed in response to a regional, extra-basinal process (Sømme et al. 2013). These observations match the C4 episode in North-East Greenland, suggesting a common tectonic phase.

The C4 episode is coeval with the onset of inversion of the Sorgenfrei-Tornquist Zone along the southern margin of the Baltic Shield and of the Sole Pit Axis in the southern North Sea, and a regional Turonian unconformity in the Faroe-Shetland Basin (Mogensen \& Korstgård 2003; Japsen et al. 2007, 2016; Stoker \& Ziska 2011; Green et al. 2017c). Kley \& Voigt (2008) argued that a Late Cretaceous event of intraplate basin inversion and basement thrusting in central Europe occurred after a change in relative motion between the European and African plates at c. $90 \mathrm{Ma}$. The pinching of west-central Europe's thin lithosphere between Baltica and Africa was attributed to this contraction. These events may be related to a global-scale, mid-Cretaceous phase of plate reorganisation (105-100 Ma; Matthews et al. 2012). There is no known counterpart for the C4 episode in West Greenland.

\subsection{Phases of exhumation after opening of the North-East Atlantic}

\subsubsection{End-Eocene episode (C6)}

The onset of C6 exhumation in East Greenland is contemporaneous with exhumation in West Greenland that began at the Eocene-Oligocene transition and thus affected both margins at about $35 \mathrm{Ma}$ (Figs 23, 41). These events led to the formation of regional peneplains on both sides of Greenland (both labelled UPS; Bonow et al. 2006a, b, 2014; Bonow \& Japsen 2021, this volume), and we conclude that they reflect the same geological phenomenon. This episode also correlates with renewed magmatic activity in East Greenland, together with block rotation and faulting (Figs 28, 29).

Offshore North-East Greenland, a significant phase of progradation occurred above a horizon that defines an erosional incision, dated broadly from late Eocene to mid-Miocene (Petersen 2019; Fig. 6E). The clinoforms are caused by extensive mass wasting into the outer part of the shelf due to tectonic uplift of the inner part of the shelf and onshore areas, south of Store Koldewey. We suggest that the mass wasting is due to the uplift of the margin of North-East Greenland during the C6 episode. Uplift of the inner margin of South-East Greenland resulted in strong influx on the shelf of coarse, siliciclastic turbidites above a middle Eocene to upper Oligocene unconformity (Larsen et al. 1994a; Japsen et al. 2014).

Oligocene sediments are absent on the shelf off central West Greenland, and the hiatus is represented by a low-angle unconformity on seismic sections (Sørensen 2006). Green et al. (2013) correlated the Oligocene unconformity offshore with the UPS onshore. Late Eocene exhumation also affected the Barents Sea, Svalbard and the north slope of Alaska according to AFTA data (Green \& Duddy 2010). Late Eocene exhumation coincided with the cessation of sea-floor spreading west of Greenland and with cessation of spreading on Aegir Ridge, and the establishment of the Kolbeinsey Ridge east of Greenland (Gaina et al. 2009). Plate reorganisation was preceded by a sharp change in the direction of spreading and a drop in spreading rates, such that the Eurasian and Greenland plates were almost stationary relative to one another (Gaina et al. 2009, 2017). Whatever the causes of these phenomena, they indicate substantial changes in the stress regime in and around the North-East Atlantic at the Eocene-Oligocene transition (Japsen et al. 2014). Interestingly, AFTA data from southern Scandinavia do not reveal a counterpart to episode C6 (Fig. 41). However, a regional, intra-upper Eocene unconformity extend along the North-West European margin, where a dramatic change in basin configuration in the region took place during late Eocene - early Oligocene (Stoker et al. 2005). This shows that major tectonic events at this time affected wide areas in the North-East Atlantic domain and beyond.

\subsubsection{Early Miocene uplift and erosion in southern Scandinavia}

Neogene uplift and erosion in southern Scandinavia began in the early Miocene (between 23 and $21 \mathrm{Ma}$; Fig. 41) and resulted in the formation of a regional peneplain, which today is represented by the Hardangervidda plateau in southern Norway and the South Småland Peneplain in southern Sweden Japsen et al. 2016 , 2018). The erosion in the Scandinavian hinterland resulted in the formation of braided fluvial systems, progradation of lower Miocene deltas and deposition of thick, coarse-grained successions across much of the present-day Danish onshore area (Rasmussen et al. 2010; Rasmussen 2014). A major, base-Neogene unconformity developed in the sedimentary basins along the margin of north-west Europe (Stoker et al. 2005). The early Miocene uplift event has no known counterpart in Greenland. 


\subsubsection{Late Miocene episode (C8)}

Exhumation in the $\mathrm{C} 8$ episode in East Greenland began at c. $10 \mathrm{Ma}$ and also affected the West Greenland margin (Figs 23, 41). On both margins, this event initiated the formation of the present relief with incision below the uplifted UPS leading to the development of the LPS. It seems likely that a common process was responsible on both margins.

Døssing et al. (2016) demonstrated that the onset of mid-late Miocene uplift of the North-East Greenland led to formation of a regional IMU and to massive progradation on the shelf (Fig. 6). Correlation between margin uplift and plate motion changes indicated that the uplift was triggered by plate tectonic forces. We suggest that the uplift onshore and the subsequent progradation offshore began during the C8 episode. Late Neogene progradation along the East Greenland margin has been documented previously (Clausen 1998; Larsen et al. 1994a; Hamann et al. 2005; Berger \& Jokat 2008, 2009; Petersen 2019).

The C8 episode has no known counterpart in southern Scandinavia, but Green \& Duddy (2010) defined a regional phase of exhumation of Svalbard and the Barents Sea beginning between 10 and 0 Ma from AFTA data, in agreement with results from Svalbard (Dörr et al. 2012, 2019).

\subsubsection{Early Pliocene episode (C9)}

The timing of uplift and incision in North-East Greenland in the $\mathrm{C} 9$ episode $(c .5 \mathrm{Ma})$ is within the limits for onset of latest Miocene-Pliocene uplift defined from AFTA data in West Greenland (7-2 Ma; Fig. 41). On both margins of Greenland, the UPS and LPS were uplifted and the modern relief was formed by incision of valleys and fjords below the LPS. We thus consider it likely that the same geological process was responsible for these events on both margins. In Scandinavia, the Hardangervidda plateau and the South Småland Peneplain reached their present elevations of 1200 and $150 \mathrm{~m}$ a.s.l., respectively, due to early Pliocene uplift (Japsen et al. 2016, 2018). Neogene exhumation of the Danish Basin began at c. $5 \mathrm{Ma}$ as revealed by AFTA data, and a regional, intra-Neogene (c. 4 Ma) unconformity across North-West Europe developed in response to pre-glacial uplift and tilting of the continental margin (Stoker et al. 2005; Japsen et al. 2007). It is therefore possible that early Pliocene uplift affected West and East Greenland and southern Scandinavia within a very narrow time interval, and that the uplifts may reflect the same geological process. The much higher elevation of East Greenland compared to West Greenland may indicate dynamic support in the east from the Iceland plume, particularly during the C9 episode that lifted the LPS to its maximum elevation of $2 \mathrm{~km}$ a.s.l. in the Blosseville Kyst region - host to the highest peaks in Greenland
(Japsen et al. 2014). This assertion matches the results of Steinberger et al. (2015) who used a mantle-flow model to show that dynamic topography reaches a maximum of $1.2 \mathrm{~km}$ for Greenland along Blosseville Kyst.

\subsection{Development of the modern topography in Greenland and Scandinavia}

In Chapter 6, we presented a model for the development of the modern topography in North-East Greenland that described three episodes of uplift and erosion (Fig. 34). In central West Greenland and in southern East Greenland, the mountains were formed by a similar sequence of events, and the correlation of these episodes in Fig. 41 highlights that these uplifts are simultaneous in West and East Greenland within the resolution of the methods applied (Japsen et al. 2006, 2014). We conclude that the present topography of West and East Greenland were formed almost simultaneously in the late Neogene and by the same processes.

In contrast, the mountains of southernmost Norway formed during two steps (Japsen et al. 2018). First, early Miocene uplift and erosion to the base level defined by the adjacent ocean led to formation of a peneplain that included the present-day Hardangervidda plateau and the South Småland Peneplain (Lidmar-Bergström et al. 2000, 2013). Second, early Pliocene uplift raised these peneplains to their present elevations and led to re-exposure of a tilted, Mesozoic surface at lower elevations. It is thus possible that the final phase of uplift, in the early Pliocene, affected both Greenland and Scandinavia at about the same time, and thus that this phase was caused by the same processes, of which dynamic support from the Iceland Plume may be one component. Otherwise, the previous Cenozoic episodes of uplift of the landscape are out of phase across the Atlantic Ocean (Fig. 41). In Greenland, the formation of the dominant peneplain began after uplift in the late Eocene, whereas the formation of the dominant peneplain in southern Norway began in the early Miocene. Uplift of these plains, which led to the formation of the present-day relief, began in the late Miocene in Greenland and in the early Pliocene in Scandinavia.

As noted by Japsen et al. (2014), synchroneity between changes in plate motion and uplift events along conjugate margins is suggestive of rapid, far-field transmission of momentum through the upper mantle by viscous stresses (Colli et al. 2018). Conversely, uplift events that have no counterpart on the conjugate margin may be related to transmission of stress within the crust (Cloetingh \& Burov 2010). The correlation - and lack of correlation - between uplift events across the North-East Atlantic (Fig. 41), thus invites speculation about the underlying processes: 
1. End-Eocene exhumation affected Arctic regions. This episode coincides with the cessation of sea-floor spreading west of Greenland and with a major plate reorganisation in the North-East Atlantic, preceded by a significant reduction in spreading rates (Gaina et al. 2009, 2017; Green \& Duddy 2010). Considering the location of the region affected, it may not be surprising that the effects in southern Scandinavia were minor (Japsen et al. 2018). The forces driving the uplift are therefore most likely linked to the stress that prevented further movements of the Greenland plate relative to North America.

2. Regional early Miocene uplift only affected the European side of the North-East Atlantic. This basic observation led Japsen et al. (2016) to suggest that the forces driving uplift most likely originated from stress transmitted from orogenic belts elsewhere on the Eurasian plate (Cloetingh \& Burov 2010). A possible source for such stress could be the early Miocene-Present Neohimalayan orogenic phase in Himalaya and southern Tibet (Hodges 2000; Jiang \& Li 2014). The 'hard' IndiaAsia collision around 25-20 Ma initiated this phase and coincides with deformation in central Asia (van Hinsbergen et al. 2012). An alternative source could be the collision between Africa and Eurasia. DeMets et al. (2015) estimated that Nubia-Eurasia plate motion decreased by c. 50\% between 20-18 Ma and $13 \mathrm{Ma}$.

3. Major late Miocene uplift affected West and East Greenland as well as Svalbard and the Barents Sea but not southern Scandinavia. The uplift was triggered by plate tectonic forces (Døssing et al. 2016), and we speculate that late Neogene changes in the absolute motion of the North American plate may explain this asymmetric behaviour across the North-East Atlantic. Sea-floor spreading rates between Eurasia - North America and Nubia - North America varied modestly from 20 to c. 8 Ma but slowed down by c. $20 \%$ between 8 and $5 \mathrm{Ma}$. Rates have remained remarkably steady since then (Merkouriev \& DeMets 2008; DeMets et al. 2015; laffaldano \& DeMets 2016). These changes in relative motions were related to a change in the absolute motion of North America and Antarctica, and they might be linked to the late Neogene dynamics of the Pacific plate (laffaldano \& DeMets 2016).

4. Early Pliocene uplift affected West and East Greenland as well as southern Scandinavia. In Scandinavia, the magnitude of rock uplift is about $1 \mathrm{~km}$ in southern Norway but only $150 \mathrm{~m}$ in southern Sweden (Lidmar-Bergström et al. 2013; Japsen et al. 2016, 2018). In West and East Greenland, it is typically $1 \mathrm{~km}$ and in central Greenland it is likely to be negligible (Solgaard et al. 2013). However, along Blosseville Kyst, where Greenland is closest to Iceland, it is about $2 \mathrm{~km}$, possibly indicative of support from the Iceland Plume (Rickers et al. 2013; Bonow et al. 2014; Japsen et al. 2014; Steinberger et al. 2015). The fact that margins on both sides of the North-East Atlantic were affected by early Pliocene uplift, suggests that this episode may have been driven by changes in upper-mantle flow, related to the Iceland Plume (Colli et al. 2018). 


\section{Discussion}

In this chapter, we illustrate the importance of imposing geological constraints on the interpretation of thermal data and discuss the role of the Neogene uplift for the development of the Greenland ice sheet. Finally, we place the development of the East Greenland margin in the context of EPCMs around the world.

\subsection{Imposing geological constraints on thermal-history reconstructions}

The development of the continental margin of East Greenland from $68^{\circ} \mathrm{N}$ to $78^{\circ} \mathrm{N}$ described here and by Japsen et al. (2014) is very different to previous ideas for the development of EPCMs in general (see Green et al. 2013) and East Greenland in particular (Chapters 3 and 4). One key reason for this difference is that whereas our studies have integrated thermal histories from AFTA with geological and landscape evidence, other studies largely ignore the abundant geological constraints exposed in North-East Greenland.

For example, Johnson \& Gallagher (2000) reported thermal histories derived from apatite fission-track data in samples of Carboniferous sandstones from Clavering $\varnothing$. However, they did not consider that Palaeogene basalts cap the sampled profile, and thus that the uppermost sample was at near-surface temperature in the Palaeogene. This led them to underestimate the final degree of Mesozoic cooling and Palaeogene re-burial prior to the onset of Cenozoic cooling (Japsen et al. 2010; Green et al. 2013). We present a thermal-history diagram based on our interpretation of AFTA data from Clavering $\varnothing$ (VT1) in Appendix 3.1.

Some authors have argued that the mountains in North-East Greenland and in Scandinavia are remnants of the Caledonian mountains (Nielsen et al. 2009; Pedersen et al. 2012; Schiffer et al. 2016). However, the highest mountain in Greenland (Gunnbjørn Fjeld) is comprised of Paleocene basalt, and all of the high terrain in East Greenland south of $70^{\circ} \mathrm{N}$, as well as all of West Greenland, is outside the Caledonian Orogen. In addition, sediments of different age rest on the basement within the former orogen where mid-Permian, Middle Jurassic and younger peneplains also occur (Haller 1971; Larsen 1988; Surlyk 2003; Bonow \& Japsen 2021, this volume). These observations testify to a history of episodic exhumation and burial rather than to a history of continuous exhumation since the Caledonian Orogeny.

Pedersen et al. (2012) suggested that the present-day mountains in North-East Greenland represent remnants of the original Caledonian topography modified during ?Devonian - Early Carboniferous rifting, and that the area has undergone slow, continuous exhumation since c. $250 \mathrm{Ma}$. But they did not take into account simple, yet robust geological constraints on the post-Caledonian development of the region (Fig. 42). Pedersen et al. (2012) based their hypothesis on inverse modelling calibrated by new apatite fission-track data from samples of exposed Caledonian basement. However, they did not consider that apatite fission-track data only register episodes of cooling from higher temperatures. Further, they did not consider that the presence of Carboniferous and Jurassic sedimentary remnants across their study area define times when the underlying basement was at the surface prior to a phase of burial and heating. Thus, integrating the apatite fission-track data with geological evidence defines multiple episodes of exhumation (cooling) and re-burial (heating).

The well-documented geological record of North-East Greenland shows that the Caledonian mountains were obliterated as topographic features during the late Palaeozoic, and the post-Caledonian record provides clear evidence of episodic, exhumation and re-burial (Haller 1971; Surlyk 1990; Japsen et al. 2013). The episodic nature of the development of Germania Land after the Caledonian collapse (points 1 to 7 in Fig. 42), is as follows:

1. Caledonian basement with eclogitic inclusions reflects high-pressure metamorphism of Devonian age (700$800^{\circ} \mathrm{C}, 410-390 \mathrm{Ma}$; Gilotti \& McClelland 2008).

2. Upper Carboniferous sediments resting on the Caledonian basement shows that the basement was exhumed to the surface by the late Carboniferous (Piasecki et al. 1994).

3. Middle Triassic C1 palaeotemperatures of $100^{\circ} \mathrm{C}$ from AFTA indicate that these Carboniferous units were buried below a $3.2 \mathrm{~km}$ thick cover of upper Carboniferous to Middle Triassic sediments in the Middle Triassic (samples GC1077-9, 10, 11; map C1 in Fig. 14; Appendix 3.13; palaeogeothermal gradient $25^{\circ} \mathrm{C} / \mathrm{km}, 20^{\circ} \mathrm{C}$ surface temperature).

4. The presence of Middle Jurassic sediments overlying the basement shows that the upper Carboniferous - Middle Triassic cover was removed by the Middle Jurassic (Bojesen-Koefoed et al. 2012).

5. Mid-Cretaceous $\mathrm{C} 4$ palaeotemperatures of $c .75^{\circ} \mathrm{C}$ from AFTA indicate that the Jurassic units were buried below a $2.2 \mathrm{~km}$ thick cover of Middle Jurassic to Turonian sediments in the mid-Cretaceous (samples GC1077-9, 11; thermal parameters as above).

6. Late Miocene C8 palaeotemperatures of $c .65^{\circ} \mathrm{C}$ from AFTA indicate that these deposits were buried below a 

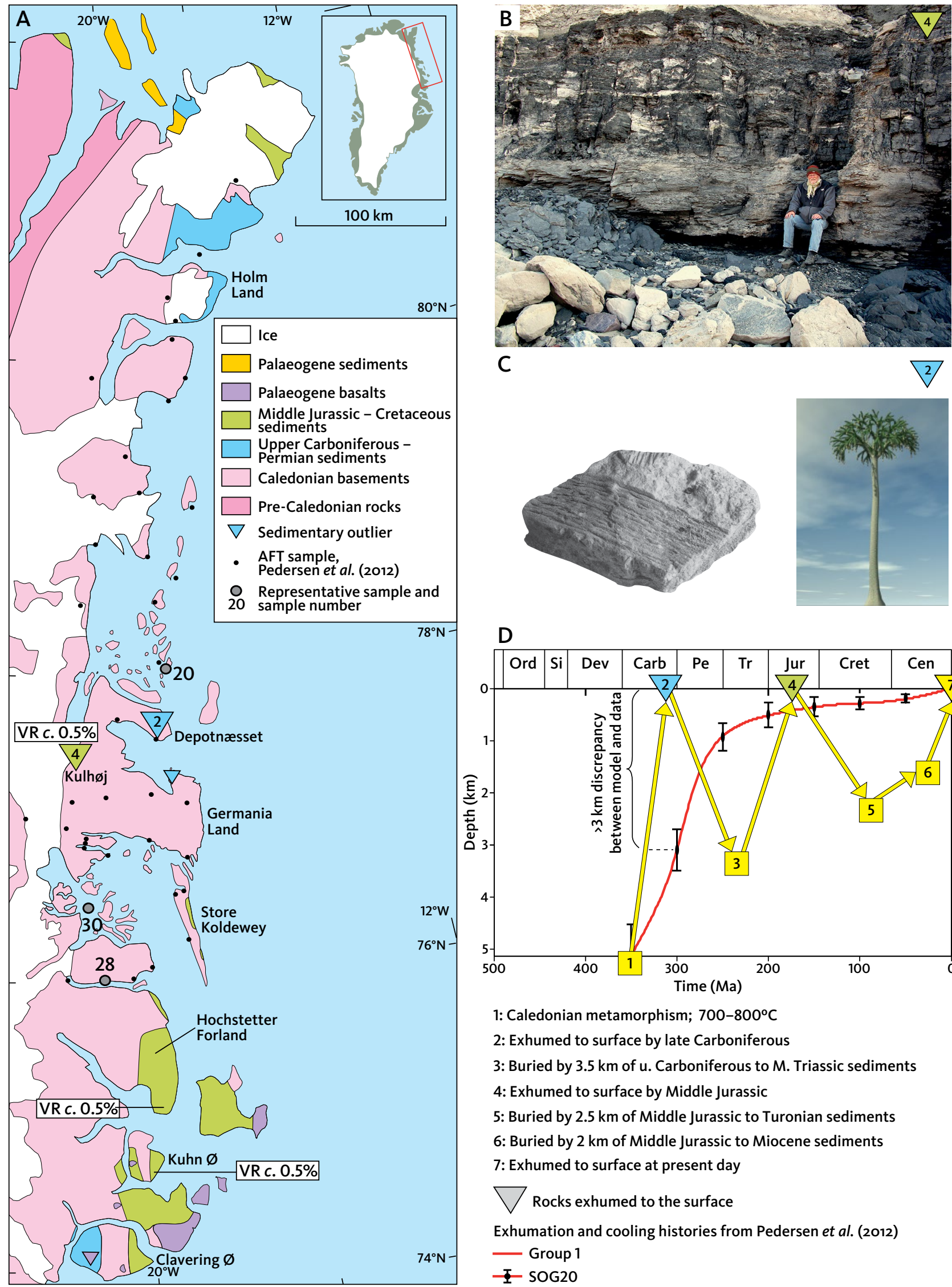

C
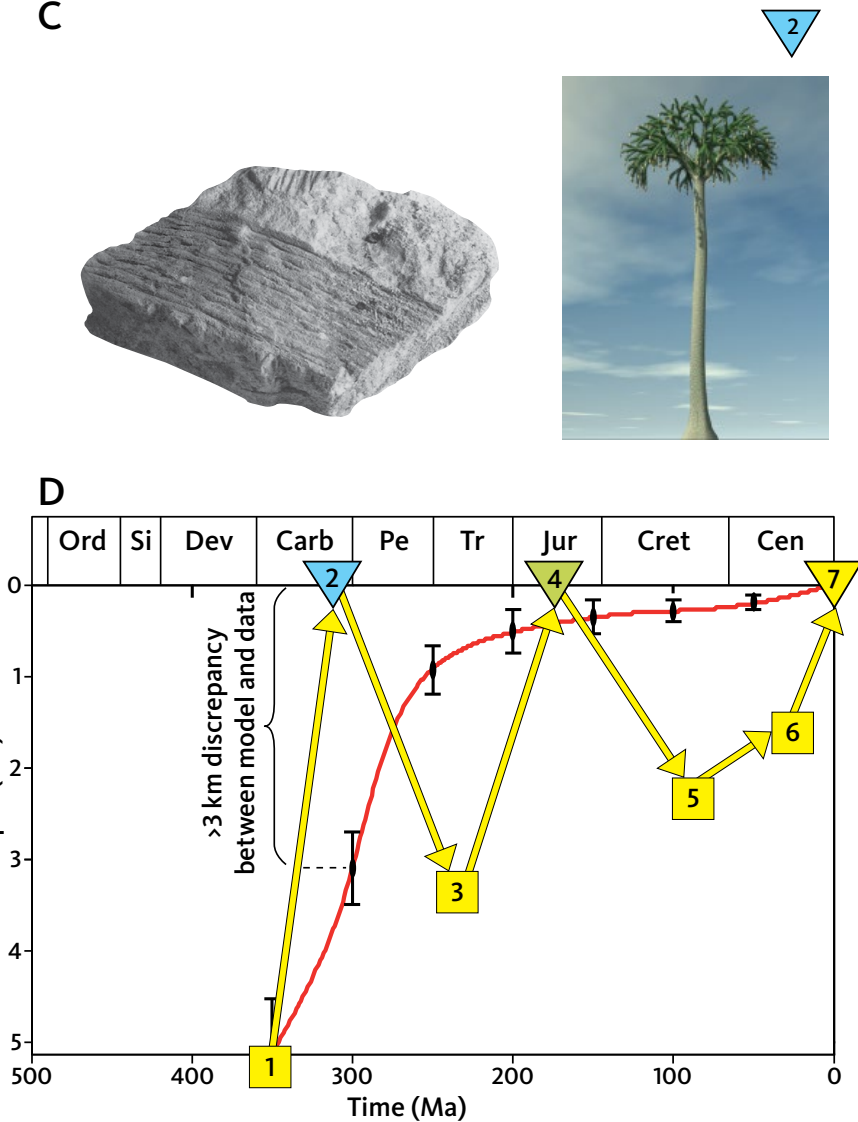

1: Caledonian metamorphism; $700-800^{\circ} \mathrm{C}$

2: Exhumed to surface by late Carboniferous

3: Buried by $3.5 \mathrm{~km}$ of $\mathrm{u}$. Carboniferous to M. Triassic sediments

4: Exhumed to surface by Middle Jurassic

5: Buried by $2.5 \mathrm{~km}$ of Middle Jurassic to Turonian sediments

6: Buried by $2 \mathrm{~km}$ of Middle Jurassic to Miocene sediments

7: Exhumed to surface at present day

$\bigvee$ Rocks exhumed to the surface

Exhumation and cooling histories from Pedersen et al. (2012)

- Group 1

I SOG20

Fig. 42 Conflicting interpretations of the post-Caledonian development in North-East Greenland. A: Geology of North-East Greenland and location of apatite fission-track samples analysed by Pedersen et al. (2012). Sedimentary outliers occur between 75 and Figure 42 continued on next page 
$80^{\circ} \mathrm{N}$ and therefore the underlying basement was at the surface prior to their deposition at these locations. Corresponding sedimentary units are more extensive farther south and north. Grey circles: Samples SOG20, 28, 30 from Pedersen et al. (2012), chosen as representative of their three groups of samples. B: Outcrop of Middle Jurassic coal (triangle 4 in A). C: Upper Carboniferous deposit (triangle 2 in A). Fossil and reconstruction of Lepidodendron (Piasecki et al. 1994). D: Exhumation path (red) based on modelling by Pedersen et al. (2012) of apatite fission-track data in a representative sample chosen by these authors. Yellow curve: Constraints from the geological record and AFTA data on the burial and exhumation history of basement rocks on Germania Land (see Appendix 3.13). Ord: Ordovician. Si: Silurian. Dev: Devonian. Carb: Carboniferous. Pe: Permian. Tr: Triassic. Jur: Jurassic. Cret: Cretaceous. Cen: Cenozoic. Modified after Japsen et al. (2013) and Green et al. (2013).

$1.8 \mathrm{~km}$ thick cover of Middle Jurassic to Miocene sediments in the late Miocene (several samples; thermal parameters in point 3).

7. Today the Caledonian basement is exposed at the surface over most of the region.

The interpretation of apatite fission-track data in terms of monotonic cooling as presented by Pedersen et al. (2012) is thus inconsistent with the presence of the sedimentary outliers and fails to capture the episodic nature of the post-Caledonian history.

\subsection{Tectonic uplift vs erosional unloading}

Geological and topographical observations from the Scoresby Sund area showed that erosional unloading due to incision below the highest peaks in the area can account for $1.1 \mathrm{~km}$ of uplift, comparable with the elevation of Mesozoic marine sediments now at $1.2 \mathrm{~km}$ a.s.l. (Medvedev et al. 2008). Later modelling results of all Greenland found that uplift due to erosional unloading could only account for 300-600 m of present elevation of marine sediments (Medvedev et al. 2013).

Medvedev et al. (2013) quantified the influence of the load of massive ice sheets on the Greenland topography and the significant erosion caused mainly by glacial carving. They concluded: (1) That the ice-sheet load causes up to $850 \mathrm{~m}$ subsidence of the bedrock topography in central Greenland, whereas the peripheral bulging caused by this ice loading has a negligible effect on uplift of the Greenland margins. (2) That glacial carving can explain up to $1.2 \mathrm{~km}$ uplift along the central parts of the margins of East and West Greenland. (3) That ice-related processes cannot explain much of Greenland's topography, and that the origin of the pre-glacial mountains was enigmatic.

Medvedev et al. $(2008,2013)$ did not consider the possibility that a sedimentary pile of unknown thickness may have accumulated above Mesozoic sediments in the Scoresby Sund area. If it had, the total amount of rock uplift of the exposed sediments since their maximum burial may have been much larger than $1.2 \mathrm{~km}$. For example, AFTA data from samples of Jurassic sediments within the study area of Medvedev et al. (2008), show that these samples, which are now at an elevation of $1200 \mathrm{~m}$ a.s.l., were heated to between 65 and $85^{\circ} \mathrm{C}$ prior to end-Eocene C6 cooling (VT13, northern Jameson Land; Appendix 2.3). Such palaeotemperatures correspond to $\mathrm{km}$-scale burial of the Jurassic rock samples for any reasonable palaeogeothermal gradient. Thus, uplift of Jurassic sediments since end-Eocene maximum burial is likely to be several times larger than the maximum amount allowed by the calculations of Medvedev et al. (2008).

The UPS forms the high ground west and south of Scoresby Sund. As an Oligocene-Miocene peneplain formed by erosion to sea level, the fully developed peneplain provided no relief to be eroded at the onset of uplift in the late Miocene. Thus, even if the erosion rate increased due to climate deterioration, no valley incision could have occurred to initiate the uplift. As there was no significant change in eustatic sea level at this time (Miller et al. 2005), a tectonic trigger was required (Japsen et al. 2014).

\subsection{Development of the Greenland ice} sheet

\subsubsection{Late Neogene onset of the formation} the Greenland ice sheet

Using an ice-sheet model coupled with a climate model, Solgaard et al. (2013) studied the build-up of ice caps before and after late Miocene C8 and early Pliocene C9 uplifts (Fig. 34). They applied forcing conditions for the late Cenozoic climate (i.e. long-term cooling superimposed by cold and warm climate excursions) and found that no ice covers were initiated for the low-lying and almost flat topography prior to late Miocene C8 uplift (i.e. the UPS at sea level). They also demonstrated a significant ice-sheet growth in response to the orographically induced increase in precipitation and the cooling of surface temperatures accompanying uplift. Large amounts of ice formed after the first (C8) uplift of the UPS, but the modelling showed that the ice sheet was sensitive to changes in climate. The second (C9) uplift, however, facilitated ice-sheet build-up and increased the stability of the ice sheet by providing anchoring points that were not available to the same extent in the previous scenarios. However, a Föhn effect was also observed that inhibited ice-sheet expansion into Greenland's interior and 
thus shifted the threshold of formation of the ice sheet towards colder temperatures. Under conditions that are colder than the present, the ice can overcome the Föhn effect, flow into the interior and form a coherent ice sheet. The results thus indicated that the Greenland ice Sheet of today is a relict formed under colder conditions.

These modelling results are consistent with the observed climatic history in Greenland. Late Miocene onset of uplift of the East Greenland margin correlate with the onset of Neogene progradation, North Atlantic Bottom Water and siliciclastic Neogene sedimentation at c. $10 \mathrm{Ma}$ and the first occurrence of glacial sediments in drill cores off South-East Greenland at c. 7 Ma (Fig. 6; Fredskild et al. 1989; Larsen et al. 1994b; Berger \& Jokat 2008, 2009; Døssing et al. 2016).

The onset of Miocene progradation off North-East Greenland therefore reflects the uplift of the margin and the subsequent incision below the UPS. The supply of glacial deposits to the shelf reflects the formation of glaciers on the newly-formed mountains onshore. Modelling of the Greenland ice sheet shows that glaciers could not have formed in the Miocene prior to the uplift in episode C8 because of the low absolute relief at that time (Solgaard et al. 2013). Thus, the late Cenozoic mountain building in Greenland augmented the effects of the climatic deterioration leading to the Northern Hemisphere glaciations. Without the Pliocene phase of uplift the Greenland ice sheet would have been more sensitive to the changes in climate over the past millions of years (Solgaard et al. 2013).

\subsubsection{Continental ice in East Greenland at the Eocene-Oligocene transition}

Several studies have suggested that continental ice may have developed in East Greenland at the Eocene-Oligocene transition. Stratigraphically extensive, ice-rafted debris, including macroscopic dropstones, occur in late Eocene to early Oligocene sediments from the Norwegian-Greenland Sea, indicating sediment rafting by continental ice, not sea ice, and East Greenland as the likely source (Eldrett et al. 2007).

Eldrett et al. (2009) presented climate estimates for the Eocene to Oligocene interval, based on spore and pollen assemblages in marine sediments from the Norwegian-Greenland Sea. The climate estimates indicated cooling across the Eocene-Oligocene transition, but also provided evidence for relatively warm summer temperatures at that time, and thus that continental ice on East Greenland was probably restricted to alpine outlet glaciers.

The evidence presented here suggests that the appearance of continental ice in the late Eocene may correspond to the onset of the regional, end-Eocene C6 phase of uplift of the East Greenland margin. The late
Eocene land surface in East Greenland was likely to be of low relative relief and near the level of the adjacent sea after Eocene post-rift subsidence and burial. The onset of exhumation by the end of the Eocene is thus likely to imply that the surface was uplifted and that a terrain of some elevation must have formed. Even if the altitude of the terrain at the Eocene-Oligocene transition in southern East Greenland is unknown, it is likely to have been significant because a rock column up to $2 \mathrm{~km}$ was removed between the late Eocene and the late Miocene in the Kangerlussuaq area, south of Blosseville Kyst Uapsen et al. 2014). We thus suggest that the high terrain generated by the end-Eocene uplift was sufficient to trigger the formation of continental ice in East Greenland. We also interpret the lack of indications of continental ice along the East Greenland margin between the late Oligocene and the late Miocene to reflect the absence of high mountains during the bevelling of the landscape and the formation of the UPS by erosion to base level prior to uplift in the late Miocene C8 episode.

A phase of exhumation starting at $30 \pm 5 \mathrm{Ma}$ has been identified in thermochronology data from North-East Greenland (Bernard et al. 2016). This is consistent with uplift and erosion in the end-Eocene $\mathrm{C} 6$ episode defined here. However, the authors explained the exhumation as the result of glacial erosion initiated by a worldwide temperature drop at the Eocene-Oligocene transition (Zachos et al. 2001). This interpretation contradicts several observations. First, continental ice in East Greenland at that time was probably restricted to alpine outlet glaciers (Eldrett et al. 2009) and thus could not produce the regional, end-Eocene exhumation documented in this study (Fig. 14). Second, end-Eocene exhumation involved block rotation and faulting, observations that are not be related to climatic conditions (Figs 28, 29). Third, the end-Eocene phase of exhumation in Greenland coincides with magmatic activity in East Greenland (Fig. 21), cessation of sea-floor spreading west of Greenland and a major plate reorganisation in the North-East Atlantic (Gaina et al. 2009), and therefore must have a tectonic origin.

\subsection{Episodic tectonic processes along margins and their hinterland}

North-East Greenland is a typical example of an EPCM where the topography developed long after break-up Uapsen et al. 2012a; Green et al. 2013, 2018). The distinct plateaus, the UPS and LPS, define the large-scale landscape of North-East Greenland and are visual evidence for episodic tectonic processes that shaped the margin after break-up at the Paleocene-Eocene transition. In general, elevated plateaus are evidence of at least two major phases of uplift. An initial phase produces the peneplain as an erosion surface that cuts 
unconformably across rocks of different age and resistance, and a second phase of uplift brings the peneplain to its present elevation above sea level. Formation of such elevated plateaus bordering Mesozoic-Palaeogene rift basins as a result of Neogene uplift, represents a major challenge to conventional geological thinking, which predicts post-rift thermal subsidence and deposition of a thick post-rift succession overlying both the rift and its margins (McKenzie 1978; White \& McKenzie 1988). However, numerous studies have documented significant Neogene uplift of many EPCMs, not only of margins in the North-East Atlantic domain but also elsewhere, in different climatic regimes (Japsen et al. 2012b; Green et al. 2013; Richards et al. 2016; Rodríguez et al. 2017; da Silva et al. 2019).

The development of the East Greenland margin was also characterised by episodic processes prior to break-up as it is well documented in numerous studies of the post-Caledonian geology (Surlyk 1978a, 2003; Clemmensen 1980; Stemmerik 2000; Larsen et al. 2008a). In particular, three phases of uplift and denudation that affected North-East Greenland and Scandinavia in the late Carboniferous, Middle Triassic and Early-Middle Jurassic, appear to be part of widespread epeirogenic uplifts that accompanied fragmentation of Pangaea (Section 9.1).

Along EPCMs elsewhere, episodic burial and exhumation, rather than slow monotonic denudation, affected the sedimentary basins and their hinterland both prior to and after break-up (Green et al. 2013, 2018). Most thermochronological studies of basement terrains are carried out within a framework of continuous cooling. However, many of the maps in Fig. 14, from basement in the west to sedimentary basins in the east, show little variation in palaeotemperatures of individual episodes, suggesting a similar, shared thermal history. This is supported by the close correlation between, for example, the Middle Triassic uplift and erosion of the basement terrains in the interior of North-East Greenland and the deposition of the coarse clastic material of the Scoresby Land Group in the rift basin. Thus, episodic cooling and exhumation also affected the hinterland far from the basin and was likely a plate-tectonic-scale event. The presence of Palaeozoic, Mesozoic and Palaeogene rocks on basement in the study area further underlines the episodic nature of the burial and exhumation history. We therefore conclude that episodic heating and cooling is the most appropriate framework for extracting thermal-history solutions from thermochronological data, both in the sedimentary basins and the basement terrains of North-East Greenland, as documented in other parts of the world.

Deciphering past geological events and modelling the physical processes that drive them are fundamental for our understanding of geological processes, such as sedimentary basin formation and the uplift of mountain belts. Efforts to date have centred largely on continuous, long-term subsidence or uplift, but here, we document that the geological record is very incomplete, and histories typically involve repeated episodes of upward and downward vertical movement. A detailed understanding of the nature of the processes underlying the development of EPCMs (as well as other geological features) requires improved geodynamic modelling to develop and test likely mechanisms (Green et al. 2018). The observations for North-East Greenland presented here can provide constraints against which projections from geodynamic models can be tested. 


\section{Conclusions}

\subsection{Palaeothermal episodes}

Our results reveal a long history of episodic burial and exhumation across North-East Greenland, where denudation across present-day basement terrains in the interior produced sedimentary input to the PalaeozoicMesozoic rift basins.

The earliest evidence for cooling in the AFTA data defines the late Carboniferous $\mathrm{CO}$ episode (that began between 320 and $300 \mathrm{Ma}$ ) of uplift and erosion that led to formation of the sub-Permian peneplain. Today, this peneplain is exhumed on Jameson Land from below upper Permian cover rocks, for example the Huledal Formation. The corresponding unconformity marks the most profound change in tectonic history and depositional environment in the post-Caledonian development of East Greenland. Late Carboniferous uplift and erosion also affected north-west Europe, and we suggest that the onset of this episode in both regions most likely happened around $310 \mathrm{Ma}$.

In many areas, Palaeozoic and older rocks were buried below a cover with a thickness of $3 \mathrm{~km}$ or more prior to exhumation in the Middle Triassic C1 episode (c. 240 Ma). In the region from Germania Land to Clavering $\varnothing$, the cover consisted of upper Carboniferous - Middle Triassic rocks. Regional uplift and erosion in the Middle Triassic produced thick, siliciclastic deposits in the rift system, such as the Pingo Dal Group. Middle Triassic uplift and erosion also affected north-west Europe at about the same time, and we suggest that the onset of this episode in both regions probably happened around $245 \mathrm{Ma}$.

Early Jurassic C2 exhumation (c. $180 \mathrm{Ma}$ ) caused denudation of the basement across much of the study area apart from the Jameson Land Basin. The episode is reflected in the base-Middle Jurassic unconformity and in an etch (weathering) surface above which Middle and Upper Jurassic sediments accumulated, for example Charcot Bugt, Pelion and Payer Dal Formations. Previous studies interpreted the Early Jurassic uplift and erosion to be caused by a dome centred north of Jameson Land, but our results show that the exhumation also affected areas far into the hinterland. Uplift and erosion also affected North-West Europe at about the same time, and we suggest that the onset of this episode in both regions probably began around $175 \mathrm{Ma}$, at the Early to Middle Jurassic transition.

Earliest Cretaceous C3 exhumation (145-140 Ma) accompanied the late Mesozoic rift climax north of Kong Oscar Fjord, and the subsequent erosion contributed to the coarse-grained sedimentary infill of the rift basins (the Wollaston Forland Group). These basins were subsequently buried during post-rift thermal subsidence. Sporadic evidence for episode C3 in the south-west indicates that uplift most likely affected much of the region.

Uplift and erosion that began in the mid-Cretaceous C4 episode (95-90 Ma) affected large parts of the region and corresponds to the mid-Turonian, erosional base of the Jackson $\varnothing$ Group. When exhumation began, a cover of Cretaceous sediments, up to $2 \mathrm{~km}$ thick, including post-rift sediments, had accumulated above the Mesozoic rifts and their hinterlands. Where the C4 episode represents maximum palaeotemperatures for the Mesozoic sediments, it thus also marks the termination of hydrocarbon generation (between Store Koldewey and Hold with Hope and possibly further south). The effects of this exhumation episode could not be resolved in the AFTA data from the Jameson Land Basin, where Cretaceous sediments are largely absent, possibly due to the many later cooling events that affected this region. Fault movements of up to $1 \mathrm{~km}$ affected the Clavering $\varnothing$ region in this episode, but the offsets were levelled out and an etch surface developed prior to eruption of the Palaeogene basalts during breakup.

Our results show no evidence for regional exhumation related to the final rifting and breakup at the Palaeocene-Eocene transition. This agrees with geological evidence that demonstrates continued subsidence and burial during and after break-up. We interpret early Eocene C5 cooling (c. $55 \mathrm{Ma}$ ) focussed around Jameson Land to reflect local heating associated with widespread Eocene intrusive activity.

Following break-up, a cover of Palaeogene basalts and Eocene sediments accumulated on the rifted margin and began to be exhumed during end-Eocene $\mathrm{C} 6$ uplift (37-35 Ma). When uplift began, all rocks that are now exposed at the surface in a zone from Wollaston Forland to Liverpool Land, were buried below a considerable rock column, typically a cover with a thickness of $1 \mathrm{~km}$ or more. The end-Eocene episode affected the entire East Greenland margin. This episode coincided with the cessation of sea-floor spreading west of Greenland, a major plate reorganisation in the NorthEast Atlantic and renewed intrusion of magmatic bodies along the coast, notably on Traill $\varnothing$ where palaeotemperatures were elevated locally by heat flow close to the intrusions.

The Early Miocene cooling C7 episode (20-18 Ma) was focussed on northern Jameson Land. It may have involved local uplift and erosion, possibly related to the Oligocene intrusive centre of Werner Bjerge and 
Malmbjerget, and the formation of the high terrain of Stauning Alper at the western edge of these intrusive centres.

Uplift in the late Miocene C8 episode (c. $10 \mathrm{Ma}$ ) initiated the development of the modern topography in East Greenland. The present relief of fjords and valleys across the entire region were incised after the late Miocene. In the interior highlands, the incision took place below the general summit level in these mountains. In the coastal zone, the present-day summits were buried below a significant rock column of primarily Miocene sediments prior to late Miocene uplift and erosion.

The early Pliocene $C 9$ episode (c. $5 \mathrm{Ma}$ ) is primarily defined by AFTA data in the region around the intrusive centre on Traill $\varnothing$. Here, end-Eocene palaeotemperatures are high due to heat from the intrusive bodies. Early Pliocene palaeotemperatures are high due to deep burial.

\subsection{Development of present-day topography}

Two elevated peneplains extending across the study area provide visible evidence of three Cenozoic phases of uplift and erosion defined from AFTA: (1) Uplift during the end-Eocene C6 episode led to formation of the UPS by erosion to the base level defined by the adjacent Atlantic Ocean. (2) Uplift during the late Miocene C8 episode of $c .1 \mathrm{~km}$ led to formation of the LPS by incision along rivers below the uplifted UPS towards the new base level. (3) Uplift during the early Pliocene C9 episode of $c .1 \mathrm{~km}$ lifted the UPS and the LPS to their present elevations of c. 2 and $1 \mathrm{~km}$ a.s.l., respectively, and initiated the formation of the present-day landscape through fluvial and glacial erosion. This implies that the low-lying UPS dominated the landscape during most of the Miocene, and that, consequently, the Greenland ice sheet could not form prior to the late Miocene uplift. The step (escarpment) between the UPS and the LPS follow the incision along the major valleys, whereas the pronounced topographical step across PDMF is caused by the differences in lithology.

\subsection{Fault offsets}

Our data document active movements along the PDMF system during the Early Jurassic C1 and Middle Triassic C2 episodes. Whereas denudation during these episodes reached far into the present-day basement terrains in the interior of the study area, the rift basins along the margin received the erosional products derived from the exhumation during these events. Therefore, the PDMF acted as the separator between the uplifted areas to the west and the subsiding basins to the east of the fault system. Our data document movements of the Dombjerg Fault during the mid-Cretaceous C4 episode.

The PDMF and adjacent fault systems were reactivated during the end-Eocene C6 and the late Miocene C8 episodes. AFTA data provide evidence of end-Eocene block rotation of $600 \mathrm{~m}$ on Hudson Land, and there is a post-basalt throw along a major fault west of Hold with Hope of over $500 \mathrm{~m}$. A pronounced increase in the estimated rock uplift since the late Miocene across short distances over the PDMF indicates differential movements, allowing primarily Miocene sediments to accumulate prior to their removal during late Miocene uplift. The sediments thus accumulated in the coastal zone during a period of crustal extension prior to late Miocene uplift during a compressional phase. The continuity of the LPS on both sides of the PDMF in the south-western part of the study area indicates that this fault system was not active during the early Pliocene C9 episode.

\subsection{Onshore-offshore correlation}

Two important phases of progradation away from North-East Greenland occurred after break-up. The first phase of progradation involving extensive mass wasting occurred after erosional incision along the shelf that happened in the interval between late Eocene and mid-Miocene. We suggest that the mass wasting offshore was due to uplift in the end-Eocene C6 episode onshore, and thus that the horizon defining the erosional incision can be dated to about $35 \mathrm{Ma}$. The next phase of massive shelf progradation occurred after the formation of the distinct IMU. The IMU marks the termination of synrift deposition in the deep-sea basins and the accelerated widening of the Fram Strait, and it is linked to mild compression and the onset of late Miocene uplift onshore and massive shelf progradation. We therefore suggest that the uplift onshore and the subsequent progradation offshore began during the late Miocene C8 episode, and thus that the IMU can be dated to about $10 \mathrm{Ma}$.

\subsection{Regionally synchronous episodes}

The timing of the regional episodes of uplift and erosion prior to break-up of the North-East Atlantic defined in this study correlates closely with events in neighbouring regions. The three earliest episodes of uplift and denudation identified here also had a profound impact in North-West Europe, and it is likely that the onset of these events was simultaneous in East Greenland and southern Scandinavia in the late Carboniferous, the Middle Triassic and at the Early-Middle Jurassic transition. Exhumation most likely resulted from thermal uplift due to accumulation of heat beneath the supercontinent, Pangaea, which preceded three phases of fragmentation of the supercontinent.

\subsection{Non-synchronous events}

Episodes of uplift after break-up are not regionally synchronous across the Atlantic. Uplift and denudation 
during the end-Eocene C6 episode primarily affected Arctic regions, including West and East Greenland, with minor effects in southern Scandinavia. Early Miocene uplift and erosion had a major impact in southern Scandinavia, but there is no known counterpart in Greenland. Uplift and incision during the late Miocene C8 episode initiated the formation of the modern relief in West and East Greenland but has no known counterpart in southern Scandinavia. Coeval events to episodes C6 and C8 are reported from Svalbard and the Barents Sea. Early Pliocene C9 uplift and incision affected both West and East Greenland as well as southern Scandinavia. We speculate that the forces driving (1) uplift during episode C6 in Greenland are most likely linked with the stress that prevented further movements of the Greenland plate relative to North America, (2) uplift during the early Miocene in Scandinavia probably originated from stress transmitted from orogenies on the Eurasian plate, (3) uplift during episode C8 in Greenland may be linked to changes in the absolute motion of North America and (4) uplift during episode C9 in Greenland and Scandinavia may be related to changes in upper-mantle flow related to the Iceland Plume.

\subsection{Episodic burial and exhumation}

As we have shown here, North-East Greenland is a typical example of an EPCM shaped by episodes of burial and exhumation both before and after break-up along the margin. In agreement with McKenzie's theory of rifting, there is evidence for Cretaceous and Eocene postrift burial of the rift basins in North-East Greenland. However, little remains of these deposits due to episodes of mid-Cretaceous and Cenozoic denudation that are not predicted by McKenzie's theory. The events of uplift that followed the break-up of Pangaea are, as yet, unexplained by conventional theories of basin development, as are the forces that lifted the peneplains that dominate the landscape of in North-East Greenland to their present-day elevations. It is our hope that geoscientists with insight into the physical properties of the Earth's interior will now use our observations to explain vertical motions of the Earth's surface on timescales of tens of millions of years.

\section{Acknowledgements}

Many colleagues from the Geological Survey of Greenland and Denmark (GEUS) contributed with samples to this study; more than we can list here. Christian Knudsen collected many of the first samples analysed for this study during a sailboat expedition in 2008. Jørgen Bojesen-Koefoed organised the expeditions to North-East Greenland in 2008-2011, during which most of the samples were acquired, and he supported our work in many ways. Kirsten Hansen made apatite separates available for this study. Niels Henriksen (Oscar) provided invaluable help in retrieving samples collected in past decades from GEUS' core store. Finn Surlyk and Sierd Cloetingh provided insightful reviews of the manuscript.

\section{Additional information}

Funding statement

The research was funded by a consortium of oil companies and GEUS.

\section{Competing interests}

The authors declare no competing interests.

\section{Author contributions}

PJ: Conceptualisation, Data curation, Investigation, Methodology, Project administration, Writing - original draft, Writing - review \& editing. PFG: Formal analysis, Methodology, Investigation, Writing - original draft, Writing - review \& editing. JMB, MB, JRH: Investigation, Writing - review \& editing.

\section{Additional files}

Five supplementary files are available at

https://doi.org/10.22008/FK2/7TVNHB

Three appendices are available at the end of this monograph. 


\section{References}

Ahnert, F. 1998: Introduction to Geomorphology, 352 pp. London: Arnold. Amante, C. \& Eakins, B.W. 2009: ETOPO1 1 Arc-Minute Global Relief Model: Procedures, Data Sources and Analysis. NOAA Technical Memorandum NESDIS NGDC-24, 19 pp.

Andrews, S.D., Kelly, S.R., Braham, W. \& Kaye, M. 2014: Climatic and eustatic controls on the development of a Late Triassic source rock in the Jameson Land Basin, East Greenland. Journal of the Geological Society (London) 171, 609-619. https://doi.org/10.1144/jgs2013-075

Andrews, S.D., Decou, A., Braham, B., Kelly, S.R., Robinson, P., Morton, A.C., Marshall, J.E. \& Hyden, F. 2020a: Exhumed hydrocarbon traps on the North Atlantic margin: Stratigraphy, palaeontology, provenance and bitumen distribution, an integrated approach. Basin Research 32(5), 1213-1233. https://doi.org/10.1111/bre.12424

Andrews, S.D., Decou, A., Braham, B., Kelly, S.R., Robinson, P., Morton, A., Marshall, J.E. \& Hyden, F. 2020b: Exhumed hydrocarbon traps in East Greenland: Reply to Christensen et al.'s comment on Andrews et al. (2019). Basin Research 32(5), 1239-1241. https://doi.org/10.1111/bre.12467

Andsbjerg, J. \& Dybkjær, K. 2003: Sequence stratigraphy of the Jurassic of the Danish Central Graben. The Jurassic of Denmark and Greenland. Geological Survey of Denmark and Greenland Bulletin 1, 265-300. https://doi.org/10.34194/geusb.v1.4675

Berger, D. \& Jokat, W. 2008: A seismic study along the East Greenland margin from $72^{\circ} \mathrm{N}$ to $77^{\circ} \mathrm{N}$. Geophysical Journal International 174, 733-748. https://doi.org/10.1111/j.1365-246x.2008.03794.x

Berger, D. \& Jokat, W. 2009: Sediment deposition in the northern basins of the North Atlantic and characteristic variations in shelf sedimentation along the East Greenland margin. Marine and Petroleum Geology 26, 1321-1337. https://doi.org/10.1016/j.marpetgeo.2009.04.005

Bernard, T., Steer, P., Gallagher, K., Szulc, A., Whitham, A. \& Johnson, C. 2016: Evidence for Eocene-Oligocene glaciation in the landscape of the East Greenland margin. Geology 44, 895-898. https://doi. org/10.1130/g38248.1

Bertelsen, F. 1980: Lithostratigraphy and depositional history of the Danish Triassic. Danmarks Geologiske Undersøgelse Serie B 4, 59pp. https://doi.org/10.34194/serieb.v4.7059

Bierman, P.R., Shakun, J.D., Corbett, L.B., Zimmerman, S.R. \& Rood, D.H. 2016: A persistent and dynamic East Greenland Ice Sheet over the past 7.5 million years. Nature 540, 256-260. https://doi.org/10.1038/ nature 20147

Birkelund, T. \& Perch-Nielsen, K. 1976: Late Palaeozoic-Mesozoic evolution of central East Greenland. In: Escher, A. \& Watt, W.S (eds): Geology of Greenland, 305-339. Copenhagen: Geological Survey of Greenland.

Bjerager, M., Seidler, L., Stemmerik, L. \& Surlyk, F. 2006: Ammonoid stratigraphy and sedimentary evolution across the Permian-Triassic boundary in East Greenland. Geological Magazine 143, 636-656. https://doi.org/10.1017/s0016756806002020

Bjerager, M. et al. 2020: Cretaceous lithostratigraphy of North-East Greenland. Bulletin of the Geological Society of Denmark 68, 37-93. https://doi.org/10.37570/bgsd-2020-68-04

Bojesen-Koefoed, J.A., Kalkreuth, W., Petersen, H.I. \& Piasecki, S. 2012: A remote coal deposit revisited: Middle Jurassic coals at Kulhøj, western Germania Land, northeast Greenland. International Journal of Coal Geology 98, 50-61. https://doi.org/10.1016/j.coal.2012.04.006

Bojesen-Koefoed, J.A., Alsen, P. \& Christiansen, F.G. 2014: Six years of petroleum geological activities in North-East Greenland (2008-2013): projects and a view of the future. Geological Survey of Denmark and Greenland Bulletin 31, 59-62. https://doi.org/10.34194/geusb.v31.4661

Bonow, J.M. 2005: Re-exposed basement landforms in the Disko region, West Greenland - disregarded data for estimation of glacial erosion and uplift modelling. Geomorphology 72, 106-127. https://doi. org/10.1016/j.geomorph.2005.05.006

Bonow, J. M., \& Japsen, P. 2021: Peneplains and tectonics in North-East Greenland after opening of the North-East Atlantic. GEUS Bulletin 45(1). 5297. https://doi.org/10.34194/geusb.v45.5297 (this volume)
Bonow, J.M., Japsen, P., Lidmar-Bergström, K., Chalmers, J.A. \& Pedersen A.K. 2006a: Cenozoic uplift of Nuussuaq and Disko, West Greenland - elevated erosion surfaces as uplift markers of a passive margin. Geomorphology 80, 325-337. https://doi.org/10.1016/j. geomorph.2006.03.006

Bonow, J.M., Lidmar-Bergström, K. \& Japsen, P. 2006b: Palaeosurfaces in central West Greenland as reference for identification of tectonic movements and estimation of erosion. Global and Planetary Change 50, 161-183. https://doi.org/10.1016/j.gloplacha.2005.12.011

Bonow, J.M., Japsen, P. \& Nielsen, T.F.D. 2014: High-level landscapes along the margin of East Greenland - a record of tectonic uplift and incision after breakup in the North-East Atlantic. Global and Planetary Change 116, 10-29. https://doi.org/10.1016/j.glop/acha.2014.01.010

Braun, J. 2010: The many surface expressions of mantle dynamics. Nature Geoscience 3, 825-833. https://doi.org/10.1038/ngeo1020

Braun, J. 2018: A review of numerical modeling studies of passive margin escarpments leading to a new analytical expression for the rate of escarpment migration velocity. Gondwana Research 53, 209-224. https://doi.org/10.1016/j.gr.2017.04.012

Braun, J. 2019: Response to comment by Japsen et al. on "A review of numerical modeling studies of passive margin escarpments leading to a new analytical expression for the rate of escarpment migration velocity". Gondwana Research 65, 174-176. https://doi.org/10.1016/j. gr.2018.10.003

Brooks, C.K. 1985: Vertical crustal movements in the Tertiary of central East Greenland: a continental margin at a hot-spot. Zeitschrift für Geomorphologie 54, 101-117.

Brooks, C.K. 2011: The East Greenland rifted volcanic margin. Geological Survey of Denmark and Greenland Bulletin 24, 96 pp. https://doi. org/10.34194/geusb.v24.4732

Brooks, C.K., Tegner, C., Stein, H. \& Thomassen, B. 2004: Re-Os and Ar-40/ Ar-39 ages of porphyry molybdenum deposits in the east Greenland volcanic-rifted margin. Economic Geology 99, 1215-1222. https://doi. org/10.2113/gsecongeo.99.6.1215

Brunsden, D. 1993: The persistence of landforms. Zeitschrift für Geomorphologie Supplementband 93, 13-28.

Bütler, H. 1955: Das variscisch gefaltete Devon zwischen Duséns Fjord und Kongeborgen in Zentral-Ostgrönland. Meddelelser om Grønland 155, $131 \mathrm{pp}$.

Chalmers, J.A. \& Pulvertaft, T.C.R. 2001: Development of the continental margins of the Labrador Sea: a review. In: Wilson, R.C.L. et al. (eds): Non-volcanic rifting of continental margins: A comparison of evidence from land and sea. Geological Society Special Publications (London) 187, 77-105. https://doi.org/10.1144/gsl.sp.2001.187.01.05

Chalmers, J.A., Green, P., Japsen, P. \& Rasmussen, E.S. 2010: The Scandinavian mountains have not persisted since the Caledonian orogeny. A comment on Nielsen et al. (2009a). Journal of Geodynamics 50, 94-101. https://doi.org/10.1016/j.jog.2010.02.001

Christ, A.J. et al. 2021: A multimillion-year-old record of Greenland vegetation and glacial history preserved in sediment beneath $1.4 \mathrm{~km}$ of ice at Camp Century. Proceedings of the National Academy of Sciences 118(13), e2021442118. https://doi.org/10.1073/pnas.2021442118

Christiansen, F.G. 2011: Greenland petroleum exploration: history, breakthroughs in understanding and future challenges. Geological Society, London, Memoirs 35, 647-661. https://doi.org/10.1144/m35.42

Christiansen, F.G., Bojesen-Koefoed, J.A., Piasecki, S., Stemmerik, L. \& Therkelsen, J. 2020: Exhumed hydrocarbon traps in East Greenland: A comment on Andrews et al. (2019). Basin Research 32(5), 1234-1238. https://doi.org/10.1111/bre.12463

Christiansen, F.G, Piasecki, S. \& Stemmerik, L. 1990: Thermal maturity history of the Upper Permian succession in the Wegener Halvø area, East Greenland. Rapport Grønlands Geologiske Undersøgelse 148, 109-114. https://doi.org/10.34194/rapggu.v148.8129

Christiansen, F.G., Larsen, H.C., Marcussen, C., Hansen, K., Krabbe, H., Larsen, L.M., Piasecki, S., Stemmerik, L. \& Watt, J.W. 1992: Uplift 
study of the Jameson Land basin, East Greenland. Norsk Geologisk Tidsskrift 72, 291-294.

Christoffersen, M. \& Jepsen, H.F. 2007: Geological maps of North and North-East Greenland 1: 250000 Copenhagen: Geological Survey of Denmark and Greenland (GEUS).

Clausen, L. 1998: Late Neogene and Quaternary sedimentation on the continental slope and upper rise offshore Southeast Greenland: Interplay of contour and turbidity processes. In: Saunders, A.D. et al. (eds): Proceedings of the Ocean Drilling Program, Scientific Results 152, 3-18. https://doi.org/10.2973/odp.proc.sr.152.202.1998

Clauser, C. \& Huenges, E. 1995: Thermal Conductivity of Rocks and Minerals. In: Ahrens T.J. (ed.): Rock Physics \& Phase Relations. 105126. https://doi.org/10.1029/RF003p0105

Clemmensen, L.B. 1980: Triassic rift sedimentation and palaeogeography of central East Greenland. Bulletin Grønlands Geologiske Undersøgelse 136, 72pp. https://doi.org/10.34194/bullggu.v136.6678

Clemmensen, L.B, Kent, D.V., Mau, M., Mateus, O. \& Milàn, J. 2020: Triassic lithostratigraphy of the Jameson Land Basin (central East Greenland), with emphasis on the new Fleming Fjord Group. Bulletin of the Geological Society of Denmark 68, 95-132. https://doi.org/10.37570/ bgsd-2020-68-05

Cloetingh, S. \& Burov, E. 2010: Lithospheric folding and sedimentary basin evolution: a review and analysis of formation mechanisms. Basin Research 23, 257-290. https://doi.org/10.1111/j.1365-2117.2010.00490.x

Cohen, K. M., Finney, S. C., Gibbard, P. L. \& Fan, J.-X. 2013: The ICS International Chronostratigraphic Chart. Episodes 36(3), 199-204. https://doi.org/10.18814/epiiugs/2013/v36i3/002

Colli, L., Stotz, I., Bunge, H.P., Smethurst, M., Clark, S., laffaldano, G., Tassara, A., Guillocheau, F. \& Bianchi, M.C. 2014: Rapid South Atlantic spreading changes and coeval vertical motion in surrounding continents: evidence for temporal changes of pressure-driven upper mantle flow. Tectonics 33, 1304-1321. https://doi.org/10.1002/2014tc003612

Colli, L., Ghelichkhan, S. \& Bunge, H.P. 2016: On the ratio of dynamic topography and gravity anomalies in a dynamic Earth. Geophysical Research Letters 43, 2510-2516. https://doi.org/10.1002/2016g/067929

Colli, L., Ghelichkhan, S., Bunge, H.-P. \& Oeser, J. 2018: Retrodictions of Mid Paleogene mantle flow and dynamic topography in the Atlantic region from compressible high resolution adjoint mantle convection models: Sensitivity to deep mantle viscosity and tomographic input model. Gondwana Research 53, 252-272. https://doi.org/10.1016/j. gr.2017.04.027

Dam, G., Pedersen, G.K., Sønderholm, M., Midtgaard, H.H., Larsen, L.M., Nøhr-Hansen, H. \& Pedersen, A.K. 2009: Lithostratigraphy of the Cretaceous-Paleocene Nuussuaq Group, Nuussuaq Basin, West Greenland. Geological Survey of Denmark and Greenland Bulletin 19, 171 pp. https://doi.org/10.34194/geusb.v19.4886

da Silva, B.V., Hackspacher, P.C., Ribeiro, M.C.S., Glasmacher, U.A., Gonçalves, A.O., Doranti-Tiritan, C., de Godoy, D.F. \& Constantino, R.R. 2019: Evolution of the Southwestern Angolan Margin: episodic burial and exhumation is more realistic than long-term denudation. International Journal of Earth Sciences 108, 89-113. https://doi. org/10.1007/s00531-018-1644-4

DeMets, C., laffaldano, G. \& Merkouriev, S. 2015: High-resolution Neogene and Quaternary estimates of Nubia-Eurasia-North America Plate motion. Geophysical Journal International 203, 416-427. https:// doi.org/10.1093/gji/ggv277

Donovan, D.T. 1957: The Jurassic and Cretaceous Systems of East Greenland. Meddelelser om Grønland 155, 214 pp.

Doornenbal, H. \& Stevenson, A. (eds) 2010: Petroleum geological atlas of the Southern Permian Basin area, 342 pp. EAGE: Houten, the Netherlands.

Doré, A.G., Lundin, E.R., Jensen, L.N., Birkeland, Eliassen, P.E. \& Fichler, C. 1999: Principal tectonic events in the evolution of the northwest European Atlantic margin. In: Fleet, A.J. \& Boldy, S.A.R. (eds): Petroleum Geology of Northwest Europe: Proceedings of the $5^{\text {th }}$ Conference, 41-61. London: Geological Society. https://doi.org/10.1144/0050041

Dörr, N., Clift, P.D., Lisker, F. \& Spiegel, C. 2012: Why is Svalbard an island? Evidence for subsidence and mantle thermal anomalies. Tectonics 32, 473-486. https://doi.org/10.1002/tect.20039
Dörr, N., Lisker, F., Piepjohn, K. \& Spiegel, C. 2019: Cenozoic development of northern Svalbard based on thermochronological data. Terra Nova 31, 306-315. https://doi.org/10.1111/ter.12402

Døssing, A., Japsen, P., Watts, A.B., Nielsen, T., Jokat, W., Thybo, H. \& Dahl-Jensen, T. 2016: Miocene uplift of the North-East Greenland margin linked to plate tectonics: Seismic evidence from the Greenland Fracture Zone, North-East Atlantic. Tectonics 35, 257-282. https://doi. org/10.1002/2015tc004079

Duddy, I., Green, P.F., Gibson, H.J. \& Hegarty, K.A. 2004: Regional Palaeothermal episodes in northern Australia. Timor Sea Symposium Proceedings, Darwin 2004, 567-591.

Eldrett, J.S., Harding, I.C., Wilson, P.A., Butler, E. \& Roberts, A.P. 2007: Continental ice in Greenland during the Eocene and Oligocene. Nature 446, 176-179. https://doi.org/10.1038/nature05591

Eldrett, J.S., Greenwood, D.R., Harding, I.C. \& Huber, M. 2009: Increased seasonality through the Eocene to Oligocene transition in northern high latitudes. Nature 459, 969-991. https://doi.org/10.1038/ nature08069

Eppelbaum, L., Kutasov, I. \& Pilchin, A. 2014: Applied Geothermics.Part of Lecture Notes in Earth System Sciences XVIII, 751 pp. Berlin: Springer. https://doi.org/10.1007/978-3-642-34023-9

Escher, A. \& Watt, W.S. (eds) 1976: Geology of Greenland, 603 pp. Copenhagen: Geological Survey of Greenland.

Escher, J.C. \& Pulvertaft, T.C.R. 1995: Geological map of Greenland, 1:2 500 000. Copenhagen: Geological Survey of Denmark.

Fredskild, B., Funder, S. Larsen, H.C. 1989: Quaternary geology of the ice-free areas and adjacent shelves of Greenland. In: Fulton, R.J. (ed.): Quaternary Geology of Canada and Greenland. Boulder: Geological Society of America. https://doi.org/10.1130/DNAG-GNA-K1.741

Fyhn, M.B., Rasmussen, T.M., Dahl-Jensen, T., Weng, W.L., BojesenKoefoed, J.A. \& Nielsen, T. 2012: Geological assessment of the East Greenland margin. Geological Survey of Denmark and Greenland Bulletin 26, 61-64. https://doi.org/10.34194/geusb.v26.4755

Gaina, C., Gernigon, L. \& Ball, P. 2009: Paleocene-Recent plate boundaries in the North-East Atlantic and the formation of the Jan Mayen microcontinent. Journal of the Geological Society (London) 166, 601616. https://doi.org/10.1144/0016-76492008-112

Gaina, C., Nasuti, A., Kimbell, G.S. \& Blischke, A. 2017: Break-up and seafloor spreading domains in the NE Atlantic. Geological Society Special Publications (London) 447, 25 pp. https://doi.org/10.1144/sp447.12

Galbraith, R.F. 2005: Statistics for Fission Track Analysis, 240 pp. New York: Chapman \& Hall/CRC. https://doi.org/10.1201/9781420034929

Gallagher, K. 1995: Evolving temperature histories from apatite fission-track data. Earth and Planetary Science Letters 136, 421-435. https://doi.org/10.1016/0012-821x(95)00197-k

Gautier, D.L. et al. 2011: Assessment of North-East Greenland: prototype for development of Circum-Arctic Resource Appraisal methodology. In: Spencer, A.M. et al. (eds): Arctic Petroleum Geology, Geological Society, London, Memoirs 35, 663-672. https://doi.org/10.1144/m35.43

Gilotti, J.A. \& McClelland, W.C. 2008: Geometry, kinematics, and timing of extensional faulting in the Greenland Caledonides - A synthesis. In: Higgins, A.K. et al. (eds): The Greenland Caledonides: Evolution of the Northeast Margin of Laurentia. The Geological Society of America Memoir 202, 251-271. https://doi.org/10.1130/2008.1202(10)

Gleadow, A.J.W. \& Brooks, C.K. 1979: Fission-track dating, thermal histories and tectonics of igneous intrusions in East Greenland. Contributions to Mineralogy and Petrology 71, 45-60. https://doi. org/10.1007/bf00371880

Goldsmith, P., Hudson, G. \& Van Veen, P. 2003: Triassic. In: Evans, D. et al. (eds): The millennium atlas: Petroleum geology of the central and northern North Sea: Geological Society (London) 105, 105-127.

Gradstein, F.M., Ogg, J.G. \& Hilgen, F.J. 2012: On The Geologic Time Scale. Newsletters on Stratigraphy 45, 171-188. https://doi. org/10.1127/0078-0421/2012/0020

Green, P.F. 1986: On the thermo-tectonic evolution of northern England: Evidence from fission track analysis. Geological Magazine 123, 493506. https://doi.org/10.1017/s0016756800035081

Green, P.F. 2009: Thermal history of outcrop samples from East Greenland north of $70^{\circ} \mathrm{N}$ based on AFTA. Geotrack Report GC1016. 405 pp. Victoria: Geotrack International. Available in Supplementary File S1. 
Green, P.F. 2011: Thermal history of outcrop samples from East Greenland north of $70^{\circ} \mathrm{N}$ based on AFTA and VR. Geotrack Report GC1077. 789 pp. Victoria: Geotrack International. Available in Supplementary File S2.

Green, P.F. 2012: Thermal history of outcrop samples from East Greenland north of $70^{\circ} \mathrm{N}$ based on AFTA and VR (an extension of GC1077). Geotrack Report GC1104. 227 pp. Victoria: Geotrack International. Available in Supplementary File S3.

Green, P.F. \& Duddy, I.R. 2010: Synchronous exhumation events around the Arctic including examples from Barents Sea and Alaska North Slope. In: Vining, B.A. \& Pickering, S.C. (eds): Petroleum Geology: From Mature Basins to New Frontiers. Geological Society, London, Petroleum Geology Conference series 7, 633-644. https://doi. org/10.1144/0070633

Green, P.F. \& Duddy, I.R. 2012: Thermal history reconstruction in sedimentary basins using apatite fission-track analysis and related techniques. In: Analyzing the Thermal History of Sedimentary Basins: Methods and Case Studies Society of Economic Paleontologists and Mineralogists (SEPM). Special Publication 103, 65-104. https://doi. org/10.2110/sepmsp.103.065

Green, P.F. \& Duddy, I. 2018: Apatite (U-Th-Sm)/He thermochronology on the wrong side of the tracks. Chemical Geology 488, 21-33. https://doi. org/10.1016/j.chemgeo.2018.04.028

Green, P.F. \& Japsen, P. 2018: Burial and exhumation history of the Jameson Land Basin, East Greenland, estimated from thermochronological data from the Blokelv-1 core.Geological Survey of Denmark and Greenland Bulletin 42, 133-147. https://doi.org/10.34194/geusb. v42.4324

Green, P.F. \& Machado, V. 2015: Pre-rift and synrift exhumation, postrift subsidence and exhumation of the onshore Namibe Margin of Angola revealed from apatite fission track analysis. In: Sabato Ceraldi, T., Hodgkinson, R.A. \& Backe, G. (eds): Petroleum Geoscience of the West Africa Margin Geological Society, London, Special Publications 438, 99-118. https://doi.org/10.1144/sp438.2

Green, P.F., Duddy, I.R., Laslett, G.M., Hegarty, K.A., Gleadow, A.J.W. \& Lovering, J.F. 1989: Thermal annealing of fission tracks in apatite 4. Quantitative modelling techniques and extension to geological timescales. Chemical Geology: Isotope Geoscience section 79, 155-182. https://doi.org/10.1016/0168-9622(89)90018-3

Green, P.F., Duddy, I.R., Hegarty, K.A., Bray, R.J., Sevastopulo, G., Clayton, G. \& Johnston, D. 2000: The post-Carboniferous evolution of Ireland: evidence from thermal history reconstruction. Proceedings of the Geologists' Association 111, 307-320. https://doi.org/10.1016/ s0016-7878(00)80087-5

Green, P.F., Duddy, I.R., Slind, L. \& Rayer, F. 2005: Multiple paleo-thermal episodes in Mackenzie Corridor, Northwest Territory, Canada revealed by apatite fission track analysis (AFTA): implications for hydrocarbon prospectivity. AAPG Calgary, Canada, 16-19 June 2005.

Green, P.F., Swart, R., Jacob, J., Ward,J. \& Bluck, B. 2009: Thermochronology and landscape development in Southern Africa. PESGB/HGS Africa meeting, London, UK, 9-10 September. Extended abstracts, 7 pp.

Green, P.F., Japsen, P., Chalmers, J.A. \& Bonow, J.M. 2011: Thermochronology, erosion surfaces and missing section in West Greenland. Journal of the Geological Society (London) 168, 817-829. https://doi. org/10.1144/0016-76492010-124

Green, P.F., Lidmar-Bergström, K., Japsen, P., Bonow, J.M. \& Chalmers, J.A. 2013: Stratigraphic landscape analysis, thermochronology and the episodic development of elevated passive continental margins. Geological Survey of Denmark and Greenland Bulletin 30, 150 pp. https://doi.org/10.34194/geusb.v30.4673

Green, P.F., Japsen, P., Guarnieri, P. \& Nielsen, T.F.D. 2014: Thermal history of outcrop samples from South-East Greenland based on apatite fission-track analysis. In: Stensgaard, B.M. (ed.): South-East Greenland Mineral Endowment Task (SEGMENT): 2014 Workshop Abstract Volume and Status Primo-2014. Danmarks og Grønlands Geologiske Undersøgelse Rapport. 2014/79. GEUS, 80 pp.

Green, P.F., Duddy, I. \& Japsen, P. 2017a: Paleothermal effects of igneous intrusions in sedimentary basins and their influence on petroleum systems: AAPG GTW Influence of Volcanism and Associated Magmatic
Processes on Petroleum Systems. Geoscience Technology Workshop Oamaru, New Zealand, 14-16 March 2017, abstract 4 pp.

Green, P.F., Duddy, I.R., Japsen, P., Bonow, J.M. \& Malan, J. 2017b: Postbreakup burial and exhumation of the southern margin of Africa. Basin Research 29(1), 96-127. https://doi.org/10.1111/bre.12167

Green, P.F., Duddy, I.R. \& Japsen, P. 2017c: Multiple episodes of regional exhumation and inversion identified in the UK Southern North Sea based on integration of palaeothermal and palaeoburial indicators. Geological Society, London, Petroleum Geology Conference series 8, 47-65. https://doi.org/10.1144/pgc8.21

Green, P.F., Japsen, P., Chalmers, J.A., Bonow, J.M. \& Duddy, I.R. 2018 Post-breakup burial and exhumation of passive continental margins: Seven propositions to inform geodynamic models. Gondwana Research 53, 58-81. https://doi.org/10.1016/j.gr.2017.03.007

Guarnieri, P. 2015: Pre-break-up palaeostress state along the East Greenland margin. Journal of the Geological Society (London) 172, 727-739. https://doi.org/10.1144/jgs2015-053

Haller, J., 1971: Geology of the East Greenland Caledonides, 413 pp. London: Interscience.

Hamann, N.E., Whittaker, R. C. \& Stemmerik, L. 2005: Geological development of the Northeast Greenland Shelf. In: Doré, A.G. \& Vining, B. (eds): Petroleum Geology: North-West Europe and Global Perspectives. Geological Society, London, Petroleum Geology Conference series 6, 887-902. https://doi.org/10.1144/0060887

Hansen, K. 1988: Preliminary report of fission track studies in the Jameson Land basin, East Greenland. Rapport Grønlands Geologiske Undersøgelse 140, 85-89. https://doi.org/10.34194/rapggu.v140.8043

Hansen, K. 1992: Post-orogenic tectonic and thermal history of a rifted continental: the Scoresby Sund area, East Greenland. Tectonophysics 216, 309-326. https://doi.org/10.1016/0040-1951(92)90403-s

Hansen, K. 1996: Thermo-tectonic evolution of a rifted continental margin: fission track evidence from the Kangerlussuaq area, SE Greenland. Terra Nova 8, 458-469. https://doi.org/10.1111/j.1365-3121.1996.tb00771.x

Hansen, K. \& Reiners, P.W. 2006: Low temperature thermochronology of the southern East Greenland continental margin: Evidence from apatite (U-Th)/He and fission track analysis and implications for intermethod calibration. Lithos 92, 115-136. https://doi.org/10.1016/j. lithos.2006.03.039

Hansen, K., Bergman, S.C. \& Henk, B. 2001: The Jameson Land basin (east Greenland): a fission track study of the tectonic and thermal evolution in the Cenozoic North Atlantic spreading regime. Tectonophysics 331, 307-339. https://doi.org/10.1016/s0040-1951(00)00285-7

Hartz, E.H., Kristiansen, S.N., Calvert, A., Hodges, K.V. \& Heeremans, M. 2006: Structural, thermal and rheological control of the late Palaeozoic basins in East Greenland. In: Scott, R.A. \& Thurston, D.K. (eds): Proceedings from the Fourth International Conference on Arctic Margins, 58-76. Nova Scotia, 30 September to 3 October 2003.

Henriksen, N. 2003: Caledonian Orogen, East Greenland $70^{\circ}-82^{\circ} \mathrm{N}$. Geological map 1:1 000 000. Copenhagen: Geological Survey of Denmark and Greenland.

Henriksen, N., Higgins, A.K., Kalsbeek, F. \& Pulvertaft, T.C.R. 2009: Greenland from Archaean to Quaternary. Descriptive text to the 1995 Geological map of Greenland, 1:2 500 000. 2nd edition. Geological Survey of Denmark and Greenland Bulletin 18, 126 pp. + map. https:// doi.org/10.34194/geusb.v18.4993

Henstra, G.A., Grundvåg, S.-A., Johannessen, E.P., Kristensen, T.B., Midtkandal, I., Nystuen, J.P., Rotevatn, A., Surlyk, F., Sæther, T. \& Windelstad, J. 2016a: Depositional processes and stratigraphic architecture within a coarse-grained rift-margin turbidite system: The Wollaston Forland Group, East Greenland. Marine and Petroleum Geology 76, 187-209. https://doi.org/10.1016/j.marpetgeo.2016.05.018

Henstra, G.A., Gawthorpe, R.L., Helland-Hansen, W., Ravnås, R. \& Rotevatn, A. 2016b: Depositional systems in multiphase rifts: seismic case study from the Lofoten margin, Norway. Basin Research 29, 447-469. https://doi.org/10.1111//bre.12183

Higgins, A.K., Gilotti, J.A. \& Smith M.P. 2008: The Greenland Caledonides: Evolution of the Northeast Margin of Laurentia. The Geological Society of America Memoir 202. https://doi.org/10.1130/MEM202 
Hodges, K.V. 2000: Tectonics of the Himalaya and southern Tibet from two perspectives. Geological Society of America Bulletin 112, 324350. https://doi.org/10.1130/0016-7606(2000)112<324:tothas $>2.0 . c 0 ; 2$

Holford, S.P., Green, P.F., Hillis, R.R., Underhill, J.R., Stoker, M. \& Duddy, I.R. 2010: Multiple post-Caledonian exhumation episodes across NW Scotland revealed by apatite fission-track analysis. Journal of the Geological Society (London) 167, 675-694. https://doi. org/10.1144/0016-76492009-167

Hopper, J.R., Funck, T., Stoker, M., Arting, U., Peron-Pinvidic, G., Doornenbal, H. \& Gaina, C. 2014: Tectonostratigraphic Atlas of the North-East Atlantic Region. Copenhagen: Geological Survey of Denmark and Greenland.

Hull, D.M., Osterman, L.E. \& Thiede, J. 1996: 35. Biostratigraphic synthesis of Leg 151, North Atlantic-Arctic Gateways 1 In: Proceedings of the Ocean Drilling Program, Scientific Results 151, 627-644. College Station, TX. Ocean Drilling Program. https://doi.org/10.2973/odp.proc. sr.151.146.1996

Iaffaldano, G. \& DeMets, C. 2016: Late Neogene changes in North America and Antarctica absolute plate motions inferred from the MidAtlantic and Southwest Indian Ridges spreading histories. Geophysical Research Letters 43, 8466-8472. https://doi.org/10.1002/2016g/070276

Japsen, P. \& Chalmers, J. A. 2000: Neogene uplift and tectonics around the North Atlantic: Overview. Global and Planetary Change 24, 165173. https://doi.org/10.1016/s0921-8181(00)00006-0

Japsen, P., Green, P.F. \& Chalmers, J.A. 2005: Separation of Palaeogene and Neogene uplift on Nuussuaq, West Greenland. Journal of the Geological Society (London) 162, 299-314. https://doi.org/10.1144/0016-764904-038

Japsen P., Bonow, J.M., Green, P.F., Chalmers, J.A. \& Lidmar-Bergström, K. 2006: Elevated, passive continental margins: Long-term highs or Neogene uplifts. New evidence from West Greenland. Earth and Planetary Science Letters 248, 330-339. https://doi.org/10.1016/j. epsl.2006.05.036

Japsen, P., Green, P.F., Nielsen, L.H., Rasmussen, E.S. \& Bidstrup, T. 2007: Mesozoic-Cenozoic exhumation events in the eastern North Sea Basin: a multi-disciplinary study based on palaeothermal, palaeoburial, stratigraphic and seismic data. Basin Research 19, 451-490. https://doi.org/10.1111/j.1365-2117.2007.00329.x

Japsen, P., Bonow, J.M., Green, P.F., Chalmers, J.A. \& Lidmar-Bergström, K. 2009: Formation, uplift and dissection of planation surfaces at passive continental margins - a new approach. Earth Surface Processes and Landforms 34, 683-699. https://doi.org/10.1002/esp.1766

Japsen, P., Green, P.F., Bonow, J.M., Rasmussen, E.S., Chalmers, J.A. \& Kjennerud, T., 2010: Episodic uplift and exhumation along North Atlantic passive margins: implications for hydrocarbon prospectivity. In: Vining, B.A., Pickering, S.C. (eds.): Petroleum Geology: From Mature Basins to New Frontiers - Proceedings of the 7th Petroleum Geology Conference. Geological Society, London, 979-1004. https:// doi.org/10.1144/0070979

Japsen, P., Chalmers, J.A., Green, P.F. \& Bonow, J.M. 2012a: Elevated, passive continental margins: Not rift shoulders, but expressions of episodic, post-rift burial and exhumation. Global and Planetary Change 90-91, 73-86. https://doi.org/10.1016/j.gloplacha.2011.05.004

Japsen, P., Bonow, J.M., Green, P.F., Cobbold, P.R., Chiossi, D., Lilletveit, R., Magnavita, L.P. \& Pedreira, A.J. 2012b: Episodic burial and exhumation history of North-East Brazil after opening of the South Atlantic. Geological Society of America Bulletin 124, 800-816. https://doi. org/10.1130/b30515.1

Japsen, P., Green, P.F. \& Chalmers, J.A. 2013: The mountains of NorthEast Greenland are not remnants of the Caledonian topography. A comment on Pedersen et al. (2012): Tectonophysics vol. 530-531, p. 318-330. Tectonophysics 589, 234-238. https://doi.org/10.1016/j. tecto.2012.07.026

Japsen, P., Green, P.F., Bonow, J.M., Nielsen, T.F.D. \& Chalmers, J.A. 2014: From volcanic plains to glaciated peaks: Burial and exhumation history of southern East Greenland after opening of the NorthEast Atlantic. Global and Planetary Change 116, 91-114. https://doi. org/10.1016/j.gloplacha.2014.01.012

Japsen, P., Green, P.F., Bonow, J.M. \& Erlström, M. 2016: Episodic burial and exhumation of the southern Baltic Shield: Epeirogenic uplifts during and after break-up of Pangea. Gondwana Research 35, 357377. https://doi.org/10.1016/j.gr.2015.06.005

Japsen, P., Green, P.F., Bonow, J.M., Wilton, D.H.C. \& Hinchey, A.M. 2017 Burial and exhumation history of the Labrador-Newfoundland margin and implications for hydrocarbon exploration on the Grand Banks and the Labrador Shelf. 9 pp. APPG, SPE International Conference \& Exhibition, London, UK, 15-18 October 2017.

Japsen, P., Green, P.F., Chalmers, J.A. \& Bonow, J.M. 2018: Mountains of southernmost Norway: uplifted Miocene peneplains and re-exposed Mesozoic surfaces. Journal of the Geological Society (London) 157, 721-741. https://doi.org/10.1144/jgs2017-157

Japsen, P., Green, P.F., Chalmers, J.A., Duddy, I. \& Bonow, J.M. 2019: Elevated passive continental margins: Numerical modeling vs observations. A comment on Braun (2018). Gondwana Research 65, 172 173. https://doi.org/10.1016/j.gr.2018.10.004

Japsen, P. Green, P. F. \& Chalmers, J. A. 2021: Thermo-tectonic development of the Wandel Sea Basin, North Greenland. GEUS Bulletin, 45(1), 5298. https://doi.org/10.34194/geusb.v45.5298 (this volume)

Jiang, X.-D. \& Li, Z.-X. 2014: Seismic reflection data support episodic and simultaneous growth of the Tibetan Plateau since 25 Myr. Nature Communications 5, 5453. https://doi.org/10.1038/ncomms6453

Johnson, K. \& Gallagher, K. 2000: A preliminary Mesozoic and Cenozoic denudation history of the North East Greenland onshore margin. Global and Planetary Change 24, 261-274. https://doi.org/10.1016/ s0921-8181(00)00012-6

Kelly, S.R.A., Whitham, A.G., Koraini, M.A. \& Price, S.P. 1998: Lithostratigraphy of the Cretaceous (Barremian -Santonian) Hold with Hope Group, North East Greenland. Journal of the Geological Society (London) 155, 993-1008. https://doi.org/10.1144/gsjgs.155.6.0993

Kley, J. \& Voigt, T. 2008: Late Cretaceous intraplate thrusting in central Europe: Effect of Africa-Iberia-Europe convergence, not Alpine collision. Geology 36, 839-842. https://doi.org/10.1130/g24930a.1

Larsen, H.C. 1990: The East Greenland shelf. In: Grantz, A. et al. (eds): The Arctic Ocean region. The Geology of North America L, 185-210. Boulder, Colorado. https://doi.org/10.1130/dnag-gna-I.185

Larsen, P.H. 1988: Relay structures in a Lower Permian basement-involved extension system, East Greenland. Journal of Structural Geology 10, 3-8. https://doi.org/10.1016/0191-8141(88)90122-8

Larsen, H.C. \& Marcussen, C. 1992: Sill-intrusion, flood basalt emplacement and deep crustal structure of the Scoresby Sund region, East Greenland. In Storey, B.C. et al. (eds): Magmatism and the causes of continental break-up. Geological Society Special Publications (London) 68, 365-386. https://doi.org/10.1144/gsl.sp.1992.068.01.23

Larsen, R.B. \& Tegner, C. 2006: Pressure conditions for the solidification of the Skaergaard intrusion: Eruption of East Greenland flood basalts in less than 300,000 years. Lithos 92, 181-197. https://doi. org/10.1016/j.lithos.2006.03.032

Larsen, H.C., Saunders, A.D., Clift, P.D. \& the Shipboard Scientific Party. 1994a: 13. Summary and principal results. In: Larsen, H.C. \& Stewart, S.K. (eds): Proceedings of the Ocean Drilling Program, Initial Reports 152, 279-292. College Station, Ocean Drilling Program, TX. https://doi. org/10.2973/odp.proc.ir.152.113.1994

Larsen, H.C., Saunders, A.D., Clift, P.D., Beget, J., Wei, W. \& Spezzaferri, S. 1994b: Seven million years of glaciation in Greenland. Science 264, 952-955. https://doi.org/10.1126/science.264.5161.952

Larsen, M., Bjerager, M., Nedkvitne, T., Olaussen, S. \& Preuss, T. 2001: Pre-basaltic sediments (Aptian-Paleocene) of the Kangerlussuaq Basin, southern East Greenland. Geology of Greenland Survey Bulletin 189, 99-106. https://doi.org/10.34194/ggub.v189.5163

Larsen, M., Piasecki, S. \& Stemmerik, L. 2002: The post-basaltic Paleogene and Neogene sediments at Kap Dalton and Savoia Halvø, East Greenland. Geology of Greenland Survey Bulletin 191, 103-110. https://doi.org/10.34194/ggub.v191.5136

Larsen, P.H., Olsen, O. \& Clark, J.A. 2008a: The Devonian basin in East Greenland - Review of basin evolution and vertebrate assemblages. In: Higgins, A.K., Gilotti, J.A. \& Smith M.P. (eds): The Greenland Caledonides: Evolution of the Northeast Margin of Laurentia. The Geological Society of America Memoir 202, 251-271. https://doi. org/10.1130/2008.1202(11) 
Larsen, B.T., Olaussen, S., Sundvoll, B. \& Heeremans, M. 2008b: The Permo-Carboniferous Oslo Rift through six stages and 65 million years. Episodes 31, 52. https://doi.org/10.18814/epiiugs/2008/v31i1/008

Larsen, L.M., Watt, W.S. \& Watt, M. 1989: Geology and petrology of the Lower Tertiary plateau basalts of the Scoresby Sund region, East Greenland. Bulletin Grønlands Geologiske Undersøgelse 157, 164 pp. https://doi.org/10.34194/bullggu.v157.6699

Larsen, L.M., Heaman, L.M., Creaser, R.A., Duncan, R.A., Frei, R. \& Hutchison, M. 2009: Tectonomagmatic events during stretching and basin formation in the Labrador Sea and the Davis Strait: evidence from age and composition of Mesozoic to Palaeogene dyke swarms in West Greenland. Journal of the Geological Society (London) 166, 999-1012. https://doi.org/10.1144/0016-76492009-038

Larsen, L.M., Pedersen, A.K., Sørensen, E.V., Watt, W.S. \& Duncan, R.A. 2013: Stratigraphy and age of the Eocene Igtertivâ Formation basalts, alkaline pebbles and sediments of the Kap Dalton Group in the graben at Kap Dalton, East Greenland. Danmarks Geologiske Forening Bulletin 61, 1-18. https://doi.org/10.37570/bgsd-2013-61-01

Larsen, L.M., Pedersen, A.K., Tegner, C. \& Duncan, R.A. 2014: Eocene to Miocene igneous activity in North-East Greenland: northward younging of magmatism along the East Greenland margin. Journal of the Geological Society (London) 171, 537-453. https://doi.org/10.1144/ jgs2013-118

Letreguilly, A., Huybrechts, P. \& Reeh, N. 1991: Steady-state characteristics of the Greenland ice sheet under different climates. Journal of Glaciology 37, 149-157. https://doi.org/10.1144/jgs2013-118

Lidmar-Bergström, K. 1996: Long term morphotectonic evolution in Sweden. Geomorphology 16, 32-39. https://doi.org/10.1016/0169-555 $x(95) 00083-h$

Lidmar-Bergström, K., Ollier, C.D. \& Sulebak, J.C. 2000: Landforms and uplift history of southern Norway. Global and Planetary Change 24, 211-231. https://doi.org/10.1016/s0921-8181(00)00009-6

Lidmar-Bergström, K., Bonow, J.M. \& Japsen, P. 2013: Stratigraphic landscape analysis and geomorphological paradigms: Scandinavia as an example of Phanerozoic uplift and subsidence. Global and Planetary Change 100, 153-171. https://doi.org/10.1016/j.g/oplacha.2012.10.015

Lidmar-Bergström, K., Olvmo, M. \& Bonow, J.M. 2017: The South Swedish Dome: a key structure for identification of peneplains and conclusions on Phanerozoic tectonics of an ancient shield. Journal of the Geological Society of Sweden, GFF 139(4), 1-16. https://doi.org/10.108 0/11035897.2017.1364293

Magnavita, L., Silva, R.d. \& Sanches, C. 2005: Guia de campo da Bacia do Recôncavo, North-East do Brasil. Boletim de Geociencias da Petrobras 13, 301-334.

Mathiesen, A., Bidstrup, T. \& Christiansen, F.G. 2000: Denudation and uplift history of the Jameson Land Basin, East Greenland - constrained from maturity and apatite fission track data. Global and Planetary Change 24, 303-309. https://doi.org/10.1016/s0921-8181(00)00013-8

Matthews, K.J., Seton, M. \& Müller, R.D. 2012: A global-scale plate reorganization event at 105-100 Ma. Earth and Planetary Science Letters 355-356, 283-298. https://doi.org/10.1016/j.epsl.2012.08.023

McKenzie, D.P. 1978: Some remarks on the development of sedimentary basins. Earth and Planetary Science Letters 40, 25-32. https://doi. org/10.1016/0012-821x(78)90071-7

McLeod, A.E., Underhill, J.R., Davies, S.J. \& Dawers, N.H. 2002: The influence of fault array evolution on synrift sedimentation patterns: Controls on deposition in the Strathspey-Brent-Statfjord half graben, northern North Sea. AAPG bulletin 86, 1061-1094. https://doi. org/10.1306/61eedc24-173e-11d7-8645000102c1865d

Medvedev, S., Hartz, E.H. \& Podladchikov, Y.Y. 2008: Vertical motions of the fjord regions of central East Greenland: Impact of glacial erosion, deposition, and isostasy. Geology 36, 539-542. https://doi. org/10.1130/g24638a.1

Medvedev, S., Souche, A. \& Hartz, E.H. 2013: Influence of ice sheet and glacial erosion on passive margins of Greenland. Geomorphology 193, 36-46. https://doi.org/10.1016/j.geomorph.2013.03.029

Merkouriev, S. \& DeMets, C. 2008: A high-resolution model for Eurasia-North America plate kinematics since $20 \mathrm{Ma}$. Geophysical Journal International 173(3), 1064-1083. https://doi.org/10.1111/j.1365-246x.2008.03761.x
Miller, K.G. et al. 2005: The Phanerozoic record of global sea-level change. Science 310, 1293-1298. https://doi.org/10.1126/science.1116412

Mogensen, T.E. \& Korstgård, J.A. 2003: Triassic and Jurassic transtension along part of the Sorgenfrei-Tornquist Zone in the Danish Kattegat. In: Ineson, J. \& Surlyk, F. (eds): The Jurassic of Denmark and Greenland. Geological Survey of Denmark and Greenland Bulletin 1, 439-458. https://doi.org/10.34194/geusb.v1.4680

Myhre, A. et al. 1995: Site 913. Proceedings of the Ocean Drilling Program. Initial reports 1995, 345-382.

Nance, R.D., Murphy, J.B. \& Santosh, M. 2014: The supercontinent cycle: A retrospective essay. Gondwana Research 25, 4-29. https://doi. org/10.1016/j.gr.2012.12.026

Neuhoff, P.S., Watt, W.S., Bird, D.K. \& Pedersen, A.K. 1997: Timing and structural relations of regional zeolite zones in basalts of the East Greenland continental margin. Geology 25, 803-806. https://doi.org/ 10.1130/0091-7613(1997)025<0803:tasror>2.3.co;2

Nielsen, L.H. 2003: Late Triassic - Jurassic development of the Danish Basin and the Fennoscandian Border Zone, southern Scandinavia. In: Ineson, J. \& Surlyk, F. (eds): The Jurassic of Denmark and Greenland. Geological Survey of Denmark and Greenland Bulletin 1, 459-526. https://doi.org/10.34194/geusb.v1.4681

Nielsen, S.B. et al. 2009: The evolution of western Scandinavian topography: a review of Neogene uplift versus the ICE (isostasy-climateerosion) hypothesis. Journal of Geodynamics 47, 72-95. https://doi. org/10.1016/j.jog.2008.09.001

Nielsen, S.B., Clausen, O.R., Jacobsen, B.H., Thomsen, E., Huuse, M., Gallagher, K., Balling, N. \& Egholm, D.L. 2010: The ICE hypothesis stands: how the dogma of late Cenozoic tectonic uplift can no longer be sustained in the light of data and physical laws. Journal of Geodynamics 50, 102-111. https://doi.org/10.1016/j.jog.2010.02.002

Nielsen, T.F.D. 2002: Palaeogene intrusions and magmatic complexes in East Greenland, 66 to $75 \mathrm{~N}$. Geological Survey of Denmark and Greenland Report 2002/113, 249 pp.

Nielsen, T.F.D., Soper, N.J., Brooks, C.K., Faller, A.M., Higgins, A.K. \& Matthews, D.W. 1981: The pre-basaltic sediments and the Lower Basalts at Kangerdlgssuaq, East Greenland: their stratigraphy, lithology, palaeomagnetism and petrology. Meddelelser om Grønland, Geoscience 6, 28 pp, \& one map.

Noe-Nygaard, A. 1976: Tertiary igneous rocks between Shannon and Scoresby Sund, East Greenland. In: Escher, A. \& Watt, W.S. 1976: Geology of Greenland, 386-402. Copenhagen: Grønlands Geologiske Undersøgelse.

Nøhr-Hansen, H. 1993: Dinoflagellate cyst stratigraphy of the Barremian to Albian, Lower Cretaceous, North-East Greenland. Bulletin Grønlands Geologiske Undersøgelse 166, 171pp. https://doi. org/10.34194/bullggu.v166.6722

Nøhr-Hansen, H., Nielsen, L.H., Sheldon, E., Hovikovski, J. \& Alsen, P. 2011: Palaeogene deposits in north-east Greenland. Geological Survey of Denmark and Greenland Bulletin 23, 61-64. https://doi. org/10.34194/geusb.v23.4867

Nøhr-Hansen, H., Piasecki, S. \& Alsen, P. 2019: A Cretaceous dinoflagellate cyst zonation for NE Greenland. Geological Magazine 157, 1-35. https://doi.org/10.1017/s0016756819001043

Oftedal, B.T., Andresen, A. \& Müller, R. 2005: Early Triassic syn-rift sedimentation at Hold with Hope, Northeast Greenland. In: Wandås, B.T.G. et al. (eds) Onshore-offshore relationships on the North Atlantic margin. Norwegian Petroleum Society, Special Publication 12, 191-206. https://doi.org/10.1016/s0928-8937(05)80049-9

Parsons, A. et al. 2017: Structural evolution and basin architecture of the Traill $\varnothing$ region, NE Greenland: A record of polyphase rifting of the East Greenland continental margin. Geosphere 13, 733-770. https:// doi.org/10.1130/ges01382.1

Pedersen, A.K., Watt, M., Watt, W.S. \& Larsen, L.M. 1997: Structure and stratigraphy of the Early Tertiary basalts of the Blosseville Kyst, East Greenland. Journal of the Geological Society (London) 154, 565-570. https://doi.org/10.1144/gsjgs.154.3.0565

Pedersen, V.K., Nielsen, S.B. \& Gallagher, K. 2012: The post-orogenic evolution of the Northeast Greenland Caledonides constrained from apatite fission track analysis and inverse geodynamic 
modelling. Tectonophysics 530-531, 318-330. https://doi.org/10.1016/j. tecto.2012.01.018

Petersen, T.G. 2019: Seismic stratigraphy of the post-breakup succession offshore Northeast Greenland: Links to margin uplift. Marine and Petroleum Geology 103, 422-437. https://doi.org/10.1016/j. marpetgeo.2019.03.007

Phillips, B.R. \& Bunge, H.-P. 2005: Low plume excess temperature and high core heat flux inferred from non-adiabatic geotherms in internally heated mantle circulation models. Physics of the Earth and Planetary Interiors 153, 3-10. https://doi.org/10.1016/j.pepi.2005.03.017

Phillips, B.R. \& Bunge, H.-P. 2007: Supercontinent cycles disrupted by strong mantle plumes. Geology 35, 847-850. https://doi.org/10.1130/ g23686a.1

Piasecki, S., Stemmerik, L., Friderichsen, J.D. \& Higgins, A.K. 1994: Stratigraphy of the post-Caledonian sediments in the Germania Land area, North-East Greenland. Rapport Grønlands Geologiske Undersøgelse, 162, 177-184. https://doi.org/10.34194/rapggu.v162.8260

Price, S.P. \& A.G. Whitham 1997: Exhumed Hydrocarbon Traps in East Greenland: Analogs for the Lower-Middle Jurassic Play of Northwest Europe. Bulletin of the American Association of Petroleum Geologists 81, 196-221. https://doi.org/10.1306/522b42e9-1727-11d7-8645000102c1865d

Price, S., Brodie, J., Whitham, A. \& Kent, R. 1997: Mid-tertiary rifting and magmatism in the Traill $\varnothing$ region, East Greenland. Journal of the Geological Society (London) 154, 419-434. https://doi.org/10.1144/ gsjgs.154.3.0419

Rasmussen, E.S. 2014: Development of an incised-valley fill under the influence of tectonism and glacio-eustatic sea-level change: valley morphology, fluvial style, and lithology. Journal of Sedimentary Research 84, 278-300. https://doi.org/10.2110/jsr.2014.24

Rasmussen, E.S., Dybkjær, K. \& Piasecki, S. 2010: Lithostratigraphy of the Upper Oligocene - Miocene succession of Denmark. Geological Survey of Denmark and Greenland Bulletin 22, 92 pp. https://doi. org/10.34194/geusb.v22.4733

Richards, F., Hoggard, M. \& White, N. 2016: Cenozoic epeirogeny of the Indian peninsula. Geochemistry, Geophysics, Geosystems 17, 49204954. https://doi.org/10.1002/2016gc006545

Rickers, F., Fichtner, A. \& Trampert, J. 2013: The Iceland-Jan Mayen plume system and its impact on mantle dynamics in the North Atlantic region: Evidence from full-waveform inversion. Earth and Planetary Science Letters 367, 39-51. https://doi.org/10.1016/j.eps/.2013.02.022

Robertson, E. 1988: Thermal properties of rocks. US Geological Survey, Open-File Report, 88-441. https://doi.org/10.3133/ofr88441

Rodríguez Tribaldos, V., White, N., Roberts, G.G. \& Hoggard, M.J. 2017: Spatial and Temporal Uplift History of South America from Calibrated Drainage Analysis. Geochemistry Geophysics Geosystems. https://doi. org/10.1002/2017gc006909

Schaefer, J.M., Finkel, R.C., Balco, G., Alley, R.B., Caffee, M.W., Briner, J.P., Young, N.E., Gow, A.J. \& Schwartz, R. 2016: Greenland was nearly icefree for extended periods during the Pleistocene. Nature. 540, 252255. https://doi.org/10.1038/nature20146

Schiffer, C., Balling, N., Ebbing, J., Jacobsen, B.H. \& Nielsen, S.B. 2016: Geophysical-petrological modelling of the East Greenland Caledonides-Isostatic support from crust and upper mantle. Tectonophysics 692, 44-57. https://doi.org/10.1016/j.tecto.2016.06.023

Seidler, L., Steel, R.J., Stemmerik, L. \& Surlyk, F. 2004: North Atlantic marine rifting in the Early Triassic: new evidence from East Greenland. Journal of the Geological Society (London) 161, 583-592. https://doi. org/10.1144/0016-764903-063

Skogseid, J., Planke, S., Faleide, J.I., Pedersen, T. \& Neverdal, F. 2000: North-East Atlantic continental rifting and volcanic margin formation. In: Nøttvedt, A. et al. (eds): Dynamics of the Norwegian Margin. Geological Society Special Publications (London) 167, 295-326. https:// doi.org/10.3997/2214-4609.201410212

Solgaard, A.M., Bonow, J.M., Langen, P., Japsen, P. \& Hvidberg, C. 2013: Mountain building and the initiation of the Greenland ice sheet. In: Solgaard, A.M. (ed.) Palaeogeography Palaeoclimatology Palaeoecology 392, 161-176. https://doi.org/10.1016/j.palaeo.2013. 09.019

Soper, N.J. \& Costa, L.I. 1976: Palynological evidence for the age of Tertiary basalts and post-basaltic sediments at Kap Dalton, central
East Greenland. Rapport Grønlands Geologiske Undersøgelse 80. https://doi.org/10.34194/rapggu.v80.7504

Sømme, T.O., Jackson, C.A.L. \& Vaksdal, M. 2013: Source-to-sink analysis of ancient sedimentary systems using a subsurface case study from the Møre-Trøndelag area of southern Norway: Part 1-depositional setting and fan evolution. Basin Research 25, 489-511. https://doi. org/10.1111/bre.12013

Sørensen, A.B. 2006: Stratigraphy, structure and petroleum potential of the Lady Franklin and Maniitsoq Basins, offshore southern West Greenland. Petroleum Geoscience 12, 221-234. https://doi. org/10.1144/1354-079305-692

Steinberger, B., Spakman, W., Japsen, P. \& Torsvik, T.H. 2015: The key role of global solid-Earth processes in preconditioning Greenland's glaciation since the Pliocene. Terra Nova 27, 1-8. https://doi.org/10.1111/ ter.12133

Stemmerik, L. 2000: Late Palaeozoic evolution of the North Atlantic margin of Pangea. Palaeogeography, Palaeoclimatology, Palaeoecology 161, 95-126. https://doi.org/10.1016/s0031-0182(00)00119-x

Stemmerik, L. \& Piasecki, S. 2004: Isotopic evidence for the age of the Røde $\varnothing$ Conglomerate, inner Scoresby Sund, East Greenland. Bulletin of the Geological Society of Denmark 51, 137-140. https://doi. org/10.37570/bgsd-2004-51-09

Stemmerik, L. \& Worsley, D. 2005: 30 years on-Arctic Upper Palaeozoic stratigraphy, depositional evolution and hydrocarbon prospectivity. Norwegian Journal of Geology/Norsk Geologisk Forening 85, 151-168. Stemmerik, L. Christiansen, F. G. \& Piasecki, S. 1990: Carboniferous lacustrine shale in East Greenland -additional source rock in northern North Atlantic? In: Katz, B.J. (ed.): Lacustrine basin exploration case studies and modern analogs. AAPG Memoir 5, 275-286. https:// doi.org/10.1306/m50523c17

Stemmerik, L., Vigran, J.O. \& Piasecki, S. 1991: Dating of late Paleozoic rifting events in the North Atlantic: New biostratigraphic data from the uppermost Devonian and Carboniferous of East Greenland. Geology 19, 218221. https://doi.org/10.1130/0091-7613(1991)019<0218:dolpre>2.3.co;2

Stemmerik, L., Christiansen, F.G., Piasecki, S., Jordt, B., Marcussen, C. \& Nøhr-Hansen, H. 1993: Depositional history and petroleum geology of the Carboniferous to Cretaceous sediments in the northern part of East Greenland. In: Vorren, T.O. et al. (eds): Arctic Geology and Petroleum Potential. NPF Special Publication 2, 67-87. https://doi. org/10.1016/b978-0-444-88943-0.50009-5

Stoker, M.S. \& Ziska, H. 2011: Cretaceous. In: Ritchie, J.D. et al. (eds): Geology of the Faroe-Shetland Basin and adjacent areas, 123-150. Nottingham, UK: British Geological Survey and Tórshavn, Faroe Islands: Jardfeingi.

Stoker, M.S., Praeg, D., Shannon, P.M., Hjelstuen, B.O., Laberg, J.S., Nielsen, T., van Weering, T.C.E., Sejrup, H.P. \& Evans, D. 2005: Neogene evolution of the Atlantic continental margin of NW Europe Lofoten Islands to SW Ireland: anything but passive. In: Doré, A.G. \& Vining, B.A. (eds): Petroleum geology: North-West Europe and global perspectives. Geological Society, London, Petroleum Geology Conference series 6, 1057-1076. https://doi.org/10.1144/0061057

Stoker, M.S. et al. 2017: An overview of the Upper Palaeozoic-Mesozoic stratigraphy of the North-East Atlantic region. Geological Society Special Publications (London) 447, 11-68. https://doi.org/10.1144/ sp447.2

Storey, M., Pedersen, A.K., Stecher, O., Bernstein, S., Larsen, H.C., Larsen, L.M., Baker, J.A. \& Duncan, R.A. 2004: Long-lived postbreakup magmatism along the East Greenland margin: Evidence for shallow-mantle metasomatism by the Iceland plume. Geology 32, 173-176. https:// doi.org/10.1130/g19889.1

Surlyk, F. 1977: Stratigraphy, tectonics and palaeogeography of the Jurassic sediments of the area north of Kong Oscars Fjord, East Greenland. Bulletin Grønlands Geologiske Undersøgelse 123, 56 pp. https://doi.org/10.34194/bullggu.v123.6665

Surlyk, F. 1978a: Jurassic basin evolution of East Greenland. Nature 274, 130-133. https://doi.org/10.1038/274130a0

Surlyk, F. 1978b: Submarine fan sedimentation along fault scarps on tilted fault blocks (Jurassic-Cretaceous boundary, East Greenland). Bulletin Grønlands Geologiske Undersøgelse 128, 108 pp. https://doi. org/10.34194/bullggu.v128.6670 
Surlyk, F. 1990: Timing, style and sedimentary evolution of Late Palaeozoic - Mesozoic extensional basins in East Greenland. In: Hardman, R.F.P. \& Brooks, J. (eds): Tectonic Events Responsible for Britain's Oil and Gas Reserves. Geological Society Special Publications (London) 55, 107-125. https://doi.org/10.1144/gs/.sp.1990.055.01.05

Surlyk, F. 2003: The Jurassic of East Greenland: a sedimentary record of thermal subsidence, onset and culmination of rifting. In: Ineson, J. \& Surlyk, F. (eds): The Jurassic of Denmark and Greenland. Geological Survey of Denmark and Greenland Bulletin 1, 659-722. https://doi. org/10.34194/geusb.v1.4674

Surlyk, F. \& Ineson, J. 2003: The Jurassic of Denmark and Greenland: key elements in the reconstruction of the North Atlantic Jurassic rift. In: Ineson, J. \& Surlyk, F. (eds): The Jurassic of Denmark and Greenland. Geological Survey of Denmark and Greenland Bulletin 1, 9-20. https:// doi.org/10.34194/geusb.v1.4644

Surlyk, F. \& Korstgård, J. 2013: Crestal unconformities on an exposed Jurassic tilted fault block, Wollaston Forland, East Greenland as an analogue for buried hydrocarbon traps. Marine and Petroleum Geology 44, 82-95. https://doi.org/10.1016/j.marpetgeo.2013.03.009

Surlyk, F. \& Noe-Nygaard, N. 2001: Cretaceous faulting and associated coarse-grained marine gravity flow sedimentation, Traill $\varnothing$, East Greenland. In: Martinsen, O.J. \& Dreyer, T. (eds): Sedimentary environments offshore Norway-Palaeozoic to Recent. NPFSpecial Publication 10, 293-319. https://doi.org/10.1016/s0928-8937(01)80019-9

Surlyk, F., Piasecki, S., Rolle, F., Stemmerik, L., Thomsen, E. \& Wrang, P. 1984: The Permian basin of East Greenland. In: Petroleum geology of the north European margin, 303-315. Norwegian Petroleum Society, Proceedings of the North European Margin Symposium, Trondheim 9-11 May 1983. https://doi.org/10.1007/978-94-009-5626-1_22

Surlyk, F., Hurst, J., Piasecki, S., Rolle, F., Scholle, P., Stemmerik, L. \& Thomsen, E. 1986: The Permian of the western margin of the Greenland Sea - a future exploration target. In: Halbouty, M.T. (Ed.) Future petroleum provinces of the world, AAPG memoir 40, 629-659.

Surlyk, F., Bjerager, M., Piasecki, S. \& Stemmerik, L. 2017: Stratigraphy of the marine Lower Triassic succession at Kap Stosch, Hold with Hope, North-East Greenland. Bulletin of the Geological Society of Denmark 65, 87-123. https://doi.org/10.37570/bgsd-2017-65-07

Surlyk, F. et al. 2021: Jurassic stratigraphy of East Greenland. GEUS Bulletin 46, 6521. https://doi.org/10.34194/geusb.v46.6521

Svensen, H., Corfu, F., Polteau, S., Hammer, Ø. \& Planke, S. 2012: Rapid magma emplacement in the Karoo large igneous province. Earth and Planetary Science Letters 325, 1-9. https://doi.org/10.1016/j. epsl.2012.01.015

Sweeney, J.J. \& Burnham, A.K. 1990: Evaluation of simple model of vitrinite reflectance based on chemical kinetics. AAPG Bulletin 74, 15591570. https://doi.org/10.1306/0c9b251f-1710-11d7-8645000102c1865d

Swift, D. A., Persano, C., Stuart, F. M., Gallagher, K. \& Whitham, A. 2008: $A$ reassessment of the role of ice sheet glaciation in the long-term evolution of the East Greenland fjord region. Geomorphology 97, 109-125. https://doi.org/10.1016/j.geomorph.2007.02.048

Thiede,J., Winkler, A., Wolf-Welling, T., Eldholm, O., Myhre, A.M., Baumann, K.H., Henrich, R. \& Stein, R. 1998: Late Cenozoic history of the Polar North Atlantic: results from ocean drilling. Quaternary Science Reviews 17, 185-208. https://doi.org/10.1016/s0277-3791(97)00076-0

Thomson, K., Green, P.F., Whitham, A.G., Price, S.P. \& Underhill, J.R. 1999: New constraints on the thermal history of North-East Greenland from apatite fission-track analysis. GSA Bulletin 111, 1054-1068. https://doi. org/10.1130/0016-7606(1999)111<1054:ncotth>2.3.co;2
Tsikalas, F., Faleide, J., Eldholm, O. \& Wilson, J. 2005: Late Mesozoic Cenozoic structural and stratigraphic correlations between the conjugate mid-Norway and North-East Greenland continental margins. Geological Society (London), Petroleum Geology Conference series 6, 785-801. https://doi.org/10.1144/0060785

Underhill, J.R. \& Partington, M.A. 1993: Jurassic thermal doming and deflation in the North Sea: implications of the sequence stratigraphic evidence. In: Parker, J.R. (ed.): Petroleum Geology of North West Europe. Geological Society, London, Petroleum Geology Conference series 4, 335-345. https://doi.org/10.1144/0040337

Upton, B.G.J., Emeleus, C.H. \& Hald, N. 1980: Tertiary volcanism in northern E Greenland: Gauss Halvø and Hold with Hope. Journal of the Geological Society (London) 137, 491-508. https://doi.org/10.1144/ gsjgs.137.4.0491

van Hinsbergen, D.J.J., Lippert, P.C., Dupont-Nivet, G., McQuarrie, N., Doubrovine, P.V., Spakman, W. \& Torsvik, T.H. 2012: Greater India Basin hypothesis and a two-stage Cenozoic collision between India and Asia. Proceedings of the National Academy of Sciences of the United States of America 109, 7659-7664. https://doi.org/10.1073/ pnas. 1117262109

Veevers, J.J. 2004: Gondwanaland from 650-500 Ma assembly through $320 \mathrm{Ma}$ merger in Pangea to 185-100 Ma breakup: supercontinental tectonics via stratigraphy and radiometric dating. Earth-Science Reviews 68, 132 pp. https://doi.org/10.1016/j.earscirev.2004.05.002

Veevers, J.J. 2013: Pangea: Geochronological correlation of successive environmental and strati-tectonic phases in Europe and Australia. Earth-Science Reviews 127, 48-95. https://doi.org/10.1016/j. earscirev.2013.09.001

Vejbæk, O.V. 1989: Effects of asthenospheric heat flow in basin modelling exemplified with the Danish Basin. Earth and Planetary Science Letters 95, 97-114. https://doi.org/10.1016/0012-821x(89)90170-2

Vigran, J.O., Stemmerik, L. \& Piasecki, S. 1999: Stratigraphy and depositional evolution of the uppermost Devonian-carboniferous (TournaisianWestphalian) non-marine deposits in north-east Greenland. Palynology 23, 115-152. https://doi.org/10.1080/01916122.1999.9989525

Vischer, A. 1943: Die Postdevonische tektonik von Ostgrönland zwischen $74^{\circ}$ und $75^{\circ} \mathrm{N}$ BR. Meddelelser om Grønland 133, $187 \mathrm{pp}$.

White, N. \& McKenzie, D. 1988: Formation of the steers head geometry of sedimentary basins by differential stretching of the crust and the mantle. Geology 16, 250-253. https://doi.org/ 10.1130/0091-7613(1988)016<0250:fotssh>2.3.co;2

Whitham, A., Price, S., Koraini, A. \& Kelly, S. 1999: Cretaceous (post-Valanginian) sedimentation and rift events in NE Greenland $\left(71-77^{\circ} \mathrm{N}\right)$. In: Fleet, A.J. \& Boldy, S.A.R. (eds): Petroleum Geology of North WestEurope. Geological Society, London, Petroleum Geology Conference series 5. https://doi.org/10.1144/0050325

Willerslev, E. et al. 2007: Ancient biomolecules from deep ice cores reveal a forested southern Greenland. Science 317, 111-114. https://doi. org/10.1126/science. 1141758

Worsley, T.R., Nance, D. \& Moody, J.B. 1984: Global tectonics and eustasy for the past 2 billion years. Marine Geology 58, 373-400. https://doi. org/10.1016/0025-3227(84)90209-3

Zachos, J.C., Pagani, M., Sloan, L., Thomas, E. \& Billups, K. 2001: Trends, rhythms, and aberrations in global climate $65 \mathrm{Ma}$ to present. Science 292, 686-693. https://doi.org/10.1126/science.1059412

Ziegler, P.A. 1990: Geological atlas of western and central Europe, 239 pp. The Hague: Shell International Petroleum Matschappij B.V.https:// doi.org/10.2307/3060311 


\section{Appendix 1 Thermal history constraints from AFTA data in individual samples and definition of regional palaeothermal episodes}

\section{Thermal history interpretation of AFTA data: principles}

Techniques for extracting thermal history constraints from AFTA data were discussed in detail by Green \& Duddy (2012) and Green et al. (2013). A brief outline based on application to sedimentary rocks is provided here. Similar principles apply to basement samples which have been buried by sedimentary cover.

Because AFTA data are dominated by maximum post- depositional temperatures, the data preserve no evidence of the history between deposition and the onset of cooling from the maximum post-depositional temperature. As such, the history between successive cooling episodes separated by periods of heating cannot be resolved. Therefore, it is not possible to constrain the entire history from the beginning of track retention. Instead, we focus on defining the palaeothermal maximum and subsequent palaeothermal peaks, within an overall framework of episodic heating and cooling, assuming heating and cooling rates of $1^{\circ} \mathrm{C} / \mathrm{Myr}$ and $10^{\circ} \mathrm{C} / \mathrm{Myr}$, respectively. An order of magnitude change in heating rate is equivalent to around a $10^{\circ} \mathrm{C}$ difference in the palaeotemperature required to produce a given degree of annealing.

We propose that thermal histories involving episodic heating and cooling are more geologically realistic than slow, monotonic cooling, even in basement rocks (Green \& Duddy 2012; Green et al. 2013, 2018). This is based on a combination of AFTA data and geological evidence where AFTA defines episodes of cooling/exhumation while remnants of former sedimentary cover define times when underlying rocks were at the surface. Such situations provide indisputable evidence of repeated burial and exhumation. Green et al. $(2013,2018)$ argued that such histories are more generally applicable in a wider variety of settings.

Thermal history solutions are extracted from data in each sample by comparing measured data with values predicted from candidate thermal histories, involving up to three episodes of heating and cooling (three being the maximum number of cooling episodes that can be obtained from AFTA data in most cases). By varying the maximum palaeotemperature and the onset of cooling in each episode (using assumed heating and cooling rates of $1{ }^{\circ} \mathrm{C} / \mathrm{Myr}$ and $10^{\circ} \mathrm{C} / \mathrm{Myr}$, respectively), we defined the range of conditions, which predict apatite fission-track ages, track length distributions and their variation with wt $\% \mathrm{Cl}$ consistent with the measured data to within 95\% confidence limits. The approach is based on likelihood theory and principles similar to those outlined by Gallagher (1995).

We emphasise that unlike other approaches, we do not attempt to constrain the entire history since the onset of track retention, because much of the history is not recorded in the data (Green \& Duddy 2012; Green et al. 2013). Instead, results are presented in terms of intervals representing 95\% confidence limits on the maximum (peak) palaeotemperature and the time at which cooling from that palaeotemperature began in up to three intervals (Appendix 1.1). It is important to

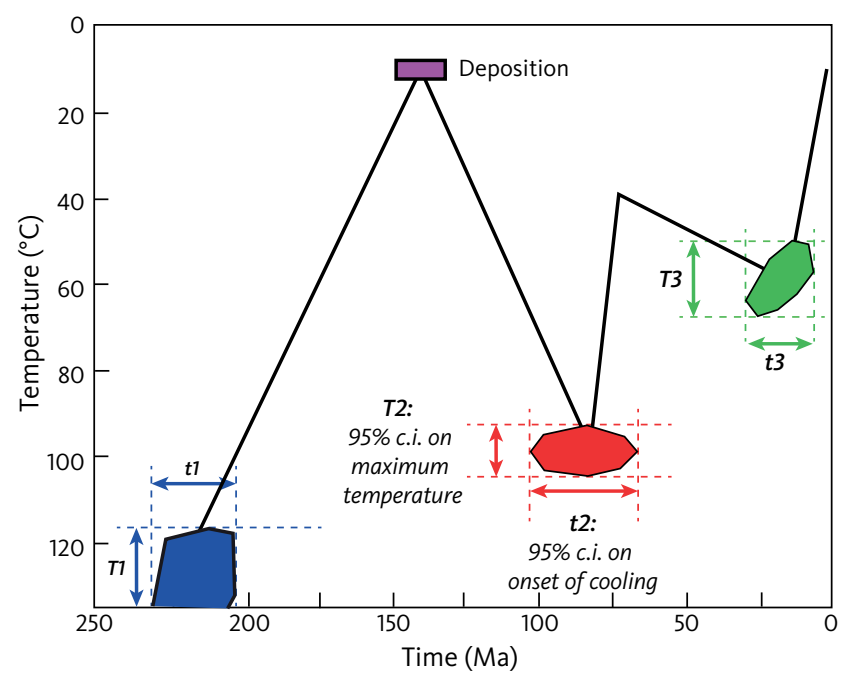

Appendix 1.1 Illustration of thermal history solutions extracted from AFTA. Results are presented in terms of up to three palaeothermal episodes, that is, when a rock sample was hotter than it is today. In the case shown, the rock sample was exposed at the surface during deposition of sediments as indicated by the small box. Note that the palaeotemperature constraint T1 is a minimum estimate since this is when apatites begin to retain tracks. In most situations, up to three episodes can be defined from AFTA, due to various factors including the natural spread in track lengths of a single population of tracks and the rapid decrease in the rate of annealing from $\mathrm{c} .110^{\circ} \mathrm{C}$ to below $60^{\circ} \mathrm{C}$. $\mathbf{t 1}, \mathbf{t} 2, \mathbf{t} 3$ : time intervals during which cooling from the peak palaeotemperature began. T1, T2, T3: palaeotemperature intervals. c.i.: Confidence limits. Colours are used to illustrate attribution to regional episodes, although those used here are purely schematic. Reproduced from Japsen et al. (2021, this volume). 
aconstrain the thermal histories derived from AFTA data by geological evidence. For outcrops of sedimentary rocks, the most fundamental constraint is the depositional age, which defines a time when the sample was at surface temperature. Thermal history solutions are derived within a framework fixed at the depositional age and the present-day. For basement samples, the most reliable solutions are obtained when cover rocks are present locally, as these define a time of surface exposure. Where cover rocks are not present, a crystallisation or metamorphic age can be used. In such cases the solutions are less well constrained.

The kinetics of fission track annealing in apatite vary significantly with chlorine content (wt\% Cl). Acceptable thermal history solutions must predict the measured

\section{Results from North-East Greenland}

Sample details and AFTA data are listed in Appendices 1.2 and 1.3 , respectively. The thermal history constraints extracted from the AFTA data in each sample are summarised in Appendix 1.4. VR data and corresponding maximum palaeotemperatures are listed in Appendix 1.5. The stratigraphic ages in these appendices are assigned following Gradstein et al. (2012), and the tables are provided online in Supplementary File S4. Appendix 1.6 shows a comparison of the constraints (95\% confidence intervals) on the onset of cooling in up to three palaeothermal episodes in each sample based on the thermal-history solutions extracted from the AFTA data in each sample.

Based on the general uniformity of the data, we have sought to define the minimum number of regionally synchronous cooling episodes, which can explain the results in all these samples. This synthesis has been apatite fission-track age length distribution and the variation of these with $\mathrm{wt} \% \mathrm{Cl}$ in each sample. $\mathrm{Wt} \% \mathrm{Cl}$ is measured in each apatite analysed, using an electron microprobe (see Appendix A in the Geotrack reports).

Where three palaeothermal episodes (i.e. periods when samples cooled from elevated temperatures) are defined in a single sample, the earliest episode is usually defined primarily from the fission-track age data and represents the episode in which samples cooled below $c .110^{\circ} \mathrm{C}$ and began to retain tracks. The two more recent episodes are defined primarily from the distribution of track lengths. Grains with higher wt $\% \mathrm{Cl}$ are more retentive, so samples containing a spread of $\mathrm{wt} \% \mathrm{Cl}$ may also define earlier cooling events.

undertaken within the context of the locations of individual samples, such that similar magnitude events in adjacent samples are interpreted in terms of a common episode. On this basis, the timing constraints defined from AFTA data, listed in Appendix 1.4, are interpreted as defining ten episodes of regional cooling (CO-C9) dating from the late Palaeozoic to the early Pliocene (Table 1). Note that the time intervals in the Table define when cooling began in each episode, and we do not imply that all cooling took place solely within these intervals. It should also be emphasised that because the AFTA data only define the palaeothermal peak and not the history prior to the onset of cooling, the total amount of cooling in each episode and the degree of re-heating leading to the subsequent palaeothermal peak is not controlled by the data. 
Appendix 1.2 Sample details. Also available online in Supplementary File S4

\begin{tabular}{|c|c|c|c|c|c|c|c|}
\hline $\begin{array}{l}\text { Sample } \\
\text { number }\end{array}$ & $\begin{array}{c}\text { Stratigraphic } \\
\text { division }\end{array}$ & $\begin{array}{c}\text { Stratigraphic } \\
\text { age (Ma) }\end{array}$ & Rock type & Latitude & Longitude & $\begin{array}{l}\text { Elevation } \\
\text { (m a.s.I.) }\end{array}$ & Location \\
\hline GC103-1 & Permian, L & 255 & Sandstone & 71.676 & -22.908 & 200 & Jameson Land N \\
\hline GC103-2 & Permian, L & 255 & Sandstone & 71.657 & -22.957 & 200 & Jameson Land N \\
\hline GC103-3 & Jurassic, L & 155 & Sandstone & 70.618 & -22.787 & 660 & Jameson Land S \\
\hline GC103-4 & Jurassic, E-M & 190 & Sandstone & 70.863 & -22.716 & 400 & Jameson Land S \\
\hline GC103-6 & Permian, L & 255 & Sandstone & 71.800 & -24.102 & 1050 & Schuchert Dal \\
\hline GC159-1 & Permian, L & 255 & Sandstone & 71.648 & -24.662 & 550 & Schuchert Dal \\
\hline GC159-2 & Permian, L & 255 & Sandstone & 71.614 & -24.543 & 260 & Schuchert Dal \\
\hline GC159-3 & Triassic, E & $251-247$ & Sandstone & 71.583 & -23.008 & 250 & Jameson Land N \\
\hline GC159-4 & Permian, L & $260-250$ & Sandstone & 71.714 & -22.702 & 400 & Jameson Land N \\
\hline GC202-1 & Permian, L & $260-250$ & Arkose & 71.534 & -24.715 & 820 & Schuchert Dal \\
\hline GC202-2 & Permo-Carboniferous & $360-245$ & & 71.753 & -24.338 & 700 & Schuchert Dal \\
\hline GC202-3 & Permian, L & 255 & Sandstone & 71.785 & -24.427 & 820 & Schuchert Dal \\
\hline GC202-4 & Permian, L & $260-250$ & Sandstone & 71.763 & -24.381 & 1000 & Schuchert Dal \\
\hline GC202-5 & Triassic, M & $245-240$ & Sandstone & 71.698 & -24.195 & 1000 & Schuchert Dal \\
\hline GC202-6 & Triassic, M & $245-240$ & Sandstone & 71.719 & -24.266 & 1310 & Schuchert Dal \\
\hline GC202-7 & Triassic, L & $235-208$ & Sandstone & 71.722 & -24.131 & 1000 & Schuchert Dal \\
\hline GC202-9 & Jurassic, E & $208-178$ & Sandstone & 71.589 & -23.731 & 900 & Jameson Land S \\
\hline GC202-11 & Triassic, L & $235-208$ & $\begin{array}{l}\text { Mudstone/ } \\
\text { sandstone }\end{array}$ & 70.997 & -22.575 & 150 & Jameson Land S \\
\hline GC202-12 & Triassic, L & $235-208$ & $\begin{array}{l}\text { Mudstone/ } \\
\text { sandstone }\end{array}$ & 71.160 & -22.503 & 130 & Jameson Land S \\
\hline GC202-16 & Permian, L & 255 & $\begin{array}{l}\text { Mudstone/ } \\
\text { sandstone }\end{array}$ & 71.737 & -24.307 & 720 & Schuchert Dal \\
\hline GC522-1 & Triassic & $245-208$ & Sediment & 72.567 & -22.417 & 500 & Traill Ø \\
\hline GC522-2 & Devonian & $416-359$ & Sediment & 72.583 & -24.250 & 30 & Traill $\varnothing$ \\
\hline GC522-3 & Devonian & $416-359$ & Sediment & 72.400 & -25.833 & 0 & Traill $\varnothing$ \\
\hline GC522-4 & Triassic & $245-208$ & Sediment & 72.283 & -23.000 & 140 & Traill $\varnothing$ \\
\hline GC522-5 & Carboniferous & $359-299$ & Sediment & 72.200 & -24.000 & 70 & Traill $\varnothing$ \\
\hline GC522-6 & Carboniferous & $359-299$ & Sediment & 72.583 & -24.250 & 150 & Traill $\varnothing$ \\
\hline GC522-7 & Jurassic, L & $161-146$ & Sediment & 74.450 & -20.252 & 150 & Wollaston Forland \\
\hline GC522-8 & Cretaceous. E & $146-132$ & Sediment & 74.585 & -20.475 & 300 & Wollaston Forland \\
\hline GC522-9 & L. Carboniferous & $313-303$ & Sediment & 72.443 & -23.801 & 140 & Traill $\varnothing$ \\
\hline GC522-10 & Bathonian & $166-161$ & Sediment & 72.366 & -23.321 & 230 & Traill $\varnothing$ \\
\hline GC522-11 & Callovian-Bathonian & $166-157$ & Sediment & 72.470 & -22.411 & 300 & Traill $\varnothing$ \\
\hline GC1016-3 & Cretaceous, E & $146-100$ & sandstone & 74.519 & -20.451 & 653.5 & Wollaston Forland \\
\hline GC1016-4 & Silurian & 430 & Monzonite & 71.054 & -26.064 & 5 & Inland S \\
\hline GC1016-5 & Devonian & $416-359$ & Conglomerate & 70.968 & -28.021 & 100 & Inland S \\
\hline GC1016-6 & Precambr./Caled. & $>400$ & Migmatite & 70.420 & -27.806 & 1 & Milne Land \\
\hline GC1016-7 & Precambr./Caled. & $>400$ & Gneiss & 70.450 & -26.251 & 2 & Milne Land \\
\hline GC1016-8 & Precambr./Caled. & $>400$ & Sandstone & 72.874 & -25.127 & 120 & Ella $\varnothing$ \\
\hline GC1016-9 & Devonian & $416-359$ & Conglomerate & 72.789 & -25.036 & 1 & Ella $\varnothing$ \\
\hline GC1016-10 & Carboniferous & $359-299$ & Sandstone & 72.270 & -23.927 & 1 & Jameson Land N \\
\hline GC1016-11 & Permian & $299-251$ & Sandstone & 72.144 & -23.693 & 50 & Jameson Land N \\
\hline GC1016-13 & Precambr./Caled. & $>400$ & Sandstone & 72.444 & -25.097 & 1 & Inland C \\
\hline GC1016-14 & Precambr./Caled. & $>400$ & Sandstone & 72.460 & -24.927 & 1 & Inland C \\
\hline GC1016-15 & Precambr./Caled. & $>400$ & Quartzite & 73.330 & -25.287 & 1 & Inland C \\
\hline GC1016-16 & Devonian & $416-359$ & Sandstone & 73.348 & -23.735 & 1 & Ymer $\varnothing$ \\
\hline GC1016-17 & Devonian & $416-359$ & Sandstone & 73.309 & -23.504 & 1 & Ymer $\varnothing$ \\
\hline
\end{tabular}


Appendix 1.2 Sample details. Also available online in Supplementary File S4 (continued)

\begin{tabular}{|c|c|c|c|c|c|c|c|}
\hline $\begin{array}{l}\text { Sample } \\
\text { number }\end{array}$ & $\begin{array}{l}\text { Stratigraphic } \\
\text { division }\end{array}$ & $\begin{array}{c}\text { Stratigraphic } \\
\text { age (Ma) }\end{array}$ & Rock type & Latitude & Longitude & $\begin{array}{l}\text { Elevation } \\
\text { (m a.s.l.) }\end{array}$ & Location \\
\hline$\overline{G C 1016-18}$ & Devonian & $416-359$ & Sandstone & 73.258 & -23.280 & 1 & Ymer $\varnothing$ \\
\hline GC1016-19 & Precambr./Caled. & $>400$ & Gneiss & 76.774 & -18.717 & 1 & Germania Land \\
\hline GC1016-20 & Precambr./Caled. & $>400$ & Gneiss & 74.410 & -20.921 & 1 & Clavering $\varnothing$ \\
\hline GC1016-21 & Eocene & $49-47$ & Sandstone & 69.447 & -24.148 & 303 & Kap Dalton \\
\hline GC1016-22 & Eocene & $49-47$ & Sandstone & 69.481 & -24.141 & 260 & Kap Dalton \\
\hline GC1016-23 & Paleocene & $65-56$ & Sandstone & 74.417 & -19.200 & 64 & Wollaston Forland \\
\hline GC1016-24 & Carboniferous & $359-299$ & Sandstone & 73.923 & -22.275 & 756 & Hudson Land \\
\hline GC1016-25 & Carboniferous? & $359-299$ & Sandstone & 73.947 & -22.165 & 189 & Hudson Land \\
\hline GC1016-26 & Carboniferous & $359-299$ & Sandstone & 73.933 & -22.244 & 479 & Hudson Land \\
\hline GC1016-27 & Jurassic-Cretaceous & $200-65$ & Sandstone & 70.502 & -23.062 & 250 & Jameson Land S \\
\hline GC1016-28 & Triassic & $251-200$ & Sandstone & 70.499 & -23.049 & 95 & Jameson Land S \\
\hline GC1016-29 & Jurassic-Cretaceous & $200-65$ & Sandstone & 72.454 & -23.299 & 730 & Traill $\varnothing$ \\
\hline GC1016-30 & Jurassic-Cretaceous & $200-65$ & Sandstone & 72.446 & -23.298 & 1075 & Traill $\varnothing$ \\
\hline GC1016-32 & Jurassic, E & $200-176$ & Sandstone & 72.460 & -23.235 & 323 & Traill $\varnothing$ \\
\hline GC1016-33 & Jurassic, E & $200-176$ & Sandstone & 72.460 & -23.278 & 460 & Traill $\varnothing$ \\
\hline GC1016-35 & Cretaceous, E & $146-100$ & Sandstone & 72.952 & -23.081 & 300 & Geographical Society $\varnothing$ \\
\hline GC1016-36 & Cretaceous, E & $146-100$ & Sandstone & 72.934 & -23.057 & 370 & Geographical Society $\varnothing$ \\
\hline GC1016-37 & Triassic & $251-200$ & Sandstone & 72.933 & -23.013 & 850 & Geographical Society $\varnothing$ \\
\hline GC1016-38 & Triassic & $251-200$ & Sandstone & 73.928 & -21.174 & 381 & Hold with Hope \\
\hline GC1016-39 & Triassic & $251-200$ & Sandstone & 73.920 & -21.160 & 751 & Hold with Hope \\
\hline GC1016-41 & Cretaceous, L & $112-65$ & Sandstone & 73.707 & -20.543 & 21 & Hold with Hope \\
\hline GC1016-42 & Ordovician-Devonian & $488-359$ & Gneiss & 70.605 & -26.000 & 41 & Milne Land \\
\hline GC1016-43 & Ordovician & $488-444$ & Granite & 70.627 & -26.082 & 362 & Milne Land \\
\hline GC1016-44 & Jurassic & $200-146$ & Sandstone & 70.616 & -26.083 & 759 & Milne Land \\
\hline GC1016-45 & Ordovician & $488-444$ & Gneiss & 70.598 & -26.043 & 458 & Milne Land \\
\hline GC1016-46 & Precambr./Caled. & $>400$ & Gneiss & 70.916 & -26.250 & 1858 & Milne Land \\
\hline GC1016-47 & Precambr./Caled. & $>400$ & Gneiss & 70.936 & -26.278 & 2 & Milne Land \\
\hline GC1016-48 & Precambr./Caled. & $>400$ & Gneiss & 74.389 & -20.240 & 28 & Wollaston Forland \\
\hline GC1016-49 & Carboniferous & $359-299$ & $\begin{array}{c}\text { Sand/ } \\
\text { Conglomerate }\end{array}$ & 74.245 & -21.875 & 846 & Clavering Ø \\
\hline GC1016-50 & Carboniferous & $359-299$ & $\begin{array}{c}\text { Sand/ } \\
\text { Conglomerate }\end{array}$ & 74.244 & -21.880 & 755 & Clavering $\varnothing$ \\
\hline GC1016-51 & Carboniferous & $359-299$ & $\begin{array}{c}\text { Sand/ } \\
\text { Conglomerate }\end{array}$ & 74.242 & -21.887 & 574 & Clavering $\varnothing$ \\
\hline GC1016-52 & Carboniferous & $359-299$ & $\begin{array}{c}\text { Sand/ } \\
\text { Conglomerate }\end{array}$ & 74.230 & -21.870 & 499 & Clavering $\varnothing$ \\
\hline GC1016-53 & Carboniferous & $359-299$ & $\begin{array}{c}\text { Sand/ } \\
\text { Conglomerate }\end{array}$ & 74.242 & -21.894 & 501 & Clavering $\varnothing$ \\
\hline GC1016-54 & Carboniferous & $359-299$ & $\begin{array}{c}\text { Sand/ } \\
\text { Conglomerate }\end{array}$ & 74.238 & -21.923 & 248 & Clavering Ø \\
\hline GC1016-55 & Carboniferous & $359-299$ & $\begin{array}{c}\text { Sand/ } \\
\text { Conglomerate }\end{array}$ & 74.234 & -21.964 & 52 & Clavering $\varnothing$ \\
\hline GC1016-57 & Precambr./Caled. & $>400$ & Gneiss & 73.828 & -21.948 & 1208 & Hudson Land \\
\hline GC1016-58 & Precambr./Caled. & $>400$ & Gneiss & 73.826 & -21.909 & 958 & Hudson Land \\
\hline GC1016-59 & Precambr./Caled. & $>400$ & Gneiss & 73.817 & -21.934 & 720 & Hudson Land \\
\hline GC1016-60 & Precambr./Caled. & $>400$ & Gneiss & 73.811 & -21.919 & 510 & Hudson Land \\
\hline GC1016-61 & Precambr./Caled. & $>400$ & Gneiss & 73.799 & -21.918 & 305 & Hudson Land \\
\hline GC1016-62 & Precambr./Caled. & $>400$ & Gneiss & 73.827 & -21.850 & 123 & Hudson Land \\
\hline
\end{tabular}


www.geusbulletin.org

Appendix 1.2 Sample details. Also available online in Supplementary File S4 (continued)

\begin{tabular}{|c|c|c|c|c|c|c|c|}
\hline $\begin{array}{l}\text { Sample } \\
\text { number }\end{array}$ & $\begin{array}{l}\text { Stratigraphic } \\
\text { division }\end{array}$ & $\begin{array}{l}\text { Stratigraphic } \\
\text { age (Ma) }\end{array}$ & Rock type & Latitude & Longitude & $\begin{array}{l}\text { Elevation } \\
\text { (m a.s.l.) }\end{array}$ & Location \\
\hline GC1016-63 & Precambr./Caled. & $>400$ & Gneiss & 73.743 & -22.101 & 569 & Hudson Land \\
\hline GC1016-65 & Precambr./Caled. & $>400$ & Gneiss & 73.712 & -22.112 & 210 & Hudson Land \\
\hline GC1016-66 & Permian & $299-251$ & Sandstone & 74.046 & -21.787 & 0 & Hold with Hope \\
\hline GC1016-67 & Triassic & $251-200$ & Sandstone & 74.028 & -21.781 & 292 & Hold with Hope \\
\hline GC1016-68 & Triassic & $251-200$ & Sandstone & 74.005 & -21.802 & 323 & Hold with Hope \\
\hline GC1016-69 & Triassic & $251-200$ & Sandstone & 73.998 & -21.880 & 94 & Hold with Hope \\
\hline GC1016-70 & Carboniferous & $359-299$ & Sandstone & 73.918 & -22.259 & 959 & Hudson Land \\
\hline GC1016-72 & Precambr./Caled. & $>400$ & Basement & 71.354 & -21.906 & 445 & Liverpool Land \\
\hline GC1016-73 & Precambr./Caled. & $>400$ & Granite & 71.416 & -22.154 & 550 & Liverpool Land \\
\hline GC1077-1 & Precambr./Caled. & $>400$ & Basement & 76.283 & -25.900 & 1800 & Inland N \\
\hline GC1077-3 & Precambr./Caled. & $>400$ & Basement & 76.783 & -25.250 & 900 & Inland N \\
\hline GC1077-4 & Precambr./Caled. & $>400$ & Basement & 75.233 & -21.783 & 100 & Hochstetter Forland W \\
\hline GC1077-5 & Precambr./Caled. & $>400$ & Basement & 76.000 & -22.100 & 340 & Dove Bugt \\
\hline GC1077-6 & Precambr./Caled. & $>400$ & Basement & 75.983 & -20.400 & 0 & Dove Bugt \\
\hline GC1077-8 & Precambr./Caled. & $>400$ & Basement & 76.333 & -20.600 & 775 & Dove Bugt \\
\hline GC1077-9 & Precambr./Caled. & $>400$ & Basement & 76.917 & -21.417 & 20 & Dove Bugt \\
\hline GC1077-10 & Precambr./Caled. & $>400$ & Basement & 76.967 & -20.483 & 200 & Dove Bugt \\
\hline GC1077-11 & Precambr./Caled. & $>400$ & Basement & 77.533 & -21.017 & 510 & Germania Land \\
\hline GC1077-12 & Barremian & $130-125$ & Sandstone & 76.380 & -18.728 & 54 & Store Koldewey \\
\hline GC1077-13 & Barremian & $130-125$ & $\begin{array}{l}\text { Sand, uncon- } \\
\text { solidated }\end{array}$ & 76.427 & -18.705 & 34 & Store Koldewey \\
\hline GC1077-15 & Jurasic, M & $176-161$ & Sandstone & 76.118 & -18.532 & 108 & Store Koldewey \\
\hline GC1077-16 & Devonian, E & $416-398$ & Gneiss & 76.117 & -18.533 & 105 & Store Koldewey \\
\hline GC1077-17 & Callovian & $165-161$ & Sandstone & 75.190 & -19.998 & 2 & Hochstetter Forland \\
\hline GC1077-18 & Neoproterozoic & 800 & Basement & 72.229 & -25.333 & 1785 & Stauning Alper \\
\hline GC1077-20 & Neoproterozoic & 800 & Basement & 72.257 & -25.359 & 373 & Stauning Alper \\
\hline GC1077-21 & Neoproterozoic & 800 & Basement & 72.267 & -25.361 & 12 & Stauning Alper \\
\hline GC1077-22 & Devonian, E & $416-398$ & $\begin{array}{l}\text { Gneiss, meta- } \\
\text { sediment }\end{array}$ & 74.880 & -20.202 & 765 & Kuhn $\varnothing$ \\
\hline GC1077-23 & Devonian, E & $416-398$ & Granite & 74.880 & -20.214 & 572 & Kuhn $\varnothing$ \\
\hline GC1077-24 & Devonian, E & $416-398$ & Granite & 74.873 & -20.227 & 400 & Kuhn $\varnothing$ \\
\hline GC1077-25 & Devonian, E & 416-398 & Granite & 74.883 & -20.237 & 225 & Kuhn $\varnothing$ \\
\hline GC1077-26 & Devonian, E & $416-398$ & Granite & 74.885 & -20.246 & 100 & Kuhn $\varnothing$ \\
\hline GC1077-27 & Devonian, E & $416-398$ & Basement & 74.290 & -22.477 & 1261 & Payer Land \\
\hline GC1077-28 & Devonian, E & $416-398$ & Basement & 74.304 & -22.514 & 939 & Payer Land \\
\hline GC1077-29 & Devonian, E & $416-398$ & Basement & 74.316 & -22.560 & 640 & Payer Land \\
\hline GC1077-30 & Devonian, E & $416-398$ & Basement & 74.316 & -22.589 & 479 & Payer Land \\
\hline GC1077-31 & Devonian, E & $416-398$ & Basement & 74.323 & -22.577 & 171 & Payer Land \\
\hline GC1077-32 & Devonian, E & $416-398$ & Basement & 74.313 & -22.458 & 32 & Payer Land \\
\hline GC1077-33 & Devonian, E & $416-398$ & Basement & 70.837 & -22.017 & 1277 & Liverpool Land \\
\hline GC1077-34 & Devonian, E & $416-398$ & Basement & 70.834 & -22.028 & 1058 & Liverpool Land \\
\hline GC1077-35 & Devonian, E & 416-398 & Basement & 70.817 & -22.052 & 600 & Liverpool Land \\
\hline GC1077-36 & Devonian, E & $416-398$ & Basement & 70.844 & -21.895 & 317 & Liverpool Land \\
\hline GC1077-37 & Callovian-Oxfordian & $165-156$ & Sandstone & 71.463 & -23.328 & 1217 & Jameson Land S \\
\hline GC1077-38 & Bajocian-Bathonian & $172-165$ & Sandstone & 71.391 & -23.339 & 857 & Jameson Land S \\
\hline GC1077-39 & Pliensbachian-Toarcian & $190-176$ & $\begin{array}{l}\text { Fine-grained } \\
\text { sandstone }\end{array}$ & 71.481 & -23.372 & 469 & Jameson Land S \\
\hline
\end{tabular}


Appendix 1.2 Sample details. Also available online in Supplementary File S4 (continued)

\begin{tabular}{|c|c|c|c|c|c|c|c|}
\hline $\begin{array}{l}\text { Sample } \\
\text { number }\end{array}$ & $\begin{array}{l}\text { Stratigraphic } \\
\text { division }\end{array}$ & $\begin{array}{l}\text { Stratigraphic } \\
\text { age (Ma) }\end{array}$ & Rock type & Latitude & Longitude & $\begin{array}{l}\text { Elevation } \\
\text { (m a.s.l.) }\end{array}$ & Location \\
\hline GC1077-40 & Paleocene-Eocene & $66-34$ & $\begin{array}{l}\text { Unconsolida- } \\
\text { ted sand }\end{array}$ & 74.028 & $-21,668$ & 739 & Hold with Hope \\
\hline GC1077-41 & Midproterozoic & 540 & Granite & 71.418 & -25.341 & 0 & Stauning Alper \\
\hline GC1077-42 & Silurian & $444-416$ & Granite & 73.270 & -22.199 & 160 & Gauss Halvø \\
\hline GC1077-43 & Precambr./Caled. & $>400$ & Basement & 73.543 & -21.954 & 87 & Gauss Halvø \\
\hline GC1077-44 & Precambr./Caled. & $>400$ & Basement & 73.540 & -21.998 & 409 & Gauss Halvø \\
\hline GC1077-45 & Permian & $299-251$ & Sandstone & 73.541 & -22.017 & 455 & Gauss Halvø \\
\hline GC1077-46 & Triassic & $251-200$ & Sandstone & 73.535 & -22.064 & 621 & Gauss Halvø \\
\hline GC1077-47 & Carboniferous & $359-299$ & Conglomerate & 74.413 & -21.867 & 120 & Payer Land \\
\hline GC1077-49 & Precambr./Caled. & $>400$ & Basement & 74.471 & -21.943 & 413 & Payer Land \\
\hline GC1077-50 & Carboniferous & $359-299$ & sandstone & 73.147 & -23.084 & 255 & Ymer $\varnothing$ \\
\hline GC1077-51 & Devonian & $416-359$ & sandstone & 73.174 & -23.182 & 103 & Ymer $\varnothing$ \\
\hline GC1077-52 & Tertiary & 36 & Syenite & 72.202 & -22.730 & 1018 & Traill $\varnothing$ \\
\hline GC1077-54 & Tertiary & 36 & Syenite & 72.190 & -22.713 & 689 & Traill $\varnothing$ \\
\hline GC1077-55 & Tertiary & 36 & Syenite & 72.184 & -22.697 & 128 & Traill $\varnothing$ \\
\hline GC1077-56 & Midproterozoic & $>400$ & Paragneiss & 71.587 & -27.059 & 0 & Inland S \\
\hline GC1077-57 & Archaeic & $>400$ & Gneiss & 71.621 & -27.602 & 0 & Inland S \\
\hline GC1077-58 & Precambr./Caled. & $>400$ & Gneiss & 71.161 & -28.708 & 800 & Inland S \\
\hline GC1077-59 & Precambr./Caled. & $>400$ & Schist & 70.464 & -28.322 & 500 & Gåseland \\
\hline GC1077-60 & Proterozoic, M-L & 540 & gneiss & 75.082 & -21.320 & 0 & Hochstetter Forland W \\
\hline GC1077-61 & Palaeoproterozoic & $>540$ & Gabbro & 75.032 & -21.666 & 360 & Hochstetter Forland W \\
\hline GC1077-62 & Precambr./Caled. & $>400$ & Semipelite & 73.742 & -29.325 & 2165 & Inland C \\
\hline GC1077-63 & Palaeoproterozoic & $>540$ & Granite & 72.314 & -26.858 & 800 & Inland C \\
\hline GC1077-64 & Palaeoproterozoic & $>540$ & Gneiss & 72.096 & -28.836 & 930 & Inland C \\
\hline GC1077-65 & Neoproterozoic & $>540$ & Granite & 73.483 & -26.504 & 870 & Inland C \\
\hline GC1077-66 & Neoproterozoic & $>540$ & Granite & 73.851 & -26.152 & 650 & Inland C \\
\hline GC1077-67 & Paleoprotorozoic? & 540 & Gneiss & 73.468 & -27.676 & 280 & Inland C \\
\hline GC1077-68 & Precambr./Caled. & $>400$ & $\begin{array}{l}\text { Metaquarts } \\
\text { diorite }\end{array}$ & 73.194 & -27.660 & 500 & Inland C \\
\hline GC1077-69 & Silurian & $444-416$ & Granite & 73.062 & -28.116 & 2110 & Inland C \\
\hline GC1077-70 & Proterozoic, M-L & 540 & Gneiss & 74.729 & -22.626 & 1150 & Payer Land \\
\hline GC1077-71 & Neoproterozoic & $>540$ & Gneiss & 74.253 & -25.242 & 950 & Inland C \\
\hline GC1077-72 & Paleocene-Eocene, E & $66-50$ & Sandstone & 74.565 & -18.984 & 402 & Sabine $\varnothing$ \\
\hline GC1077-73 & Cretaceous, E & $146-100$ & Conglomerate & 74.584 & -19.339 & 150 & Wollaston Forland \\
\hline GC1077-74 & Devonian, E & $416-398$ & Granite & 74.584 & -19.334 & 154 & Wollaston Forland \\
\hline GC1077-75 & Cretaceous & $146-66$ & Sandstone & 74.596 & -19.542 & 340 & Wollaston Forland \\
\hline GC1077-76 & Triassic, L & $228-200$ & Sandstone & 70.719 & -22.661 & 110 & Jameson Land S \\
\hline GC1077-77 & Jurassic, L & $161-146$ & Sandstone & 70.658 & -22.699 & 717 & Jameson Land S \\
\hline GC1077-78 & Rhaetian-Sinemurian & 204-189 & Sandstone & 70.745 & -22.674 & 40 & Jameson Land S \\
\hline GC1077-79 & Triassic & $251-200$ & Sandstone & 73.933 & -21.215 & 150 & Hold with Hope \\
\hline GC1077-80 & Cretaceous? & $145-65$ & Sandstone & 74.359 & -20.576 & 457 & Clavering $\varnothing$ \\
\hline GC1077-81 & Cretaceous & $146-66$ & Sandstone & 74.378 & -20.593 & 303.5 & Clavering $\varnothing$ \\
\hline GC1077-82 & Devonian, E & $416-398$ & Gneiss & 74.378 & -20.593 & 303 & Clavering $\varnothing$ \\
\hline GC1077-83 & Devonian, E & $416-398$ & Basement & 76.232 & -18.585 & 107 & Store Koldewey \\
\hline GC1077-84 & Cretaceous, E & $146-100$ & Sandstone & 74.346 & -19.291 & 58 & Wollaston Forland \\
\hline GC1077-85 & Eocene, E & 55 & Sandstone & $73 ., 755$ & -21.940 & 320 & Hudson Land \\
\hline GC1077-86 & Precambr./Caled. & $>400$ & Basement & 74.169 & -20.771 & 778 & Clavering Ø \\
\hline
\end{tabular}


www.geusbulletin.org

Appendix 1.2 Sample details. Also available online in Supplementary File S4 (continued)

\begin{tabular}{|c|c|c|c|c|c|c|c|}
\hline $\begin{array}{l}\text { Sample } \\
\text { number }\end{array}$ & $\begin{array}{l}\text { Stratigraphic } \\
\text { division }\end{array}$ & $\begin{array}{c}\text { Stratigraphic } \\
\text { age (Ma) }\end{array}$ & Rock type & Latitude & Longitude & $\begin{array}{l}\text { Elevation } \\
\text { ( } m \text { a.s.l.) }\end{array}$ & Location \\
\hline GC1077-87 & Triassic & $251-200$ & Sandstone & 74.169 & -20.771 & 778 & Clavering $\varnothing$ \\
\hline GC1077-88 & Precambr./Caled. & $>400$ & Basement & 74.342 & -20.086 & 327 & Wollaston Forland \\
\hline GC1077-89 & Cretaceous, E & $146-100$ & Conglomerate & 74.582 & -20.751 & 500 & Dombjerg \\
\hline GC1077-90 & Precambr./Caled. & $>400$ & Basement & 74.582 & -20.751 & 500 & Dombjerg \\
\hline GC1077-91 & Precambr./Caled. & $>400$ & Basement & 74.546 & -20.789 & 1446 & Dombjerg \\
\hline GC1077-92 & Precambr./Caled. & $>400$ & Basement & 74.534 & -20.683 & 234.696 & Dombjerg \\
\hline GC1077-93 & Precambr./Caled. & $>400$ & Basement & 74.335 & -20.793 & 820 & Clavering $\varnothing$ \\
\hline GC1077-94 & Precambr./Caled. & $>400$ & Basement & 74.336 & -20.783 & 890 & Clavering $\varnothing$ \\
\hline GC1077-95 & Precambr./Caled. & $>400$ & Basement & 74.350 & -20.745 & 1233 & Clavering $\varnothing$ \\
\hline GC1077-96 & Paleocene, sub-basalt & $65-56$ & Sandstone & 74.350 & -20.745 & 1233 & Clavering $\varnothing$ \\
\hline GC1077-97 & Precambr./Caled. & $>400$ & Basement & 74.342 & -20.701 & 427 & Clavering $\varnothing$ \\
\hline GC1077-98 & Jurassic, L & $161-146$ & Sandstone & 74.645 & -20.054 & 50 & Wollaston Forland \\
\hline GC1077-99 & Devonian, E & $416-398$ & Basement & 74.645 & -20.059 & 100 & Wollaston Forland \\
\hline GC1077-100 & Miocene, E & $23-16$ & Sill & 74.520 & -18.751 & 81 & Hvalros $\varnothing$ \\
\hline GC1077-101 & Valanginian? & $140-136$ & Sandstone & 76.297 & -18.634 & 77 & Store Koldewey \\
\hline GC1077-102 & Devonian, E & $416-398$ & Gneiss & 76.297 & -18.634 & 77 & Store Koldewey \\
\hline GC1077-103 & Devonian, E & $416-398$ & Gneiss & 76.169 & -18.659 & 663 & Store Koldewey \\
\hline GC1077-104 & Devonian, E & $416-398$ & Gneiss & 76.318 & -18.777 & 524 & Store Koldewey \\
\hline GC1077-105 & Paleocene & $65-56$ & Sandstone & 74.344 & -19.360 & 420 & Wollaston Forland \\
\hline GC1104-1 & Precambr./Caled. & $>400$ & Metagabbro & 77.138 & -18.573 & 280 & Germania Land \\
\hline GC1104-2 & Precambr./Caled. & $>400$ & Gneiss & 76.697 & -19.844 & 192.5 & Dove Bugt \\
\hline GC1104-3 & Precambr./Caled. & $>400$ & Orthogneiss & 76.288 & -20.352 & 830 & Dove Bugt \\
\hline GC1104-4 & Precambr./Caled. & $>400$ & Granite & 70.938 & -25.580 & 600 & Milne Land \\
\hline GC1104-5 & Precambr./Caled. & $>400$ & Granite & 70.842 & -26.144 & 1270 & Milne Land \\
\hline GC1104-6 & Precambr./Caled. & $>400$ & $\begin{array}{l}\text { Migmatite } \\
\text { neosome }\end{array}$ & 70.855 & -25.855 & 1280 & Milne Land \\
\hline GC1104-7 & Precambr./Caled. & $>400$ & Granite & 71,480 & -25.228 & 1090 & Stauning Alper \\
\hline GC1104-8 & Precambr./Caled. & $>400$ & Granite & 71.468 & -25.304 & 300 & Stauning Alper \\
\hline GC1104-9 & Precambr./Caled. & $>400$ & Granite & 71.468 & -25.304 & 1450 & Stauning Alper \\
\hline GC1104-10 & Precambr./Caled. & $>400$ & Migmatite & 71.960 & -24.781 & 1280 & Stauning Alper \\
\hline GC1104-12 & Precambr./Caled. & $>400$ & Gneiss & 72.003 & -25.528 & 20 & Stauning Alper \\
\hline GC1104-13 & Precambr./Caled. & $>400$ & Granite & 72.132 & -25.519 & 50 & Stauning Alper \\
\hline GC1104-14 & Precambr./Caled. & $>400$ & Granite & 73.606 & -25.846 & 1100 & Inland C \\
\hline GC1104-15 & Campanian? & $83.5-70.6$ & Sandstone & 72.849 & -22.441 & 656 & Geographical Society $\varnothing$ \\
\hline GC1104-16 & Triassic & $251-200$ & Sandstone & 72.727 & -23.144 & 570 & Traill $\varnothing$ \\
\hline GC1104-17 & Jurassic? & $200-146$ & conglomerate & 72.727 & -23.144 & 570 & Traill $\varnothing$ \\
\hline GC1104-18 & Jurassic? & $199.6-145.5$ & Sandstone & 72.459 & -22.384 & 471 & Traill $\varnothing$ \\
\hline GC1104-19 & Triassic & 251-199 & Sandstone & 72.751 & -23.306 & 1069 & Traill $\varnothing$ \\
\hline GC1104-20 & Precambr./Caled. & $>400$ & Basement & 76.105 & -18.502 & 48 & Store Koldewey \\
\hline GC1104-21 & Precambr./Caled. & $>400$ & $\begin{array}{l}\text { Porphyritic } \\
\text { band }\end{array}$ & 70.902 & -25.376 & 2 & Milne Land \\
\hline GC1104-22 & Precambr./Caled. & $>400$ & Basement & 76.334 & -18.667 & 54 & Store Koldewey \\
\hline GC1104-23 & Valanginian & $140.2-136.4$ & Sandstone & 76.334 & -18.667 & 54 & Store Koldewey \\
\hline GC1104-24 & Santonian & $85.8-83.5$ & Sandstone & 73.707 & -20.546 & -5 & $\begin{array}{l}\text { Hold with Hope, Nanok } \\
\text { bh }\end{array}$ \\
\hline
\end{tabular}

For definition of sub-regions Inland N, Inland C and Inland S, see Figure 11A. Caled.: Caledonian; E: Early; L: Late; M: Middle; Precambr.: Precambrian. 
Appendix 1.3 AFTA data. Also available online in Supplementary File S4

\begin{tabular}{|c|c|c|c|c|c|c|c|c|}
\hline $\begin{array}{l}\text { Sample } \\
\text { number }\end{array}$ & $\begin{array}{c}\text { Stratigraphic } \\
\text { age }^{a}(\mathrm{Ma})\end{array}$ & $\begin{array}{c}\rho_{\mathrm{D}}^{\mathrm{b}} \\
\left(10^{6} \text { tracks } / \mathrm{cm}^{2}\right)\end{array}$ & $\begin{array}{c}\rho_{\mathrm{s}}{ }^{\mathrm{b}} \\
\left(10^{6} \text { tracks } / \mathrm{cm}^{2}\right)\end{array}$ & $\begin{array}{c}\rho_{\mathrm{i}}{ }^{\mathrm{b}} \\
\left(10^{6} \mathrm{tracks} / \mathrm{cm}^{2}\right)\end{array}$ & $\begin{array}{l}\mathrm{P}\left(\chi^{2}\right)^{\mathrm{c}} \\
\text { (number } \\
\text { of grains) }\end{array}$ & $\begin{array}{l}\text { Fission-track } \\
\text { age d }(\mathrm{Ma})\end{array}$ & $\begin{array}{l}\text { Mean track } \\
\text { length } \mathrm{e}(\mu \mathrm{m}) \\
\text { (Number of } \\
\text { lengths) }\end{array}$ & $\begin{array}{c}\text { Standard } \\
\text { deviation }{ }^{f} \\
(\mu \mathrm{m})\end{array}$ \\
\hline GC103-1 & 255 & $1.486(2357)$ & $0.370(236)$ & 6.359 (4054) & $29(20)$ & $17.0 \pm 1.2$ & $12.6 \pm 0.2(102)$ & 1.98 \\
\hline GC103-2 & 255 & $1.488(2357)$ & $0.279(145)$ & $5.464(2840)$ & $49(20)$ & $14.9 \pm 1.3$ & $12.5 \pm 0.2(107)$ & 2.28 \\
\hline GC103-3 & 155 & $1.490(2357)$ & $1.106(456)$ & 2.737 (1128) & $<1(20)$ & $119.5 \pm 17.7^{*}$ & $10.3 \pm 0.2(106)$ & 2.36 \\
\hline GC103-4 & 190 & $1.492(2357)$ & $0.260(234)$ & $1.076(970)$ & $52(20)$ & $70.3 \pm 5.5$ & $11.1 \pm 0.2(100)$ & 2.49 \\
\hline GC103-6 & 255 & $1.496(2357)$ & $1.488(618)$ & 3.814 (1584) & $<1(20)$ & $153.4 \pm 17.5^{*}$ & $10.2 \pm 0.3(102)$ & 2.62 \\
\hline GC159-1 & 255 & $1.391(2205)$ & $0.515(302)$ & 3.364 (1971) & $79(20)$ & $40.4 \pm 2.7$ & $12.7 \pm 0.2(100)$ & 1.58 \\
\hline GC159-2 & 255 & $1.392(2205)$ & $0.510(438)$ & 5.255 (4514) & $<1(20)$ & $27.0 \pm 2.5^{*}$ & $12.4 \pm 0.2(75)$ & 1.97 \\
\hline GC159-3 & $251-247$ & $1.394(2205)$ & $0.139(120)$ & 2.074 (1795) & $<1(20)$ & $17.7 \pm 1.7$ & $13.9 \pm 0.3(14)$ & 1.05 \\
\hline GC159-4 & $260-250$ & $1.396(2205)$ & $0.371(327)$ & $5.371(4732)$ & $<1(20)$ & $17.7 \pm 1.9 *$ & $13.3 \pm 0.2(61)$ & 1.44 \\
\hline GC202-1 & $260-250$ & 1.440 (2198) & $1.617(806)$ & $3.363(1676)$ & $<1(20)$ & $132.8 \pm 13.0^{*}$ & $11.3 \pm 0.3(106)$ & 2.62 \\
\hline GC202-2 & $360-245$ & 1.433 (2198) & $0.386(223)$ & 2.702 (1559) & $57(20)$ & $40.1 \pm 3.1$ & $11.9 \pm 0.2(101)$ & 2.15 \\
\hline GC202-3 & 255 & 1.426 (2198) & $0.708(366)$ & $3.912(2021)$ & $<1(20)$ & $54.7 \pm 8.6^{*}$ & $11.0 \pm 0.2(101)$ & 2.23 \\
\hline GC202-4 & $260-250$ & 1.419 (2198) & $0.690(420)$ & $2.746(1671)$ & $<1(20)$ & $65.6 \pm 10.0^{*}$ & $11.4 \pm 0.3(103)$ & 2.58 \\
\hline GC202-5 & $245-240$ & 1.412 (2198) & $0.847(464)$ & 2.169 (1189) & $<1(20)$ & $98.6 \pm 12.3^{*}$ & $10.9 \pm 0.2(103)$ & 2.27 \\
\hline GC202-6 & $245-240$ & 1.404 (2198) & $1.592(627)$ & $2.498(984)$ & $<1(20)$ & $120.4 \pm 19.4^{*}$ & $10.8 \pm 0.2(104)$ & 2.02 \\
\hline GC202-7 & $235-208$ & $1.390(2198)$ & $1.115(228)$ & 7.525 (1539) & $60(11)$ & $40.5 \pm 3.3^{*}$ & $12.7 \pm 0.2(51)$ & 1.59 \\
\hline GC202-9 & $208-178$ & $1.383(2198)$ & $0.661(442)$ & 2.608 (1743) & $<1(20)$ & $66.6 \pm 6.3^{*}$ & $12.1 \pm 0.2(103)$ & 2.22 \\
\hline GC202-11 & $235-208$ & 1.375 (2198) & 0.401 (309) & 2.544 (1958) & $<1(20)$ & $44.7 \pm 4.4^{*}$ & $12.4 \pm 0.2(113)$ & 2.21 \\
\hline GC202-12 & $235-208$ & 1.368 (2198) & $0.144(113)$ & 1.265 (991) & $3(20)$ & $29.6 \pm 4.8^{*}$ & $12.6 \pm 0.3(51)$ & 2.25 \\
\hline GC202-16 & 255 & 1.361 (2198) & $0.965(531)$ & 8.544 (4699) & $<1(20)$ & $30.3 \pm 2.3^{*}$ & $12.2 \pm 0.2(123)$ & 2.42 \\
\hline GC522-1 & $245-208$ & $1.656(2712)$ & $0.286(170)$ & 1.766 (1049) & $<1(20)$ & $37.3 \pm 9.7^{*}$ & $13.5 \pm 0.3(44)$ & 1.92 \\
\hline GC522-2 & $416-359$ & $1.666(2712)$ & $0.830(267)$ & $2.220(714)$ & $<1(20)$ & $104.4 \pm 14.7^{*}$ & $11.4 \pm 0.3(55)$ & 2.36 \\
\hline GC522-3 & $416-359$ & $1.676(2712)$ & $2.220(1031)$ & $2.799(1300)$ & $3(20)$ & $229.5 \pm 14.4^{*}$ & $12.3 \pm 0.2(105)$ & 2.01 \\
\hline GC522-4 & $245-208$ & 1.685 (2712) & $0.112(65)$ & $1.902(1105)$ & $41(19)$ & $17.6 \pm 2.3$ & $10.7 \pm 1.3(11)$ & 4,21 \\
\hline GC522-5 & $359-299$ & $1.467(2300)$ & $0.151(101)$ & $3.090(2061)$ & $<1(20)$ & $11.3 \pm 2.1$ * & $12.4 \pm 0.3(58)$ & 2.44 \\
\hline GC522-6 & $359-299$ & $1.466(2300)$ & 1.519 (347) & 3.607 (824) & $<1(19)$ & $111.3 \pm 14.7^{*}$ & $10.6 \pm 0.3(78)$ & 2.38 \\
\hline GC522-7 & $161-146$ & $1.464(2300)$ & $2.006(654)$ & $3.006(980)$ & $16(20)$ & $173.6 \pm 10.0$ & $10.4 \pm 0.3(103)$ & 3.06 \\
\hline GC522-8 & $146-132$ & $1.462(2300)$ & 1.975 (1065) & 2.129 (1148) & $81(20)$ & $239.8 \pm 12.2$ & $11.2 \pm 0.2(105)$ & 1.89 \\
\hline GC522-9 & $313-303$ & 1.267 (2088) & $0.476(191)$ & $5.562(2233)$ & $<1(20)$ & $20.6 \pm 4.4^{*}$ & $12.1 \pm 0.4(45)$ & 2.87 \\
\hline GC522-10 & $166-161$ & 1.257 (2088) & $0.183(79)$ & 2.591 (1117) & $10(20)$ & $16.1 \pm 2.7^{*}$ & $11.1 \pm 0.4(59)$ & 2.79 \\
\hline GC522-11 & $166-157$ & 1.247 (2088) & $0.308(92)$ & $2.476(740)$ & $<1(20)$ & $24.1 \pm 8.5^{*}$ & $10.4 \pm 0.3(103)$ & 3.11 \\
\hline GC1016-3 & $146-100$ & 1.327 (2127) & 3.045 (1483) & 4.609 (2245) & $<1(20)$ & $158.2 \pm 13.9 *$ & $12.9 \pm 0.1(101)$ & 1.21 \\
\hline GC1016-4 & 430 & 1.331 (2127) & 2.517 (1902) & 3.664 (2769) & $<1(20)$ & $168.4 \pm 10.4^{*}$ & $13.4 \pm 0.1(103)$ & 1.35 \\
\hline GC1016-5 & $416-359$ & 1.334 (2127) & 2.691 (1629) & $3.082(1866)$ & $<1(20)$ & $218.8 \pm 17.3^{*}$ & $12.4 \pm 0.1(102)$ & 1.33 \\
\hline GC1016-6 & $>400$ & $1.338(2127)$ & $1.649(553)$ & $2.045(686)$ & $46(20)$ & $201.9 \pm 12.7$ & $13.1 \pm 0.2(49)$ & 1.37 \\
\hline GC1016-7 & $>400$ & 1.341 (2127) & 2.207 (1942) & 3.078 (2708) & $<1(20)$ & $179.2 \pm 12.6^{*}$ & $12.6 \pm 0.1(101)$ & 1.25 \\
\hline GC1016-8 & $>400$ & 1.345 (2127) & $0.565(95)$ & $1.053(177)$ & $20(11)$ & $135.9 \pm 17.6$ & $13.7 \pm 0.4(6)$ & 0.89 \\
\hline
\end{tabular}


Appendix 1.3 AFTA data. Also available online in Supplementary File S4 (continued)

\begin{tabular}{|c|c|c|c|c|c|c|c|c|}
\hline $\begin{array}{l}\text { Sample } \\
\text { number }\end{array}$ & $\begin{array}{c}\text { Stratigraphic } \\
\text { age a (Ma) }\end{array}$ & $\begin{array}{c}\rho_{\mathrm{D}}{ }^{\mathrm{b}} \\
\left(10^{6} \text { tracks } / \mathrm{cm}^{2}\right)\end{array}$ & $\begin{array}{c}\rho_{\mathrm{s}} \mathrm{b}^{2} \\
\left(10^{6} \mathrm{tracks} / \mathrm{cm}^{2}\right)\end{array}$ & $\begin{array}{c}\rho_{\mathrm{i}}{ }^{\mathrm{b}} \\
\left(10^{6} \mathrm{tracks} / \mathrm{cm}^{2}\right)\end{array}$ & $\begin{array}{c}\mathrm{P}\left(\mathrm{X}^{2}\right)^{\mathrm{c}} \\
\text { (number } \\
\text { of grains) }\end{array}$ & $\begin{array}{l}\text { Fission-track } \\
\text { age d }(\mathrm{Ma})\end{array}$ & $\begin{array}{l}\text { Mean track } \\
\text { length e }(\mu \mathrm{m}) \\
\text { (Number of } \\
\text { lengths) }\end{array}$ & $\begin{array}{c}\text { Standard } \\
\text { deviation } \\
(\mu \mathrm{m})\end{array}$ \\
\hline GC1016-9 & $416-359$ & $1.348(2127)$ & $1.533(551)$ & $2.346(843)$ & $<1(20)$ & $164.3 \pm 14.4^{*}$ & $13.3 \pm 0.2(55)$ & 1.28 \\
\hline GC1016-10 & $359-299$ & $1.352(2127)$ & $0.232(248)$ & 3.496 (3738) & $4(20)$ & $16.7 \pm 1.6^{*}$ & $13.5 \pm 0.3(46)$ & 1.70 \\
\hline GC1016-11 & $299-251$ & $1.356(2127)$ & $0.218(120)$ & 3.483 (1920) & $<1(20)$ & $19.4 \pm 6.9 *$ & $11.6 \pm 0.7(9)$ & 2.22 \\
\hline GC1016-13 & $>400$ & 1.359 (2127) & $1.152(530)$ & $2.200(1012)$ & $<1(20)$ & $129.8 \pm 14.5^{*}$ & $10.1 \pm 0.3(26)$ & 1.76 \\
\hline GC1016-14 & $>400$ & $1.363(2127)$ & $1.033(303)$ & $1.933(567)$ & $<1(20)$ & $138.9 \pm 17.2^{*}$ & $11.6 \pm 0.5(14)$ & 2.02 \\
\hline GC1016-15 & $>400$ & 1.366 (2127) & 1.041 (323) & 1.724 (535) & $<1(15)$ & $156.8 \pm 18.2^{\star}$ & $12.5 \pm 0.4(19)$ & 1.72 \\
\hline GC1016-16 & $416-359$ & 1.370 (2127) & $0.969(643)$ & 1.776 (1179) & $<1(20)$ & $131.7 \pm 14.8^{*}$ & $11.6 \pm 0.2(80)$ & 1.59 \\
\hline GC1016-17 & $416-359$ & $1.373(2127)$ & $1.812(1615)$ & 4.507 (4016) & $<1(20)$ & $104.2 \pm 8.2^{*}$ & $11.3 \pm 0.2(79)$ & 1.80 \\
\hline GC1016-18 & $416-359$ & 1.284 (1945) & $0.431(225)$ & $1.861(971)$ & $<1(20)$ & $58.2 \pm 8.0^{*}$ & $11.1 \pm 0.2(108)$ & 2.32 \\
\hline GC1016-19 & $>400$ & 1.277 (1945) & $0.782(281)$ & $1.058(380)$ & $100(20)$ & $182.9 \pm 15.4$ & $12.8 \pm 0.1(107)$ & 1.46 \\
\hline GC1016-20 & $>400$ & 1.270 (1945) & $0.993(590)$ & $1.397(830)$ & $48(20)$ & $175.0 \pm 10.7$ & $12.7 \pm 0.1(112)$ & 1.58 \\
\hline GC1016-21 & $49-47$ & 1.264 (1945) & $1.496(913)$ & $2.343(1430)$ & $<1(20)$ & $144.4 \pm 16.6^{*}$ & $11.8 \pm 0.1(133)$ & 1.66 \\
\hline GC1016-22 & $49-47$ & $1.257(1945)$ & $0.092(105)$ & $0.425(485)$ & $24(20)$ & $53.2 \pm 5.9$ & $13.3 \pm 0.3(81)$ & 2.59 \\
\hline GC1016-23 & $65-56$ & $1.250(1945)$ & $1.824(900)$ & 2.345 (1157) & $<1(20)$ & $173.3 \pm 15.0 *$ & $11.5 \pm 0.2(105)$ & 1.85 \\
\hline GC1016-24 & $359-299$ & $1.243(1945)$ & $1.792(662)$ & $2.802(1035)$ & $22(13)$ & $157.6 \pm 11.1^{*}$ & $12.5 \pm 0.2(113)$ & 1.87 \\
\hline GC1016-25 & $359-299$ & 1.236 (1945) & $1.429(706)$ & $2.522(1246)$ & $<1(20)$ & $136.3 \pm 12.2^{*}$ & $11.9 \pm 0.2(122)$ & 1.74 \\
\hline GC1016-26 & $359-299$ & 1.229 (1945) & $1.930(1007)$ & 2.682 (1399) & $2(20)$ & $171.6 \pm 8.7$ & $12.1 \pm 0.2(106)$ & 1.68 \\
\hline GC1016-27 & $200-65$ & 1.223 (1945) & $2.075(658)$ & 3.140 (996) & $<1(20)$ & $148.8 \pm 15.9 *$ & $10.0 \pm 0.2(113)$ & 2.00 \\
\hline GC1016-28 & $251-200$ & $1.216(1945)$ & $0.599(217)$ & $1.995(723)$ & $<1(20)$ & $73.5 \pm 13.6^{*}$ & $10.1 \pm 0.2(101)$ & 2.37 \\
\hline GC1016-29 & $200-65$ & 1.209 (1945) & $0.476(313)$ & $2.340(1540)$ & $<1(20)$ & $34.7 \pm 7.9 *$ & $11.9 \pm 0.3(68)$ & 2.24 \\
\hline GC1016-30 & $200-65$ & 1.202 (1945) & $0.390(279)$ & 2.698 (1932) & $<1(20)$ & $34.1 \pm 3.7^{*}$ & $12.3 \pm 0.2(108)$ & 2.38 \\
\hline GC1016-32 & $200-176$ & 1.195 (1945) & $0.701(317)$ & $6.378(2886)$ & $<1(20)$ & $28.6 \pm 3.7^{*}$ & $12.4 \pm 0.2(100)$ & 1.93 \\
\hline GC1016-33 & $200-176$ & $1.373(2131)$ & $0.823(232)$ & $6.888(1942)$ & $<1(20)$ & $34.7 \pm 3.6^{*}$ & $11.6 \pm 0.2(109)$ & 2.15 \\
\hline GC1016-35 & $146-100$ & $1.370(2131)$ & $1.660(605)$ & 2.734 (996) & $<1(20)$ & $183.4 \pm 18.0^{*}$ & $11.0 \pm 0.3(59)$ & 2.03 \\
\hline GC1016-36 & $146-100$ & $1.368(2131)$ & $3.073(1050)$ & 3.626 (1239) & $7(20)$ & $226.6 \pm 13.7^{*}$ & $11.1 \pm 0.1(103)$ & 1.49 \\
\hline GC1016-37 & $251-200$ & $1.365(2131)$ & $1.975(640)$ & $2.734(886)$ & $<1(20)$ & $189.4 \pm 19.3^{*}$ & $11.3 \pm 0.2(104)$ & 2.10 \\
\hline GC1016-38 & $251-200$ & $1.362(2131)$ & 2.561 (1109) & 3.167 (1371) & $<1(20)$ & $224.3 \pm 16.2^{*}$ & $11.0 \pm 0.2(106)$ & 1.84 \\
\hline GC1016-39 & $251-200$ & $1.360(2131)$ & $3.613(973)$ & $5.101(1374)$ & $<1(17)$ & $169.9 \pm 18.1$ * & $11.9 \pm 0.2(100)$ & 1.64 \\
\hline GC1016-41 & $112-65$ & 1.357 (2131) & $0.736(237)$ & $1.695(546)$ & $<1(16)$ & $128.7 \pm 16.1^{*}$ & $11.7 \pm 0.4(40)$ & 2.22 \\
\hline GC1016-42 & $488-359$ & 1.355 (2131) & $5.894(2422)$ & $11.576(4757)$ & $<1(20)$ & $141.7 \pm 15.6^{*}$ & $11.5 \pm 0.2(110)$ & 1.77 \\
\hline GC1016-43 & $488-444$ & $1.352(2131)$ & $4.992(1310)$ & $6.360(1669)$ & $<1(20)$ & $202.8 \pm 12.5^{*}$ & $11.7 \pm 0.1(123)$ & 1.45 \\
\hline GC1016-44 & $200-146$ & $1.349(2131)$ & $4.736(1228)$ & 5.357 (1389) & $<1(19)$ & $224.9 \pm 20.1$ * & $12.3 \pm 0.2(103)$ & 1.55 \\
\hline GC1016-45 & $488-444$ & $1.347(2131)$ & 4.937 (2122) & $6.414(2757)$ & $9(20)$ & $199.7 \pm 9.2^{*}$ & $10.4 \pm 0.2(121)$ & 1.72 \\
\hline GC1016-46 & $>400$ & $1.344(2131)$ & 7.544 (2051) & $8.298(2256)$ & $17(20)$ & $235.7 \pm 9.9$ & $12.4 \pm 0.1(108)$ & 1.50 \\
\hline GC1016-47 & $>400$ & $1.341(2131)$ & $3.651(1011)$ & $5.580(1545)$ & $<1(20)$ & $168.9 \pm 10.7 *$ & $12.2 \pm 0.1(106)$ & 1.54 \\
\hline GC1016-48 & $>400$ & $1.339(2131)$ & $0.532(272)$ & $2.286(1168)$ & $10(20)$ & $60.8 \pm 5.2^{*}$ & $11.2 \pm 0.2(104)$ & 1.87 \\
\hline GC1016-49 & $359-299$ & 1.234 (1997) & 2.285 (1874) & $2.278(1868)$ & $<1(20)$ & $229.8 \pm 21.7 *$ & $12.9 \pm 0.1(100)$ & 1.29 \\
\hline
\end{tabular}


Appendix 1.3 AFTA data. Also available online in Supplementary File S4 (continued)

\begin{tabular}{|c|c|c|c|c|c|c|c|c|}
\hline $\begin{array}{l}\text { Sample } \\
\text { number }\end{array}$ & $\begin{array}{l}\text { Stratigraphic } \\
\text { age a (Ma) }\end{array}$ & $\begin{array}{c}\rho_{\mathrm{D}}^{\mathrm{b}} \\
\left(10^{6} \text { tracks } / \mathrm{cm}^{2}\right)\end{array}$ & $\begin{array}{c}\rho_{\mathrm{s}}{ }^{\mathrm{b}} \\
\left(10^{6} \text { tracks } / \mathrm{cm}^{2}\right)\end{array}$ & $\begin{array}{c}\rho_{\mathrm{i}}^{\mathrm{b}} \\
\left(10^{6} \mathrm{tracks} / \mathrm{cm}^{2}\right)\end{array}$ & $\begin{array}{l}\mathrm{P}\left(\chi^{2}\right)^{c} \\
\text { (number } \\
\text { of grains) }\end{array}$ & $\begin{array}{l}\text { Fission-track } \\
\text { age }{ }^{d}(\mathrm{Ma})\end{array}$ & $\begin{array}{l}\text { Mean track } \\
\text { length e }(\mu \mathrm{m}) \\
\text { (Number of } \\
\text { lengths) }\end{array}$ & $\begin{array}{c}\text { Standard } \\
\text { deviation } \\
(\mu \mathrm{m})\end{array}$ \\
\hline GC1016-50 & $359-299$ & 1.240 (1997) & $2.252(1859)$ & $1.977(1632)$ & $<1(20)$ & $256.4 \pm 14.8^{*}$ & $12.6 \pm 0.1(113)$ & 1.33 \\
\hline GC1016-51 & $359-299$ & 1.245 (1997) & $0.927(805)$ & $1.214(1054)$ & $<1(20)$ & $189.8 \pm 18.8^{*}$ & $12.2 \pm 0.2(94)$ & 1.60 \\
\hline GC1016-52 & $359-299$ & 1.251 (1997) & $2.662(1920)$ & $2.456(1771)$ & $<1(20)$ & $236.0 \pm 18.6$ * & $12.1 \pm 0.2(101)$ & 1.54 \\
\hline GC1016-53 & $359-299$ & 1.256 (1997) & 3.326 (3106) & 3.195 (2984) & $<1(20)$ & $247.2 \pm 19.0^{*}$ & $12.4 \pm 0.1(100)$ & 1.39 \\
\hline GC1016-54 & $359-299$ & 1.261 (1997) & $2.395(1842)$ & 2.475 (1903) & $16(20)$ & $225.5 \pm 10.6$ * & $12.2 \pm 0.2(99)$ & 1.63 \\
\hline GC1016-55 & $359-299$ & 1.267 (1997) & $1.482(1330)$ & 2.094 (1879) & $<1(20)$ & $174.8 \pm 13.9 *$ & $12.3 \pm 0.2(99)$ & 1.58 \\
\hline GC1016-57 & $>400$ & $1.272(1997)$ & $1.104(708)$ & $1.528(980)$ & $<1(15)$ & $174.7 \pm 14.0 *$ & $12.2 \pm 0.2(59)$ & 1.58 \\
\hline GC1016-58 & $>400$ & 1.277 (1997) & 2.406 (2476) & $2.960(3046)$ & $<1(20)$ & $190.3 \pm 11.1^{*}$ & $11.6 \pm 0.2(101)$ & 1.53 \\
\hline GC1016-59 & $>400$ & $1.283(1997)$ & $2.788(1660)$ & $6.351(3781)$ & $<1(20)$ & $108.8 \pm 8.0 *$ & $11.6 \pm 0.2(109)$ & 2.01 \\
\hline GC1016-60 & $>400$ & 1.288 (1997) & $2.243(2003)$ & 5.544 (4951) & $<1(20)$ & $98.2 \pm 6.2^{*}$ & $12.1 \pm 0.2(105)$ & 1.86 \\
\hline GC1016-61 & $>400$ & 1.294 (1997) & $1.205(711)$ & 4.935 (2913) & $<1(20)$ & $60.6 \pm 6.4^{*}$ & $12.4 \pm 0.2(102)$ & 2.22 \\
\hline GC1016-62 & $>400$ & 1.299 (1997) & $0.558(526)$ & 1.679 (1582) & $<1(20)$ & $72.0 \pm 8.5^{*}$ & $12.5 \pm 0.2(86)$ & 2.18 \\
\hline GC1016-63 & $>400$ & $1.348(2106)$ & 2.795 (1261) & $4.291(1936)$ & $5(20)$ & $172.1 \pm 9.5^{\star}$ & $11.4 \pm 0.2(127)$ & 2.02 \\
\hline GC1016-65 & $>400$ & $1.346(2106)$ & $0.473(356)$ & 3.361 (2532) & $13(20)$ & $37.3 \pm 2.7^{*}$ & $12.7 \pm 0.2(104)$ & 2.43 \\
\hline GC1016-66 & $299-251$ & 1.345 (2106) & 1.539 (1264) & $1.883(1546)$ & $<1(20)$ & $208.2 \pm 17.0^{*}$ & $11.3 \pm 0.2(106)$ & 1.68 \\
\hline GC1016-67 & $251-200$ & $1.343(2106)$ & $2.903(1257)$ & $2.520(1091)$ & $<1(20)$ & $291.2 \pm 20.1$ * & $11.8 \pm 0.1(106)$ & 1.36 \\
\hline GC1016-68 & $251-200$ & $1.342(2106)$ & $2.170(1521)$ & $2.033(1425)$ & $8(20)$ & $276.2 \pm 15.2^{*}$ & $12.1 \pm 0.1(125)$ & 1.58 \\
\hline GC1016-69 & $251-200$ & $1.340(2106)$ & $1.514(946)$ & $1.818(1136)$ & $12(20)$ & $216.3 \pm 13.3^{*}$ & $11.3 \pm 0.2(109)$ & 2.41 \\
\hline GC1016-70 & $359-299$ & 1.339 (2106) & $2.344(1326)$ & 2.395 (1355) & $8(20)$ & $249.8 \pm 14.5^{*}$ & $11.9 \pm 0.2(131)$ & 1.87 \\
\hline GC1016-72 & $>400$ & 1.337 (2106) & $0.770(500)$ & $1.012(657)$ & $20(20)$ & $196.9 \pm 13.0$ & $11.5 \pm 0.2(101)$ & 2.16 \\
\hline GC1016-73 & $>400$ & $1.336(2106)$ & $0.353(308)$ & 2.437 (2124) & $<1(20)$ & $39.2 \pm 3.6^{*}$ & $12.6 \pm 0.3(100)$ & 2.65 \\
\hline GC1077-1 & $>400$ & $1.102(1737)$ & $1.866(1038)$ & 2.191 (1219) & $53(20)$ & $176.1 \pm 9.0$ & $13.9 \pm 0.1(101)$ & 1.28 \\
\hline GC1077-3 & $>400$ & 1.106 (1737) & $0.368(278)$ & $0.701(530)$ & $31(20)$ & $109.4 \pm 8.7$ & $13.3 \pm 0.2(65)$ & 1.82 \\
\hline GC1077-4 & $>400$ & 1.109 (1737) & $5.724(3040)$ & 5.411 (2874) & $<1(20)$ & $214.2 \pm 14.4^{*}$ & $13.1 \pm 0.1(103)$ & 1.38 \\
\hline GC1077-5 & $>400$ & 1.112 (1737) & $4.511(1740)$ & $5.669(2187)$ & $1(20)$ & $168.0 \pm 8.7^{\star}$ & $12.3 \pm 0.2(103)$ & 1.71 \\
\hline GC1077-6 & $>400$ & 1.115 (1737) & $1.028(884)$ & 1.325 (1139) & $<1(20)$ & $160.7 \pm 11.4^{*}$ & $13.2 \pm 0.1(100)$ & 1.19 \\
\hline GC1077-8 & $>400$ & 1.119 (1737) & 1.470 (1795) & 1.764 (2154) & $<1(20)$ & $180.8 \pm 12.6^{*}$ & $13.4 \pm 0.1(112)$ & 1.58 \\
\hline GC1077-9 & $>400$ & $1.122(1737)$ & $1.338(1608)$ & 1.419 (1706) & $<1(20)$ & $197.6 \pm 11.2 *$ & $12.6 \pm 0.2(106)$ & 1.66 \\
\hline GC1077-10 & $>400$ & $1.002(1612)$ & $0.380(352)$ & $0.335(310)$ & $78(20)$ & $219.7 \pm 18.4$ & $12.5 \pm 0.1(109)$ & 1.52 \\
\hline GC1077-11 & $>400$ & 1.005 (1612) & 1.711 (869) & $1.447(735)$ & $7(20)$ & $231.3 \pm 16.3^{*}$ & $12.8 \pm 0.2(112)$ & 2.43 \\
\hline GC1077-12 & $130-125$ & $1.008(1612)$ & 2.597 (1332) & 1.965 (1008) & $61(20)$ & $256.6 \pm 13.4$ & $11.8 \pm 0.2(105)$ & 1.77 \\
\hline GC1077-13 & $130-125$ & $1.012(1612)$ & $1.384(499)$ & $1.348(486)$ & $<1(20)$ & $203.4 \pm 20.8^{*}$ & $11.3 \pm 0.2(104)$ & 2.39 \\
\hline GC1077-15 & $176-161$ & 1.015 (1612) & 3.047 (1415) & 2.397 (1113) & $20(20)$ & $248.6 \pm 12.6$ & $12.2 \pm 0.2(105)$ & 1.66 \\
\hline GC1077-16 & $416-398$ & $1.018(1612)$ & $2.230(1301)$ & $1.611(940)$ & $48(20)$ & $271.0 \pm 14.4$ & $12.2 \pm 0.1(107)$ & 1.41 \\
\hline GC1077-17 & $165-161$ & $1.021(1612)$ & $2.547(723)$ & $2.304(654)$ & $33(20)$ & $218.1 \pm 13.6$ & $11.7 \pm 0.2(102)$ & 1.68 \\
\hline GC1077-18 & 800 & $1.452(2181)$ & $1.510(496)$ & $2.350(772)$ & $18(20)$ & $175.0 \pm 11.1$ & $12.5 \pm 0.2(31)$ & 1.37 \\
\hline GC1077-20 & 800 & $1.443(2181)$ & $0.600(153)$ & $1.310(334)$ & $9(19)$ & $120.9 \pm 15.5^{*}$ & $12.5 \pm 0.4(9)$ & 1.15 \\
\hline
\end{tabular}


Appendix 1.3 AFTA data. Also available online in Supplementary File S4 (continued)

\begin{tabular}{|c|c|c|c|c|c|c|c|c|}
\hline $\begin{array}{l}\text { Sample } \\
\text { number }\end{array}$ & $\begin{array}{l}\text { Stratigraphic } \\
\text { age a (Ma) }\end{array}$ & $\begin{array}{c}\rho_{\mathrm{D}}{ }^{\mathrm{b}} \\
\left(10^{6} \text { tracks } / \mathrm{cm}^{2}\right)\end{array}$ & $\begin{array}{c}\rho_{\mathrm{s}}{ }^{\mathrm{b}} \\
\left(10^{6} \text { tracks } / \mathrm{cm}^{2}\right)\end{array}$ & $\begin{array}{c}\rho_{\mathrm{i}}{ }^{\mathrm{b}} \\
\left(10^{6} \text { tracks } / \mathrm{cm}^{2}\right)\end{array}$ & $\begin{array}{c}\mathrm{P}\left(\chi^{2}\right)^{\mathrm{c}} \\
\text { (number } \\
\text { of grains) }\end{array}$ & $\begin{array}{l}\text { Fission-track } \\
\text { age d }(\mathrm{Ma})\end{array}$ & $\begin{array}{l}\text { Mean track } \\
\text { length e }(\mu \mathrm{m}) \\
\text { (Number of } \\
\text { lengths) }\end{array}$ & $\begin{array}{c}\text { Standard } \\
\text { deviation }{ }^{f} \\
(\mu \mathrm{m})\end{array}$ \\
\hline GC1077-21 & 800 & $1.434(2181)$ & $0.588(77)$ & 0.909 (119) & $17(6)$ & $174.2 \pm 25.9$ & $12.3 \pm 0.8(7)$ & 2.00 \\
\hline GC1077-22 & $416-398$ & $1.426(2181)$ & 4.937 (1631) & $6.792(2244)$ & $<1(20)$ & $198.6 \pm 15.0$ * & $12.2 \pm 0.1(102)$ & 1.15 \\
\hline GC1077-23 & $416-398$ & $1.417(2181)$ & $1.635(782)$ & $2.287(1094)$ & $<1(20)$ & $187.2 \pm 16.5^{*}$ & $12.1 \pm 0.2(70)$ & 1.48 \\
\hline GC1077-24 & $416-398$ & $1.408(2181)$ & $1.910(1106)$ & $2.344(1357)$ & $<1(20)$ & $206.5 \pm 15.9 *$ & $11.8 \pm 0.2(100)$ & 1.87 \\
\hline GC1077-25 & 416-398 & $1.399(2181)$ & $6.523(3904)$ & 8.966 (5366) & $<1(20)$ & $190.3 \pm 8.2^{*}$ & $12.1 \pm 0.2(101)$ & 1.80 \\
\hline GC1077-26 & $416-398$ & $1.391(2181)$ & 3.155 (1892) & $4.537(2721)$ & $<1(20)$ & $177.7 \pm 9.8^{*}$ & $11.6 \pm 0.2(51)$ & 1.47 \\
\hline GC1077-27 & $416-398$ & $1.382(2181)$ & $1.159(808)$ & $1.651(1151)$ & $<1(20)$ & $180.0 \pm 14.0 *$ & $13.2 \pm 0.2(62)$ & 1.61 \\
\hline GC1077-28 & $416-398$ & $1.373(2181)$ & $0.662(570)$ & $0.981(845)$ & $<1(20)$ & $164.7 \pm 14.4^{*}$ & $13.0 \pm 0.2(42)$ & 1.48 \\
\hline GC1077-29 & $416-398$ & $1.364(2181)$ & $0.764(563)$ & $1.411(1040)$ & $<1(20)$ & $146.7 \pm 12.5^{*}$ & $13.1 \pm 0.2(41)$ & 1.44 \\
\hline GC1077-30 & $416-398$ & $1.356(2181)$ & $1.022(632)$ & $1.495(925)$ & $<1(20)$ & $178.3 \pm 14.4^{*}$ & $13.4 \pm 0.2(29)$ & 1.11 \\
\hline GC1077-31 & $416-398$ & 1.347 (2181) & $0.660(541)$ & 1.267 (1039) & $<1(20)$ & $125.2 \pm 14.0 *$ & $12.0 \pm 0.3(27)$ & 1.54 \\
\hline GC1077-32 & $416-398$ & $1.338(2181)$ & 3.288 (2034) & 5.359 (3315) & $<1(20)$ & $151.9 \pm 9.0^{*}$ & $12.9 \pm 0.2(98)$ & 1.61 \\
\hline GC1077-33 & $416-398$ & $1.329(2181)$ & $0.305(281)$ & $0.435(401)$ & $13(20)$ & $171.1 \pm 17.2^{*}$ & $12.1 \pm 0.2(53)$ & 1.38 \\
\hline GC1077-34 & $416-398$ & $1.321(2181)$ & $0.168(168)$ & $0.380(381)$ & $80(20)$ & $109.8 \pm 10.6$ & $11.8 \pm 0.2(45)$ & 1.28 \\
\hline GC1077-35 & $416-398$ & $1.444(2283)$ & 1.049 (494) & $1.897(893)$ & $77(20)$ & $155.1 \pm 9.7$ & $11.0 \pm 0.2(106)$ & 2.23 \\
\hline GC1077-36 & $416-398$ & 1.445 (2283) & $0.048(31)$ & $0.349(226)$ & $81(20)$ & $38.8 \pm 7.5$ & $11.4 \pm 0.4(45)$ & 2.58 \\
\hline GC1077-37 & $165-156$ & $1.446(2283)$ & 1.748 (99) & $2.048(116)$ & $19(4)$ & $238.0 \pm 33.2$ & $12.3 \pm 0.4(22)$ & 1.65 \\
\hline GC1077-38 & $172-165$ & 1.447 (2283) & $1.621(514)$ & $2.478(786)$ & $<1(20)$ & $165.2 \pm 20.5^{*}$ & $10.3 \pm 0.2(113)$ & 2.47 \\
\hline GC1077-39 & $190-176$ & 1.447 (2283) & $0.399(205)$ & 2.466 (1268) & $<1(20)$ & $49.2 \pm 6.3^{*}$ & $11.8 \pm 0.2(112)$ & 2.19 \\
\hline GC1077-40 & $66-34$ & $1.448(2283)$ & $1.883(1344)$ & $2.187(1561)$ & $<1(20)$ & $240.4 \pm 11.2$ & $12.3 \pm 0.2(112)$ & 2.20 \\
\hline GC1077-41 & 540 & $1.273(2005)$ & 4.517 (3633) & $5.822(4682)$ & $<1(20)$ & $182.2 \pm 8.1$ * & $11.9 \pm 0.1(100)$ & 1.27 \\
\hline GC1077-42 & $444-416$ & $1.273(2005)$ & $0.075(62)$ & $1.269(1051)$ & $1(19)$ & $13.4 \pm 2.8^{*}$ & $13.9 \pm 1.1$ (3) & 1.92 \\
\hline GC1077-43 & $>400$ & $1.274(2005)$ & $0.073(56)$ & $0.734(563)$ & $75(19)$ & $24.1 \pm 3.4$ & $13.7 \pm 0.4$ (3) & 0.66 \\
\hline GC1077-44 & $>400$ & $1.274(2005)$ & $0.355(146)$ & 3.648 (1499) & $<1(20)$ & $23.8 \pm 3.1^{*}$ & $12.3 \pm 0.2(101)$ & 1.78 \\
\hline GC1077-45 & $299-251$ & $1.274(2005)$ & $0.336(37)$ & $2.606(287)$ & $4(10)$ & $32.2 \pm 7.8^{*}$ & $10.5 \pm 1.4(2)$ & 1.98 \\
\hline GC1077-46 & $251-200$ & 1.275 (2005) & $0.593(421)$ & 3.931 (2793) & $<1(20)$ & $37.4 \pm 3.9 *$ & $13.0 \pm 0.1(100)$ & 1.47 \\
\hline GC1077-47 & $359-299$ & 1.275 (2005) & $0.968(426)$ & $2.055(904)$ & $<1(12)$ & $107.1 \pm 16.1$ * & $12.7 \pm 0.4(20)$ & 1.69 \\
\hline GC1077-49 & $>400$ & 1.275 (2005) & $1.117(388)$ & $2.058(715)$ & $<1(15)$ & $113.2 \pm 18.6^{*}$ & $12.7 \pm 0.5(8)$ & 1.37 \\
\hline GC1077-50 & $359-299$ & 1.275 (2005) & $0.743(416)$ & $3.839(2150)$ & $<1(20)$ & $42.9 \pm 6.8^{*}$ & $11.1 \pm 0.3(71)$ & 2.22 \\
\hline GC1077-51 & $416-359$ & $1.276(2005)$ & $0.244(238)$ & 2.187 (2137) & $<1(19)$ & $32.7 \pm 6.8^{*}$ & $11.9 \pm 0.2(65)$ & 1.81 \\
\hline GC1077-52 & 36 & $1.276(2005)$ & $0.043(36)$ & $0.291(241)$ & $97(20)$ & $36.2 \pm 6.5$ & $13.5 \pm 0.5(10)$ & 1.54 \\
\hline GC1077-54 & 36 & $1.276(2005)$ & $0.099(62)$ & $0.799(500)$ & $<1(20)$ & $32.6 \pm 7.5^{*}$ & $11.9 \pm 0.7(4)$ & 1.37 \\
\hline GC1077-55 & 36 & 1.277 (2005) & $0.021(19)$ & $0.543(496)$ & $78(20)$ & $9.3 \pm 2.2$ & $12.1 \pm 0.4(4)$ & 0.76 \\
\hline GC1077-56 & 540 & 1.336 (2074) & $4.334(150)$ & $3.583(124)$ & $70(3)$ & $309.8 \pm 38.7$ & $11.9 \pm 0.2(107)$ & 1.79 \\
\hline GC1077-57 & 540 & 1.338 (2074) & $0.321(243)$ & $0.524(397)$ & $80(20)$ & $158.9 \pm 13.7$ & $12.7 \pm 0.2(101)$ & 1.54 \\
\hline GC1077-58 & $>400$ & $1.224(1868)$ & $0.591(569)$ & $1.330(1281)$ & $<1(20)$ & $103.3 \pm 9.1$ * & $12.6 \pm 0.2(76)$ & 1.61 \\
\hline GC1077-59 & $>400$ & $1.221(1868)$ & $1.226(1356)$ & $2.220(2456)$ & $<1(20)$ & $124.1 \pm 11.0 *$ & $12.8 \pm 0.1(102)$ & 1.43 \\
\hline
\end{tabular}


Appendix 1.3 AFTA data. Also available online in Supplementary File S4 (continued)

\begin{tabular}{|c|c|c|c|c|c|c|c|c|}
\hline $\begin{array}{l}\text { Sample } \\
\text { number }\end{array}$ & $\begin{array}{c}\text { Stratigraphic } \\
\text { age }^{\text {a }(\mathrm{Ma})}\end{array}$ & $\begin{array}{c}\rho_{\mathrm{D}}{ }^{\mathrm{b}} \\
\left(10^{6} \text { tracks } / \mathrm{cm}^{2}\right)\end{array}$ & $\begin{array}{c}\rho_{\mathrm{s}} \mathrm{b} \\
\left(10^{6} \text { tracks } / \mathrm{cm}^{2}\right)\end{array}$ & $\begin{array}{c}\rho_{\mathrm{i}}{ }^{\mathrm{b}} \\
\left(10^{6} \text { tracks } / \mathrm{cm}^{2}\right)\end{array}$ & $\begin{array}{c}\mathrm{P}\left(\chi^{2}\right)^{c} \\
\text { (number } \\
\text { of grains) }\end{array}$ & $\begin{array}{l}\text { Fission-track } \\
\text { age d (Ma) }\end{array}$ & $\begin{array}{l}\text { Mean track } \\
\text { length e }(\mu \mathrm{m}) \\
\text { (Number of } \\
\text { lengths) }\end{array}$ & $\begin{array}{l}\text { Standard } \\
\text { deviation }{ }^{\mathrm{f}} \\
\quad(\mu \mathrm{m})\end{array}$ \\
\hline GC1077-60 & 540 & $1.217(1868)$ & $2.258(1607)$ & $3.983(2835)$ & $<1(20)$ & $131.3 \pm 8.3^{*}$ & $12.3 \pm 0.2(101)$ & 1,55 \\
\hline GC1077-61 & $>540$ & $1.213(1868)$ & 3.857 (1245) & $6.852(2212)$ & $<1(20)$ & $131.1 \pm 7.9 *$ & $11.9 \pm 0.2(68)$ & 2,02 \\
\hline GC1077-62 & $>400$ & 1.209 (1868) & $1.713(1674)$ & $2.520(2463)$ & $<1(20)$ & $154.6 \pm 9.6^{*}$ & $12.2 \pm 0.2(101)$ & 1.74 \\
\hline GC1077-63 & $>540$ & $1.206(1868)$ & $3.448(3320)$ & $5.326(5128)$ & $<1(20)$ & $145.4 \pm 7.0^{*}$ & $12.6 \pm 0.1(103)$ & 1.49 \\
\hline GC1077-64 & $>540$ & 1.202 (1868) & $0.632(730)$ & $1.146(1324)$ & $<1(20)$ & $118.4 \pm 11.2^{*}$ & $12.6 \pm 0.2(95)$ & 2.09 \\
\hline GC1077-65 & $>540$ & $1.198(1868)$ & $2.322(2712)$ & 3.469 (4052) & $<1(20)$ & $147.3 \pm 8.6^{*}$ & $12.5 \pm 0.2(102)$ & 1.59 \\
\hline GC1077-66 & $>540$ & 1.195 (1868) & 1.575 (1764) & $2.465(2761)$ & $<1(20)$ & $148.0 \pm 10.2^{*}$ & $12.5 \pm 0.2(101)$ & 1.71 \\
\hline GC1077-67 & 540 & $1.191(1868)$ & $1.798(1418)$ & 3.701 (2918) & $<1(20)$ & $113.1 \pm 8.5^{*}$ & $12.3 \pm 0.2(101)$ & 1.58 \\
\hline GC1077-68 & $>400$ & $1.187(1868)$ & $1.893(1176)$ & 3.151 (1957) & $15(20)$ & $133.2 \pm 7.0$ * & $12.6 \pm 0.2(106)$ & 1.70 \\
\hline GC1077-69 & $444-416$ & $1.184(1868)$ & 6.032 (4984) & 7.199 (5948) & $<1(20)$ & $180.6 \pm 8.9 *$ & $12.7 \pm 0.1(102)$ & 1.45 \\
\hline GC1077-70 & 540 & $1.180(1868)$ & $4.452(2317)$ & 4.602 (2395) & $<1(20)$ & $227.8 \pm 15.9 *$ & $13.7 \pm 0.1(103)$ & 1.48 \\
\hline GC1077-71 & $>540$ & $1.176(1868)$ & $1.948(2131)$ & 2.937 (3212) & $<1(20)$ & $143.6 \pm 9.6^{*}$ & $13.4 \pm 0.1(100)$ & 1.48 \\
\hline GC1077-72 & $66-50$ & $1.173(1868)$ & $0.892(547)$ & 3.872 (2373) & $<1(20)$ & $50.6 \pm 4.0 *$ & $13.3 \pm 0.3(32)$ & 1.45 \\
\hline GC1077-73 & $146-100$ & 1.169 (1868) & $0.702(471)$ & 2.992 (2007) & $<1(20)$ & $54.9 \pm 6.8^{*}$ & $12.7 \pm 0.2(103)$ & 1.55 \\
\hline GC1077-74 & $416-398$ & 1.165 (1868) & $0.825(792)$ & 5.558 (5337) & $<1(19)$ & $34.0 \pm 2.6^{*}$ & $11.7 \pm 0.2(101)$ & 1.81 \\
\hline GC1077-75 & $146-66$ & $1.162(1868)$ & $0.591(515)$ & 3.518 (3064) & $<1(20)$ & $38.4 \pm 3.4^{*}$ & $13.3 \pm 0.1(103)$ & 1.33 \\
\hline GC1077-76 & $228-200$ & $1.158(1868)$ & $0.350(355)$ & 2.157 (2191) & $<1(20)$ & $35.7 \pm 3.8^{*}$ & $11.8 \pm 0.2(100)$ & 2.32 \\
\hline GC1077-77 & $161-146$ & 1.154 (1868) & 0.989 (739) & 2.561 (1913) & $<1(20)$ & $79.2 \pm 9.3^{*}$ & $10.0 \pm 0.3(78)$ & 2.31 \\
\hline GC1077-78 & 204-189 & 1.285 (1938) & $0.334(315)$ & 2.160 (2039) & $<1(20)$ & $41.5 \pm 4.8^{*}$ & $12.1 \pm 0.3(47)$ & 2.31 \\
\hline GC1077-79 & $251-200$ & $1.280(1938)$ & $0.652(312)$ & 3.427 (1639) & $<1(18)$ & $48.5 \pm 6.2^{\star}$ & $12.5 \pm 0.2(36)$ & 1.34 \\
\hline GC1077-80 & $145-65$ & 1.275 (1938) & $0.636(366)$ & 3.565 (2053) & $<1(20)$ & $45.3 \pm 4.4^{*}$ & $13.6 \pm 0.3(34)$ & 1.58 \\
\hline GC1077-81 & $146-66$ & $1.270(1938)$ & $2.063(1259)$ & 2.559 (1562) & $2(20)$ & $190.3 \pm 11.3^{*}$ & $11.3 \pm 0.1(105)$ & 1.41 \\
\hline GC1077-82 & $416-398$ & 1.265 (1938) & 2.616 (1707) & 3.975 (2594) & $<1(20)$ & $155.7 \pm 9.8^{*}$ & $10.4 \pm 0.2(107)$ & 1.94 \\
\hline GC1077-83 & $416-398$ & 1.260 (1938) & 1.403 (989) & 2.168 (1528) & $<1(20)$ & $152.7 \pm 9.8^{*}$ & $12.1 \pm 0.2(100)$ & 1.60 \\
\hline GC1077-84 & $146-100$ & 1.255 (1938) & $1.424(1001)$ & $2.596(1825)$ & $<1(20)$ & $128.3 \pm 10.6^{*}$ & $12.8 \pm 0.2(104)$ & 1.64 \\
\hline GC1077-85 & 55 & 1.250 (1938) & $1.299(242)$ & $2.292(427)$ & $<1(12)$ & $150.0 \pm 24.2^{*}$ & $13.6 \pm 0.5(10)$ & 1.60 \\
\hline GC1077-86 & $>400$ & 1.245 (1938) & $1.749(252)$ & $1.624(234)$ & $22(5)$ & $250.0 \pm 23.7$ & $11.7 \pm 0.5(9)$ & 1.45 \\
\hline GC1077-87 & $251-200$ & 1.239 (1938) & $1.794(568)$ & $2.625(831)$ & $<1(20)$ & $159.6 \pm 16.7^{*}$ & $11.1 \pm 0.3(31)$ & 1.59 \\
\hline GC1077-88 & $>400$ & 1.234 (1938) & $0.499(529)$ & 3.064 (3251) & $<1(20)$ & $38.6 \pm 2.7^{*}$ & $12.8 \pm 0.2(103)$ & 1.98 \\
\hline GC1077-89 & $146-100$ & 1.229 (1938) & 1.759 (1348) & $1.900(1456)$ & $<1(20)$ & $218.6 \pm 16.0 *$ & $13.0 \pm 0.1(104)$ & 1.40 \\
\hline GC1077-90 & $>400$ & 1.224 (1938) & $0.716(454)$ & 2.868 (1819) & $<1(18)$ & $59.4 \pm 5.1^{*}$ & $13.4 \pm 0.2(103)$ & 1.78 \\
\hline GC1077-91 & $>400$ & 1.219 (1938) & $1.479(941)$ & 1.987 (1264) & $<1(20)$ & $178.5 \pm 13.6^{*}$ & $13.0 \pm 0.2(107)$ & 1.71 \\
\hline GC1077-92 & $>400$ & $1.214(1938)$ & $1.512(922)$ & 2.852 (1739) & $<1(20)$ & $122.6 \pm 9.5^{\star}$ & $12.7 \pm 0.2(103)$ & 1.69 \\
\hline GC1077-93 & $>400$ & 1.209 (1938) & $2.606(1950)$ & $2.614(1956)$ & $<1(20)$ & $227.7 \pm 14.7^{*}$ & $12.7 \pm 0.1(100)$ & 1.21 \\
\hline GC1077-94 & $>400$ & 1.204 (1938) & 3.022 (1339) & $3.282(1454)$ & $<1(20)$ & $211.5 \pm 13.3^{*}$ & $12.3 \pm 0.2(100)$ & 1.59 \\
\hline GC1077-95 & $>400$ & 1.199 (1938) & $2.839(1981)$ & $2.940(2052)$ & $5(20)$ & $217.5 \pm 10.4^{*}$ & $12.9 \pm 0.1(103)$ & 1.07 \\
\hline GC1077-96 & $65-56$ & 1.194 (1938) & 1.327 (1322) & 1.679 (1673) & $<1(20)$ & $167.3 \pm 21.0^{*}$ & $13.2 \pm 0.1(100)$ & 1.41 \\
\hline
\end{tabular}


Appendix 1.3 AFTA data. Also available online in Supplementary File S4 (continued)

\begin{tabular}{|c|c|c|c|c|c|c|c|c|}
\hline $\begin{array}{l}\text { Sample } \\
\text { number }\end{array}$ & $\begin{array}{c}\text { Stratigraphic } \\
\text { age a (Ma) }\end{array}$ & $\begin{array}{c}\rho_{\mathrm{D}}^{\mathrm{b}} \\
\left(10^{6} \text { tracks } / \mathrm{cm}^{2}\right)\end{array}$ & $\begin{array}{c}\rho_{\mathrm{s}} \mathrm{b} \\
\left(10^{6} \text { tracks } / \mathrm{cm}^{2}\right)\end{array}$ & $\begin{array}{c}\rho_{\mathrm{i}}{ }^{\mathrm{b}} \\
\left(10^{6} \text { tracks } / \mathrm{cm}^{2}\right)\end{array}$ & $\begin{array}{c}\mathrm{P}\left(\chi^{2}\right)^{c} \\
\text { (number } \\
\text { of grains) }\end{array}$ & $\begin{array}{l}\text { Fission-track } \\
\text { age d }(\mathrm{Ma})\end{array}$ & $\begin{array}{l}\text { Mean track } \\
\text { length e }(\mu \mathrm{m}) \\
\text { (Number of } \\
\text { lengths) }\end{array}$ & $\begin{array}{c}\text { Standard } \\
\text { deviation }^{f} \\
\quad(\mu \mathrm{m})\end{array}$ \\
\hline GC1077-97 & $>400$ & 1.189 (1938) & 2.846 (1999) & $3.543(2488)$ & $<1(20)$ & $169.1 \pm 14.1^{*}$ & $10.9 \pm 0.1(109)$ & 1.39 \\
\hline GC1077-98 & $161-146$ & 1.184 (1938) & $0.788(247)$ & $1.532(480)$ & $19(20)$ & $114.8 \pm 9.5$ & $11.4 \pm 0.5(20)$ & 2.39 \\
\hline GC1077-99 & $416-398$ & 1.190 (1977) & $4.326(1293)$ & $7.638(2283)$ & $<1(20)$ & $135.7 \pm 11.2^{*}$ & $11.5 \pm 0.2(111)$ & 2.34 \\
\hline GC1077-100 & $23-16$ & 1.196 (1977) & $0.063(37)$ & $0.608(356)$ & $85(20)$ & $24.4 \pm 4.3$ & $14.0 \pm 0.3(30)$ & 1.79 \\
\hline GC1077-101 & $140-136$ & $1.203(1977)$ & $1.251(1101)$ & 1.101 (969) & $15(20)$ & $263.2 \pm 16.6^{*}$ & $11.7 \pm 0.2(106)$ & 2.02 \\
\hline GC1077-102 & $416-398$ & 1.209 (1977) & $2.033(495)$ & 2.435 (593) & $4(17)$ & $198.6 \pm 16.5^{\star}$ & $11.5 \pm 0.2(108)$ & 1.66 \\
\hline GC1077-103 & $416-398$ & 1.215 (1977) & $2.547(1183)$ & $2.332(1083)$ & $7(20)$ & $253.7 \pm 14.8 *$ & $13.4 \pm 0.1(104)$ & 1.39 \\
\hline GC1077-104 & $416-398$ & $1.222(1977)$ & $1.717(604)$ & $1.643(578)$ & $48(20)$ & $246.0 \pm 16.0$ & $12.4 \pm 0.2(114)$ & 2.04 \\
\hline GC1077-105 & $65-56$ & 1.228 (1977) & $1.229(362)$ & $1.681(495)$ & $<1(17)$ & $189.3 \pm 24.0^{*}$ & $12.8 \pm 0.2(112)$ & 1.87 \\
\hline GC1104-1 & $>400$ & $1.203(1913)$ & $0.770(493)$ & $0.695(445)$ & $54(21)$ & $256.7 \pm 18.4$ & $12.9 \pm 0.2(107)$ & 1.86 \\
\hline GC1104-2 & $>400$ & $1.212(1913)$ & $0.418(301)$ & $0.427(307)$ & $65(20)$ & $229.3 \pm 19.8$ & $12.7 \pm 0.1(107)$ & 1.35 \\
\hline GC1104-3 & $>400$ & $1.220(1913)$ & $1.229(785)$ & $1.335(853)$ & $30(20)$ & $216.9 \pm 12.5$ & $13.0 \pm 0.1(114)$ & 1.32 \\
\hline GC1104-4 & $>400$ & 1.229 (1913) & $1.537(412)$ & $1.537(412)$ & $27(20)$ & $236.9 \pm 17.9$ & $10.9 \pm 0.2(105)$ & 2.08 \\
\hline GC1104-5 & $>400$ & $1.237(1913)$ & $2.736(1157)$ & $3.133(1325)$ & $2(20)$ & $208.8 \pm 13.0 *$ & $12.2 \pm 0.1(151)$ & 1.53 \\
\hline GC1104-6 & $>400$ & 1.245 (1913) & $4.138(1440)$ & $4.121(1434)$ & $12(20)$ & $241.1 \pm 11.5$ & $12.2 \pm 0.2(106)$ & 1.64 \\
\hline GC1104-7 & $>400$ & $1.254(1913)$ & 3.160 (1197) & 3.519 (1333) & $11(20)$ & $217.5 \pm 10.8$ & $11.9 \pm 0.1(115)$ & 1.51 \\
\hline GC1104-8 & $>400$ & $1.262(1913)$ & $1.214(964)$ & $1.316(1045)$ & $93(20)$ & $224.8 \pm 12.0$ & $11.6 \pm 0.2(111)$ & 1.80 \\
\hline GC1104-9 & $>400$ & $1.271(1913)$ & $2.159(1405)$ & 1.979 (1288) & $50(20)$ & $266.7 \pm 13.0$ & $12.8 \pm 0.1(104)$ & 1.41 \\
\hline GC1104-10 & $>400$ & 1.279 (1913) & $0.378(74)$ & $2.412(472)$ & $<1(10)$ & $41.0 \pm 10.0 *$ & $11.9 \pm 0.3(48)$ & 2.28 \\
\hline GC1104-12 & $>400$ & $1.287(1913)$ & 2.618 (1099) & $3.450(1448)$ & $4(20)$ & $189.0 \pm 11.0 *$ & $11.6 \pm 0.2(103)$ & 1.87 \\
\hline GC1104-13 & $>400$ & $1.296(1913)$ & $2.589(958)$ & 4.262 (1577) & $<1(19)$ & $156.0 \pm 12.2^{*}$ & $11.2 \pm 0.2(116)$ & 1.85 \\
\hline GC1104-14 & $>400$ & $1.145(1820)$ & 2.144 (1946) & 3.567 (3237) & $<1(20)$ & $129.7 \pm 6.2^{*}$ & $12.4 \pm 0.2(104)$ & 1.59 \\
\hline GC1104-15 & $83.5-70.6$ & $1.147(1820)$ & $0.343(308)$ & 1.149 (1032) & $<1(20)$ & $63.9 \pm 9.4^{*}$ & $13.4 \pm 0.2(43)$ & 1.35 \\
\hline GC1104-16 & $251-200$ & $1.148(1820)$ & $0.696(507)$ & 3.837 (2794) & $<1(20)$ & $42.0 \pm 5.6^{*}$ & $12.2 \pm 0.2(86)$ & 1.78 \\
\hline GC1104-17 & $200-146$ & $1.150(1820)$ & $0.310(74)$ & $1.866(445)$ & $75(14)$ & $36.3 \pm 4.7$ & $12.0 \pm 1.6(2)$ & 2.31 \\
\hline GC1104-18 & $199.6-145.5$ & $1.152(1820)$ & $0.590(244)$ & 4.820 (1993) & $<1(20)$ & $26.3 \pm 2.8^{*}$ & $14.1 \pm 0.2(33)$ & 1.21 \\
\hline GC1104-19 & 251-199 & $1.153(1820)$ & $1.051(753)$ & $5.281(3782)$ & $<1(20)$ & $47.7 \pm 5.3^{*}$ & $12.6 \pm 0.2(100)$ & 1.59 \\
\hline GC1104-20 & $>400$ & 1.155 (1820) & $2.540(1512)$ & 3.564 (2122) & $<1(20)$ & $152.5 \pm 10.9$ * & $11.8 \pm 0.1(100)$ & 1.34 \\
\hline GC1104-21 & $>400$ & $1.156(1820)$ & 3.385 (2075) & $4.813(2950)$ & $<1(20)$ & $151.0 \pm 8.6^{*}$ & $11.0 \pm 0.1(102)$ & 1.48 \\
\hline GC1104-22 & $>400$ & $1.158(1820)$ & $3.158(924)$ & $4.238(1240)$ & $<1(20)$ & $170.7 \pm 18.9$ * & $12.0 \pm 0.1$ & 1.37 \\
\hline GC1104-23 & $140.2-136.4$ & $1.159(1820)$ & $1.416(484)$ & $1.823(623)$ & $6(20)$ & $167.2 \pm 13.6^{*}$ & $11.7 \pm 0.2(101)$ & 1.59 \\
\hline GC1104-24 & $85.8-83.5$ & $1.477(2262)$ & $1.329(603)$ & $2.133(968)$ & $<1(20)$ & $190.0 \pm 18.0 *$ & $10.9 \pm 0.2(104)$ & 2.14 \\
\hline
\end{tabular}

a All numerical values for stratigraphic ages assigned following Gradstein et al. (2012). ${ }^{b} \rho_{\mathrm{s}}=$ spontaneous track density. $\rho_{\mathrm{i}}=$ induced track density. $\rho_{\mathrm{D}}=$ glass dosimeter track density. Numbers in parentheses show the number of tracks counted in determining track densities. c Probability that all single-grain ages belong to a single population (Galbraith 2005). d Central age (Galbraith 2005), used for samples containing a significant spread in single-grain ages $\left(\mathrm{P}\left(\chi^{2}\right)<5 \%\right)$ is denoted with *, otherwise the pooled age is quoted. All errors quoted at $\pm 1 \sigma$. e All analytical details are as provided in Supplementary File S1, S2, S3. ${ }^{f}$ Standard deviation of the track-length distribution. 


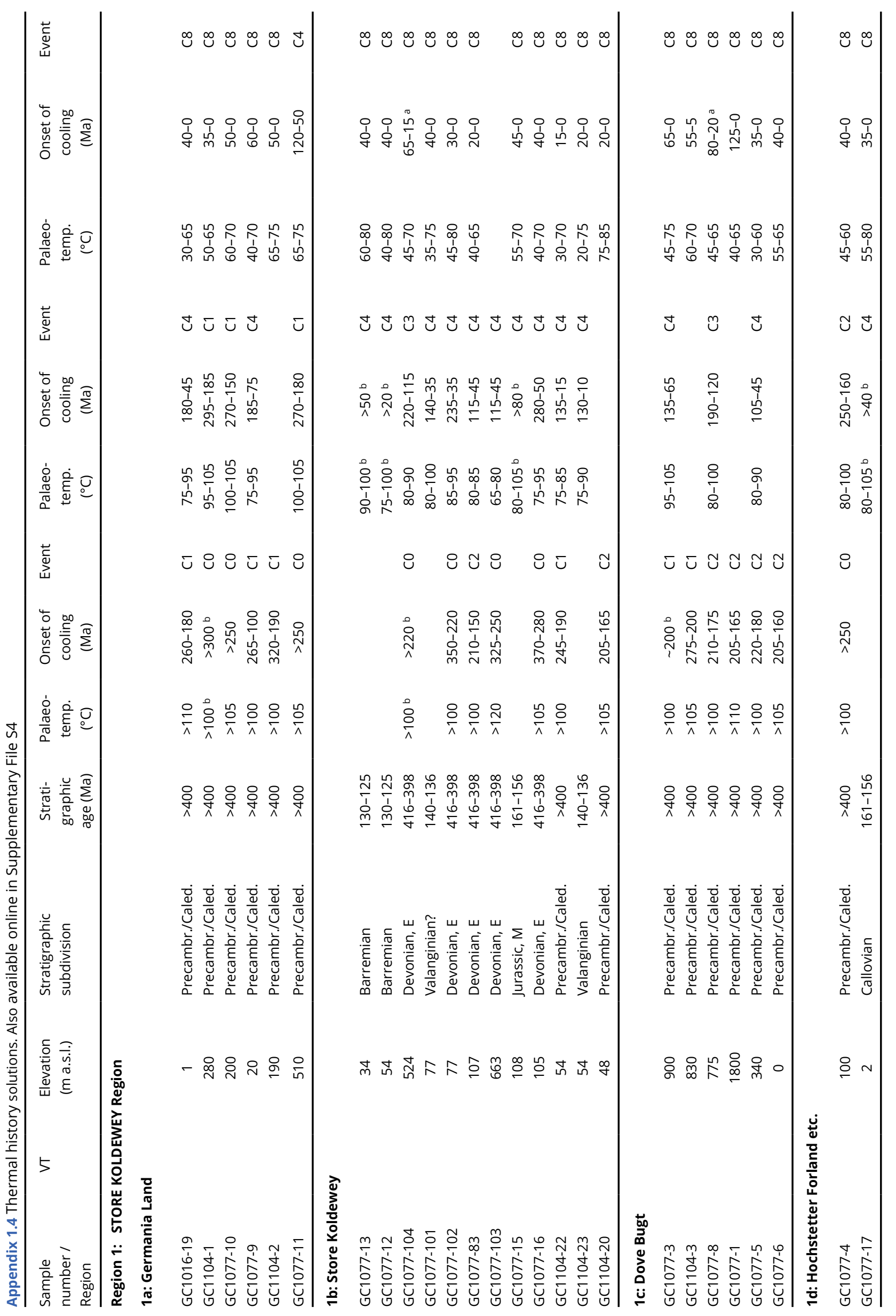




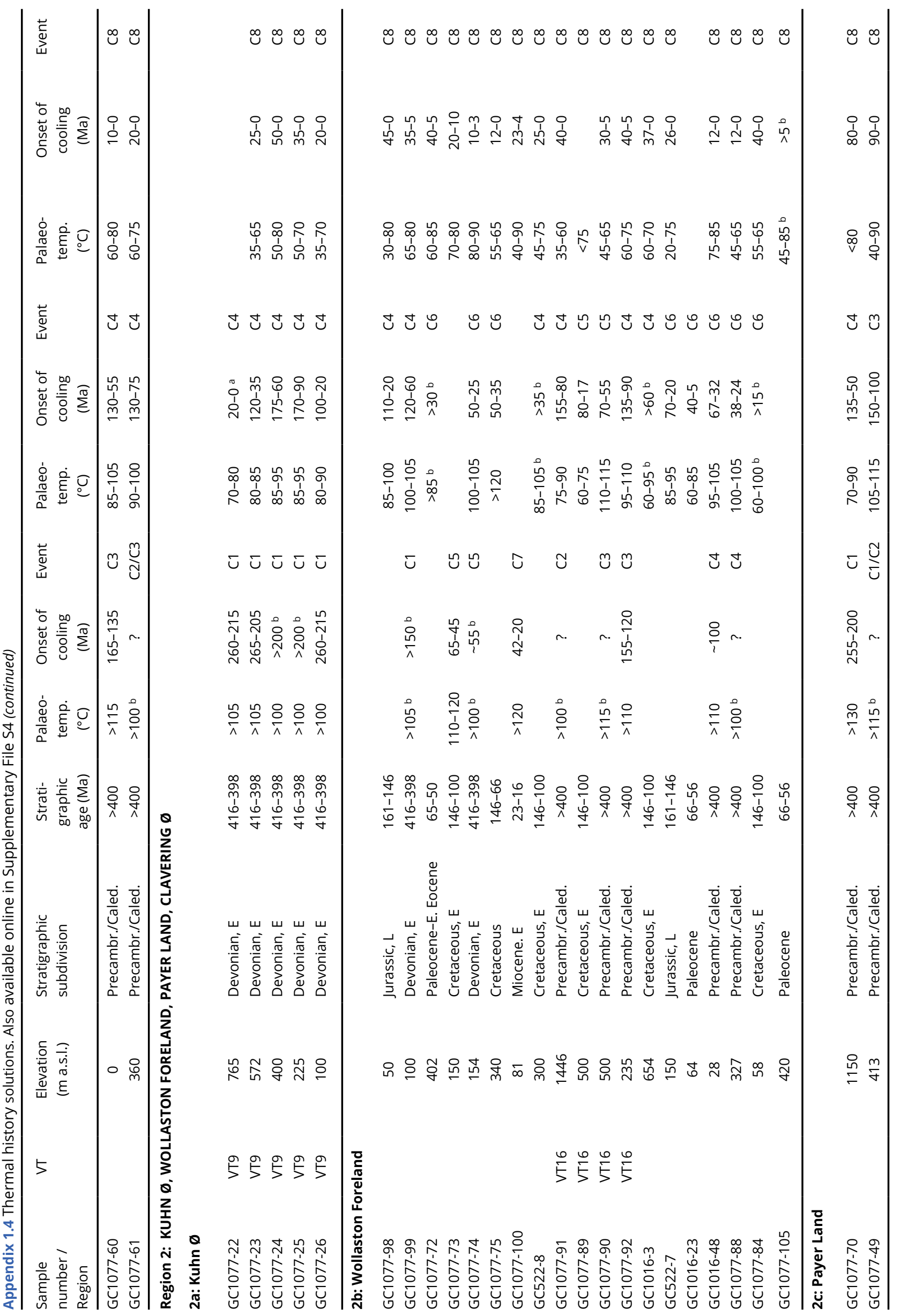




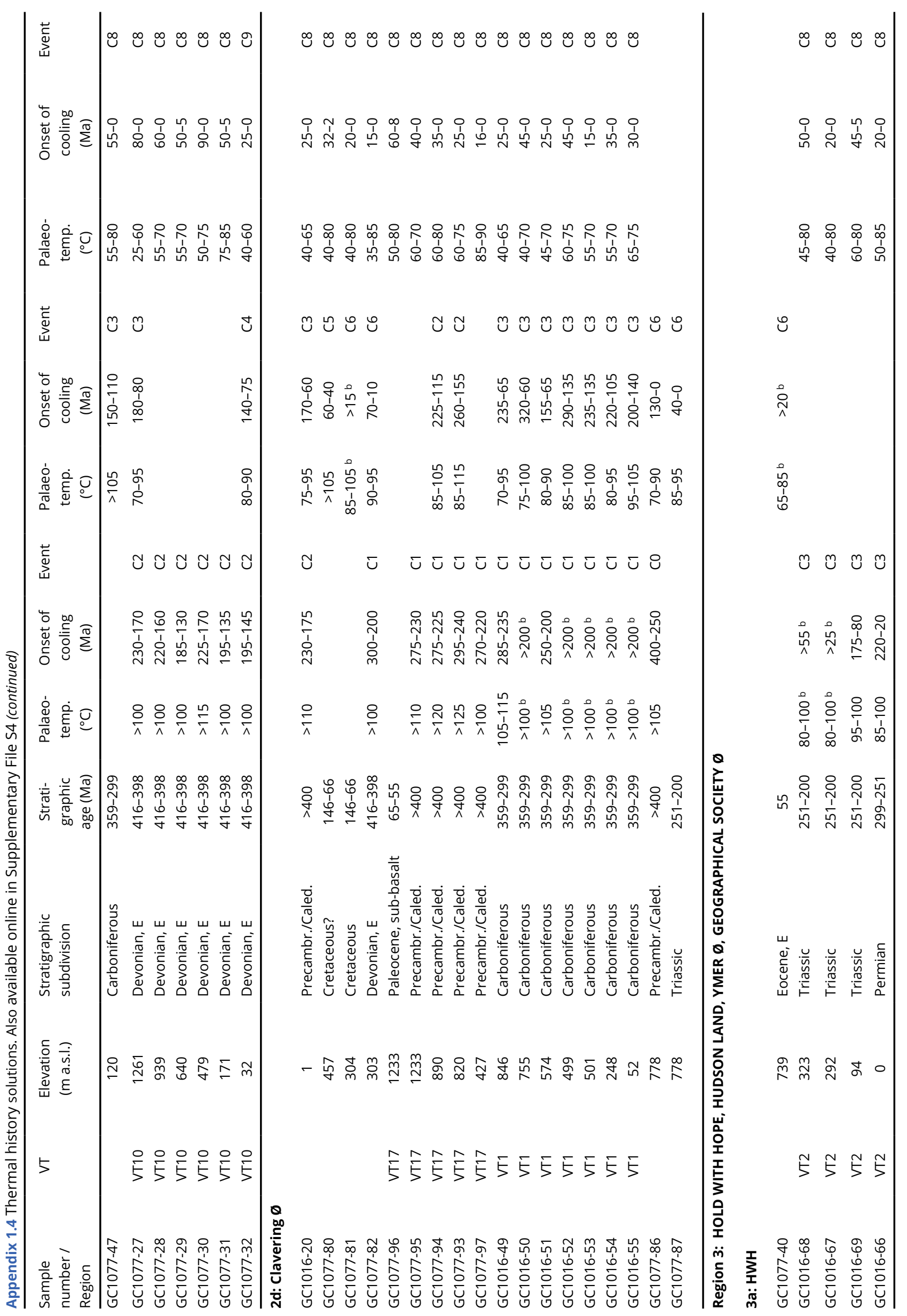




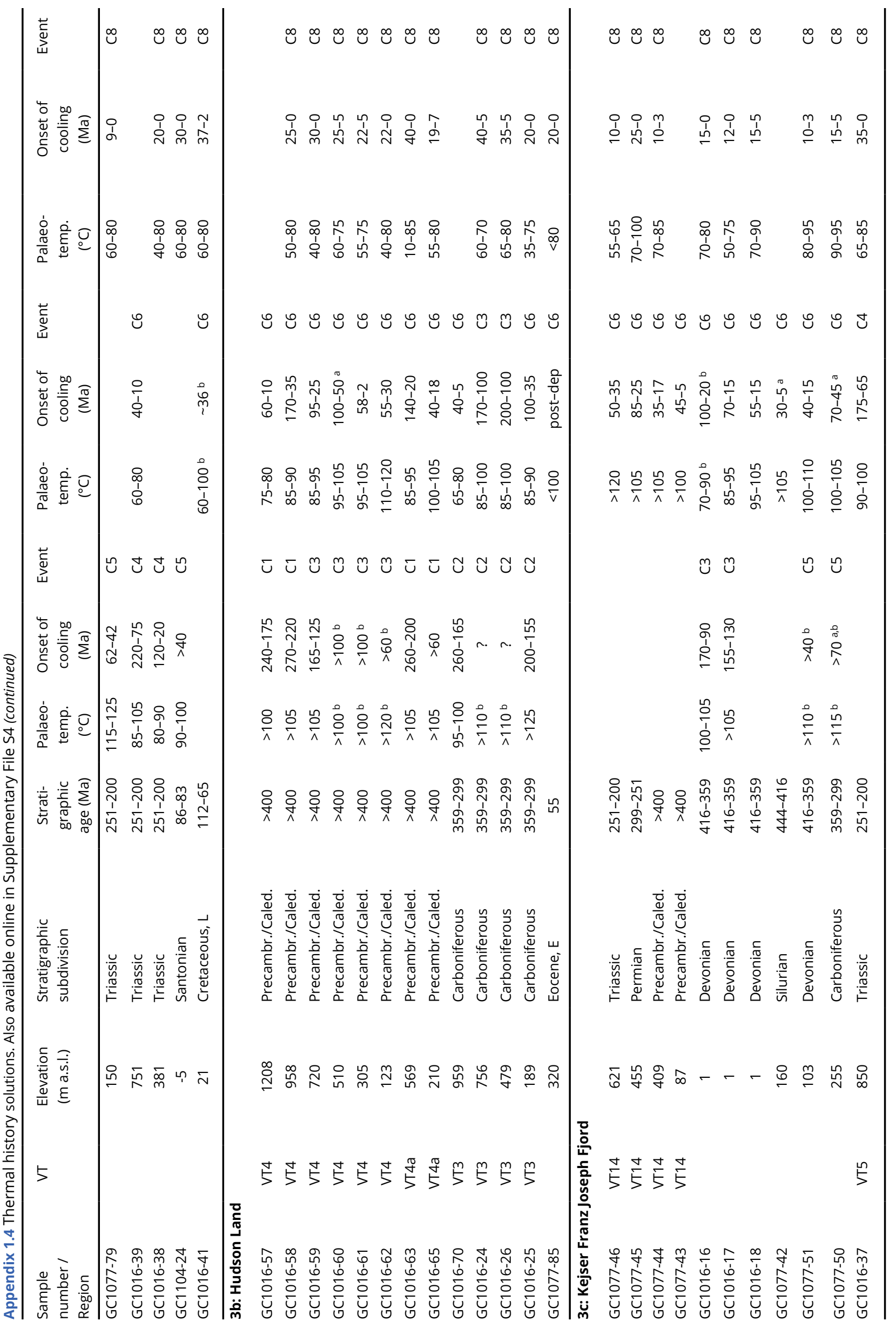




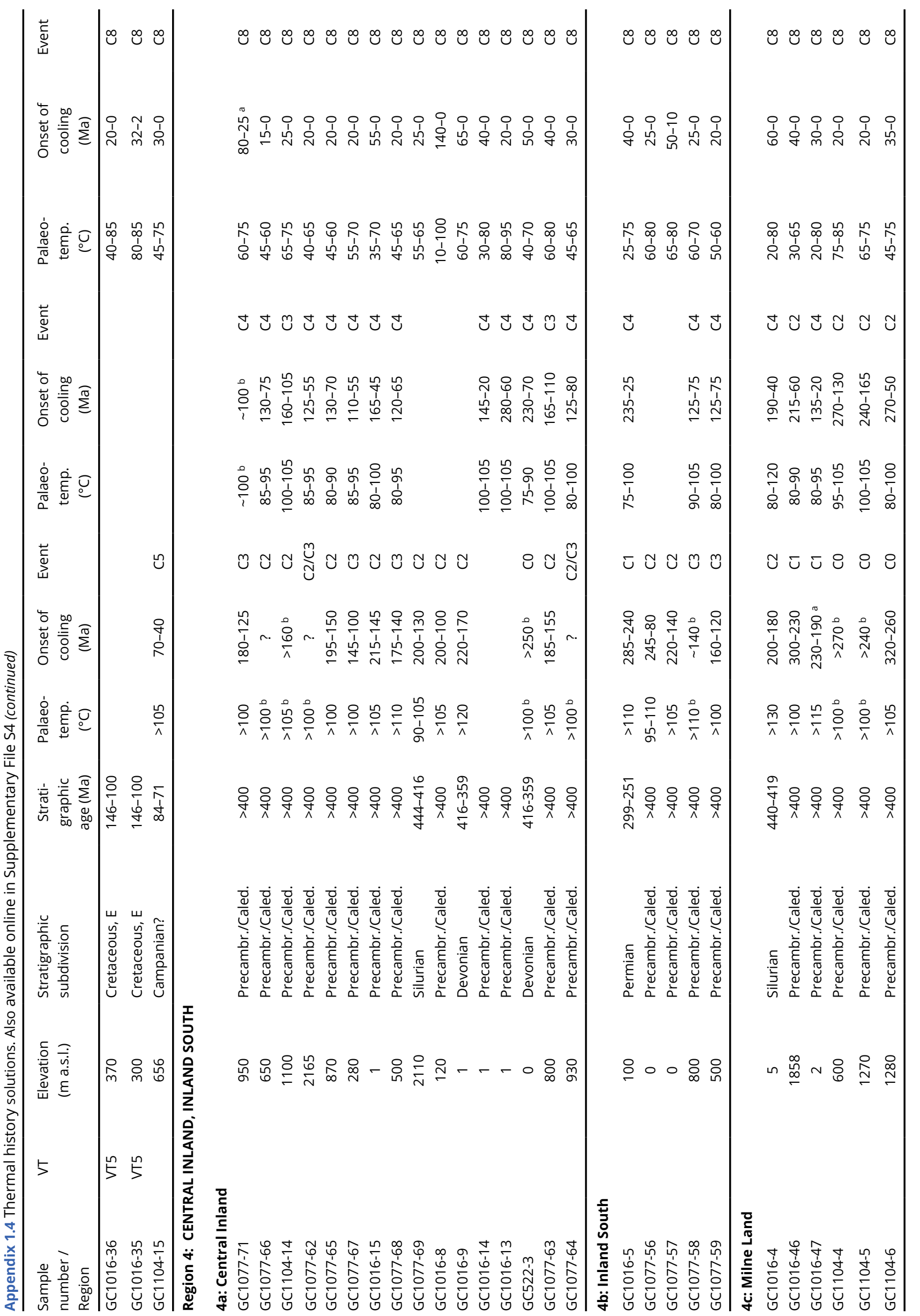




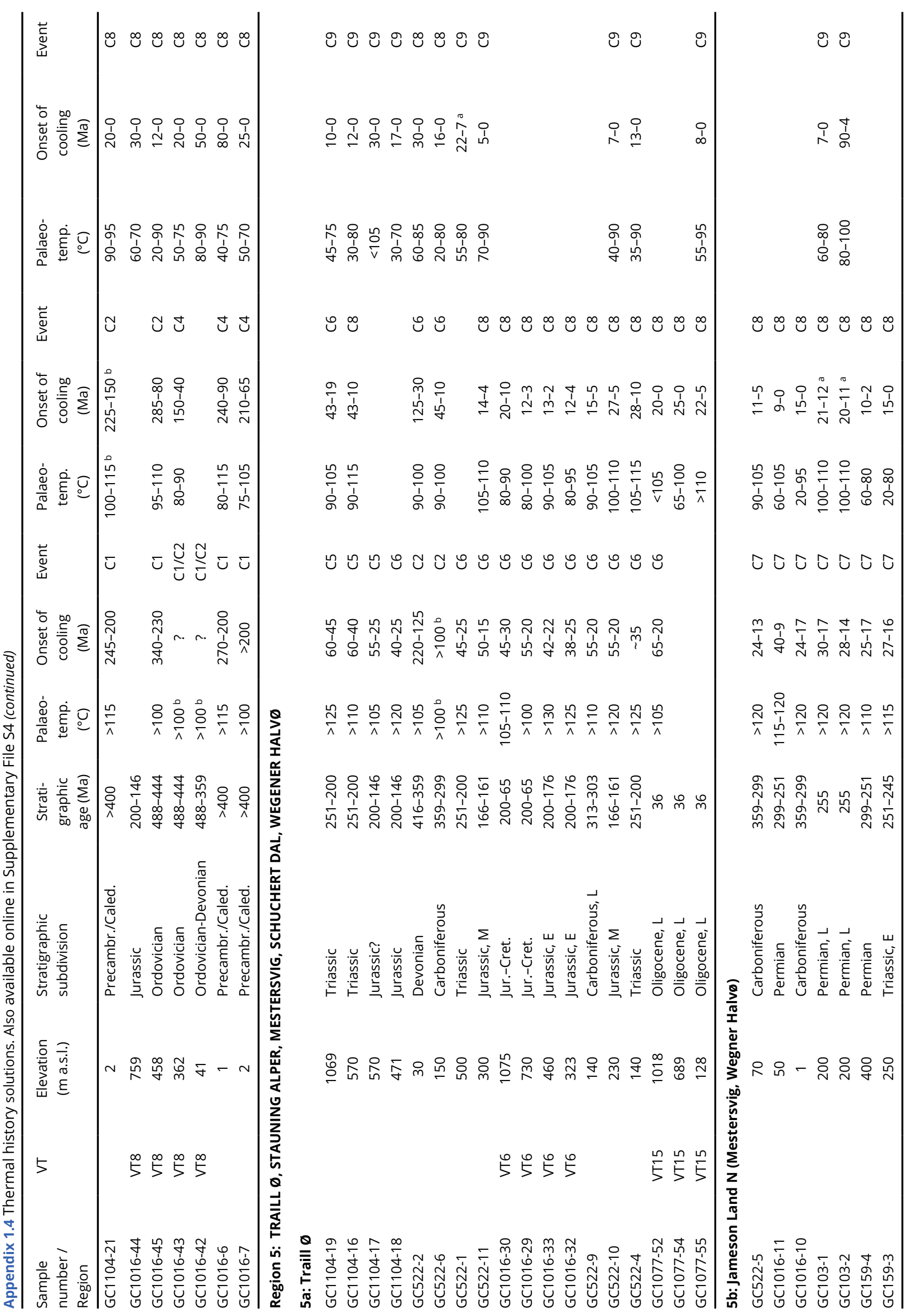




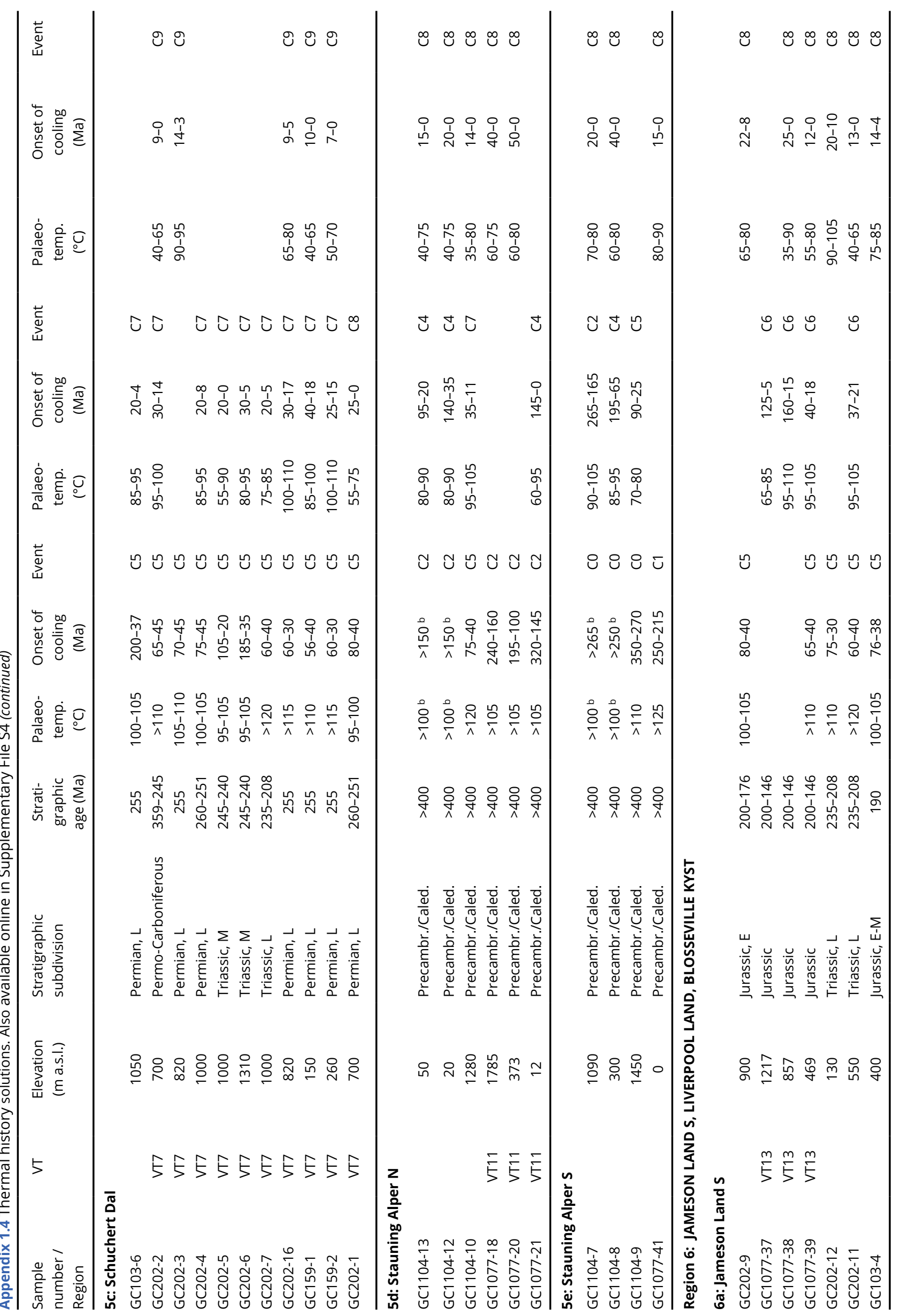




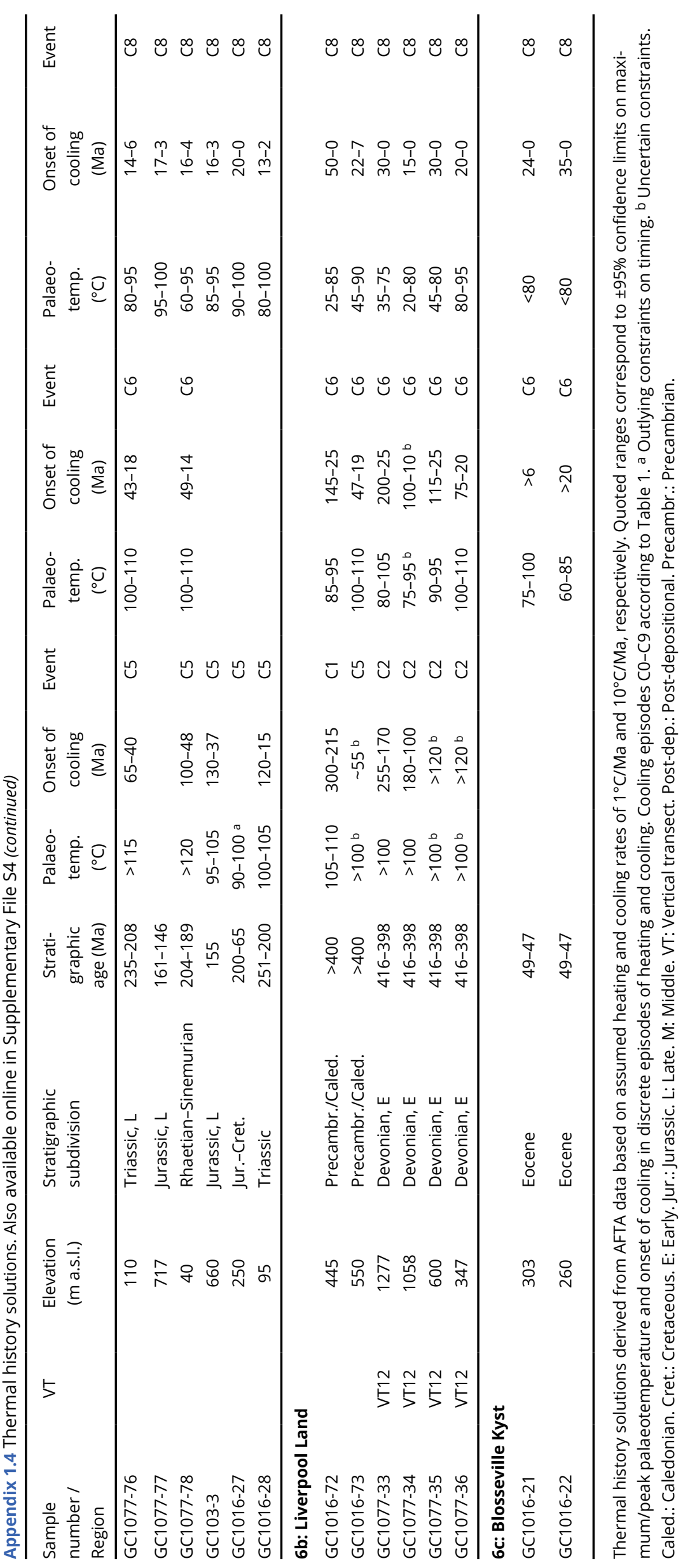


Appendix 1.5 Maximum palaeotemperatures from VR data in outcrop samples. Also available online in Supplementary File S4

\begin{tabular}{|c|c|c|c|c|c|c|c|c|c|c|c|c|}
\hline $\begin{array}{l}\text { Sample } \\
\text { number } \\
\text { GC1077- }\end{array}$ & $\begin{array}{l}\text { Source } \\
\text { number }\end{array}$ & Locality & Latitude & Longitude & $\begin{array}{l}\text { Elevation } \\
\text { (m a.s.l.) }\end{array}$ & $\begin{array}{l}\text { Stratigraphic } \\
\text { subdivision }\end{array}$ & $\begin{array}{l}\text { Strat. } \\
\text { age } \\
\text { (Ma) }\end{array}$ & $\begin{array}{c}\mathrm{R}_{0} \max \\
\text { (range) } \\
(\%)\end{array}$ & $\begin{array}{l}\text { Eq. VR } \\
\text { from IR } \\
(\%)^{a}\end{array}$ & $\mathrm{~N}^{\mathrm{b}}$ & $\begin{array}{l}\text { Max. } \\
\text { palaeo- } \\
\text { temp. } \\
\left({ }^{\circ} \mathrm{C}\right)^{c}\end{array}$ & $\begin{array}{l}\text { Cooling } \\
\text { episode }\end{array}$ \\
\hline 106.1 & 118352 & $\begin{array}{l}\text { Cardiocer- } \\
\text { asdal, } \\
\text { Wollaston } \\
\text { Forland }\end{array}$ & 74.454 & -20.140 & 415 & $\begin{array}{l}\text { Bernbjerg Fm } \\
\text { (Oxfordian - } \\
\text { Kimmeridgian) }\end{array}$ & $161-151$ & $\begin{array}{c}0.59 \\
(0.51- \\
0.68)\end{array}$ & & 25 & 97 & C4 \\
\hline 107.1 & 118461 & $\begin{array}{l}\text { Cardiocer- } \\
\text { asdal, } \\
\text { Wollaston } \\
\text { Forland }\end{array}$ & 74.463 & -20.165 & 400 & $\begin{array}{l}\text { Bernbjerg Fm } \\
\text { (Oxfordian - } \\
\text { Kimmeridgian) }\end{array}$ & $161-151$ & $\begin{array}{c}0.54 \\
(0.42- \\
0.68)\end{array}$ & & 25 & 90 & C4 \\
\hline 108.1 & 118473 & $\begin{array}{l}\text { Cardiocer- } \\
\text { asdal, } \\
\text { Wollaston } \\
\text { Forland }\end{array}$ & 74.463 & -20.165 & 400 & $\begin{array}{l}\text { Bernbjerg Fm } \\
\text { (Oxfordian - } \\
\text { Kimmeridgian) }\end{array}$ & $161-151$ & $\begin{array}{c}0.47 \\
(0.37- \\
0.56)\end{array}$ & & 25 & 79 & C4 \\
\hline 109.1 & 327654 & $\begin{array}{l}\text { Kap Stosch, } \\
\text { Hold With } \\
\text { Hope }\end{array}$ & 74.050 & -21.700 & 50 & $\begin{array}{l}\text { Ravnefjeld Fm } \\
\text { (Permian) }\end{array}$ & $251-299$ & $\begin{array}{c}0.39 \\
(0.26- \\
0.58)\end{array}$ & & 25 & 65 & \\
\hline 110.1 & 427850 & $\begin{array}{l}\text { Stensbyb- } \\
\text { jerg, Gulelv } \\
\text { Hold With } \\
\text { Hope }\end{array}$ & 73.900 & -21.211 & 400 & $\begin{array}{c}\text { Bernbjerg Fm } \\
\text { (Late Oxfordian - } \\
\text { Early } \\
\text { Kimmeridgian) }\end{array}$ & 157-154 & $\begin{array}{c}0.48 \\
(0.39- \\
0.62)\end{array}$ & & 25 & 80 & C6 \\
\hline 111.1 & 427851 & $\begin{array}{l}\text { Stensbyb- } \\
\text { jerg, Gulelv } \\
\text { Hold With } \\
\text { Hope }\end{array}$ & 73.900 & -21.211 & 400 & $\begin{array}{c}\text { Bernbjerg Fm } \\
\text { (Late Oxfordian - } \\
\text { Early } \\
\text { Kimmeridgian) }\end{array}$ & 157-154 & $\begin{array}{c}0.50 \\
(0.44- \\
0.61)\end{array}$ & & 25 & 83 & C6 \\
\hline 112.1 & 468940 & $\begin{array}{c}\text { Sabine } \varnothing, \\
\text { Pendulum } \\
\varnothing \text { Øer }\end{array}$ & 74.578 & -18.987 & 180 & Paleocene & $66-56$ & $\begin{array}{c}0.62 \\
(0.51- \\
0.71)\end{array}$ & & 25 & 102 & C6 \\
\hline 113.1 & 468950 & $\begin{array}{c}\text { Sabine } \varnothing, \\
\text { Pendulum } \\
\varnothing \text { Øer }\end{array}$ & 74.567 & -18.987 & 400 & Paleocene & $66-56$ & $\begin{array}{c}0.72 \\
(0.64- \\
0.83)\end{array}$ & & 16 & 118 & C6 \\
\hline 114.1 & 468951 & $\begin{array}{c}\text { Sabine } \varnothing, \\
\text { Pendulum } \\
\varnothing \text { er }\end{array}$ & 74.567 & -18.987 & 400 & Paleocene & $66-56$ & $\begin{array}{c}0.68 \\
(0.60- \\
0.78)\end{array}$ & & 25 & 113 & C6 \\
\hline 115.1 & 468954 & $\begin{array}{c}\text { Sabine } \varnothing, \\
\text { Pendulum } \\
\varnothing \text { Øer }\end{array}$ & 74.566 & -18.989 & 445 & Paleocene & $66-56$ & $\begin{array}{c}0.75 \\
(0.62- \\
0.85)\end{array}$ & & 25 & 122 & C6 \\
\hline 116.1 & 569833 & $\begin{array}{l}\text { Brorson } \\
\text { Halvø, } \\
\text { Wollaston } \\
\text { Forland }\end{array}$ & 74.598 & -19.588 & 175 & $\begin{array}{c}\text { Bernbjerg Fm } \\
\text { (L. Jurassic) }\end{array}$ & $161-146$ & $\begin{array}{c}0.64 \\
(0.55- \\
0.72)\end{array}$ & & 25 & 106 & C6 \\
\hline 117.1 & 469856 & $\begin{array}{l}\text { Brorson } \\
\text { Halvø, } \\
\text { Wollaston } \\
\text { Forland }\end{array}$ & 74.598 & -19.588 & 175 & Cretaceous, M & $145-65$ & $\begin{array}{c}0.65 \\
(0.56- \\
0.77)\end{array}$ & & 25 & 108 & C6 \\
\hline 118.1 & 469857 & $\begin{array}{c}\text { Brorson } \\
\text { Halvø, } \\
\text { Wollaston } \\
\text { Forland }\end{array}$ & 74.598 & -19.588 & 175 & Cretaceous, M & $145-65$ & $\begin{array}{c}0.62 \\
(0.52- \\
0.71)\end{array}$ & & 14 & 100 & C6 \\
\hline 119.1 & 470117 & $\begin{array}{l}\text { Dronning } \\
\text { Augusta Dal, } \\
\text { Wollaston } \\
\text { Forland }\end{array}$ & 74.343 & -19.347 & 304 & Thanetian & $59-56$ & $\begin{array}{c}0.46 \\
(0.36- \\
0.63)\end{array}$ & & 25 & 78 & C6 \\
\hline
\end{tabular}


Appendix 1.5 Maximum palaeotemperatures from VR data in outcrop samples. Also available online in Supplementary File S4 (continued)

\begin{tabular}{|c|c|c|c|c|c|c|c|c|c|c|c|c|}
\hline $\begin{array}{l}\text { Sample } \\
\text { number } \\
\text { GC1077- }\end{array}$ & $\begin{array}{l}\text { Source } \\
\text { number }\end{array}$ & Locality & Latitude & Longitude & $\begin{array}{c}\text { Elevation } \\
\text { (m a.s.l.) }\end{array}$ & $\begin{array}{l}\text { Stratigraphic } \\
\text { subdivision }\end{array}$ & $\begin{array}{l}\text { Strat. } \\
\text { age } \\
\text { (Ma) }\end{array}$ & $\begin{array}{c}\mathrm{R}_{0} \max \\
\text { (range) } \\
(\%)\end{array}$ & $\begin{array}{l}\text { Eq. VR } \\
\text { from IR } \\
(\%)^{a}\end{array}$ & $\mathrm{Nb}$ & $\begin{array}{l}\text { Max. } \\
\text { palaeo- } \\
\text { temp. } \\
\left({ }^{\circ} \mathrm{C}\right)^{\mathrm{c}}\end{array}$ & $\begin{array}{l}\text { Cooling } \\
\text { episode }\end{array}$ \\
\hline 120.1 & 470118 & $\begin{array}{c}\text { Dronning } \\
\text { Augusta Dal, } \\
\text { Wollaston } \\
\text { Forland }\end{array}$ & 74.343 & -19.347 & 304 & Thanetian & $59-56$ & $\begin{array}{c}0.43 \\
(0.34- \\
0.51)\end{array}$ & & 25 & 72 & C6 \\
\hline 121.1 & 470121 & $\begin{array}{l}\text { Dronning } \\
\text { Augusta Dal, } \\
\text { Wollaston } \\
\text { Forland }\end{array}$ & 74.343 & -19.347 & 304 & Thanetian & $59-56$ & $\begin{array}{c}0.48 \\
(0.40- \\
0.55)\end{array}$ & & 5 & 80 & C6 \\
\hline 122.1 & 472012 & $\begin{array}{c}\text { Aucella } \\
\text { Bjerg, } \\
\text { Wollaston } \\
\text { Forland }\end{array}$ & 74.524 & -20.466 & 700 & $\begin{array}{l}\text { E. Aptian - E. } \\
\text { Albian }\end{array}$ & $125-112$ & $\begin{array}{c}0.51 \\
(0.41- \\
0.61)\end{array}$ & & 25 & 84 & $\mathrm{C} 4$ \\
\hline 123.1 & 472014 & $\begin{array}{c}\text { Aucella } \\
\text { Bjerg, } \\
\text { Wollaston } \\
\text { Forland }\end{array}$ & 74.524 & -20.466 & 700 & $\begin{array}{l}\text { E. Aptian - E. } \\
\text { Albian }\end{array}$ & $125-112$ & $\begin{array}{c}0.47 \\
(0.41- \\
0.54)\end{array}$ & & 25 & 79 & $\mathrm{C} 4$ \\
\hline 124.1 & 472016 & $\begin{array}{c}\text { Aucella } \\
\text { Bjerg, } \\
\text { Wollaston } \\
\text { Forland }\end{array}$ & 74.524 & -20.466 & 700 & $\begin{array}{l}\text { E. Aptian - E. } \\
\text { Albian }\end{array}$ & $125-112$ & $\begin{array}{c}0.43 \\
(0.33- \\
0.53)\end{array}$ & & 25 & 72 & $\mathrm{C} 4$ \\
\hline 125.1 & 492906 & $\begin{array}{c}\text { Djæv- } \\
\text { lekløften, } \\
\text { Clavering } \varnothing\end{array}$ & 74.359 & -20.576 & 457 & Cretaceous, M? & $145-65$ & $\begin{array}{c}4.36 \\
(4.01- \\
5.01)\end{array}$ & & 25 & $>250$ & C6 \\
\hline 126.1 & 492907 & $\begin{array}{c}\text { Djæv- } \\
\text { lekløften, } \\
\text { Clavering } \varnothing\end{array}$ & 74.359 & -20.576 & 457 & Cretaceous, M? & $145-65$ & $\begin{array}{c}4.45 \\
(3.94- \\
5.04)\end{array}$ & & 25 & $>250$ & $\mathrm{C} 6$ \\
\hline 127.1 & 492930 & $\begin{array}{l}\text { Dolomitdal, } \\
\text { Clavering } \emptyset\end{array}$ & 74.378 & -20.593 & 304 & Cretaceous & $145-65$ & 0,5 & & 1 & 83 & $\mathrm{C} 6$ \\
\hline 128.1 & 492931 & $\begin{array}{l}\text { Dolomitdal, } \\
\text { Clavering } \emptyset\end{array}$ & 74.378 & -20.593 & 304 & Cretaceous & $145-65$ & $\begin{array}{c}1.42 \\
(0.84- \\
1.86)\end{array}$ & 0.54 & 25 & 90 & $\mathrm{C} 6$ \\
\hline 129.1 & 492933 & $\begin{array}{l}\text { Dolomitdal, } \\
\text { Clavering } \varnothing\end{array}$ & 74.378 & -20.593 & 304 & Cretaceous & $145-65$ & $\begin{array}{c}0.54 \\
(0.45- \\
0.61)\end{array}$ & & 25 & 90 & $\mathrm{C} 6$ \\
\hline 130.1 & 493938 & $\begin{array}{c}\text { Store } \\
\text { Koldewey }\end{array}$ & 76.232 & -18.579 & 80 & Cretaceous & $145-65$ & $\begin{array}{c}0.55 \\
(0.44- \\
0.68)\end{array}$ & & 25 & 91 & $\mathrm{C} 4$ \\
\hline 131.1 & 493941 & $\begin{array}{c}\text { Store } \\
\text { Koldewey }\end{array}$ & 76.232 & -18.579 & 80 & Cretaceous & $145-65$ & $\begin{array}{c}0.55 \\
(0.49- \\
0.63)\end{array}$ & & 14 & 91 & $\mathrm{C} 4$ \\
\hline 132.1 & 493942 & $\begin{array}{c}\text { Store } \\
\text { Koldewey }\end{array}$ & 76.232 & -18.579 & 80 & Cretaceous & $145-65$ & $\begin{array}{c}0.54 \\
(0.43- \\
0.66)\end{array}$ & & 12 & 90 & $\mathrm{C} 4$ \\
\hline 133.1 & 493960 & $\begin{array}{c}\text { Store } \\
\text { Koldewey }\end{array}$ & 76.297 & -18.634 & 77 & Cretaceous & $145-65$ & $\begin{array}{c}0.43 \\
(0.36- \\
0.51)\end{array}$ & & 25 & 72 & $\mathrm{C} 4$ \\
\hline 134.1 & 493961 & $\begin{array}{c}\text { Store } \\
\text { Koldewey }\end{array}$ & 76.297 & -18.634 & 77 & Cretaceous & $145-65$ & $\begin{array}{c}0.51 \\
(0.42- \\
0.59)\end{array}$ & & 6 & 84 & $\mathrm{C} 4$ \\
\hline
\end{tabular}


Appendix 1.5 Maximum palaeotemperatures from VR data in outcrop samples. Also available online in Supplementary File S4 (continued)

\begin{tabular}{|c|c|c|c|c|c|c|c|c|c|c|c|c|}
\hline $\begin{array}{l}\text { Sample } \\
\text { number } \\
\text { GC1077- }\end{array}$ & $\begin{array}{l}\text { Source } \\
\text { number }\end{array}$ & Locality & Latitude & Longitude & $\begin{array}{l}\text { Elevation } \\
\text { (m a.s.l.) }\end{array}$ & $\begin{array}{l}\text { Stratigraphic } \\
\text { subdivision }\end{array}$ & $\begin{array}{l}\text { Strat. } \\
\text { age } \\
(\mathrm{Ma})\end{array}$ & $\begin{array}{c}\mathrm{R}_{0} \max \\
\text { (range) } \\
(\%)\end{array}$ & $\begin{array}{l}\text { Eq. VR } \\
\text { from IR } \\
(\%)^{a}\end{array}$ & $\mathrm{Nb}$ & $\begin{array}{l}\text { Max. } \\
\text { palaeo- } \\
\text { temp. } \\
\left({ }^{\circ} \mathrm{C}\right)^{\mathrm{c}}\end{array}$ & $\begin{array}{l}\text { Cooling } \\
\text { episode }\end{array}$ \\
\hline 135.1 & 493962 & $\begin{array}{c}\text { Store } \\
\text { Koldewey }\end{array}$ & 76.297 & -18.634 & 77 & Cretaceous & $145-65$ & $\begin{array}{c}0.58 \\
(0.55- \\
0.60)\end{array}$ & & 2 & 96 & C4 \\
\hline 136.1 & 495913 & $\begin{array}{c}\text { Store } \\
\text { Koldewey }\end{array}$ & 76.143 & -18.542 & 77 & Cretaceous & $145-65$ & $\begin{array}{c}0.51 \\
(0.40- \\
0.64)\end{array}$ & & 25 & 84 & C4 \\
\hline 137.1 & 495915 & $\begin{array}{c}\text { Store } \\
\text { Koldewey }\end{array}$ & 76.143 & -18.542 & 77 & Cretaceous & $145-65$ & $\begin{array}{c}0.51 \\
(0.41- \\
0.64)\end{array}$ & & 25 & 84 & C4 \\
\hline 138.1 & 495915 & $\begin{array}{c}\text { Store } \\
\text { Koldewey }\end{array}$ & 76.143 & -18.542 & 77 & Cretaceous & $145-65$ & $\begin{array}{c}0.51 \\
(0.41- \\
0.62)\end{array}$ & & 25 & 84 & C4 \\
\hline 139.1 & 516065 & $\begin{array}{l}\text { Kap Ehren- } \\
\text { berg, Payer } \\
\text { Land }\end{array}$ & 74.413 & -21.867 & 120 & Carboniferous & $359-299$ & & 0.73 & 25 & 120 & \\
\hline 140.1 & 516083 & $\begin{array}{l}\text { Kuplen, } \\
\text { Wollaston } \\
\text { Forland }\end{array}$ & 74.342 & -20.086 & 327 & E. Cretaceous & $146-100$ & $\begin{array}{c}0.61 \\
(0.53- \\
0.68)\end{array}$ & & 7 & 100 & C6 \\
\hline 141.1 & 516085 & $\begin{array}{l}\text { Kap Schum- } \\
\text { acher, } \\
\text { Wollaston } \\
\text { Forland }\end{array}$ & 74.645 & -20.054 & 50 & L. Jurassic & $161-146$ & $\begin{array}{c}0.54 \\
(0.40- \\
0.67)\end{array}$ & & 25 & 90 & C6 \\
\hline 142.1 & 517106 & $\begin{array}{c}\text { Store } \\
\text { Koldewey }\end{array}$ & 76.380 & -18.728 & 54 & Barremian & $130-125$ & $\begin{array}{c}0.49 \\
(0.39- \\
0.60)\end{array}$ & & 25 & 81 & C4 \\
\hline 143.1 & 517107 & $\begin{array}{c}\text { Store } \\
\text { Koldewey }\end{array}$ & 76.380 & -18.728 & 54 & Barremian & $130-125$ & $\begin{array}{c}0.48 \\
(0.41- \\
0.56)\end{array}$ & & 25 & 80 & C4 \\
\hline 144,1 & 523402 & $\begin{array}{l}\text { Stensbyb- } \\
\text { jerg, Hold } \\
\text { With Hope }\end{array}$ & 73.918 & -21.157 & 770 & $\begin{array}{l}\text { Stensbybjerg Fm } \\
\text { Rødelv Mb } \\
\text { (Aptian - Early } \\
\text { Albian) }\end{array}$ & $125-108$ & $\begin{array}{c}0.54 \\
(0.41- \\
0.65)\end{array}$ & & 25 & 90 & C6 \\
\hline 145.1 & 523404 & $\begin{array}{l}\text { Stensbyb- } \\
\text { jerg, Hold } \\
\text { With Hope }\end{array}$ & 73.918 & -21.157 & 770 & $\begin{array}{l}\text { Stensbybjerg Fm } \\
\text { Gulelv Mb } \\
\text { (Late Barremian - } \\
\text { Aptian) }\end{array}$ & 127-125 & $\begin{array}{c}0.46 \\
(0.32- \\
0.57)\end{array}$ & & 3 & 78 & C6 \\
\hline
\end{tabular}

a Equivalent VR derived from mean inertinite reflectance. ${ }^{b}$ Number of fields measured. A target of 25 fields is usually considered to characterise an analysis of the highest quality. c All estimates of maximum palaeotemperature were determined using an assumed heating rate of $1^{\circ} \mathrm{C} / \mathrm{Myr}$ (Sweeney \& Burnham 1990). Cooling episodes C0-C9 according to Table 1. 


\section{Timing constraints derived from AFTA data in individual samples}

The constraints are organised into six regions (Appendix 1.6.1-1.6.6) from north to south along the coast, locations in Fig. 11A. Horizontal coloured bars represent $95 \%$ confidence intervals on the onset of cooling, as illustrated in Appendix 1.1. Vertical columns represent the constraints for the onset of each of the ten regional cooling episodes defined assuming that the episodes are regionally synchronous (Table 1). Time-temperature constraints for each sample are listed in Appendix 1.4.

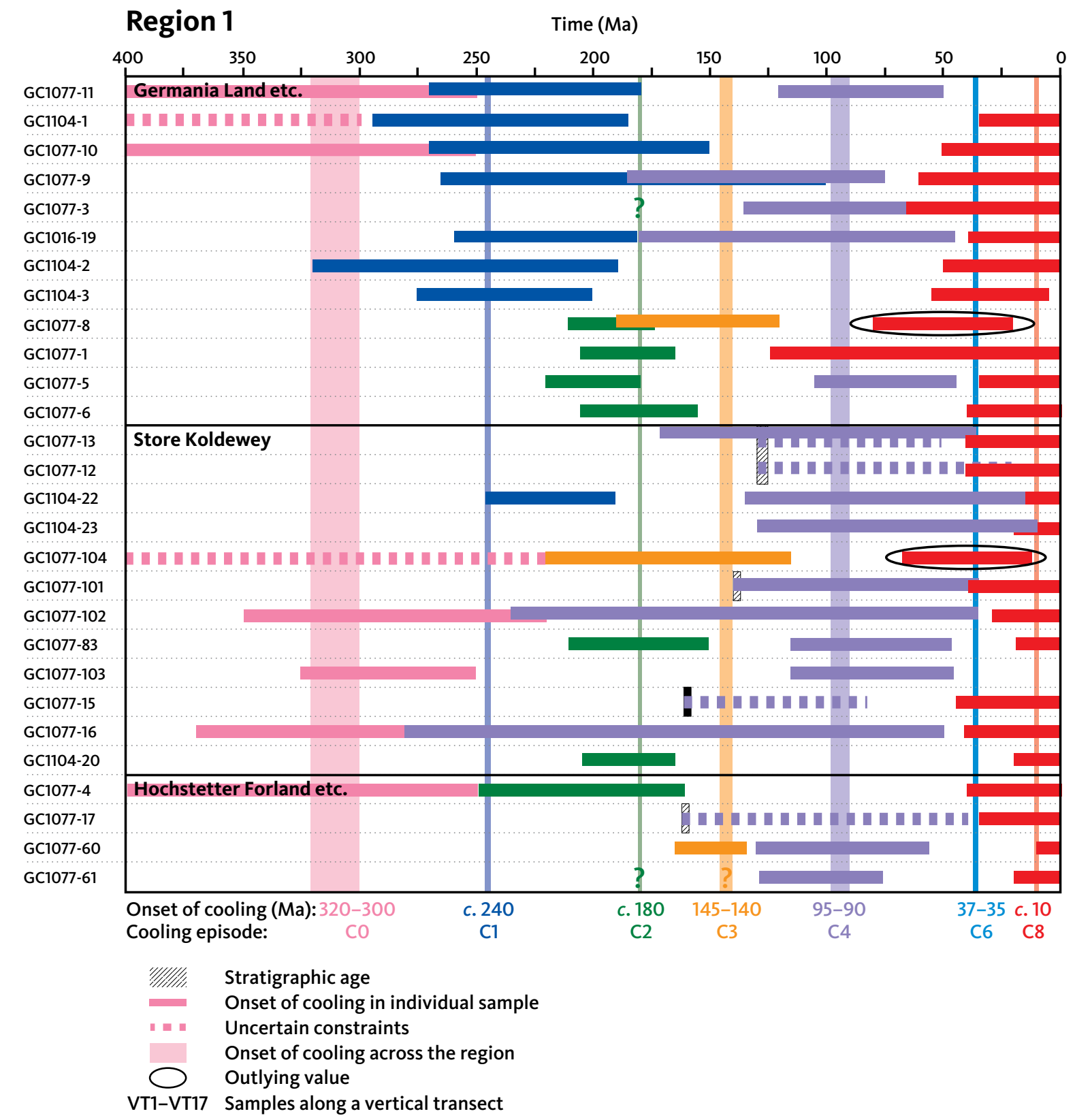

Appendix 1.6.1 Timing constraints derived from AFTA data in individual samples in region 1. 


\section{Region 2}

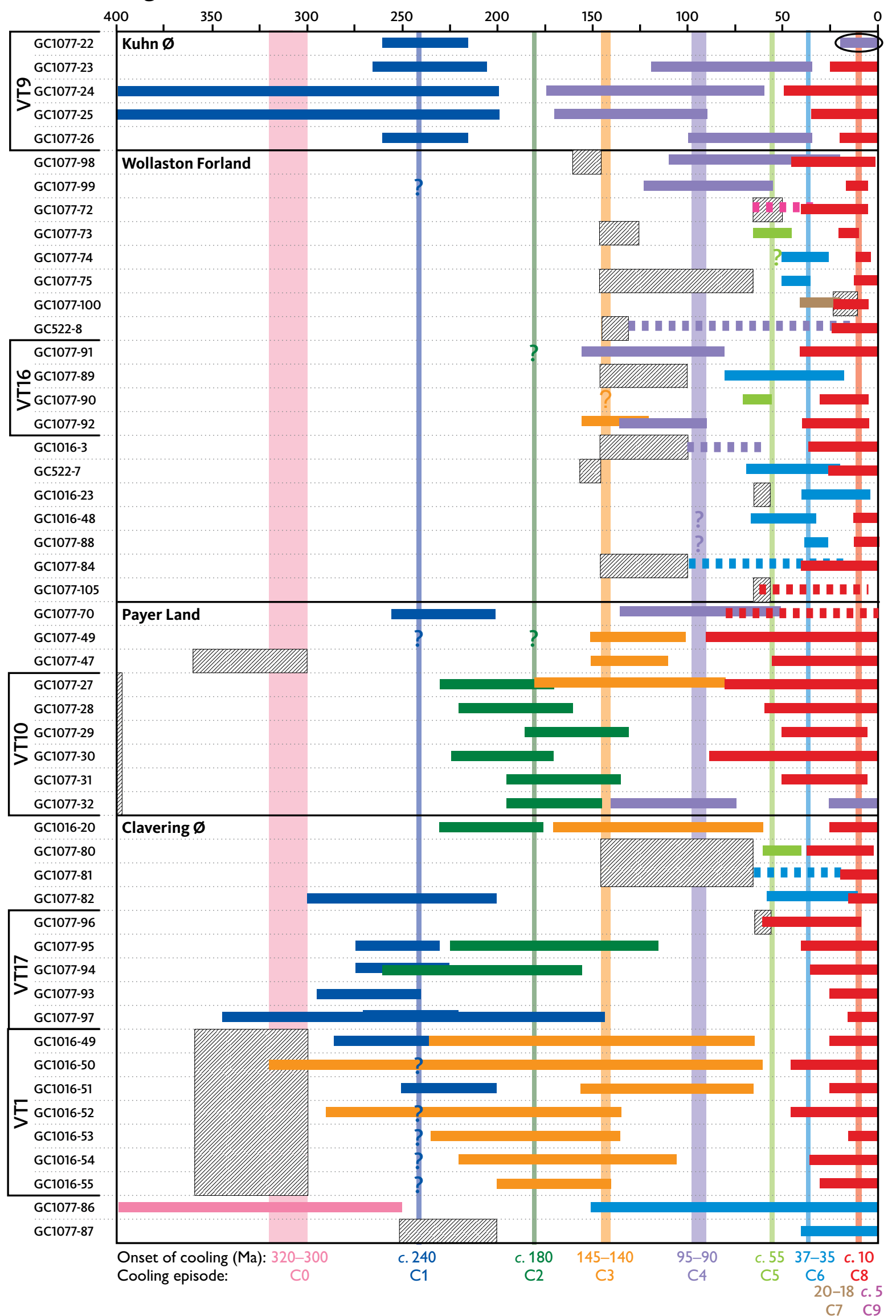

Appendix 1.6.2 Timing constraints derived from AFTA data in individual samples in region 2. 


\section{Region 3}

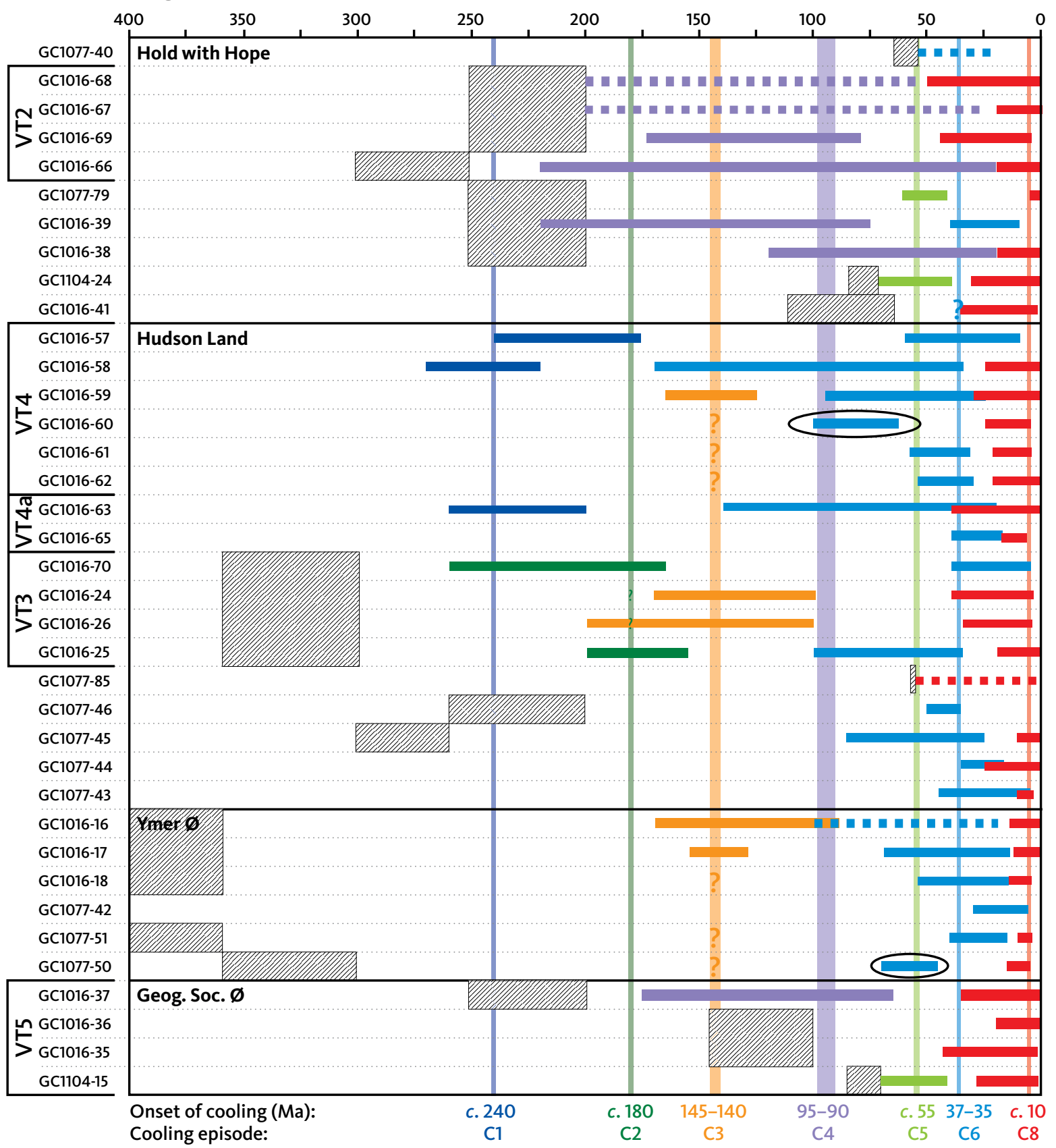

Appendix 1.6.3 Timing constraints derived from AFTA data in individual samples in region 3. 


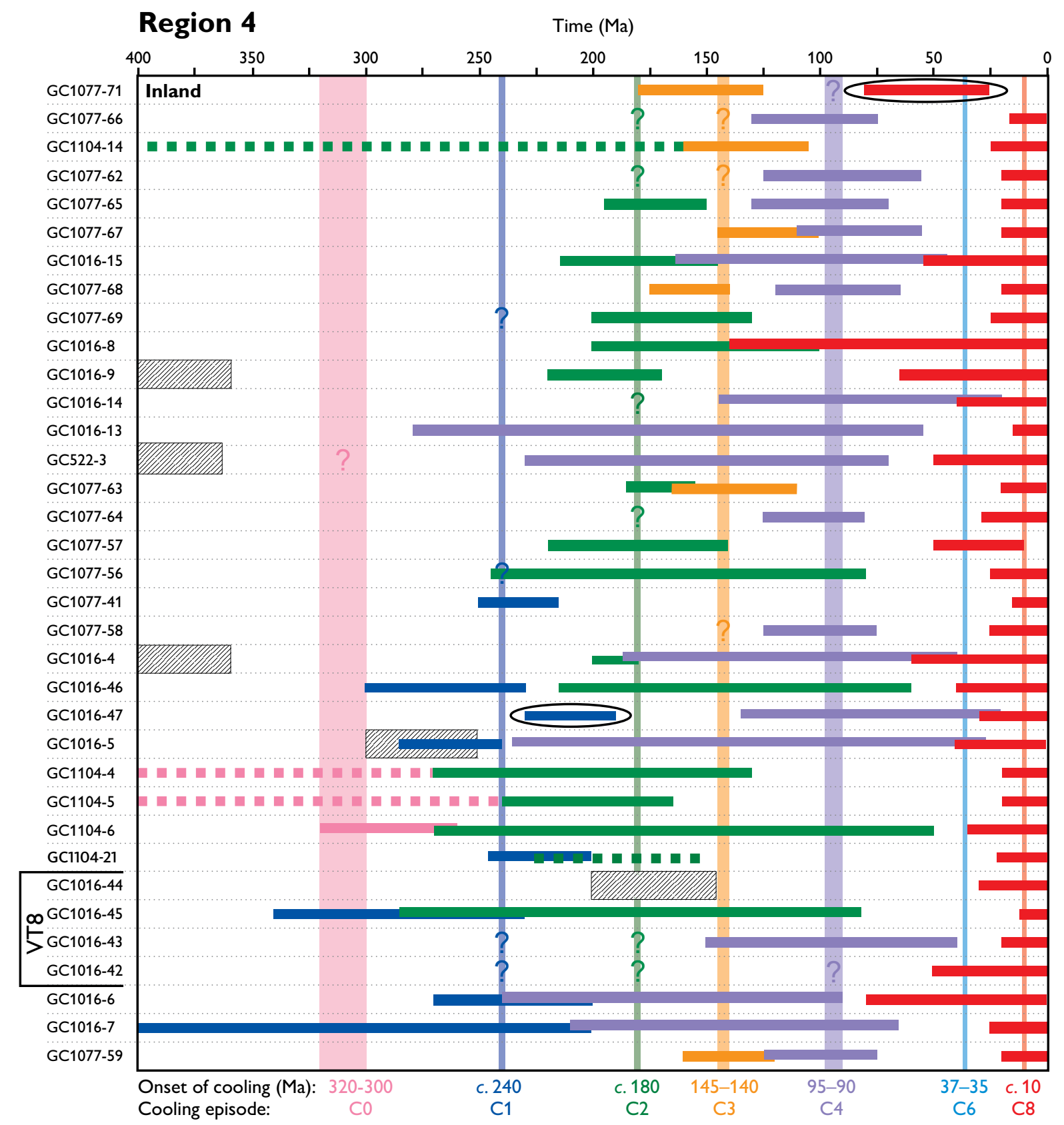

Appendix 1.6.4 Timing constraints derived from AFTA data in individual samples in region 4. 


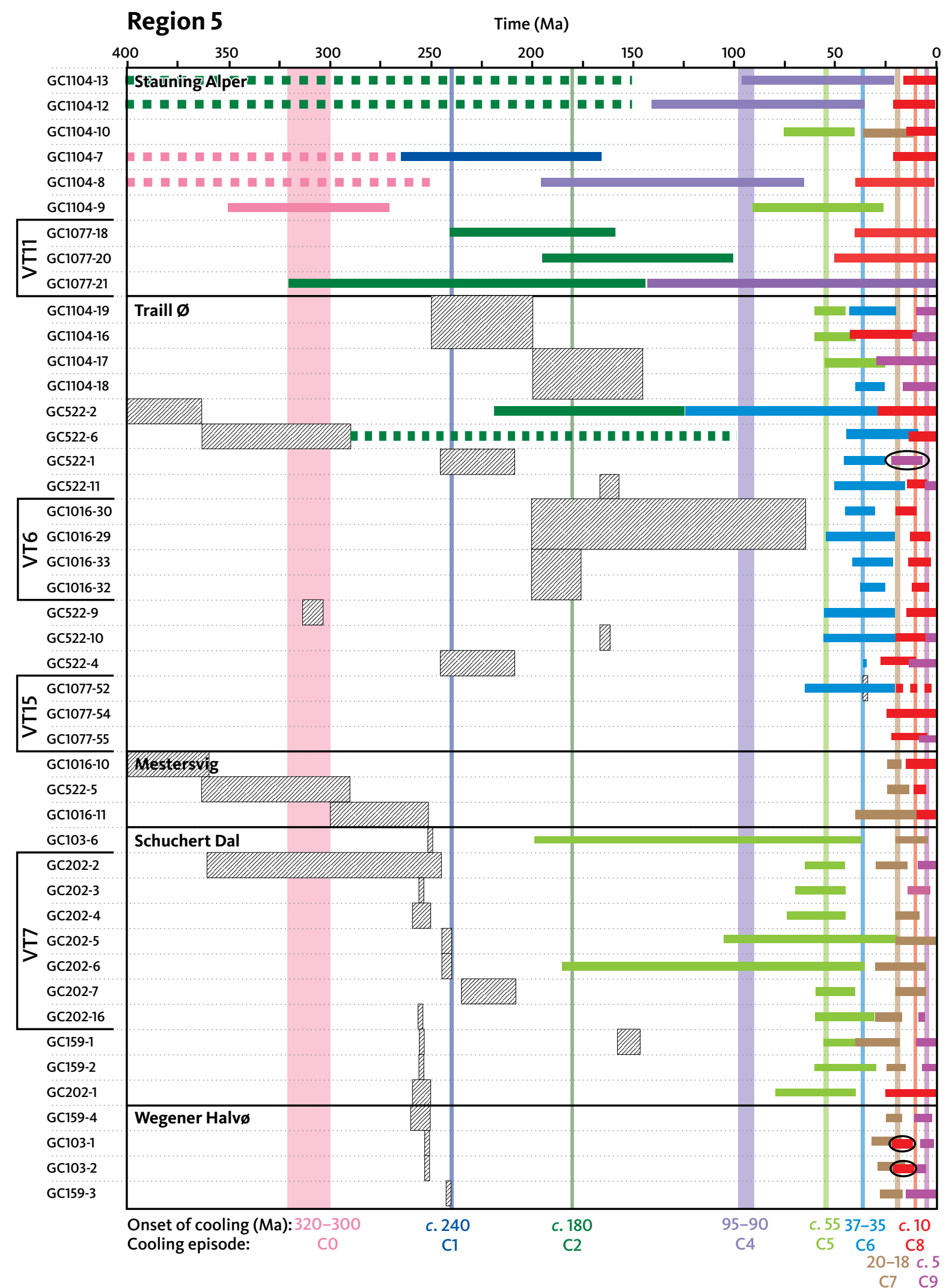

Appendix 1.6.5 Timing constraints derived from AFTA data in individual samples in region 5. 


\section{Region 6}

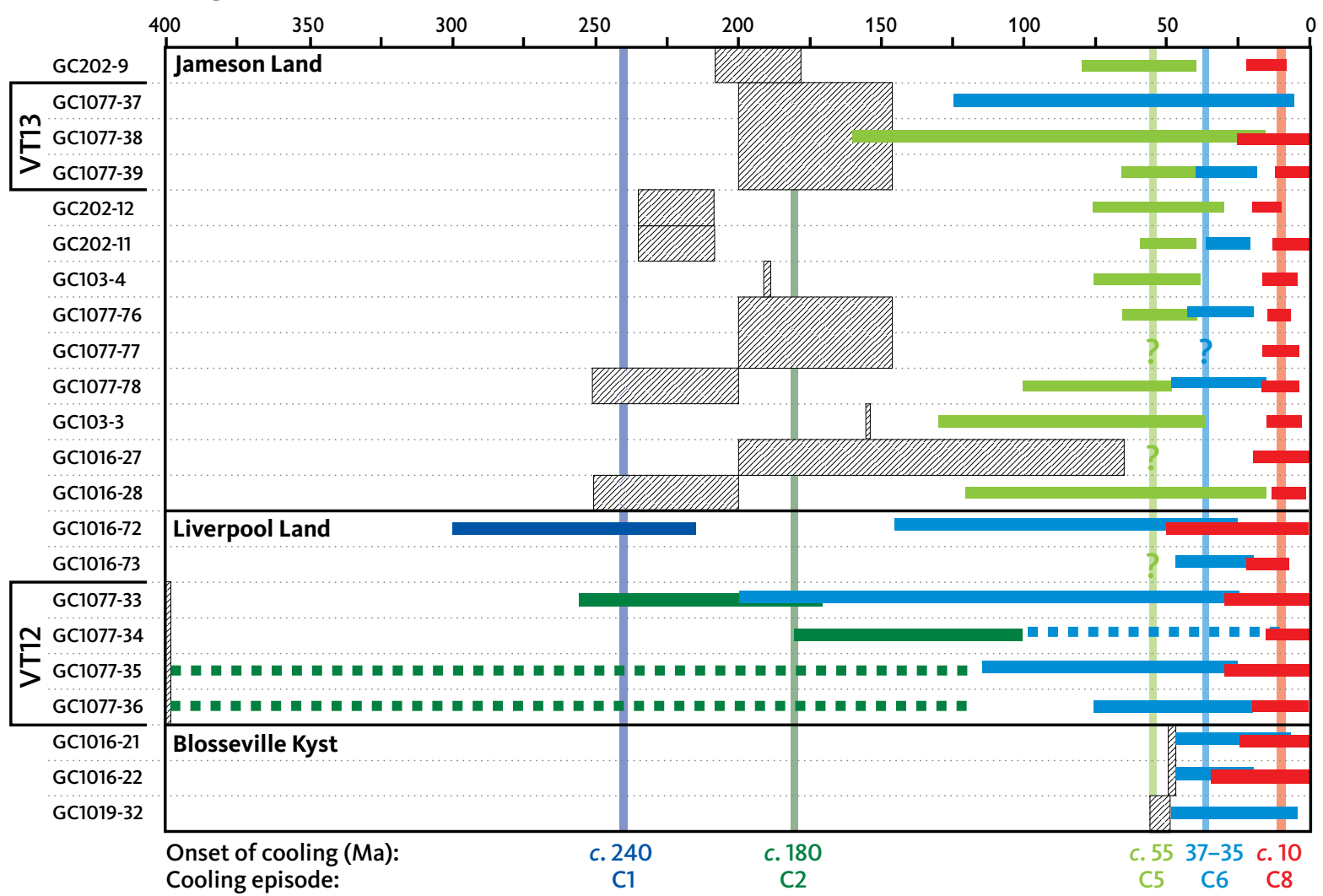

Appendix 1.6.6 Timing constraints derived from AFTA data in individual samples in region 6. 
www.geusbulletin.org

Appendix 1.7 Thermal history interpretations for samples of the Traill Ø region. Also available online in Supplementary File S4

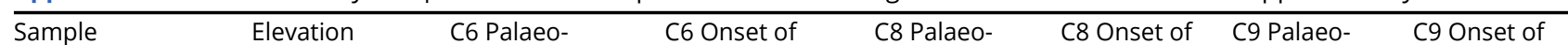
number (m a.s.l.) temp. cooling temp. cooling temp. cooling

$\left({ }^{\circ} \mathrm{C}\right)$

(Ma)

$\left({ }^{\circ} \mathrm{C}\right)$

(Ma)

$\left({ }^{\circ} \mathrm{C}\right)$

(Ma)

\section{Zone 0}

GC522-6

150

$90-100$

45-10

20-80

16-0

GC522-2

30

90-100

125-30

60-85

30-0

GC1016-14

1

GC1016-16

GC1016-17

70-90 b

100-20 b

30-80

40-0

GC1016-18

85-95

70-15

70-80

15-0

1

95-105

55-15

50-75

12-0

\section{Zone 1}

GC1016-37

850

GC1016-36

370

GC1016-35

300

GC1077-50

255

160

140

103

$100-105$
$>105$
$>110$
$100-110$

Zone 2

GC1016-30

1075

105-110

90-105

$>100$

$>105$

GC1016-29

1069

730

570

570

GC1104-16

570

GC1104-15

460

323

230

\section{4}

70-90

15-5

GC1016-32

$>130$

$>125$

$>120$

$70-45^{a}$
$30-5 a$
$55-20$
$40-15$

65-85

35-0

40-85

20-0

80-85

$32-2$

90-95

15-5

GC522-10

Zone 3

GC1077-52

1018

$>105$

45-30

43-19

90-105

15-5

80-95

10-3

GC1077-54

689

55-20

55-25

GC522-1

500

$>125$

$>120$

$>110$

GC522-11

471

$>125$

42-22

38-25

55-20

80-90

20-10

80-100

45-75

10-0

$12-3$

90-115

$<105$

30-0

43-10

30-80

12-0

45-75

30-0

GC522-4

140

128

90-105

13-2

80-95

12-4

100-110

27-5

40-90

7-0

GC1077-55

65-20

$<105 b$

20-0 b

65-100

25-0

45-25

40-25

105-110

14-4

55-80

$22-7^{a}$

50-15

105-115

28-10

30-70

17-0

$\sim 35$

$>110$

22-5

70-90

5-0

$35-90$

13-0

55-95

$8-0$

Zones 0-3 are defined in Figure 32. Cooling episodes C6, C8 and C9 according to Table 1. a Outlying constraints on timing. b Uncertain constraints. 


\section{Appendix 2 Results from vertical transects}

\section{Individual vertical transects}

Samples were collected along 17 near-vertical transects (VT1 to VT17; locations in Appendix 2.1). Geological constraints on the burial and exhumation history for the samples in each vertical transect are summarised in Appendix 2.2. For each transect we omitted samples from too wide a horizontal distance to guard against lateral variation in the magnitude of palaeothermal effects, which might arise due to variation in heat flow, differential uplift (tilting) or offsets across major faults.

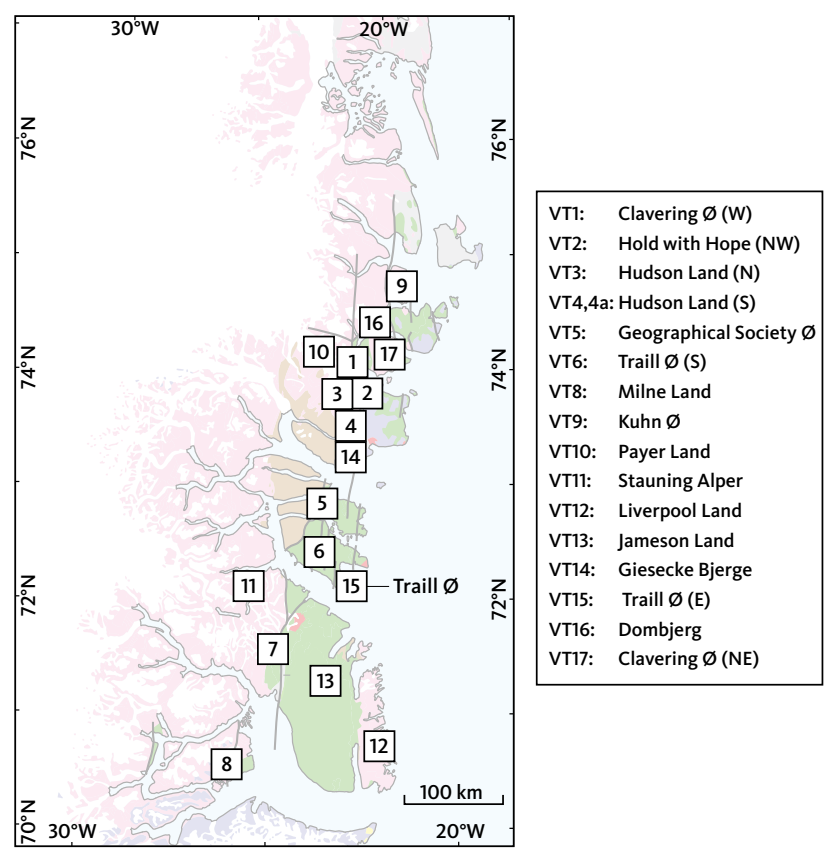

Appendix 2.1 Location of vertical transects VT1 to VT14.
Comparison of results from adjacent profiles shows that this approach is justified. The palaeothermal constraints for the samples along each transect are shown in Appendix 2.3. For a number of these transects, sufficient constraints are available to justify quantitative determination of palaeogeothermal gradients and removed sections (Appendix 2.4). Palaeotemperature constraints for the Mesozoic and end-Eocene episodes from the various transects are compared in Appendix 2.5. 
www.geusbulletin.org

Appendix 2.2 Geological constraints on the burial and exhumation history of vertical transects provided in Appendix 2.3. Locations in Appendix 2.1

\begin{tabular}{|c|c|c|c|c|}
\hline VT & Area & Palaeozoic & Mesozoic & Cenozoic \\
\hline VT1 & Clavering $\varnothing(\mathrm{W})$ & $\begin{array}{l}\text { Upper Carboniferous sediments a } \\
\text { (on basement) }\end{array}$ & & Palaeogene basalts (summits) \\
\hline VT2 & Hold with Hope (NW) & $\begin{array}{l}\text { Upper Permian sediments a } \\
\text { (on basement) }\end{array}$ & Triassic sediments a & Palaeogene basalts (summits) \\
\hline VT3 & Hudson Land (N) & $\begin{array}{l}\text { Upper Carboniferous sediments a } \\
\text { (on basement) }\end{array}$ & & \\
\hline VT4 & Hudson Land (E) & & & \\
\hline VT5 & Geographical Society $\varnothing$ & & $\begin{array}{c}\text { Triassic, Lower Cretaceous } \\
\text { sediments a }\end{array}$ & \\
\hline VT6 & Traill $\varnothing(S W)$ & & $\begin{array}{c}\text { Jurassic - Lower Cretaceous } \\
\text { sediments a }\end{array}$ & \\
\hline VT7 & Schuchert Dal & $\begin{array}{l}\text { Carboniferous-Permian } \\
\text { sediments a }\end{array}$ & Triassic sediments a & \\
\hline VT8 & Milne Land & & $\begin{array}{l}\text { Middle Jurassic sediments a } \\
\text { (on basement) }\end{array}$ & Palaeogene basalts (summits) \\
\hline VT9 & Kuhn $\varnothing$ & & $\begin{array}{l}\text { Middle Jurassic sediments } \\
\quad \text { (on basement) }\end{array}$ & Palaeogene basalts (summits) \\
\hline VT10 & Payer Land & & & \\
\hline VT11 & Stauning Alper & & & \\
\hline VT12 & Liverpool Land & $\begin{array}{l}\text { Sub-Permian peneplain along } \\
\text { western Liverpool Land }\end{array}$ & & \\
\hline VT13 & Jameson Land & & Jurassic sediments a & \\
\hline VT14 & Giesecke Bjerge & $\begin{array}{l}\text { Upper Permian sediments a } \\
\text { (on basement) }\end{array}$ & $\begin{array}{l}\text { Triassic - Lower Cretaceous a } \\
\text { sediments }\end{array}$ & Palaeogene basalts (summits) \\
\hline VT15 & Traill $\varnothing(E)$ & & & Palaeogene intrusives a \\
\hline VT16 & Dombjerg & & $\begin{array}{l}\text { Lower Cretaceous sediments a } \\
\text { (on basement) }\end{array}$ & Palaeogene basalts (summits) \\
\hline VT17 & Clavering $\varnothing(N E)$ & $\begin{array}{l}\text { Upper Permian carbonates } \\
\text { (on basement in the summits) }\end{array}$ & $\begin{array}{l}\text { Triassic - Lower Cretaceous } \\
\text { sediments (in nearby rift basin) }\end{array}$ & Palaeogene basalts (summits) \\
\hline
\end{tabular}

a Samples included in the vertical transect (other than basement samples). 
VT1: Clavering $\boldsymbol{\emptyset}(\mathbf{W})$. Seven samples of the Carboniferous Traill $\varnothing$ Group were collected over an elevation difference of c. $800 \mathrm{~m}$ from the south-west corner of Clavering $\varnothing$. The highest local summit reaches $1123 \mathrm{~m}$ a.s.l. where Palaeogene basalts are present here and at other summits in this region. AFTA data in samples from VT1 define three palaeothermal episodes: Middle Triassic (C1), earliest Cretaceous (C3) and late Miocene (C8).

Palaeotemperatures characterising the earliest Cretaceous and late Miocene palaeothermal episodes define linear profiles, broadly consistent with palaeogeothermal gradients of c. $25^{\circ} \mathrm{C} / \mathrm{km}$. The variation of Middle Triassic palaeotemperatures with elevation is not clear because all but the highest elevation sample were totally annealed in this episode. The linear variation of palaeotemperatures with elevation for the earliest Cretaceous and late Miocene episodes suggests that these palaeotemperatures reflect additional depth of burial, and that cooling was due predominantly to exhumation. No such insights are possible into the origin of palaeotemperatures characterising the Middle Triassic episode, but a similar conclusion seems likely.

The late Miocene palaeotemperature profile intersects the local summit level at c. $40^{\circ} \mathrm{C}$, which is higher than any reasonable value of surface temperature, implying that a significant amount of cover was present at the onset of this cooling episode. Since Palaeogene basalts are present in the summits, the additional burial required to explain the late Miocene palaeotemperatures must have been deposited after the preserved basalts were laid down. This most likely represented younger basalts together with Eocene-Miocene sedimentary units. Similarly, the earliest Cretaceous palaeotemperatures intersect the summit level at a value of c. $70^{\circ} \mathrm{C}$, implying that a considerable thickness of post-Carboniferous succession has been eroded on the unconformity below the Palaeogene basalts. The Middle Triassic palaeotemperatures intersect the summit level at $100-110^{\circ} \mathrm{C}$. Since all samples along VT1 are of Upper Carboniferous sediment, the heating to the Middle Triassic palaeotemperature was due to burial below Upper Carboniferous to Middle Triassic sediments. Note that the earliest Cretaceous and the late Miocene events are identified in all samples. This implies that the late Miocene palaeotemperatures are likely to be highly reliable.

VT2: Kap Stosch (Hold with Hope). Four samples of Permian and Triassic sedimentary rocks were collected over an elevation difference of c. $320 \mathrm{~m}$ at the northwest tip of Hold with Hope, north-west of the Spath Plateau, comprised of Palaeogene basalts. The local summit reaches $1211 \mathrm{~m}$ a.s.l. where thin Palaeogene basalts are present. Just to the south-east, the PermianTriassic succession is faulted against a huge thickness of Palaeogene basalts (Upton et al. 1980). AFTA data in samples from VT2 define two palaeothermal episodes: earliest Cretaceous (C3) and late Miocene (C8).

The range of elevations over which palaeotemperatures have been defined is not sufficiently large to define the variation of palaeotemperatures with elevation for each episode. However, palaeotemperatures in the mid-Cretaceous and late Miocene episodes are similar to those at the same elevations from VT1 (western Clavering Ø). It seems likely that similar mechanisms of heating and cooling apply at both locations. Given the narrow interval over which samples have been analysed at this location, quantitative determination of palaeogeothermal gradients and removed section is unlikely to provide tight constraints from this transect. However, these data do provide useful insights into the regional framework when compared with other transects. Note that the mid-Cretaceous and the late Miocene episodes are identified in all samples, implying that the late Miocene palaeotemperatures are highly reliable.

VT3: Hudson Land (N). Four samples of the Carboniferous Traill $\varnothing$ Group were collected over an elevation difference of c. $800 \mathrm{~m}$ from north-east Hudson Land. The highest local summit reaches $c .1100 \mathrm{~m}$ a.s.l. and no Palaeogene basalts are present. However, basalts are present at low elevations to the south-east in faulted contact with older sedimentary units. AFTA data in samples from VT3 define four palaeothermal episodes: Early Jurassic (C2), earliest Cretaceous (C3), end-Eocene (C6) and late Miocene (C8).

Not all events are recognised in every sample and data from these samples lack the degree of consistency seen elsewhere, for example VT1 (western Clavering Ø). This is probably due to difficulties in resolving palaeotemperatures in multiple palaeothermal episodes, particularly when they are closely spaced in time and magnitude. While the earlier of these episodes is identified in samples GC1016-25 and -70, the more recent episode is recognised in samples GC1016-24 and -26, in which C3 palaeotemperatures are also identified.

The Early Jurassic palaeotemperatures could be explained in terms of a linear palaeotemperature profile characterised by an extremely high palaeogeothermal gradient in excess of $100^{\circ} \mathrm{C} / \mathrm{km}$. This seems unlikely, given the lack of supporting evidence from similar locations. We interpret the rapid increase of palaeotemperature in this episode between samples GC1016-70 and -24 as more likely due to major tectonic offset across a major fault, which has not yet been identified. Note that the end-Eocene and the late Miocene events are identified in the lowermost sample, and thus the late Miocene palaeotemperature range for this sample is highly reliable. 
VT4, 4a: Hudson Land (E). Six samples of Precambrian basement rocks were collected over an elevation range of c. $1100 \mathrm{~m}$ in north-east Hudson Land, south of VT3. An additional three samples (two of Precambrian basement and one Devonian sedimentary rock, which failed to yield apatite) were collected farther to the south-west. These samples are referred to as VT4a. The highest local summit reaches c. $1500 \mathrm{~m}$ a.s.l., and no Palaeogene basalts are present, although basalts are present at low elevations to the south-east in faulted contact with Precambrian rocks (and to the north on Clavering Ø). AFTA data in samples from VT4 define four palaeothermal episodes: Middle Triassic (C1), earliest Cretaceous (C3), end-Eocene (C6) and late Miocene (C8).

Linear variation of palaeotemperatures with elevation for the end-Eocene and late Miocene episodes suggests that palaeotemperatures in both episodes reflect additional depth of burial. An additional component of elevated heat flow during the end-Eocene episode is also possible, since these locations are close to the late Eocene igneous centre at Myggbukta. Palaeotemperatures in the end-Eocene (C6) episode appear to define a distinct hot spot around this centre (map C6 in Fig. 14). The constraints for episodes $\mathrm{C} 6$ and $\mathrm{C} 8$ are consistent with a palaeogeothermal gradient $30^{\circ} \mathrm{C} / \mathrm{km}$ and $25^{\circ} \mathrm{C} /$ $\mathrm{km}$, respectively. Pre-Palaeogene episodes are identified in these transects only in isolated samples, and in all cases these samples were totally annealed prior to the onset of cooling in the respective episodes. Therefore, no information is available on the variation of palaeotemperature with elevation for these episodes, or on the relevant mechanisms of heating and cooling.

Similar to VT1, the late Miocene palaeotemperature profile for VT4 intersects the local summit level at $c$. $40^{\circ} \mathrm{C}$. This is higher than any reasonable value of surface temperature, implying that a significant amount of cover was present at the onset of this cooling episode. Similar comments apply to the end-Eocene episode, for which the summit intercept is closer to $70^{\circ} \mathrm{C}$. Since no Palaeogene basalts are present on the summit, the age of the additional section that is required to explain the late Miocene and end-Eocene palaeotemperatures remains uncertain at this location.

End-Eocene palaeotemperatures from VT4a (samples GC1016-63, -65) are consistently lower than in samples from VT4 (VT4a is located about $10 \mathrm{~km}$ south of VT4). This offset suggests either a difference in basal heat flow or in the amount of post-end-Eocene exhumation between these locations. Given the presence of downfaulted Palaeogene basalts not far to the south, differential exhumation across a fault between the two locations appears likely. Note that the end-Eocene and the late Miocene events are identified in all samples. This condition and the high late Miocene palaeotemperatures from which these samples have cooled, implies that the late Miocene palaeotemperatures are highly reliable.

VT5: Geographical Society $\emptyset$. Two samples of Lower Cretaceous and one of Triassic sedimentary rocks were collected over an elevation difference of c. $550 \mathrm{~m}$ from the centre of Geographical Society $\emptyset$. The highest local summit reaches c. $1060 \mathrm{~m}$ a.s.l. and no Palaeogene basalts are recognised within the vicinity. AFTA data in samples from VT5 define just two palaeothermal episodes: mid-Cretaceous (C4) and late Miocene (C8).

Palaeotemperatures characterising the mid-Cretaceous episode are identified only in the single sample of Triassic age, so no information is available on the form of the profile characterising this episode. Late Miocene palaeotemperatures are consistent with a linear profile defining a palaeogeothermal gradient of c. $25^{\circ} \mathrm{C} /$ $\mathrm{km}$, although the quite broad palaeotemperature constraints allow a range of interpretations.

VT6: Traill $\emptyset$ (SW). Five samples were analysed from Jurassic and Cretaceous sedimentary units on Traill $\varnothing$, over an elevation difference of c. $800 \mathrm{~m}$. The highest local summit reaches c. $1400 \mathrm{~m}$ a.s.l. and no Palaeogene basalts are present in the immediate vicinity, although they are present on summits to the north, at lower elevations. Late Eocene syenites are also present at the eastern extreme of the island, forming Kap Simpson and Kap Parry. AFTA data in samples from VT6 define three palaeothermal episodes: End-Eocene (C6), late Miocene (C8) and early Pliocene (C9; see also Fig. 32).

Palaeotemperatures characterising the end-Eocene and late Miocene episodes define linear profiles, consistent with palaeogeothermal gradients around c. $40^{\circ} \mathrm{C} /$ $\mathrm{km}$ and $25^{\circ} \mathrm{C} / \mathrm{km}$, respectively. The early Pliocene episode is only recognised in a single sample at low elevation, presumably because palaeotemperatures in higher elevation samples were too low to be resolved with confidence. In sample GC1016-32, the late Miocene palaeotemperature is lower than the trend defined for this episode by data in other samples. This may reflect the difficulty in resolving the late Miocene and early Pliocene episodes in a single sample. It seems likely that the solution for this sample represents the unresolved effects of these two episodes. A fault offset could provide an alternative explanation.

Linear variation of palaeotemperatures with elevation for the end-Eocene and late Miocene episodes suggests that these palaeotemperatures reflect additional depth of burial. The apparent decrease in palaeogeothermal gradient from end-Eocene to late Miocene suggests a significant decrease in basal heat flow over that period. Thus, cooling in these episodes is interpreted as due to a combination of exhumation and a decrease in 
basal heat flow. No such insights are possible into the origin of palaeotemperatures characterising the early Pliocene episode, but it seems likely that this episode represents the final stages of exhumation.

The end-Eocene palaeotemperature profile intersects the local summit level at c. $90^{\circ} \mathrm{C}$. The corresponding value for the late Miocene profile is $c .70^{\circ} \mathrm{C}$. These values imply that a significant amount of cover was present at the onset of these cooling episodes. Since no Palaeogene basalts are present on the local summit, the additional burial required to explain the end-Eocene palaeotemperatures probably consisted of more Cretaceous sedimentary units as well as basalts and Eocene sedimentary units. Clearly, some of the additional section remained until the onset of late Miocene cooling, although some degree of re-burial between the two cooling episodes is possible. Note that the end-Eocene and the late Miocene events are identified in all samples. Together with the high late Miocene palaeotemperatures, from which these samples have cooled, this implies that the late Miocene palaeotemperatures are highly reliable.

VT7: Schuchert Dal. Eleven samples of Carboniferous to Jurassic sedimentary units were analysed over an elevation difference of more than $1000 \mathrm{~m}$ from Schuchert Dal, western Jameson Land. The highest local summits in the vicinity of the samples reach c. $2000 \mathrm{~m}$ a.s.l. but peaks up to $2.5 \mathrm{~km}$ are present to the west in Stauning Alper. Palaeogene basalts are not present in the vicinity of these samples, although the igneous centre of Werner Bjerge is not far away to the north-east.

Precise locations for the samples were not available, so the co-ordinates adopted for these samples in this study were obtained by digitising maps from Hansen et al. (2001), from which elevations were derived. Unfortunately, those maps are not sufficiently detailed to identify precise co-ordinates, and elevations obtained by this process are different to those published by Hansen et al. (2001), which in turn are different from those in the original Geotrack reports (see Green 2009). The results do not define consistent palaeotemperature profiles. It is thus uncertain whether this lack of consistency reflects real complexity in the nature of the palaeothermal processes, or uncertainty in sample locations. AFTA data in samples from VT7 define three palaeothermal episodes: early Eocene (C5), early Miocene (C7) and early Pliocene (C9).

Palaeotemperatures characterising all three palaeothermal episodes define highly nonlinear profiles, suggesting that a simple interpretation of all data as representing a single coherent rock mass that has undergone conductive heating and cooling is not tenable. The profile characterising the early Eocene (C5) episode in particular shows erratic variation through the section. We interpret this episode as reflecting the effects of contact heating and hydrothermal effects associated with Palaeogene igneous activity, which explains this erratic variation through the section. The early Miocene (C7) cooling episode occurs slightly later than intrusive activity recognised at Werner Bjerge dated at $26.8 \pm 0.1$ Ma age (Brooks et al. 2004). However, the close proximity between the sample reflecting early Miocene cooling and the intrusive centre (map C7 in Fig. 14), suggests $a$ direct link between the two. This may explain the non-linear variation of palaeotemperatures with elevation in these samples, where distance to the intrusive centre as well as possible late-stage hydrothermal effects will also affect the magnitude and timing of this episode. The early Pliocene cooling episode is only identified in two samples, but even these do not show a progressive increase with depth through the section.

Alternatively, it is quite possible that the elevations are incorrect. Other explanations involving differential exhumation or localised heating and cooling are possible, but unlikely. Another problem in deriving reliable thermal history constraints from AFTA data in the vicinity of VT7 is the convergence of the effects of a number of palaeothermal episodes in this region, particularly the early Eocene and early Miocene episodes. Both of these episodes appear to involve a significant enhancement of basal heat flow associated with intrusive activity, as well as the early Eocene episode, which we also attribute largely to localised igneous activity. The interplay between these competing processes, involving broadly similar palaeotemperatures in the vicinity of VT7, makes it quite likely that the effects of one episode may have been attributed to another, or that individual events identified from AFTA data may in fact represent unresolved effects of both.

The consistent definition of the early Miocene episode in samples from VT7 and adjacent locations, and the resulting highly consistent association between this episode and the Werner Bjerge intrusion (Fig. 5), suggests that the sample locations are broadly correct. However, given the uncertainties, we have not attempted any quantitative analysis of palaeotemperature profiles from this transect.

VT8: Milne Land. Three samples of Ordovician granite-gneiss and one sample from a Jurassic outlier were collected over an elevation difference of c. $750 \mathrm{~m}$ from the south coast of Milne Land. The highest local summit reaches $1720 \mathrm{~m}$ a.s.l. and Palaeogene basalts, up to 700 $\mathrm{m}$ thick, are present. Four palaeothermal episodes are recognised in the AFTA data in samples from VT8: Middle Triassic (C1), Early Jurassic (C2), mid-Cretaceous (C4) and late Miocene (C8).

Palaeotemperatures characterising the Middle Triassic and Early Jurassic episodes are only definitively 
recognised in single samples of the Ordovician granite-gneiss, so the variation of palaeotemperature with elevation for these episodes cannot be defined. Similarly, the mid-Cretaceous episode is only identified in one sample (GC1042-43), although this episode is identified from the AFTA data from other adjacent locations. The lack of evidence for this episode in other samples is most likely due to the influence of competing episodes. The Early Jurassic palaeotemperature of c. $100^{\circ} \mathrm{C}$ for sample GC1016-45, which is located near a Middle Jurassic outlier, indicates that significant exhumation took place between the onset of episode C2 and the deposition of sediments in the Middle Jurassic.

Palaeotemperatures characterising the late Miocene episode in samples from this transect define a linear profile, broadly consistent with a palaeogeothermal gradient of $c .25^{\circ} \mathrm{C} / \mathrm{km}$. The form of this profile suggests that these palaeotemperatures reflect additional depth of burial, and that cooling was due predominantly to exhumation. The late Miocene palaeotemperature profile intersects the local summit level at c. $40^{\circ} \mathrm{C}$, which is higher than any reasonable value of surface temperature. However, only sample GC1016-43 defines the mid-Cretaceous event. Regional analysis of the variation of palaeotemperatures in the late Miocene episode relative to elevation (Fig. 22) reveals that palaeotemperatures for samples -42 and -44 represent the combined effects of unresolved cooling episodes.

VT9: Kuhn $\boldsymbol{\emptyset}$. Five samples of early Devonian granite were collected over an elevation difference of c. $665 \mathrm{~m}$ from Kuhn $\varnothing$. The highest local summit lies to the south at an elevation of $1300 \mathrm{~m}$ a.s.l. where Palaeogene basalts are present. AFTA data in samples from VT9 define three palaeothermal episodes: Middle Triassic (C1), mid-Cretaceous (C4) and late Miocene (C8).

Palaeotemperatures characterising the mid-Cretaceous and late Miocene palaeothermal episodes are broadly consistent with palaeogeothermal gradients of c. $25^{\circ} \mathrm{C} / \mathrm{km}$. The form of the profile characterising the Middle Triassic episode is not as well defined because all samples were totally annealed in this episode and provide only minimum values. The linear variation of palaeotemperatures with elevation for the earliest Cretaceous and late Miocene episodes suggests that these palaeotemperatures reflect additional depth of burial, and that cooling was due predominantly to exhumation. No such insights are possible into the origin of palaeotemperatures characterising the Middle Triassic episode, but a similar conclusion seems likely.

The late Miocene palaeotemperature profile intersects the local summit level between 30 and $40^{\circ} \mathrm{C}$, which is higher than any reasonable value of late Miocene surface temperature. In contrast to VT8, however, all samples from this profile define the mid-Cretaceous (C4) episode, and it is reasonable to assume that the C8 palaeotemperatures are reliable. This implies that a significant amount of cover was present at the onset of this cooling episode. Since Palaeogene basalts are present on the summit, the additional section required to explain the late Miocene palaeotemperatures must have been deposited after the preserved basalts were laid down, and most likely represented younger basalts together with Eocene-Miocene sedimentary units.

Similarly, the mid-Cretaceous palaeotemperatures intersect the summit level at c. $60^{\circ} \mathrm{C}$. Middle Triassic values are higher, implying that a considerable thickness of granite and possible post-Devonian cover has been eroded at the unconformity below the Palaeogene basalts in these two episodes. VT9 is sampled on a basement block covered by Middle Jurassic and younger sediments on its western flank, not far from the summit sample. Thus, a significant column of Caledonian basement to Lower Triassic sediments was removed between the Middle Triassic and the deposition of Middle Jurassic sands. Since Middle Jurassic sediments are not far from the summits of Kuhn $\varnothing$, the mid-Cretaceous palaeotemperature of $\mathrm{c} .60^{\circ} \mathrm{C}$ at summit level corresponds to a heating of $40^{\circ} \mathrm{C}$ below a Middle Jurassic to lowermost Upper Cretaceous cover around $95 \mathrm{Ma}$ (surface temperature $20^{\circ} \mathrm{C}$ ). The thickness of this cover was about $1.5 \mathrm{~km}$ for a gradient of $25^{\circ} \mathrm{C} / \mathrm{km}$, and it was removed prior to eruption of basalts.

VT10: Payer Land. Six samples of Palaeozoic basement rocks were collected over an elevation difference of more than $1200 \mathrm{~m}$ on Payer Land. The highest local summit is close to the highest sample at an elevation of c. $1300 \mathrm{~m}$ a.s.l. No Palaeogene basalts are present in the immediate vicinity of this transect. AFTA data in samples from VT10 define five palaeothermal episodes: Early Jurassic (C2), earliest Cretaceous (C3), mid-Cretaceous (C4), late Miocene (C8) and early Pliocene (C9).

The two Cretaceous episodes and the early Pliocene episode are represented only in single samples in each case, and do not define the form of the corresponding palaeotemperature profiles. Palaeotemperatures characterising the late Miocene palaeothermal episode define a linear profile consistent with palaeogeothermal gradients of $c .25^{\circ} \mathrm{C} / \mathrm{km}$. The variation of palaeotemperature with elevation for the Early Jurassic episode is not defined because all samples were totally annealed in this episode and provide only minimum values. Note that the single constraint attributed to the mid-Cretaceous episode in sample GC1077-32, close to sea level, plots around the profile of late Miocene palaeotemperatures at higher elevations. This seems to be due to the competing effects of multiple unresolved 
cooling episodes in the data and may indicate that the C8 palaeotemperatures in sample -32 and above are overestimated due to unresolved effects of episode C4. In addition, the Pliocene episode is identified only in this sample. Attribution to the Pliocene episode is largely based on the mismatch between this and the projected late Miocene values.

Linear variation of palaeotemperatures with elevation for the late Miocene episode suggests that these palaeotemperatures reflect additional depth of burial, and that cooling was due predominantly to exhumation. No such insights are possible into the origin of palaeotemperatures characterising the Early Jurassic episode, but a similar conclusion seems likely. The late Miocene palaeotemperature profile intersects the local summit level at $c .45^{\circ} \mathrm{C}$. Mid-Cretaceous palaeotemperatures at this location are likely to have been of similar magnitude. Earliest Cretaceous and Jurassic palaeotemperature profiles intersect the summit level at values of $c .70^{\circ} \mathrm{C}$ and $c$. $100^{\circ} \mathrm{C}$, respectively, implying erosion of a considerable thickness of post-Palaeozoic cover in these two episodes.

VT11: Stauning Alper. Four samples of Precambrian basement rocks were collected over an elevation difference of over $1750 \mathrm{~m}$ from Stauning Alper. One failed to yield any apatite suitable for analysis (GC1077-19). The highest local summits rise to c. $2100 \mathrm{~m}$ a.s.l. and higher. No Palaeogene basalts are present in the region. AFTA data in samples from VT11 define three palaeothermal episodes: Early Jurassic (C2), mid-Cretaceous (C4) and late Miocene (C8).

The mid-Cretaceous episode is represented only in a single sample. The late Miocene episode is identified in only two samples, which do not define a linear palaeotemperature profile (Fig. 22). The profile characterising the Early Jurassic episode is not well defined since all samples were totally annealed in this episode and provide only minimum values of palaeotemperature. For this reason, results from this transect provide only very broad constraints on the palaeogeothermal gradients and removed section. However, these data do provide useful insights into the regional framework when compared with results from other transects.

VT12: Liverpool Land. Four samples of Caledonian basement rocks were collected over an elevation difference of over $930 \mathrm{~m}$ from Liverpool Land. The highest local summit reaches c. $1300 \mathrm{~m}$ a.s.l., and no Palaeogene basalts are present in the region. AFTA data in samples from VT12 define three palaeothermal episodes: Early Jurassic (C2), end-Eocene (C6) and late Miocene (C8).

Palaeotemperatures characterising the end-Eocene and late Miocene palaeothermal episodes define linear profiles, consistent with palaeogeothermal gradients of c. $25^{\circ} \mathrm{C} / \mathrm{km}$, although a wide range would be allowed. The variation of Early Jurassic palaeotemperatures with elevation is not well defined because all samples were totally annealed in this episode and provide only minimum values. The linear variation of palaeotemperatures with elevation for the end-Eocene and late Miocene episodes suggests that these palaeotemperatures reflect additional depths of burial, and that cooling was due predominantly to exhumation. No such insights are possible into the origin of palaeotemperatures characterising the Early Jurassic episode, but a similar conclusion seems likely.

The late Miocene palaeotemperature profile intersects the local summit level at c. $60^{\circ} \mathrm{C}$. This is higher than any reasonable value of late Miocene surface temperature, implying that a significant amount of cover was present at the onset of this cooling episode. Similar comments apply to the end-Eocene episode. The sub-Permian peneplain extends across the western flanks of Liverpool Land (see Chapter 2), but it is heavily dissected towards the Atlantic margin. This implies that the summits around VT12 are located near the sub-Permian peneplain and that the samples at highest elevation were near the surface in mid-Permian times. Consequently, the Early Jurassic palaeotemperatures in excess of $100^{\circ} \mathrm{C}$ for these samples represent heating below a cover of upper Permian to Lower Jurassic sediments. Note that both the end-Eocene and the late Miocene events are identified in all samples, indicating that late Miocene palaeotemperatures are highly reliable.

VT13: Jameson Land. Three samples of Jurassic sedimentary rocks were collected over an elevation difference of $c .750 \mathrm{~m}$ from Jameson Land. The highest peak in the region lies at an altitude of c. $1245 \mathrm{~m}$ a.s.I. No Palaeogene basalts are present in the region. AFTA data in samples from VT13 define three palaeothermal episodes: early Eocene (C5), end-Eocene (C6) and late Miocene (C8).

Each episode is represented in only two of the three samples, but no episode is constrained in all three. Given the narrow interval over which samples have been analysed at this location, quantitative determination of palaeogeothermal gradients and removed section is unlikely to provide tight constraints. However, comparison with results from other transects (e.g. VT11 and VT12) support the attributions shown here. Note the good definition of the late Miocene episode in sample GC1077-39 for which the end-Eocene (C6) episode is also identified. In contrast, episode C6 is not identified in sample -38, and this probably explains the broad interval of palaeotemperatures allowed for episode C8 in this sample.

VT14: Giesecke Bjerge. Two samples of basement rocks and two from overlying Permian and Triassic 
sedimentary rocks were collected over an elevation difference of c. $540 \mathrm{~m}$ from Giesecke Bjerge, to the southeast of Hudson Land and south-west of Hold with Hope. The highest summit in the region is c. $1 \mathrm{~km}$ a.s.l., and the mountains are capped by extensive Palaeogene basalts. The sedimentary section contains numerous intrusions. AFTA data in samples from VT14 define two palaeothermal episodes: end-Eocene (C6) and late Miocene (C8).

The late Miocene episode is represented in three samples over a very restricted vertical range, while all samples were totally annealed in the end-Eocene episode and provide only minimum palaeotemperatures. These results therefore do not define the form of the corresponding palaeotemperature profiles in sufficient detail to allow quantitative analysis. However, these data do provide useful insights into the regional framework when compared with results from other transects. Both the end-Eocene and the late Miocene events are identified in three samples, and this indicates that late Miocene palaeotemperatures are highly reliable.

VT15: Traill $\emptyset$ (E). Four samples of late Eocene syenite were collected over an elevation difference of c. $900 \mathrm{~m}$ from Japetus Bjerg, eastern Traill $\varnothing$. The highest summit in the region lies at an altitude of $1042 \mathrm{~m}$ a.s.l. The transect and surrounding region consists entirely of late Eocene intrusive rocks. One sample failed to yield any apatite suitable for analysis. AFTA data in the samples from VT15 define three palaeothermal episodes: end-Eocene (C6), late Miocene (C8) and early Pliocene (C9).

The late Miocene palaeotemperatures appear to define a linear profile and can be described by a palaeogeothermal gradient around $40^{\circ} \mathrm{C} / \mathrm{km}$, although constraints are available in only three samples. A wide range of palaeogradients would be allowed, given that the highest elevation sample provides only a maximum limit to the allowed palaeotemperature in this episode and the lowest elevation sample provides only a minimum limit. Therefore, it is difficult to reach firm conclusions regarding the nature of this episode from these data alone. In addition, the end-Eocene episode is recognised only in a single sample, and thus provides only a minimum limit to the palaeotemperature in this episode. Thus, these results do not define the form of the corresponding palaeotemperature profiles in sufficient detail to allow quantitative analysis. The data do, however, provide useful insights into the regional framework when compared with results from other transects and with results from other samples in the Traill $\varnothing$ area (Fig. 32). The end-Eocene and the late Miocene events are identified in all samples. This and the high palaeotemperatures in the late Miocene imply that these palaeotemperatures are highly reliable.
VT16: Dombjerg. Three samples of Caledonian crystalline basement and one sample of overlying Lower Cretaceous conglomerate were collected over an elevation difference of over $1200 \mathrm{~m}$ from Dombjerg, north of Clavering $\varnothing$. The highest local summit reaches c. $1500 \mathrm{~m}$ a.s.l. and is capped by Palaeogene basalt. AFTA data in samples from VT16 define five palaeothermal episodes: Early Jurassic (C2), earliest Cretaceous (C3), mid-Cretaceous (C4), early Eocene (C5) and late Miocene (C8).

AFTA data in sample GC1077-91 provide only tentative evidence for the Early Jurassic episode. The earliest Cretaceous episode is only identified definitively in one sample and tentatively in another. Therefore, no information is available on the form of the palaeotemperature profiles characterising these episodes. The early Eocene episode is identified in two samples, but a major difference in C5 palaeotemperature is evident between the two samples, which are separated by only a small difference in elevation. This episode is interpreted as representing contact and/or hydrothermal heating associated with Eocene intrusives in the region. Late Miocene palaeotemperatures define a linear profile, consistent with a palaeogeothermal gradient of c. $25^{\circ} \mathrm{C} / \mathrm{km}$. Although only two samples define the mid-Cretaceous episode at this location, the palaeotemperatures characterising this episode are consistent with a similar profile.

Linear variation of palaeotemperatures with elevation characterising the late Miocene and mid-Cretaceous episodes suggests that these palaeotemperatures reflect additional depth of burial, and that cooling was due predominantly to exhumation. While no such insights into the origin of palaeotemperatures characterising the earliest Cretaceous and Early Jurassic episodes are possible, a similar conclusion seems likely for these. VT16 is sampled along the flank of an Early Cretaceous fault block that was covered by Lower Cretaceous sediments (GC1077-89). The mid-Cretaceous palaeotemperature $\left(75-90^{\circ} \mathrm{C}\right)$ for the summit sample is therefore due to burial below a cover of Lower Cretaceous to Turonian sediments.

The late Miocene palaeotemperature profile intersects the local summit level at a value around 30 to $40^{\circ} \mathrm{C}$. This is higher than any reasonable value of late Miocene surface temperature, implying that a significant amount of cover of basalts and Eocene--Miocene sediments were present at the onset of this cooling episode.

VT17: Clavering $\emptyset$ (NE). Four samples of basement rocks and one sample of overlying Paleocene sandstones were collected over an elevation difference of $c .800 \mathrm{~m}$ from north-east Clavering $\varnothing$. The highest local summit reaches $1370 \mathrm{~m}$ a.s.l. Palaeogene basalts are present here and at other summits at similar elevations in this region. A sample of Palaeogene sediments (GC1077-96) 
preserved below the basalts, is included in this transect. AFTA data in samples from VT17 define three palaeothermal episodes: Middle Triassic (C1), Early Jurassic (C2) and late Miocene (C8).

Palaeotemperatures characterising the late Miocene palaeothermal episode define a linear profile, broadly consistent with palaeogeothermal gradients of $c .25^{\circ} \mathrm{C} /$ $\mathrm{km}$. The Early Jurassic episode is recognised in only two samples from very similar elevations, so the profile characterising this episode is not well defined. Similarly, the form of the profile characterising the Middle Triassic episode is not well defined because all samples were totally annealed prior to the onset of cooling. But results for each of these episodes would be consistent with profiles similar to that defined for the late Miocene. The linear variation of palaeotemperatures with elevation for the late Miocene episode suggests that these palaeotemperatures reflect additional depth of burial, and that cooling was due predominantly to exhumation. No such insights are possible into the origin of palaeotemperatures characterising the Middle Triassic episode, but a similar conclusion seems likely.
The late Miocene palaeotemperature profile intersects the local summit level at c. $60^{\circ} \mathrm{C}$. This is higher than any reasonable value of surface temperature, implying that a significant amount of cover was present at the onset of this cooling episode. Since Palaeogene basalts are present on nearby summits, the additional section required to explain the late Miocene palaeotemperatures must have been deposited after the preserved basalts were laid down. The section most likely consisted of younger basalts together with Eocene-Miocene sedimentary units. Similarly, the Early Jurassic palaeotemperature profile intersects the summit level at c. $80^{\circ} \mathrm{C}$ while Middle Triassic values are higher still (assuming a palaeogeothermal gradient of $25^{\circ} \mathrm{C} / \mathrm{km}$ ). This implies that a considerable thickness of post-Carboniferous succession has been eroded at the unconformity below the Palaeogene basalts in these two episodes. The mid-Cretaceous episode is, however, not resolved in any of the VT17 samples, and it is thus likely that the late Miocene palaeotemperatures are affected by unresolved effects of multiple episodes. 
Palaeotemperature $\left({ }^{\circ} \mathrm{C}\right)$

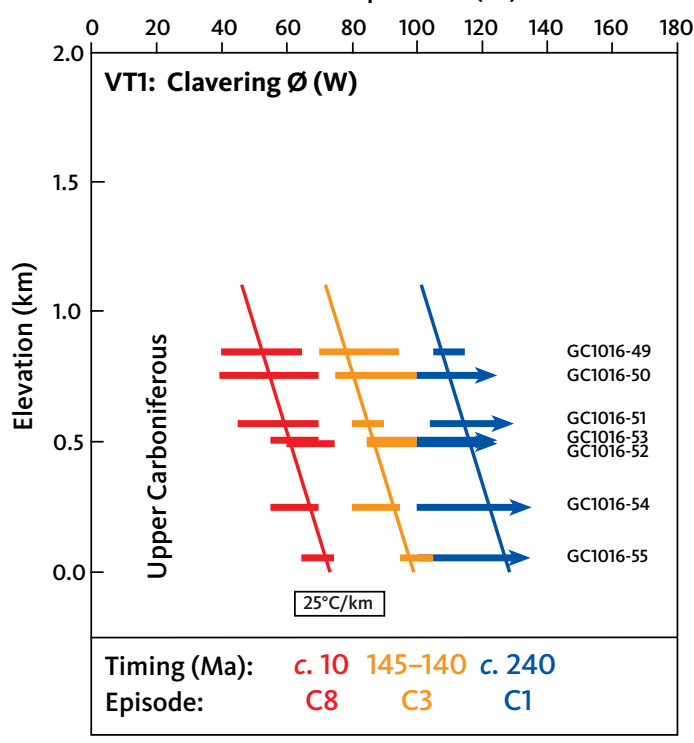

Palaeotemperature $\left({ }^{\circ} \mathrm{C}\right)$

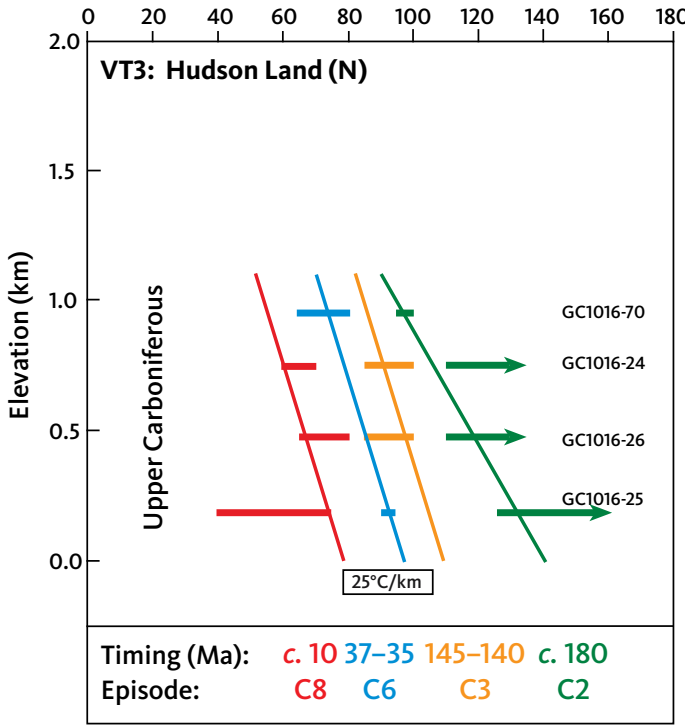

Palaeotemperature $\left({ }^{\circ} \mathrm{C}\right)$

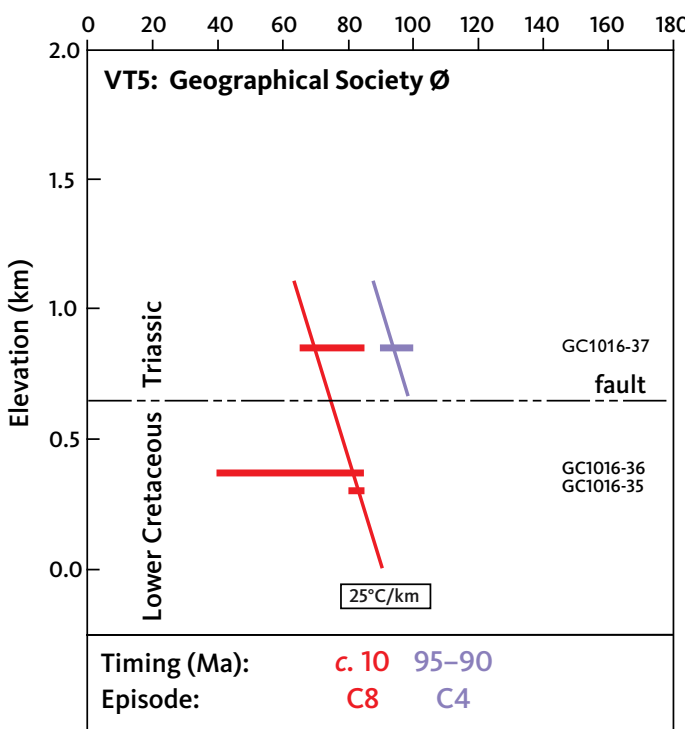

Palaeotemperature $\left({ }^{\circ} \mathrm{C}\right)$

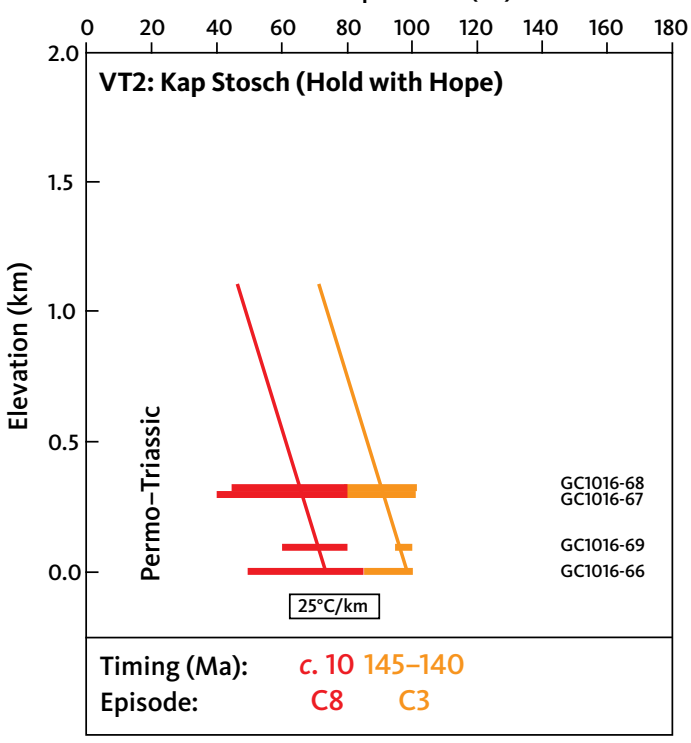

Palaeotemperature $\left({ }^{\circ} \mathrm{C}\right)$

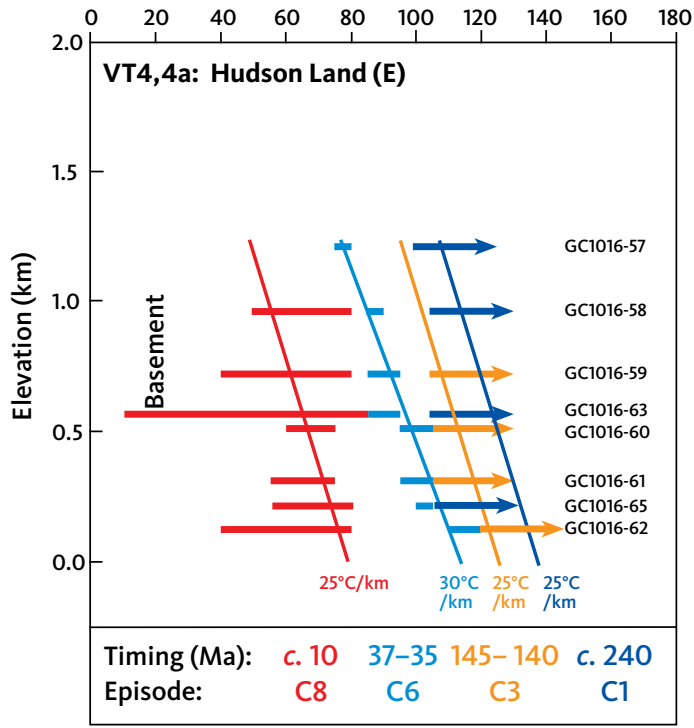

Palaeotemperature $\left({ }^{\circ} \mathrm{C}\right)$

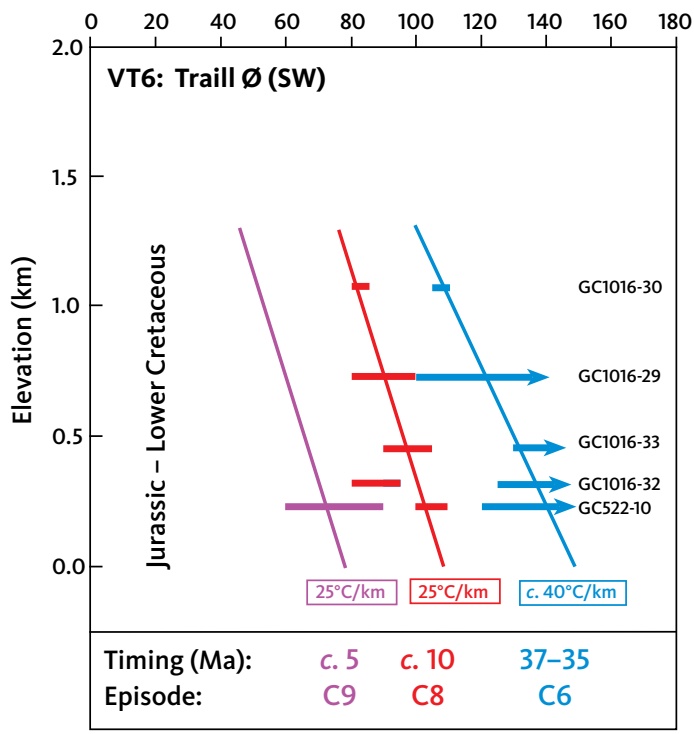

Appendix 2.3 Palaeotemperature constraints derived from AFTA data from vertical transects 1 to 17 plotted against elevation (a.s.I.). Horizontal lines indicate range of palaeotemperatures estimated from AFTA data. Arrows indicate lack of upper or lower limit for the estimated range. See Appendix 2.2 for a summary of the geological constraints on the burial and exhumation history at the locations of these transects. Locations in Appendix 2.1. 
Palaeotemperature $\left({ }^{\circ} \mathrm{C}\right)$

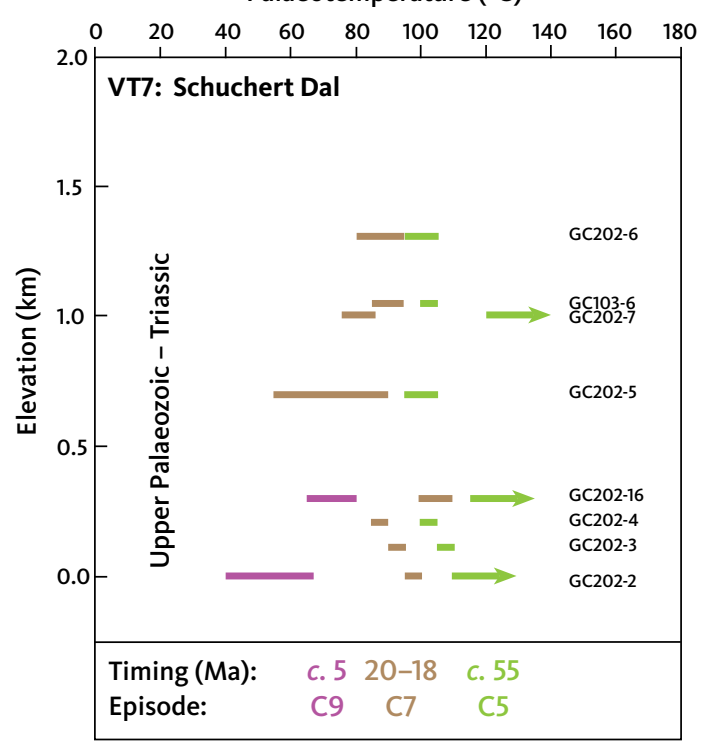

Palaeotemperature $\left({ }^{\circ} \mathrm{C}\right)$

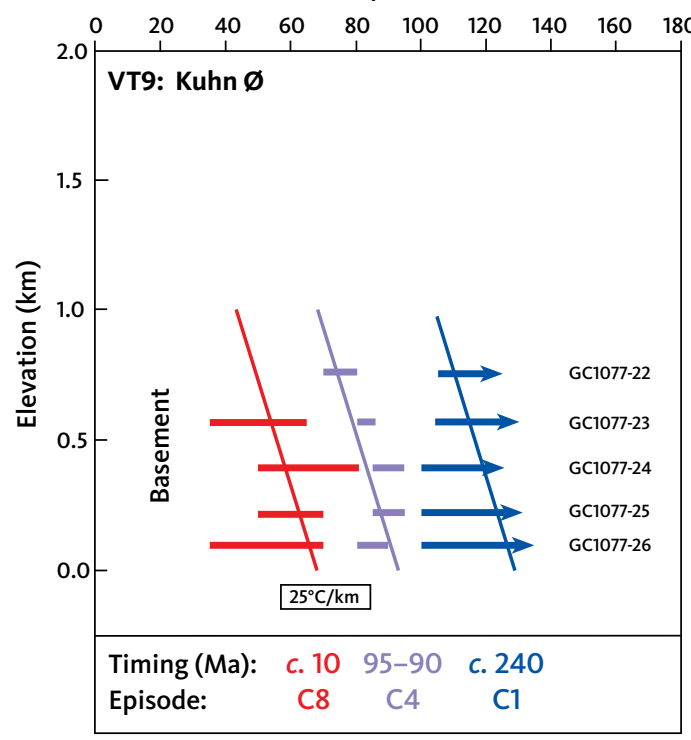

Palaeotemperature $\left({ }^{\circ} \mathrm{C}\right)$

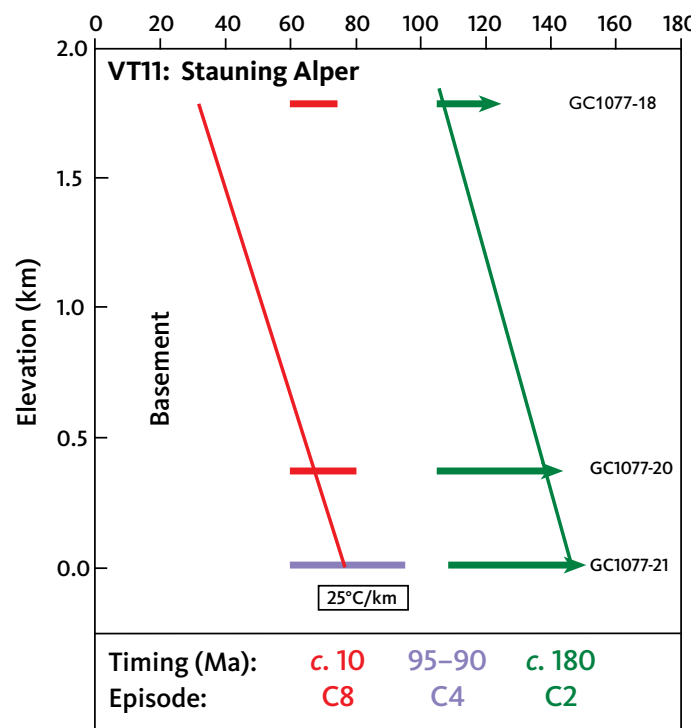

Palaeotemperature $\left({ }^{\circ} \mathrm{C}\right)$

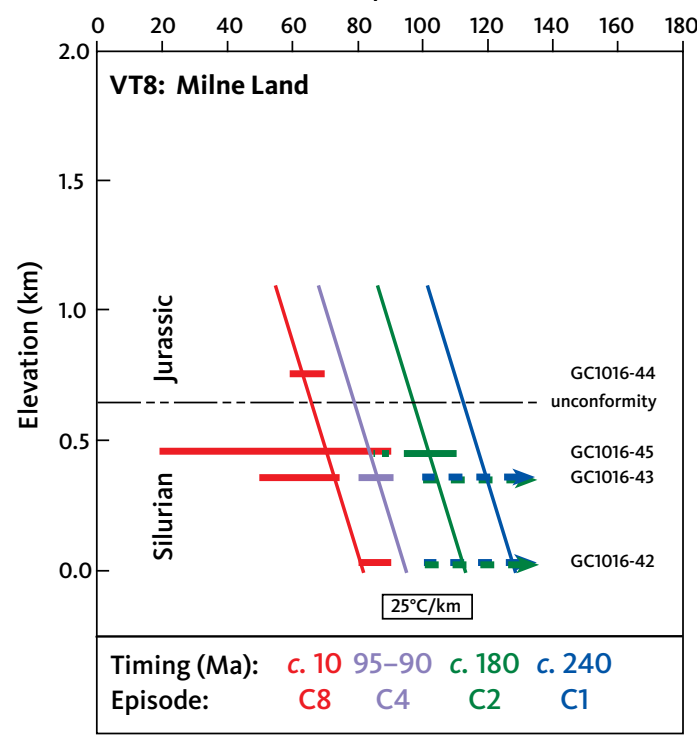

Palaeotemperature $\left({ }^{\circ} \mathrm{C}\right)$

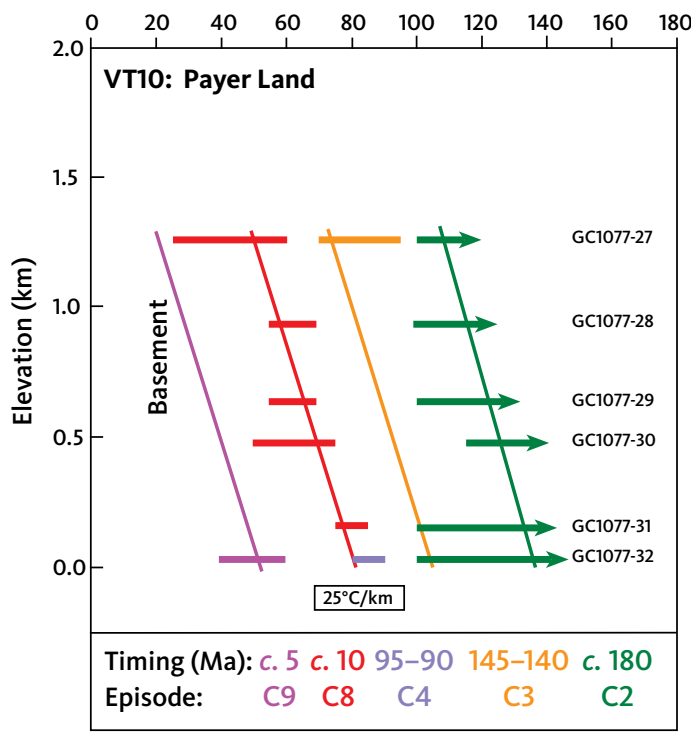

Palaeotemperature $\left({ }^{\circ} \mathrm{C}\right)$

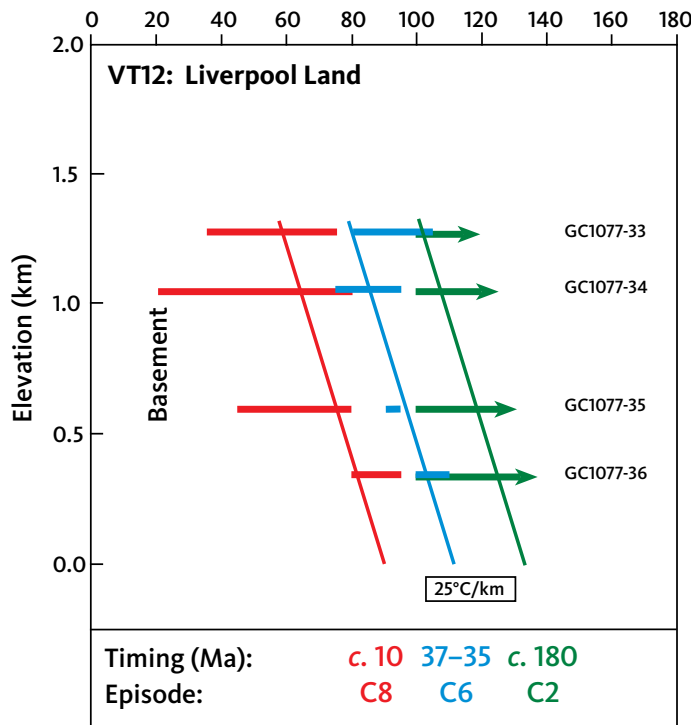

Appendix 2.3 (continued) Palaeotemperature constraints derived from AFTA data from vertical transects 1 to 17 plotted against elevation (a.s.l.). Horizontal lines indicate range of palaeotemperatures estimated from AFTA data. Arrows indicate lack of upper or lower limit for the estimated range. See Appendix 2.2 for a summary of the geological constraints on the burial and exhumation history at the locations of these transects. Locations in Appendix 2.1. 

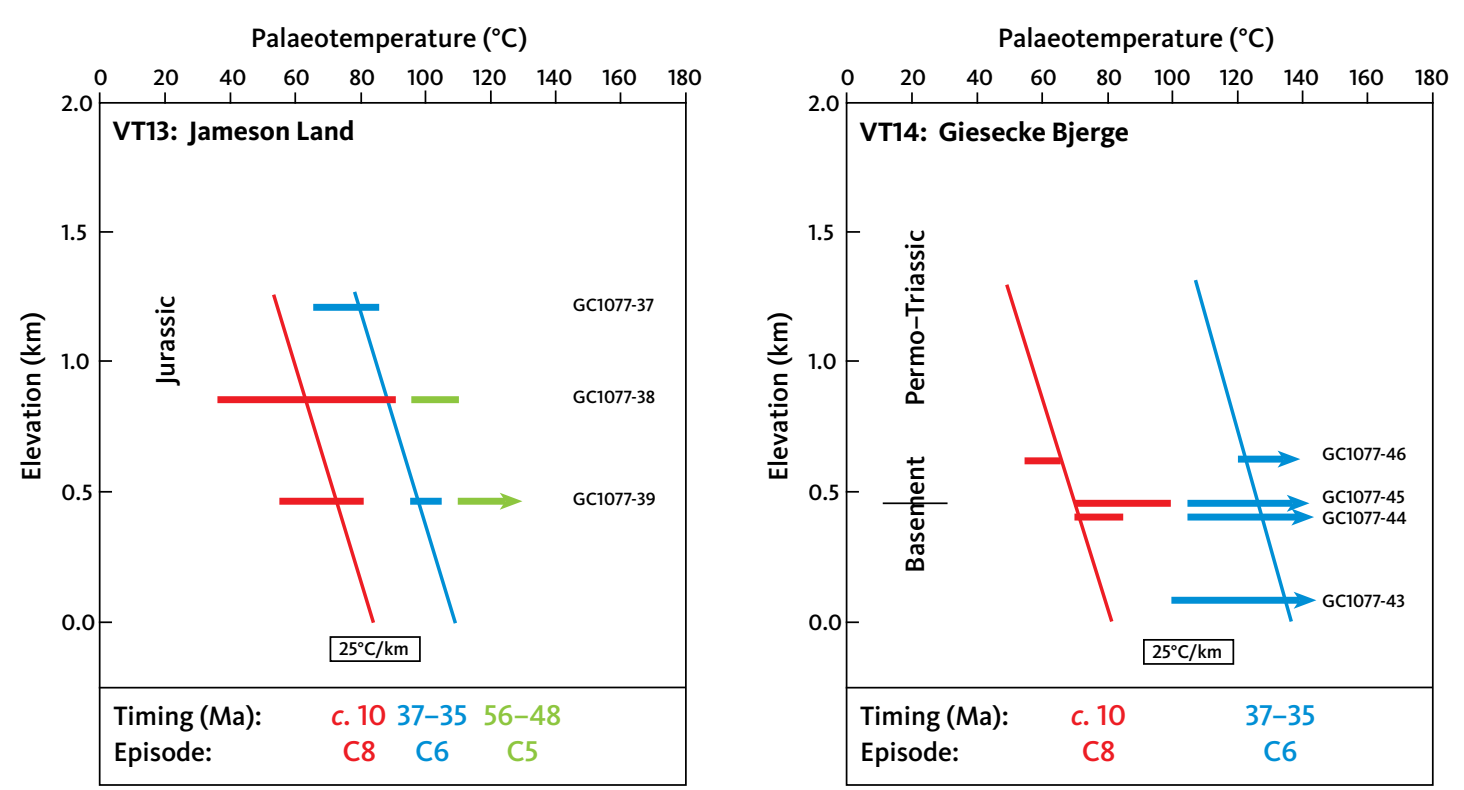

Palaeotemperature $\left({ }^{\circ} \mathrm{C}\right)$

Palaeotemperature $\left({ }^{\circ} \mathrm{C}\right)$
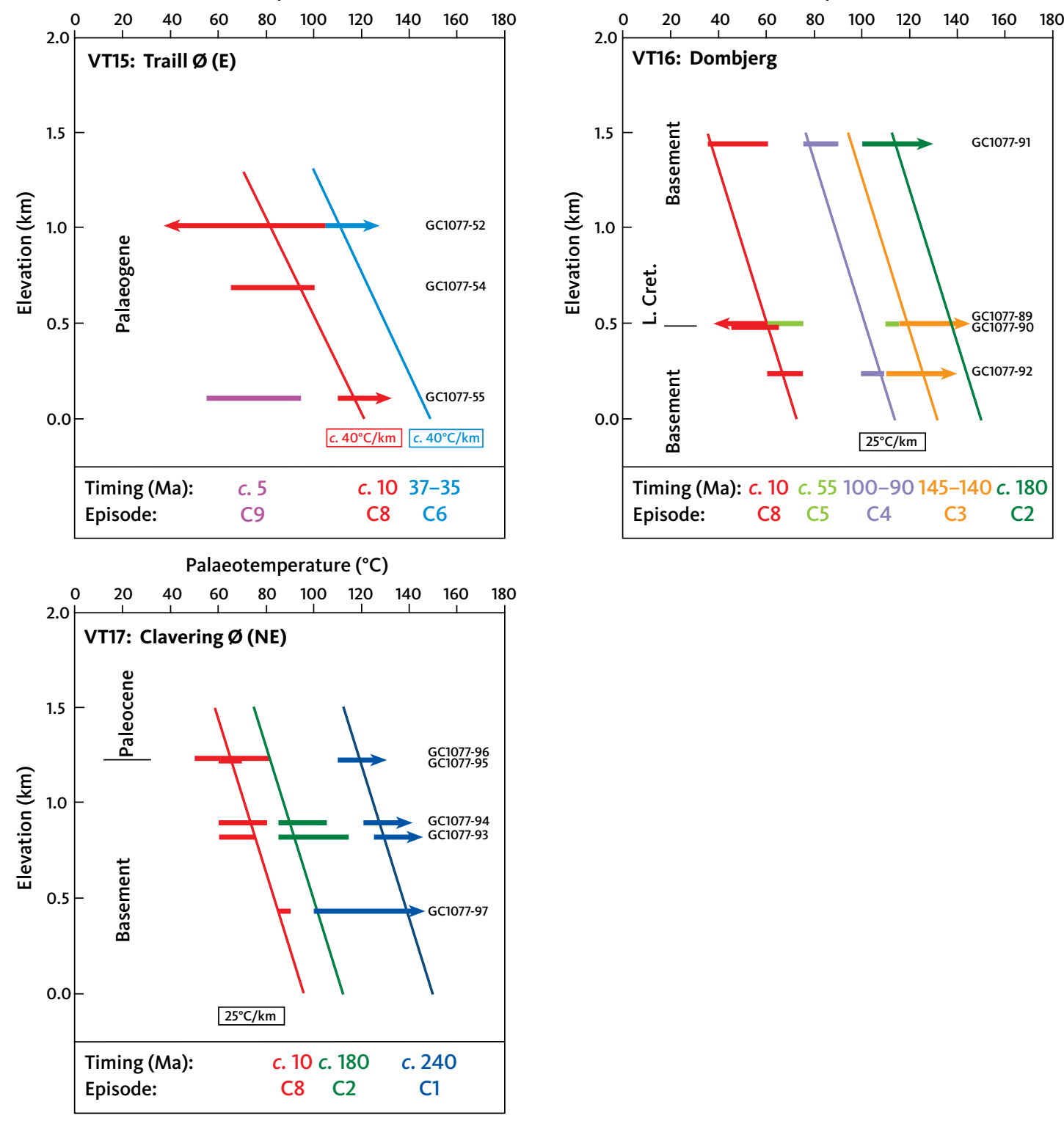

Appendix 2.3 (continued) Palaeotemperature constraints derived from AFTA data from vertical transects 1 to 17 plotted against elevation (a.s.l.). Horizontal lines indicate range of palaeotemperatures estimated from AFTA data. Arrows indicate lack of upper or lower limit for the estimated range. See Appendix 2.2 for a summary of the geological constraints on the burial and exhumation history at the locations of these transects. Locations in Appendix 2.1. 


\section{Mechanisms of heating and cooling estimated from vertical transects Palaeogeothermal gradients and amount of removed sections}

Using the approach outlined in Chapter 4 and methods documented in Green et al. (2013), we have determined the range of palaeogeothermal gradients consistent with the palaeotemperature constraints from AFTA at the location of each vertical transect for palaeothermal episodes in which sufficient constraints are available (episodes C3, C4, C6 and C6 in Appendix 2.4).

Extrapolation of allowed palaeogeothermal gradients makes it possible to determine the amounts of removed section required to explain the observed palaeotemperatures in each episode. Note that determining amounts of removed section in this way is based on a number of assumptions, particularly that the palaeogeothermal gradient was linear throughout the entire succession when cooling from the palaeothermal peak began in each cooling episode. This is equivalent to assuming that the missing section and the preserved section comprised similar lithologies such that no significant contrasts in thermal conductivity existed, which may have resulted in a non-linear palaeotemperature profile (see fig. 32 of Green et al. 2013). Thermal conductivities measured in rocks of different types show wide variation from around $1 \mathrm{Wm}^{-1} \mathrm{~K}^{-1}$ or less to over $5 \mathrm{Wm}^{-1} \mathrm{~K}^{-1}$, related to lithology, water content, porosity, temperature and other factors (e.g. Robertson 1988; Clauser \& Huenges 1995; Eppelbaum et al. 2014). If the cover rocks that were removed during an episode of exhumation were relatively unconsolidated sediments with lower thermal conductivities compared to the underlying basement rocks, then the palaeogeothermal gradient in the overlying section would have been higher. In that case, the amount of cover required to explain the Miocene palaeotemperatures would be correspondingly reduced, perhaps by a factor of two, based on the range of typical thermal conductivities in the works cited above. The assumption of linearity will be invalid if the palaeotemperatures were caused by processes involving lateral or local introduction of heat, such as by confined fluid flow or igneous intrusion or where non-linear palaeotemperatures reflect palaeotopography.

A palaeosurface temperature of $20^{\circ} \mathrm{C}$ was assumed in order to estimate amounts of removed section for the earliest Cretaceous, the mid-Cretaceous and the end-Eocene episodes, decreasing to $10^{\circ} \mathrm{C}$ for the late Miocene episode (based on Zachos et al. 2001). Changing the value of palaeosurface temperature is equivalent to a constant offset in the amount of missing section required to explain the observed palaeotemperatures. For example, increasing the palaeosurface temperature by $10^{\circ} \mathrm{C}$, for a palaeogeothermal gradient of $25^{\circ} \mathrm{C} / \mathrm{km}$, would require a reduction of $400 \mathrm{~m}$ in the amount of removed section needed to explain the observed palaeotemperatures.
For all episodes, amounts of additional (removed) section have been calculated with reference to the elevation of the highest local summit level. Therefore, the reported values of removed section define how much was present above this level at the onset of each cooling episode. Note, where Palaeogene basalts are preserved at the summit (Appendix 2.2), this provides a prime reference for calculating amounts of removed section for the end-Eocene and younger events, as deposition required to explain these events must post-date deposition of the basalts. Estimates of removed section for pre-Palaeogene events are only possible at three locations (VT1 for the earliest Cretaceous episode and VT9 and VT16 for the mid-Cretaceous). In these cases, the estimate of removed section material relative to the top of the basalts represents a convenient approximation, as the base of the basalts represents the unconformity on which the additional section material was removed. Of course, the base of the basalts would provide a more appropriate reference for calculation, but as the basalts are not too thick at the locations of the transects, the effect on the final calculation of removed section is only slight.

Early Jurassic episode (C2): Late Jurassic palaeotemperature constraints from the VT3 transect suggest a high palaeogeothermal gradient (Appendix 2.3). If the Early Jurassic episode was characterised by elevated heat flow, we would expect rapid increase in palaeotemperature with depth. Therefore, this episode should be preferentially identified in samples close to sea level. This is not the case. Instead, we see evidence for the older events still preserved at lower elevations close to present-day sea level. It seems more likely that this apparent anomaly results either from one of the palaeotemperatures being a statistical outlier or from offsets due to faulting.

Earliest Cretaceous episode (C3): Constraints on the earliest Cretaceous episode are only available from VT1 (Clavering $\varnothing$ ). The allowed range of palaeogeothermal gradient (Appendix 2.4) is quite well defined, but the range is broad, largely because constraints are available over an elevation range of only c. $800 \mathrm{~m}$. Similarly, the range of allowed values of additional section is very broad as this is magnified by the degree of extrapolation required by the analysis. The crossplot of removed section vs. palaeogeothermal gradient provides relatively well-defined ranges of removed section for specific values of palaeogradients. For example, a palaeogeothermal gradient of $25^{\circ} \mathrm{C} / \mathrm{km}$ corresponds to a thickness of 1950 to $2200 \mathrm{~m}$ of additional section 

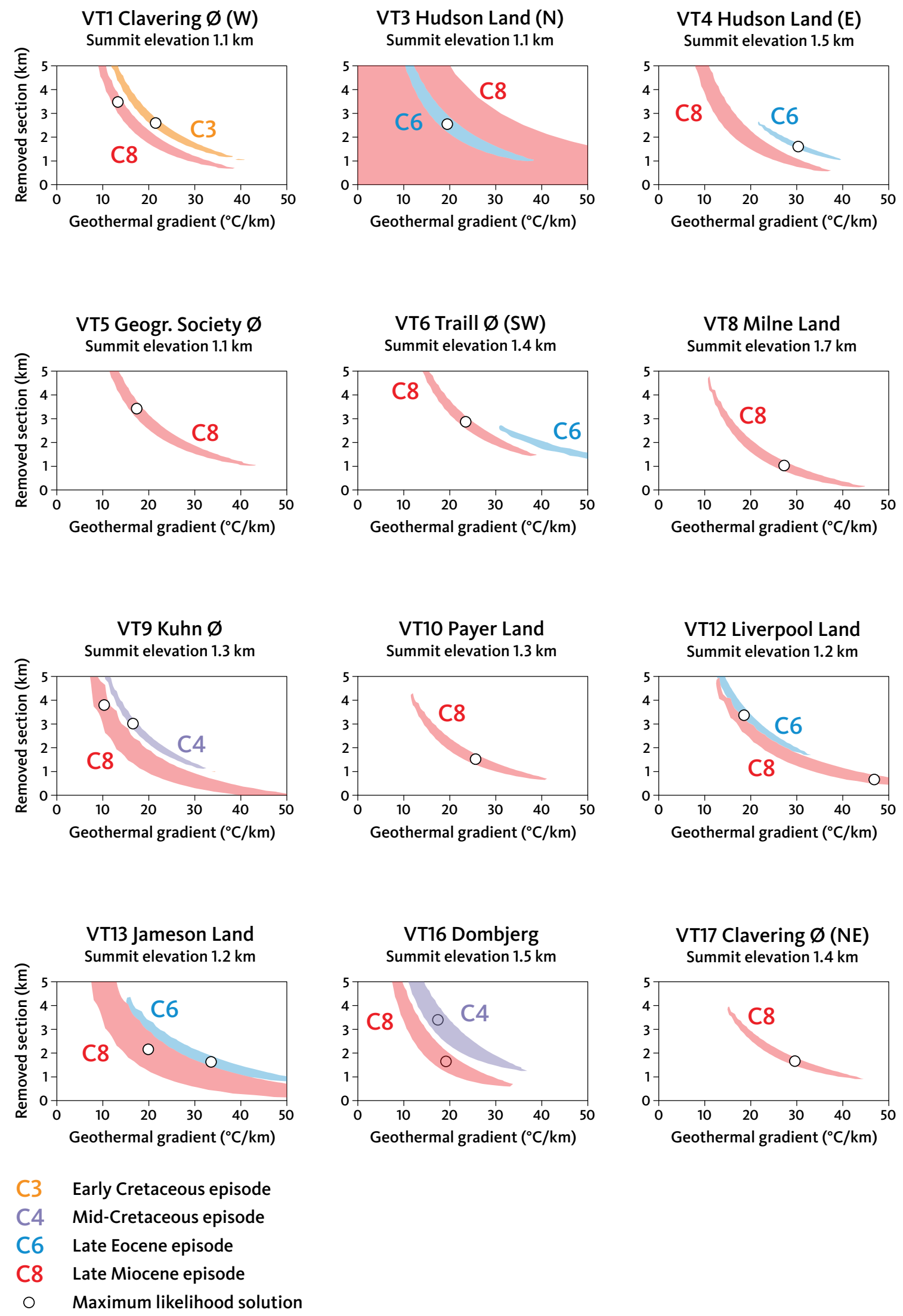

Appendix 2.4 Comparison of allowed palaeogeothermal gradients vs. amount of removed section above and up to the present-day summit elevation as derived from AFTA data from 12 vertical transects (Appendix 2.3). Locations in Appendix 2.1. 
that must have been present above the present-day summits of Clavering $\varnothing$ to explain palaeotemperatures in episode C3. Palaeogeothermal gradients in excess of $40^{\circ} \mathrm{C} / \mathrm{km}$ are not allowed. So, for any reasonable value of palaeogeothermal gradient, the palaeotemperature constraints characterising this clearly require deposition and removal of around $2 \mathrm{~km}$ of post-Carboniferous succession, prior to the onset of cooling in the interval 145 to $140 \mathrm{Ma}$. On this basis, cooling is interpreted as due largely to exhumation. Since Palaeogene basalts and underlying sedimentary units are present at the summit of this transect, erosional removal of all the additional section must have been accomplished by around the end of the Cretaceous.

Mid-Cretaceous episode (C4): Constraints on the mid-Cretaceous episode are only available from transects VT9 (Kuhn Ø) and VT16 (Dombjerg). Appendix 2.4 shows that the ranges of allowed values of palaeogeothermal gradients for each transect are well defined, despite the relatively narrow intervals over which constraints are available in these transects. However, the range of allowed removed sections is magnified by the degree of extrapolation required to determine the amount of missing section. Nevertheless, the crossplot of removed section vs. palaeogeothermal gradient provides relatively well-defined ranges of removed section for specific values of palaeogradient. These plots show that a palaeogeothermal gradient of $25^{\circ} \mathrm{C} / \mathrm{km}$ corresponds to a thickness of 1550 to $1850 \mathrm{~m}$ of additional section for VT9 and 1800 to $2600 \mathrm{~m}$ for VT16. At both locations, palaeogeothermal gradients in excess of $35^{\circ} \mathrm{C} / \mathrm{km}$ are not allowed, so for any reasonable value of palaeogeothermal gradient, the palaeotemperature constraints characterising this episode, clearly require deposition and removal of around $2 \mathrm{~km}$ of section, prior to the onset of cooling in the interval 95 to $90 \mathrm{Ma}$. Since Palaeogene basalts and underlying sedimentary units are present at the summit of this transect, erosional removal of all the additional section must have been accomplished by around the end of the Cretaceous.

End-Eocene episode (C6): Constraints on the end-Eocene episode are available from transects VT3, VT4, VT6 VT12 and VT13 (Appendix 2.4). Results from VT4 (Hudson Land) provide the best definition of the palaeotemperature profile for this episode, in terms of numbers of samples and the vertical extent of samples. The plot of removed section vs. palaeogeothermal gradient for VT4 shows a relatively narrow range of allowed values between c. 20 and $40^{\circ} \mathrm{C} / \mathrm{km}$. Results from VT6 are also quite well defined, while the ranges of allowed palaeogradients for other transects (e.g. VT3, VT12 and VT13) are wider. Nevertheless, the crossplots of removed section vs. palaeogeothermal gradient provide relatively well-defined ranges of removed section for specific values of palaeogradient for all five transects.

For VT4, the best-fit palaeogeothermal gradient of $30^{\circ} \mathrm{C} / \mathrm{km}$ corresponds to around $1.65 \mathrm{~km}$ of additional section required to explain the end-Eocene palaeotemperatures, and for any value of palaeogradient within the allowed range, km-scale additional section is required. Since no Palaeogene basalts are present at this location, some of this additional section could represent basalt. Results from transect VT6 tend to favour higher values of palaeogeothermal gradient while others generally tend to favour values around 20 to $30^{\circ} \mathrm{C} / \mathrm{km}$. While higher palaeogradients require lower amounts of additional section, for any reasonable value of palaeogradient, km-scale burial and exhumation are required to explain the end-Eocene palaeotemperature constraints derived from AFTA data in all five transects.

Late Miocene episode (C8): Of all the palaeothermal episodes, the late Miocene is most clearly expressed over the majority of vertical transects (Appendix 2.4), and it is the most widely recognised across the entire region (map C8 in Fig. 14). This episode appears to dominate the development of the present-day continental margin. Constraints on the late Miocene episode are available from all transects except VT7, VT14 and VT15. Transect VT7 is excluded because of uncertainty surrounding exact sample elevations, VT14 because samples are only available over a narrow depth interval and VT15 because the palaeothermal constraints are too broad.

The range of allowed values of additional section is very broad for all transects, with no upper limit being defined in many cases. But the crossplots of removed section vs. palaeogeothermal gradient in most cases provide relatively well-defined ranges of removed section for specific values of palaeogradient. The more well-constrained results from these transects tend to favour palaeogeothermal gradients in the range 20 to $30^{\circ} \mathrm{C} / \mathrm{km}$, while results from many transects are not consistent with palaeogradients above c. $40^{\circ} \mathrm{C} / \mathrm{km}$. Palaeogradients around 20 to $30^{\circ} \mathrm{C} / \mathrm{km}$ generally correspond to amounts of removed section between 1 and $2 \mathrm{~km}$. Since these calculations have been carried out with respect to local summit elevations, the results shown here require removal of a considerable amount of additional section over the last $10 \mathrm{Myr}$. And since early Eocene basalts are present at many of the summits, the additional section required to explain the late Miocene palaeotemperatures, must represent additional Eocene basalts and younger sediments deposited in the time interval between eruption of the basalts and the onset of exhumation at c. $10 \mathrm{Ma}$. 


\section{Comparison of transects for the Mesozoic and end-Eocene events}

Appendix 2.5 shows palaeotemperatures characterising the Middle Triassic (C1), Early Jurassic (C2), earliest Cretaceous (C3) and end-Eocene (C6) palaeothermal episodes in each of the vertical transects plotted against a common axis of sample elevation for each episode. Results from each transect and for each episode can generally be described by profiles with gradients of c. $25^{\circ} \mathrm{C} / \mathrm{km}$, although only a small number of transects provide any real constraints on the palaeogeothermal gradient. The figure also illustrates how the earlier episodes are only identified at locations where the respective maximum palaeotemperatures are sufficiently higher than those in later episodes. Again, we emphasise that the apparent high gradient defined by the Early Jurassic palaeogeothermal gradient from VT3 stands out as anomalous when compared with other results.

Palaeotemperatures during the earliest Cretaceous (C3) episode highlight some major differences between transects. In particular, palaeotemperatures in samples from VT4 and VT16 are offset to higher elevations by between 500 and $1000 \mathrm{~m}$ from those in samples from VT1 and VT3, while the single value from VT10 plots at an intermediate position. Such offsets clearly demand major differential exhumation between these locations during or after the earliest Cretaceous cooling episode.

Appendix 2.5 provides a comparison of palaeotemperatures in the end-Eocene (C6) episode at eight vertical transects where this episode is identified by AFTA. Some clear differences are evident. VT3 palaeotemperatures are lower than those from VT4, VT11, VT11, VT12 and VT13, while those from VT6, VT14 and VT15 are higher than the other five. Palaeotemperature constraints from most of the transects can be described by palaeogradients around $25^{\circ} \mathrm{C} / \mathrm{km}$. VT6 defines a distinctly higher palaeogeothermal gradient, in line with VT14 and VT15. These higher palaeogradients can be explained in terms of their proximity to the middle Eocene - early Oligocene intrusions at Myggbukta (VT14) and Traill $\varnothing$ (VT6 and VT15). 

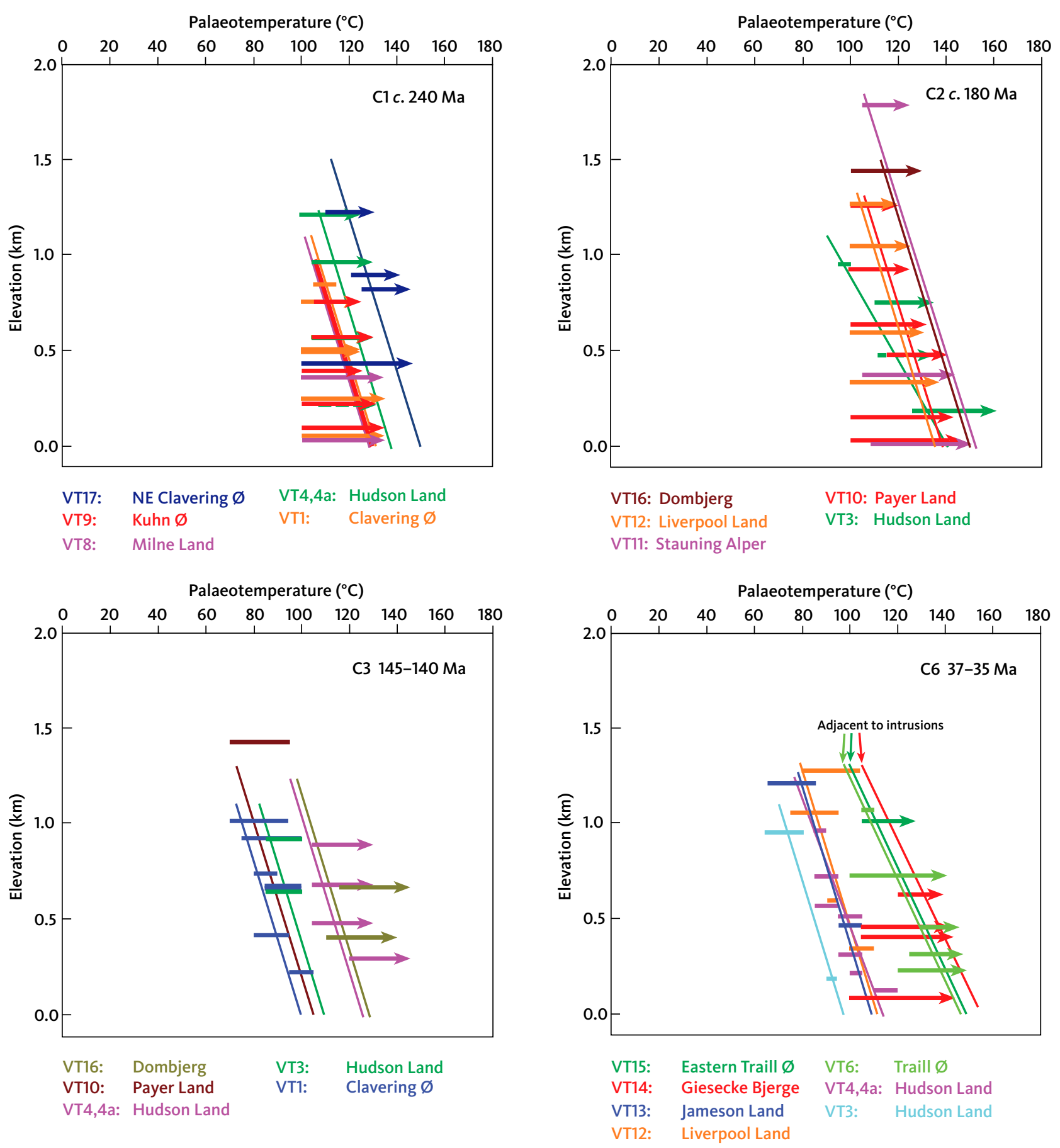

Appendix 2.5 Comparison of palaeotemperature constraints for four episodes derived from AFTA plotted against elevation (a.s.l.), in samples from vertical transects: C1 Middle Triassic, C2 Early Jurassic, C3 earliest Cretaceous and C6 end-Eocene. Constraints for each transect are colour-coded as indicated. Results for the end-Eocene episode fall into three dominant groupings for low, medium and high palaeotemperatures for a particular elevation. Highest values are all close to middle Eocene - early Oligocene intrusions, and these results suggest high palaeogeothermal gradients $\left(45^{\circ} \mathrm{C} / \mathrm{km}\right.$ for VT6, VT14 and VT15) in contrast to lower profiles ( $25^{\circ} \mathrm{C} /$ km). Locations in Appendix 2.1. 


\section{Appendix 3 Thermal-history diagrams}

Appendices 3.1 to 3.13 illustrate the thermal history at summit level above a VT or a group of samples, based on palaeothermal constraints from AFTA (Appendix 2), the geological record (Fig. 3; Appendix 2.2) and stratigraphic landscape analysis (Chapter 3 ). The diagrams are constructed in the simplest possible manner to provide an overview of the available constraints. Note that the time axis has two different scales before and after $65 \mathrm{Ma}$. We have assumed that 8 of the 10 cooling episodes affected most of the study area even if the AFTA data only resolve a minor number of episodes at a given location (Table 1).

Location of VTs and plots of palaeothermal constraints vs. elevation for each transect are shown in Appendices 2.1, 2.3. Amounts of removed section vs. palaeogeothermal gradient are shown for each transect in Appendix 2.4. A map of the extent of the UPS and LPS is shown in Fig. 9.

Palaeotemperature constraints are projected to the summit level for a palaeogeothermal gradient of $25^{\circ} \mathrm{C} /$ $\mathrm{km}$ for each cooling episode recognised in AFTA data for the samples along each transect unless otherwise indicated. The ranges of palaeotemperatures for the summit level in different episodes are plotted as boxes with a height corresponding to the allowed range; typically $10-20^{\circ} \mathrm{C}$. To enhance the readability of the diagram, the width of the boxes is fixed in centimetres and does thus not reflect the constraints on the onset of cooling from the samples along the transect. Boxes are extended below the $x$-axis of the diagram where the palaeothermal constraints place only a lower limit on the palaeotemperature (e.g. $>110^{\circ} \mathrm{C}$ ). Coloured vertical bars define the onset of regional cooling episodes (Table 1).

Red triangles mark constraints from geology; e.g. the time of sediment deposition or extrusion of basalts for rocks that outcrop at the summits. At that time, the rock (often basement) below these outcrops was exposed at the surface and thus had a palaeotemperature of $10-20^{\circ} \mathrm{C}$ depending on the climate. The horizontal blue arrows mark the time available for the formation of the UPS between the onset of uplift and cooling in the end-Eocene (C6) and the inferred onset of Miocene reburial which is arbitrarily taken to start at $20 \mathrm{Ma}$. If instead, the LPS coincides with the summit level, and we assume that the LPS was incised $500 \mathrm{~m}$ below a previously existing UPS, then the rocks at summit level were cooled to about $20^{\circ} \mathrm{C}$ (c. $10^{\circ} \mathrm{C}+0.5 \mathrm{~km}$ per $25^{\circ} \mathrm{C} / \mathrm{km}$ ). The horizontal red arrows mark the time available for the formation of the LPS between the onset of uplift and cooling in the late Miocene (C8) and the onset of uplift in the early Pliocene (C9). For simplicity, the cooling path between the late Miocene palaeotemperature and the present-day surface temperature (arbitrarily shown as $0^{\circ} \mathrm{C}$ ) is shown as a straight line. Interpretations are provided in the appendix captions. 


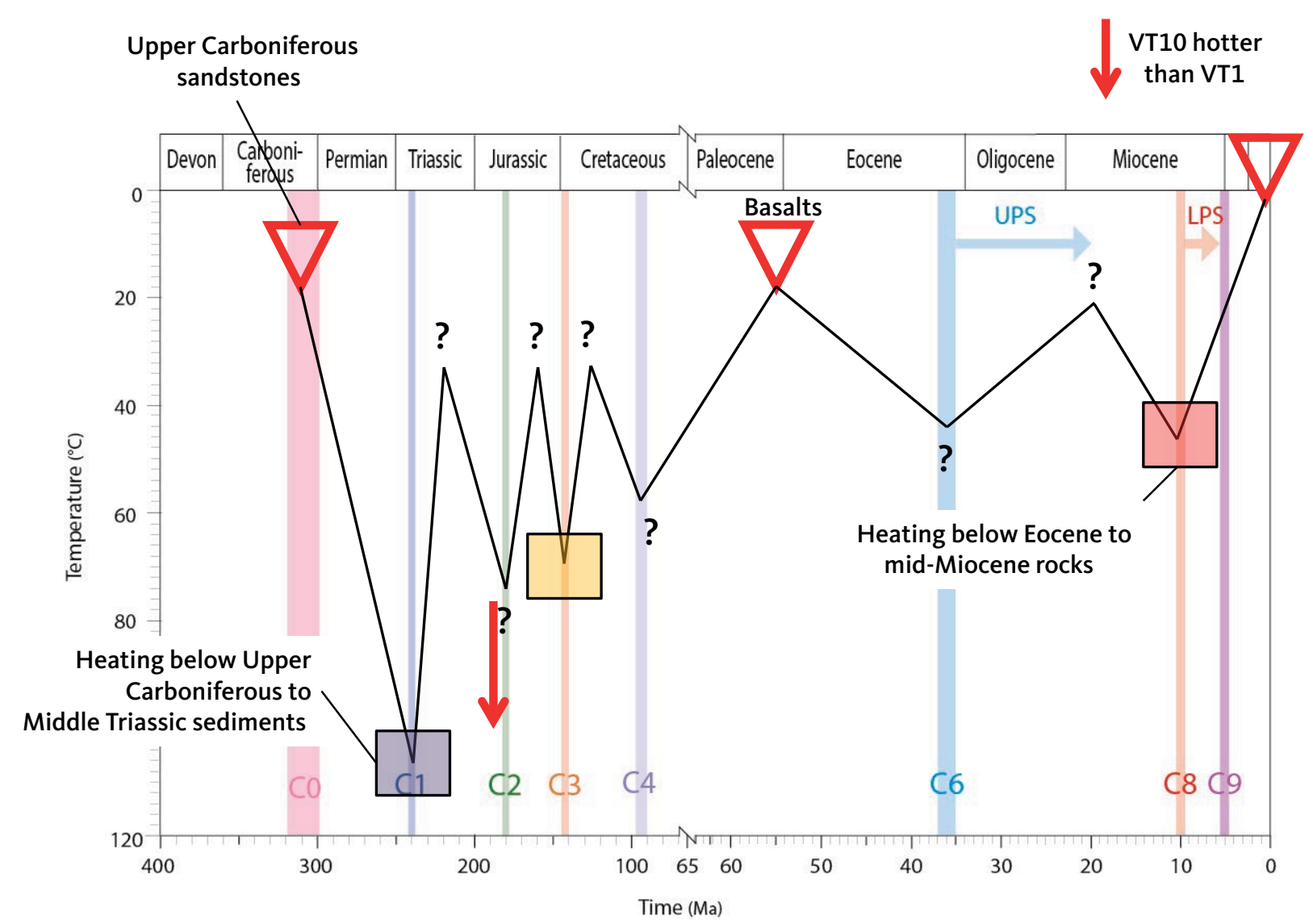

Appendix 3.1 VT1. Summits of western Clavering $\emptyset$. Local summits $1.2 \mathrm{~km}$ (close to the LPS). Upper Carboniferous sandstones are present in the summits on western Clavering $\emptyset$, just below Palaeogene basalts. The sandstones were therefore exposed at the surface in the Carboniferous and in the early Eocene. This implies that late Miocene C8 palaeotemperatures are due to burial below Palaeogene basalts and post-basalt sediments deposited between c. 55 and 10 Ma. Middle Triassic C1 palaeotemperatures are due to burial below upper Carboniferous to Middle Triassic sediments. C2 palaeotemperature s are not resolved for VT1, but must have been between the C1 and C3 values. We suggest that C2 palaeotemperatures for VT1 must be lower than those resolved for VT10, Payer Land (i.e. $<100^{\circ} \mathrm{C}$ ). 


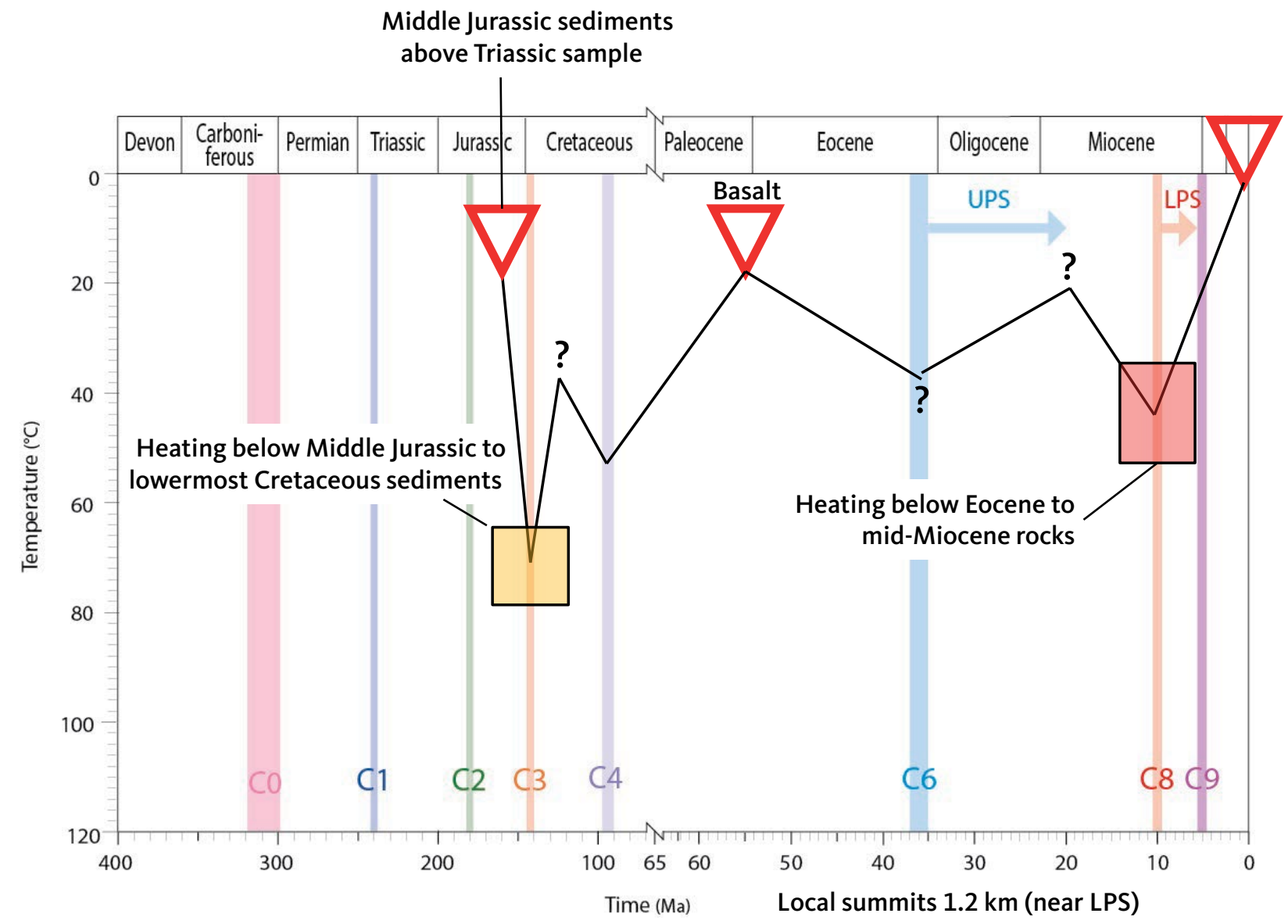

Appendix 3.2 VT2. Summits at north-west Hold with Hope. Local summits $1.2 \mathrm{~km}$ (close to the LPS). Middle Jurassic sandstone units present near the summits of VT2 were deposited on Triassic sediments at the surface at a temperature of $c .20^{\circ} \mathrm{C}$. AFTA data show that a sample of Triassic sandstone was heated to $60-80^{\circ} \mathrm{C}$ during the earliest Cretaceous $\mathrm{C} 3$ episode. This implies the deposition of a kilometre-thick cover of Middle Jurassic to lowermost Cretaceous sediments prior to the onset of episode C3. 


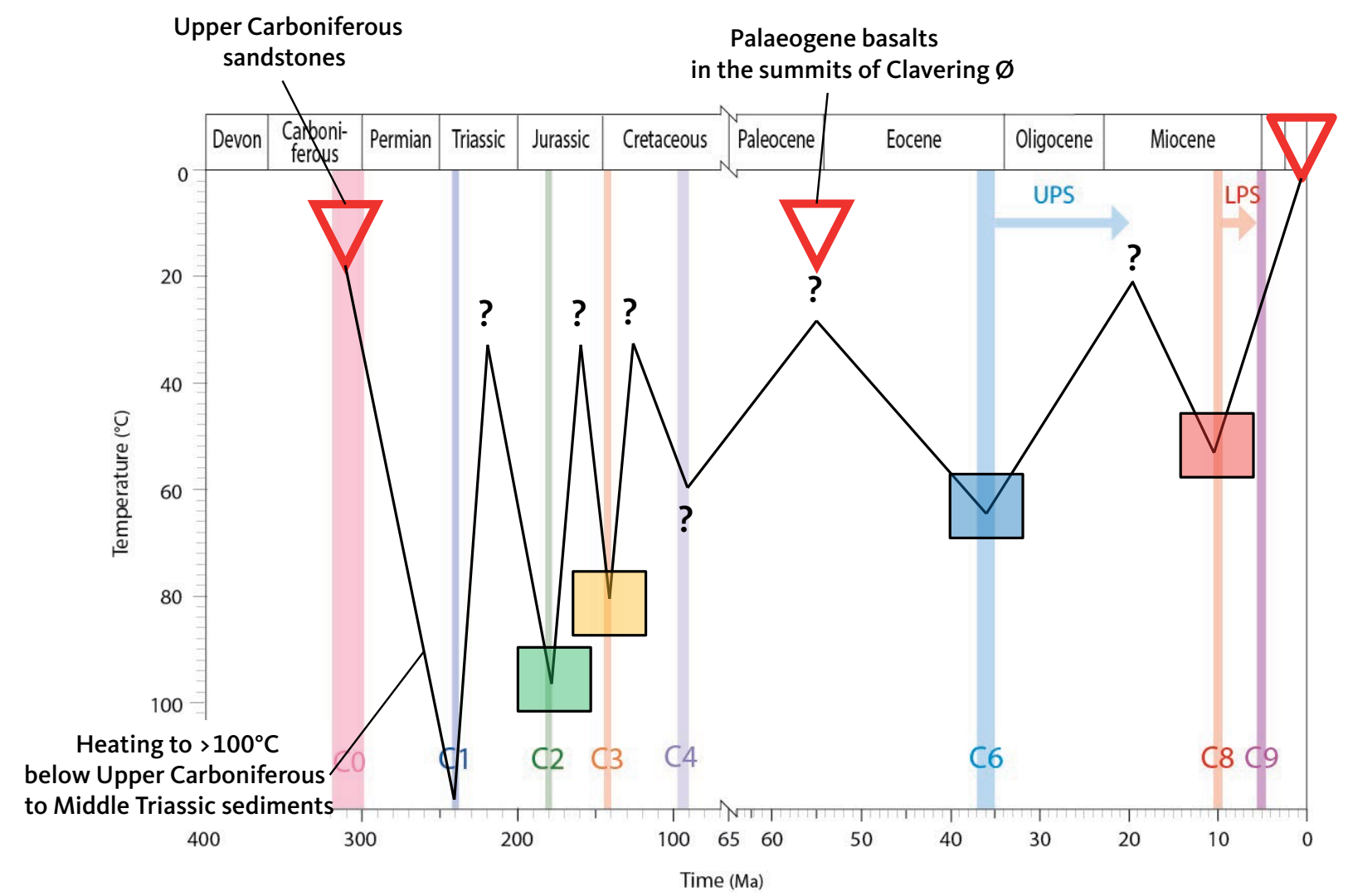

Appendix 3.3 VT3. Summits of Hudson Land (N). Local summits $1.3 \mathrm{~km}$ (close to the LPS). UPS at $1.8 \mathrm{~km}$. All VT3 samples are of Upper Carboniferous sandstones and each sample was therefore at surface temperature during deposition. No Palaeogene basalts are present in the summits above VT3, but basalts are present in the summits of Clavering $\varnothing$ and on Hold with Hope. 
Upper Carboniferous sandstones in the summits of VT3
Palaeogene basalts

in the summits of Clavering $\varnothing$

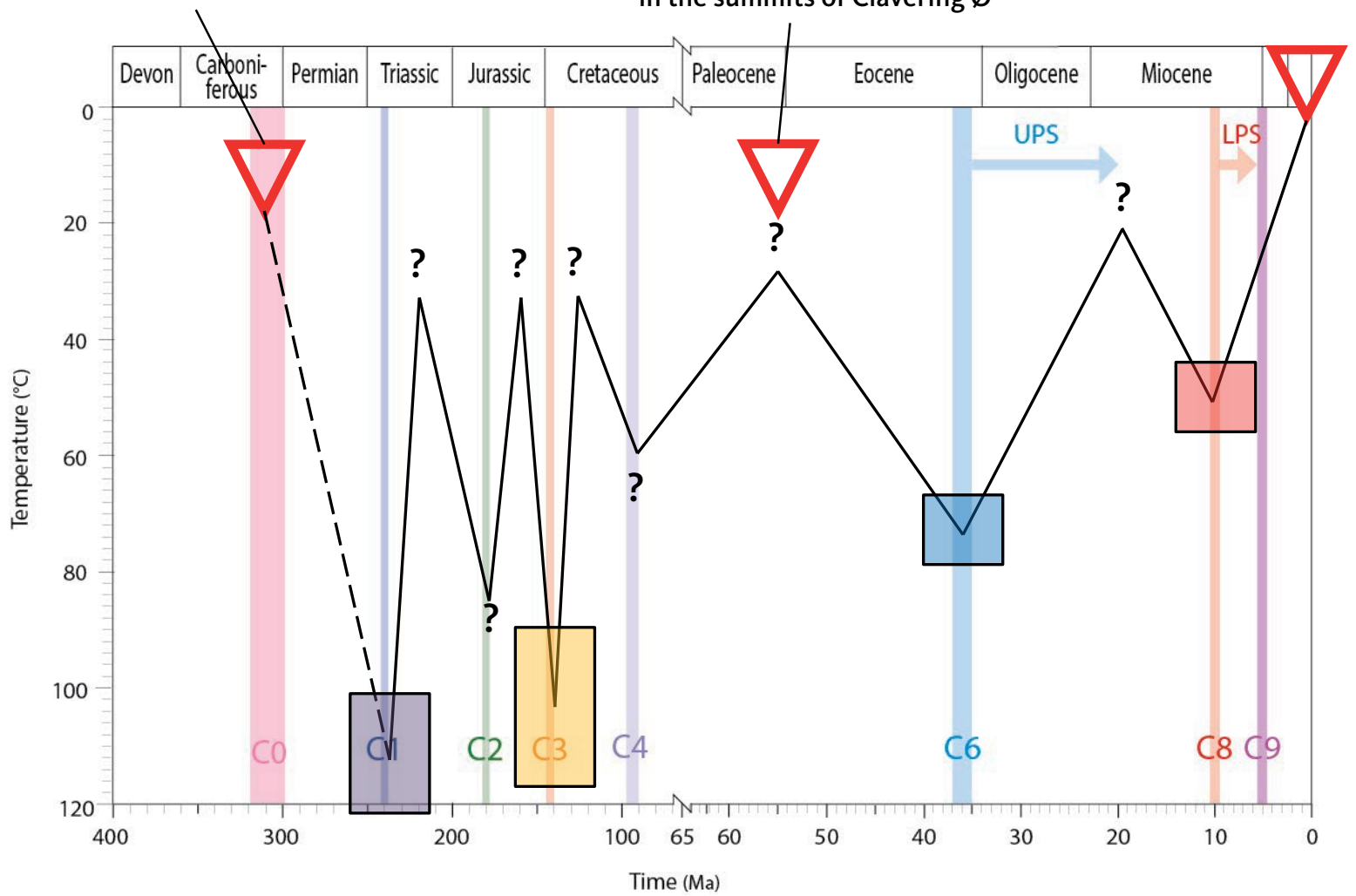

Appendix 3.4 VT4. Summits of Hudson Land (S). Local summits $1.3 \mathrm{~km}$ (close to the LPS). UPS at $1.8 \mathrm{~km}$. All VT4 samples are of basement rocks, but Upper Carboniferous sandstones are present nearby (VT3). Heating to temperatures above $100^{\circ} \mathrm{C}$, characteristic of episode C1, reflects burial below Carboniferous to Middle Triassic sediments. No Palaeogene basalts are present in the summits above VT4, but basalts are present in the summits of Clavering $\varnothing$ and Hold with Hope. 


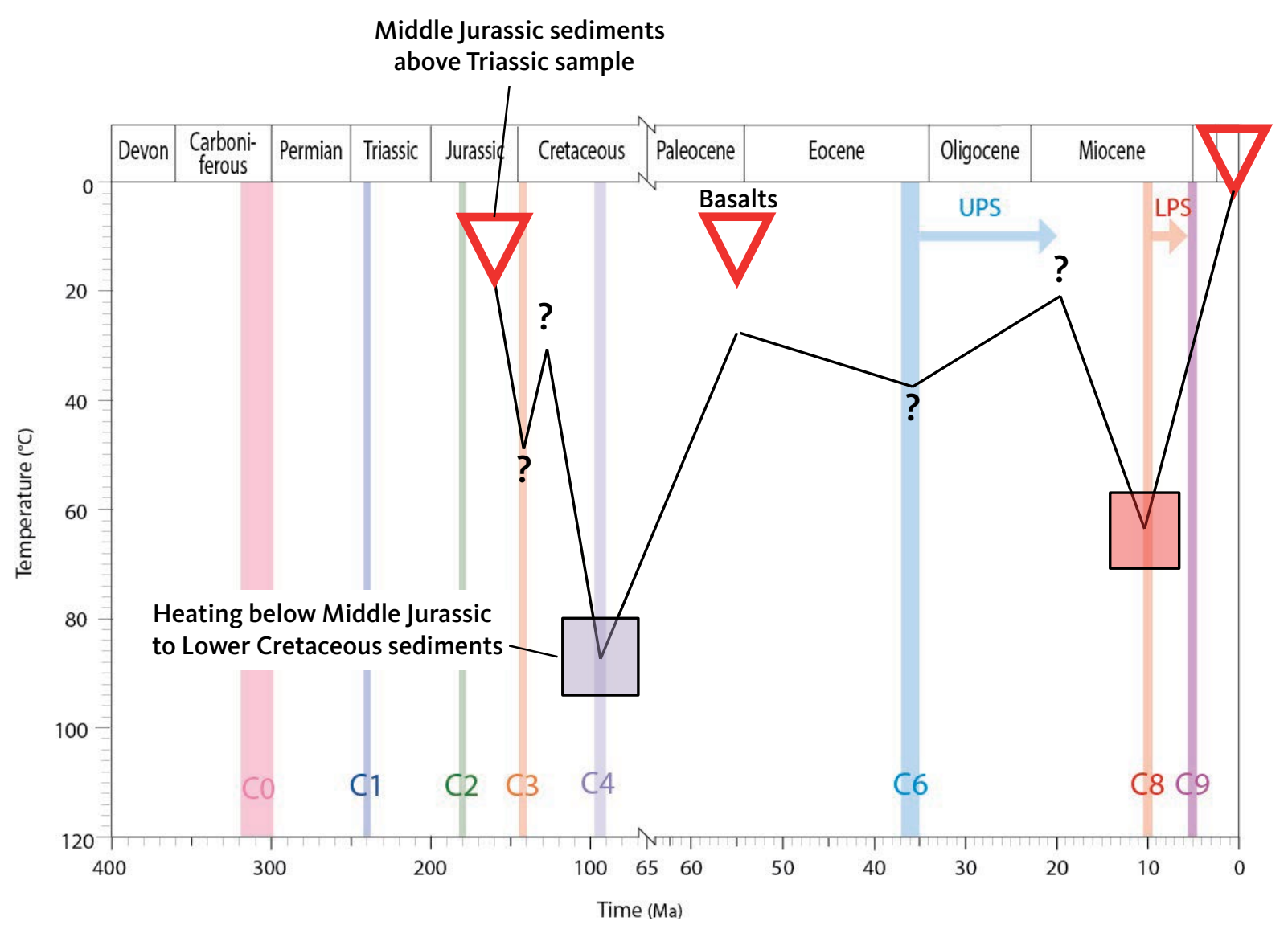

Appendix 3.5 VT5. Summits on Geographical Society $\emptyset$. Local summits $1.1 \mathrm{~km}$ (close to the LPS). Triassic sandstone units were deposited at the surface at a temperature of $c .20^{\circ} \mathrm{C}$, and now crop out below Middle Jurassic sediments. AFTA data show that the Triassic sample was heated to almost $90^{\circ} \mathrm{C}$ during the mid-Cretaceous $\mathrm{C} 4$ episode. This implies the deposition of a kilometre-thick cover of Middle Jurassic to Lower Cretaceous sediments prior to the onset of episode C4. 


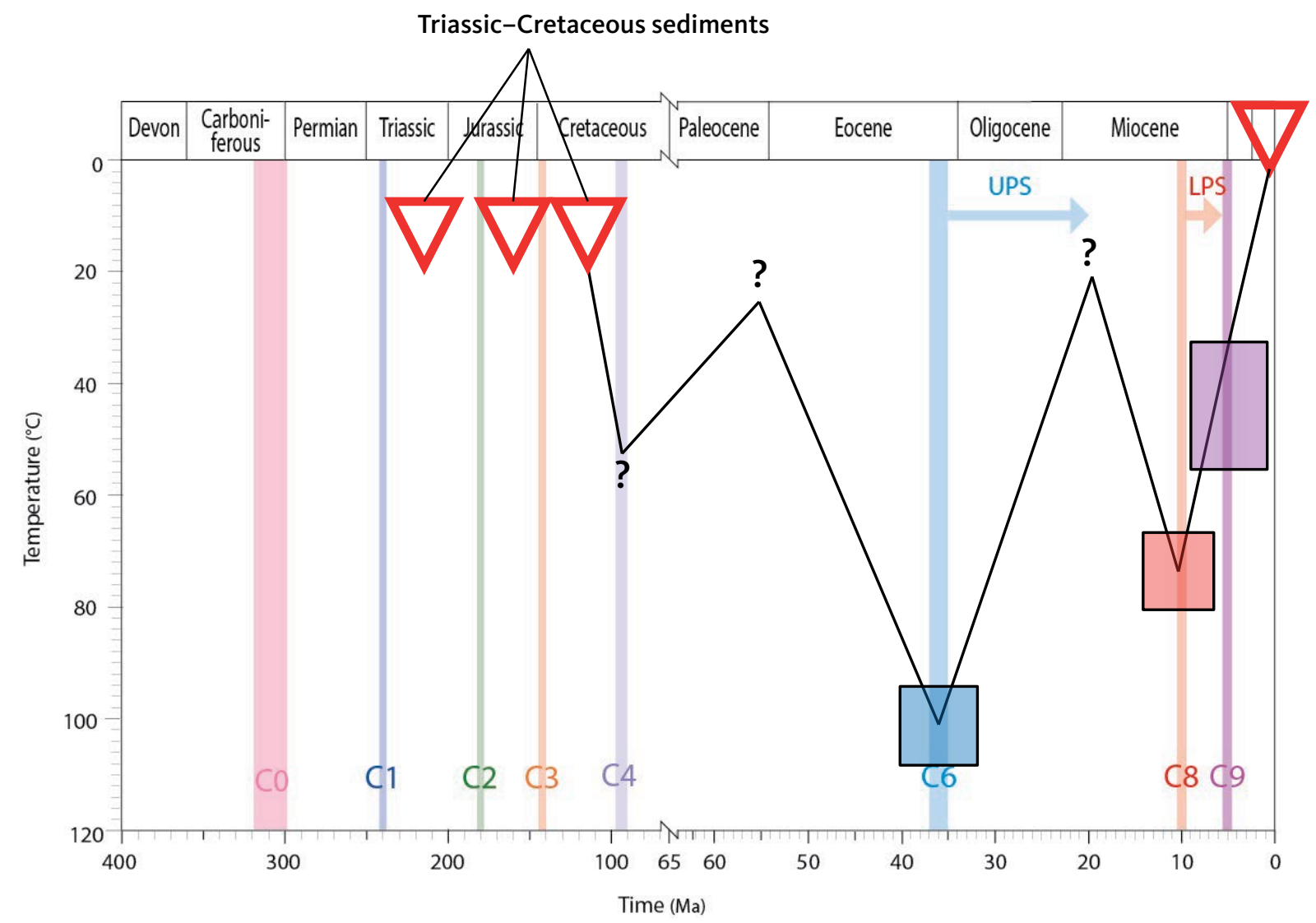

Appendix 3.6 VT5. Summits on Geographical Society $\emptyset$. Local summits $1.1 \mathrm{~km}$ (close to the LPS). Triassic sandstone units were deposited at the surface at a temperature of $c .20^{\circ} \mathrm{C}$, and now crop out below Middle Jurassic sediments. AFTA data show that the Triassic sample was heated to almost $90^{\circ} \mathrm{C}$ during the mid-Cretaceous $\mathrm{C} 4$ episode. This implies the deposition of a kilometre-thick cover of Middle Jurassic to Lower Cretaceous sediments prior to the onset of episode C4. 


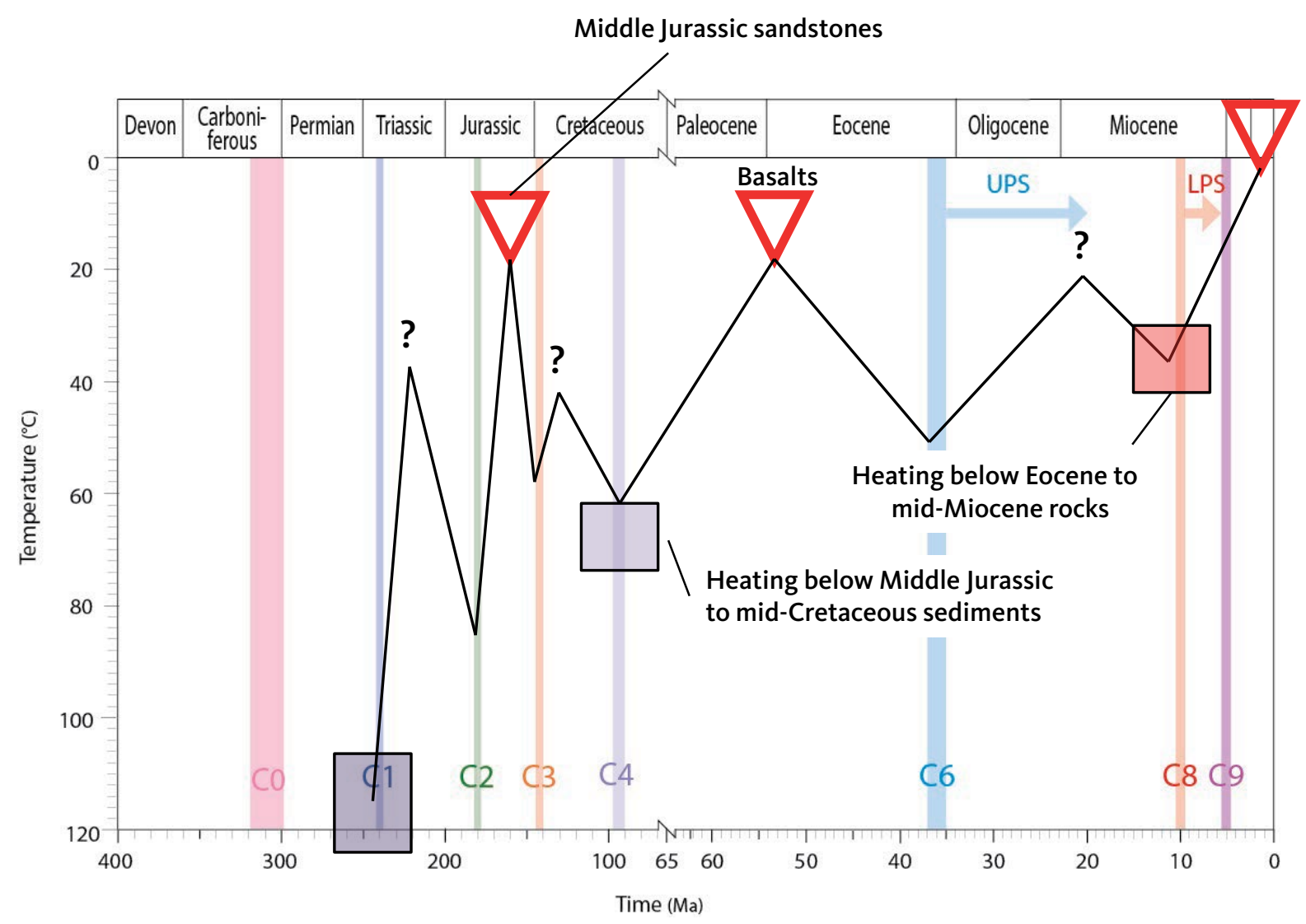

Appendix 3.7 VT9. Summits of Kuhn $\varnothing$. Local summits $1.2 \mathrm{~km}$ (close to the LPS). Kuhn $\varnothing$ is a tilted Late Jurassic - Early Cretaceous fault block where Middle Jurassic sediments onlap basement on the western side of the island. The basement rocks in the summits were thus near the surface in the Middle Jurassic, and the mid-Cretaceous C4 palaeotemperatures therefore correspond to burial below a thick cover of Middle Jurassic - mid-Cretaceous sediments. Palaeogene basalts are present in the summits. Thus, the basement rock was near the surface in the early Eocene. This implies that C8 palaeotemperatures at $10 \mathrm{Ma}$ are due to burial below basalts and post-basalt sediments deposited between c. 55 and $10 \mathrm{Ma}$. 


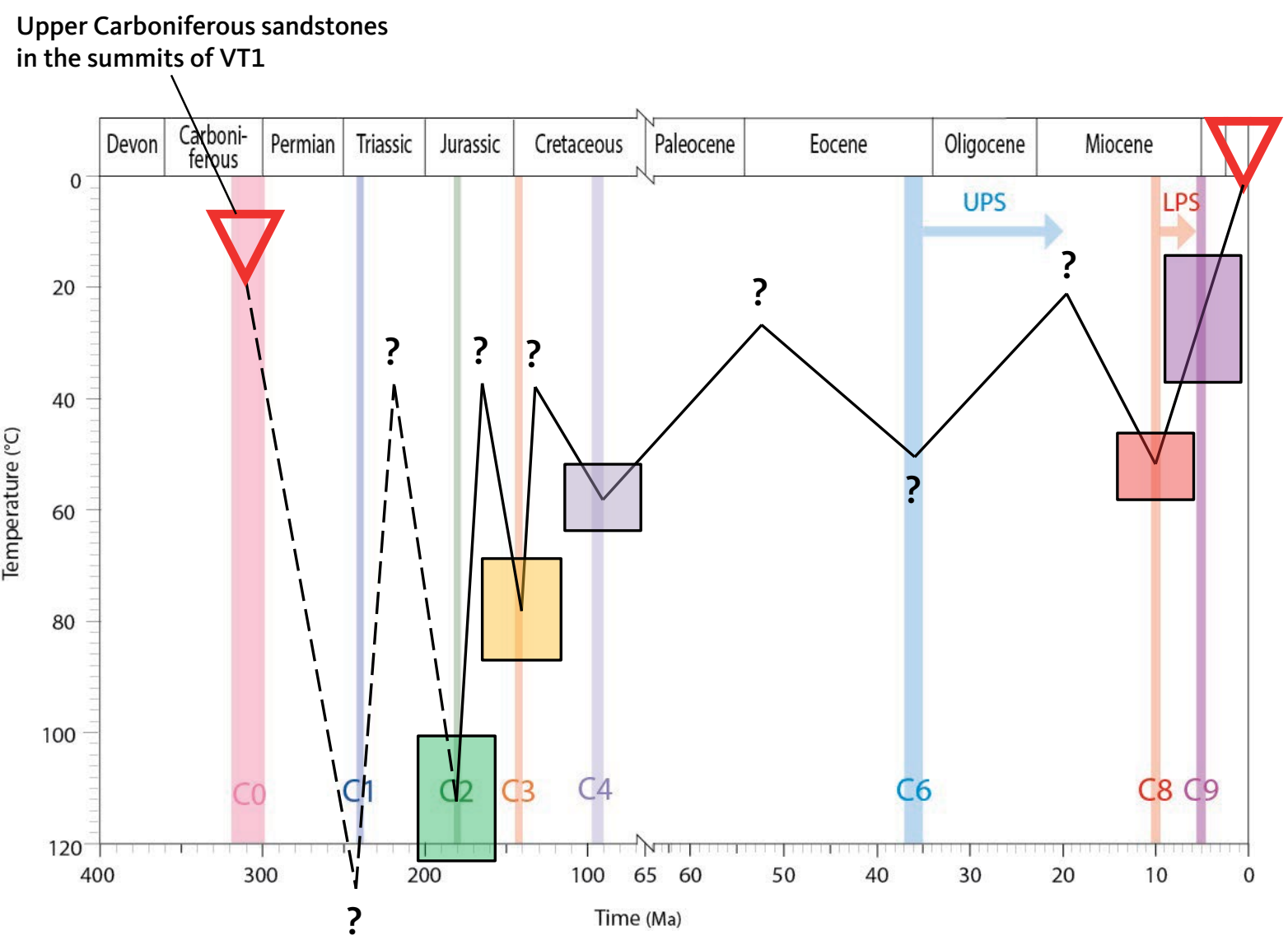

Appendix 3.8 VT10. Summits of Payer Land. Local summits $1.3 \mathrm{~km}$ (close to the LPS). On Payer Land there are no deposits present that constrain the Phanerozoic development. However, results from the nearby VT1 on eastern Clavering $\varnothing$ show that much of the heating prior to C2 cooling must have involved burial below Upper Carboniferous sediments. One sample at low elevation provides constraints on the Pliocene palaeotemperature. 


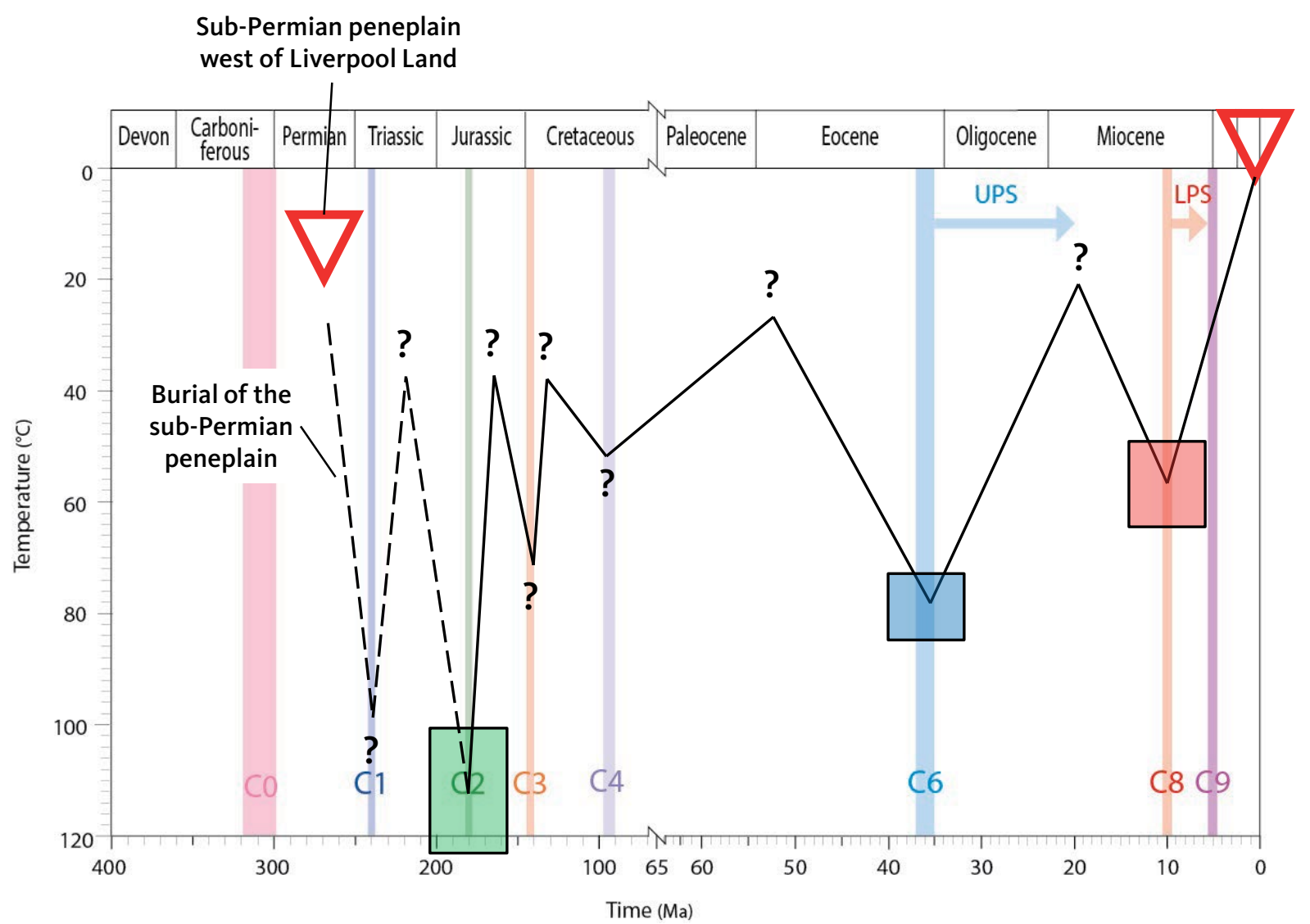

Appendix 3.9 VT12. Summits of Liverpool Land. Local summits $1.2 \mathrm{~km}$ (close to the LPS). A westward tilted, sub-Permian peneplain extends across the western flanks of Liverpool Land and below upper Permian and Triassic sediments in the Jameson Land Basin. The basement rocks in the summits were thus not far from the surface in the mid-Permian. Palaeotemperatures in the Early Jurassic $\mathrm{C} 2$ episode are in excess of $100^{\circ} \mathrm{C}$, implying that the summits at that time were buried below a thick cover of upper Permian - Lower Jurassic sediments. Heating to high palaeotemperatures in the late Eocene was probably partly due to Eocene burial of the margin. Likewise, heating in the late Miocene also reflects Miocene reburial of the margin. 


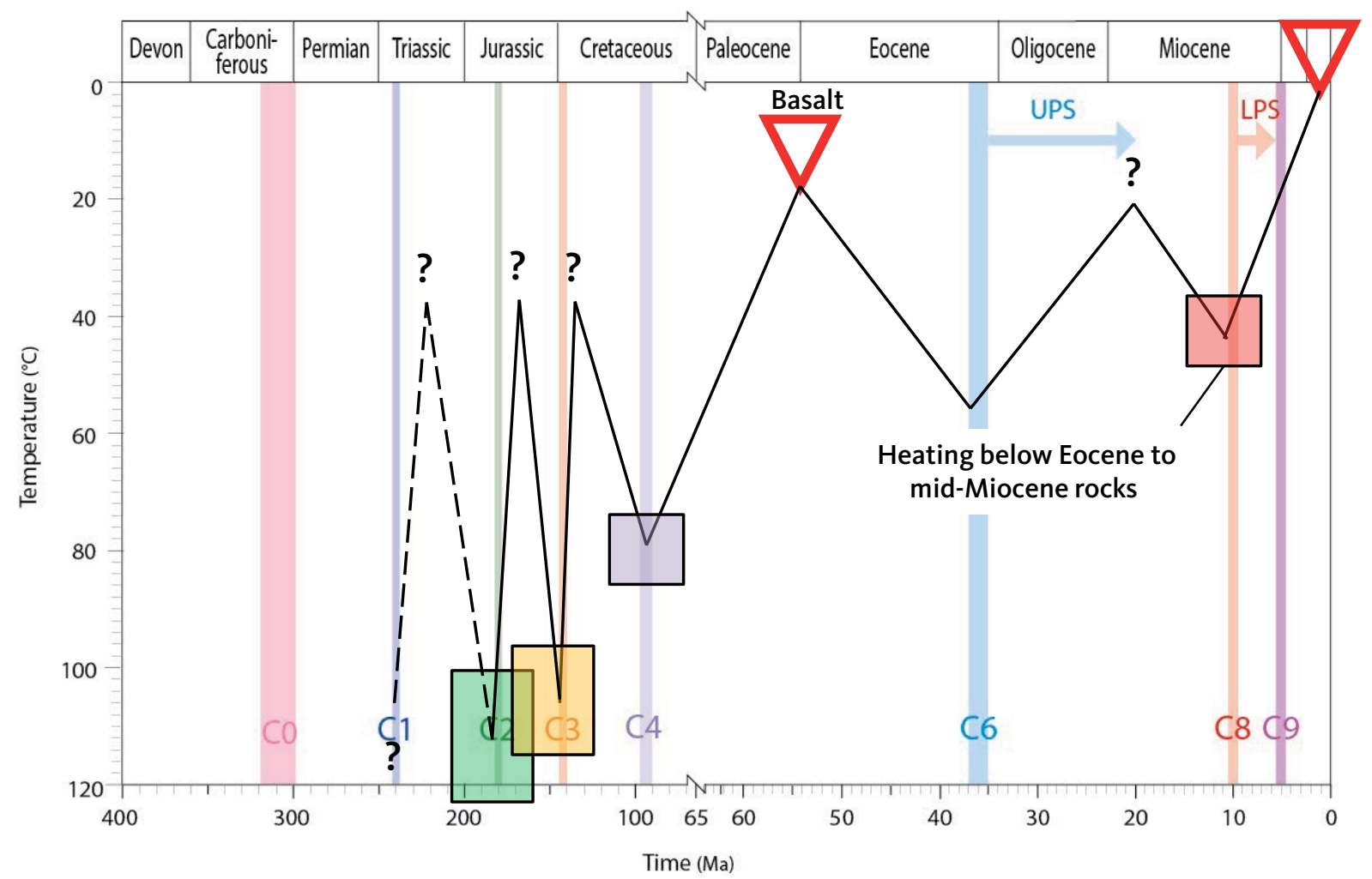

Appendix 3.10 VT16. Summits of Dombjerg. Local summits $1.4 \mathrm{~km}$ (close to the LPS). Palaeogene sandstones and basalts are present in the summits of Dombjerg. The basement rocks just below the Palaeogene deposits were thus exposed at the surface in the earliest Eocene. This implies that the C8 palaeotemperatures at 10 Ma were due to burial below post-basalt sediments deposited between c. 55 and $10 \mathrm{Ma}$. 


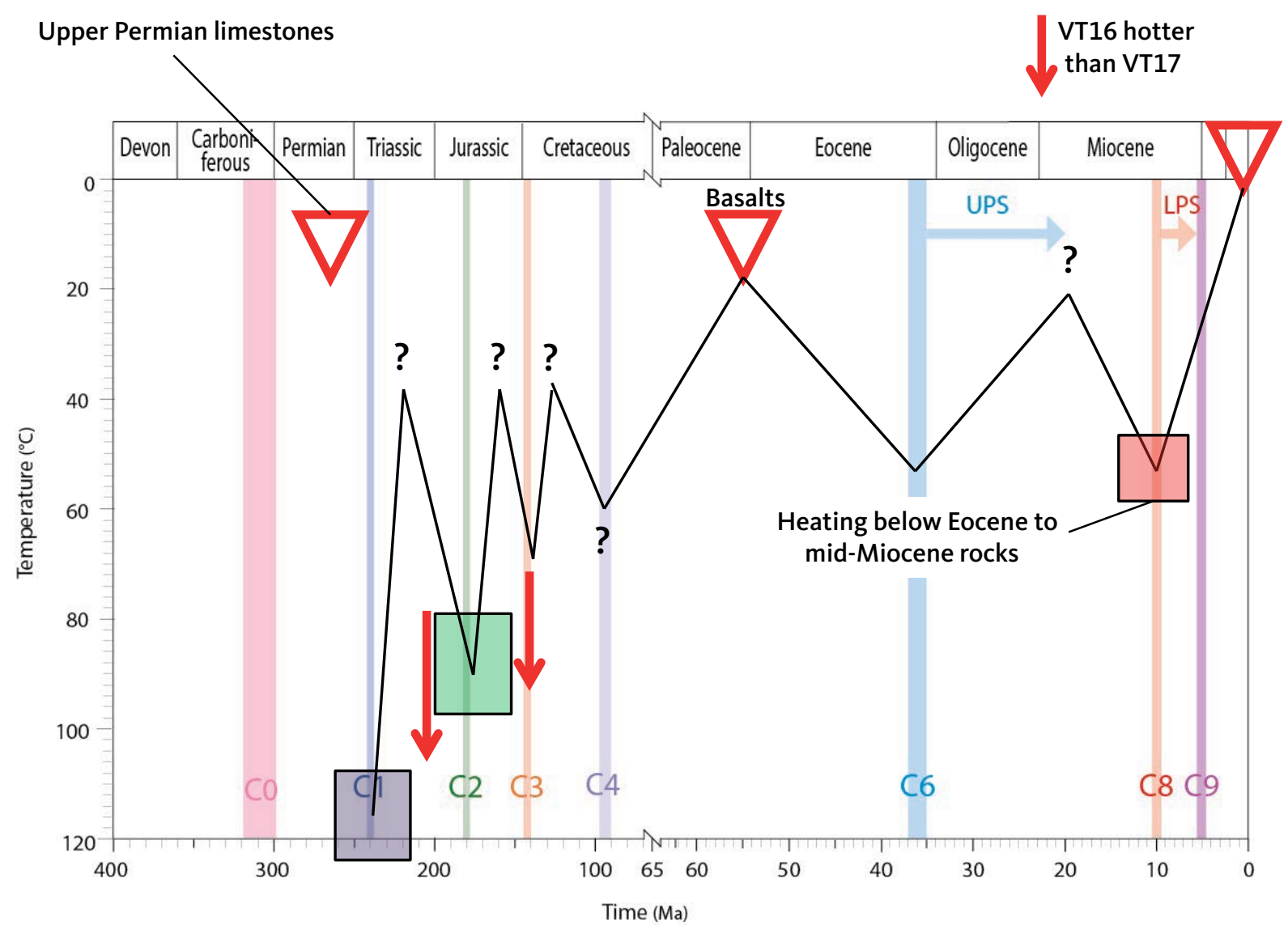

Appendix 3.11 VT17. Summits of north-east Clavering $\varnothing$. Local summits $1.2 \mathrm{~km}$ (close to the LPS). Upper Permian carbonates crop out in the summits of Clavering $\varnothing$ where basement samples from adjacent locations were heated to a Middle Triassic C1 palaeotemperature in excess of $110^{\circ} \mathrm{C}$. Heating at locations where carbonates are not present, was caused by burial below a thick cover of upper Permian to Middle Triassic sediments plus an unknown column of basement rocks. Palaeogene sandstones and basalts are present in the summits of VT17. Basement rocks just below the Palaeogene deposits were thus exposed at the surface in the early Eocene. This implies that late Miocene C8 palaeotemperatures were due to burial below basalts and post-basalt sediments deposited between c. 55 and 10 Ma. C3 palaeotemperature in VT17 is not resolved, but it must have been lower than C2 in this transect (i.e. $<80^{\circ} \mathrm{C}$ ). This would be substantially lower than that resolved for C3 in VT16 (Dombjerg, Appendix 3.10). These differences between VT16 and VT17 were levelled out prior to the eruption of the Palaeogene basalts (present in the summits at both locations at about the same elevation); possibly during the mid-Cretaceous C4 episode. 


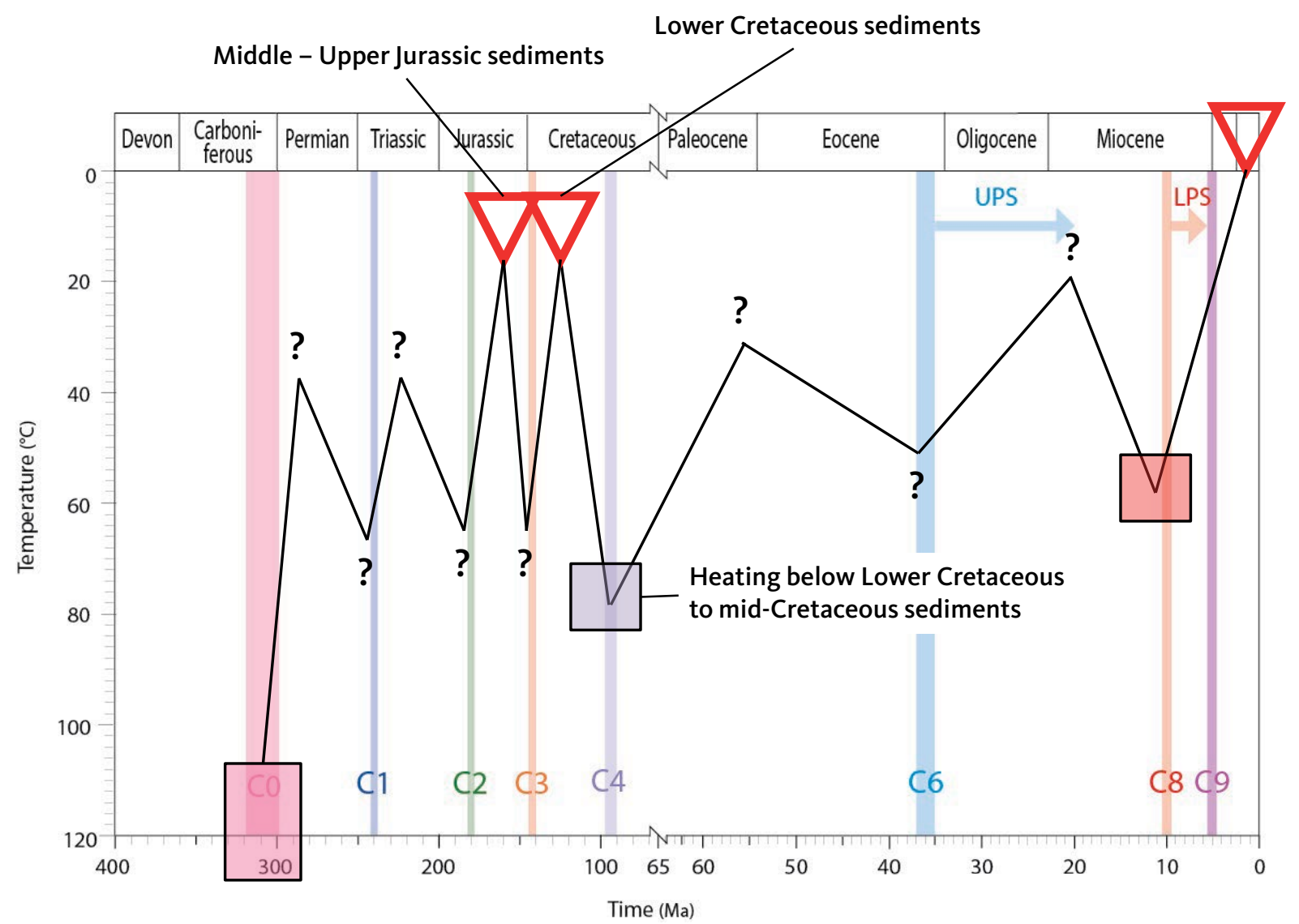

Appendix 3.12 Store Koldewey at sea level. Basement sample GC1077-16 cooled below $110^{\circ} \mathrm{C}$ in the late Carboniferous C0 episode. This sample and a sample of Middle Jurassic sandstone cooled from about $80^{\circ} \mathrm{C}$ in the mid-Cretaceous C4 episode. Both samples are adjacent to Lower Cretaceous sediments at outcrop, and this implies deposition of a kilometre-thick Lower Cretaceous - mid-Cretaceous cover prior to onset of uplift and erosion in episode C4. The samples were heated to $\mathrm{C} .60^{\circ} \mathrm{C}$ prior to cooling in the late Miocene C8 episode. 


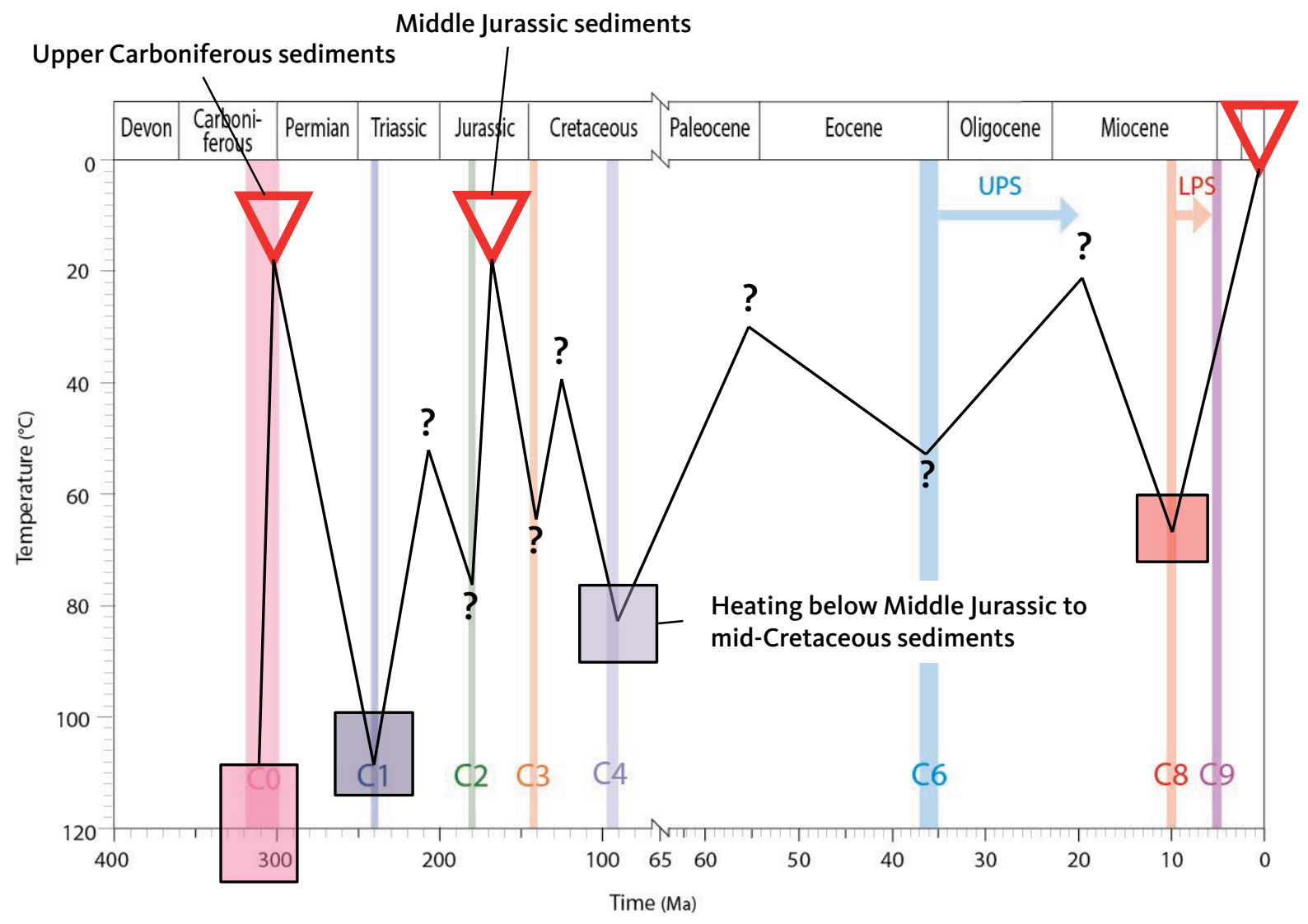

Appendix 3.13 Germania Land at sea level. Basement samples GC1077-10 and -11 cooled below $105^{\circ} \mathrm{C}$ in the late Carboniferous C0 episode. Assuming this episode corresponds to the unconformity between basement and an Upper Carboniferous outlier on Germania Land (Piasecki et al. 1994), then the cooling from these palaeotemperatures to surface conditions represents kilometre-scale exhumation prior to late Carboniferous deposition. Heating of samples GC1077-9, -10 and -11 to palaeotemperatures of c. $100^{\circ} \mathrm{C}$ or more in the Middle Triassic C1 episode reflects burial below a thick Upper Carboniferous - Middle Triassic cover. Middle Jurassic sedimentary outliers also rest directly on basement on Germania Land (Bojesen-Koefoed et al. 2012), again implying kilometre-scale exhumation between the onset of Middle Triassic cooling and Middle Jurassic deposition. Samples GC1017-9 and -11 reached a palaeotemperature of $c .75^{\circ} \mathrm{C}$ prior to mid-Cretaceous cooling and thus reflect significant burial during Middle Jurassic to mid-Cretaceous. 